Early Buddhist Transmission and Trade Networks 


\title{
Dynamics in the History of Religion
}

\author{
Editor-in-Chief \\ Volkhard Krech \\ Ruhr-University Bochum, Germany
}

Advisory Board

Jan Assmann - Christopher Beckwith - Rémi Brague José Casanova - Angelos Chaniotis - Peter Schäfer Peter Skilling - Guy Stroumsa - Boudewijn Walraven

VOLUME 2 


\section{Early Buddhist Transmission and Trade Networks}

Mobility and Exchange within and beyond the Northwestern Borderlands of South Asia

By

Jason Neelis

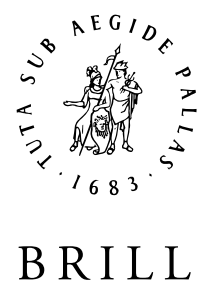


B R I L L This is an open access title distributed under the terms of the CC-BY-NC License, which permits any non-commercial use, distribution, and reproduction in any medium, provided the original author(s) and source are credited.

An electronic version of this book is freely available, thanks to the support of libraries working with Knowledge Unlatched. More information about the initiative can be found at www.knowledgeunlatched.org.

Cover illustration: Detail of the Śibi Jātaka in a petroglyph from Shatial, northern Pakistan (from Ditte Bandini-König and Gérard Fussman, Die Felsbildstation Shatial. Materialien zur Archäologie der Nordgebiete Pakistans 2. Mainz: P. von Zabern, 1997, plate Vb).

Library of Congress Cataloging-in-Publication Data

Neelis, Jason Emmanuel.

Early Buddhist transmission and trade networks : mobility and exchange within and beyond the northwestern borderlands of South Asia / By Jason Neelis.

p. cm. - (Dynamics in the history of religion; v. 2)

Includes bibliographical references and index.

ISBN 978-90-04-18159-5 (hardback : alk. paper)

1. Buddhist geography-Asia. 2. Trade routes-Asia-History. 3. Buddhists-Travel-Asia. I. Title. II. Series.

BQ270.N44 2010

294.3'7209021-dc22

2010028032

ISSN $1878-8106$

ISBN 9789004181595

Copyright 2011 by Koninklijke Brill nv, Leiden, The Netherlands.

This work is published by Koninklijke Brill Nv. Koninklijke Brill NV incorporates the imprints Brill, Brill Hes \& De Graaf, Brill Nijhoff, Brill Rodopi and Hotei Publishing.

Koninklijke Brill NV reserves the right to protect the publication against unauthorized use and to authorize dissemination by means of offprints, legitimate photocopies, microform editions, reprints, translations, and secondary information sources, such as abstracting and indexing services including databases. Requests for commercial re-use, use of parts of the publication, and/or translations must be addressed to Koninklijke Brill NV.

This book is printed on acid-free paper and produced in a sustainable manner. 
For my inspiring and persevering muses, Dahvi and Talia 
Jason Neelis - 978-90-04-19458-8 Downloaded from Brill.com $04 / 26 / 2023$ 11:30:22AM via free access 


\section{CONTENTS}

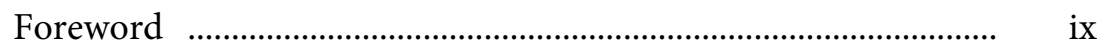

Acknowledgments ...................................................................... xi

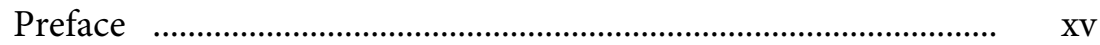

List of Tables, Maps and Figures ................................................... xvii

Chapter One Introduction: Road Map for Travelers ……….... 1

Models for the Movement of Buddhism .................................. 2

Merit, Merchants, and the Buddhist Sangha ............................ 12

Sources and Methods for the study of Buddhist

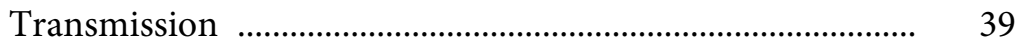

Outline of Destinations ................................................................ 60

Chapter Two Historical Contexts for the Emergence and

Transmission of Buddhism within South Asia ....................... 65

Initial Phases of the Establishment of Buddhist

Communities in Early India .................................................. 67

Legacy of the Mauryans: Aśoka as Dharmarāja ...................... $\quad 78$

Migrations, Material Exchanges, and Cross-Cultural

Transmission in Northwestern Contact Zones

Saka Migrants and Mediators between Central Asia and

South Asia ........................................................................... 109

Dynamics of Mobility during the Kuṣāna Period .................. 132

Shifting Networks of Political Power and Institutional

Patronage during the Gupta Period .................................... 145

Cross-Cultural Transmission between South Asia and

Central Asia, ca. 500-1000 CE ……………….................... 157

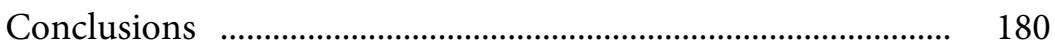

Chapter Three Trade Networks in Ancient South Asia .......... 183

Northern Route (Uttarāpatha) ................................................ 186

Southern Route (Dakșināpatha) ............................................... 205

Seaports and Maritime Routes across the Indian Ocean ....... 217

Conclusions .............................................................................. 227 
Chapter Four Old Roads in the Northwestern Borderlands ...

Environmental Conditions for Buddhist Transmission in

Gandhāra

Gandhāran Material and Literary Cultures

Gandhāran Nodes and Networks

Routes of Buddhist Missionaries and Pilgrims to and from

Gandhāra

Domestication of Gandhāran Buddhism

Conclusions

Chapter Five Capillary Routes of the Upper Indus

Geography, Economy, and Capillary Routes in a High

Altitude Environment

Graffiti, Petroglyphs, and Pilgrims

Enigma of an Absence of Archaeological Evidence and

Manifestations of Buddhist Presence

Conclusions

Chapter Six Long-Distance Transmission to Central Asian

Silk Routes and China

Silk Routes of Eastern Central Asia

Long-distance Transmission Reconsidered

Conclusions

Chapter Seven Conclusion: Alternative Paths and

Paradigms of Buddhist Transmission

Catalysts for the Formation and Expansion of the Buddhist Sangha

Changing Paradigms for Buddhist Transmission within and beyond South Asia

Bibliography 


\section{FOREWORD}

The series "Dynamics in the History of Religions" is publishing results produced by the Käte Hamburger Kolleg at Ruhr University Bochum (Germany). The Kolleg began its activities in April 2008 with funding from the German Federal Ministry of Education and Research. The international consortium explores the history of religions, especially inter- and intrareligious relations between Asia and Europe from the 1st millennium BCE down to the present. The research is based on the thesis that the so-called world religions are not, nor have they ever been, homogeneous or isolated constructions, but rather the product of dynamic interaction between adaption and demarcation. The processes of formation, evolution and expansion are mainly the results of interplay between different competing religious traditions.

The Käte Hamburger Kolleg is a multi-disciplinary venture between several subject areas at Ruhr University Bochum such as Comparative Religion, Protestant and Catholic Theology, Jewish Studies, Islamic Studies, Philosophy, Classical Philology, History, Social Sciences, South Asian Studies, Chinese, Korean and Japanese Studies. It integrates and coordinates the research activities of scholars from Ruhr University, international fellows, postdoctoral researchers, und postgraduates.

The series focuses on the crucial role played by mutual encounters in the origins, development and internal differentiation of various religious traditions. The interconnected processes of adaption and demarcation, self-perception and perception by others are considered to be important factors in the historical dynamics of the religious field. With research being focused on contact-driven dynamics and their historiographic implications, the series creates systematic reference points which allow for the integration of diachronically and synchronically heterogeneous material into a general history of religions. Through abductive research, the scholarly studies develop theories and concepts through the interplay between hypothetical conceptualization and empirical studies, between object-language and meta-language. The studies build bridges between and reconcile academic meta-discourses on religion with religious discourses and religious self-descriptions, thus helping to avoid a type of scholarly theorizing which is disconnected from empirical data and atheoretical or naïve positivism. 
The series seeks to make a contribution to a better understanding of the interdependence between religious traditions and processes of religious transfer, thus opening up innovative avenues for conceptualising the history of religions.

The author of this work, Jason Neelis, was a fellow at the Käte Hamburger Kolleg from March 2009 to April 2010. During his stay in Bochum he completed his study on the spread of Buddhism through South and Central Asia by trade networks and shared his expertise with the members of the consortium at numerous meetings and workshops. Many of us will recall the conference on "Trading Religions: Religious Formation, Transformation and Cross-Cultural Exchange between East and West" held in January 2010 at Ruhr University that could not have been planned and organised without his committed efforts. Jason Neelis' presence and participation greatly enriched our work.

As chief editor of the series I would like to express my thanks to the German Federal Ministry of Education and Research for generously funding the consortium and making its publications possible, Marion Steinicke and Maarten Frieswijk for their editorial work and Wendy Shamier for supervising the series. But I especially want to thank Jason Neelis for coming to Bochum and teaming up with us.

-Volkhard Krech 


\section{ACKNOWLEDGMENTS}

I am profoundly grateful to Brill and to the Käte Hamburger Kolleg at Ruhr University Bochum for allowing me to contribute this volume to the series for "Dynamics in the History of Religions." A research fellowship to participate in "Dynamics in the History of Religions between Asia and Europe" in Bochum in 2009-2010 provided a productive environment for completing and revising the manuscript, which greatly benefited from stimulating ideas and models discussed extensively within and outside of organized workshops, conferences (including "Trading Religions" in January 2010) and research presentations. In addition to Volkhard Krech, who has graciously written a Foreword for this volume in fulfillment of one of his many roles as series editor and consortium director, I would like to thank Marion Steinicke for coordinating our activities and always providing helpful assistance. I am thankful to German colleagues at Ruhr University Bochum who read and commented on partial drafts of the manuscript, including Alexander-Kenneth Nagel, Nikolas Jaspert, Jörg Plassen, and Knut Martin Stünkel, as well as to Sven Bretfeld (who extended needed support as director of the Center for Religious Studies, or CERES), Christian Frevel and Peter Wick (for their efforts to supervise the research field on "Formation"), and Hans Martin Krämer and Sven Wortmann. Andrea Philips, a student of cartography at Ruhr University Bochum, helped to improve the quality of this publication by working very hard on the layout of the maps.

I benefited immensely from feedback, comments, and suggestions offered by other international fellows in Bochum, whose constant encouragement and valuable perspectives from different disciplinary backgrounds and fields of research carried this project forward. Abhishek Singh Amar thoroughly read the entire manuscript and was a helpful talking partner. Damien János not only shared an office, but also carefully reviewed drafts of several chapters and helped me to think through complicated issues of cross-cultural exchange. Geoffrey Herman provided assistance with Sasanian historical contexts and Paolo Filigheddu supplied bibliographic suggestions and a translation of an important article from Italian. Al Makin, Izak Cornelius, Svevo D’Onofrio, Lucia Dolce, Georgios Halkias, Jun'ichi Isomae, Adele Reinhartz, Amy 
Remensnyder, and Joan Westenholz offered personal, professional and intellectual support.

In North America, I am especially indebted to Dan Boucher for timely "interventions" which were absolutely crucial for shaping and promoting this publication. For generous comments on a very early draft, I am grateful to Travis Smith, and for constant prodding and steadfast faith that this book would be finished (if not in a timely manner), I am thankful to Vasudha Narayanan. Students at the University of Florida, in particular Phillip Green, provided assistance and inputs on aspects of my research work presented in classes and seminars.

The genesis of this book can be traced back to the University of Washington, where Richard Salomon, Collett Cox, Frank Conlon, Michael Shapiro, and Dan Waugh guided me through graduate studies and have continued to serve as effective mentors. I have continued to benefit from long-lasting bonds with members of the "Kharoșthi Klub" including Timothy Lenz, Mark Allon, Stefan Baums, Andrew Glass, and Tien Chang Shih. The American Institute of Pakistan Studies supported the initial phase of field research in Pakistan, where Adam Nayyar (whose passing is lamented), Muhammad Usman Ghani, and Deedar and Ishtiaq Ali rendered hospitality along the way. Shayne Clarke, Suchandra Ghosh, Hermann Kreutzmann, Peter Skilling, Ingo Strauch, and Michael Willis have aided me with useful remarks on specific topics, additional references, and difficult-to-obtain articles and books.

I gratefully acknowledge Harald Hauptmann for granting permission to reproduce images of petroglyphs and inscriptions from Antiquities of Northern Pakistan (vol. 1) and from volumes of Materialien zur Nordgebiete Pakistans that appear on the cover and in figures 5.1-4. Martin Bemmann, Ditte Bandini-König and coworkers in the Forschungsstelle für Felsbilder und Inschriften am Karakorum Highway in the Heidelberger Akademie der Wissenschaften have complied with many of my requests for images from the photographic archive. The American Institute of Indian Studies supplied photographs of a Gandharan sculpture of the Gift of Two Merchants in the Chandigarh Museum (figure 1.1) and the Heliodoros Pillar in Vidiśa (figure 2.1) from the photo archive of the Centre for Art \& Achaeology in Gurgaon. A digital image of the Mathura Lion Capital (figure 2.3) was supplied courtesy of the British Museum, and Noriyuki Kudo provided files of the Gilgit Bronze Image of Prajñāpāramità (figure 2.4) previously published in the Annual Report of the Institute for Advanced Buddhology 
(vol. 10, 2007: plate 1). I also wish to acknowledge the efforts of Elizabeth Saluk of the Cleveland Museum of Art to obtain permission for me to reproduce the Reliquary Stüpa of Senavarman (figure 2.2) from Stanislaw J. Czuma with Rekha Morris, Kushan Sculpture: Images from Early India (1985: 165, no. 82). Finally, I acknowledge the generosity of the Indian Museum in Kolkata for permitting me take pictures of images on display in the Mathura and Bharhut galleries (figures 1.2, 1.3 , and 3.1).

Maarten Frieswijk and Birgitta Poelmans at Brill have displayed tremendous patience and diligence in working with me on this volume of Dynamics in the History of Religions. I have appreciated their professional assistance and attention to publication details.

I must acknowledge that the people most responsible for these results are my teachers and senior scholars. Richard Salomon and Gregory Schopen initiated me into the study of the history of South Asian Buddhism and continue to actively influence my approaches to questions asked in this book. Oskar von Hinüber and Gérard Fussman have kept me supplied with offprints of their indispensable publications. My debts to many other scholars are acknowledged in bibliographic references.

Finally, I wish to express thanks to my immediate and extended family of relatives who have nurtured and sustained my pursuit of academic interests. My mom, Betty, my dad, Frank, and my sisters, Nicole, Meri, and Lyla, as well as my Fradkin in-laws have always been available for succour through both challenging periods and the bon temps. Above all, I am grateful to Dahvi and Talia, to whom this book is dedicated. 
Jason Neelis - 978-90-04-19458-8 Downloaded from Brill.com $04 / 26 / 2023$ 11:30:22AM via free access 


\section{PREFACE}

The concepts for this book emerged from field research in northern Pakistan leading to a Ph.D. dissertation. ${ }^{1}$ As a graduate student focusing on the study of graffiti written on rocks by ancient visitors to Hunza-Haldeikish, I was interested in what these inscriptions could reveal about the history of Buddhism in this local setting and regional environment. In the dissertation, I aimed to place the data from Buddhist inscriptions and petroglyphs at other sites in northern Pakistan within economic and historical contexts of Buddhist transmission. This book is centrally concerned with these broader contexts for the transregional establishment and expansion of Buddhist institutions throughout and beyond South Asia.

While the geographical focus on the region of the Northern Areas of Pakistan is restricted to a single chapter (Chapter 5: Capillary Routes of the Upper Indus), I have expanded the treatment of other networks for early Buddhist mobility between South Asia and Central Asia. Inevitably, it has not been possible to cover all aspects of this rich topic, but significant attention is given to formative phases and routes for Buddhist expansion in the Indian subcontinent in the earlier chapters (especially 2-3), and the later chapters (4-6) emphasize the northwestern borderlands as contact zones for Buddhist transmission between South Asia and Central Asia.

As discussed in greater depth in the first chapter, I have utilized a variety of relevant sources for this synthesis, but my methodological preference for material sources (such as inscriptions, manuscripts and archaeological remains) does not mean that literary sources have been neglected. A comprehensive survey of doctrinal developments is not attempted, nor has it been possible to retrace complex lines of textual transmission. I have extrapolated from available sources to connect patterns of early Buddhist transmission with trade networks and other economic, social and political catalysts, but limitations of these

${ }^{1}$ Neelis, Jason. 2001. Long-distance Trade and the Transmission of Buddhism through Northern Pakistan, Primarily based on Kharoșthī and Brāhmī Inscriptions. Seattle: University of Washington (supervised by Richard Salomon). 
sources often constrain against reconstructing links with intellectual and philosophical movements. However, I hope that this work will provide useful background for braver and better equipped scholars to more adequately contextualize Buddhist ideological developments as well as art and imagery associated with particular ordination lineages, scholastic traditions, and the Mahāyāna and Vajrayāna in specific chronological and regional frameworks.

I have adopted various conventions for presenting this material as clearly and as consistently as possible. Diacritics have been applied to Sanskrit terms (or terms cited from Pāli, Gāndhārī, and sources other than English), ancient proper names and toponyms, but have not been used with most modern personal or place names. Initial references to footnoted items provide full information with titles and publication details, while subsequent citations refer only to the author, publication date and specific page numbers (more extensive information is available in the bibliography). Citations refer to original publication dates, unless the work cited is a translation, later edition or reprint (e.g., in an edited volume of collected essays), in which case the earlier date appears in brackets. In some cases (for example, articles published in academic journals behind in their publication runs), bracketed dates indicate the year in which an item actually appeared rather than the ostensible year of publication. Abbreviations have largely been forsaken, with a few exceptions:

ANP: Antiquities of Northern Pakistan (Jettmar, Karl, et al., eds. 1989-. Mainz: P. von Zabern)

CKI: Catalog of Kharoșthī Inscriptions (Baums, Stefan and Andrew Glass. In progress. http://gandhari.org/a_inscriptions.php)

MANP: Materialien zur Archäologie der Nordgebiete Pakistans (Bandini-König, Ditte, et al. 1994-. Mainz: P. von Zabern) 


\section{LIST OF TABLES, MAPS AND FIGURES}

\section{Tables}

Table 2.1: Proposed Dates for the Historical Buddha ................ $\quad 69$

Table 2.2: Saka Networks in South Asia ………........................ 124

Table 2.3: Kușāṇa Rulers and Dates ............................................. 145

Table 2.4: Vākāțaka-Gupta Genealogy and Chronology ........... 156

Table 2.5: Genealogy and Chronology of the Palola Șāhi

Dynasty ................................................................................... 177

Table 3.1: Caityas, Ghäț and Seaports in Western India ......... 216

\section{Maps}

Map 2.1: Sixteen Mahājanapadas of Ancient India ................... $\quad 75$

Map 2.2: Distribution of Aśokan inscriptions …………….......... 84

Map 3.1: Routes and Nodes of the Uttarapatha ........................ 185

Map 3.2: Routes and Nodes of Dakșinapatha ............................ 204

Map 3.3: Indian Ocean Maritime Network …………................. 218

Map 4.1: Gandhāran Nodes and Networks ………………….... 230

Map 4.2: Archaeological Sites in Afghanistan ............................ 247

Map 5.1: Capillary Networks in Northern Pakistan .................. 259

Map 6.1: Tarim Basin .................................................................. 290

\section{Figures}

Fig. 1.1: Gift of Two Merchants, Gandhāran Sculpture,

Chandigarh Museum (Courtesy of the American Institute of Indian Studies)

Fig. 1.2: Siṃhala avadāna, Mathura sculpture, Indian Museum, Kolkata (author's photo)

Fig. 1.3: Bharhut Pillar donated by Bhikṣuṇi Nāgilā, Indian Museum, Kolkata (author's photo) 
Fig. 2.1: Heliodoros Pillar (Courtesy of the American Institute of Indian Studies)

Fig. 2.2: Reliquary Stūpa of Senavarman, King of Oḍi (Source: Stanislaw J. Czuma with the assistance of Rekha Morris. 1985. Kushan Sculpture: Images from early India. Cleveland: Cleveland Museum of Art in cooperation with Indiana University Press, 165, no. 82)

Fig. 2.3: Mathura Lion Capital (Courtesy of the British Museum)

Fig. 2.4: Gilgit Bronze image of Prajñāpāramitā, donated by Mañgalahaṃsikā, Chief Queen of Vajrādityanandin (Source: Oskar von Hinüber. 2007. "Three New Bronzes from Gilgit." Annual Report of the International Research Institute for Advanced Buddhology at Soka University 10, plate 1)

Fig. 3.1: Bharhut Pillar depicting a scene from the Mahaumagga jātaka, Indian Museum, Kolkata (author's photo)

Fig. 5.1: Petroglyphs of Vāsudeva-Kṛṇna and BaladevaBalarāma at Chilas II (Source: Karl Jettmar, ed. 1989. ANP 1, plate 18)

Fig. 5.2: Triptych with a Stūpa and Sibi Jätaka at Shatial (Source: Ditte Bandini-König and Gérard Fussman. 1997. Die Felsbildstation Shatial. MANP 2. Mainz: P. von Zabern, plate $\mathrm{Vb}$ )

Fig. 5.3: Stūpa Petroglyphs donated by Bhita the scribe at Hodar (Source: Ditte Bandini-König. 1999. Die Felsbildstation Hodar. MANP 3. Mainz: P. von Zabern, plate Ia)

Fig. 5.4: Stūpa veneration at Chilas II (Source: Karl Jettmar, ed. 1989. ANP 1, plate 22) 


\section{CHAPTER ONE}

\section{INTRODUCTION: ROAD MAP FOR TRAVELERS}

This exploration follows in the footsteps of travelers who left traces of their journeys in a wide range of literary and epigraphic records, devotional images, and archaeological artifacts with the goal of understanding how and why various Buddhist traditions flourished outside of the original homeland of the historical Buddha in ancient India. Interpretation of these sources helps to discern internal and external factors, along with historical contexts and socio-economic catalysts, which set this religion in motion throughout and beyond South Asia. The injunction purportedly spoken by the Buddha (and preserved in monastic codes, or vinayas) to "wander the path for the benefit and satisfaction of many people and out of compassion for the world" in order to "teach the dharma" gave canonical warrant for Buddhist mobility, although his instruction that "two must not go by a single (way)" was not strictly followed. ${ }^{1}$ Investigation of the religious agendas and practical details of their journeys helps to develop a fuller picture of the monks and nuns and other travelers who set out across the world's highest mountain ranges, deep river valleys, and formidable deserts.

Rather than restricting themselves to a single Buddhist superhighway, Buddhist missionaries followed various itineraries, including major arteries, minor capillary routes, and "middle paths" to travel back and forth between destinations. Their roads frequently overlapped and intertwined with those of merchants and traders in pursuit of both religious and economic goals. Since both itinerant monks and cenobitic communities inhabiting residential monasteries depended upon donations for material support, the dynamic growth of Buddhist institutions was directly linked with the generation of surplus resources. Thus, Buddhist transmission, which necessarily involved the transformation of basic ideas and common practices through

\footnotetext{
${ }^{1}$ Mahāvagga 1.11.1: Caratha bhikkhave cārikam bahujanahitāya bahujanasukhāya lokānukampāya...Mā ekena dve agamittha. Desetha bhikkhave dhammam...(Oldenberg, Hermann, ed. 1879. The Vinaya Pițaka. London: Pali Text Society, 1.21).
} 
interactions with local host cultures and other religious traditions, was symbiotically related to parallel processes of commercial and cultural exchanges. This book demarcates networks for the transmission of Buddhism and cross-cultural exchanges with the goal of explaining the ultimate success of the multidirectional movement of this panAsian religious tradition.

This introductory chapter provides a "road map" to theoretical models of religious mobility, critical issues in the study of religion and economics, and methodologies for analyzing primary sources. In the first section (Models for the Movement of Buddhism), a brief treatment of different metaphors and paradigms for understanding patterns of Buddhist movement widens the range of perspectives by exploring possible alternatives to the typical view of the spread of Buddhism by gradual diffusion. The following section (Merit, Merchants, and the Buddhist Sangha) highlights linkages between Buddhist networks and trade exchanges after engaging with debates over relationships between economics and religions. The third section (Sources and Methods for the Study of Buddhist Transmission) is an overview of relevant literary, epigraphic and archaeological sources and a guide to methods of interpretation, which is intended to familiarize readers with recent discoveries of manuscripts, inscriptions, and other materials. A synopsis of the other chapters (Outline of Destinations) at the end of this chapter is the starting point for an investigation of historical and economic contexts for networks of Buddhist transmission, commercial exchanges, and cross-cultural contact between South Asia and Central Asia.

\section{Models for the Movement of Buddhism}

Themes of mobility pervade Buddhist imagery, beginning with the religious biography of Saakyamuni Buddha, who relinquished his destiny of becoming a "wheel-turning" ruler (cakravartin) when he "set out" (Sanskrit: pravrajita) as a renouncer rather than fulfilling his duties as a settled householder in Kapilavastu. After a period of ascetic wandering and his subsequent awakening at Bodh Gaya, Sākyamuni set the "wheel of dharma" (dharmacakra) in motion with his first teaching at Sarnath. The wheel symbolizes this hagiographic event, which is also recalled by the Buddha's gesture of "turning the wheel of dharma" 
in recurring iconographic patterns. ${ }^{2}$ Dynamic turning of a wheel has polyvalent meanings in Buddhist art and literature, including the widespread metaphor of the "wheel of becoming" (bhavacakra) to depict the cycle of rebirth in medieval Buddhist art from India, Central Asia, China, and Tibet. ${ }^{3}$ In addition to the wheel, motifs of roads, ways, and paths are employed as analogies for the teachings of the Buddha, who is characterized as the re-discoverer of an ancient road. ${ }^{4} \mathrm{~A}$ basic feature of Buddhist rhetoric is the "Middle Way" between extreme practices of ascetic self-mortification and luxurious self-indulgence and between philosophical extremes of nihilism and eternalism. Another prominent example is the "Noble Eightfold Path" elaborated by the Buddha during his first teaching at Sarnath, which is glossed as the "Way leading to the end of suffering" (dukhanirodhagàmani pratipad) in commentaries. Buddhist texts with titles such as the Path of Purification (Visuddhimagga), and the Lamp for the Path to Awakening (Bodhipathapradīpa) demonstrate that Buddhaghosa, Atīsa, and other Buddhist scholars from very different traditions framed methods of reaching religious goals in terms of "paths" (märga). ${ }^{5}$ Many of these Buddhist texts schematically 'map' doctrinal complexities and meditation techniques for reaching Nirvāna, fulfilling Bodhisattva vows, and realizing Buddhahood. ${ }^{6}$ On the basis of the variety of "mārga schemes" for reaching Buddhist goals, Robert Buswell and Robert Gimello argue that "the concept of 'path' has been given an explication more sustained, comprehensive, critical, and sophisticated than that provided by any other single religious tradition" (1992: 2). ${ }^{7}$ The project of finding pathways of practice and thought to escape from suffering is

${ }^{2}$ Brown, Robert L. 1996. The Dvāravatī Wheels of the Law and the Indianization of South East Asia. Leiden: Brill.

3 Teiser, Stephen F. 2006. Reinventing the Wheel: Paintings of rebirth in medieval Buddhist temples. Seattle: University of Washington Press.

${ }^{4}$ Samyutta Nikāya ii.105-6.

5 Additional titles include the Path of Discrimination (Pāli Pațisambhidàmagga), Sequence of the Path of Apparition (Mãyadhvakrama of Niguma), and the Great Exposition of the Stages of the Path (Lamrimchenmo of Tsongkhapa in Tibetan), as well as verses under the heading of magga/märga in Dhammapada/Udānavarga anthologies.

${ }^{6}$ Examples include the thirty-seven factors of awakening, five paths, six/ten stages of the Bodhisattva's career (according to the Daśabhümika Sütra), six/ten perfections, and the Bodhisattva path in fifty-three stages.

7 Buswell, Robert E. and Robert M. Gimello, eds. 1992. Paths to Liberation: the Mārga and its transformations in Buddhist thought. Honolulu: University of Hawaii Press. 
not exclusively Buddhist, but the repeated emphasis and continuous elaboration of märga-type imagery shows that metaphors and motifs related to journeying are particularly apt. Epithets of the Buddha as a "caravan leader" (sārthavāha) and narratives of Bodhisattva merchants discussed later in this chapter suggest that literary and visual allusions to wheels, pathways, and vehicles to express abstract goals of release may have had considerable basis in the experiences of everyday Buddhist monks and merchants who traveled on ordinary roads to reach conventional destinations. ${ }^{8}$

\section{Diffusion vs. Long-Distance Transmission}

Buddhist traditional terms related to movement on multiple worldly and supramundane paths reflect an institutional history of remarkable mobility, which can hardly be characterized as a straightforward process of gradual diffusion. A theory of diffusion from point-to-point along established routes does not account for rapid accelerations, sudden halts, and periodic declines in the growth of the Sangha, or for the irregular travel patterns of Buddhist monks, merchants, and pilgrims who did not follow fixed itineraries. Models of "geographical diffusionism" involve an implicit assumption that cultural and religious changes emanate from a dominant core, typically a center of economic or political power, to dependent peripheries. ${ }^{9}$ In standard models for the "spread of Buddhism" by diffusion, Buddhist institutions gradually expanded from India to Central Asia and eventually to China in a gradual sequence. ${ }^{10}$ Erik Zürcher labels the basic pattern of

${ }^{8}$ Juxtapositions between the "inferior vehicle" (Hìnayāna), the "superior vehicle" (Mahāyāna), and the "diamond / thunderbolt vehicle" (Vajrayāna) refer to polemic differences over the interpretation and application of Buddhist doctrines, textual authenticity, and a host of other issues. Here it is sufficient to remark that the trope of 'vehicle' ( $y \bar{a} n a)$ can also be tied to metaphors of mobility.

9 Blaut, James M. 1993. The Colonizer's Model of the World: Geographical diffusionism and Eurocentric history. New York: Guilford Press. Blaut criticizes the "supertheory" of diffusionism as a mechanism for explaining cultural innovation and change as a result of Eurocentric Inside-Outside models, but does not offer clear alternatives to the basic assumptions.

${ }^{10}$ Early comments by Erik Zürcher typify the perspective that Buddhism “... must have slowly infiltrated from the North-West, via the two branches of the continental silk-road which entered Chinese territory at Tunhuang, and from there through the corridor of Kansu to the 'region within the Passes' and the North China plain..." (Zürcher, Erik. 1959. The Buddhist Conquest of China: The spread and adaption of Buddhism in early medieval China. Leiden: Brill. 2 vols., vol. 1. 22-3). 
diffusion in which wandering Buddhist ascetics established residential monasteries near agricultural and commercial centers along trade and travel routes as "contact expansion." ${ }^{11}$ According to Zürcher, diffusion by contact expansion required adequate surpluses generated by lay donors (dānapatis) to support economically "parasitic" communities of monks and nuns:

Since the local monastic community was-economically speaking-parasitic, the maximum number of monks in a given parish (simma, "begging circuit") was defined by the surplus production of the local lay believers who supported the sangha by their gifts. If the local monastic community grows-as every successful institution tends to do-surplus monks will wander away, in search of new hospitable localities; they will move along the main routes to places where new dannapati are to be found: a prosperous agrarian region, or a big city. In this way a continuous process of outward movement and gradual expansion is set into motion-a process that must have started very early, and that forms the most basic, grass-roots level force behind the spread of Buddhism as a monastic system. (1999: 9-10)

In this paradigm of contact expansion, the proximity of monasteries located on the main routes next to each other facilitated regular communication and constant feedback, thus accounting for complicated monastic organizations, formalized textual collections, and integrated religious doctrines. ${ }^{12}$ In contrast to smaller monasteries in the countryside, large-scale monasteries clustered near cities on a "network of

The approach is similar in Zürcher, Erik 1962. Buddhism: Its origin and spread in words, maps, and pictures. New York: St Martin's Press and Zürcher, Erik "Buddhist Missions" in Eliade, Mirceau and Charles J. Adams. 1987. The Encyclopedia of Religion. New York: Macmillan, vol. 9, 570-573. In "The Spread of Chan (Zen) Buddhism" in Heirman, Ann, and Stephan Peter Bumbacher. 2007. The Spread of Buddhism. Leiden: Brill, 433-456, T. Griffith Foulk questions the use of metaphors related to the "spread" of Buddhism (434-5), and suggests that the spread of fire is particularly apt for Chan tropes of "transmitting the flame" (449-50). Separate historical periods for the "spread" of Buddhism from India to Tibet are traditionally standardized as the "first diffusion," "second diffusion," etc. (Heirman and Bumbacher 2007: 11-12).

${ }_{11}$ Zürcher, Erik. 1990. "Han Buddhism and the Western Region." In Hulsewé, A.F.P., W.L. Idema, and E. Zürcher. 1990. Thought and Law in Qin and Han China: Studies dedicated to Anthony Hulsewé on the occasion of his eightieth birthday. Leiden: Brill, 169-171; Zürcher, Erik. 1999. "Buddhism Across Boundaries: The Foreign Input.” In Zürcher, E., Lore Sander, et al. 1999. Collection of Essays 1993: Buddhism across Boundaries: Chinese Buddhism and the Western Regions. Sanchung, Taiwan: Fo Guang Shan Foundation for Buddhist \& Culture Education. 1-60, esp. 6-12. Both articles are significant reassessments of Zürcher's earlier views.

12 Zürcher 1990: 181. 
highways" (Zürcher 1999: 11) benefited from élite patronage by rulers and merchants. Although contact expansion accounts for gradual movement between closely connected monastic centers, this structural framework for institutional spread by diffusion restricts the scope of changes in religious practices and ideologies, local contingency, interactions with regional cultures, and distinctive features of multiple centers.

Zürcher's juxtaposition of oversimplified yet pervasive assumptions of diffusion by contact expansion to an alternative model of "longdistance transmission" is a very useful heuristic tool for understanding different patterns of Buddhist movement across transit zones between India and China. In contrast to his earlier views expressed in the Buddhist Conquest of China (1959) and other works, in later publications Zürcher argued that contact expansion does not apply to the initial phases of Chinese Buddhism during the Later Han period in the first two centuries CE. ${ }^{13}$ Anomalous 'cultic' practices and images associated with "Hybrid Court Buddhism" (1990: 159-162) appear quite early during this period and "a nucleus of organized monastic Buddhism" characterized by Zürcher as the "Church of Luoyang" (1990: 163) began to flourish by the middle of the second century with the arrival of An Shigao in $148 \mathrm{CE}$. However, Buddhist monasteries were only established later in the Tarim Basin of eastern Central Asia (modern Xinjiang), which remained a "Buddhological vacuum" (1990: 172) or a "mere transit zone" (1999: 13) until at least the middle of the third century CE.

In order to address this problematic gap and to explain anomalous features of early Chinese Buddhism that were not consistent with contact expansion, Zürcher developed a theory of long-distance transmission. Zürcher attributed irregular travel by foreign monks, unusual hybrid images, lack of coherent doctrines, and absence of monastic ordination rituals in the initial phases of Chinese Buddhism during the Later Han period to distinctive features of long-distance transmission, including "incidental and intermittent contact, long and difficult routes of communication, lack of feed-back, and unsystematic borrowing of elements detached from their original context" (Zürcher 1999: 15). He also emphasized that "Chinese Buddhism became a melting pot of different types of Buddhism, a mass of scriptural, dis-

${ }_{13}$ See notes 10-11 for references to Zürcher's earlier $(1962,1987)$ and later (1990, 1999) publications. 
ciplinary, and scholastic traditions of various provenance that not seldom contradicted each other" because missionaries, texts, images, and rituals came via overland and maritime routes "from many centres simultaneously...from virtually the whole Buddhist world" (ibid., 16). Therefore, many distinctive elements of early Chinese Buddhism result from more dynamic process of long-distance transmission via multiple routes over great distances rather than regular patterns of diffusion from closely linked locations. ${ }^{14}$

Perhaps Zürcher's deliberate contrast between contact expansion and long-distance transmission is overdrawn, since the two modes of movement overlap. After all, itinerant monks and prominent translators followed similar routes and benefited from élite patronage of monastic centers. Other objections have to do with the notion of "transmission" as a process in which Buddhist ideas, symbols, and institutions remain unchanged by cross-cultural encounters and exchanges, thus reifying unproductive lines of debate between 'Indianization' and 'Sinification' of Buddhism. ${ }^{15}$ Nevertheless, the model of long-distance transmission as formulated by Zürcher necessarily involves a high degree of transformation, and can help to clarify separate chronological stages, sociological levels, and geographical patterns in the movement of Buddhism, not only to early China, but throughout Asia in pre-modern periods.

\section{Aquatic Metaphors of Religious Flows and Buddhist Networks}

Hydraulic metaphors of religious 'flows' across boundaries also help to conceptualize changing patterns of long-distance transmission and transformation of Buddhism. Acknowledging that "Root metaphors have their limits" (2002: 261), Thomas Tweed expands upon spatial and locative themes of religious geography emphasized by other

\footnotetext{
${ }^{14}$ Although Zürcher does not precisely define "long-distance," his hypothesis that long-distance transmission implies that transmission over great distances rather than proximate contact with South Asia was responsible for innovations in early Chinese Buddhism.

15 Teiser 2006, for example, criticizes a theory of transmission (without explicit reference to Zürcher's model of long-distance transmission) which does not account for regional and local transformation of Buddhist symbols, such as the bhavacakra. Sharf, Robert H. 2002. Coming to Terms with Chinese Buddhism: A reading of the treasure store treatise. Honolulu: University of Hawai'i Press, comments on scholarly predispositions to "to highlight fidelity to the Indian tradition (the Buddhist conquest of China) or the overpowering force of sinitic culture (the Chinese transformation of Buddhism)" (10).
} 
scholars (such as Jonathan Z. Smith) to develop a theory of itinerant religions as 'flows' that are "on the move" rather than homogeneous unchanging static entities fixed in place. ${ }^{16}$ Tweed proposes to define religions as "confluences of organic-cultural flows that intensify joy and confront suffering by drawing on human and suprahuman forces to make homes and cross boundaries" (2006: 167). As he observes, 'aquatic metaphors' in Buddhist, Jain, and Hindu literature have multivalent applications: river crossings refer to 'terrestrial' pilgrimage places, 'corporeal' life-cycle rituals are associated with different lifestages, and the "flood" of sensory attachments must be overcome in order to reach the "far shore" of the "ocean" of rebirth. ${ }^{17}$ For example, very early Buddhist verses preserved in the first chapter of the Pāli Suttanipāta (Sn), Gāndhārī manuscripts of the Dharmapada, and Sanskrit versions of the Udānavarga implore monks to give up desire (literally "thirst"), doubt, and other hindrances in order to leave this shore and the far shore (present life and future rebirth), just as a snake sheds its skin:

That monk who has completely cut off his thirst,

Having dried up the swift-flowing stream of desire,

Leaves behind this life and the next,

Just as a snake leaves behind his old, worn-out skin. $(\mathrm{Sn} 3)^{18}$

16 Tweed, Thomas A. 2002. "On Moving Across: Translocative Religion and the Interpreter's Position" Journal of the American Academy of Religion 70: 253-278. Tweed, Thomas A. 2006. Crossing and Dwelling: A theory of religion. Cambridge, Mass: Harvard University Press. See also Smith, Jonathan Z. 1978. Map is not Territory: Studies in the history of religions. Leiden: Brill, Smith, Jonathan Z. 1987. To Take Place: Toward theory in ritual. Chicago: University of Chicago Press, and Smith, Jonathan Z. 2004. Relating Religion: Essays in the study of religion. Chicago: University of Chicago Press, particularly Topography of the Sacred (pp. 101-116) in which he succinctly identifies a contrast between an essentially spatial and classificatory understanding of the sacred and the profane (102) and the sacred (or the holy) as a positive religious force and reality (103). In much of Smith's work, the focus is on issues of demarcation of a "locative, imperial worldview" by "scribal elites who had a deep vested interest in restricting mobility and valuing place" (1978: 293), whereas Tweed and others emphasize mobility across artificially constructed borders. In his presidential address to the Association for Asian Studies "Maps in the Mind and the Mobility of Asia," Journal of Asian Studies 62.4 (2003), 1057-1078, David Ludden comments on "... very old histories of mobility animate the Asia that South Asia inhabits today" (2003: 1061) despite the fact that "The vast record of territorial order banished disorderly mobility to the outlands" (ibid.).

17 Tweed 2006: 155-6, n. 36.

18 Brough, John. 1962. The Gāndhārī Dharmapada. London: Oxford University Press, 130 (verse 84). Lenz, Timothy. 2003. A New Version of the Gāndhārì Dharmapada and a Collection of Previous-birth Stories: British Library Kharoșthi fragments 
The monk who rids himself of the of the five hindrances is without affliction,

Has crossed over doubt, and is free from pain,

Leaves behind this world and the next,

Just as a snake leaves behind his old worn-out skin. (Sn 17) ${ }^{19}$

These verses addressed to monks exemplify ideals of homeless itinerancy, but Tweed's theory of religion also accounts for ways in which religious practitioners (including Buddhist monastic renouncers) establish "dwellings" and "make homes" by localizing narratives, rituals, codes, and artifacts (Tweed 2006: 162). His elegant description of spatial practices of mapping social and natural terrain according to "spiritual cartographies" seems to refer to processes of domestication, which is an important dynamic in Buddhist contexts of interaction between lay and monastic communities that must adapt to different environments and host cultures. ${ }^{20} \mathrm{He}$ regards economy, society, and politics as other types of "transfluvial currents" (2006: 131) that compel and block religious flows, thus viewing exogenous networks as secondary formations at institutional levels. ${ }^{21}$ Tweed admits that his 'flow' models of religious transmission (crossing) and domestication (dwelling) are imprecisely situated in historical contexts and risk submerging individual agency in impersonal streams $(2006: 172,174)$. He poses the question: "... if we try to trace the complex flows that emerge from 'initial conditions,' will interpreters be washed away while trying to chart the transfluence of innumerable causal currents?" (2006: 172). If the movement of Buddhist itinerants, ideologies, and visual repertoires can be viewed as religious flows, the task of this exploration is to map networks for channeling these flows across geographical

$16+25$. Seattle: University of Washington Press, 63 (verse 7). Norman, K.R. 1985. The Rhinoceros Horn and other Early Buddhist Poems: The group of discourses (SuttaNipäta). London: The Pali Text Society, 1 (verse 3). The translation follows Lenz, but Norman's translation of the second and third pädas of the Pāli verse (which is not completely preserved in either Gāndhārī version) is more literal: “... like one drying up a fast-flowing stream, leaves this shore and the far shore" (1985: 1).

19 Brough 1962: 131 (verse 90), Lenz 2003: 75 (verse 13), Norman 1985: 2 (verse 17). Except for "crossed over" (which is preserved in the Pāli version, but not in Gāndhārī or Sanskrit), the translation follows Lenz.

${ }_{20}$ Models for the "domestication of the Sangha" are elaborated in the subchapter on Domestication of Gandhäran Buddhism in Chapter 4, 253-256.

${ }^{21}$ Tweed provides examples of Aśoka's role in promoting Buddhist expansion (2006: 131) and the Silk Road as a "trans-Asian network" (2006: 132). These examples are discussed in greater detail in Chapters 2 and 6. 
territories and historical periods without getting washed away in a deluge of details.

A "networks approach" to patterns of Buddhist transmission also helps to understand relationships between religious mobility and cultural, intellectual, material, and, of course, economic exchanges. In the broadest sense, networks facilitate the movement or "flow" of material and cultural goods as well as people and ideas through "conduits" joined by variable "nodes" of economic, political, and/or religious power. Just as trade networks accelerate commercial exchanges of commodities via multiple routes connected to "hubs," religious networks contribute to dynamic processes of conversion, migration, patronage, and institutional expansion, as well as the transfer and permutation of doctrines, practices, and artifacts. Since network analysis has been applied more extensively to the natural and social sciences, especially to studies of economic transactions, scholars in the humanities in general and religious studies in particular suspect that these models are overly functional, reductionist, and deterministic. ${ }^{22}$ Network analysis has been criticized for limiting the role of intention and agency, since extreme applications aim to show how actors are governed by systematic patterns in a structured system. ${ }^{23}$ However, rulers, administrators, merchants, scholars, and religious specialists create their own networks for interactions amongst themselves and with other groups rather than merely being acted upon by static structures. Rather than embedding religious mobility and cross-cultural transmission within economic, political, and social networks, it is possible to map parallel overlapping networks. Routes and nodes belonging to these networks frequently overlap, since centers of power, wealth, and administration often have multiple functions as places of religious veneration and cultural production of literature and art. While social, economic, and cultural factors can impose limits or act as catalysts for expansion, par-

${ }^{22}$ Vasquez, Manuel. 2008. "Studying Religion in Motion: A Networks Approach" Method and Theory in the Study of Religion 20: 151-184 argues for the primacy of "power" relationships, and proposes that a networks approach is a useful corrective to deterritorialized metaphors of hydraulic flows and spatial approaches that "reify the local... as a bounded whole held together by a unified cultural system" (167). While acknowledging the "dangers" of reductive network approaches (168), he suggests that networks can be re-conceptualized as dynamic structures that facilitate movement.

${ }^{23}$ Emirbayer, Mustafa and Jeff Goodwin. 1994. "Network Analysis, Culture, and the Problems of Agency." American Journal of Sociology 99: 1411-1454 criticize network analysis for limiting the scope of intention. 
allel networks for religious mobility are not strictly confined to trade networks or fixed political boundaries.

Despite resistance to adapting a networks model to the study of religion, scholars working in different fields and separate religious traditions have successfully developed frameworks for network applications. James Heitzman (1997: 181-201), for example, analyzed donor networks for the patronage of Chola period Hindu temples based on an onomastic study of personal names in inscriptions. ${ }^{24}$ Monica Smith applies a network model to a comparative archaeological and historical study of "ancient states" of the Incas, Sasanians, and Mauryans, with ramifications for models of Buddhist patronage. ${ }^{25}$ Rodney Stark and William Sims Bainbridge examine the role of pre-existing social networks in attracting converts to a Doomsday group, a New Age commune, and the Mormon church. ${ }^{26}$ Links between Islamic networks and Sufi master-disciple brotherhoods, missionary traders, political dynasties, literary cultures, social movements, ethnic identities, and kinship classifications have recently received considerable scholarly attention. ${ }^{27}$

Although Buddhist networks have not received as much attention, significant archaeological, epigraphic and literary evidence demonstrates links between regional networks of shrines and monasteries that facilitated religious transmission and long-distance trade networks used for exchanges of high-value commodities between South Asia and Central Asia. ${ }^{28}$ An interpretation of these sources situates the

${ }^{24}$ Heitzman, James. 1997. Gifts of Power: Lordship in an early Indian state. Delhi: Oxford University Press.

${ }_{25}$ Smith, Monica. 2005. "Networks, Territories, and the Cartography of Ancient States" Annals of the Association of American Geographers 95.4: 832-849.

${ }^{26}$ Stark, Rodney and William Sims Bainbridge. 1980. "Networks of Faith: Interpersonal Bonds and Recruitment to Cults and Sects" American Journal of Sociology 85: 1376-1395.

${ }^{27}$ Recent edited volumes on Islamic networks include Allievi, Stefano and Jørgen Nielsen, eds. 2003. Muslim Networks and Transnational Communities in and across Europe. Leiden/Boston: Brill; Cooke, Miriam and Bruce Lawrence, eds. 2005. Muslim Networks from Hajj to Hip Hop. Chapel Hill: University of North Carolina; and Loimeier, Roman, ed. 2000. Die islamische Welt als Netzwerk: Möglichkeiten und Grenzen des Netzwerkansatzes im islamischen Kontext. Würzburg: Ergon. Also see Loimeier, Roman and Stefan Reichmuth. 1996. "Zur Dynamik religios-politischer Netzwerke in Muslimischen Gesellschaften" Die Welt des Islams 36.2: 145-185 and Reichmuth, Stefan. 2000. "Netzwerk und Weltsystem: Konzepte zur neuzeitlichen 'Islamischen Welt' und ihrer Transformation" Saeculum 51: 267-293.

${ }^{28}$ Notable exceptions include Stanley Tambiah's work on monastic educational networks for the mobility of modern Thai novices and monks: Tambiah, Stanley Jeyaraja. 
establishment and growth of Buddhist networks in specific geographical contexts and historical frameworks from the middle of the first millennium BCE to the end of the first millennium CE. Interconnected networks of arteries and capillaries were used for ancient migrations into the Indian subcontinent, interregional and long-distance trade, and cross-cultural transmission. Mapping of conduits between nodes for the localization of religious, economic and political power in India and the northwestern borderlands of Gandhāra is based on distribution of remains of stüpas, monastic and wayside shrines, images, artifacts, coins, inscriptions, and manuscripts, as well as eyewitness accounts of visitors. Graffiti and petroglyphs of individual travelers, visitors to shrines, itinerant monks, novices, students, long-distance traders, and local donors reflect different stages and levels of Buddhist transmission and multicultural flows through northern Pakistan, which served as a pivotal transit zone to the southern Tarim Basin in eastern Central Asia. ${ }^{29}$ Exchanges of material and religious commodities at Central Asian hubs located on branches of the so-called silk routes that formed an overland network across Asia demonstrate links between commercial and cultural transmission.

\section{Merit, Merchants and the Buddhist Sangha}

An investigation of a nexus between historical patterns of Buddhist transmission and transcultural trade exchanges inevitably raises questions related to longstanding debates about theoretical frameworks for the study of economy and religion. Forging a "middle way" between polarizing disputes over the primacy of economy or religion by demonstrating mutual imbrication of these two seemingly separate spheres would be a suitable Buddhist solution, but it is necessary to recognize

1976. World Conqueror and World Renouncer: A study of Buddhism and polity in Thailand against a historical background. Cambridge: Cambridge University Press, chapter 15: Monastic Careers and Monastic Network, pp. 313-364. He also refers to routinized networks of forest-monks in Tambiah, Stanley Jeyaraja. 1984. The Buddhist Saints of the Forest and the Cult of Amulets: A study in charisma, hagiography, sectarianism, and millennial Buddhism. Cambridge: Cambridge University Press, p. 334. A conference on Buddhism Across Asia: Networks of Material, Intellectual and Cultural Exchange held in Singapore on February 16-18, 2009 was an initial step in applying network-type approaches to Buddhist studies (proceedings are forthcoming).

${ }^{29}$ Inscriptions and petroglyphs from northern Pakistan are treated in detail in Chapter 5: Capillary Routes of the Upper Indus, 268-273, 278-287. 
at the outset that distinctions between 'profane' economic patterns and 'sacred' religious realms are largely contrived. The dichotomy between the study of economy and the study of religion is largely due to late eighteenth century theories about the "naturalization" of economic patterns acting according to their own laws and the demarcation of religion as a separate sphere of belief and practice removed from the material world. ${ }^{30}$ From strictly "formalist" standpoints, ${ }^{31}$ Buddhism and other religious traditions are epiphenomenal results of economic causes of supply and demand, production and consumption, and class dialectics (according to Marxist analysis). However, models of economic determinism that require the quantification of capital, population, land ownership, and other inputs are very difficult to apply to pre-modern non-western societies, since the preserved sources typically lack sufficient economic data to test hypotheses. ${ }^{32}$

Max Weber argued against economically determinist positions by seeking to identify religious influences on social and political economies in world history. In his introduction to Collected Essays in the Sociology of Religion, he asserted: "The magical and religious forces, and the ethical ideas of duty based upon them, have in the past always been among the most important formative influences on conduct" (1922/1930: xxxix; 2001: 160). ${ }^{33}$ In The Protestant Ethic and the Spirit

30 On the "naturalization" of economy, see Morley, Neville. 2007. Trade in Classical Antiquity. Cambridge: Cambridge University Press and Robertson, Roland. 1987. "Economics and Religion." In Eliade, Mircea and Charles J. Adams, eds. 1987. The Encyclopedia of Religion. New York: Macmillan, vol. 5, 1-11. Robertson points out that "...it was not until as recently as the end of the eighteenth century that 'the economy' became fully thematized (and then only in the Western world) as a relatively autonomous realm of human life" (1987: 1). The historical development of the study of religion as a modern academic field, including the study of Buddhism as a "world religion," is critically analyzed by Balagangadhara, S.N. 1994. "The Heathen in his Blindness": Asia, the West, and the dynamic of religion. Leiden: Brill, Masuzawa, Tomoko. 2005. The Invention of World Religions, or, How European universalism was preserved in the language of pluralism. Chicago: University of Chicago Press, and Smith, Jonathan Z. 1998, "Religion, Religions, Religious." In Taylor, Mark C., ed. Critical Terms for Religious Studies. Chicago: University of Chicago Press, 269-284.

31 Formalist-Substantivist positions are clearly outlined by Curtin, Philip D. 1984. Cross-cultural Trade in World History. Cambridge: Cambridge University Press, 14.

${ }^{32}$ Morley comments that "The application of modern economic categories and concepts is tantamount to 'modernising' the ancient economy..." (2007: 11).

${ }^{33}$ Weber, Max. 1922. Gesammelte Aufsatze zur Religionssoziologie. Tübingen: Mohr (translated by Talcott Parsons as Collected Essays in the Sociology of Religion. London: Allen and Unwin, 1930, reprinted with an introduction by Anthony Giddens as Max Weber: The Protestant Ethic and the Spirit of Capitalism. London and New York: Routledge Classics, 2001). The translation by Kalberg, Stephen, 2001. The Protestant 
of Capitalism and in later volumes on the "Economic Ethics of World Religions," including The Religion of India, he proposed to identify "inner-worldly asceticism" (1958 [1921]: 337) with the underlying "spirit" of Protestant capitalism in northern Europe, in contrast to the "world-indifferent behavior" (ibid. 333) exemplified by Buddhist renunciation. ${ }^{34}$ However, his attempt to identify European economic success with a Protestant ethic and to attribute "the lack of economic rationalism and rational life methodology in Asia" (1958 [1921]: 340) to Buddhist and other renouncer movements not only oversimplifies interactions between monastic communities and lay donors in Asia, but also overlooks significant relationships between European Christian monastic institutions and economic history. ${ }^{35}$

Weber's arguments for the role of religion as an underlying motivation has continued to shape the perspectives of "substantivists" such as Karl Polanyi, who aimed to show that long-distance trade exchanges and other economic processes are embedded in social relationships and religious values. ${ }^{36}$ Polanyi posited a sequential hierarchy of reci-

Ethic and the Spirit of Capitalism. 3rd Roxbury edition. Los Angeles: Roxbury is cited here.

${ }^{34}$ Weber, Max. 1921. Hinduismus und Buddhismus. Tübingen: Mohr (reprint, Weber, Max. 1996. Gesamtausgabe Die Wirtschaftsethik der Weltreligionen Hinduismus und Buddhismus, 1916-1920. Tübingen: Mohr and translated by Hans W. Gerth and Don Martindale as 1958. The Religion of India: The Sociology of Hinduism and Buddhism. Glencoe, IL: Free Press). For critical essays, see Schluchter, Wolfgang, ed. 1984. Max Webers Studie über Hinduismus und Buddhismus: Interpretation und Kritik. Frankfurt am Main: Suhrkamp.

${ }^{35}$ Ilana Friedrich-Silber discusses Weber's "Western" and more specifically "Calvinist" bias against monasticism in general, and refers (fn. 27) to scholars (such as Tambiah 1973) who emphasize that "Buddhism's potential for economic dynamism and worldly involvement may have been much greater than Weber granted" (1995: 10) in Friedrich-Silber, Ilana. 1995. Virtuosity, Charisma, and Social Order: A comparative sociological study of monasticism in Theravada Buddhism and medieval Catholicism. Cambridge: Cambridge University Press. Stark, Rodney. 2005. The Victory of Reason: How Christianity led to freedom, capitalism, and Western success. New York: Random House comments that Weber's thesis “... was widely embraced despite the fact that it was so obviously wrong" (2005: xi), but his own argument that "the Christian commitment to rational theology that surely predated Protestantism by far more than a millennium" (xiii) was responsible for Western (European) capitalism is also deeply flawed due to his apparent lack of awareness of pre-modern interactions between Asian religions and economies.

${ }^{36}$ Polanyi, Karl. 1957. “The Economy as Instituted Process.” In Polanyi, Karl, Conrad Arensberg, and H.W. Pearson, eds. Trade and Market in the Early Empires; Economies in History and Theory. Glencoe, Ill: Free Press, (reprint: Polanyi, Karl. 1968. Primitive, Archaic, and Modern Economies: Essays of Karl Polanyi, ed. George Dalton. Garden City, N.Y.: Anchor Books, 139-175), “Traders and Trade.” In Sabloff, Jeremy A., 
procity tied with tribal society, redistribution associated with archaic societies, and market exchange only emerging after 1800 in western societies. However, Buddhist literary, epigraphic, and archaeological sources indicate that all three forms of transaction were simultaneous. ${ }^{37}$ Andre Gunder Frank dismissed Polanyi's theory of a "Great Transformation" to a market economy in Europe during the nineteenth century as Eurocentric since Asia, not Europe, played the major role in "a single global world economy with a world-wide diffusion of labor and multilateral trade from 1500 onward" (1988: 52). ${ }^{38}$ Other advocates of "world systems" propose the integration of earlier Afro-Eurasian regional trade networks, including maritime trade across the Indian Ocean between India and China between the eleventh and fifteenth centuries, with even earlier precedents in Buddhist exchanges via overland routes across Central Asia. ${ }^{39}$ Critics of the world system model caution against "definition being mistaken for explanation" (Renfrew and Bahn 1991: 334) when ancient and modern economic worldviews, internal and external exchanges, and scales of commercial and cultural flows are insufficiently distinguished. ${ }^{40}$ Marxist-oriented theories of economic and cultural exchanges within world systems have also been criticized for limiting the concepts of center and periphery to functionalist paradigms in which exogenous changes (such as the impact of Buddhism) are imposed on peripheral satellites by powerful core regions. ${ }^{41}$ Nevertheless, more flexible conceptions of multiple centers as shifting nodes within dynamic networks are useful rubrics

and C.C. Lamberg-Karlovsky, eds. 1975. Ancient Civilization and Trade. Albuquerque: University of New Mexico Press, 133-154.

${ }^{37}$ Liu, Xinru. 1988. Ancient India and Ancient China: Trade and religious exchanges, $A D$ 1-600. Delhi: Oxford University Press, 77.

${ }^{38}$ Frank, Andre Gunder. 1998. ReOrient: Global economy in the Asian Age. Berkeley: University of California Press.

39 Sen, Tansen. 2003. Buddhism, Diplomacy, and Trade: The realignment of SinoIndian relations, 600-1400. Honolulu: University of Hawai'i Press discusses models of Indian Ocean "world systems" reconstructed by Jerry Bentley (ca. 1000 CE) and Janet Abu-Lughod (13th century), and argues for a "gradual restructuring of commercial exchanges between India and China from a Buddhist-centered to a market-dominated activity" (2003: 202) by the end of the 10th century, with a vigorous phase between the $11 / 12$ th and $14 / 15$ th centuries.

${ }^{40}$ Renfrew, Colin, and Paul G. Bahn. 1991. Archaeology: Theories, methods, and practice. New York: Thames and Hudson. See also Morley 2007: 90-102 (Chapter 6: The limits of ancient globalization).

${ }^{41}$ Champion, Timothy. 1989. "Introduction" to Champion, T.C., ed. 1989. Centre and Periphery: Comparative studies in archaeology. London: Unwin Hyman, 1-21 (especially 9-10 for Renfrew's critique); Rowlands, Michael. "Centre and periphery: A review 
for understanding patterns of trade exchanges and religious transmission in peripheral regions, which as transit zones linked core areas of political and cultural power but independently adapted and transformed outside influences to develop localized markets for transregional economic and religious interactions.

While this treatment focuses on overlapping networks for crosscultural trade and Buddhist transmission along long-distance routes in South and Central Asia, a "new paradigm" of "religious markets" provides an alternative model for viewing similarities between economic and religious behavior in comparative historical contexts. ${ }^{42} \mathrm{~A}$ basic premise of this model is that "ordinary people behave religiously just as they presumably behave economically" (Warner 2002: 7). ${ }^{43}$ Rodney Stark and Roger Finke distinguish between a "demand-side" of "religious consumers" who employ rational choice in their doctrinal affiliations and institutional participation on the one hand and a "supply-side" of constantly shifting religious organizations which fill market niches on the other hand. ${ }^{44}$ As a corollary, they propose that competition for market share between religious firms (churches, denominations, sects, and cults) to meet the needs and preferences of religious customers (devotees, patrons, "joiners," and committed renouncers) stimulates participation..$^{45}$ This economic model for religious participation and patronage is potentially useful as a heuristic tool for assessing the growth of Buddhist monasticism in very competitive religious markets of ancient India and its ultimate success in filling niches in Central Asia and East Asia. However, Steve Bruce caustically observes that "There is rather a good case for saying that economics does not explain economic action terribly well but, leaving that aside, it provides little or no purchase on religious action" (2002: 182).$^{46}$ Bruce acknowledges that propositions of rational choice and religious economics "sometimes coincide with the truth" (ibid.), but

of a concept." In Kristiansen, Kristian, and M.J. Rowlands, eds. 1998. Social Transformations in Archaeology: Global and local perspectives. London: Routledge, 219-242.

${ }^{42}$ Jelen, Ted G., ed. 2002. Sacred Markets, Sacred Canopies: Essays on religious markets and religious pluralism. Lanham, Md: Rowman \& Littlefield Publishers.

${ }^{43}$ Warner, R. Stephen. 2002. "More Progress on the New Paradigm." In Jelen 2002, $1-30$.

${ }_{44}^{44}$ Stark, Rodney and Roger Finke. 2002. "Beyond Church and Sect: Dynamics and Stability in Religious Economics.” In Jelen 2002, 31-62.

${ }^{45}$ Stark and Finke 2002: 39-45 (proposition 7, H1-4).

${ }^{46}$ Bruce, Steve. 2002. "The Poverty of Economism or the Social Limits on Maximizing." In Jelen 2002, 167-185. 
traditional religious behavior is not dependent on economism. The application of rational choice theories of religious identity to Asian traditions that do not require exclusive allegiance is especially problematic, since it is not necessary to switch between 'brands' when multiple affiliations are possible, and the boundaries between religions are not very well defined. Although a "market model" can not be imposed on Buddhist transmission, aspects of "religious economics" help to clarify basic economic structures which are necessary for the expansion of monastic institutions and to point out relationships between Buddhist values and material cultures, commodities, and other spheres of cultural transaction.

\section{Buddhist Economies of Merit}

A symbiotic structural exchange of material donations for religious merit directly connects the establishment, maintenance, and growth of Buddhist monastic institutions to networks of social and economic support. As ascetic renouncers (śramanas), Buddhist monks and nuns ostensibly depend on gifts from donors to sustain their religious lifestyle, since monastic regulations mandate against their direct participation in economic activities. ${ }^{47}$ After going forth on the path of homeless wandering, monks, nuns, and novices must reject all worldly possessions except the "requisites" of food, clothing, shelter, and medicine supplied by lay patrons, according to normative vinaya codes. ${ }^{48}$ In practice, a much broader range of donations is permitted in order to maintain residential monasteries inhabited throughout the year. ${ }^{49}$ Although the accumulation of personal wealth is forbidden, rules governing communal ownership of property by the sangha allowed Buddhist monasteries to receive unlimited donations. ${ }^{50}$ As monks and nuns make themselves available to give religious

47 Friedrich-Silber 1995: 85-86.

48 Wijayaratna, Mohan. 1990. Buddhist Monastic Life according to the Texts of the Theravāda Tradition. Cambridge: Cambridge University Press (Translated by Claude Grangier and Steven Collins from Le moine bouddhiste selon les textes du Theravâda. Paris: Éditions du Cerf, 1983) clearly summarizes monastic rules concerning food, clothing, and dwelling places based exclusively on Pāli sources.

${ }^{49}$ Hinüber, Oskar von. 2006a. "Everyday Life in an Ancient Indian Buddhist Monastery." Annual Report of the International Research Institute for Advanced Buddhology at Soka University 9, 1-31, esp. 13-17 discusses the expansion of material requisites.

${ }^{50}$ Hinüber 2006a: $18 \mathrm{ff}$. With regard to the Chinese context, Kieschnick, John. 2003. The Impact of Buddhism on Chinese Material Culture. Princeton: Princeton University 
instruction to lay supporters in return for material donations, they participate in a symbiotic relationship in which "the 'gift of the law' (dharmadāna) compensates for the 'material gift' (ämiṣadāna)" (Lamotte 1988 [1958]: 66). ${ }^{51}$ In exchange for their religious gifts, donors receive religious merit ( $p$ unya), which can be transferred to relatives, teachers, and "all beings" (as widely attested in Buddhist epigraphic formulae). ${ }^{52}$ The practice and promotion of generous giving (dāna) simultaneously encourages selfless renunciation of material wealth, especially if it is given away with the proper intentions, and embeds an economic stimulus for its acquisition, since additional donations result in greater merit. ${ }^{53}$ In this structure of mutual and symbiotic

Press explains that "although individual monks were not supposed to amass personal wealth, the corporate wealth of the monastic community was not restricted" (2003: 6).

${ }^{51}$ Lamotte, Étienne. 1988. History of Indian Buddhism from the Origins to the Saka Era. Louvain-la-Neuve: Université catholique de Louvain, Institut Orientaliste (Translated by Sara Webb-Boin from Histoire du bouddhisme indien: des origines à l'ère Śaka. Louvain: Université de Louvain, 1958). Hereafter dates in brackets refer to the original publication date [1958].

${ }^{52}$ Friedrich-Silber states that the "dāna relation" of particularized and general exchange "...played a crucial role in a complex and expansive economy of merit" in which merit could be converted into a "reified, fluid, and transferable substance" (1995: 95). On epigraphic formulae for the transfer of merit to "all beings" see Schopen, Gregory. 1985a. "Two Problems in the History of Indian Buddhism: The Layman/ Monk Distinction and the Doctrine of the Transference of Merit." Studien zur Indologie und Iranistik 10, 9-47 (reprinted in Schopen, Gregory. 1997a. Bones, Stones, and Buddhist Monks: Collected papers on the archaeology, epigraphy, and texts of monastic Buddhism in India. Honolulu: University of Hawai'i Press. 23-55). Walsh, Michael J. 2007. "The Economics of Salvation: Toward a Theory of Exchange in Chinese Buddhism." Journal of the American Academy of Religion 75.2, 353-382 discusses merit exchange and transfer in the context of Chinese Buddhism, which he regards as "the quintessential social mechanism of Buddhist material exchange" (356).

${ }^{53}$ In Sizemore, Russell F. and Donald K. Swearer, eds. 1990. Ethics, Wealth, and Salvation: A study in Buddhist social ethics. Columbia: University of South Carolina Press, the editors argue that "... Buddhism gives at least a provisional affirmation to material prosperity... and there are many norms for handling wealth which intimately link lay and monastic society" (1). The concept of the "gift" in Indian Buddhist traditions is extensively theorized by Reiko Ohnuma $(2005,2007)$ in "Gift" in Lopez, Donald S., ed. 2005. Critical Terms for the Study of Buddhism. Chicago: University of Chicago Press, 103-123 and Head, Eyes, Flesh, and Blood: Giving away the body in Indian Buddhist literature. New York: Columbia University Press, especially 140-166 (chapter IV, Dāna: The Buddhist Discourse on Giving). Ohnuma critiques Marcel Mauss' theory that gifts are always reciprocated by arguing that "unreciprocated" gifts are regarded more highly in Buddhist literary traditions, while "reciprocated" gifts in which donors receive merit "... bind one to the world and are thoroughly mundane in nature" (2007: 147). For a similar critique based on a wider range of Buddhist, Jain and Hindu sources, see Heim, Maria. 2004. Theories of the Gift in South Asia: Hindu, Buddhist, and Jain reflections on dàna. New York: Routledge. Such critiques tend to diminish the practical impor- 
exchange in which monastic communities depend upon lay patrons for material donations, an economic surplus is necessary to support the growth of Buddhist monastic institutions. ${ }^{54}$ While acknowledging that basic material conditions of surplus resources must be available for monastic communities to survive, the institutional expansion of Buddhism is not fully determined by economics alone, since other social and cultural factors, as well as religious motivations, play important roles. Nevertheless, monastic dependence on lay support directly connects material support of the sangha to commercial networks for long-distance trade exchanges and patronage by merchants and other wealthy donors.

\section{Buddhist Material Culture and Long-Distance Trade}

The distribution of archaeological sites of Buddhist shrines and monasteries on routes for commercial exchange indicate symbiotic relationships between religious institutions and economic networks.

tance of the material gift (amișadāna), thus reifying an apparent bias against mundane exchanges in Mauss's theory of the gift, as succinctly noted by Tambiah: "... Mauss was partially color-blind to the margins of material gain that greased the spirit of reciprocity" (1984: 340). Laidlaw, James. 1995. Riches and Renunciation: Religion, economy, and society among the Jains. Oxford: Clarendon Press, $294 \mathrm{ff}$. examines Jain theories and practices of gift-giving based on ethnographic studies, and observes that monks and nuns acknowledge that they reciprocate for donations by teaching the laity (325). Also see Walsh 2007 for a very useful assessment of theories of gifts (Mauss, Derrida) and commodities (Marx, Bourdieu) applied to Chinese Buddhist concepts of merit.

${ }^{54}$ The "idea of a surplus" is discussed by Bailey, Greg and Ian W. Mabbett 2003. The Sociology of Early Buddhism. Cambridge: Cambridge University Press, 66-76. However, their conclusion that a surplus above subsistence level was not necessary for Buddhist donations (234) contradicts earlier statements that "... an ascetic movement like Buddhism could not have survived in the absence of a broadly based disposable surplus of production above subsistence needs" (66). Benavides, Gustavo. 2005. "Economy" in Lopez 2005, 77-102 remarks that "... a degree of abundance is the prerequisite for asceticism" (2005: 82). Max Weber refers to the location of monasteries near cities as an advantage to "the purely parasitic character of Buddhistic income seeking" (1958 [1921]: 230). In a keynote address to the IABS conference in Bangkok in 2002 ("Relying on the dharma and not the Person: Reflection on Authority and Transmission in Buddhism and Buddhist Studies." Journal of the International Association of Buddhist Studies 26.1, 9-24), Paul Harrison wryly remarks that "Both the Saingha and academia are also institutions sustained by the economic surpluses of society, in which people are afforded the leisure and the means to pursue objectives which many outside simply do not understand or see the point of. Monks and nuns, like academics, have throughout the history of Buddhism been regularly denounced as parasites, and have just as enthusiastically been supported by the societies in which they lived" (2003: 24). 
In a brief article on "Early Buddhism, Trade and Empire," James Heitzman (1984) suggested that relatively early Buddhist sites clustered near cities or on routes connecting cities provided opportunities for "ostentatious display" (132) and thus functioned as "symbols of hierarchy" (133). ${ }^{55} \mathrm{~A}$ triad of Buddhist institutions, trade routes, and political power implies that the spheres of religion, commerce, and rulership significantly overlapped, but determining the economic role of early Buddhist monasteries in trade networks and their impact on the changing political landscape of ancient India based solely on archaeological evidence remains a formidable challenge. ${ }^{56}$ Kathleen Morrison (1995) lodges criticism against an overemphasis on connections between urban and monastic centers patronized by powerful and wealthy donors at the expense of smaller Buddhist establishments in rural hinterlands with significant agricultural resources supported by a broad array of donors. ${ }^{57}$ P. Krishna Mohan Reddy has argued that a

${ }^{55}$ Heitzman, James. 1984. "Early Buddhism, Trade and Empire." In Kennedy, Kenneth A.R. and Gregory Possehl, eds. 1984. Studies in the Archeology and PalaeoAnthropology of South Asia. New Delhi: American Institute of Indian Studies, 121-137. This short contribution, which is invariably cited in contexts of relations between Buddhism, trade, urbanism, and patronage, is now updated by Heitzman's final article: "The Urban Context of Early Buddhist Monuments in South Asia," in Hawkes, Jason and Akira Shimada, eds. 2009. Buddhist Stūpas in South Asia: Recent archaeological, art-historical, and historical perspectives. Delhi: Oxford University Press, 192-215. In his earlier article, Heitzman defines an early Buddhist monastic site as a place with structural remains of stüpas, caityas, monasteries, or temples for Buddhist images (122), but the architecture and layout of monasteries only developed after the period of Aśoka, and most archaeological remains of vihäras do not date before the first century CE (Allchin, F. Raymond. 1995. The Archaeology of Early Historic South Asia: The emergence of cities and states. Cambridge: Cambridge University Press, 246; Schopen, Gregory. 1994c. "Doing Business for the Lord: Lending on Interest and Written Loan Contracts in the Mülasarvāstivāda-vinaya." Journal of the American Oriental Society 114.4, 527-553, esp. 548-551, reprinted in Schopen, Gregory 2004. Buddhist Monks and Business Matters: Still more papers on monastic Buddhism in India. Honolulu: University of Hawaii Press, 45-90).

${ }^{56}$ Himanshu Prabha Ray sees links between long-distance trade and Buddhist monastic networks operating at ideological, social, economic, and community levels. She asks but does not directly answer questions about "the role of long-distance trade in stimulating social change" (1995: 143) in "Trade and Contacts," in Thapar, Romila, ed. 1995. Recent Perspectives of Early Indian History. Bombay: Popular Prakashan, 142-175. She is equally circumspect in The Winds of Change: Buddhism and the maritime links of early south Asia. Delhi: Oxford University Press: "What is being envisaged is not a causal relationship between the emergence of Buddhism and the expansion of trading networks, but an interactive support system that constantly evolved and adapted itself between $300 \mathrm{BC}$ and AD 300" (1994: 122).

${ }_{57}$ Morrison, Kathleen. 1995. "Trade, Urbanism, and Agricultural Expansion: Buddhist Monastic Institutions and the State in Early Historic Western Deccan." World Archaeology 27.2, 203-221. 
connection between trade and Buddhist establishments has been overgeneralized in the Andhra region of eastern India, since stupas and monasteries are concentrated in coastal areas of the Godavari delta, but not on important inland routes across the Deccan plateau. ${ }^{58}$ The importance of products from the local and regional hinterlands of central India leads Monica Smith to suggest that "...the overall impact of long-distance exchange on the socio-political constructs of the subcontinent may be overestimated when exchange is investigated solely from the point of view of exotic commodities" (2002: 148). ${ }^{59}$ Such critiques do not invalidate the general model of a symbiosis between Buddhist monastic institutions and trade networks, but do illustrate local and regional complexity.

While archaeological investigations can contribute valuable perspectives on the study of local and long-distance trade networks based on the distribution of materials, there are significant limitations to reconstructing a "complete system" of cultural and economic exchange because geographical origins, centers of production, and patterns of consumption are often difficult to identify. ${ }^{60}$ According to C.C. Lamberg-Karlovsky, archaeological studies of trade relationships require chronological frameworks, data to determine production, supply and demand, quantitative and contextual analysis, and knowledge of geology, composition, and modes of production of trade goods. ${ }^{61}$ In his report on contacts between Shortughaï in northeastern Afghanistan and lower Indus valley sites in the second millennium BCE, Henri-Paul Francfort points out the difficulty of mapping commercial routes on the basis of archaeological finds, since it is not possible to determine frequency of exchanges. ${ }^{62}$ Archaeological critiques raise broad questions

${ }^{58}$ Reddy, P. Krishna Mohan. 1998. "God, Trade and Worship: A Glimpse into the Religion of Early Āndhradeśa.” East and West 48, 291-311.

${ }_{59}$ Smith, Monica. 2002. "The Role of Local Trade Networks in the Indian Subcontinent during the Early Historic Period." Man and Environment 27.1, 148; she also criticizes the general emphasis on "luxury goods as the driving force of exchange activity" (114) in Smith, Monica. 1999. "The Role of Ordinary Goods in Premodern Exchange." Journal of Archaeological Method and Theory 6.2, 109-135.

${ }^{60}$ Renfrew and Bahn 1991: 307-338 provide a useful overview of issues and methods in the archaeological study of contact, exchange, and cultural interaction.

${ }^{61}$ Lamberg-Karlovsky, C.C. 1975. "Third Millennium Modes of Exchange and Modes of Production." In Sabloff and Lamberg-Karlovsky, eds. 1975: 341-368.

${ }^{62}$ Francfort, Henri-Paul. 1989. Fouilles de Shortughaï: Recherches sur l'Asie Centrale protohistorique. Paris: Mission archéologique française en Asie centrale. vol. 2, 413. Robin Coningham comments that "...the most we can do is to identify items not available locally" (in Allchin 1995: 64) when a distinction between "down-the-lineexchange" and "direct trade" is unclear. 
about whether long-distance trade is a "catalyst of civilization" or a "simple epiphenomenon" (Francfort 1989: 1.281). Caution against over-interpretation of limited primary source materials is necessary, but the "mutually appropriative movement of goods between hands" (Polanyi 1957: 266) through intermediate and long-distance trade networks enhances demand and intensifies the value of certain commodities and also closely parallels the movement of technical knowledge, religious and cultural ideologies, and symbolic systems. ${ }^{63}$

Buddhist donations of precious commodities demonstrate an intertwined relationship between religious and economic values, since high-value / low-volume objects were highly significant as both commercial goods in long-distance trade exchanges and as Buddhist symbols. Commodities referred to as the "seven jewels" (saptaratna), including gold, silver, crystal, beryl, carnelian, coral, and pearls, are frequently found among the contents of reliquary deposits and valorized as laudable donations in Buddhist texts (especially but not exclusively Mahāyāna sūtras). ${ }^{64}$ Based on archaeological patterns and

${ }^{63}$ Appadurai, Arjun. 1986. "Commodities and the Politics of Value." In Appadurai, Arjun, ed. 1986. The Social Life of Things: Commodities in cultural perspective. Cambridge: Cambridge University Press, 29, 42; Helms, Mary 1988. Ulysses' Sail: An ethnographic odyssey of power, knowledge, and geographical distance. Princeton, N.J.: Princeton University Press: 5-7; Helms, Mary. 1993. Craft and the Kingly Ideal: Art, trade, and power. Austin: University of Texas Press, 99; Renfrew, Colin. 1975. "Trade as Action at a Distance: Questions of integration and communication." In Sabloff and Lamberg-Karlovsky 1975: 3-59.

${ }^{64}$ As Xinru Liu demonstrates in "Buddhist ideology and the Commercial Ethos in Kuṣāna India" (1988: 92-101, reprinted in Hawkes and Shimada 2009: 177-191), components of the saptaratna vary considerably in Sanskrit and Pāli literary sources. The standard list of items in the Mahāvastu includes gold (suvarna), silver (rūpya), beryl (vaidūrya), crystal (sphatika), red precious stones (lohitikā), coral (musāragalva), and pearls $(m u k t \bar{a})$. Other lists refer to varieties of red precious stones as rohitamukti and replace pearls or other items with aśmagarbha (amber, coral, diamond, or emerald). The model for this list was probably the "seven jewels" of a king: disc (cakra), elephant (hastin), horse (aśva), gem (mani), queen (strī), minister (parināyaka or $\bar{a} m \bar{a} t y a)$, and treasurer (grhapati), which are frequently referred to in Buddhist literature and depicted in Buddhist art (for example, on the pedestals of Pāla period sculptures and miniature stüpas at Bodh Gaya). In addition to Liu's reference (1988: 94) to the Kalawān stūpa at Taxila, also see Errington, Elizabeth. 1998. "Gandhāra Stūpa Deposits." Arts of Asia 28.2, 80-87; Errington, Elizabeth, and Joe Cribb. 1992. The Crossroads of Asia: Transformation in image and symbol in the art of ancient Afghanistan and Pakistan. Cambridge: Ancient India and Iran Trust, 172-197; Willis, Michael D. 2000. Buddhist Reliquaries from Ancient India. London: Published for the Trustees of the British Museum by British Museum Press, particularly p. 90, no. 19, fig. 103 for deposits in the Bhojpur stūpas at Sāñcī; Subrahmanyam, B. 1999. Buddhist 
literary references to the seven jewels, Xinru Liu argues that “...the circulation of luxury commodities stimulated the standardization of the concept of the saptaratna, and the ritual meaning the Buddhist movement brought to these goods increased their value and enlarged their market" (1988: 100 / 2009: 189). Liu's conclusion that "Buddhist values created and sustained the demand for certain commodities traded between India and China during the first to the fifth centuries AD” (1988: 175) is highly debatable, since commodities such as gold with intrinsic economic values can be adopted for religious purposes, even in traditions (like Buddhism and Christianity) that explicitly reject worldly riches. ${ }^{65}$ Furthermore, the symbolic value of gold, jewels, gems, and other luxury commodities in Buddhist relic deposits in Gandhāra (at least) may have been influenced by the use of these items in royal burial practices in neighboring areas of western Central Asia. ${ }^{66}$ Although arguments for the influence of commercial and cultural factors on the symbolic values of religious commodities tend to be more convincing than vice versa (i.e., ritual demand determining economic value), scholarship on 'material culture' emphasizes the impact of commodities on social transformation and explores the roles of religious practices, ethics, and norms in the "moral economy" underlying the "objective economy." ${ }^{67}$ By positing that "... merit, like goods, could be transferred and exchanged” (Liu 1988: 101 / 2009: 190), Xinru Liu, Michael Walsh, and Andy Rotman extend market theories of religion promulgated by Rodney Stark, Rodney Finke other theorists of the

Relic Caskets in Andhradesa. Secunderabad: Ananda Buddha Vihara Trust, 35-84; and Czuma, Stanislaw J., and Rekha Morris. 1985. Kushan Sculpture: Images from early India. Cleveland, Ohio: Cleveland Museum of Art in cooperation with Indiana University Press, $165-167$.

${ }^{65}$ Compare, for example, the sumptuous display of gold, silver, gems, and textiles in Christian contexts in Janes, Dominic. 1998. God and Gold in Late Antiquity. Cambridge: Cambridge University Press.

${ }_{66}$ Brown, Robert. 2006. "The Nature and Use of the Bodily Relics of the Buddha in Gandhāra." In Behrendt, Kurt and Pia Brancaccio, eds. 2006. Gandhāran Buddhism: Archaeology, art, and texts. Vancouver: UBC Press, 182-209.

${ }^{67}$ Such approaches are exemplified by Arjun Appadurai, Patrick Geary, Igor Kopytoff, and other contributors to Appadurai, ed. 1986. Now also see Binsbergen, Wim M.J. van, and Peter Geschiere. 2005. Commodification: Things, agency, and identities: The social life of things revisited. Münster: Lit. Kieschnick 2003 presents several case studies to show how the use of relics, images, texts, silk robes, and numerous other objects of Chinese Buddhist donations increased their total social and religious value and had impacts on Chinese material culture. 
so-called 'new paradigm' to Buddhist economies of merit, whereby merit is to be viewed as a material commodity. ${ }^{68}$

\section{Buddhist Inscriptions of Meritorious Merchants}

Buddhist inscriptions demonstrate that patronage networks played critical roles in the growth of monastic institutions and provide concrete evidence of donors with commercial backgrounds. Donative inscriptions at stupas, caityas, and monastic sites in early India reveal that donors came from a broader range of social backgrounds than the traditional élite of Brahmin householders and ksatriya rulers. ${ }^{69}$ At many sites (e.g., Bharhut and Sãñī), the largest single group of donors were monks and nuns, who evidently owned personal property despite prohibitions on private wealth. ${ }^{70}$ The fact that monks and nuns often acted as patrons of Buddhist shrines and images provides evidence that the monastic community was not completely dependent on donations from lay supporters. Nevertheless, many lay donors whose occupational backgrounds are indicated by specific titles in donative inscriptions clearly belonged to merchant groups or families. The most common mercantile designation in Indian Buddhist inscriptions is śreșthin (Sanskrit), sețhin (Pāli/Prakrit), and other variants, which D.C. Sircar defines as "a banker or merchant or the foreman of

${ }^{68}$ Walsh in particular strongly argues for an economistic view that "... merit was a commodity, a commodified object of exchange, and in this sense always part of a distribution of power that constituted part of an exchange for salvation.... Merit, as an object of exchange in the Chinese Buddhist context, was (and is) a product of labor, a direct result of a donor who labors to produce the donation, and the recipient who labors to award the merit and explicate its meaning to a wider society, a process that was the direct consequence of an agricultural culture" (2007: 373). Rotman, Andy. 2003. Monks, Merchants, and a Moral Economy: Visual culture and the practice of faith in the Divyāvadāna. Thesis (Ph. D.) University of Chicago, Dept. of South Asian Languages and Civilizations, 277-284 similarly argues for a "commodification of merit" in which "everything is for sale" through donations to the sangha.

69 Dehejia, Vidya. 1992. "The Collective and Popular Basis of Early Buddhist Patronage: Sacred Monuments, 100 BC-AD 250." In Miller, Barbara Stoler, ed. 1992. The Powers of Art: Patronage in Indian culture. Delhi: Oxford University Press, 35-45.

${ }^{70}$ Lamotte 1988 (1958): 414 observes that of 126 donors at Bhārhut, 24 were bhikșus and 14 were bhikșunis. Schopen, Gregory 1996a. "What's in a Name? The Religious Function of the Early Donative Inscriptions.” In Dehejia, Vidya, ed. 1996. Unseen Presence: The Buddha and Sanchi. Mumbai: Marg Publications, 58-73 (= Schopen 2004: 382-394) calculates that almost $40 \%$ of donors at Sãñi were monks or nuns, with the proportion rising to $60 \%$ at Sãñī stūpa 2. For the relative proportions of monastic to lay donors at other early Indian Buddhist sites, see Schopen 1997a [1985a]: 30ff. 
a guild" (1966: 317). ${ }^{71}$ Other merchant titles attested in Indian Buddhist inscriptions include sārthavāha / sathavāha ${ }^{72}$ (perhaps denoting a merchant involved in long-distance trade in inscriptions), vanij / vāniya $a^{73}$ (probably traders in basic goods), negama ${ }^{74}$ (members of guilds of traders or artisans), hairanyaka / heranika ${ }^{75}$ (goldsmiths or treasurers), gandhika (usually translated as "perfumers" but a broadly meaning merchants and shopkeepers), and vyāvahārika (a general term for a businessman). Merchant titles appear in inscriptions marking individual and group donations, as well as in donations by wives, daughters, sons, and other members of merchant families. For example, an inscription written on a large stone bowl found on the outskirts of Mathura records a donation to the Mahopadesaka teachers in the "goldsmiths' monastery" (Suvanakāra-vihāra):

The gift of Ayala, the son of Imdrasama (Indraśarman), for the worship of all Buddhas in the Suvanakäravihära for the acceptance of the Mahopadesaka teachers. ${ }^{76}$

While Indian Buddhist inscriptions from Mathura reflect the role of merchants, traders, their wives, and their relatives as significant patrons, it is important to note that Jain monasteries in Mathura also received gifts of images and other items from similar groups of commercial donors. ${ }^{77}$ Although occupational titles are not very common in inscriptions from further Northwest in the Indian subcontinent,

${ }^{71}$ Sircar, Dineschandra. 1966. Indian Epigraphical Glossary. Delhi: Motilal Banarsidass. Lüders, Heinrich. 1912. "A List of Brāhmī Inscriptions from the Earliest Times to about 400 AD" Epigraphia Indica 10 [Appendix] (reprinted as Lüders, Heinrich. 1973. A list of Brahmi Inscriptions from the Earliest Times to about AD 400 with the Exeception (sic.) of those of Asoka. Delhi: Indological Book House) cites twenty-four attestations of śresthin, śrestin, sethin, or sethin.

${ }_{72}$ Lüders 1912 (1973): nos. 1062, 1065, 1066 at Kuḍa in western India

${ }^{73}$ Lüders 1912 (1973): nos. 1213, 1214, 1229, 1230, 1239, 1278, 1281 (väniya) and nos. 1285, 1292 (vāniyinī [wives]) at Amarāvatī in southeastern India

${ }^{74}$ Lüders 1912 (1973): nos. 987, 995, 998, 1000, 1001, 1024 at Kāṇherī (Mumbai/ Bombay), nos. 1127, 1139 at Nāsik, and no 1172 at Junnar in western India

${ }^{75}$ Lüders 1912 (1973): nos. 987, 993, 996, 1033 at Kāṇherī and nos. 1239, 1247, 1297 at Amarāvatī

${ }^{76}$ Lüders, Heinrich and Klaus Ludwig Janert. 1961. Mathurā Inscriptions. Unpublished papers edited by Klaus L. Janert. Göttingen: Vandenhoeck \& Ruprecht, 122123 , no. 89.

${ }_{77}$ Lüders and Janert 1961: 46-47, no. 15 (pedestal inscription from the remains of a Jain stūpa at Kankālī Țila recording the gift of an image of Rsạabha by Dattā, the wife of a cotton-dealer: kärppāsika); Quintanilla, Sonya Rhie. 2007. History of Early Stone Sculpture at Mathura, ca. 150 BCE-100 CE. Leiden: Brill, 277-278, nos. 17, 19, figs. 153, 156-8 (àyāgapața plaques from Kankkālī Ṭila donated by the goldsmith 


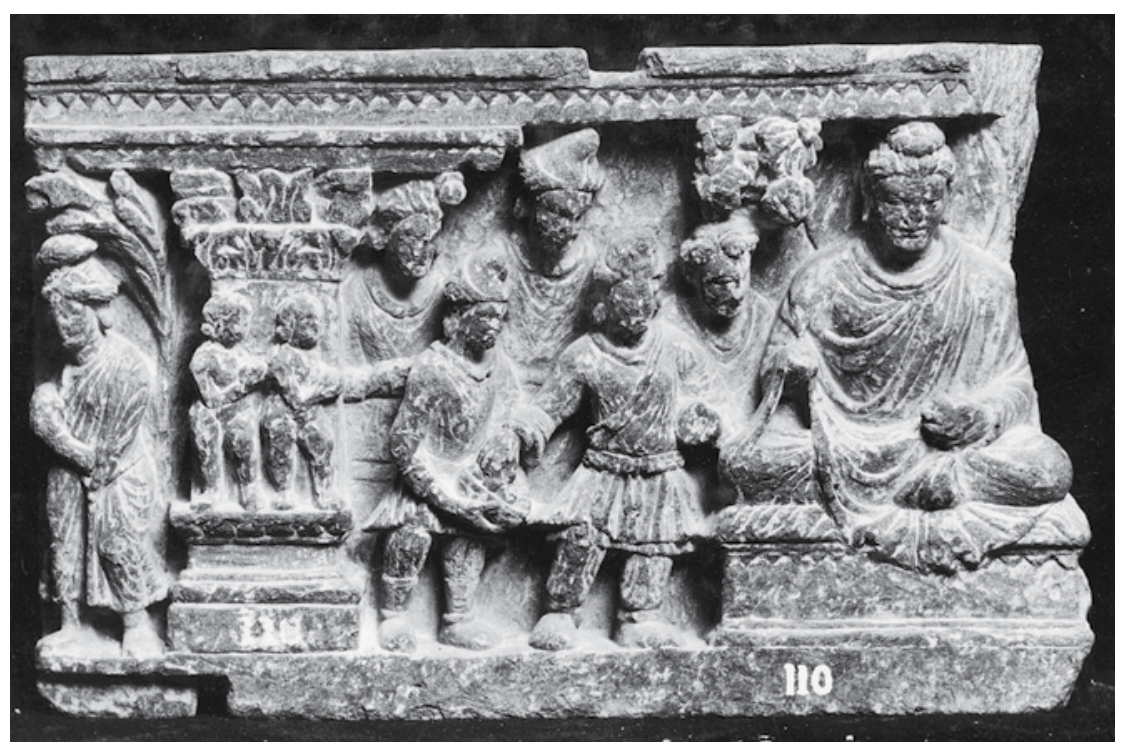

Figure 1.1. Trapuṣa and Bhallika, Gandhāran Sculpture, Chandigarh Museum Courtesy of the American Institute of Indian Studies

graffiti of itinerant merchants in the upper Indus region of northern Pakistan show that they were engaged in Buddhist patronage and long-distance trade. ${ }^{78}$

Nāṃdighoṣa and Sihanāmeika, the son of Siṃhaka, a vānika, probably a merchant, although Lüders tentatively translates the title as 'musician' or 'singer').

${ }^{78}$ For the title of sarthavāha in graffiti from northern Pakistan, see Hinüber, Oskar von. 1989a. "Brāhmī Inscriptions on the History and Culture of the Upper Indus Valley." In Jettmar, Karl, ed. Antiquities of Northern Pakistan: Reports and studies. Mainz: P. von Zabern, vol. 1, 46, no. 28, pl. 71 (śrī vița sarthavahasya); Bandini-Konig, Ditte and Gérard Fussman 1997. Die Felsbildstation Shatial. Mainz: P. von Zabern, no. 39: 23. A reliquary inscription from Charsada (now in the Peshawar Museum) may record the establishment of a monastery by a merchant from Varānasī (varanasi-sarthabaho), but the reading proposed by Harry Falk in a catalog entry contributed to Luczanits, Christian, ed. 2008. Gandhära, the Buddhist Heritage of Pakistan: Legends, monasteries, and paradise. Mainz: P. von Zabern, 205 (catalog no. 122) is problematic and depends on interpretation of a "...garbled but not hopelessly unrecognizable miscopying of a standard donative formula" (Salomon, Richard 1997: 368 in "The Rededication of Buddhist Reliquaries: A Clue to the Interpretation of Problematic Kharosthī Inscriptions." In F. Raymond Allchin, Bridget Allchin, eds. 1997. South Asian Archaeology, 1995. New Delhi: Published for the Ancient India and Iran Trust, Cambridge, 368-371). Salomon reconstructs the formula: "relics of the Lord in his own stūpa" (bhagavato śarira tanuvae thubae) based on parallels with other Kharosthī inscriptions. For earlier readings, see Majumdar, N.G. 1937b. "Inscriptions on Two Relic-caskets from Charsadda." Epigraphia Indica 24, 8-10; Konow, Sten. 1940. "A New Charsadda Inscrip- 


\section{Patronage Patterns in Buddhist Literary Narratives}

By extolling the generosity of donors who gave material support to the Buddha and the early monastic community, Buddhist textual traditions promote merchants as exemplary figures to be emulated by other patrons. Donors from the lifetime of the Buddha range from villagers of Uruvilvā who made simple gifts of milk-rice and grass to wealthy supporters such as Anāthapiṇdada in Śrāvastī, whose gift of the Jetavana monastery with its pavement of coins is commemorated in literary and artistic narratives. The widely transmitted story of two merchants named Trapusa and Bhallika who gave gruel and honey in bowls provided by the guardians of the directions to the Buddha emphasizes the role of merchants as the first lay devotees (Fig. 1.1). ${ }^{79}$ According to some versions, they received relics of the Buddha's hair and nails, which the Buddha instructed them to enshrine in stüpas in their home countries. ${ }^{80}$ The portrayal of Trapușa and Bhallika as early

tion." In Law, Bimala Churn, and Devadatta Ramkrishna Bhandarkar, eds. 1940. D.R. Bhandarkar Volume. Calcutta: Indian Research Institute, 305-310; Konow, Sten. 1948. "Charsadda Kharosthî Inscription of the Year 303." Acta Orientalia 20, 107-119. See Baums, Stefan and Andrew Glass. In Progress. Catalog of Kharosthī Inscriptions no. 178 (http://www.ebmp.org/a_inscription.php?catid=CKI0178) [hereafter CKI] for further references.

79 Citations in Pāli, Sanskrit, and Chinese are compiled by Malalasekera, G.P. 1937. Dictionary of Pāli Proper Names. London: J. Murray, vol. 1. 991; Lamotte 1988 [1958]: 66, n. 155; and Bareau, André. 1963. Recherches sur la biographie du Buddha dans les Sütrapitaka et les Vinayapitaka anciens. Paris: École française d'Extrême-Orient, 106-123. A Gāndhārī version is also preserved in a Kharoșthī manuscript from the second century CE: Allon, Mark. 2007. "Introduction: The Senior Manuscripts." In Glass, Andrew. 2007a. Four Gāndhārī Samyuktāgama Sutras: Senior Kharoșthī fragment 5. Seattle: University of Washington Press, 17-18, 24-25. This episode is commonly cited as historical evidence of Buddhist patronage by merchants: Chakraborti, Haripada. 1966. Trade and Commerce of Ancient India, c. 200 BC-c. 650 AD Calcutta: Academic Publishers, 25; Liu 1988: 113; Ray 1994: 127-128. Granoff, Phyllis. 2005. "The Gift of the Two Merchants: Defining the Buddhist community through story." East and West 55, 129-138 re-examines Sanskrit narratives not as reflections of historical reality, but as reworking of Jain hagiographies of Rșabha which she argues are appropriated to "... set the Buddha and the Buddhist community apart from the Jains" (2005: 137). Since early Buddhist and Jain donors were drawn from the same urban milieu (Laidlaw 1995: 87), it is significant that both renouncer movements sought to appeal to merchants by incorporating them into narratives.

${ }_{80}$ Strong, John. 2004a. Relics of the Buddha. Princeton, N.J.: Princeton University Press, 72-82 discusses traditions connecting the distribution of the hair relics given to Trapusa and Bhallika to sites in Myanmar (Burma) and Sri Lanka, but the place of origin of Trapusa and Bhallika is associated with Bactria in the pilgrimage of Xuanzang. This localization probably reflects a late association of Bhallika with Bāhlika (the Sanskrit geographical term for Bactria), sometimes confused with Vāhìka, "an old 
donors and promoters of relic veneration and stuppa worship in other regions suggests that Buddhist authors valued the material support of traders, merchants, and wealthy figures (like Anāthapiṇ̣ada) and hoped to draw more donors like them into patronage networks.

In addition to hagiographical accounts of Saakyamuni's present lifetime, numerous stories about merchants, long-distance trade, and overland and maritime journeys connected with previous births of the Buddha and bodhisattvas appealed to this important audience of donors. Pāli commentaries on jätaka stories about the circumstances of his earlier births before his rebirth as Prince Siddhārtha link the bodhisattva to families of traders sixty-seven times ${ }^{81}$ Merchants also play significant roles as protagonists in avadānas (a closely related genre of previous-birth narratives) in Buddhist Sanskrit literature. Among avadānas in the Divyāvadāna, an anthology drawn largely from the Mülasarvāstivāda-vinaya, a sizeable proportion (9 out of 38 avadānas) involve merchant caravans or maritime journeys, leading Andy Rotman to identify an "unmistakable commercial ethos" (2003: 35). ${ }^{82}$ Merchants and stories about trade are also prominently represented among narratives collected in the Avadānaśataka and the Mahāvastu. ${ }^{83}$ Merchants are portrayed as wealthy bankers, caravan

name of the Punjab" (Sircar, Dineschandra. 1971a. Studies in the Geography of Ancient and Medieval India. 2nd ed. Delhi: Motilal Banarsidass, 101).

${ }^{81}$ Gokhale, Balakrishna Govind. 1977. “The Merchant in Ancient India." Journal of the American Oriental Society 97.2, 125-130. Pāli jātaka commentaries (to be distinguished from the canonical verses) were composed by the fifth century CE.

${ }_{82}$ Rotman 2003: 35, fn. 41 lists 9 avadānas with accounts of merchant caravans or maritime journeys: Koțikarna-avadāna (no. 1), Pūrna-avadāna (no. 2), Supriyaavadāna (no. 8), Dharmaruci-avadāna (no. 18), Sahasodgata-avadāna (no. 21), Saṃgharakșita-avadāna (no. 23), Cüdapakșa-avadāna (no. 35), Mākandika-avadāna (no. 36), Maitrakanyaka-avadāna (no. 38). If the Mülasarvāstivāda-vinaya is dated after the time of Kanișka in the second century CE (although Schopen 2004: 20-22 suggests that it may belong to pre-Kuṣāna or early Kuṣāna periods prior to Kaniṣka), a relatively later date for the Divyāvadana in the 3rd-5th century seems likely. Rotman, Andy (translator). 2008. Divine Stories: Divyāvadāna. Boston: Wisdom Publications refers to a scholarly consensus for dating the text of the Divyāvadāna between 200-350 CE (6) and discusses its Mūlasarvāstivāda affiliation (15-19).

${ }^{83}$ The Avadānaśataka (edited by Speyer, J.S. 1906-9. Avadānaçataka: A century of edifying tales belonging to the Hinayāna. 2 vols. St. Petersbourg: Commissionnaires de l'Académie Impériale des Sciences; translated by Feer, Léon. 1891. Avadāna-Çataka: Cent légends bouddhiques. Paris: Musée Guimet (reprint, Amsterdam; APA-Oriental Press, 1979) includes a Sārthavāha-avadāna (no. 4) and a Śreșthī-avadāna (no. 48), along with other stories involving sārthavāhas (nos. 6, 11, 23, 24, 36, 77, 80, 81, 85, 86, 88), śresthīs or characters in their families, and maritime voyages. A date for the for- 
leaders and itinerant traders in petty commodities. In the Cüdapakșaavadāna (Divyāvadāna 35), for example, a poor servant is able to accumulate enough wealth through commercial transactions to become a rich merchant. Wealthy characters are not always portrayed favorably, since avarice (mätsarya) necessarily leads to misfortune. ${ }^{84}$

Many stories emphasize rewards to poor donors who give relatively small donations of whatever they possess with selfless intentions in order to illustrate the karmic results of generosity and to stimulate more elaborate donations by wealthier patrons. According to Dhammapāla's (Pāli) commentary on Vimānavatthu 1.1:

... even so little as a handful of rice-beans or a piece of rag or a spread of grass or leaves or a gall-nut in decomposing (cattle-) urine bestowed with devout heart upon a person who is worthy of receiving a gift of devotion will be of great fruit, of great splendor, and of great pervasiveness. (Falk 1990:140) $)^{85}$

Since these narratives illustrate karmic causation, birth into a wealthy family or into a powerful position is depicted as a positive result of donations given during previous lifetimes. Such positive valuations of wealth are certainly not unique to Buddhist literature, since Sanskrit and Prakrit didactic narratives in the Pañcatantra, Kathāsaritsāgara, and Jain traditions share thematic concerns with the karmic consequences of generous donations. However, normative dharmaśāstra and arthaśāstra texts assign merchants to a relatively low status, since their economic power is considered inferior to the ritual importance

mation the Sanskrit version before the 6th century CE (which differs from a Chinese translation in the 5th/6th century) is supported by analysis of Sanskrit manuscript fragments in the Schøyen collection: see Demoto Hahn, Mitsuyo, 2006. "Fragments of the Avadānaśataka." In Braarvig, Jens, ed. 2006, Buddhist Manuscripts 3. Oslo: Hermes Pub, 209-212. In the Mahāvastu (Senart, Émil, ed. 1882. Le Mahāvastu. 3 vols. Paris: Imprimerie nationale; Jones, J. J. trans. 1949. The Mahāvastu. London: Luzac) the Bodhisattva is a merchant in 7 out of 35 previous birth stories, according to Lewis, Todd. 2000. Popular Buddhist texts from Nepal: Narratives and rituals of Newar Buddhism. Albany: SUNY, 189, n. 3.

${ }^{84}$ The fifth decade of the Avadāna-śataka is a collection of stories about the karmic results of avarice.

${ }^{85}$ Falk, Nancy Auer. 1990. "Exemplary Donors of the Pāli Tradition." In Sizemore and Swearer 1990: 140 quotes the translation of Horner, I.B., trans. 1974. Vimänavatthu: Stories of the mansions. London: Pali Text Society, 1-2. This passage is also translated by Peter Masefield, assisted by N.A. Jayawickrama. 1989. Elucidation of the Intrinsic Meaning so named Commentary on the Vimāna Stories (Paramattha-dīpanī nāma Vimānavatthu-ațthakathā. Oxford: Pali Text Society, 11. 

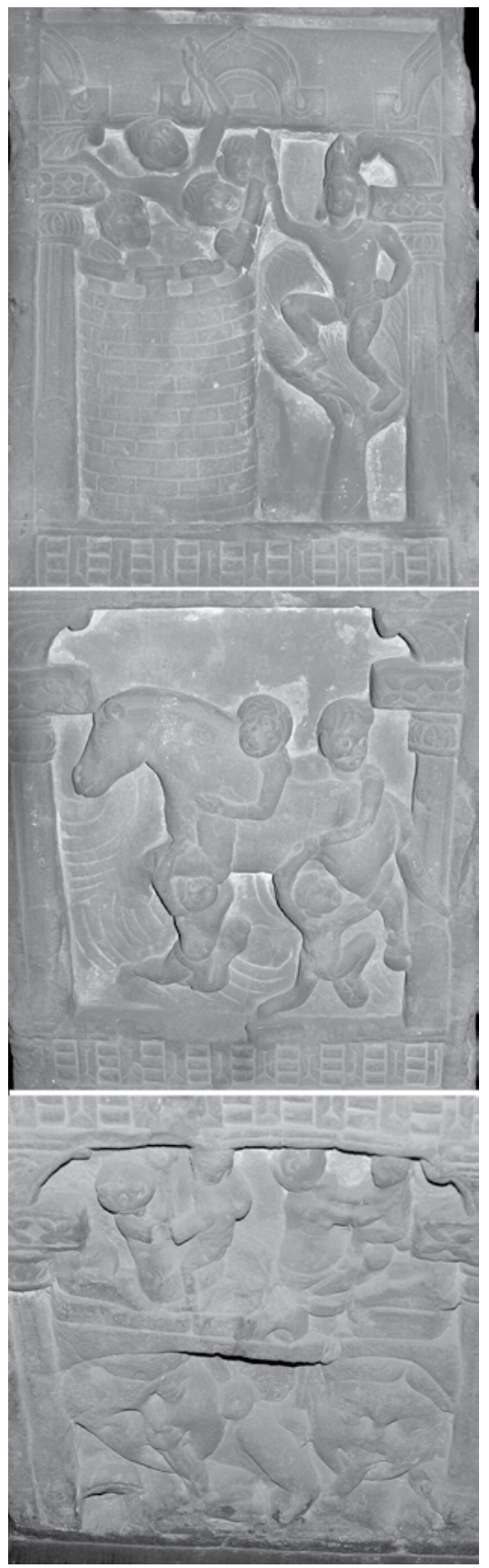

Figure 1.2. Simhala avadāna, Mathura sculpture, Indian Museum, Kolkata (author's photo). The middle of the panel depicts the rescue of merchants by a horse (Avalokiteśvara). 
of Brahmins and to the political authority of Kșatriyas. ${ }^{86}$ Rather than demeaning the value of material wealth, Buddhist literary viewpoints on merchants and trade implicitly acknowledge the necessity of receiving donations from prosperous patrons as well as other marginalized social groups.

The bodhisattva who rescues travelers from distress during overland and maritime journeys is also a significant fixture in Buddhist stories about merchants. H.P. Ray points out that while dharmaśästra rules forbid orthodox Brahmins from traveling by sea, "it is however in Buddhism that the notion of a protector who could be called upon in distress either by merchants traveling in caravans or by seafarers, developed into the ideal of a Bodhisattva" (1994: 153). Illustrations of seafarers in distress in Buddhist art from India and Central Asia (as in the so-called "cave of the swimmers" in Kizil) have been identified with Buddhist literary narratives. ${ }^{87}$ Narratives about bodhisattvas who rescue shipwrecked merchants and sailors in Sanskrit, Pāli, Gāndhārī, and other Buddhist literary sources demonstrate that the popularity of this motif, regardless of geographical orientation. For example, a Gāndhārī summary of a previous birth story of a bodhisattva (bosisatva-provayoge) who was a "merchant of the great ocean" ([sa]mudr[ava]nige) cast ashore when his ship was destroyed is similar but not exactly parallel to narratives about a bodhisattva merchant who gave up his own life to save the lives of his companions. ${ }^{88}$ Expanded versions of stories about merchants

${ }^{86}$ Gokhale 1977: 125-130 problematically links anti-mercantile attitudes with Indian feudalism, but dharmasütra and dharmaśästra texts reflecting such views generally belong to earlier periods in the late centuries BCE and early centuries CE than the time assigned to the emergence of feudalism after the Guptas. It is tempting to attribute the secondary status of merchants and traders to a social divide between conservative Brahmins belonging to rural village milieus and other groups in dynamic urban settings, but such a division is overdrawn since Brahmins (and the literature they produced) were not confined to the countryside. In general, religious condemnation of trade is minimal in Hindu culture compared with Christian and Islamic cultures (Laidlaw 1995: 325, referring to Jonathan Parry).

${ }^{87}$ Schlingloff, Dieter. 1987. Studies in the Ajanta Paintings: Identifications and Interpretations. New Delhi: Ajanta Books International, 195-218 (Chapter 22: "Ships and Seafaring"); Bell, Alexander Peter. 2000. Didactic Narration: Jätaka Iconography in Dunhuang with a Catalogue of Jätaka Representations in China. Münster: Lit includes helpful references to avadāna and jātaka illustrations from Bhārhut, Sāñcī, Mathurā, Gandhāra, Kizil, and Dunhuang, but the lists are not exhaustive.

${ }^{88}$ Lenz 2003: $150-157, \$ 11.2 .2$ (Pūrvayoga 1), with clarifications of the story based on an alternative reading of liyavido in place of liśavido by Oskar von Hinüber (review of Lenz 2003 in Journal of the American Oriental Society 124.4, 2004, 805). 
rescued from peril during difficult maritime journeys are connected with avadānas of Pūrṇa, ${ }^{89}$ Dharmalabdha, ${ }^{90}$ Maitrakanyaka, and Śronakoțikarṇa. ${ }^{91}$ The story of a caravan leader (sārthavāha) named Simhala who is rescued by a bodhisattva in the form of a horse (identified with Avalokiteśvara in Mahāyāna versions) from female ogres (rākșasiss) when shipwrecked on an island is retold in numerous Buddhist texts and artistic representations (fig. 1.2). ${ }^{92}$ The role of Avalokiteśvara as a savior of merchants in distress is elaborated in Mahāyāna sūtras, as illustrated by invocations in the Lotus Sūtra (Saddharmapundarikasūtra) to chant his name when ships are blown off course towards lands of rākșasas and when merchants are traveling on dangerous roads infested with robbers. ${ }^{93}$ Since Avalokiteśvara and other bodhisattvas who rescue travelers from distress have a spe-

89 Tatelman, Joel. 2000. Glorious Deeds of Pürna: a translation and study of the Pürnāvadāna. Richmond, Surrey: Curzon translates versions from the Divyāvadāna, Bodhisattvāvadānakalpalatā, Pāli commentaries, and the Chinese Mahāsamghikavinaya and discusses illustrations of the Pūrna story in in cave paintings at Ajantā and Kyzil. See also Tatelman, Joel. 2005. The Heavenly Exploits: Buddhist Biographies from the Divyāvadāna. vol. 1. Clay Sanskrit Library, New York University Press, 103-218 and Rotman 2008: 78-117 for more recent translations of the Sanskrit version of the Divyāvadāna (chapter 2).

${ }_{90}$ Liu 1988: 115 cites Mahāvastu (Senart 1882: 3.286-300; Jones 1949: 274-287).

${ }_{91}$ A version of the Śronakotịarna story in chapter 1 of the Divyāvadāna is translated by Tatelman 2005: 25-102 and Rotman 2008: 39-70.

${ }_{92}$ Schlingloff 1987: 256-264 regards the Mülasarvāstivāda-vinaya rather than a Pāli jātaka (no. 196) as the source of depictions of the Simhala avadāna at Mathurā and Ajanțā, as well as other versions in the Mahāvastu (Senart 1882: 3.67-76) and the Kāraṇdavyūha. Lienhard, Siegfried. 1985. Die Abenteuer des Kaufmanns Simhala: eine Nepalische Bilderrolle aus der Sammlung des Museums für Indische Kunst, Berlin. Berlin: Museum für Indische Kunst refers to parallels in Khotanese, Tibetan, Chinese, and Japanese Buddhist texts and depictions in the Buddhist art of Mathura, Ajanțā, Angkor, Borobudur, Central Asia, East Asia, and Nepal. For analysis of versions of the story that still circulate in Nepal, see Lewis, Todd. 1993. "Newar-Tibetan Trade and the Domestication of the Simhalasārthabāhu Avadāna." History of Religions 33.2, 135-160; Lewis, Todd. 1995. "Story of Simhala the Caravan Leader." In Lopez, Donald S., ed. 1995a. Buddhism in Practice. Princeton, N.J.: Princeton University Press, 153-169; Lewis 2000: 49-88 (chapter 3).

${ }_{93}$ Kern, Hendrik, and Bunyiu Nanjio, eds. 1912. Saddharmapundarīka. Bibliotheca Buddhica 10. St. Pétersbourg: Impr. de l'Académie Impériale des Sciences (reprint: Delhi: Motilal Banarsidass, 1992), 439.2- 441.7, translated from Sanskrit by Kern, Hendrik. 1884. Saddharmapundarika, or The Lotus of the True Law. Oxford: Clarendon press, 407-8 (reprint, New York, NY: Dover Publications, 1963) and from Chinese by Tsugunari Kubo and Akira Yuyama. 1993. The Lotus Sutra, Translated from the Chinese of Kumārajiva. Berkeley, CA: Numata Center for Buddhist Translation and Research, 311-2. Also see Schlingloff 1987: 175-180 (Chapter 18: “Avalokiteśvara the Saviour”) for connections between the painting of Avalokiteśvara in Ajanțā cave 2 and the list of 8 dangers described in the Lotus Sütra. 
cial appeal for traders and other devotees on long-distance journeys, it is not surprising to find them portrayed in petroglyphs and venerated in inscriptions at wayside shrines in the upper Indus region. ${ }^{94}$

In Pāli and Buddhist Sanskrit literature, the commercial epithet of "caravan leader" (sārthavāha) is applied to the Buddha in order to portray him in the role of a guide and protector of his followers on the journey across the worldly realm of samsära to the 'other shore' of nirvāna. ${ }^{95}$ In the Milindapañha, for example, Nāgasena explains to King Milinda that the Buddha "is like a caravan leader (Pāli: satthavāha) to men in that he brings them beyond the sandy desert of rebirths." ${ }^{\prime 96}$ The epithet of the Buddha as a "Great Caravan Leader" (Mahasarthavaha) also appears in a first century CE Buddhist reliquary inscription of King Senavarman of Oḍi (fig. 2.2), perhaps located in the Swat valley of northwestern Pakistan. ${ }^{97}$ Since the epithet of "caravan-leader" (satthavāha) is also given to the Yakșa Mānibhadra in a first century BCE inscription found near Kauśāmbī in northern India, ${ }^{98}$ a case could be made

${ }_{94}$ Hinüber, Oskar von. 1989b. "Buddhistische Inschriften aus dem Tal des oberen Indus.” In Jettmar, ed. 1989, 84-89, nos. 80-88, pls. 157-158, 163.

${ }_{95}$ Pāli references to the Buddha as satthavāha include Samyutta Nikāya 1.192: "So they attend on the victor in battle, the unsurpassed caravan leader-the disciples bearing the triple knowledge, who have left Death far behind" (Bodhi, Bhikkhu, trans. 2000. The Connected Discourses of the Buddha: A New Translation of the Samyutta Nikäya. vol. 1. Boston: Wisdom, 288), with a commentarial explanation that "He is the caravan leader (satthavāha) because he leads beings across the desert of samsära on the chariot of the Noble Eightfold Path" (463, n. 517). In the Mahàvastu, "caravan leader" occurs as an epithet of Siddhārtha (Senart 1883: 2.164.11) and as an epithet for a devotee who will become a Buddha by removing withered flowers from a shrine (2.393).

${ }^{96}$ Rhys-Davids, T.W., trans. 1890. The Questions of King Milinda. Sacred Books of the East, v. 35-36. Oxford: Clarendon Press (reprint, Delhi: Motilal Banarsidass, 1965), 274.

${ }_{97}$ The reading of line $4 \mathrm{~b}$ : te tasa bhagavato abhutapurușa-naravara-kujarasa mahasarthavah[o] is translated: "(this relic) of that lord, the wonderful person, best of men, the elephant, the great caravan-leader" by Salomon, Richard. 1986. "The Inscription of Senavarma, King of Odii." Indo-Iranian Journal 29.4, 270; Hinüber, Oskar von. 2003. Beiträge zur Erklärung der Senavarma-Inschrift. Abhandlungen der Geistes- und Sozialwissenschaftlichen Klasse, Jahrg. 2003, Nr. 1. Mainz: Akademie der Wissenschaften und der Literatur is the most recent edition and reading. For additional references to earlier publications of this inscription by Bailey (1980) and Fussman (1982) and a comparison of readings, consult CKI 249: http://www.ebmp. org/a_inscription.php?catid=CKI0249.

${ }_{98}$ Quintanilla 2007: 256-257 (Appendix 1, no. 5: 1.1. namo bhagavato 1.2. sathavāhasa 1.3. mänibhadasa...) interprets sathavāha as a title of the father of one of the donors instead of an epithet of Mānibhadra, as translated by Dineschandra Sircar: "Adoration to the Holy One, the leader (protector?) of caravans, Mānibhada!" 
that the Buddha was promoted as a superior tutelary figure for traders in an environment of inter-religious competition for surplus resources. Literary motifs of the Buddha and the Bodhisattva Avalokiteśvara as patron saints of caravan traders and narratives of merchants as donors to the Buddhist sangha reflect intimate connections between religious transmission and trade. While it is very difficult to glean a kernel of objective historical reality from Buddhist textual traditions, monastic authors employed commercial epithets, allusions to merchants, and laudatory references to traders to promote donative practices and to illustrate core doctrines of karmic retribution (with rewards for generosity and punishments for stinginess). By cultivating networks of commercial patrons as significant donors, whose roles are apparent in donative inscriptions and in the archaeological distribution of monasteries and stuppas on long-distance and regional routes between urban nodes, Buddhist institutions benefited from a basic structural impetus to exchange material gifts for religious merit. Having introduced ways in which literary discourses link commercial patronage to the accumulation of merit by merchants, who (along with other classes of donors) helped to supply the resources necessary for the expansion of the Buddhist sangha, the following section addresses the role of Buddhist institutions in the development of trade networks by reading between the lines of normative rules in monastic codes.

\section{Religious Economy of Buddhist Monasteries in Vinaya Literature}

Analysis of normative vinaya rules intended to regulate almost all aspects of monastic life and social interactions of monks and nuns with lay communities reveals many interesting details about monastic participation in commercial transactions and interactions with merchants involved in trading activities. The relevance of vinaya texts for investigating Buddhist patronage, material culture and everyday life has long been recognized, as Lamotte comments: "the Vinaya is an inexhaustible mine of curious and precise information on Indian life in general and that of the Buddhist monks in particular" (1988 [1958]: 167). The relative dating of codes belonging to separate lineages and various layers of these complex texts is still disputed, so scholars now hesitate to accept information gleaned from vinayas as an accurate reflection of socio-economic conditions during or shortly after the time of Sankyamuni. Many problems arise from a basic rule (common to all vinayas) specifying punishments for monks and 
nuns who handle gold and silver and engage in "buying and selling" (krayavikrayam). ${ }^{99}$ Myriad exceptions to this rule in vinaya texts such as the Mūlasarvāstivādin Uttaragrantha permit the monastic community to accept money, invest perpetual endowments, lend and borrow on interest, deal in commodities, and own servants and slaves. ${ }^{100}$ Based on rules for handling money in versions of vinayas preserved in Chinese translations, Jacques Gernet comments: "[I]t appears that commercial and financial activities were unevenly developed in the circles in which the Vinaya were compiled and that the various Buddhist sects adopted a more or less conciliatory attitude with regard to commerce" (1995 [1956]: 162). ${ }^{101}$ Although idealized views of Buddhist monks and nuns assume that rules restricting their possessions prevent economic engagement, the involvement of the saigha in the economic life of society is apparent. ${ }^{102}$ While lay officials with titles such as "monastery superintendents" (vihārasvāmin) and "legitimizers" (kalpikāra) acted as intermediaries for some transactions, Buddhist inscriptions recording permanent endowments and specific vinaya rules concerning the ways and means of financing residential Buddhist monasteries clearly indicate that monks and nuns participated in a range of economic

99 Juo-Hsüeh Bhikkhunī addresses monastic rules for handling money in "Who is Afraid of Gold and Silver? A Study of the Rule against Monetary Gifts in the Various Vinayas." In Gombrich, Richard and Cristina Scherrer-Schaub, eds. 2008. Buddhist Studies. Delhi: Motilal Banarsidass, 35-95. Problems in the interpretation of prescriptions against handling money are addressed by Gregory Schopen in 2000a. "The Good Monk and His Money in a Buddhist Monasticism of 'The Mahāyāna Period." Eastern Buddhist 32.1, 99-105 and 2001. "Dead Monks and Bad Debts: Some Provisions of a Buddhist Monastic Inheritance Law" Indo-Iranian Journal 44, 120-125 (= Schopen 2004: $12-15$ and 142-147).

100 Schopen 2000a: 103-105 (2004: 14-15) gives an expanded list of economic activities of Buddhist monks sanctioned in the Mülasarvāstivada-vinaya, which is the primary basis for Schopen's analysis in other articles collected in Schopen 2004.

101 Gernet, Jacques. 1995. Buddhism in Chinese Society: An Economic History from the Fifth to the Tenth Centuries. Translated by Franciscus Verellen. New York: Columbia University Press (Originally published as Gernet, Jacques. 1956. Les aspects économiques du bouddhisme dans la société chinoise $d u V^{e}$ au $X^{e}$ siècle. Saigon: Ecole française d'Extrême-Orient).

${ }_{102}$ Schopen, Gregory. 1994a. "Ritual Rights and Bones of Contention: More on Monastic Funerals and Relics in the Mülasarvāstivāda-vinaya." Journal of Indian Philosophy 22, 31-80 suggests that reluctance to acknowledge the commercial and financial roles of Buddhist monasteries may be related to Protestant or Romantic bias in the study of Buddhism: "Perhaps because of the Protestantization-or at least romanticization-of early Buddhism, we are not in the habit of thinking about the economic aspects of Buddhist monastic practice" (1994a: $56=2004: 307)$. 
activities. ${ }^{103}$ Some of the ways in which Buddhist 'renouncers' participated in commercial transactions at individual and institutional levels in spite of vinaya restrictions against handling gold and silver may be compared to the role of Roman Catholic clergy and monastic orders in the medieval European profit economy (after ca. 1050) despite vows of religious poverty and prohibitions of usury. ${ }^{104}$

Although monastic rules developed in the Sri Lankan Theravādin milieu do not necessarily apply more generally to other South Asian monastic communities, Pāli vinaya references to Buddhist monks traveling with caravans indicate that commercial and religious mobility often coincided. Rules attributed to the Buddha, such as "I allow you, monks, to enter on the rains in a caravan" and "I allow you, monks, to enter on the rains in a boat" 105 explicitly acknowledge that monks are allowed to travel with trade caravans during the rainy season retreat (Pāli vassavāsa). Provisions for expiation of offenses allude to monastic participation in commercial travel. ${ }^{106}$ For example, monks

${ }^{103}$ For several examples taken from the Uttaragrantha of the Mūlasarvāstivādavinaya, see Schopen 2001 (=2004: 122-169). Silk, Jonathan. 2008. Managing Monks: Administrators and administrative roles in Indian Buddhist monasticism. Oxford: Oxford University Press is a detailed study of lay and monastic administrative titles found in literary and epigraphic sources.

${ }^{104}$ Little, Lester K. 1978. Religious Poverty and the Profit Economy in Medieval Europe. Ithaca, NY: Cornell University Press examines the roles of various religious orders which adapted to an economic shift to a profit economy in the middle of the 11th century by establishing monasteries in rapidly growing cities (25), acting as monastic landlords (64), becoming involved in moneylending (65), using a "marketplace vocabulary" (200) to critique new moral problems associated with avaricewhich replaces pride as "the root of all evil"(36), and benefiting from the material support of patrons (203-205). Also see Stark 2005: 57-66 for a succinct overview of "The Rise of Religious Capitalism" although his arguments for linking the dominance of capitalism in Europe to 'rational' Christian theology (in juxtaposition to Islamic prohibitions of lending with interest) deliberately oversimplify much more complex historical and economic processes and ignore cases in which earlier religious movements (such as Buddhism) facilitated commercial trends without the leading to the results that he attributes to Christianity. Friedrich-Silber cautions that “... we must be careful not to project upon traditional monasticism as a whole a picture of economic expansion and "rationalization"” (1995: 144) and distinguishes the entrepreneurial successes of medieval Catholic monasteries from Theravāda monasteries in Sri Lanka (145).

${ }^{105}$ Horner, I.B., trans. 1938-1966. The Book of the Discipline. London: Luzac \& Co., vol. 4, 201 [1.152, \$3.12.2] (references in brackets indicate volume and page of the PTS edition by Oldenberg 1879, followed by chapter and paragraph divisions). This rule is also discussed by Bailey and Mabbett 2003: 62 and Ray 1994: 132.

${ }^{106}$ I am grateful to Mark Allon for suggesting that the Pâcittiyavagga is a rich source for rules concerning merchant caravans and monks. 
who arrange to travel with traders knowing that their purpose is robbery or tax evasion must admit their mistake, but "there is no offense if they go not having arranged" or if they do not realize that the caravan is going to engage in plunder or corruption. ${ }^{107}$ Another rule limiting donations from caravans is connected with a delay caused by excessive alms taken from a devotee (upāsaka) who was subsequently robbed when he set out to travel. ${ }^{108}$ These examples indicate that itinerant monks not only followed the same travel routes as long-distance traders, but often traveled together with them and solicited them for donations. This intermingling of monks and merchants on overlapping religious and commercial missions can be extrapolated to the journeys of other travelers, including Chinese pilgrims and envoys to India. ${ }^{109}$

Other vinaya regulations offer detailed instructions for the monastic community's involvement in commercial transactions. For example, the section on "Lodgings" (Sayanāsana) in the Cullavagga of the Pâli vinaya stipulates that valuable textiles given to monasteries could be traded for "(something) advantageous" in order to increase other provisions. ${ }^{110}$ Such "advantageous" exchanges allowed monasteries to acquire various commodities, such as produce necessary to feed visitors, including itinerant merchants. ${ }^{111}$ Xinru Liu's suggestion that "the Buddhist sangha provided valuable services for the traders" (1988: 122) may be compared to medieval European cloisters such as the St. Denis priory of Toury "where merchants and pilgrims found... a pleasant

107 Horner 1938-66: vol. 3, 15-17 [4.131-2, \$66.2]; Bailey and Mabbett connect this passage with the value of monks as impartial mediators, but the rebuke of a monk who "had travelled with a caravan which he knew was engaged in theft" (2003: 218) suggests that this rule was not only directed at dishonest monks, but also at limiting harm to the sangha's reputation through association with unscrupulous merchants.

${ }^{108}$ Horner 1938-1966, vol. 2, 322-2 [4.79, \$24.2].

${ }_{109}$ In addition to the journeys of Song Yun and Huisheng to Gandhara and Swat in 518-522 CE (Beal, Samuel, trans. 1884. Si-yu-ki. Buddhist records of the Western World. London: Kegan Paul, Trench, Trubner, lxxxiv-cviii), diplomatic exchanges between the Tang court and the rulers of Kanauj in northern India between 619-753 demonstrate the overlap of military and religious aims (Sen 2003: 16-21,34-44). While Xuanzang's meeting with King Harșavardhana of Kanauj initiated these exchanges, Wukong's pilgrimage journeys in India began with his participation in an official mission to Kapiśa, located in modern Afghanistan (Chavannes, Édouard and Sylvain Lévi 1895. "L'itinéraire d'Ou-k’ong (751-90)." Journal Asiatique 6 n.s. 9, 341-384).

${ }_{110}$ Horner 1938-66, vol. 5, 245 [2.174, \$6.19].

111 Schopen cites an episode in the Mülasarvāstivāda-vinaya in which the Buddha orders monks to sell rice to a visiting group of merchants, and comments "... being in one business, the business of attracting donors, required engaging in other businesses as well, like buying and selling grain” (2004: 33). 
reception" (Bloch 1961 [1939]: 1.64). ${ }^{112}$ Permanent endowments of tax-free landholdings to Buddhist monasteries lessened their dependence on donations from individual donors, to the extent that they were able to function as significant economic institutions. Medieval Sri Lankan monasteries, for example, controlled a significant proportion of the arable land and large irrigation networks, thus functioning as important economic as well as religious hubs. ${ }^{113}$

The intertwining of religious and economic networks stimulated material and ideological exchanges and processes of cross-cultural mobility. As monastic institutions expanded and consolidated support networks throughout Asia in the first millennium CE, the Buddhist sarigha facilitated commercial transactions long before medieval Catholic monasteries participated in the profit economy in Europe during the second feudal age. Buddhist monks and nuns were not just passive recipients of unreciprocated gifts restricted to basic necessities of food, clothing, shelter, and lodgings, but made their own donations of personal property to earn merit for themselves and their relatives while accumulating significant resources of land and portable wealth to sustain and strengthen the economic position of the corporate sangha. Rather than inhibiting trade and economic growth (as Weber assumed by contrasting the otherworldly asceticism of Asian renouncer movements with this-worldly asceticism of Protestantism), Buddhist religious economies based on symbiotic exchanges of material donations for religious merit stimulated the generation of surplus resources. By using merchant commercial metaphors, incorporating merchants into narrative motifs, and promoting the Buddha as a "caravan leader" and Avalokiteśvara as a patron and protector of merchants, the monastic authors who gave the "gift of dharma" (dharma-dāna) encouraged itinerant traders, financiers, and other donors to accumulate commodities, and profits, which could be generously given to the sangha in

112 Bloch, Marc L. 1961. Feudal Society. 2 vols. Chicago: University of Chicago (translated by L.A. Manyon from La société féodale. Paris: A. Michel, 1939-1949).

113 Gunawardana, Ranavira 1979. Robe and Plough: Monasticism and economic interest in early medieval Sri Lanka. Tucson: Published for the Association for Asian Studies by University of Arizona Press examines the economic and political position of Buddhist monasteries in medieval Sri Lanka. Also see Friedrich-Silber 1995: 86-87, who refers to the economic activity of "Sri Lanka's regime of monastic landlordism" as a transgression of interdictions against commerce, although a more thorough analysis of Pāli vinaya texts would reveal other allowances for institutional commercial transactions in addition to those cited here. 
exchange for more important religious goods. Patterns of movement by monks and nuns who were the primary religious agents of longdistance transmission overlapped considerably with the itineraries and commercial interests of commercial agents who generated the surplus wealth which was necessary to establish shrines and to sustain residential monasteries. Before mapping geographical and historical contexts for specific linkages between Buddhist networks of transmission and trade networks in the following chapters, a guide to methodologies for interpreting relevant primary sources serves as an inspection of the components of the vehicle (to borrow another Buddhist trope connected with mobile traditions).

\section{Sources and Methods for the study of Buddhist Transmission}

A synthesis of texts, inscriptions, and archaeological materials reveals patterns of Buddhist transmission which stand out in sharper relief when multiple sources are utilized for interpretation. Such an approach requires consideration of fundamental questions about how the primary sources related to the social and economic history of Buddhism:

1) What is the basis for situating these sources in chronological and geographical contexts? Addressing issues of time and place is necessary to discern the viewpoints of authors and producers of textual and material artifacts, as well as their audiences.

2) How does source analysis shed light on issues of institutional expansion, trade networks, and mobility? Is it possible to use evidence from religious sources to address questions about cultural, social, and economic contexts without reductionist oversimiplification?

3) How can internal Buddhist discourses illuminate historical processes of cross-cultural exchange, inter- and intra-religious dialogues, and shifting practices? While scholarly skepticism requires further questioning of emic claims of conversion narratives, for example, examination of underlying motives and assumptions can help to understand the practical and ideological concerns of Buddhist communities.

4) Can external sources be correlated with Buddhist sources to provide more comprehensive viewpoints on religious, historical, and economic contexts? 'Outside' sources include travel itineraries, 
coins and seals, and other written and visual materials that are not directly connected with monastic production.

5) Which etic perspectives in the academic study of Buddhism help to clarify relationships between sources, and which scholarly biases have clouded their interpretation? While the field of Buddhist Studies has inherited a tendency to privilege literary texts from the so-called Oriental Renaissance in the nineteenth century when scholars such as Eugène Burnouf initially identified common features in accounts of the Buddha's life, teachings, and community in Sanskrit, Pāli, and Tibetan texts, ${ }^{114}$ many recent scholars have challenged uncritical acceptance of this basic bias (which is certainly not unique to the study of Buddhism). ${ }^{115}$ Gregory Schopen characterizes this longstanding bias as a "Protestant Presupposition" in that Protestant reformers located religion in scripture rather than 'vulgar' external works and elevated doctrinal ideas over manifestations of devotion. ${ }^{116}$ Such methodological critiques are not intended to dismiss the importance of textual sources for illuminating key doctrines, but to seek answers to questions about material culture, religious practices, and socio-economic concerns by broadening inquiries to include a wider variety of literary discourses, epigraphic

114 Burnouf, Eugène. 1844. Introduction à l'histoire du bouddhisme indien. Paris: Imprimerie royale (translated by Katia Buffetrille and Donald S. Lopez, Jr. as Introduction to the History of Indian Buddhism. Chicago; London: University of Chicago Press, 2010). For appreciative accounts of Burnouf's contributions, see Schwab, Raymond. 1984. Oriental Renaissance: Europe's Rediscovery of India and the East, 1680-1880. New York: Columbia University Press, 1984 (translation by Gene Patterson-Black and Victor Reinking of La renaissance orientale. Paris: Editions Payot, 1950) and Yuyama, Akira. 2000. Eugène Burnouf: The Background to his Research into the Lotus Sutra. Tokyo: International Research Institute for Advanced Buddhology, Soka University. The contributions of other influential figures in the history of the discipline are described by de Jong, J.W. 1987. A Brief History of Buddhist Studies in Europe and America. Delhi: Sri Satguru Publications (2nd rev. ed.) and Silk, Jonathan. 2004. "Buddhist Studies." In Buswell, Robert, ed. 2004. Encyclopedia of Buddhism. New York: MacMillan Reference, vol. 1, 94-101.

115 Almond, Philip. 1988. The British Discovery of Buddhism. Cambridge: Cambridge University Press, 37; Lopez, Donald S., ed. 1995b. Curators of the Buddha: The study of Buddhism under colonialism. Chicago and London: University of Chicago Press, 6-7; Balagangadhara 1994: 133; Masuzawa 2005: 126.

116 Schopen, Gregory. 1991b. "Archaeology and Protestant Presuppositions in the Study of Indian Buddhism," History of Religions 31, 1-23 (= Schopen 1997a: 1-22). Kieschnick 2003: 20 traces a tendency to distinguish "scriptures as the source of spiritual insights" from religious artifacts as "outward things" to Mircea Eliade's dichotomy between sacred and profane. Lewis 2000: 167-177 criticizes an overemphasis on a limited range of "master texts" and a focus on scholastic doctrines, monastic concerns, and orthodox viewpoints at the expense of everyday practices. 
sources, and archaeological remains. While striving to avoid "the bugaboo of binary oppositions" (Swearer 2008: 109) ${ }^{117}$ between literary and material sources, élite scholasticism and popular practice, and the abstract thought and concrete practices, the goal here is to synthesize different genres of textual sources, epigraphic evidence, and archaeological materials, while acknowledging limits to their interpretation. The following outline of sources aims to introduce methodologies for approaching these valuable sources.

\section{Panorama of Buddhist Literature}

Texts belonging to Buddhist and non-Buddhist literary traditions contribute significantly to understanding social and historical contexts for various stages in the inception and expansion of Buddhism beyond South Asia. While traditional narratives touch on particular features, episodes, and themes in the transmission of the Buddha's teachings and the history of different communities, the complete story is not related in any one text or language. Instead of a unified account, versions of the "Buddha's words" (buddhavacana) were initially transmitted orally in multiple languages, and his followers were instructed to transmit his teachings "in their own dialects" (Pāli: sakāya niruttiya $).{ }^{118}$ Recovering the original words, teachings, language, or languages spoken by the Buddha is difficult if not impossible, since relatively late Pāli sources refer to the first written transmission of Buddhist texts in Sri Lanka only in the first century BCE. ${ }^{119}$ Information gleaned through philological comparisons of Buddhist texts preserved in different languages from separate periods is extremely valuable, but the normative ideals prescribed in Buddhist literature are not necessarily descriptions of historical reality (as indicated by the discussion of vinaya prohibitions against monetary transactions in the previous section). This cautionary

117 Donald Swearer cautions against “...privileging the epigraphic, the cultic, and the magical at the expense of the canonical text, the scholar-monk, and the philosophical" (Swearer, Donald. 2004. Becoming the Buddha: The Ritual of Image Consecration in Thailand. Princeton and Oxford: Princeton University Press), 109.

${ }_{118}$ Lamotte 1988 [1958]: 552-555; Brough, John. 1980. "Sakāya niruttiyā: cauld kale het.” In Bechert, Heinz, ed. 1980. Die Sprache der ältesten Buddhistischen Überlieferung. (= The Language of the Earliest Buddhist Tradition). Göttingen: Vandenhoeck und Ruprecht, 35-42 (reprinted in Brough, John. 1996. Collected Papers, ed. Minoru Hara and J.C. Wright. London: School of Oriental and African Studies, 461-468).

119 Norman, K.R. 1997b. A Philological Approach to Buddhism. London: School of Oriental and African Studies (revised ed. London: Pali Text Society, 2006), 99-121 (Chapter V: Buddhism and Writing). 
point about using literary sources does not exclude the possibility that Buddhist texts reflect practical details about the everyday lives of monks, nuns, and devotees, especially since such details reveal important viewpoints and attitudes.

Literature in Pāli is more extensive and accessible than other Indian Buddhist literary traditions largely due to its continuous use, reproduction, and preservation by Theravāda communities in Sri Lanka and Southeast Asia. The authoritative collection of texts into the "three baskets" (Tipitaka) along with important para-canonical texts, commentaries, and digests have been edited and translated into English in publications of the Pāli Text Society and electronic versions are available online. ${ }^{120}$ However, Pāli texts do not necessarily represent the oldest or relatively "pure" versions of the Buddha's teachings, since new material continued to be added to the "canon" until at least the fifth century $\mathrm{CE}$ during the time of Buddhaghosa's commentaries. ${ }^{121}$ Although the Theravāda tradition views Pāli as equivalent to Māgadhì, a vernacular language of northeastern India believed to have been spoken by the historical Buddha, scholars have convincingly demonstrated that Pâli is an artificial literary language more closely related to the languages of western India, with some features of other contemporary regional vernaculars and later Sanskritisms. ${ }^{122}$ Thus, a treatment of the early history of Buddhist transmission can not rely solely on Pāli texts, but must also engage with other South Asian Buddhist literary traditions.

The earliest Buddhist manuscripts (or South Asian literary texts in general) are not in Pāli, but in a related vernacular language of the Northwest called Gāndhārī. ${ }^{123}$ This regional language was written in the Kharoșthī script, which was used from the third century BCE in

${ }^{120}$ Pāli literature is surveyed by Hinüber, Oskar von. 1996. A Handbook of Pāli Literature. Berlin: Walter de Gruyter, 1996 (reprint, Delhi: Munshiram Manoharlal, 2001) and Norman, K.R. 1983. Pāli Literature, Including the Canonical Literature in Prakrit and Sanskrit of all Hinayāna Schools of Buddhism. Wiesbaden: Otto Harrassowitz. The Pāli Canon Online Database is available at: http://www.bodhgayanews. net/pali.htm (accessed 29 June, 2009).

${ }_{121}$ Norman 1997b: 139.

122 Oberlies, Thomas. 2003. "Aśokan Prakrit and Pāli." In Cardona, George and Dhanesh Jain, eds. 2003. The Indo-Aryan Languages. London/New York: Routledge succinctly lays out the evidence for the argument that "Pāli as we have it... is basically a language of western India" (166).

${ }_{123}$ Bailey, Harold W. 1946. "Gāndhārī.” Bulletin of the School of Oriental and African Studies 11, 764-797 is responsible for coining the name of this language, which had previously been termed Northwest Prakrit. 
Aśokan rock edicts in northwestern Pakistan to the fourth century CE in administrative documents from the southern Tarim Basin in Xinjiang. ${ }^{124} \mathrm{~A}$ single manuscript of an incomplete version of the Dharmapada in Gāndhārī found near Khotan in 1892 suggested that a more extensive Buddhist literature in Gāndhārī may have flourished, but until recently Kharoșthī inscriptions, coin legends, and other types of documents provided only tangential confirmation. ${ }^{125}$ The discovery of additional collections of birch-bark scrolls and fragments of Kharoșthi manuscripts acquired by the British Library, Robert Senior, Martin Schøyen, and the University of Peshawar in the 1990s confirms that Buddhist monastic communities in ancient Gandhāra composed, transposed, and preserved a significant corpus of Buddhist texts "in their own language." 126 While the general content of sūtras and verse

${ }^{124}$ Falk, Harry. 1993. Schrift im alten Indien: Ein Forschungsbericht mit Anmerkungen. Tübingen: Gunter Narr, 84-105; Salomon, Richard. 1998a. Indian Epigraphy: A guide to the study of inscriptions in Sanskrit, Prakrit, and Other Indo-Aryan languages. New York/Oxford: Oxford University Press, 42-56; Salomon, Richard. 2003a. "Writing Systems of the Indo-Aryan Languages." In Cardona and Jain 2003: 90-94. For the late survival of Kharosthin in biscript and triscript potsherd inscriptions from southern Uzbekistan and in biscript Tocharian documents from Kucha in Xinjiang perhaps dated to periods between the 5th-7th centuries CE, see Salomon, Richard. 2008b. "Whatever Happened to Kharosthī? The Fate of a Forgotten Indic Script." In Baines, John, John Benet, and Stephen Houston, eds. 2008. The Disappearance of Writing Systems: Perspectives on literacy and communication. London: Equinox, 139-155. Kharoșthī inscriptions are discussed in more detail below with epigraphic sources pp. 53-54.

125 Brough 1962: 43, 48-50.

126 Salomon, Richard. 1999a. Ancient Buddhist Scrolls from Gandhāra: The British Library Kharosthī Fragments. Seattle/London: University of Washington Press/ British Library is a general introduction to the British Library collection. For overviews of other recently discovered collections, see Salomon, Richard. 2002a. "Gāndhārī and the other Indo-Aryan languages in the light of newly-discovered Kharoșthī manuscripts." In Sims-Williams, Nicholas, ed. 2002. Indo-Iranian languages and peoples. Proceedings of the British Academy 116, 119-134; Salomon, Richard. 2003c. "The Senior Manuscripts: Another Collection of Gandhāran Buddhist Scrolls." Journal of the American Oriental Society 123, 73-92; Salomon, Richard. 2006. "New Manuscript Sources for the Study of Gandhāran Buddhism.” In Behrendt and Brancaccio 2006: 135-147. More recent discoveries in Bajaur are introduced by Nasim, Khan M. and M. Sohail Khan. 2004 (2006). "Buddhist Kharosthī Manuscripts from Gandhāra: A New Discovery." The Journal of Humanities and Social Sciences [Peshawar] 12, 9-15, and Nasim Khan, M. 2008. Kharoșthi manuscripts from Gandhara. Peshawar: M. Nasim Khan. For a more thorough overview of the Bajaur collection, see Strauch, Ingo. 2007-08. The Bajaur collection: A new collection of Kharoșthī manuscripts. A preliminary catalogue and survey (in progress reports available from http://www.geschkult. fu-berlin.de/e/indologie/bajaur/publication/index.html, accessed 29 June, 2009) and Strauch, Ingo. 2008. "The Bajaur Collection of Kharoșthī Manuscripts-a preliminary survey." Studien zur Indologie und Iranistik 25, 103-126. An online Bibliography of 
texts, Abhidharma commentaries, vinaya texts (in the Bajaur collection), summaries of Avadānas and Pūrvayoga stories of previous births, and some early or Mahāyāna texts (in the Schøyen and Bajaur collections) is not unexpected, published editions of some of these texts reveal interesting similarities with and differences between versions in other Buddhist languages. ${ }^{127}$ Early Buddhist texts in Gāndhārī fill gaps in knowledge of textual transmission between northern India, the northwestern borderlands, the silk routes of Central Asia, and China. ${ }^{128}$ Since these manuscripts have only recently become available, examples drawn from these texts receive considerable attention here.

In contrast to the regional use of Gāndhārī and the limited application of Pāli as the canonical language of the Theravāda tradition, Sanskrit was eventually adopted as the predominant language of panBuddhist transmission by the middle of the first millennium CE. Since the historical Buddha is understood to have instructed his followers to transmit his teachings in vernacular languages, the role of Sanskrit as a Buddhist literary language may seem paradoxical, as K.R. Norman remarks:

... Buddhism, which had started out as a revolt against the social and religious system which was exemplified by the use of Sanskrit for literary and religious purposes, now began itself to embrace Sanskrit as a medium for the propagation of the Buddhavacana. (1997: 95)

Gāndhārī Studies is available at http://www.ebmp.org/a_bibliography.php\#s. Allon, Mark, Richard Salomon, Geraldine Jacobsen, and Ugo Zoppi. 2006. "Radiocarbon Dating of Kharoșthì Fragments from the Schøyen and Senior Manuscript Collections." In Braarvig, ed. 2006: 279-292 address results of radiocarbon dating of some fragments. For futher analysis of these manuscript collections, see Chapter 4, subchapter: Gandhāran Material and Literary Cultures.

${ }_{127}$ Six volumes have been published in the Gandhāran Buddhist Texts series (GBT) edited by Richard Salomon: Salomon, Richard. 2000. A Gāndhārī Version of the Rhinoceros Sütra: British Library Kharoșthī Fragment 5B. GBT 1. Seattle/London: University of Washington Press; Allon, Mark. 2001. Three Gāndhārī EkottarikāgamaType Sütras: British Library Kharoșthī Fragments 12 and 14. GBT 2. Seattle/London: University of Washington Press; Lenz 2003 (GBT 3); Glass 2007a (GBT 4); Salomon, Richard. 2008a. Two Gändhārì manuscripts of the Songs of Lake Anavatapta (Anavatapta-gāthā): British Library Kharosthi fragment 1 and Senior Scroll 14. Seattle: University of Washington Press (GBT 5); Lenz, Timothy. 2010. Gandhāran Avadānas: British Library Kharoșthi fragments $1-3$ and 21 and supplementary fragments $A-C$. Seattle: University of Washington Press (GBT 6).

${ }^{128}$ Boucher, Daniel. 1998. "Gāndhārī and the Early Chinese Translations Reconsidered: The Case of the Saddharmapundarikasūtra." Journal of the American Oriental Society 118.4, 471-506. 
Oskar von Hinüber plausibly links the use of Sanskrit to the pragmatics of Buddhist expansion: "... as soon as Buddhism began to spread over a larger area, the development of a language widely understood became imperative" (1989c: 351). ${ }^{129}$ In a recent treatment of the "literarization" of Sanskrit, Sheldon Pollock argues that the Buddhist shift from resistance to appropriation of Sanskrit was connected to a broad expansion of the "prestige economy" (2006: 59) of Sanskrit, which was no longer restricted to religious purposes but was also used in royal eulogies and formal poetry. ${ }^{130}$ The adoption of Sanskrit in Buddhist literary texts parallels a transition in the languages of Indian inscriptions from Prakrit to "Epigraphical Hybrid Sanskrit" by the middle of the second century CE. ${ }^{131}$ Patterns of "Sanskritization" or insertion of Sanskritic features in Pāli, Gāndhārī, and other hypothetical "Buddhist Middle Indic" literary languages can be identified in varieties of mixed Sanskrit and Buddhist Sanskrit that Franklin Edgerton termed "Buddhist Hybrid Sanskrit."132 Buddhist Sanskrit texts range in literary

129 Hinüber, Oskar von. 1989c."Origin and Varieties of Buddhist Sanskrit." In Caillat, Colette, ed. 1989. Dialectes dans les littératures indo-aryennes: Actes du colloque international. Paris: Collège de France, Institut de civilisation indienne, 341-367.

130 Pollock, Sheldon. 2006. Language of the Gods in the World of Men: Sanskrit, culture, and power in premodern India. Berkeley: University of California Press, 51-59, 100.

${ }_{131}$ Lamotte 1988 [1958]: 577-580; Norman 1997b: 124-5; Salomon 1998a: 81-95. For the use of "epigraphical hybrid Sanskrit" in Buddhist, Jain, and other inscriptions in Mathura, see Damsteegt, Theo. 1978. Epigraphical Hybrid Sanskrit: Its Rise, Spread, Characteristics and Relationship to Buddhist Hybrid Sanskrit. Leiden: Brill.

${ }_{132}$ Edgerton, Franklin. 1953. Buddhist Hybrid Sanskrit Grammar and Dictionary. 2 vols. New Haven: Yale University Press. Edgerton proposed that Buddhist Hybrid Sanskrit [BHS] was an artificial literary language of Buddhist transmission, but his conclusions have been disputed by Lamotte (1988: 582), who distinguishes "mixed Sanskrit" from relatively standard "Buddhist Sanskrit." Oskar von Hinüber argues that "... a common Buddhist language, which may be called 'Buddhist Middle Indic' [was the] earliest literary language of Buddhism, from which Pāli and Buddhist Sanskrit branched off..." (1983a: 9) ("The Oldest Literary Language of Buddhism." Saeculum 34, 1-9 = Hinüber, Oskar von. 1994. Selected papers on Pāli studies. Oxford: Pali Text Society, 177-194). Hinüber compares features of "Middle Indic" languages in Das ältere Mittelindisch im Überblick. 2nd ed. Vienna: Verlag der Österreichischen Akademie der Wissenschaften, 2001 (1st ed. 1986). Norman distinguishes Middle Indo-Aryan [MIA] texts (particularly Pāli) with "Sanskritisms" inserted from texts translated from MIA into BHS and texts originally composed in BHS or Buddhist Sanskrit in "Buddhism and Sanskritisation" (chapter 6 of Norman 1997b: 124). In a survey of sanskritized epigraphic Gāndhārī and examples of non-sanskritized and sanskritized Gāndhārī manuscript fragments from the first to third centuries, Richard Salomon (2001. "'Gāndhārī Hybrid Sanskrit': New Sources for the Study of the Sanskritization of Buddhist Literature." Indo-Iranian Journal 44, 241-252) observes that "Buddhist literary Gāndhārī followed essentially the same path as that of the midland 
style from the Mahãvastu with archetypal features of Buddhist Hybrid Sanskrit (especially in verse sections) to classical Sanskrit in the epic poems (mahākāvyas) of Aśvaghoșa and learned treatises (śāstra) of Buddhist thinkers such as Nāgārjuna. ${ }^{133}$ Lamotte's observation that Buddhist authors who transposed passages from Buddhist languages into Sanskrit or composed texts in Sanskrit were not merely "repeaters" but could "add new to the old" (1988: 581) seems especially valid with regard to Mahāyāna sūtras, although recent identifications of Gāndhārī manuscripts of Mahāyāna texts complicate Lamotte's presupposed connection between Buddhist Sanskrit and Mahāyāna literature. ${ }^{134}$ Discoveries of Buddhist Sanskrit manuscripts in Xinjiang, Bamiyan (central Afghanistan), and Gilgit (northern Pakistan) dating from between the second and early eighth centuries $\mathrm{CE}$ and from later periods in Nepal and Tibet reflect the widespread persistence of Sanskrit as an important Buddhist literary language. ${ }^{135}$ Although versions of many Buddhist texts in Indic languages are no longer extant,

MIA dialects of Buddhism, which similarly became more and more sanskritized until, in effect, they turned into Sanskrit" (2001: 246-7). Also see Salomon, Richard. 1998b. "Kharosthī Manuscript Fragments in the Pelliot Collection, Bibliothèque Nationale de France." Bulletin d'études indiennes 16, 123-160 for analysis of Kharoșthī fragments in a "more or less Sanskritized variety of Gāndhārī" (1998b: 152) from Kucha in the northern Tarim Basin of Xinjiang.

${ }^{133}$ Brough, John. 1954. "The Language of the Buddhist Sanskrit Texts." Bulletin of the School of Oriental and African Studies 16.2, 351-375 (reprinted in Brough 1996: 130-154).

${ }^{134}$ Glass, Andrew. 2004. "Kharoșthī Manuscripts: A Window on Gandhāran Buddhism." Nagoya Studies in Indian Culture and Buddhism: Saṃbhāsāa 24, 129152 refers to Gāndhārī fragments in the Schøyen collection of the Bhadrakalpikasūtra, which Chinese and Tibetan traditions regard as a Mahāyāna text (2004: 141). Also see Strauch 2007-8 for reports on a Gāndhārī version of a text similar to the Aksobhyavyūhā-sūtra.

${ }^{135}$ A survey of recent discoveries of Buddhist Sanskrit manuscripts remains a desideratum, but helpful contributions include Sander, Lore. 1999. "Early Prakrit and Sanskrit Manuscripts from Xinjiang (second to fifth/sixth Centuries CE): Paleography, Literary Evidence, and Their Relation to Buddhist Schools.” In Zürcher, et al. 1999: 61-106; Hartmann, Jens-Uwe. 2004. "Buddhism along the Silk Road: On the Relationship between the Buddhist Sanskrit Texts from Northern Turkestan and those from Afghanistan." In Durkin, Desmond, et al. eds. 2004. Turfan Revisited: The first century of research into the arts and cultures of the Silk Road. Berlin: Reimer, 125-128; Kapstein, Matthew. 2003. “The Indian Literary Identity in Tibet.” In Pollock, Sheldon, ed. 2003. Literary Cultures in History: Reconstructions from South Asia. Berkeley: University of California, $755 \mathrm{ff}$.; and articles in Berkwitz, Stephen C., Juliane Schober, and Claudia Brown, eds. 2009. Buddhist Manuscript Cultures: Knowledge, ritual, and art. Milton Park, Abingdon, Oxon: Routledge. 
Chinese and Tibetan translations give scholars access to an extensive corpus of Buddhist literature. ${ }^{136}$

Relationships between Buddhist literary cultures can be discerned by studying patterns of textual transmission based on languages of Buddhist translation, relative chronologies, and distribution of manuscripts. Systematic selection, redaction, classification, and preservation of Buddhist texts in separate but related Pāli, Gāndhārī, Sanskrit, Chinese, and Tibetan collections reflect the choices made by monastic agents who were responsible for transmitting the Dharma to include or exclude certain ideas, values, and practices which they attributed to the normative sanction of the Buddha's words (buddhavacana). Rather than accepting traditional accounts of the codification of the Buddha's teachings in early communal recitations or 'councils' (sangitis) convened after his parinirvāna, differences between these collections show that fluid processes of generating Buddhist discourses considerably varied as monks and nuns belonging to separate ordination lineages moved from place to place with the expansion of the sangha. Instead of uncritically accepting what is transmitted in textual traditions as authoritative evidence for "what the Buddha taught," it is necessary to ask questions about why Buddhist authors and transmitters chose to feature particular narratives and individuals (such as stories about previous births of the Buddha and Bodhisattvas as merchants), doctrinal concepts, devotional rituals, meditation techniques, epithets, and formulae (which are sometimes found in epigraphs as well). Although definitive conclusions about imagined audiences, the role of host cultures in shaping the types of texts selected for transmission, translation, and (re-)composition, and the impact of economic and political forces

${ }^{136}$ The formation of Chinese and Tibetan collections of Buddhist literature is beyond the scope of this survey, but it is important to note that many apocryphal texts were not directly translated from Sanskrit or other Indic originals. Nattier, Jan. 2008. A Guide to the Earliest Chinese Buddhist Translations: Texts from the Eastern Han and Three Kingdoms Periods. Tokyo: International Research Institute for Advanced Buddhology, Soka University emphasizes that "... we should assume that any text translated in the second or third century CE was not based on Sanskrit, but rather on one or another of the many Prakrit vernaculars" (2008: 22). In a useful survey of Indian Buddhist literature preserved in Chinese and Tibetan, Paul Demiéville observed that in contrast to Pāli and Tibetan sources, "Dans le Canon chinois...toutes les écoles indiennes sont représentées par des traductions qui s'échelonnent sur près de dix siècles, du $\mathrm{II}^{\mathrm{e}}$ au XI ${ }^{\mathrm{e}}$ " (In Renou, Louis and Jean Filliozat, eds. 1947-1953. L'inde classique: manuel des études indiennes. Paris: Payot [reprint, Paris: École française d'Extrême-Orient, 2000]), vol. 2, 399). 
on the Buddhist literary milieu are difficult to reach, the effort to find intertextual connections can reveal links between Buddhist intellectual networks, which often produced manuscripts and other religious commodities at or near hubs for long-distance trade. A discrepancy between methods of interpreting literary and material sources commented upon by Nicola Di Cosmo with regard to the study of ancient Chinese history certainly also applies to the study of Buddhism:

The textual sources often refer to an inherited tradition and, in any case, incorporate the thought process of their authors; the material evidence (as a body) is relatively accidental, and its interpretation and usefulness depend on the questions asked by modern scholars. (2002: 3$)^{137}$

This investigation aims to bridge the gap by taking both potential sources of evidence into account in order to find common patterns of cross-cultural transmission.

\section{Buddhist Inscriptions: Epigraphic markers of transmission}

Inscriptions offer unique perspectives on the study of trade networks and Buddhist transmission, but they have been underutilized in comparison to literary sources. ${ }^{138}$ Inscriptions are typically used to corroborate textual references, but disagreements between the two types of sources can result in an "awkward situation" in which epigraphic and archaeological sources "... have to sit quietly in the corner spinning cloth for the emperor's new clothes" (Schopen 1991b [1997a]: 3). ${ }^{139}$ Richard Salomon comments:

The resolution of such conflicts is no simple matter, but there can be no question that in Buddhological studies as a whole the testimony of inscriptions has not generally been given the weight it merits, and that the entire field of the history of Buddhism, which has traditionally been

137 Di Cosmo, Nicola. 2002. Ancient China and its Enemies: The Rise of Nomadic Power in East Asian History. Cambridge, UK, New York: Cambridge University Press.

138 Tsukamoto, Keisho. 1996-. Indo Bukkyō himei no kenkyū (A Comprehensive Study of the Indian Buddhist Inscriptions). 3 vols. Kȳoto-shi: Heirakuji Shoten is not exhaustive, but does provide useful bibliographic references, notes, and maps; Hazra, Kanai Lal. 2002. Buddhism and Buddhist Literature in Early Indian Epigraphy. New Delhi: Munshiram Manoharlal is rather eclectic and unreliable.

${ }^{139}$ Chattopadhyaya, Brajadulal. 1994. Making of Early Medieval India, Delhi: Oxford University Press makes similar remarks in regard to early medieval Rajasthan: "epigraphic evidence, while it may not always contradict the evidence of literary texts... does not happily blend with the evidence of such texts either" (1994: 90). 


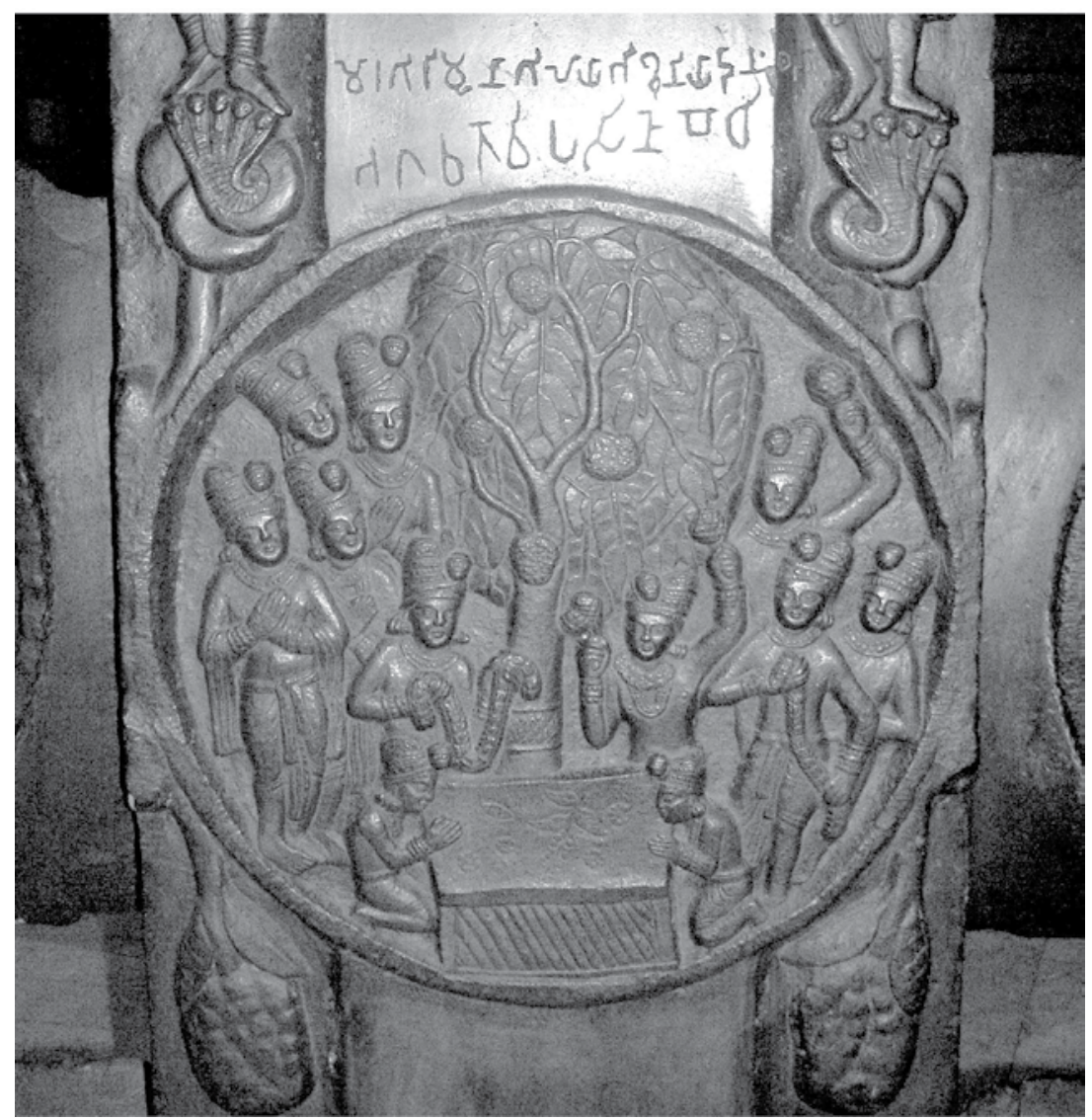

Figure 1.3. Bharhut Pillar donated by Bhikșuṇi Nāgilā (author's photo). The scene below the donative inscription is labeled as the Bodhi tree of "Blessed Vipasi" (previous Buddha Vipaśyin).

dominated by a strongly text-oriented approach, must be reexamined in this light (1998a: 242).

Gregory Schopen provocatively argues that epigraphic material “...predates what we can definitely know from literary sources..." and more accurately depicts "... what a fairly large number of practicing Buddhists actually did" (1997a [1985a]: 30). Buddhist inscriptions typically provide enduring written records of merit for donors who gave various items to monastic communities. Among the inscriptions from the stone railing that surrounded the stūpa at Bharhut, located in central India on overland routes between the Ganga-Yamuna doāb to the 
north and the Deccan peninsula to the south, are several recording donations of pillars, such as this example:

Pillars (thabhā), the Gift of Bhikhunī Nāgilā from Moragiri. (fig. 1.3)

This donative inscription, which is written above another label inscription in a different hand identifying the Bodhi tree of the previous Buddha Vipaśyin, ${ }^{141}$ indicates that the donor of this carved stone pillar was a Buddhist nun who came to Bharhut from Moragiri (Sanskrit: Mayūragiri), which, along with the inscriptions of donors from Vidiśā and Pātaliputra, demonstrates significant mobility on routes passing through Bharhut in the 2nd-1st century BCE. ${ }^{142}$ An inscription from Mathura in northern India recording a gift of a pillar by a monk named Jivaka, who was originally from Uḍ̣iyāna, or the Swat valley in northwestern Pakistan, provides another example of mobility and circulation between monastic communities around $300 \mathrm{CE}$ :

In the year 77 , in the 4 th (month) of summer, on the 4th day, in the monastery of Mahārāja Rājātirāja Devaputra Hūvisska the gift of the monk Jivaka, the Oḍiyanaka (native of Uḍḍiyāna), (consisting in) pillarbase 25. May welfare and happiness of all sentient beings prevail. To the community of the four quarters. ${ }^{143}$

Many donative inscriptions also give important details about the titles of nuns and monks and the identity of their ordination lineages, thus illustrating the geographical distribution of mainstream Buddhist schools and Mahāyāna affiliations of individuals in particular areas in certain periods. ${ }^{144}$ For instance, two inscriptions at Bodh Gaya record donations of a shrine and an image of the Buddha by a Sri Lankan

${ }^{140}$ Lüders, Heinrich. 1963. Bharhut inscriptions. Corpus Inscriptionum Indicarum, v. 2, pt. 2. Ootacamund: Government Epigraphist for India, 25, no. A 29 (pl. 5) reads: moragirimha nāgilāya a bhikhuniyā dānam thabhà (thabhā is not visible in my photograph).

${ }^{141}$ Lüders 1963: 82, no. B 13 (pl. 33): bhagavato vipasino bodhi.

${ }^{142}$ Hawkes, Jason. 2009. "The Wider Archaeological Contexts of the Buddhist Stūpa Site of Bharhut." In Hawkes and Shimada 2009: 146-174 suggests "There would, in fact, seem to have been a conscious effort on the part of the monastic community to establish the site in relation to these routes" (2009: 161). The location of Bharhut within a network of interregional routes is discussed in Chapter 3 within the subchapter on the Southern Route (Daksinapatha) pp. 211-212.

${ }^{143}$ Lüders 1961: 68, no. 62, $\$ 31$.

${ }^{144}$ Lamotte 1988 [1958]: 523-528; Schopen, Gregory. 1979. "Mahāyāna in Indian Inscriptions." Indo-Iranian Journal 21, 1-19 (reprint, Schopen 2005: 223-246); Shastri, Ajay Mitra. 1965. An Outline of Early Buddhism: A historical survey of Buddhology, Buddhist schools \& Sanghas mainly based on the study of pre-Gupta inscriptions. Varanasi: Indological Book House, 42-111. 
monk (sthavira) named Mahānāman, whose title of śäkyabhikșu and donative formula are employed widely but not exclusively in Mahāyāna inscriptions of this period (6th century $\mathrm{CE}$ ):

Om! This is the religious offering (deyadharmmo'yam) of the Sākyamonk (śäkyabhikșu), the Elder (sthavira) from Āmradvipa (Sri Lanka), Mahānāman. May whatever merit there is (in this gift) be for the attainment of supreme knowledge by all beings. ${ }^{145}$

Buddhist records of donations of material items provide concrete information about the daily life of monastic residents and their interactions with a wide range of patrons, including but not limited to rulers, administrators, merchants, craftsmen, and (significantly) their wives and daughters. This record of a lay female devotee (upassikā) named Harisvāminī in 450-451 CE illustrates her patronage of a monastery at Sāñcī, which she supported with a perpetual endowment (akșayanìvi) of coins for maintaining lamps to illuminate images of the Buddha and the four previous Buddhas, with directions that the merit of her act be directed to her parents:

By the female lay devotee Harisvāminī, the wife of the male lay devotee Sanasiddha, having directed (the merit) to her parents, these twelve coins (dināras) are given as a perpetual endowment to the noble saingha of the four directions at the great monastery (mahāvihāra) of Kākanādaboța (Sāñci).... With the increase (of interest) on one coin given to the throne of the four Buddhas a lamp of the blessed Buddha is to be lit daily at the throne of the four Buddhas... ${ }^{146}$

An enormous corpus of graffiti inscriptions from the Upper Indus region in the modern Northern Areas of Pakistan discovered only recently since the construction of the Karakorum Highway merits attention in Chapter 5, since these epigraphic sources record the movement of visitors on routes between the frontiers of South and Central Asia.

${ }^{145}$ Fleet, John Faithful. 1888. Inscriptions of the Early Gupta Kings and their Successors. Corpus Inscriptionum Indicarum, v. 3. Calcutta: Printed by the Superintendent of Government Printing, India (2nd rev. ed. Varanasi: Indological Book House, 1963), 274-279, nos. 71-72 (pl. 41A-B); for the first inscription, also see Sircar, Dineschandra. 1983. Select Inscriptions bearing on Indian History and Civilization: from the sixth to the eighteenth century AD. Vol. 2. Delhi: Motilal Banarsidass, 56-58, no. 12: Bodhgayā Inscription of Mahānāman, (Gupta) year 268 (587 AD).

${ }^{146}$ Fleet 1888: 260-262, no. 62 (pl. 38B); Majumdar, Nani Gopal. "Inscriptions" in Marshall, John Hubert, A. Foucher, and Nani Gopal Majumdar. 1940. The monuments of Sāñchi. London: Probsthain, 389-390, no. 834 (pl. 130, 105). 
Since Indian epigraphic sources for the study of trade and transmission receive considerable emphasis in this study, additional background information about the historical development of writing systems and languages will be helpful. Rock edicts and other inscriptions of the Mauryan emperor Aśoka provide the first definite attestations of the Brāhmī and Kharoșthī scripts in the middle of the third century BCE. ${ }^{147}$ Brāhmī was widely used for writing Buddhist inscriptions in Prakrit regional vernacular languages in the post-Mauryan period throughout most of the Indian subcontinent. As Sanskrit gradually eclipsed regional Prakrits in northern Indian inscriptions in the early centuries CE (as already discussed), regional styles of Brāhmī develop. ${ }^{148}$ After a period of overlap in the third to fourth century CE, Brāhmī replaced Kharoșthi in the Northwest as well, so that the vast majority (approximately eighty percent) of graffiti inscriptions from the Upper Indus region is written in Brāhmi from about the fourth to seventh centuries CE. Other scripts derived from regional varieties of Brāhmī were eventually adopted for writing South Asian languages as well as nonIndic languages in Southeast Asia, Central Asia, and Tibet. ${ }^{149}$ Just as the use of Sanskrit linked widespread Buddhist communities within and outside of India proper, so also the broad dissemination of writing systems based on Brāhmī probably facilitated communication.

${ }^{147}$ Hultzsch, E. 1925. Inscriptions of Aśoka. New Edition. Corpus Inscriptionum Indicarum, vol. 1. Oxford: Clarendon Press (reprint, New Delhi: Archaeological Survey of India, 1991) remains a standard reference, but more recent discoveries and advances in the field have been compiled by Falk, Harry. 2006. Aśokan Sites and Artefacts: A Source-book with Bibliography. Mainz: P. von Zabern. Discoveries of Brāhmī graffiti on potsherds from Anuradhapura in Sri Lanka in strata from the 4th-5th centuries BCE have led some scholars to question whether Aśokan edicts preserve the earliest forms of Brāhmī (Allchin 1995: 178-181). Falk (1993: 205-218), however, argues that internal developments in the Brāhmi script point to northern India as the place of its origin. Hazra (2002: 24-60) devotes a chapter to pre-Mauryan period inscriptions, but the early Brāhmī inscriptions on the Piprāwā vase and the Mahāsthān stone plaque cannot be dated with any certainty before the inscriptions of Aśoka. For additional comments on the origins and antiquity of Brāhmī and Kharoșthī, see Salomon 1998a: 10-31 and Salomon 2003a: 85-93. See Chapter 2: Legacy of the Mauryans: Aśoka as Dharmarāja (pp. 78-94) for historical details and analysis.

148 Dani, Ahmad Hasan. 1963. Indian Palaeography. Oxford: Clarendon Press (2nd ed. New Delhi: Munshiram Manoharlal, 1986) remains a very helpful reference for the regional differentiation of Brāhmī scripts.

${ }_{149}$ Salomon, Richard. 1996a. "South Asian Writing Systems." In Daniels, Peter T., and William Bright, eds. 1996. The World's Writing Systems. New York: Oxford University Press, 371-431. For the development of the Tibetan writing system from Siddhamātrọkā, see van der Kuijp, Leonard. 1996. "The Tibetan Script and Derivatives." In Daniels and Bright, eds. 1996: 431-441. 
In contrast to Brāhmī, which was widely used in Buddhist and nonBuddhist inscriptions, manuscripts, and other materials in numerous languages, the Kharoșthi script was reserved almost exclusively for writing Gāndhārī, a northwestern Prakrit which served as an important Buddhist literary language in early manuscripts. The geographical range of Kharoșțī radiated outwards from ancient Gandhāra (where Aśokan edicts in Kharoșțī at Shahbazgarhi and Mansehra in modern Northwest Pakistan are the earliest examples) to the Punjab and northwestern India (including Mathura), and throughout Afghanistan to southern Tajikistan and Uzbekistan in the Oxus/Amu Darya watershed, and extended to the Tarim Basin in modern Xinjiang. Kharoșthi inscriptions generally record Buddhist donations of reliquaries, sculptures, and a variety of other objects, but the use of Kharoșthi for writing visitors' inscriptions, coin legends, and administrative documents indicate that the script was utilized for secular as well as for religious purposes. ${ }^{150}$ A gradual transition from Kharoșthī to Brāhmī in the third to fourth century reflects the decline of Gāndhāri and the transition to Sanskrit as the primary language of Buddhist transmission between the northwestern frontiers of South Asia and the silk routes of Central Asia.

An extensive range of written materials in addition to Buddhist inscriptions in Brāhmī and Kharoșțhì shed valuable light on crosscultural interactions. Graffiti inscriptions at sites in the Upper Indus region of northern Pakistan written in South Asian languages and scripts (including Proto-Saaradā, a closely related script which replaced Brāhmī in the seventh century in Northwest Pakistan and Kashmir) as well as Middle Iranian (particularly Sogdian, but also Bactrian), Chinese, and Tibetan certainly reflect transregional movements in a

${ }^{150}$ Earlier discoveries (before 1929) of Kharoșthī inscriptions were edited by Konow, Sten. 1929. Kharoshthì Inscriptions with the exception of those of Aśoka. Corpus Inscriptionum Indicarum, vol. 2, part 1. Calcutta: Government of India, 1929 (reprint, New Delhi: Archaeological Survey of India, 1991) and Central Asian Kharosthīi documents were edited by Boyer, A.M., E.J. Rapson, and E. Senart. 1920-1929. Kharosthi Inscriptions Discovered by Sir Aurel Stein in Chinese Turkestan. 3 vols. Oxford: Clarendon Press (reprint, Delhi: Cosmo Publications, 1997). Subsequent discoveries of 69 additional Kharoșthī inscriptions are referred to by Fussman, Gérard. 1989a. "Gāndhārī écrite, Gāndhārī parlée." in Caillat, ed. 1989: 433- 501. Publications of Central Asian documents are updated by Lin, Meicun. 1996. "Kharosthī Bibliography: The Collections from China (1897-1993)." Central Asiatic Journal 40, 188-220. Baums and Glass. For current updates on recent discoveries and publications, the Catalog of Kharoșthi Inscriptions (CKI) is available online at: http://www.ebmp.org/a_inscriptions.php. 
multilingual environment. As explicitly Buddhist inscriptions from this area make up a relatively small proportion of the graffiti, nonBuddhist inscriptions can indicate important details about cultural and regional identities and shed light on interactions with foreigners from outside of the Indian subcontinent and with local indigenous inhabitants and their religious beliefs. Visitors' graffiti with proper names, records of donations of petroglyph images as "religious offerings," and label inscriptions invariably provide more information about religious practices rather than doctrinal ideals. When inscriptions are found in situ (as in the case of graffiti or excavated written materials) or if the find-spot is known, the evidence from epigraphic sources can be situated in particular places with much greater security than information gleaned from literary sources. Formulae of dated inscriptions with references to historical eras and palaeographic analysis of written characters permit the chronological range to be narrowed down with greater certainty than is possible for textual traditions. Unlike literary sources, inscriptions retain their original form without selective emendation through processes of editorial transmission. Despite the difficulties of incomplete preservation and limited scope due to the repetition of formulaic patterns, the treatment of inscriptions is given significant weight in this study because epigraphic materials offer useful perspectives on Buddhist practices, patterns of mobility, and everyday concerns of individual agents of transmission in specific places and times.

\section{Archaeological Sources: Material Contexts for the Establishment of Buddhism}

Archaeological materials arguably provide the most tangible evidence for Buddhist mobility by demonstrating localization of Buddhist presence and movement of artifacts, images, and coins from one region to another. Early Buddhist art and archaeology amply demonstrate that the presence of the Buddha was localized at stuppas, which functioned as memorial mounds for the bodily relics of Sākyamuni Buddha (or objects and events linked to his hagiographical accounts), previous Buddhas, Bodhisattvas, prominent followers, and narratives of former lives. ${ }^{151}$ Veneration of stupas was the primary way worshipping the

${ }^{151}$ Now see Hawkes and Shimada, eds. 2009 for alternative approaches to those in Dallapicola, Anna Libera, and Stephanie Zingel-Avé Lallemant, eds. 1980. The Stūpa: 
Buddha at particular places, where his presence was localized. Stūpas are identifiable by ubiquitous architectural features ranging from a basic platform (medhi) with a dome (anda) surmounted by a row of disks (chattrāvalī) to much more elaborate structures surrounded by decorated railings and elaborate gateways, staircases up multiple terraced levels to paths for circulation around the central dome, and pillars, niches, and detailed superstructures. Excavations of stuppas frequently reveal chronological stages of construction and reconstruction involving enlargement of the early core, renovations with new materials, and expansion of the complex with addition of elements as veneration and patronage increased. Mortuary patterns of burial 'ad sanctos' in which smaller subsidiary stūpas with anonymous deposits of bones and ashes of monastic devotees and lay followers surround the central stūpa indicate that physical proximity to the remains of the Buddha had special significance for devotees. ${ }^{152}$ As stupas function as the pre-eminent archaeological indicators of devotional practices for worshipping the Buddha, these shrines supply valuable evidence for discerning levels of transmission in a given area.

The religious function of Buddhist stupas is directly connected to the worship of different types of relics, which establish the "actual living presence of the Buddha" (Schopen 1997a [1987a]: 134). ${ }^{153}$ According to versions of his final days in the Mahāparinirvāna sūtra, Sākyamuni’s explicit instructions that his bodily relics (śarira) were to be placed in stüpas at crossroads following the customary burial practice for a ruler

Its Religious, Historical and Architectural Significance. Wiesbaden: Franz Steiner. Also see Brown, Robert L. 1986. "Recent Stupa Literature: A Review Article." Journal of Asian History 20, 215-232; Fussman, Gérard. 1986b. "Symbolisms of the Buddhist Stūpa." Journal of the International Association of Buddhist Studies 9.2, 37-53, and De Marco, Giuseppe . 1987. "The Stūpa as a Funerary Monument: New Iconographical Evidence." East and West 37, 191-246. Kevin Trainor (1997) provides a very useful overview of scholarly literature on stüpas and the closely related term caitya (particularly from the perspective of Pāli literary sources) in Relics, Ritual, and Representation in Buddhism: Rematerializing the Sri Lankan Theraväda Tradition. Cambridge: Cambridge University Press, 32-65, 96-117.

${ }_{152}$ Schopen, Gregory. 1987a. "Burial Ad Sanctos and the Physical Presence of the Buddha in Early Indian Buddhism: A Study in the Archaeology of Religions." Religion 17, 193-225 (= Schopen 1997a: 114-147) and Schopen, Gregory. 1994b. "Stūpa and Tirtha: Tibetan Mortuary Practices and an Unrecognized Form of Burial Ad Sanctos at Buddhist Sites in India." In Skorupski, T. and Ulrich Pagel, eds. 1994. Buddhist Forum III. London: School of Oriental and African Studies, 273-293 (= Schopen 2005: 350-369).

${ }^{153}$ Schopen, Gregory. 1998. "Relics." In Taylor 1998: 256-268 makes additional comparisons with Christian conceptions of relics as living entities. 
(cakravartin) directly connect the relic cult to the construction of stūpas (and monasteries) near junctions of trade and travel routes. ${ }^{154}$ The portability of Buddhist relics across Asia is attested widely in archaeological finds, and materials from relic deposits serve as historical data for practices central to the establishment and transmission of Buddhism. ${ }^{155}$ Epigraphic and textual evidence confirms that the merit resulting from the establishment of relics in stüpas in new areas was a powerful incentive for localizing the presence of the Buddha and expanding Buddhist sacred geography. ${ }^{156}$ John Strong emphasizes that "... relics came to be seen not just as spreaders of the presence of the Buddha, but also as exotic emblems of this new religion of Buddhism-something that Brahmanism, Confucianism, or Shintō did not have" (2004a: 232).

${ }^{154}$ Przyluski, Jean. 1936. "Le partage des reliques du Buddha." Mélange chinois et bouddhiques 4, 341-67; Schopen, Gregory. 1991a. "Monks and the Relic Cult in the Mahāparinibbāna-sutta: An Old Misunderstanding in Regard to Monastic Buddhism." In Shinohara, Koichi and Gregory Schopen, eds. 1991. From Benares to Beijing: Essays on Buddhism and Chinese Religion, Koichi Shinohara and Gregory Schopen. Oakville, Ontario: Mosaic Press, 187-201 (= Schopen 1997a: 99-113).

${ }^{155}$ John Strong 2004a examines worship of various types of Buddhist relics and connected narratives in South and Southeast Asia. Articles on Buddhist relic veneration in Sri Lankan, medieval Indian, Thai, Tibetan, Japanese, and other contexts appear in Germano, David and Kevin Trainor, eds. 2004. Embodying the Dharma: Buddhist Relic Veneration in Asia. Albany: State University of New York. Skilling, Peter. 2005. "Cutting Across Categories: Relics in Pāli Texts, the Bhadrakalpika-sūtra, and the Saddharmapundarika-sütra." Annual Report of the International Research Institute for Advanced Buddhology at Soka University 8, 269-332 assesses an extensive range of textual discussions of relics, on which he bases his argument that "the cult of relics is central to all Buddhisms" and links the history of Buddhism to the history of relics. Also see Cribb and Errington 1992: 172-197, catalogue nos. 169-196, Kieschnick 2003: 29-52, and Sen 2003: chapter 2.

${ }^{156}$ Kevin Trainor (writing about relic veneration in Sri Lanka) emphasizes the locative aspect of relic worship: "The power of the relic to identify particular locations as centers of sacrality, that is, to create places of powerful religious significance, constitutes one of the distinctive functions of the relic cult in the Buddhist tradition" (1997: 97). John Kieschnick (focusing in the relic cult in Chinese Buddhism) connects the "portability of relics" to proselytization: "...the portability of relics, a tangible way of transporting Buddhist devotional practices and concomitant religious doctrines to new regions, was well suited to the Buddhist proclivity for proselytizing (2003: 30). Salomon, Richard and Gregory Schopen. 1984. "The Indravarman (Avaca) Casket Inscription Reconsidered: Further Evidence for Canonical Passages in Buddhist Inscriptions." Journal of the International Association of Buddhist Studies 7, 107-123 have found that donative formulae in Kharosthi reliquary inscriptions from the early first century CE and in textual passages from the Gilgit Sanskrit manuscript of the Sanghabhedavastu and the Ekottarāgama quoted by Yaśomitra in his Abhidharmakośa commentary refer to the "Brāhma merit" generated by the establishment of relics in a "previously unestablished place." 
This study expands upon contributions to the study of relics and Buddhist devotional rituals, regional history, and religious symbolism by situating archaeological and epigraphic evidence for relic veneration in economic contexts of long-distance trade networks.

The concept of a relic extended beyond physical relics (śarira) to materials that had been contacted by the Buddha or could be used to commemorate his life and teachings. Relics of commemoration are added relatively later to Pāli literary classifications, but the observation by Michael Willis that "the three relic types... should be taken as points on a sliding scale which to some extent allowed one type of relic to be substituted and transformed into another" (2000:16) points towards structural incentives for expanding relic categories. ${ }^{157}$ The "sliding scale" of relics was eventually broadened to include textual materials regarded as "dharma relics" (such as manuscripts, inscriptions, seals, dhāraṇīs, etc.). ${ }^{158}$ Mahāyāna Buddhist traditions associated with the "Cult of the Book" (as Gregory Schopen terms a range of practices calling for the worship of sütra texts) regard such textual relics as the "Dharma body" (dharmakâya), which some polemic discourses claim are superior to other forms of worshipping the Buddha's physical body. ${ }^{159} \mathrm{~A}$ verse formula giving a brief synopsis of the doctrine of causation and cessation (beginning ye dharmā hetuprabhavā...) inscribed on clay seals deposited in miniature stūpas and images in shrines throughout the Buddhist world also served as a focus for

157 Willis 2000: 13 points out that relics of commemoration (uddesika dhātu) were probably accepted as worthy of veneration after the development of the Buddha image in the first century CE, while the two other types of relics (bodily relics and relics of contact) were accepted earlier in the Pāli tradition. According to Trainor, "this threefold classification was well-established by the commentarial period (fifth century CE)" (1997: 89, fn. 82 [also see Germano and Trainor 2004: 16, 26, note 33]) based on references in the Khuddakapattha Pāli commentary on the seventh verse of the Nidhikandasutta.

${ }^{158}$ John Strong broadly observes that “... both dharma relics and body relics could be used in similar ways as stand-ins for the Buddha" (2004a: 9).

159 Schopen, Gregory. 1975. "The Phrase sa prthvippradeśas caityabhūto bhavet in the Vajracchedikā: Notes on the Cult of the Book in Mahāyāna." Indo-Iranian Journal 17, 147-181 (= Schopen 2005: 25-62). Drewes, David. 2007. "Revisiting the phrase 'sa prthvīpradeśaś caityabhūto bhavet' and the Mahāyāna Cult of the Book." Indo-Iranian Journal 50, 101-143 challenges Schopen's thesis of a competition between a Mahāyāna "Cult of the Book" and mainstream stüpa worship, but his argument that "... it is in fact not clear that sūtra worship was not especially important for the Mahāyāna at all" is contradicted by his acknowledgement that "Mahāyāna sūtras commonly advocate the veneration of written sütras..." (137). 
devotional and donative practices by infusing these objects with the Buddha's dharmakāya. ${ }^{160}$

Like bodily and textual relics, images materialize the presence of the Buddha in particular places. The earliest anthropomorphic images of the Buddha appear in Mathura, Gandhara and Swat in the first century $\mathrm{CE}$ after a long phase of symbolic representation. ${ }^{161}$ The "Image Cult" was promoted by monastic and lay patrons who labeled their gifts of sculptures to stūpa complexes, murals in Buddhist cave monasteries, as well as smaller or more rudimentary images, including petroglyphs, as "religious offerings" (deyadharma/devadharma). ${ }^{162}$ Since Buddhist narratives about seemingly insignificant donations (of grass, dirt, flowers, etc.) repeatedly emphasize that the intention motivating a gift is considered more important than an object's physical value, gifts of "ordinary images" and elaborate works of art from donors with different social backgrounds have similar results and fulfill identical purposes: they generate merit for donors and expand opportunities

${ }^{160}$ Bentor, Yael. 1995. "On the Origins of the Tibetan Practice of Depositing Relics and Dhärañis in Stūpas and Images." Journal of the American Oriental Society 115.2, 248-261; Boucher, Daniel. 1991. "The Pratityasamutpāda and Its Role in the Medieval Cult of the Relics." Journal of the International Association of Buddhist Studies $14,1-27$.

${ }_{161}$ Art historical / iconological debates about the "aniconic" phase of early Buddhist art between Susan Huntington and Vidya Dehejia are summarized by Karlsson, Klemens. 2000. Face to Face with the Absent Buddha: The Formation of Buddhist Aniconic Art. Uppsala, Sweden: Uppsala University. Also see Brown, Robert L. 1998. “The Miraculous Buddha Image: Portrait, God, or Object?” In Davis, Richard H., ed. 1998. Images, Miracles, and Authority in Asian Religious Traditions. Boulder, Colorado: Westview Press, 37-54, esp. 42-44, for arguments against Huntington's restrictive explanations of the absence of the Buddha's human image as resulting from depictions of places rather than events. Carter, Martha. 1993. "Petroglyphs at Chilas II: Evidence for a Pre-iconic Phase of Buddhist Art in Gandhara." In Gail, Adalbert J. and Gerd J.R. Mevissen, eds. 1993. South Asian Archaeology 1991. Stuttgart: Franz Steiner, 349-366, demonstrates that earlier rock drawings accompanied by Kharoșthī inscription do not depict the Buddha in human form in contrast to later petroglyphs from other sites around Chilas and Thalpan.

${ }^{162}$ Schopen, Gregory. 1988. “On Monks, Nuns, and 'Vulgar' Practices: The Introduction of the Image Cult into Indian Buddhism" Artibus Asiae 49.1-2, 153-168 (= Schopen 1997a: 238-257) argues against the view of the worship of images as a corruption of the Buddha's ethics by pointing out that inscribed images of the Buddha were often donated by monks and nuns. Deyadharma formulae are also used to record donations of a wide range of non-visual materials to Buddhist communities, including architectural elements (doors, cells, pillars) in western Indian cave inscriptions, water pots from Gandhara (including those found with the British Library collection of Kharoșthī manuscripts), and Sanskrit manuscripts from Gilgit. 
for worshipping and remembering the Buddha. ${ }^{163}$ Colossal images of the Buddha located along important trade routes at Bamiyan, Gilgit, and the Upper Indus served as devotional landmarks for local patrons, monastic residents, visiting pilgrims, and traveling merchants. Just as the deposit of relics in stüpas localizes and expands the geographical range of Buddhist devotional practices, the installation and consecration of images as "commemorative relics" broadened the "field of merit" by stimulating more devotees to make selfless acts of generosity with pure thoughts and intentions.

With the aid of numismatic and epigraphic evidence of donative inscriptions on sculptures and other visual materials, Buddhist art can be better situated in chronological and regional contexts. ${ }^{164}$ Since coins are datable to relatively specific periods and localized at geographical centers of production, they serve as useful indicators of cross-cultural interactions. ${ }^{165}$ Hoards of Roman coins in southern India and Sri Lanka and Saka and Kuṣāna coins in Khotan (Xinjiang) provide numismatic evidence of long-distance trade networks between the Indian subcontinent, the Mediterranean world, and Central Asia in the early centuries CE. When the historical framework is fairly secure, studies of coins and images reveal complex patterns of cross-cultural transmission through borrowing of specific elements from outside on the one hand and appropriation and transformation of symbolic values in response to various internal circumstances on the other hand. While the adoption or incorporation of stylistic elements is often still viewed

${ }^{163}$ The term "ordinary images" is borrowed from Abe, Stanley K. 2002. Ordinary Images. Chicago and London: University of Chicago, which he uses to designate "a large body of visual imagery 'of the usual class'... created for those of a lesser social, political, and economic standing" (1). Abe specifies that the patrons of "ordinary images" were not the lowest class, but "subélites" including small landowners, merchants, lower officials, and others without high political or aristocratic standing (2-3).

${ }^{164}$ For an example of contextualization of Buddhist art using numismatic and epigraphic sources, see Fussman, Gérard. 1987a. "Numismatic and Epigraphic Evidence for the Chronology of Early Gandharan Art." In Yaldiz, Marianne and Wibke Lobo, eds. 1987a. Investigating Indian Art. Berlin: Museum für Indische Kunst, 67-88. Similar approaches are adopted in contributions to Alram, Michael and Deborah Klimburg-Salter, eds. 1999. Coins, Art, and Chronology: Essays on the Pre-Islamic History of the Indo-Iranian Borderlands. Vienna: Österreichische Akademie der Wissenschaften and Srinivasan, Doris, ed. 2007. On the Cusp of an Era: Art in the Pre-Kușāna World. Leiden: Brill.

${ }^{165}$ Renfrew and Bahn observe that: "coins often give an accurate indication of the intensity of interactions in space and time because they can usually be dated and because the place of issue is frequently indicated" (1991: 333). 
as resulting from a process of gradual diffusion of influences from one region to another, the actual routes, economic conditions, and political, religious, social, and cultural background frequently remain vague. This effort to map networks is intended to clarify these contexts for the movement of Buddhist images across geographical and chronological boundaries. A synthesis of the literary, epigraphic, and archeological sources (including visual images) is the basis for investigating relationships between trade networks and the transmission of Buddhism.

\section{Outline of Destinations}

Having outlined some of the sources, methods, and theories at the outset of the journey, where do paths of Buddhist transmission lead? Before embarking, it is necessary to identify a starting point and destinations, both in terms of chronological time and geographical space.

Chapter 2: Historical Contexts for the Emergence and Transmission of Buddhism within South Asia

The second chapter establishes a diachronic foundation for the study of trade and transmission beginning with the emergence of Buddhism in northern India during the time of the historical Buddha around the fifth century BCE and continuing through the first millennium CE. Issues related to the emergence and growth of renouncer movements in very competitive social, economic, and religious environments are addressed in this re-examination of the initial phases of Buddhist formation in northeastern India from approximately the fifth century $\mathrm{BCE}$ to the Mauryan period. The focus of the historical overview shifts to contacts between India, Iran, and Central Asia in the early centuries $\mathrm{CE}$, since various groups migrated to South Asia along routes that were also used in the transmission of Buddhism in the opposite direction to their former homelands. Although it will not be possible to completely fill every gap in the history of Indian and Central Asian Buddhism, historical contexts for the patronage of Buddhist monastic institutions in later periods during the first millennium $\mathrm{CE}$ receive particular emphasis. 


\section{Chapter 3: Trade Networks in Ancient South Asia}

Roads for the expansion of Buddhist communities throughout ancient India known as the 'Northern Route' (uttarāpatha) and 'Southern Route' (daksinapatha) are explored in the third chapter. These terms generally designate geographical / cultural regions of northern and southern India, often in relation to the location of the author of a text, the original homelands of travelers, or the domain of rulers whose exploits are eulogized in inscriptions. These arteries of commercial and cultural exchange, which were linked to much larger overland and maritime networks, served as paths of Buddhist transmission. Literary references as well as epigraphic and archeological evidence associated with particular nodes demarcate paths and patterns for the transmission of Buddhism in the Indian subcontinent.

\section{Chapter 4: Old Roads in the Northwestern Borderlands}

An extension of the Northern Route beyond the northwestern frontier of South Asia is a particularly significant part of the itinerary and is detailed in the fourth chapter. This chapter focuses on the domestication of Buddhist narratives, art and architecture, literary culture, and monastic institutions in ancient Gandhara, a pivotal border region for cross-cultural contact between Indian, Iranian, Hellenistic, and Central Asian spheres located in northwestern Pakistan and eastern Afghanistan. Archaeological remains of stüpas and monasteries, distinctive artistic traditions which had a wide impact beyond South Asia as well as donative inscriptions and several collections of early Buddhist manuscripts written in the Gāndhārī regional language amply demonstrate that Buddhist institutions flourished in many impressive centers of cultural production in the Gandhāran region. Buddhist cultures in the Swat valley (ancient Uḍdiyāna) and Bajaur in northwestern Pakistan and in Kashmir were closely linked with Gandhāra, but developed their own artistic and literary traditions and localized shrines and narratives, as attested in the accounts of Chinese pilgrims.

\section{Chapter 5: Capillary Routes and Buddhist Manifestations in the Upper} Indus

Inscriptions and rock drawings in the Upper Indus, Gilgit, and Hunza valleys of northern Pakistan demarcate a network of capillary routes 
that directly connected branches of the Northern Route with the socalled 'Silk Routes' in the Tarim Basin of eastern Central Asia. Manifestations of a Buddhist presence in petroglyphs of stūpas, jätakas, hagiographical events in the life of Sākyamuni, and previous Buddhas and Bodhisattvas and the names of Buddhist visitors and local devotees who patronized wayside shrines are examined in detail in the fifth chapter. Although Buddhist monasteries did not proliferate until the Palola Șāhis of Gilgit acted as literary and artistic patrons in the late sixth to early eighth century $\mathrm{CE}$, this region was a crucial transit zone for Indian, Iranian, and Chinese travelers. A careful examination of different layers of Buddhist evidence from this area shows that although the high mountain desert environment lacked adequate surplus resources to support large-scale residential monasteries, travelers on pathways through the deep river valleys and across passes through the western Himalayas, Hindu Kush, and Karakorum mountain ranges still acted as successful agents of long-distance transmission.

\section{Chapter 6: Long-Distance Transmission to Central Asian Silk Routes} and China

An investigation of trans-regional exchanges between South Asia, Central Asia and China in the sixth chapter provides the broad context for understanding the initial pattern of long-distance transmission of Buddhism through the transit zone of Xinjiang via numerous routes from multiple centers. Material evidence for Buddhist establishments in Khotan, Miran, and other oases in the southern Tarim Basin during the first centuries CE is emphasized, but artistic traditions and literature connected with centers on the northern and intermediate silk routes near Kucha, Turfan, and Dunhuang are also discussed. Diverse Central Asian and Chinese Buddhist traditions did not arrive from either Bactria or Gandhara via a single main artery of the Silk Road, but resulted from more complex processes of transplantation, transmission, and transformation.

Chapter 7: Conclusion: Alternative Paths and Paradigms of Buddhist Transmission

The concluding chapter of this exploration of premodern trans-Asian networks demonstrates that routes for economic and cultural exchange functioned as paths for the transmission of Buddhism. Intermediate 
and long-distance trade routes across topographical, linguistic, and cultural boundaries enabled Buddhist missionaries to "spread the dharma" at élite and sub-élite levels. Manifestations of the presence of the Buddha in the form of reliquary stupas, inscriptions, and images show that the process of transmission involved more than adoption of philosophical ideas and religious ideals. As flexible religious systems rather than monolithic unchanging entities with fixed doctrines and rigid orthodox rules, Buddhist traditions were able to adapt to different environments. The ability to change with shifting conditions of economic support and to appeal to a wide audience of potential patrons differentiates the lasting success of Buddhist missions outside of the Indian subcontinent from other religions originating in South Asia. This reassessment of sources, methods, and models illuminates paths and processes of Buddhist transmission across Asia in order to answer longstanding questions about why the sangha was able to successfully transmit the dharma in its various manifestations beyond the homeland of Sākyamuni Buddha. 
Jason Neelis - 978-90-04-19458-8 Downloaded from Brill.com $04 / 26 / 2023$ 11:30:22AM via free access 


\section{HISTORICAL CONTEXTS FOR THE EMERGENCE AND TRANSMISSION OF BUDDHISM WITHIN SOUTH ASIA}

Interpreting the past is a critical concern for Buddhist communities, despite stereotypes that associate mystical disregard of history with Buddhism and other South Asian religious traditons. Flexible narratives about the past have shaped Buddhist identities by providing models of meritorious action and have contributed to expansion beyond northeastern India by establishing locative links to the Buddha's presence. Stories about the Buddha's life and the formation of the sangha connect his birth, awakening, teachings, miraculous performances, and recruitment of followers to specific places and temporal frameworks. Hagiographical accounts of the rediscovery of the "True Dharma" (saddharma) taught by previous Buddhas in earlier ages and the turning of the "Wheel of Dharma" (dharmacakra) in the present auspicious age (bhadrakalpa) may seem ahistorical, since the accomplishments attributed to Sākyamuni Buddha are not particular to his own historical circumstances. ${ }^{1}$ Although restrictive views of history as an objective chronicle of past events would deny any value to traditional identifications of links between causes in past lives and consequences in present or future lifetimes in Buddhist literary sources, maximalist conceptions of history as an effort to understand "how human actions are significant and have a notable impact on our world" (Nattier 1991: 139) provide more scope for understanding why interpretation of past actions was important for present concerns.

The aim of this chapter is to clarify geographical and chronological contexts for patterns and processes in the formation of Buddhism in ancient and early medieval South Asia and its transregional expansion

${ }^{1}$ For literary traditions about Buddhas of the past, auspicious present aeon (bhadrakalpa), and the future, see Nattier, Jan. 1991. Once Upon a Future Time: Studies in a Buddhist prophecy of decline. Berkeley, Calif: Asian Humanities Press, 19-26; Strong, John. 2001. The Buddha: A short biography. Oxford: Oneworld, 20-21, Table 1.1 and Strong 2004a: 25-49. Nattier emphasizes that “... it is a central contention of virtually all schools of Buddhism that the Buddha's experience is by definition repeatable and is accessible (at least in theory) to all living beings" (1991: 7-8). 
outside of the Indian subcontinent, particularly in the northwesten frontiers of areas of modern Pakistan and Afghanistan. Beginning with the period of the historical Buddha's lifetime in the fifth century $\mathrm{BCE}$, the chronological range of this overview extends to the late first millennium CE. A detailed macrohistory of South Asian Buddhism is beyond the intended scope, but significant junctures between political, economic, and social networks for Buddhist mobility are emphasized in an effort to identify factors and catalysts for cross-cultural transmission. An historical-critical approach to literary, epigraphical, numismatic, and archaeological sources elucidates regional variation and different actors, features, stages, and levels of Buddhist movement, which fluctuated considerably with shifting political and commercial alignments. This effort to investigate the role of trade exchanges, intercultural encounters, and inter- and intrareligious relationships in the establishment, expansion, and decline of Buddhist institutions spurs several questions, which are addressed throughout the chapter. What was at stake for Buddhist communities in formulating stories about the Buddha's present and past lives, describing the formation of the saigha, and locating events in regional settings? How did interactions with other groups, including competing renouncer movements, Brahmins, and exogenous migrants, shape Buddhist perspectives and practices? What do available sources from within and outside of Buddhist traditions reveal about the impact of social and economic changes on Buddhist institutions? Which roles did Buddhist models of exchange, patronage, and supramundane power play in commerce and sociopolitical legitimation?

In the following subsections, which are structured diachronically and regionally, I explore the formation and transmission of Buddhist ideologies and institutions in changing historical and cultural environments, since Buddhist traditions did not originate autonomously or remain static.

A. Initial Phases of the Establishment of Buddhist Communities in Early India

B. Legacy of the Mauryans: Aśoka as Dharmarāja

C. Migrations, Material Exchanges, and Intercultural Interactions in Northwestern Contact Zones

D. Saka Migrants and Mediators between Central Asia and South Asia

E. Dynamics of Mobility during the Kuṣāna Period 
F. Shifting Networks of Political Power and Institutional Patronage during the Gupta Period

G. Cross-Cultural Transmission between South Asia and Central Asia, ca. $500-100 \mathrm{CE}$

\section{Initial Phases of the Establishment of Buddhist Communities in Early India}

Hagiographic accounts of the Buddha's religious biography combine legendary narratives with information about the religious, social, economic, and political climate of his time, as viewed through later literary lenses. ${ }^{2}$ Rather than separating historical fact from literary fiction in order to demythologize the life story of the Buddha, the analysis of Buddhist literary sources postdating the lifetime of the Buddha and archaeological findings presented here is intended to establish basic chronological and geographical parameters and to undertand the contexts in which he and his followers flourished. Although the historical Buddha's precise dates are difficult to pinpoint, situating his lifetime in the fifth century BCE has widespread implications for South Asian history as well as religious and intellectual traditions during a period of dynamic social and cultural change.

Scholarly consensus on Saakyamuni Buddha's date, which is in fact the earliest historical date for building a relative chronology of late Vedic religions and ancient Indian political dynasties, has recently shifted in favor of a "short chronology" from a "long chronology" in response to a 1988 symposium in Göttingen and the multivolume publication of proceedings edited by Heinz Bechert. ${ }^{3}$ Although a "Nirvāna era" beginning with Śākyamuni's parinirvāna in 543 BCE is attested

${ }^{2}$ Strong 2001 provides a useful overview of hagiographical traditions for the life (and previous lives) of the Buddha according to various literary sources. Strong's stated goal is to portray the "Buddha of story" rather than the "Buddha of history" since traditional legends "... are certainly more plentiful, more interesting, and more revelatory of the ongoing concerns of Buddhists" (2001: 2). Historicist approaches privileging Pāli and Sanskrit literary sources over vernacular biographies of the Buddha are criticized by Hallisey, Charles. 1995. "Roads Taken and Not Taken in the Study of Theravāda Buddhism.” In Lopez 1995b: 31-61 (reprinted in Derris, Karen, and Natalie Gummer, eds. 2007. Defining Buddhism(s): A reader. London: Equinox Pub.).

${ }_{3}$ Bechert, Heinz, ed. 1991-1997. The Dating of the Historical Buddha = Die Datierung des historischen Buddha. 3 vols. Göttingen: Vandenhoeck \& Ruprecht. 
in Pāli vamsa literature, Bechert observes that “...there is no reliable second source to corroborate the validity of this chronology" (1989: 97). ${ }^{4}$ A "corrected long chronology" places the end of the Buddha's lifetime in ca. $486 \mathrm{BCE}$ by adjusting the date for the parinirvanna 218 years before the Mauryan ruler Aśoka was consecrated in ca. 270-268 BCE. ${ }^{5}$ However, literary sources outside of the Pāli tradition support a "short chronology" for the parinirvanna only one century before Aśoka's consecration, therefore corresponding to ca. 370 BCE. ${ }^{6}$ The suspiciously round number (100) probably indicates an approximate rather than absolute date, so an "adjusted short chronology" of the Buddha's death around 400 BCE is now widely favored. ${ }^{7}$ This somewhat arbitrary date avoids a problematic link between the beginning of Aśoka's rule and a second Buddhist communal recitation (sangiti) or "council" at Vaiśālī, which was also supposed to have taken place a century after the parinirvanna but is not as clearly linked with Aśoka as later councils. ${ }^{8}$ The issue of determining the date of the historical

${ }^{4}$ Bechert, Heinz. 1989. "The Problem of the Determination of the Date of the Historical Buddha." Wiener Zeitschrift für die Kunde Südasiens 33, 93-120. Lamotte (1988 [1958]: 13) discusses internal contradictions within the Pāli chronicles (Dìpavamsa 6.1.19-20, Mahāvamsa 5.21) and commentaries (Samantapāsādikā, Atthasālinī).

${ }^{5}$ As detailed in the following subsection of this chapter, Aśoka's 13th Major Rock Edict provides a firm synchronism between the reign of Aśoka and five contemporary Hellenistic rulers in ca. 255 BCE.

${ }^{6}$ Evidence for a "short chronology" of the Buddha's parinirvānā 100 years before Aśoka's consecration in Dīpavamsa 1.24-26 and 5.55-59 supports Bechert's hypothesis that the long chronology" of 218 years was a later development (1989: 104 ff., 1991: 329-343). The earliest attested link between the Buddha's parinirvāna and Aśoka's reign a century later occurs in an avadāna set during the time of Aśoka "a century after the Blessed Buddha achieved parinirvāna" (vașaśada parinurvude budhe bhagavade) in a first century CE Kharosthī manuscript (British Library fragment 4.6 recto).

7 Prebish, Charles. 2008. "Cooking the Buddhist Books: The implications of the new dating of the Buddha for the history of early Indian Buddhism." Journal of Buddhist Ethics 15 observes that "... most participants [in the Göttingen symposium] suggested that the Buddha died within approximately a few decades on either side of 400 BCE" (1).

${ }^{8}$ Prebish examines implications of the "short chronology" for the dating of early councils at Rājagraha, Vaiśālī, and Pātaliputra, concluding that the Vaišálī council occured 37 years before Aśoka's coronation in 268 BCE, followed shortly by a "noncanonical" council at Pātaliputra marking the beginning of Buddhist sectarianism and another "canonical" council in Pātaliputra (attested only in Pāli sources) 18 years later (ca. 250 BCE). Prebish's argument that “... we should use all the sources available to us, and not just those that affirm a hypothesis that is convenient to our suppositions and anticipated expectations" (2008: 14-15) implies that conflicting sources should be accepted in order to construct a hybrid chronology for the date of the Buddha's parinirvāna. 
Buddha is also intertwined with traditional Jain dates for the nirvāna of Mahāvira (alleged to be a Jain contemporary of Saakyamuni) in 528 or 510 BCE. ${ }^{9}$ If we follow a short chronology for the historical Buddha's parinirvāna between ca. 400 and ca. 370 BCE, his lifespan of 80 years began in the early-mid fifth century BCE.

Table 2.1: Proposed dates for the Historical Buddha

\begin{tabular}{|c|c|c|}
\hline & Birth & Parinirvāṇa \\
\hline $\begin{array}{l}\text { Long Chronology } \\
\text { (Nirvāṇa Era) }\end{array}$ & 623 & $543 \mathrm{BCE}$ \\
\hline Corrected Long Chronology & 566 & $486 \mathrm{BCE}^{10}$ \\
\hline Adjusted Short Chronology & ca. 480 & $400 \mathrm{BCE}$ \\
\hline Short Chronology & ca. 450 & $370 \mathrm{BCE}^{11}$ \\
\hline
\end{tabular}

In addition to situating the historical Buddha's lifetime in a relatively specific time-frame between the middle of the fifth century and the beginning of the fourth century BCE, it is also possible to locate hagiographical events memorialized in Buddhist literature, inscriptions, monuments, and art in a geographical network of sacred sites. For example, an inscription of Aśoka marks the location where Māyā gave birth to Siddhārtha Gautama in a forest near the village of Lumbinī in southern Nepal:

The King, Beloved of the gods, of Loving Regard, when he had been anointed twenty years, came in person and worshiped, because the Buddha Sākyamuni was born here. He had constructed walls inlaid with stone (?) and had erected [this] stone pillar, because [i.e., to proclaim that] the Lord was born here. The village of Lummini was made exempt from taxation and [subject to paying only] one-eighth share [of its produce]. ${ }^{12}$

9 Śvetāmbara and Digambara dates for Mahāvīra's nirvāna conflict with Hemacandra's report of a time-span of 155 years before the reign of Candragupta, who began ruling after the Indian expedition of Alexander of Macedon between 327-5 BCE (Bechert 1989: 98-101).

${ }_{10} 218$ years before Aśoka's coronation in ca. 370-368 BCE.

11100 years before Aśoka's coronation.

12 Translated by Salomon 1998a: 264 (Appendix, selection 1: Rummindeì Minor Pillar Edict of Aśoka; see Falk 2006: 177-180 for further references and a discussion of silavagadabhīca or $-c a$, which he translates as "stone railing" instead of "walls inlaid with stone"). 
The epigraphic evidence of Aśoka's commemoration of a visit to the Buddha's birthplace at Lumbini confirms the localization of pilgrimage practices connected with this event by the middle of the third century BCE. The location of Kapilavastu, where Siddhārtha was raised by his aunt Mahāprajāpati as the son of Suddhodana, a chief of the Saakya clan, remains controversial. ${ }^{13}$ An early set of four sites placing the awakening at Bodh Gaya, initial teaching at Sarnath, and parinirvāna at Kuśinagara were later expanded to a list of eight sites, each with their own narrative cycles. ${ }^{14}$ Noting that the hagiography of the Buddha grew in tandem with the proliferation of Buddhist pilgrimage places, John Strong remarks: “...'where’ something happened is as significant as 'what' happened there" (2001: 5). Locative connections reinforce claims to antiquity of oral discourses said to have been spoken by the Buddha, doctrinal principles and monastic rules linked with early recitations, and pilgrimage and ritual centers. While Jonathan Z. Smith identifies the promotion of a "locative, imperial worldview" with "scribal elites who had a deep vested interest in restricting mobility and valuing place" (1978: 293), ${ }^{15}$ Buddhist efforts to localize hagiographic events in northeastern India and the Terai region of modern Nepal did not inhibit or restrict mobility.

Having situated the historical Buddha in northeastern India, what can be said about the society in which he lived and taught? Portrayals of Siddhārtha as a royal prince indicate that he was to be viewed as an archetypal Kșatriya scion in the traditional socio-religious hierarchy. However, fifth-fourth century BCE social contexts are difficult to reconstruct because Buddhist textual sources from periods later than the time of the historical Buddha tend to reflect their own contemporary social mores. ${ }^{16}$ Non-Buddhist traditions prescribing rigid stratification

${ }^{13}$ The sites of Gotihawa and Pipri near Lumbini have been excavated and the surrounding area has been surveyed by Verardi, Giovanni. 2007. Excavations at Gotihawa and Pipri, Kapilbastu District, Nepal. Rome: IsIAO.

14 Strong 2001: 6.

${ }^{15}$ For further theoretical and comparative perspectives on the locativization of religious geography, see Smith, Jonathan Z. 1987. To Take Place: Toward Theory in Ritual. Chicago: University of Chicago, and essays on "Topography of the Sacred" and "Here, There, and Everywhere" in Smith, Jonathan Z. 2004. Relating religion: essays in the study of religion. Chicago: University of Chicago Press, 101-116, 323-349.

${ }_{16}$ This distinction is not always maintained in works dealing with the social history of early Buddhism, including Bailey and Mabbett 2003 (especially chapters 2 and 5), Chakravarti, Uma. 1987. The Social Dimensions of Early Buddhism. Delhi: Oxford University Press, and Fick, Richard. 1897. Die sociale gliederung im nordöstlichen Indien 
among the four varnas (Brahmins, Kṣatriyas, Vaiśyas, and Sūdras) are not descriptive of social realities, but tend to reflect normative models and ideals. ${ }^{17}$ Buddhist literary texts consistently reflect these normative distinctions between Brahmins, Kṣatriyas, and other wealthy householders (often termed grhapatis) and groups of laborers, servants, and the poor with status largely determined by birth. ${ }^{18}$ Rather than challenging social and economic structures, Buddhist arguments against alleged Brahminical claims to purity valorize the superiority of ethical purity over ritual action. ${ }^{19}$ Didactic verses collected in the "Brāhmana Varga" of widely transmitted Dharmapada/Udānavarga collections clearly illustrate this critique, ${ }^{20}$ which is expressed in the first verse of a Kharoșthi manuscript of the Dharmapada from Khotan:

One does not become a Brahmin by matted dreadlocks, clan, or birth; but having expelled small and large wrongs in every way, an expeller of wrongs is someone called a Brahmin. ${ }^{21}$

$z u$ Buddha's zeit. Kiel: C.F. Haeseler (translated by Shrishirkumar Maitra, The Social Organization in North-East India in Buddha's Time. University of Calcutta, Calcutta: 1920, reprint, Varanasi: 1972). Wagle, N. K. 1966. Society at the time of the Buddha. Bombay: Popular Prakashan, clearly distinguishes earlier strata of Pāli Nikāya, Vinaya, and Sutta Nipāta texts from later Jätakas and Abhidharma texts, but his assertion that "the Nikayya and Vinaya material can safely be taken as a reliable guide to conditions during 500-300 BC" (1966: 3) needs further qualification, since there are very few texts among these collections that can be reliably dated before the third century BCE.

${ }_{17}$ Patrick Olivelle's comments on the social background of the Upanișads (Olivelle, Patrick. 1996. Upanișads. Oxford: Oxford University Press, xxiv-xxix) are directly relevant to Saākyamuni Buddha's context. However, Dharmasūtras, which are more concerned with maintaining separate varnas, belong to periods later than the middle of the third century BCE, according to Olivelle (1999. Dharmasutras: the Law Codes of Ancient India. Oxford: Oxford University Press, xxxii-xxxiii). Olivelle compiles Dharmasütra passages on the varna system in 2005. Dharmasütra parallels: containing the Dharmasūtras of Āpastamba, Gautama, Baudhāyana, and Vasiștha. Delhi: Motilal Banarsidass, 41-50.

18 Bailey and Mabbett 2003: 42-3 cite numerous Pāli passages listing degraded families (nīcā kulā) of candālas, hunters, bamboo workers, chariot-makers, and refuseremovers in juxtaposition to a list of people reborn into high families of wealthy warriors, priests, and householders.

19 Bailey and Mabbett 2003: 108-129, Chakravarti 1987: 39-46.

${ }^{20}$ Bailey and Mabbett 2003: 196 ff. (Chapter 9: The Dhammapada and the images of the Bhikkhu).

${ }^{21}$ It is interesting to note that the Brāhmana Varga is the first chapter of the Khotan Gāndhārī Dharmapada (Brough 1962: 119-125), but the final chapter of the Sanskrit Udānavarga (Bernhard, Franz, ed. 1965. Udānavarga. Göttingen: Vandenhoeck \& Ruprecht., 1.460-509) and the Pāli Dhammapada (Norman, K. R., trans. 1997a. The word of the doctrine (Dhammapada). Oxford: The Pali Text Society, 55-59). The first Gāndhārī verse (Brough 1962: 119, 178, pl. I) corresponds partially to Pāli Dhammapada 393, 265, 267 and Sanskrit Udānavarga 33.8 (Bernhard 1965: 462). 
Although the Buddha is sometimes portrayed in modern accounts as a social reformer or revolutionary through selective citation of passages critical of Brahmins, ${ }^{22}$ social contexts reflected in Buddhist literature are probably best understood against a background of dynamic social change rather than reactions against stagnant social hierarchies.

Buddhist hagiographic traditions clearly acknowledge that Ājīvikas and Jain śramana movements competed for religious and intellectual eminence in northern India when Siddhārtha renounced his duties to become a wandering mendicant. In accounts of the six years prior to his awakening in Bodh Gaya, Siddhārtha encountered other śramana proponents of heterodox viewpoints and ascetic practices. ${ }^{23}$ Johannes Bronkhorst provocatively argues that a "fundamental spiritual ideology" shared in common by Buddhism, Jainism, and Ājīiikism was "a product of the spiritual culture of Greater Magadha" (2007: 28), which had "... a culture of its own which was different from the culture of the authors of Vedic and early post-Vedic literature" (2007: 9).$^{24}$ Although Bronkhorst's attempt to localize shared assumptions about rebirth and karmic retribution in Magadha is not ultimately convincing, his point that early Buddhist doctrines were formulated in the context of debates between different śramana communities rather than in reaction to "Hindu" religious ideas and norms resonates with Louis de la Vallée Poussin's opinion that "the Brāhmanism from which Buddhism sprang is not the Brāhmanism of the Brāhmaṇa and the Upanișad, but represents, even better than the latter, the ancient Indian yoga" (quoted by Lamotte 1988 [1958]: 7).

${ }^{22}$ Remarking that "To present him as a sort of socialist is a serious anachronism" (2006: 30), Richard Gombrich rejects attempts to portray the Buddha as a social revolutionary (Gombrich, Richard F. 2006. Theravāda Buddhism: A social history from ancient Benares to modern Colombo. 2nd rev. ed. London: Routledge [1st ed. 1988]).

${ }^{23}$ Pāli, Sanskrit, Chinese, and Tibetan versions of the Srāmanyaphala-sūtra (MacQueen, Graeme. 1988. A study of the Śrämanyaphala-sūtra. Wiesbaden: O. Harrassowitz) may now be compared with a partial Gāndhārī manuscript version in the second scroll of the Senior collection (Allon, Mark. 2007. "Introduction: The Senior Manuscripts.” In Glass 2007a: 8; Salomon 2003c: 79-80).

${ }^{24}$ Bronkhorst, Johannes. 2007. Greater Magadha: Studies in the Culture of Early India. Leiden/Boston: Brill. Also see Bronkhorst, Johannes. 2004. "Hinduism and Buddhism." In Buswell 2004: 1.329. In my review of Bronkhorst 2007 (Journal of the Royal Asiatic Society 18.3 [2008], 381-3), I do not accept Bronkhorst's localization of a single underlying "spiritual ideology" exclusively in Magadha (however broadly he intends to define the cultural region as wherever the historical Buddha lived) because the origins of basic ideas about rebirth, karmic retribution, the self, and ascetic practices probably belonged to a more extensive geographical and cultural milieu. 
What is at issue is the extent to which basic theories of a self (atman) that transmigrates through the cycle of continuous rebirth (the samsāra paradigm) originated internally from the Vedic background or were introduced through processes of inter-religious contact, structural developments of rebirth eschatologies, or other external possibilities. ${ }^{25}$ While certain Vedic ideas and practices (such as animal sacrifice and Brahminical authority) are clearly rejected by Jains and Buddhists, the composers of the early Upanișads (particularly the Brhadàranyaka Upanișad and Chāndogya Upanișad) were also questioning, challenging, and reformulating Vedic rituals, cosmologies, and established mores. Since śramana traditions and the early Upanișads belong to a similar climate of intellectual ferment in northern India during a period of significant social and religious change, scholars have attempted to establish relative chronological relationships and to identify directional influences. In contrast to the consensus view that Buddhism and Jainism "emerged not long after the composition of the early Upanișads" (Olivelle 1996: xxiii), Bronkhorst argues that "at least some portions of the early Upanișads-perhaps precisely the portions that introduce the belief in rebirth and karmic retribution into the Veda-were composed more or less at the time of the Buddha, or later" (2007: 258). Although K.R. Norman finds “... echoes of Upanișadic statements in the Buddha's sermons" (1997b: 33), especially in the opposition between the Buddhist doctrine of "no self" (Sanskrit anātman / Pāli anattā) and the equivalence between the individual self (ätman) and universal self (brahman) in the Chändogya Upanișad, it is not clear that Buddhists were responding to specific passages in early Upanișads. ${ }^{26}$ Instead of postulating that Buddhist ideas developed in reaction to prior speculations in the early Upanișads, it seems quite likely that they emerged from a shared nexus of intense intellectual

${ }^{25}$ Obeyesekere, Gananath. 2002. Imagining Karma: Ethical Transformation in Amerindian, Buddhist, and Greek Rebirth. Berkeley: University of California Press describes this theory as a "karmic eschatology" and proposes structural parallels with theories of rebirth in other cultures.

${ }_{26}$ Although he acknowledges possible similarities in thought and language, Bronkhorst rejects Norman's arguments for a specific link between the Buddhist doctrine of anattā as expressed in in the Alagaddūpama Sutta (Majjhima Nikāya I 136) and the equation of àtman and brahman attributed to Saṇ̣̃ilya in the Chāndogya Upanișad by pointing out that the Păli sutta does not mention the concept of brahman and the notion of a permanent "immutable" self is "largely absent from the early Upanișads" (2007: 217). Bronkorst dismisses other "superficial similarities" (2007: 218) proposed by Richard Gombrich as evidence for early Buddhist familiarity with Upanișads. 
and philosophical debate and competition with other śramanas and Brahmins in the middle of the first millennium BCE.

Economic conditions of rural prosperity, urban growth, political consolidation, and expanding trade networks contributed to the institutional organization of the Buddhist saigha, which emerged in an environment of material prosperity rather than hardship. While agricultural surplus was not the only causal factor of a "second urbanization" in the Ganga-Yamuna doāb following a long hiatus of about a millennium from the "mature phase" of the Indus Valley civilization (ca. 2300-1800 BCE), urban centers remained "predator[s] on the countryside" (Erdösy 1987: 17). ${ }^{27}$ Although the presence of Northern Black Polished (NBP) ware beginning ca. 550 BCE in the eastern Ganges plain is a sign of "incipient urbanism" (Thapar 2003: 140), ${ }^{28}$ archaeological evidence does not display traits of "thriving urbanisation" (Erdösy 1987: 14) until the third century BCE. Buddhist literary references to large cities at the time of the Buddha have led many interpreters, including Max Weber, to posit causal relationships between the growth of cities and the emergence of Buddhism..$^{29}$ However, Gregory Bailey and Ian Mabbett criticize the "urbanization hypothesis" as a "post hoc ergo propter hoc fallacy" of "treating effects as causes" (2003: 34). They acknowledge that the Pāli canonical texts on which they depend to support their argument that Buddhism arose after a period of rapid urbanization belong to later periods (2003: 4), but nevertheless base their analysis of economic and social contexts from the fifth century BCE down to the time of Aśoka almost exclusively on this problematic textual tradition, which "does not coincide with the earliest phase of urbanization, but with the more mature period" (Thapar

27 Erdösy, George. 1987. "Early Historic Cities of Northern India." South Asian Studies 3, 1-23.

${ }^{28}$ Thapar, Romila. 2003. Early India: From the origins to AD 1300. Berkeley: University of California Press refers to a general pattern in which "Closely placed, small settlements of the Painted Grey Ware gave way to appreciably larger settlements..." (140) associated with NBP. Erdösy, George. 1995. "City States of North India and Pakistan at the Time of the Buddha" in Allchin 1995: 100-105 reviews the chronology for the appearance of NBP, and concludes that 550-400 BCE is the most likely date for its early phase, a date which is considerably later than ca. 700 BCE proposed for the beginning of the NBP phase at Sringaverapura cited by other authorities, including Chakrabarti 1995: 169.

${ }^{29}$ Bailey and Mabbett 2003: 35 and Gombrich 2006: 50 refer to Max Weber's view that "... Buddhism presents itself as a product of the time of urban development, of urban kingship and the city nobles” (Weber 1958: 204). 


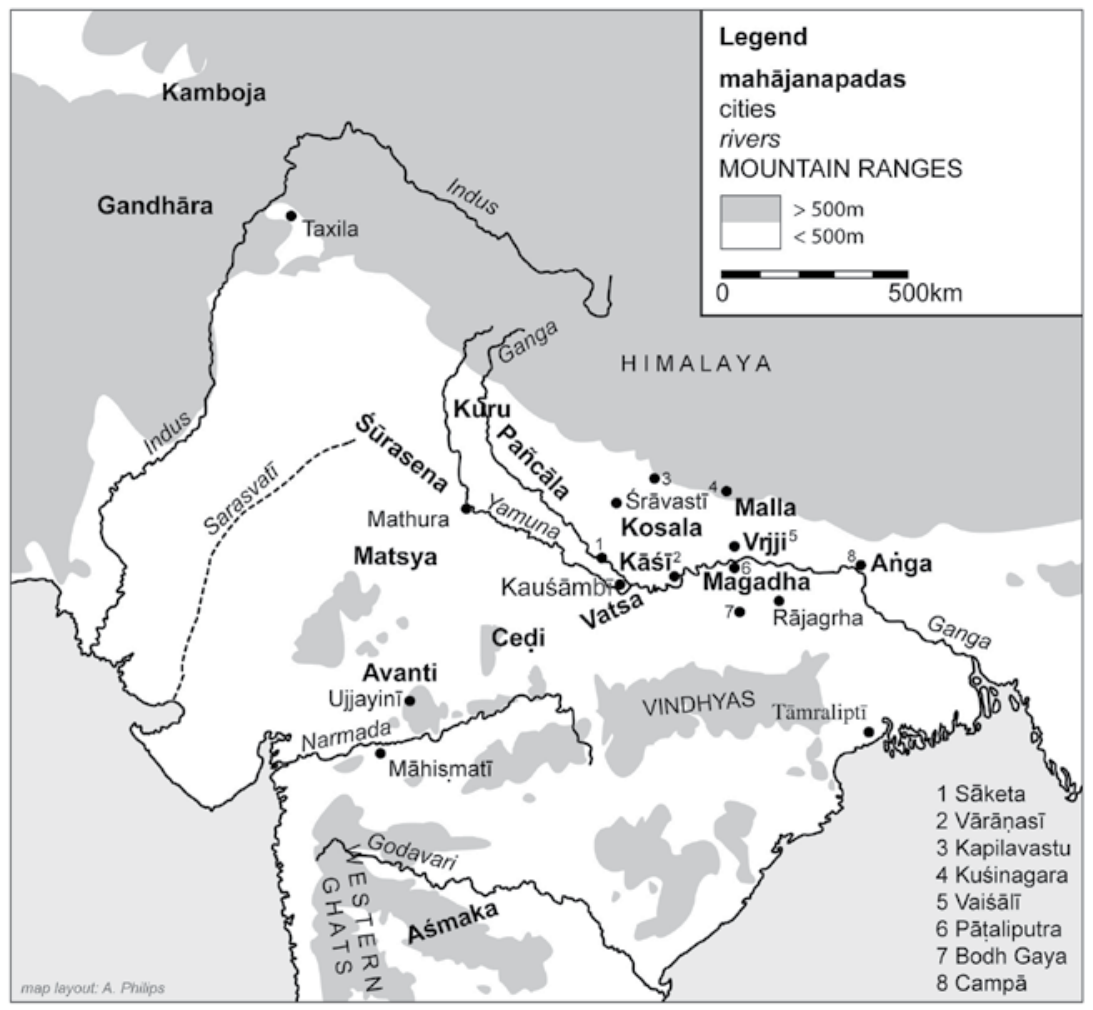

Map 2.1: Sixteen Mahājanapadas of ancient India ${ }^{30}$

2003: 140). Thus, many features reflected in archaeological and textual sources from this general period in the late first millennium CE, including the expansion of local, regional, and long-distance trade networks, must instead be seen as concurrent with rather than prior or posterior to the formation of early Buddhism.

Later Buddhist, Jain and purānic sources refer back to sixteen "great countries" (mahäjanapadas) of ancient India which competed for political and economic preeminence in the mid-late first millennium BCE. ${ }^{31}$ Rather than designating states with fixed boundaries, the term

\footnotetext{
30 Adopted from Allchin 1995: 116, fig. 7.4.

${ }^{31}$ Raychaudhuri, Hemchandra. 1923. Political History of Ancient India from the accession of Parikshit to the extinction of the Gupta dynasty. Calcutta: University of Calcutta, 1923, 45-79 compiles references to rulers of the mahajjanapadas in Buddhist, Jain, and purānic sources, which belong to varying periods. Lamotte 1988 [1958]:
} 
janapada generally corresponds to a "socio-cultural region" (Wagle 1966: 30) composed of smaller units of villages, towns, and cities. Thus, the major janapadas are closely linked with the emergence of urban administrative capitals. The geographical distribution of these territories extended from the Northwest (Gandhāra and Kamboja) to central and southern India (Avanti, Cedi, and Asmaka), with the heaviest concentration in the Ganges basin (including Magadha and Anga at the eastern extreme). This range was much broader than the Brahmanical limits of the "Land of the Āryas" (Āryāvarta), which is defined in the Dharmasūtras and the Mahābhāsya of Patañjali (probably second century $\mathrm{BCE}$ ) as "The region to the east of where the Sarasvati disappears, west of Kàlaka forest, south of the Himalayas, and north of the Pāriyātra mountains" (Olivelle 2005: 36). ${ }^{32}$ The exclusion of Magadhans and other easterners from the Brahminical heartland of Āryāvarta may suggest that they were "still not completely brahmanized" (Lamotte 1988 [1958]: 7). Romila Thapar observes that the widening of geographical horizons in Jain and Buddhist traditions parallels an eastward shift in the religious "epicentre" (2003: 138) from Vedic centers in the west to the northeastern regions where śramana movements originated and flourished.

7-8 lists the 16 great countries with their capitals based on Mahābhärata 8.40.29-8.45.14-16, 28, 34, 40, Mahāvastu 1.34, and Dīgha Nikāya III, p. 200. Kirfel, Willibeld. 1920. Die Kosmographie der Inder nach den quellen dargestellt. Bonn; Leipzig: K. Schroeder, 255-6 refers to Jain sources, but only six mahäjanapadas overlap. Tripathi, Rama Shankar. 1942. History of Ancient India. Delhi: Motilal Banarsidass, 82-85 adds references to Anguttara Nikāya I, 213, IV, 252, 256, 260. Law, Bimala Churn. 1932. Geography of Early Buddhism . London: Kegan Paul, Trench, Trübner \& Co. (reprint, New Delhi: Oriental Books Reprint Corporation, 1979), 2 ff. provides further details. For variants, see Fussman, Gérard. 1987-1988. "Histoire du monde indien: Les populations de l'Inde ancienne, d'après les texts." Annuaire du Collége de France 1987-88, 579-585. Fussman comments that the list of 16 mahajanapadas should be interpreted only in cultural and ideological terms rather than as a document of political history (1987-88: 582). Erdösy 1995: 115 and Thapar, Romila. 1995. “The First Millennium BC in Northern India." In Thapar 1995: 111 harmonize literary and archaeological evidence.

${ }^{32}$ This definition of Āryāvarta is found in Baudhāyana Dharmasūtra (1.2.9), Vasiștha Dhamasūtra (1.8) and in Mahābhāsya (I p. 475 1. 3). In Mānavadharmaśāstra 2.21-22 (maybe second century CE), virtually identical boundaries ("The land between the Himalaya and Vindhya ranges, to the east of Vinaśana and west of Prayāga") correspond to the "Middle Region" (madhyadeśa), while Āryāvarta more broadly includes areas "from the eastern to the western sea" (Olivelle, Patrick, trans. 2004. The Law Code of Manu, Oxford: Oxford University Press, 24). 
A realignment of political power among the rulers of northeastern India is illustrated in Buddhist texts, which emphasize the importance of early patrons. During Sākyamuni's lifetime, the kingdom of Magadha vied with Kosala for control of northern India. ${ }^{33}$ Since the Buddha stayed in Śrāvastī, the capital of Kosala, during many rainy seasons (varșavāsa), King Prasenajit is depicted as a prominent patron, along with his chief queen Mallikā and other local donors, especially the wealthy merchant Anāthapinḍada. ${ }^{34}$ For example, a story about the Buddha's acceptance of an invitation from Anāthapiṇadada's female servant Puniga (Sanskrit: Pūrṇikā; Pāli: Puṇnikā or Puṇnāa is briefly summarized in an avadāna in a first century Kharoșțī manuscript:

Puniga was the ( ${ }^{*}$ maid) of the householder Anasapiḍiga (Anāthapiṇ̣ada). The Bhagavat was addressed by King Praseniga (Prasenajit). The Buddha did not agree [to his request] ... and he did not agree [to the request] of all the householders. ${ }^{35}$

This narrative exemplifies the role of female patrons, including individuals like the maidservant Punniga, whose offer to the Buddha to stay in Srāvastī is deemed more sincere than invitations from Prasenajit, Anāthapiṇ̣ada and other wealthy male householders. However, the localization of Buddhist literary narratives in Kosala is a common archetype, since Śrāvastī during the reign of Prasenajit is the formulaic setting for numerous discourses attributed to the Buddha. ${ }^{36}$

Under King Bimbisāra, a brother-in-law of Prasenajit who was also lauded as a patron of the early Buddhist community, Magadha became the most powerful kingdom in northern India, with the capital at Rajjagrha regarded as a wealthy center and major site for the early

${ }^{33}$ Lamotte 1988 [1958]: 10-12, Raychaudhuri 1923: 199-209, and Tripathi 1942: 89 describe relationships between the four major kingdoms of Vatsa ruled by Udena, Avanti ruled by Pradyota, Kosala ruled by Prasenajit, and Magadha ruled by Bimbisāra, while Thapar lists the "four rival states" (2003: 151) as Kāśí, Kośala, Magadha, and the the Vrijji oligarchy.

${ }_{34}$ Malalasekera 1937: s.v. Anāthapiṇ̣ika, Kosala, Mallikā, Pasenadi (Pāli citations).

35 Allon 2001: 304 (Appendix 2: The Gāndhārī Avadāna of Puniga). A Pāli version of this episode is preserved in Manorathapürani $\overline{4}$ 4.34-5 (also see Malalasekera 1937: sv. Punnāa Therī 3 for further citations to verses attributed to her in Therīgāthā 236-251).

${ }^{36}$ Schopen, Gregory. 1997b. "If You Can't Remember, How to Make It Up: Some Monastic Rules for Redacting Canonical Texts." In Bauddhavidyāsudhākarah: Studies in Honour of Heinz Bechert on the Occasion of His 65th Birthday, ed. Petra KiefferPülz and Jens-Uwe Hartmann. Swisttal-Odendorf: Indica et Tibetica Verlag, 571-582 [= Schopen 2004: 395-407]. 
Buddhist saingha. ${ }^{37}$ Ajātaśatru, the infamous parricide who imprisoned and starved Bimbisāra to death eight years before the Buddha's parinirvāna, further consolidated Magadhan control of overland routes and established a small fort at Pātaligrāma, which later became the city of Pātaliputra. Despite his connection with a failed attempt by Devadatta to assassinate the Buddha, Ajātaśatru later hosted the Buddha and his entourage in Rājagṛha before his final journey to Kuśinagara. Ajātaśatru and his ministers play major roles in the events preceding and following the Buddha's Mahāparinirvāna. Ajātaśatru continued to rule for another 24 years, followed by five successive parricides, rule by the minister Siśunāga, and the rise and fall of the Nanda dynasty. ${ }^{38}$ Although the historical memory of these figures preserved in religious and literary sources can not be corroborated by coins, inscriptions, or reliable historiographical traditions from outside of South Asia, the emergence of the Mauryan empire based in Magadha coheres well with archaeological evidence for the growth of powerful cities in the prior period.

\section{Legacy of the Mauryans: Aśoka as Dharmarāja}

Mauryan control of important nodes along overland routes in the Indian subcontinent significantly influenced early patterns for the growth and expansion of the Buddhist sarigha. While the sangha's

${ }^{37}$ Chronological details connected with Bimbisāra's genealogy and reign remain unclear. Raychaudhuri acknowledges that "There is considerable disagreement between the Purānas and the Ceylonese Chronicles regarding the chronology of the kings of the Bimbisārian (or Nāga) and Saiśunāga dynasties" (1923: 116). Magadhan dynastic genealogies in Buddhist and Jain sources are compiled by Lamotte 1988 [1958]: 87-104 and Tripathi 1942: 113-114, who gives a separate table following purānic chronologies, which limit his reign to 28 rather than 52 years (Tripathi 1942: 94, fn. 1). According to Lamotte 1988 [1958]: 4, Magadha was organized as a kingdom only during the Buddha's time.Tripathi 1942: 104-108 comments on economic conditions and Thapar 2003: 152-155 discusses administration. The total of 200 years for the total length of the reign of Bimbisāra, Ajātaśatru, and their successors until the time of the first Nanda ruler in chronologies reported by Pāli vamsas is very suspicious, while purānic alternatives transpose numerous figures.

38 If a short chronology for the Buddha's parinirvana around 370 BCE is adopted, only about 30 years is allowed between the end of Ajātaśatru's reign and Candragupta Maurya's accession. Pāli chronologies limit the "9 Nandas" to 22 years, but the reigns of Śiśunāga (Susunāga), and Kālāśoka and his ten sons would have to be telescoped from 68 years to less than 10 years. Lamotte 1988 [1958]: 89 doubts the existence of Kālāśoka, thus shortening the chronology. 
horizons were initially limited to the Ganges River basin in northern India during the time of the Buddha, the initial extension of Buddhist establishments throughout South Asia was greatly accelerated by high level support from the Mauryan emperor Aśoka, who is portrayed as an ideal patron in Buddhist literature. In comparison to what can only be vaguely known about conditions in the period of the historical Buddha, a wider variety of contemporary sources provide more reliable evidence of religious and political life during the Mauryan period from about the last quarter of the fourth century $\mathrm{BCE}$ to the beginning of the second century BCE. As the earliest written evidence for the study of ancient South Asia, Aśokan inscriptions directly indicate conditions in which Buddhist institutions began to flourish by the middle of the third century BCE. ${ }^{39}$ The fragmentary reports of Megasthenes, a Seleukid ambassador to the Mauryan court at Pātaliputra under Aśoka's grandfather Candragupta, preserve an outsider's cross-cultural perspective on India seen through Greek lenses. ${ }^{40}$ Candragupta and Aśoka are primarily remembered in Jain and Buddhist literature, but the literary images of these Mauryan rulers as exclusive patrons

${ }^{39}$ In addition to Hultszch 1925 and Falk 2006 cited in the first chapter (p. 52, fn. 147), also see translations by Bloch, Jules. 1950. Les inscriptions d'Asoka. Paris: Les Belles Lettres; Sircar, Dineschandra. 1967b. Inscriptions of Aśoka. Rev. ed. New Delhi: Publications Division, Ministry of Information and Broadcasting, Govt. of India; and Thapar, Romila. 1961. Aśoka and the Decline of the Mauryas: With a new afterword, bibliography, and index. London: Oxford University Press (revised edition, Delhi: Oxford University Press, 1997), 250-266. For further references to important studies of Aśokan inscriptions by Paul Kent Andersen, Colette Caillat, K.R. Norman, Ulrich Schneider, and previous scholars, see the extensive bibliography in Falk 2006: 13-54 and the general survey in Salomon 1998a: 133-140. A running tabulation includes 14 Major Rock Edicts inscribed at 9 locations, 6 Major Pillar Edicts at 6 sites (19-20 Aśokan pillars have been discovered, but not all are inscribed, and some are inscribed with edicts other than the set of 6 Major Pillar Edicts), similar versions of Minor Rock Edicts at 17 sites, separate edicts at 7 sites, 3 locations of cave inscriptions, and versions of Greek and Aramaic edicts. Updated editions of the entire corpus of Aśokan inscriptions remains a desideratum.

${ }^{40}$ McCrindle, John W. 1877. Ancient India as described by Megasthenes and Arrian. Calcutta: Thacker, Spink (Reprint, New Delhi: Today \& Tomorrow's Printers \& Publishers, 1972 available as e-book) translates fragments of Megasthenes quoted by various classical authors. Karttunen, Klaus. 1997a. India and the Hellenistic world. Helsinki: Finnish Oriental Society, 69-93 assesses scholarship on Megasthenes, emphasizing that he was "a Greek author writing to a Greek audience" (76). Also see remarks on Megasthenes by Lamotte 1988 [1958]: 221, Parker 2008: 42-47, and Thapar 1961 [1997]: 57-70; 2003: 177-8. 
exaggerate their religious affiliations at the expense of rival traditions. ${ }^{41}$ The Arthaśāstra attributed to Kauṭilya, Candragupta's Brahmin minister, presents itself as a guide to ancient Indian statecraft and political economy during the Mauryan period, although it primarily reflects much later third century CE conditions. ${ }^{42}$ In this survey of historical contexts for Buddhist transmission in Mauryan India, inscriptions of Aśoka are privileged over literary sources, which must be approached carefully with an understanding that biases of later periods have influenced how the Mauryan legacy is remembered.

Candragupta Maurya, the founder of the dynasty, seized control of Magadha after rising to power from obscure origins. Candragupta can be identified with Sandrokottos, an Indian ruler who may have encountered Alexander of Macedon during his expedition to Gandhāra, Punjab, and the lower Indus valley between 327-325 BCE. ${ }^{43}$ Based on a reported meeting between Candragupta and Alexander, historians propose that Candragupta probably began to rule between 324-313 BCE. ${ }^{44}$

${ }^{41}$ Buddhist literary sources on Aśoka are examined by Strong, John. 1983. The Legend of King Aśoka: A study and translation of the Aśokāvadāna. Princeton, N.J.: Princeton University Press. In "Aśoka and the Buddha Relics" (2004a: 124-149), Strong treats Buddhist traditions connected with Aśoka outside of South Asia. He remarks that "Aśoka was best known to Buddhists not through his edicts but through the legends that were told about him" (Strong, John. 2004b. "Aśoka." In Encyclopedia of Buddhism, ed. Robert Buswell, New York: Macmillan, vol. 1, 34).

${ }^{42}$ Kangle, R.P. 1969-. The Kautilīya Arthaśästra. University of Bombay studies, no. 1-2. [Bombay]: University of Bombay, 3 vols. The dating of the text is extensively discussed by Trautmann, Thomas R. 1971. Kautilya and the Arthaśāstra; a statistical investigation of the authorship and evolution of the text. Leiden, Brill. Thapar acknowledges that the text was reworked by Viṣnugupta in the third or fourth century CE, but still uses the text to treat Mauryan administration based on her opinion that "the institutions are in the main Mauryan" (1961: 224).

${ }^{43}$ Karttunen 1997a: 36-7, 257-264 suspects that the "Candragupta legend" may be apocryphal, but does not deny the possibility of a meeting with Alexander. Lamotte 1988 [1958]: 218-219 comments on references to the meeting with Alexander in accounts of Justin (15, 4, 12 ff.) and Plutarch (Life of Alexander, 62, 9). Bongard-Levin, G.M. 1998. Ancient Indian History and Civilization. Delhi: Ajanta (1st ed. New Delhi : Arnold-Heinemann, 1985), 64 adds further details about the supposed meeting, which could have taken place after Candragupta had initially attempted to overthrow the Nandas. According to Thapar 2003: 177, William Jones first identified Sandrocottus with Candragupta. Also see Raychaudhuri 1923: $137 \mathrm{ff}$.

${ }^{44}$ Lamotte 1988 [1958]: 219 claims that Candragupta seized power in 324 BCE, Thapar 2003: 175 states that the Mauryan empire was founded ca. 321 BCE, BongardLevin 1998: 65 favors 317 BCE, Karttunen 1997a: 259 suggests that he first participated in an uprising against Macedonian rule in the Northwest between 317-312 BCE, and Bechert 1989: 101 opts for 313 BCE based on Jain sources which date the accession of Candragupta 155 years after the Nirvāṇa of Mahāvīra in 468 BCE. 
In exchange for 500 trained war elephants, Candragupta acquired the northwestern provinces (including Gandhāra) from Seleukos Nikator, a successor of Alexander, in $303 \mathrm{BCE} \cdot{ }^{45}$ Although the extent of direct administrative control is unclear, the expansion of Mauryan power from Magadha to Gandhāra under Candragupta essentially unified the older mahajjanapadas along the "Northern Route" (uttarāpatha) for the first time in South Asian history. ${ }^{46}$ According to Jain traditions, Candragupta stepped down to accompany the Jain elder Bhadrabāhu to Sravana-Belgola in South India, where he fasted to death. ${ }^{47}$ Candragupta's successor, Bindusāra, may have extended Mauryan dominion further into the Deccan peninsula and favored the Ājivikas while ruling for a period of about 25 years, but his reign is not documented as well as those of Candragupta and Aśoka. ${ }^{48}$

The Mauryan empire reached its zenith during the reign of Aśoka (ca. 270-232 BCE), whom Buddhist traditions revere as an ideal emperor (cakravartin), although he is virtually ignored by other traditions until his rediscovery in the nineteenth century. Aśoka's murky background may support Buddhist literary accounts in which he assumed the throne as "Aśoka the cruel" (Caṇ̣āśoka) after a struggle with rival

45 For discussion and references, see Kartunnen 1997a: 261 and Lamotte 1988 [1958]: 220. Tarn, W.W. 1984 [1951]. The Greeks in Bactria and India, 3rd ed. Chicago: Ares, 100 discusses the geographical extent of Seleukid territories ceded to Candragupta, but Karttunen 1997a: 263 points out that Greek and Aramaic inscriptions of Aśoka in Afghanistan indicate that the ceded territories were more extensive. Seleukos Nikator used the elephants acquired from Candragupta to defeat Antigonus at the battle of Ipsus in 301 BCE (Bernard, Paul. 1994a. "The Seleucids in Central Asia." In History of Civilizations of Central Asia, vol. 2: The development of sedentary and nomadic civilizations: 700 BC to AD 250, ed. János Harmatta. Paris: Unesco, 90).

46 Northern Route (Uttaräpatha) is discussed in detail in the third chapter (pp. 186-203). Fussman, Gérard. 1987b. "Central and Provincial Administration in Ancient India: The Problem of the Mauryan Empire" Indian Historical Review 14.1-2, views Candragupta's use of military force to expand Mauryan dominion as the impetus for a "complex administration" with a "communications network" (55) along a system of roads described by Megasthenes and referred to in Aśokan inscriptions, but points out that administrative control was not necessarily centralized in Pātaliputra since provincial officials had considerable autonomy.

47 Lamotte 1988 [1958]: 221-2; Thapar 1961: 17, 2003: 178.

48 Lamotte 1988 [1958]: 222-3; Thapar 1961: 17-18, 2003: 178. Bindusāra ruled for $27 / 28$ years according to Pāli vaṃsas, 25 years according to purānic chronologies. These figures can be calculated from the date of Aśoka's consecration (ca. $270 \mathrm{BCE}$ ), although Pāli traditions refer to a 4 year hiatus between the death of Bindusāra and Aśoka's reign. 
contenders, who were eliminated in fratricidal conflicts. ${ }^{49}$ However, Pāli narratives of mass slaughter of ninety-nine brothers are likely to have been embellished, since Aśoka refers to his brothers and sisters in inscriptions..$^{50}$ In the Divyāvadāna, Aśoka's subjugation of a revolt while he was serving as heir-apparent prince in Taxila suggests instability before he became the Mauryan ruler, but Pāli chronicles place him in Ujjain instead of Taxila. ${ }^{51}$ In any case, the gory details behind Aśoka's rise to power figure prominently in literary biographies, which portray him as an especially cruel and violent ruler before his transformation into a Buddhist patron.

As discussed in the previous section, dates for the historical Buddha hinge upon Aśoka's consecration in the middle of the third century BCE. Aśokan inscriptions are not dated in a continuous era that can be correlated with the Common Era, but references to five contemporary Hellenistic rulers in the 13th Major Rock Edict issued after the 13th year of his reign serve as "the bedrock of the chronology of Indian history, interlocking the date of the Mauryas with Hellenistic kings" (Thapar 2003: 182). ${ }^{52}$ The synchronism between the dates for these rulers and the internal chronology of Aśoka's regnal years establishes almost certain dates for the beginning of his rule between 274-268 $\mathrm{BCE}$, making a consecration around $270 \mathrm{BCE}$ (or slightly later) fairly

49 Lamotte 1988 [1958]: 249 refers to Dīpavamsa VI, 21-2, Mahāvamsa V, 20-21, 39-40, 189, Samantapāsādikā p. 41, and Mahābodhivaṃsa pp. 98-99. Mookerji, RadhaKumud. 1962 [1928]. Asoka. 3rd rev. ed. Delhi: Motilal Banarsidass, 3-4 contrasts Sanskrit accounts of Aśoka's violent rise to power in the Aśokāvadāna of the Divyāvadāna (chapter 26) with Pāli narratives, concluding that "The northern and southern legends, however, agree as regards the disputed succession, which may therefore be taken as fact" (1962 [1928]: 4).

${ }^{50}$ Bloch 1950: 105 and Hutszch 1925: 192 provide a synoptic tables for a passage in the 5th Major Rock Edict in which Aśoka refers to the households of his brothers, sister, and other relatives.

${ }^{51}$ Lamotte 1988 [1958]: 223; Mookerji 1962 [1928]: 3 refer to Dipavamsa VI, 15 and Mahāvamsa V, 39. Strong 1983: 209-209 translates the passage from Divyāvadāna (pp. 370-371 in Cowell, Edward B. and Robert Alexander Neil, eds. 1886. The Divyâvadâna, a Collection of Early Buddhist legends. Cambridge: University Press).

52 Bloch 1950: 130 and Hultszch 1925: 210 gives synoptic texts of the 13th Major Rock Edict based on versions from Girnar, Kalsi, Shahbazgarhi, and Mansehra. Amtiyoga is identified with Antiochus II Theos of Syria (261-246 BCE), Tulamaya with Ptolemy II Philadelphus of Egypt (285-247 BCE), Antekina with Antigonus Gonatas of Macedonia (276-239 BCE), and Maka with Magas of Cyrene (deceased before 250 BCE). Alikyashudala (Alikasudara in Kharostthī) can be identified with Alexander of Epirus (272-255 BCE) or Alexander of Corinth (252-244 BCE). 
sure. ${ }^{53}$ This approximate date not only provides the crucial linchpin for the history of South Asian Buddhism, but also has important ramifications for the relative chronology of ancient Indian political, intellectual, and cultural history.

Patterns of distribution of Aśokan inscriptions indicate the geographical extent of the Mauryan empire at its peak (Map 2.2: Distribution of Aśoka's Inscriptions). Major Rock Edicts located in the Mauryan borderlands demonstrate that Aśoka's domain eventually extended to ancient Kalinga (modern Orissa) in eastern India, the western coast of India (Girnar in Gujarat and Sopara in Maharashtra), southern India (as far as Suvarnagiri in Karnataka), and the northwestern frontiers in modern Pakistan and eastern Afghanistan. While most of Aśoka's inscriptions are written in Middle-Indo-Aryan Prakrit vernacular languages using the Brāhmī script (which was probably developed for this purpose during the Mauryan period), Major Rock Edicts written in Kharoșthi at Mansehra and Shahbazgarhi (in northwestern Pakistan) reflect linguistic and cultural differences within the Mauryan realm. ${ }^{54}$ Greek and Aramaic versions of Aśokan inscriptions from Kandahar (southeastern Afghanistan) show that Mauryan officials also used non-Indic administrative languages and scripts for transmitting imperial messages. ${ }^{55}$

In addition to supplying concrete evidence for the dates of his reign and the territorial boundaries of his empire, inscriptions issued by Aśoka refer to administrative policies, patronage of various religious communities, and the application of his principles of Dharma. Aśoka addressed his orders to various officials who were responsible for writing and transmitting his instructions. For example, the Rājukas (rural

${ }^{53}$ Bongard-Levin 1998: 68 proposes an absolute date of 268 BCE for Aśoka's consecration based on an astronomical calculations of a solar eclipse in 249 BCE, which he proposes to link with Aśoka's pilgrimage to Lumbini in his twentieth regnal year based on literary references to a solar eclipse during his tour of Buddhist sites. Some additional time may be allowed for communications about contemporary rulers to filter through the ancient world to Aśoka's court (Karttunen 1997a: 266).

${ }^{54}$ Salomon 1998a: 73-75.

55 Pugliese Carratelli, Giovanni and Giovanni Garbini. 1964. A Bilingual GraecoAramaic edict by Aśoka: The first Greek inscription discovered in Afghanistan. Roma: Istituto italiano per il medio ed estremo Oriente. Falk 2006: 241-254 updates references to publications of Greek and Aramic inscriptions of Aśoka from Kandahar, and points that Aramaic inscriptions from Taxila, Laghman, and Pul-I Darunta are not versions of Aśokan edicts. Fussman 1987b: 59-60 comments on the non-standardized bureaucratic use of foreign languages and scripts and Karttunen 1997a: 268-270 differentiates the use of Aramaic as a chancellery language from Greek translations for a foreign Hellenized audience. 


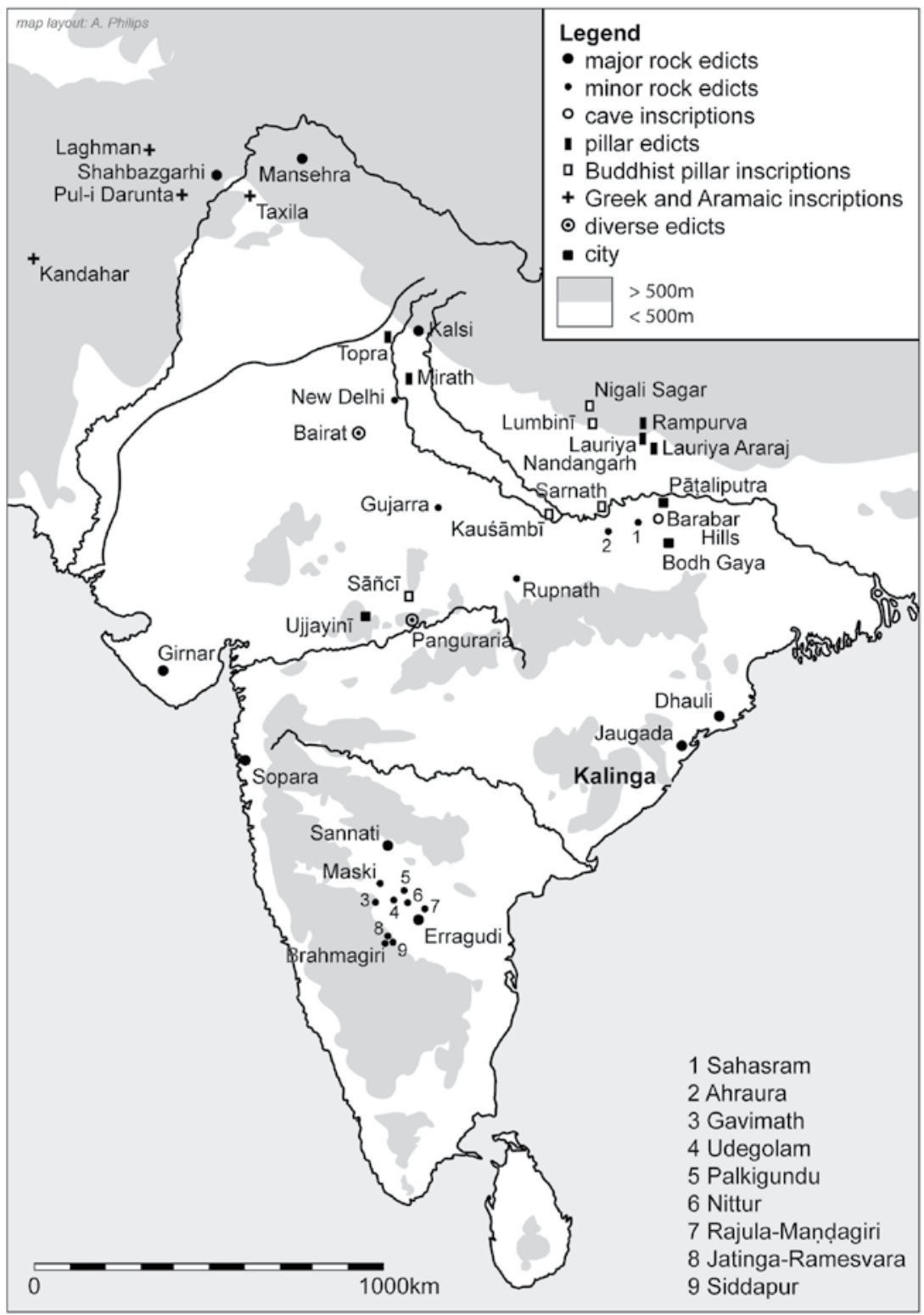

Map 2.2: Distribution of Aśokan inscriptions (based on coordinates in Falk 2006) 
officials) who were appointed for "the welfare and happiness of the country people" were given "independent authority in judgement and punishment" although he instructs them to allow a respite of three days to men condemned to capital punishement. ${ }^{56}$ Passages in several inscriptions seem to reflect an ideal view that ethical interactions should transcend social and religious differences. He encouraged his subjects to perform Dharma ceremonies which promote "regard for slaves and servants, respect for teachers, restrained behavior towards living beings, and donations to śramanas and Brahmins" ${ }^{\prime 57}$ and defined the "gift of Dharma" (Dhammadāna / Dhramadane) as "good behavior towards slaves and servants, obedience to mother and father, generosity towards friends, acquaintances, and relatives and towards śramanas and Brahmans." ${ }^{58}$ Other passages called for generous donations to both Brahmans and śramanas and expressed a tolerant attitude towards "all sects" (Bloch 1950: 121) or "religious communities" (Sircar 1967b: 55):

King Priyadarśin, Beloved of the Gods, honors all religious groups (pāsamida, prasamda), both ascetics and householders, with various gifts and honors. But the Beloved of the Gods does not consider gifts or honors to be as valuable as increasing what is essential for all religious groups. This increase in what is essential is manifold, but its basis is restraint of speech, so as not to extol one's own religious group or denigrate others' at improper occasions, or only do so mildly on appropriate occasions. ${ }^{59}$

Although Aśoka promoted "restraint of speech" (vacigutti), the admonition against sectarian polemics reflects intensive competition between groups of Brahmans and śramanas for imperial patronage. Inscriptions lauding generosity to Brahmans and recording donations of caves to the Ājivikas at Barabar indicate that Aśoka's patronage

\footnotetext{
56 Translation of in the 4th Pillar Edict issued in his 26th regnal year follows Thapar 1961: 263, who also discusses this pillar edict in more detail (1961: 103-108). Fussman explains that the expression janasa athe refers to "the material affairs, the material happiness of the people" (1987b: 57).

57 9th Major Rock Edict (Thapar 1961: 254).

58 11th Major Rock Edict (Thapar 1961: 254-255).

59 12th Major Rock Edict, with modifications based on translations by Bloch 1950: 121-122, Sircar 1967b: 55, and Thapar 1961: 255.
} 
extended to multiple religious communities and not exclusively to Buddhists. ${ }^{60}$

The promulgation of "Dharma" in Aśoka's inscriptions raise questions about the role of the Mauryan state in the growth of Buddhist institutions during his reign. Before addressing this issue directly, it is necessary to recognize that Aśoka interpreted Dharma broadly as religious piety, personal morality, and social ethics applicable to his entire realm rather than adopting a specifically Buddhist sense of the term. The governing principles of Dharma are succinctly defined in the 2nd Pillar Edict:

Dharma is good. And what is Dharma? (It is) few faults, abundant virtues, compassion, generosity, truthfulness, and purity. ${ }^{61}$

Aśoka's view of Dharma encompasses ideals of nonviolence, tolerance, moderation, and respect for parents, teachers, and elders, which are drawn from a wide variety of orthodox Brahmanical perspectives and heterodox Buddhist, Jain, and probably Ājīvika values. Since Buddhist doctrines of the Four Truths, Eightfold Path, "no self" (anātman), or release from rebirth through the attainment of nirvanna are not mentioned in non-Buddhist inscriptions, scholars have debated the extent to which Aśoka intended to implement Buddhist principles or appropriated certain elements to formulate official propaganda to unify disparate religious groups within the Mauryan empire with an acceptable ideology. Although Richard Gombrich and Romila Thapar, for example, hold that Buddhist ideas inspired Aśoka's formulation of Dharma, K.R. Norman regards his Dharma policy as "exclusively a moral one" with "no hint of anything exclusively Buddhist" (1997b: 117) ${ }^{62}$ In sets

${ }^{60}$ Falk 2006: 258-269 re-examines the architecture and inscriptions of the Barabar caves, and presents a new reading and translation of three donations by Aśoka in his 12th and 19th regnal years. The excavation of caves in the Nāgārjuni hills (nearby Barabar) donated to the Ājivivikas by Daśaratha, one of Aśoka's descendants, may have begun while Aśoka was ruling (Falk 2006: 257, 276).

${ }_{61}$ Bloch 1950: 162; Hultzsch 1925: 120-121; Sircar 1967b: 71; Thapar 1961: 262. It is interesting to note that dharma is translated as eusebeia ("piety") in a bilingual Greek-Aramic inscription and in partial Greek translations of the 12th-13th major rock edicts in Kandahar (Falk 2006: 242-245; Lamotte 1988 [1958]: 714-715; Pugliese Carratelli and Garbini 1964: 33). Bongard-Levin observes that the Greek term "conveys the idea of righteousness, not religious belief" and explains that Aśoka's moral precepts were "traditional ethical principles easily comprehended by various strata of the population regardless of their ethnic origin or religious allegiance" (1998: 79).

${ }_{62}$ Gombrich attempts to identify "distinctively Buddhist values" (2006: 131) in Aśokan inscriptions by pointing out similarities with prescriptions for Buddhist lay 
of major rock edicts and pillar edicts inscribed throughout the Mauryan domain, Aśoka appears to have maintained a distinction between the official Dharma and his own commitment as a Buddhist devotee, which he clearly expressed in other inscriptions discussed below.

The violent conquest of Kalinga was a pivotal turning point that caused Aśoka to express deep remorse and to adopt "Victory of Dharma" (dharmavijaya) as the goal of his rule. ${ }^{63}$ In the 13th Major Rock Edict, Aśoka declared that the impetus for him to practice, desire, and teach Dharma was the mass deportation of 150,000 people, killing of 100,000, and the subsequent loss of life of many more resulting from the subjugation of Kalinga during the eighth year of his reign. ${ }^{64}$ In this singular epigraphic record, Aśoka juxtaposes military conquests to the "Victory of Dharma" by proclaiming:

This Dharma inscription has been written so that my sons and grandsons would not pursue new conquests. They should delight their own minds, regarding real victory (won by) patience and leniency. They must realize Victory of Dharma is the real conquest. ${ }^{65}$

The bloodshed in Kalinga may have prompted Aśoka to embrace Jain and Buddhist principles of nonviolence (ahimsāa), but the application of this ideal was tempered by the need to suppress rebellions and punish criminals. In the same inscription, a threat to punish forest tribes makes it very clear that Aśoka was not willing to relinquish the use of violence if his power was threatened. ${ }^{66}$ Thus, Aśoka's admonitions

morality in Pāli texts such as the Sīgālovāda sutta and the Kütadanta sutta. According to Thapar, "... much of the ideology of Dhamma which he enunciated was inspired by Buddhism. But to equate it totally with Buddhism and to suggest that Aśoka was propagating Buddhism as a state religion is to read more into the edicts than was intended by the monarch" (1975: 42). Thapar believes that Aśoka's Dhamma served as a "group of unifying principles" (2003: 201) rather than a narrow sense of religious piety. Lamotte asserted that "Aśoka himself makes a clear distinction between his personal Dharma... and the Buddhist Law" (1988 [1958]: 228).

${ }^{63}$ Norman 1997b: 114-115 attributes Aśoka's Buddhist conversion to remorse for carnage in a war with Kalinga, but the chronology of the undated Minor Rock Edicts (which Norman believes were issued in his 11th regnal year) does not necessarily indicate that he became a Buddhist upāsaka after the Kalinga war.

${ }^{64}$ Norman's view that “...Aśoka expanded his empire by force, but thereafter devised the principle of victory by morality [Dharma] and commended it to his successors" (1997b: 118) seems apparent from the evidence of the 13th Major Rock Edict.

${ }_{65}$ Bloch 1950: 132; Sircar 1967b: 59; Thapar 1961: 256-257.

${ }^{66}$ Fussman's comments on this passage in the 13th Major Rock Edict help to clarify the apparent contrast between the ideal of nonviolence and its application: "...the 
against violence coupled with threats against resistance argue strongly against over-idealizing his image as a ruler who governed according to nonviolent principles, since it was still necessary for him to enforce Mauryan power.

Aśoka's inscriptions recording visits to Buddhist sites and addressed directly to the Buddhist sangha deserve particular attention for illuminating early pilgrimage practices, tensions within monastic cummunities, and the circulation of orally transmitted texts. Aśoka explicitly identifies himself as a Buddhist lay follower in fourteen versions of his Minor Rock Edicts composed in his tenth regnal year and distributed widely throughout the Mauryan empire:

Thus speaks the Beloved of the Gods. More than two and a half years have passed since I became a Buddhist layman (upāsake), but I was not zealous. Now more than a year has passed since I approached the sangha and have become more zealous. ${ }^{67}$

His visits to the site of the Buddha's awakening (sambodhi), Siddhārtha's birthplace at Lumbinī and the stūpa of the previous Buddha Konākamana at Nigāli Sāgar indicate a strong proclivity to Buddhist devotional practices. ${ }^{68}$ These epigraphic records show that his literary reputation as "the stūpa builder par excellence" (Strong 1983: 109) had some basis, although no Aśokan inscriptions discovered to

king's orders should be applied everywhere, even among the populations who live on the fringe of the Empire, under the threat of violent repression" (1987b: 51). More bluntly, "If persuasion did not succeed, there was always force" (ibid., 53).

${ }^{67}$ Andersen, Paul Kent. 1990. Studies in the Minor Rock Edicts of Aśoka. Freiburg: Hedwig Falk, 112-113, 123-124 presents a synoptic text and reconstructed edition of this passage in all 14 versions, but further in situ investigations of these sites by Harry Falk (2006: 55-103) have clarified many earlier readings. For translations, see Bloch 1950: 145-147 (synoptic translation and edition of Brahmagiri, Rupnath, etc.); Hutzsch 1925: xliv (commentary), 174-177 (Maski and Brahmagiri), 228 (synoptic edition); Sircar 1967b: 39-41 (Rupnath, Maski, Gujarra); and Thapar 1961: 259 ("a conflation of various versions). Also see comments by Norman 1997b: 115 .

${ }^{68}$ The assumption that sambodhi refers to the Bodhi tree shrine in Bodh Gaya is challenged by Basham, A.L. 1979. "Sambodhi in Aśoka's 8th Rock Edict." Journal of the International Association of Buddhist Studies 2, 81-83, who argues that this term refers Aśoka's own conversion ("awakening"). Konākamana, who precedes the previous Buddha Kāśyapa in the present Bhadrakalpa, is known elsewhere as Konāgamena (Bhārhut inscription B 16, Lüders 1963: 85-86), Konagamuni (Library of Congress ${ }^{\star}$ Bahubuddha-sūtra Kharoșțī scroll, Salomon, forthcoming), Koṇāgamana (Pāli, Malalasekera 1937: 1.681-2), and Koṇākamuni/Kanakamuni (Edgerton 1953 [BHSD]: 167). The Lumbini inscription is treated earlier in the previous section of this chapter, and see Falk 2006: 187-189 (Niglīiā) and Hultzsch 1925: 164-165 for Nigāli Sāgar. 
date are connected with the establishment of relics or the construction of stūpas of Śàkyamuni.

Three versions of the so-called "Schism edict" written on pillars at Sarnath, Sāñcī, and Kauśāmbī seem to indicate that Aśoka ordered his administrators to intervene directly in the affairs of the Buddhist sangha. Common to all three versions is an admonition against causing a split in the community: "Whoever creates a schism in the saingh, whether monk or nun, is to be dressed in white garments, and to be put in an uninhabited place." ${ }^{\prime 69}$ Although their interpretation remains disputed, the inscriptions refer to problems of division in the community (sainghabheda), which Aśoka may have been called upon to police. ${ }^{70}$ K.R. Norman (1997b: 122-129) compares the anti-schism edicts to different Pāli versions of a third communal recitation believed by the Theravāda tradition to have been held at Pạtaliputra during the time of Aśoka. Norman concludes that the Aśokan inscriptions and Pâli accounts of a third council do not necessarily refer to the same event, but suggests that Aśoka may have indirectly intervened to evict infiltrators who were not Buddhist monks or nuns from a royally supported monastery or monasteries.

A separate Aśokan edict found at Bairat in Rajasthan but brought to the Asiatic Society in Calcutta after its discovery recommends particular texts to Buddhist monks, nuns, laymen, and laywomen. ${ }^{71}$ While some identifications remain uncertain, the seven "discourses on dharma" (Prakrit: dhamma-paliyāyāni / Sanskrit: dharma-paryāyāhn) referred to in this inscription provide a valuable glimpse of the types of texts that were being circulated through oral transmission in the middle of the third century BCE. ${ }^{72}$ As K.R. Norman observes, "... we can say

${ }^{69}$ Bloch 1950: 152-153; Hultzsch 1925: 159-164; Mookerji 1928: 193-200, 243-244; Sircar 1967b: 66-67; Thapar 1961: 262. Lamotte interprets this passage to mean that "The king's intention was to reduce dissidents to lay status, by forcing them to return to the white robe of householders" (1988 [1958]: 238).

70 Sasaki, Shizuka. 1989-1999. "Buddhist Sects in the Aśoka Period" (1-8). BukkyōKenkyū 18: 181-202; 21: 157-176; 22: 167-199; 23: 55-100; 24: 165-225; 25 : 29-63; 27: 1-55; 28: 1-10.

${ }^{71}$ Bloch 1950: 154-155; Falk 2006: 106-108, Hultszch 1925: 172-174, Lamotte 1988 [1958]: 234-237, Mookerji 1928: 117-119.

72 Lamotte 1988 [1958]: 235 discusses identifications of Vinaya-samukasa ("Praise of Discipline"), Aliya-vasāni ("Genealogy of the Noble (äryas)"), Anāgata-bhayāni ("Future Dangers"), Munigāthā ("Stanzas of the Sage"), Moneyasūte ("Discourse on Silence"), Upatisa-pasine ("Questions of Upatissa") and Läghulovāde musāvādam ("[Discourse on] Falsehood spoken to Rāhula"). Only three of these identifications (Munigāthā with Suttanipāta vv. 207-221, Moneyasūte with Suttanipāta vv. 699-723, 
that some sort of collection of the Buddhavacana was in existence in Aśoka's time" (1997b: 142). The short individual verse texts selected by Aśoka belong to a very early stratum of Buddhist literature, probably before they were classified into fixed textual categories of nikāyas, àgamas, and pitakas. The significance of Aśoka's recommendation of these texts extends beyond issues of textual classifications and relative chronology, since he explained that his motive for addressing the lay and monastic community was to ensure the durability of the "True Dharma" (Prakrit: sadhamma / Sanskrit: saddharma). His concern about the vulnerability of the Buddha's teachings to decline or disappearance was probably not merely formulaic, but grounded in the turbulent political and religious realities of his age.

Buddhist traditions claim that Aśoka played an active role in the transmission of Buddhism by sending missionaries beyond Mauryan India, but his inscriptions do not provide corroboration. In the 13th Major Rock Edict, Aśoka lists realms of contemporary Hellenistic rulers, neighboring kingdoms, and imperial territories where his prescriptions for Dharma are followed, and grandiloquently claims that his instructions are followed even in places not visited by his envoys. ${ }^{73}$ Even if such exaggerated proclamations were believable at some level (if Aśoka's envoys did reach distant lands), the Dharma that was transmitted would not have been the Dharma taught by Buddhist monks and nuns, but the more general imperial ideology brought by royal Mauryan messengers. Similar reservations apply to another passage in the 5th Major Rock Edict in which Aśoka refers to the appointment of "Dharma Ministers" (dharma-mahāmātras):

They are busy in all sects, establishing Dhamma, increasing the interest in Dhamma, and attending to the welfare and happiness of those who are devoted to Dhamma among the Greeks (Yonas), the Kambojas, the Gandhārans, the Risțhikas, the Pitinikas, and the other peoples of the west. $^{74}$

References to the borderland inhabitants of the northwestern frontiers of the Mauryan empire suggest that the Dharma-mahämātras were

and Upatisa-pasine with Suttanipāta vv. 955-975) are uncertainly agreed upon (Schopen 1997a [1985a]: 24-5).

${ }_{73}$ Thapar 1961: 256.

${ }^{74}$ Translation according to Thapar 1961: 252 (see pp. 156-158 for additional commentary on mahämätras, although viewing these officials as social welfare agents is probably anachronistic). 
Mauryan imperial agents rather than Buddhist missionaries. While it is possible that Buddhist monks and nuns may have accompanied diplomatic missions, the strongest support for such an interaction is not from inscriptions, but from much later accounts in Pāli chronicles attributing the conversion of Sri Lanka to Aśoka's son Mahinda and daughter Sanghamittā. ${ }^{75}$ Although Aśokan Buddhist inscriptions and the remains of Mauryan period stuppas and monasteries generally support his portrayal as an ardent patron of the sangha, the expansion of Buddhism during this period should be attributed to relatively stable political and economic conditions rather than state patronage. ${ }^{76}$

A virtual silence in Brahmanical Sanskrit sources with regard to Aśoka's legacy contrasts sharply with his legendary status in Buddhist literature. Despite Aśoka's undoubtable historical achievements, characters with the name of Aśoka are rarely mentioned in the Mahäbhārata, perhaps in oblique association with demonic asuras. ${ }^{77}$ Although "Buddhism was in the air for the poets of the Mahäbhärata" (Hiltbeitel 2005: 129), there is not a single explicit reference to the Buddha or to the Buddhist tradition. Such omissions of important historical figures and religious ideologies suggest that Aśoka's role was deliberately downplayed because of his support for the Buddhist sangha in the post-Mauryan period, when the core of the Mahäbhärata may have been composed. ${ }^{78}$

${ }^{75}$ Lamotte 1988 [1958]: 297 does not regard Pāli accounts of the initial transmission of Buddhism to Sri Lanka as reliable, but Gombrich 2006: 135-136 believes the accounts of Aśokan missions are more credible. According to Kevin Trainor, there is "solid historical evidence that the basic facts of the mission to Sri Lanka are trustworthy" (1997: 86), but the primary evidence is a Brāhmī inscription marking a stūpa of the Idika (Itthhiya) and Mahinda, a common name that is not clearly preserved.

${ }_{76}$ Following Lamotte 1988 [1958]: 215 and Norman 1997b: 129 rather than Gombrich 2006: 136. As Norman observes, "Buddhists appropriated Aśoka for their own use" (1997b: 127).

77 Biardeau, Madeleine. 2002. Le Mahābhārata: Un récit fondateur du brahmanisme et con interprétation. Paris: Éditions du Seuil, 1.112 refers to an asura known as Aśvapati who became an invincible king named Aśoka in Mahābhārata 1.67.13b-15a. Mahäbhärata 12.4.6-8 lists Aśoka among the kings who attended the svayamvara for king Citrāngada's daughter, who was abducted by Duryodhana with the aid of charioteer Karna (Biardeau 2002: 1.112, n. 30, Fitzgerald, James, translator. 2004. The Mahäbhärata. vol. 7 Book 11, The book of women. Book 12, The book of peace, part one. Chicago/London: University of Chicago, 175, and Hiltbeitel, Alf. 2005. "Buddhism and the Mahābhārata: Boundary Dynamics in Textual Practice." In Boundaries, Dynamics and Construction of Traditions in South Asia, ed. Frederico Squarcini. Firenze, Italy: Firenze University Press / Munshiram Manoharlal, 119).

${ }^{78}$ The dating of the Mahäbhärata as a whole remains disputed due to conflicting views about what is considered to be the "core" of the epic narrative as opposed to 
Mahäbhärata scholars have long attempted to find reflections of Aśoka in certain characters and to identify heterodox ideologies expressed in the treatment of Dharma. ${ }^{79}$ Starting with the premise that "...political and religious ideas are profoundly influenced by the events and social trends in which they arise" (1997: 333), Nick Sutton suggests that ideological tensions between Dharma and the use of violence are voiced by "the fictional Yudhișthira representing the historical Aśoka and other kings of similar inclination" (1997: 334). ${ }^{80}$ Sutton argues that their mutual "abhorrence of warfare" (1997: 335) following military conquests in Kalinga and the battle at Kuruksetra illustrate unease with normative Kṣatriya values. James Fitzgerald agrees that a "Double Crisis of Dharma" was precipitated by Aśoka and other rulers who "elevated the world-denying, brahmin criticizing movements to positions of imperial honor equal to or superior to that of the Vedas" (2004: 115). However, Fitzgerald views Yudhișthira not as a representation of Aśoka but as a rebuttal or refutation of his "blithe embrace" (137) of nonviolence, since Yudhișthira and his Pạṇạa brothers and allies justify violent actions to restore Dharma. Thus, the composers of the Mahābhārata in the centuries following Aśoka consciously juxtaposed Yudhisțhira, the ideal Kșatriya ruler who "stands steady in battle," to the Buddhist emperor (cakravartin) and Dharmarajja Aśoka. Alf Hiltbeitel accepts the possibility of polysemic juxtapositions between Yudhișthira and Aśoka, suggests parallels between the Brah-

later additions, which continued at least until the Gupta period. Fitzgerald 2004: xvi, n. 2 argues that the "written Sanskrit text" provoked by Aśoka's "dharma-campaign" was substantially completed during or shortly after the time of the Sungas and Kannvas (between the middle of the 2nd century BCE and the end of the 1st century BCE, although 1st century CE is also possible), with systematic expansions continuing until ca. 400 CE. Hiltbeitel 2005: 113 opts for a more constricted period of composition from about $150 \mathrm{BCE}$ to $0 \mathrm{CE}$. While earlier scholars proposed more cautious estimates between ca. $400 \mathrm{BCE}-400 \mathrm{CE}$, specialists are attempting to define phases of composition in the last two centuries BCE followed by significant interpolations in the 1st-3rd centuries CE, with a final form as late as ca. $500 \mathrm{CE}$.

${ }^{79}$ Hiltbeitel comments that questions about relationships between the Mahābhārata and Buddhism were raised by Adolf Holtzmann, whose 'inversion theory' linked Aśoka with a foreign Buddhist Duryodhana, and, as he puts it, "certain authors are still playing with the same gamepieces" (2005: 108). Biardeau 2002 proposed that the "initial shock" (l'ébranlement initial, 1.103) of Aśoka's embrace of Buddhism led to a Brahmanical reaction (1.113), resulting in an epic "riposte to the Buddhist menace" (1.136). Biardeau elaborated on this hypothesis in her conclusion: "Épopée et Bouddhisme" (2.747-782).

${ }^{80}$ Sutton, Nick. 1997. "Aśoka and Yudhișthira: A Historical Setting for the Ideological Tensions of the Mahābhārata?" Religion 27, 333-341. 
min general Drona and the historical figure of Puṣyamitra Sunga, and notices similarities between the denigration of stūpa (edīka) worship in Mārkandeya's ex eventu prophecies of barbarization and criticisms of religious festivals in Aśokan inscripions. ${ }^{81}$ However, he cautions that "one-to-one readings [such as Yudhisthira as a representation or refutation of Aśoka] may have something persuasive about them without being as singly correct as their proposers propound" (2005: 129). While juxtapositions between Aśoka's interpretation of Dharma and Yudhișthira's reconfiguration of Kṣatriya identity have stimulated scholarly interpretations, reading the Mahäbhärata as a response to issues of religious patronage and rivalry during the Mauryan period may circumscribe this complex text too neatly and narrowly. The Mahābhārata may just as likely belong to chronological and historical contexts from the second century BCE through third century CE when Indo-Greek, Saka, and Kușanna rulers established dominion over northern India and Buddhist institutions expanded beyond central nodes and main routes formerly controlled by the Mauryans.

The historical memory of Aśoka as a model royal Buddhist patron persisted far beyond South Asia, but his impact on ancient Indian political history and non-Buddhist religious traditions is difficult to assess. The dynastic succession after Aśoka is vague, and the Mauryan empire disintegrated within fifty years of his death in ca. 230 BCE. ${ }^{82}$ Daśaratha, who may have directly followed Aśoka, donated caves to the Ājīvikas at Nāgārjunī Hill near Barabar and is known in some purānic genealogies, but is not mentioned in Buddhist or Jain sources. ${ }^{83}$ In the Divyāvadāna, Asoka's successor Kuñāla was sent to subdue a revolt in Taxila, where he was blinded as a result of an order issued by Tiṣyarakșitā, the chief queen. ${ }^{84}$ According to this account, Kunāla's son Samprati (who is known in Jain literature as a great patron) then became emperor after Aśoka exhausted the empire's resources by

${ }^{81}$ Hiltbeitel 2005: 113, 126. According to Hiltbeitel, "further reminders of an interface with a Buddhism compounded by mlecchification" (2005: 127) reflect a basic antipathy between Brahmins and heterodox Buddhists. His decoding (following Biardeau 2002: 2.753-758) of Jarāsaṃdha as a representation of Māra (or Aśoka) in juxaposition to Kṛṣna as a figure of Bhakti devotionalism associated with Mathura is less convincing.

${ }^{82}$ Thapar 1961: 182-196.

${ }^{83}$ Falk 2006: 270 ff.; Lamotte 1988 [1958]: 259; Thapar 1961: 186-187.

${ }^{84}$ Lamotte 1988 [1958]: 246-248; Strong 1983: 268-286; Thapar 1961: 185. 
making donations to the Buddhist sangha. ${ }^{85}$ The last Mauryan ruler, according to purānic sources, was Brhadratha, who was overthrown by his Brahmin general Puṣyamitra, the founder of the Sunga dynasty, around 185 BCE. ${ }^{86}$ Historians have attributed the rapid decline of the Mauryas within a span of less than fifty years after Aśoka's death to the impossibility of administering such an immense territitory, a cumbersome bureaucracy, an economic crisis marked my devaluation of Mauryan coinage, Brahmanical reaction to official patronage of Buddhists and other śramanas, and the failure of Aśoka's nonviolent Dharma policy to meet the needs of governance or to fufill Kṣatriya norms. While a completely satisfying explanation can not be offered here, the salient point to note is that political and religious dynamics of the Mauryan period provided a crucial impetus for the expansion of Buddhist institutions, which survived the downfall of the dynasty of the Buddhist tradition's most famous patron.

\section{Migrations, Material Exchanges, and Cross-Cultural Transmission in Northwestern Contact Zones}

Movements of people, materials, languages, symbols, and religious ideas and rituals have had numerous impacts on the northwestern frontier of South Asia, which was never an isolated or static enclave. Multiple itineraries used by exogenous migrants for crossing rivers (particularly the Indus and its tributaries in the Punjab), mountain ranges (such as the Hindu Kush, Pamirs, and Karakorum), and deserts demonstrate that permeable geographical boundaries did not hinder mobility. A brief treatment of much earlier material exchanges and migrations introduces themes of contact and mobility, thus setting the stage for the arrival of various groups in the northwestern borderlands after the collapse of the Mauryans in the early second century BCE. The wide distribution of lower Indus Valley seals and other artifacts from the Persian Gulf to Shortughaï in the Amu Darya/ Oxus River valley in Badakhshan (northeastern Afghanistan) demon-

${ }^{85}$ Lamotte 1988 [1958]: 259-260; Strong 1983: 288-292; Thapar 1961: 187-188.

${ }^{86}$ Lamotte 1988 [1958]: 354-357; in the Divyāvadāna (Strong 1983: 292-294) Pusyamitra belongs to the Mauryan line, but he is remembered as an enemy to the sangha. 
strates long-distance maritime and overland trade connections until ca. 1800 BCE. ${ }^{87}$ Similarities between burial practices associated with the Bactria-Margiana Archeological Complex (BMAC, ca. 2100-1500 $\mathrm{BCE}$ ) and the Gandhara Grave Culture (ca. 1700-1400 BCE) as well as grave sites in Baluchistan suggest a pattern for the movement of Proto-Indo-Aryans from the western Central Asian steppes through the Oxus basin and across the Hindu Kush of central Afghanistan to northwestern South Asia. ${ }^{88}$ Nüristānī languages still spoken in northeastern Afghanistan may also represent vestiges of early migrations, since they belong to a separate linguistic branch of Indo-Aryan that appears to have diverged from archaic forms of Old Indo-Aryan (as preserved in vedic Sanskrit). ${ }^{89}$ References in the Rgveda to rivers and other toponyms located in modern Afghanistan and northwestern Pakistan strongly indicate geographical familiarity with the northwestern subcontinent. ${ }^{90}$ Protohistoric networks of long-distance trade contacts, archeological evidence of migrations between Central Asia and South Asia, and the spread of Indo-Aryan languages are preludes for later historical contexts of Buddhist transmission to the northwestern frontiers of South Asia.

${ }^{87}$ Francfort 1989 : 2.389-421 ; Karttunen, Klaus. 1989. India in Early Greek Literature. Helsinki: Finnish Oriental Society, 11-15.

${ }^{88}$ Mallory, J.K. 2002. "Archaeological models and Asian Indo-Europeans," Proceedings of the British Academy 116 [Sims-Williams 2002], 31, fig. 8; Parpola, Asko. 2002. "From the dialects of Old Indo-Aryan to Proto-Indo-Aryan and Proto-Iranian." Proceedings of the British Academy 116 [Sims-Williams 2002], 66-72. Parpola cautions against using archaeological data to track linguistic change, since the producers of an archaeological culture may speak several languages or may adopt new languages. For a more skeptical view of proposed linkages between archaeological patterns and later texts (Avesta and Rgveda), see Lyonnet, Bertille. 1994. "Central Asia, the IndoAryans and the Iranians: Some reassessments from recent archaeological data." In South Asian Archaeology 1993, eds. Asko Parpola and Petteri Koskikallio. Helsinki: Suomalainen Tiedeakatemia, vol. 1, 425-434.

89 Degener, Almuth. "The Nuristani Languages." Proceedings of the British Academy 116 [Sims-Williams 2002], 103-117 reaches this conclusion following a succinct overview of hypotheses of Nüristānī affiliations with Iranian, Indian (Indo-Aryan), or a separate branch of Old Indo-Iranian (as Georg Morgenstierne proposed). Cardona and Jain 2003: 22-25 also opt for an Indo-Aryan affiliation of Nüristānī.

90 Witzel, Michael. 1987. "On the Localization of Vedic Texts and Schools (Materials on Vedic Śakhas, 7)." In India and the Ancient World: History, Trade, and Culture Before AD 650, ed. Gilbert Pollet. Leuven: Departement Oriëntalistiek), 173-213. 


\section{Iranian Contacts in the Northwest}

Contacts with the Achaemenid empire of ancient Iran and the Hellenistic successors of Alexander of Macedon initiated a series of cross-cultural encounters in the Northwest. Old Persian inscriptions of Darius I (522-486 BCE) and Xerxes (486-465 BCE) indicate that Gandhāra (Gadāra) and Sindh (Hiduš) in present-day northwestern and southern Pakistan were the easternmost Achaemenid provinces. ${ }^{91}$ Relying on the account of Scylax of Caryanda, the Greek historian Herodotus (4.44) briefly refers to an expedition sent by Darius I to explore the Indus River around 518-519 BCE. ${ }^{92}$ This account seems to confirm that the lower Indus valley was included in the domain of Darius I, who received 360 talents of powdered gold in tribute from this province, thus exceeding the amount of revenue from any other province. ${ }^{93}$ Despite these epigraphic and literary references to Achaemenid tributary provinces in India, it is important to acknowledge significant differences between official images and the difficult reality of administering an empire extending from the Mediterranean to the Indus. Pierre Briant wisely cautions:

${ }^{91}$ For editions and translations of Old Persian inscriptions, see Kent, Roland. 1953. Old Persian: Grammar, Texts, Lexicon. 2nd rev. ed. New Haven: American Oriental Society, 116-138, 150-151. Vogelsang, W.J. 1992. The Rise and Organisation of the Achaemenid Empire: The Eastern Iranian Evidence. Leiden: Brill, 94-179 devotes considerable attention to Achaemenid royal inscriptions, Apadāna reliefs, and the Persepolis fortification tablets. Pierre Briant. 2002 [1996]. From Cyrus to Alexander: A History of the Persian Empire, translated by Peter T. Daniels (Histoire de l'Empire perse: de Cyrus à Alexandre. Paris: Fayard). Winona Lake, Indiana: Eisenbrauns, 173 provides a helpful table of "empire lists" in Old Persian inscriptions. References by Herodotus (3.91-94) to the tribute received by Darius from Asia and his account of the expansion of the Achaemenid empire to the east are discussed by Karttunen 1989: 32-38, Parker 2008: 21-28, and Vogelsang 1992: 200-207. Fleming, David. 1993. "Where was Achaemenid India?" Bulletin of the Asia Institute 7, 67-72, suggests that Taxila may have been the capital of the "Indian" satrapy.

${ }_{92}$ Briant 2002 [1996]: 140, 904; Karttunen 1989: 40-48, 65-68; Parker 2008: $14-18$.

${ }^{93}$ Herodotus (3.94-95) calculates that 360 talents of gold-dust annually received by Darius from the twentieth satrapy of India (the lower Indus) is equivalent to 4680 silver talents, since gold is worth thirteen times the value of silver. The story relayed by Herodotus $(3.98,102-105)$ of how the Indians acquired such a large supply of gold by using great ants "in size somewhat less than dogs, but bigger than foxes" (Rawlinson, George, trans. 1942. The Persian Wars. New York: Random House, 262) raises suspicions about the credibility of this figure. Tarn 1985 [1951]: 108 dismisses the story, but Karttunen 1989: 37-38, 171-176 discusses possible sources for the story of the golddigging ants and points out that the source of the gold was not the lower Indus. 
It appears clear that neither the country lists nor the depictions of peoples are intended to give a realistic picture of the administration or the geography of the Empire. Instead, the lists and depictions are primarily the vehicles of the very idea of royal and imperial power. (Briant 2002 [1996]: 183)

The extent of direct Achaemenid control over the northwestern Indian subcontinent remains unclear, especially in regard to Taxila and areas east of the Indus River.

Fragmentary accounts of the Persika and Indika attributed to Ctesias of Knidos, a Greek physician who served in the Achaemenid court for sixteen or seventeen years until 398/7 BCE, illustrate how fantastic and factual information about India was filtered to a Greek audience through Iran. ${ }^{94}$ Unfortunately, Ctesias' account of the Achaemenid network of routes across the Iranian plateau and western Central Asia to the Indian subcontinent has not survived, since the 'Royal Road' between Sardis and Susa described by Herodotus (5.52-4) was "just one royal road among many others" (Briant 2002 [1996]: 357). ${ }^{95}$ As Pierre Briant comments, "...many other itineraries, often much shorter and often following mountain or desert routes, are left out" and "It was in fact impossible to travel by such routes without local guides" (2002 [1996]: 360). While official documents indicate that the main roads primarily served political and military purposes, Briant observes that "information on customs and tolls seems to confirm the breadth and density of trade" (387).

Cross-cultural borrowings from Achaemenid Iran were certainly possible, but Indian sources do not explicitly refer to transmission

${ }_{94}$ Karttunen 1989: 80-85 discuses the "bad reputation" (80) of Ctesias among classical authors and modern scholars, but cautions that "we cannot always use modern criteria when judging ancient authors" (81). Karttunen's observation that authors like Herodotus and Megasthenes who are viewed as (relatively) more trustworthy were also "fond of marvels" (82) is contested by Parker, who argues that "The marvel, so important to Ctesias' ethnography with its tendencies towards natural history, became an embarrassment to the development of a new kind of historiography that was beginning to emerge" (30-31). Parker reviews current scholarship, including a commentary on fragments attributed to Ctesias by Lenfant, Dominique. 2004. La Perse; l'Inde; autres fragments. Collection des universités de France, v. 435. Paris: Belles lettres. Now also see Nichols, Andrew. 2008. The Complete Fragments of Ctesias of Cnidus: Translation and commentary with an introduction. Gainesville: University of Florida Ph.D. Dissertation.

${ }_{95}$ According to Photius' summary, the Persika of Ctesias "described the relays (stathmoi), days elapsed, and parasangs between Ephesus and Bactria and India" (Briant 2002 [1996]: 357). 
in either direction. The derivation of the Kharoșthi script from Aramaic, which was used throughout the Achaemenid realm, is relatively straightforward, but the development of Brāhmī as a chancellery script for writing Aśokan inscriptions may have also been related to an effort to emulate the royal inscriptions of Achaemenid or later Seleukid rulers. ${ }^{96}$ Achaemenid influences on Mauryan art and architecture have also been suggested, but the evidence for this period of Indian art is very limited. ${ }^{97}$ The possibility of Iranian influences on later layers of rock art in the Upper Indus valley is stronger, but Achaemenid sources seem unlikely. Nevertheless, the long period of Achaemenid control (however nominal) of the northwestern borderlands prior to the conquests of Alexander of Macedon is likely to have enhanced its already hybrid Indo-Iranian culture by opening additional channels of trade, travel and communication.

\section{Hellenistic Interactions}

Alexander's attempt to invade India initiated cross-cultural interactions between Hellenistic and South Asian civilizations in the contact zones between the Indus and Oxus rivers. After conquering the Achaemenid heartland of ancient Iran following the battle of Gaugamela in $331 \mathrm{BCE}$, Alexander of Macedon led a large military expedition to Central Asia (Bactria and Sogdia) and the northwestern regions of South Asia (Gandhāra, Punjab, and the lower Indus) between 330-325 BCE. ${ }^{98}$ Since he retreated down the Indus River following a difficult expedition rather than pursing further conquests in the Indian subcontinent, the question of whether he intended to subdue only the eastern borderlands of the Achaemenid empire or to complete a world

\footnotetext{
${ }^{96}$ Falk 1993: 92-104, 337-340; Salomon 1998a: 28-30, 51-54; Salomon 2003a: 88, 92-93.

97 Thapar 1961: 129, 266-270.

98 Alexander's campaigns in Central Asia and South Asia have received considerable attention. For Central Asian campaigns, see Holt, Frank. 1989. Alexander the Great and Bactria: The Formation of a Greek Frontier in Central Asia. Leiden: Brill. Karttunen 1997a: 19-54 discusses the significance of Alexander's campaigns in South Asia. Both authors address western classical literary sources for the history of Alexander and issues of modern historiography, especially the contrast between the views of Tarn 1984 [1951] and Narain, A.K. 1957. The Indo-Greeks. Oxford: Clarendon [reprint, Delhi: Oxford University Press, 1980].
} 


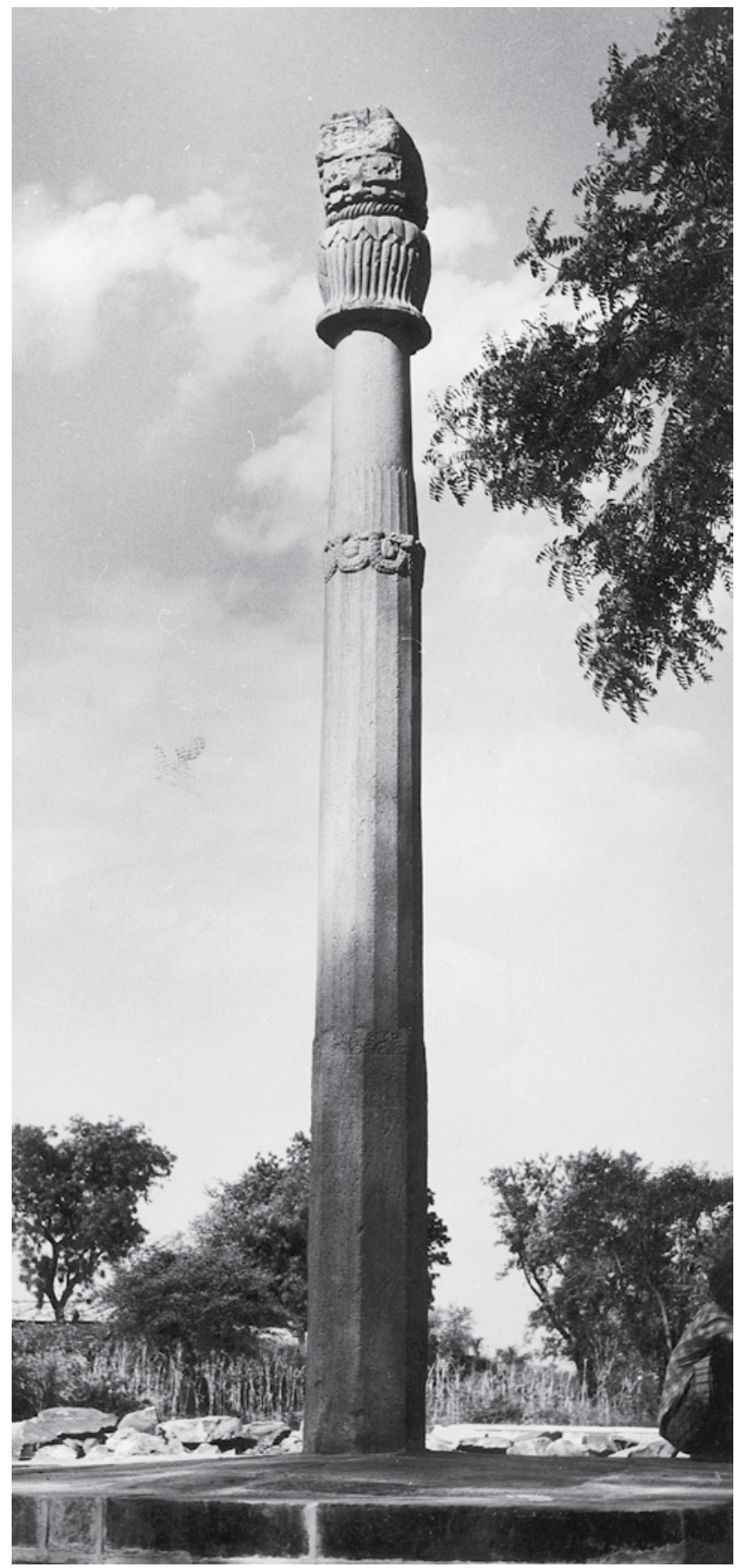

Fig. 2.1: Heliodoros Pillar in Vidiśā (courtesy of the American Institute of Indian Studies). 
conquest remains open to debate. ${ }^{99}$ Along the way, he established garrisons at important nodes where Greek colonists maintained Hellenistic cultural and religious ties long after his death in Babylon in 323 BCE. ${ }^{100}$ Although localizations of eponymous "Alexandrias" and other cities purportedly founded during his South Asian campaigns are uncertain, relatively recent discoveries of archaeological evidence from Kandahar (Alexandria in Arachosia) and Ai Khanum confirm the survival of Hellenistic cultural life in border areas of South Asia. ${ }^{101}$ In addition to Greek and Aramaic inscriptions of Aśoka in Kandahar (discussed previously), a second century BCE Greek epitaph from the family tomb of a trader named Sophytos, the son of Naratos, indicates that Hellenistic literary culture continued to be cultivated:

For a long time the house of my forefathers was flourishing when the irresistible fury of the Three Fates destroyed it. I, unfortunate Sophytos, scion of the family of Naratos, quite young and deprived of the wealth of my family, who had cultivated the arts of Apollo the archer and the Muses together with the virtue of wisdom, considered how to restore my ancestors' house to a new grandeur. Having borrowed money to make it fructify, I left my country, determined not to return before amassing a great fortune. Therefore, I took up commerce in many cities. I accumulated great wealth without suffering any harm. Here I am, having returned after innumerable years to my fatherland, with much praise and amidst my friends' rejoicing. And at one and the same time, I have reconsctructed and beautified my ancestors' house, which was dilapidated, and since the family tomb had fallen to the ground, I rebuilt a new one. And I had this stele erected next to the road so that it will speak thus: look at my accomplishements. Well worthy to be imitated. May my sons and grandsons preserve the house which they owe to me. ${ }^{102}$

${ }^{99}$ In assessing the legacy of Alexander in Asia, Holt emphasizes that "We might avoid preconceptions about Alexander's personality and impact by asking what the king did rather than dreamt..." (1989: 8). Foucher, Alfred. 1942-1947. La vieille route de l'Inde de Bactres á Taxila. 2 vols. Paris: Éditions d'art et d'histoire, argued that Alexander "would do no more than place his feet in the imprints left by Cyrus and Darius I" (2.191).

${ }^{100}$ For identifications of cities reportedly founded by Alexander, see Karttunen1997a: 46-54 and Rapin, Claude. 2005. "L'Afghanistan et l'Asie Centrale dans la géographie mythique des historiens d'Alexandre et dans la toponymie des géographes gréco-romains." In Afghanistan: Ancien carrefour entre l'est et l'ouest, eds. Osmund Bopearachchi and Marie-Françoise Boussac. Turnhout, Belgium: Brepols, 143-172.

${ }_{101}$ Ghosh, Suchandra. Forthcoming. "In Search of Hellenism at Ai Khanum and Kandahar." In Revisiting Early India through Epigraphy and Other Texts. Essays in memory of D.C. Sircar, ed. Suchandra Ghosh et al. Calcutta.

102 Bernard, Paul, Georges-Jean Pinault, and Georges Rougemont. 2004. "Deux nouvelles inscriptions grecques de l'Asie centrale." Journal des savants, 227-356. Rougemont, Georges. 2005. "Nouvelles inscriptions grecques de l'Asie centrale." In Bope- 
This inscribed stele shows that Indian merchants like Sophytos, whose name is probably equivalent to Subhūti and whose father's name may be derived from Nārada in Sanskrit, adapted Greek religious practices and philosophical outlooks while "amassing great fortune" through "commerce in many cities."103

Hellenistic culture also flourished at Ai Khanum, "a full Greek polis" (Karttunen 1997a: 47) located at the confluence of the Oxus and Kokcha rivers in northeastern Afghanistan. Excavations by the French Archaeological Mission in Afghanistan between 1965-1978 revealed Greek and Iranian temples, a gymnasium, a theatre, an arsenal, and a palace, as well as Greek dedicatory and funerary inscriptions and copies of Delphic maxims set up by Clearchus of Soli. ${ }^{104}$ Archaeological, epigraphic, and numismatic evidence for the presence of Greek colonists and Hellenized local inhabitants at Ai Khanum (until its abandonment around $145 \mathrm{BCE}$ ) demonstrates that long-distance contacts and exchanges between the Mediterranean, Iranian, and Indian worlds continued long after the period of Alexander's expedition. Although Alexander was not remembered in ancient South Asian sources, recent discoveries associated with his successors who adapted to dynamic political, economic, and religious conditions in borderland outposts challenge the earlier assessments of W.W. Tarn and A.K. Narain, who juxtaposed imperialistic Greeks to proto-nationalistic Indians. ${ }^{105}$

arachchi and Boussac 2005: 127-136. I am grateful to Suchandra Ghosh for sharing her English translation, which is adopted here with minimal modifications.

${ }^{103}$ For onomastic analysis, see Pinault's contribution to Bernard, et al. 2004: 249259 and Pinault, Georges-Jean. 2005. "Remarques sur les noms propres d'origine indienne dans le stèle de Sôphytos." In Bopearachchi and Boussac 2005: 137-142. According to Rougemont (2004: 240-241, 2005: 131), the phrase "I took up commerce in many cities" recalls the 3rd verse of Homer's Odyssey, reflecting a widely invoked topos of the itinerant life in funerary poems across the Hellenistic world.

104 Bernard, Paul et al. 1973-1992. Fouilles d'Aï Khanoum I-VIII. Mémoires de la Délégation Archéologique Française en Afghanistan 21, 26-31, 33. Paris: Klincksieck. For succinct English overviews, see Bernard, Paul. 1967. Ä̈ Khanum on the Oxus: a Hellenistic city in central Asia. Albert Reckitt archaeological lecture, 1967. London: Oxford University Press (= Proceedings of the British Academy 53 [1967], 71-95), Bernard, Paul. 1982. "An Ancient Greek City in Central Asia." Scientific American 246, 148-159 and Bernard 1994b: 88-129. The archaeological site of Ai Khanum has been devastated by looting, but objects from the National Museum in Kabul have been displayed in an international exhibition (Bernard, Paul. 2008. "The Greek colony at Aï Khanum and Hellenism in Central Asia." In Hiebert, Fredrik T. and Pierre Cambon, eds. Afghanistan: Hidden Treasures from the National Museum, Kabul. Washington, D.C.: National Geographic, 81-129.)

${ }_{105}$ Tarn unfavorably compared the military impact of Alexander's expedition to his Achaemenid predecessors: "His success was far more evanescent than that of Darius; a few years after his death the only traces left of his rule, not counting the Paropamisadae 
From around $250 \mathrm{BCE}$ until the late first century BCE, Bactrian and Indo-Greek kings successfully established control of regional domains while struggling to defend against Sakas and other groups migrating across Central Asia. ${ }^{106}$ Their dynastic history is mostly reconstructed through numismatic analysis of widely distributed coinage, which along with other forms of material evidence reflects a synthesis of Greek, Indian and Iranian languages and writing systems, political titles, religious symbols, and artistic styles. ${ }^{107}$ For example, Agathokles, an Indo-Greek ruler around 190-180 BCE, issued a special series of silver coins with the earliest attested images of Kṛṇa-Vāsudeva and his brother Balarāma-Samkarșana, and another series of bronze coins with either Subhadrā, their sister, or Lakșmī, the Indian goddess of wealth and fortune. ${ }^{108}$ Osmund Bopearachchi (1993: 23) suggests that

[Achaemenid Gandhāra], were two or three of the cities he had founded, islands now in an Indian sea" (1984 [1951]: 130). A.K. Narain, held that the impact of Alexander's successors was very limited: "Their history is part of the history of India and not of the Hellenistic states; they came, they saw, but India conquered" (1957: 11).

${ }^{106}$ Holt, Frank. 1999. Thundering Zeus: The Making of Hellenistic Bactria. Berkeley: University of California Press integrates archaeological, numismatic and literary sources to reconstruct the history of the Bactrian Greeks. Karttunen 1997a: 277 provides a helpful chart of different chronologies for the end of Indo-Greek rule following a succinct treatment of classical western literary sources. Saka and Kușāna migrations and conflicts with the Bactrian Greeks are discussed in the following section (pp. 109-145).

${ }_{107}$ Since earlier studies by Tarn and Narain, numismatic analysis by Osmund Bopearachchi has made significant progress in clarifying relative chronologies of Bactrian Greek and Indo-Greek rulers: Bopearachchi, Osmund. 1991. Monnaies gréco-bactriennes et indo-grecques: catalogue raisonné. Paris: Bibliothèque nationale; Bopearachchi, Osmund. 1993. Indo-Greek, Indo-Scythian and Indo-Parthian coins in the Smithsonian Institution. Washington: National Numismatic Collection, Smithsonian Institution; Bopearachchi, Osmund, and Aman Ur Rahman. 1995. Pre-Kushana coins in Pakistan. Karachi (Pakistan): Mughal Print. \& packaging (Pvt) Ltd; Bopearachchi, Osmund. 1998. "Foreign Powers in Ancient Northern India from the Bactrian Greeks until the time of the Early Kushans." Part 2 of Bopearachchi, Osmund and Wilfried Pieper. 1998. Ancient Indian coins. Turnhout: Brepols, 177-273. Recent updates and alternative chronologies are summarized by Cribb, Joe. 2005. "The Greek kingdom of Bactria, its coinage and its collapse." In Bopearachchi and Boussac 2005: 207-225 and MacDowall, David. 2007a. "Numismatic Evidence for a Chronological Framework for Pre-Kaniṣkan Art, from Kalchayan to Gandhāra.” In Srinivasan 2007: 95-117. Errington and Cribb 1992 provide many excellent illustrations of cross-cultural exchanges and assimilation between the Indo-Greeks, Iranians, and Indians in the "Crossroads of Asia."

${ }^{108}$ Bopearachchi 1991: 172-180; Bopearachchi 1993: 23; Errington and Cribb 1992: 62. Holt comments that Agathokles "was a man of two worlds, a scion of east and west" (1989: 1). According to Ghosh, Suchandra. 2007. "Understanding Transitions at the Crossroads of Asia: c. Mid Second Century BCE to c. Third Century CE" Studies in History 23.2, 289-310, the images on these coins are "...the oldest depiction[s] of Indian deities that we have, and as such are symbolic of an intermingling of Hellenistic with Indian cultures" (2007: 304, fig. 4). 
these coins of Agathokles with legends written in Greek, Brāhmī and Kharoșthi may have been issued for the Indian territories where he had only recently proclaimed himself king. Although his predecessor Demetrius is usually regarded as the first Greek ruler to have made conquests south of the Hindu Kush, ${ }^{109}$ on the basis of a recent discovery of a Kharoșthi inscription dated in year 201 "of the Greeks" (yonana) and year 73 of the Azes era beginning in 58/7 BCE, Richard Salomon argues that Agathokles may have been responsible for initiating an "Indo-Greek era" in 186/5 BCE. ${ }^{110}$ In addition to instituting the first continuous historical era, the Indo-Greek rulers also left imprints in the form of military and political titles, Macedonian month names used in epigraphical dating formulae, and the use of the Greek alphabet for writing the Bactrian language. Contact and exchange was generally limited to the northwestern frontiers, where layers of Hellenistic influence persisted after the last Indo-Greek rulers disappeared from the political scene in the first century BCE.

The presence of Indo-Greeks in the Northwest during the last two centuries BCE has stimulated debates about their responses to religious and cultural features of the Indo-Iranian borderland environment. Although many deities depicted on their coins belonged to the Hellenistic pantheon, Indo-Greek rulers from Agathokles onwards (as well as Sakas, Parthians, and Kușāṇas) adopted a wide range of Iranian and Indian deities, Buddhist symbols, and South Asian titles and

109 Karttunen 1997a: 273-4 discusses the extent of the Indian domains of Demetrius based on literary references, which also associate Greek conquests of India after Alexander with Apollodotus and Menander. A recently discovered Greek inscription of Heliodotus (Bernard, et al. 2004: 333 ff.; Rougemont 2005: 133-4, fig. 2) from Kuliab in Tajikistan recording a dedication to Hestia refers to Demetrius as a "glorious victor" (kallinikos is a laudative epithet) and to his father Euthydemos as "the greatest of all kings" but does not indicate that their dominion extended beyond ancient Bactria. MacDowall, David. 2005. "The Role of Demetrius in Arachosia and the Kabul Valley." In Bopearachchi and Boussac 2005: 197-206 focuses on the silver and copper coins of Demetrius (also see MacDowall 2007: 99).

110 Salomon, Richard. 2005a. "The Indo-Greek Era of 186/5 BC in a Buddhist Reliquary Inscription.” In Bopearachchi and Boussac 2005: 359-401 (CKI 405: http:// www.ebmp.org/a_inscription.php?catid=CKI0405). Salomon discusses other Brāhmī, Kharosthī, and Bactrian inscriptions that may be dated in this era, which is explicitly attested in a Brāhmī inscription in year 116 "of the reign of the Yavanas" (yavanarajyasya), which would correspond to ca. 70 BCE. Jakobsson, Jens. 2009. "Who Founded the Indo-Greek Era of 186/5 BCE?" Classical Quarterly 59.2, 505-510 speculates that the era may have been promoted by Menander and Antimachus II. I have not yet seen an article by Widemann, François. 2004. "Une confirmation numismatique de l'era yavana de 186/5." Nomismatika Chronika 23, 37-45. 
epithets. ${ }^{111}$ W.W. Tarn attempted to explain Indo-Greek patronage of Buddhism as a strategy to gain local support against Indian rulers such as Pusyamitra, who seized power after the collapse of the Mauryans and restored Brahmanical institutions, according to Sanskrit purānic traditions. ${ }^{12}$ Such a juxtaposition between foreign Greek supporters of Buddhism in the Northwest and traditional Indian kings who maintained "Hindu" orthodoxy oversimplifies more complex patterns of religious patronage of multiple South Asian religious traditions.

Greek patronage of Buddhism is most clearly associated with Menander, a powerful Indo-Greek ruler of the Punjab and northwestern India around 150 BCE who issued numerous coins and is known in both Buddhist and western classical literary traditions. ${ }^{113}$ However, Menander's silver coins showing Athena in various martial poses do not indicate a Buddhist affiliation and his bronze coins depict an eclec-

${ }^{111}$ Karttunen 1997a: 309-315 discusses the representation and localization of Greek gods and the representation of local gods in Greek form. In "The Greek Kingdoms of Central Asia" (in Harmatta 1994: 98-129), Paul Bernard observes that "With very few exceptions, the official state pantheon was entirely Greek" (1994b: 114), but temples dedicated to local and Iranian deities at Ai Khanum "owed nothing to Greek tradition" (ibid., 115). Bernard ameliorates this apparent discrepancy between numismatic iconography and religious architecture, archaeology and art by commenting that "the Greeks themselves had probably never, except in their own official state religion, put up any barriers between their own gods and those of their subjects, and so had paved the way to their progressive assimilation" (127). MacDowall, David. 2007b. "Coinage from Iran to Gandhāra-with special reference to divinities as coin types." In Srinivasan 2007: 233-266 surveys deities depicted on Bactrian, Indo-Greek, Indo-Scythian, and Indo-Parthian coins.

112 Although Narain 1957: 98-9 effectively counters Tarn 1984 [1951]: 175, similar arguments are adopted by Lamotte 1988 [1958]: 385 and Seldeslachts, Erik. 2007. "Greece, the Final Frontier? The Westward Spread of Buddhism." In Heirman and Bumbacher 2007: 131-166, who writes that "The Greek struggle with Pusyamitra gave the Buddhists the prospect of renewed influence... What may be sensed is that strategic reasons made some Greeks the promoters of Buddhism and some Buddhists supporters of the Greeks" (141).

${ }_{113}$ Bopearachchi, Osmund. 1990. "Ménandre Sôter, un roi Indo-grec. Observations chronologiques et géographiques." Studia Iranica 19, 39-85 and Fussman, Gérard. 1993a. "L'Indo-grec Ménandre ou Paul Demiéville revisité." Journal Asiatique 231, 61-138 make important corrections to views offered by Foucher 1947: 273-276, Lamotte 1988 [1958]: 420-426, Narain 1957: 74-100, and Tarn 1984 [1951]: 225-269. A fragmentary Kharosthī inscription on the lid of a Buddhist reliquary casket from Shinkot in Bajaur dedicated by the Aprajaraja Vijayamitra in the mid-late first century BCE may refer to an era of "Mahārāja Menander" (minedrasa maharajasa) (CKI 176: http://www.ebmp.org/a_inscription.php?catid=CKI0176). Falk, Harry. 2005. "The Introduction of Stūpa-worship in Bajaur." In Bopearachchi and Boussac 2005: $347-358$ argues that this part of the inscription is not genuine (351-2, fig. 4), but it seems unlikely to have been a forgery. 
tic mixture of ambiguous symbols, including the wheel which could be associated with a wheel-turning emperor (cakravartin) or the wheel of dharma (dharmacakra). ${ }^{114}$ In contrast to the numismatic evidence, Pāli and Chinese Buddhist texts invariably portray Menander as an important Buddhist patron. ${ }^{115}$ In shorter and earlier versions, Menander is satisfied with the responses of the learned monk Nāgasena and donates an expensive wool blanket and 800 meals to the Buddhist community, but it is only in the expanded Pāli version that Menander (Milinda) relinquishes his throne, converts to Buddhism, and becomes a lay follower (upāsaka). ${ }^{116}$ Although the Moralia of Plutarch refer to the distribution of Menander's relics (mnēmeia), such burial practices are more likely to be connected with Hellenistic hero cults than Buddhist worship of the relics of a lay patron. ${ }^{117}$ Thus, Buddhist literary traditions

114 Bopearachchi 1990: 48 and Fussman 1993a: 85-90 agree that the numismatic evidence does not confirm Menander's conversion to Buddhism, but comments by Paul Bernard (see note 110) on discrepancies between the official state pantheon and religious architecture and archaeology may help to reconcile differences between depictions of deities on Menander's coinage and his reputation as a Buddhist patron in Buddhist literary traditions.

${ }^{115}$ Fussman 1993: 66-82 and Lamotte 1988 [1958]: 423-426 largely base their comparisons of Pāli and Chinese literary traditions of dialogues between Menander and Nāgasena on Demiéville, Paul. 1924. "Les versions chinoises du Milindapañha." Bulletin de l'École Française d'Extrême Orient 24, 1-264. According to Demiéville, an earlier version was translated into Chinese (Taishō 1670: "Sūtra of the Bhikșu Nāgasena") from a middle Indic version between 317-420 CE, and a short synopsis of dialogues between Nāgasena and Menander is included among avadānas compiled in the Za bao zang jing (Taishō 203, chapter 9, 492c-493b) by T'an-yao in $472 \mathrm{CE}$ (Willemen, Charles, trans. 1994. The Storehouse of Sundry Valuables. Berkeley, CA: Numata Center for Buddhist Translation \& Research, 224-227). The later expansion (with an additional four chapters) of the 5th century CE Pāli version of the Milindapañha (Trenckner, V., ed. 1880. The Milindapañho: Being dialogues between King Milinda and the Buddhist sage Nägasena. London: Williams Norgate) has frequently been translated into English: Rhys Davids, T.W. 1890-1894. The Questions of King Milinda. Pts. 1-2. Oxford: Clarendon Press; and Horner, I.B. 1963. Milinda's Questions. 2 vols. London: Luzac. Additional references to the paracanonical Pāli text and commentary are compiled by Hinüber 1996: 82-6, \$172-180, who observes that "although Milinda is Greek, there is not traceable Greek influence on form or content..." (1996: 83).

116 Fussman, Gérard. 1994a. "Upāya-kauśalya: L'implantation du bouddhisme au Gandhāra." In Bouddhisme et cultures locales: Quelques cas de réciproques adaptations, eds. Fukui Fumimasa and Gérard Fussman. Paris: École Française d'Extrême Orient, 25-26 remarks that Menander's conversion to Buddhism and assumption of upāsaka status should be understood only in the sense that he was not hostile to Buddhism, since aside from the Milindapañha's version, there is no other indication that affirms his exclusive preference for Buddhism.

117 References to Menander in Plutarch's Moralia (821 D-E) are discussed by Fussman 1993a: 65 and Lamotte 1988 [1958]: 421. According to Burkert, Walter. 1985 [1977]. Greek Religion. Translated by John Raffan. Cambridge: Harvard University 
adopt Menander "as one of theirs" (Lamotte 1988 [1958]: 425) but do not prove that he was exclusively Buddhist, since he probably supported a wide array of religious groups seeking his support, just like any other South Asian ruler.

In adopting South Asian models of religious patronage, the distinctive identity of the Indo-Greeks eventually disappeared as they became fully Indianized. While King Menander is praised as a Buddhist patron (if not a convert), a Greek ambassador (yonadūta) named Hēliodōros sent from Taxila to Vidiśā in central India by the IndoGreek king Antialkidas, refers to himself as a devotee (bhägavata) of Viṣnu in a late second century BCE Brāhmī inscription (fig. 2.1: Heliodoros Pillar). ${ }^{118}$ Hēliodōros donated a pillar of Garuda, the eagle who serves as Viṣnu's animal emblem, during his visit to the court of Kāśīputra Bhāgabhadra, whom historians have attempted to identify with Sunga kings listed in purānicic genealogies such as Bhadraka/ Odraka or Bhāga(-vata). ${ }^{119}$ Some Greek names and titles also appear in Buddhist inscriptions from the Northwest and in Buddhist cave inscriptions from western India. ${ }^{120}$ However, references to Yavana (or

Press, "A hero cult involves setting apart one particular grave, known as a heroon, from other burials by marking off a special precinct, by bringing sacrifices and votive gifts, and occasionally by building a special grave monument" (1985: 203). Burkert's comments about connections between the rise and popularity of hero cults during Hellenistic times and the establishment of "effectice presence" in a "specific locality" suggest structural resonances with Buddhist relic cults that may have appealed to a Greek audience in the Northwest.

118 Salomon 1998a: 265-267 (Appendix 2: Besnagar Pillar Inscription of Hēliodōros, fig. 12, with further references on p. 266).

${ }_{119}$ Sircar, Dineschandra. 1965. Select Inscriptions bearing on Indian History and Civilization. Vol. 1: From the Sixth Century BC to the Sixth Century AD 2nd ed. Calcutta: University of Calcutta, 88-89 suggests that "Bhāgabhadra may be identified with Bhadraka, the fifth Sunga king according to the Bhägavata Puräna (88, n. 4). However, this identification is dismissed by Narain 1957: 119, who instead identifies Bhāgabhadra with the ninth Śunga king known as Bhāga or Bhāgavata. A Śunga connetion remains hypothetical, since Kāśiputra Bhāgabhadra may have been a local or regional ruler of Vidiśā.

${ }_{120}$ Fussman 1994a: 26 points out that only the Kharoșţi inscription of the Meridarch Theodoros may belong to the period of the Indo-Greek rulers in the Northwest, although other Greek names appear in later inscriptions. Since very few Kharoșthi inscriptions (with the exception of the Aśokan edicts) can be dated before ca. $50 \mathrm{BC}$, it would be misleading to conclude that "This lack of information on the Greeks in the inscriptions of Gandhāra and Panjab seems to indicate that there was no noticeable Greek influence on Buddhism..." (Dietz, Siglinde. 2007. "Buddhism in Gandhāra." In Heirman and Bumbacher 2007: 56). For Yavanas in western Indian inscriptions, see Karttunen 1997a: 297-298, who refers to hypotheses for associating them with merchants advanced by Stein, Otto. 1935. "Yavanas in early Indian inscriptions." Indian 
Yona) donors with Indian and Iranian names do not strictly designate Greek descendants, since "...the connotation of Yavana underwent changes from being identified as Greek to Graeco-Iranian, Hellenist Indian, Indianized Greek, and Graeco-Roman or anyone coming from the West" (Ghosh 2007: 291).

Alfred Foucher strongly advocated for the importance of an amalgamation of Hellenistic models with Indian and Iranian traditions in the Buddhist art of Gandhāra. ${ }^{121}$ However, Foucher's theory of a "Graeco-Buddhist" school of art and his arguments for a Greek origin of anthropomorphic images of the Buddha remain controversial. ${ }^{122}$ Foucher and other proponents of Hellenistic influences in Gandhāran Buddhist art have struggled to explain a chronological gap between the heyday of Indo-Greek rule in the Northwest in the second century BCE and the first appearance of identifiable Hellenistic features in Buddhist art of Gandhāra only in the first century CE. ${ }^{123}$ Lamotte, for example, acknowledged that "...this influence took a long time to become apparent and that although it was implanted during the IndoGreek occupation, it did not bear fruit until first the Saka-Pahlava period, and then the Kușanana" (1988 [1958]: 429). This problematic lag between the hypothetical 'implantation' and concrete 'manifestation' of a proposed Hellenistic 'synthesis' in Gandhāran Buddhist art raises questions about the impetus, extent, and significance of the long survival of Greek stylistic features, which were transmitted through numerous intermediaries and are more related to technical

Culture 1, 343-357 (= Stein, Otto. 1985. Kleine Schriften. Ed. F. Wilhelm, GlasenappStiftung 25. Stuttgart: Steiner Verlag Wiesbaden, 351-365).

${ }^{121}$ Foucher, Alfred. 1905-1951. L'art gréco-bouddhique du Gandhâra; étude sur les origines de l'influence classique dans l'art bouddhique de l'Inde et de l'Extrême-Orient. Paris: E. Leroux. 3 vols.; Foucher 1947: 306-354.

${ }_{122}$ Art historical debates provoked by Foucher are succinctly treated by Zwalf, Wladimir. 1996. A Catalogue of the Gandhära Sculpture in the British Museum. London: British Museum, 67-76. For very different assessments of Foucher's legacy, see Abe, Stanley. 1995. "Inside the Wonder House: Buddhist Art and the West." In Lopez 1995b, 75-84, Olivier-Utard, Françoise. 2003 [1997]. Politique et Archéologie: Histoire de la Délégation archéologique française en Afghanistan, 1922-1982. 2nd ed. Paris: Éditions Recherche sur les Civilisations, 29-81, and Nehru, Lolita. 1989. Origins of the Gandhāran Style: A Study of Contributory Influences. Delhi: Oxford University Press.

${ }^{123}$ Foucher posited that Hellenism lay dormant in Gandhāra until a combination of factors including the expansion of Buddhism and increasing commerce led to a "rebirth of influence under the Indianized form" (1947: 324) when "the Hellenistic seed bore its fruits under a dynasty not very different from that which implanted it" (1947: 333). Fussman 1994a: 26 points out that the period of Buddhism's success in Gandhāra is either contemporary with or posterior to the downfall of the Indo-Greek rulers. 
detail rather than religious ideology. ${ }^{124}$ Maurizio Taddei identified Hellenistic models and narrative motifs in Gandhāran Buddhist art and architecture, but recognized that these foreign elements were appropriated from a wide range of Hellenized cultures extending from the Mediterranean to Egypt, Parthia, and Gandhāra, where local and exogenous groups chose to adopt, preserve, and innovatively develop distinctive styles of art and iconography. ${ }^{125}$ Since Italian excavations of an Indo-Greek urban center at Barikot in the Swat valley of northwestern Pakistan have revealed "the undeniable presence of workshops and craftsmen of Hellenistic tradition active in the Northwest" (Callieri 2007: 158), ${ }^{126}$ Hellenistic ateliers may have continued to contribute to the mélange of iconographic elements and architectural styles evident in Gandhäran Buddhist art in the early centuries CE.

Relationships between Iranian and Hellenistic cultures and the Buddhist traditions of Gandhāra and Central Asia are addressed further in Old Roads in the Northwestern Borderlands (Chapter 4) and Long-Distance Transmission to Central Asian Silk Routes and China (Chapter 6). A tendency of many earlier scholars such as Foucher and Lamotte to overemphasize the impact of the Achaemenids and Indo-Greeks on the history of Buddhism has been counterbalanced by efforts to downplay 'foreign' influence. Interactions between Brahmins who were already well established in the region since vedic times, Buddhist newcomers, socially assimilated exogenous migrant groups, and local intermediaries (like Sophytos) who appropriated Iranian and Greek languages, writing systems, titles, customs, and ideas for their own political and economic benefit contributed to dynamic hybridity. ${ }^{127}$

${ }^{124}$ Fussman, while accepting the possibility of a "synthèse hellénico-Bouddhique" (1994a: 27) long after the end of Indo-Greek political domination, argues that the artistic traditions of Gandhāran Buddhism are ideologically identical to those of Mathura and Amarāvatī.

${ }_{125}$ Taddei, Maurizio. 2003. On Gandhāra: Collected articles, ed. Giovanni Verardi and Anna Filigenzi. Napoli: [M. D'Auria?] includes Taddei's studies and reviews of Gandhāran art history, archaeology, and cultural history published over a span of 40 years.

${ }^{126}$ Callieri, Pierfrancisco. 2007. "Barikot, an Indo-Greek Urban Center in Gandhāra.” In Srinivasan 2007: 133-164.

${ }^{127}$ Conversations with Georgios Halkias and Damien Janos, modern yavanas in Bochum, Germany, dialogues with Suchandra Ghosh and Abhishek Singh Amar, and the participation of colleagues in a project on Dynamics in the History of Religion between Asia and Europe for the International Consortium for Research in the Humanities (IKGF) have helped to clarify issues related to the synthesis of 
Thus, intercultural exchanges in the northwestern borderlands in the late first millennium BCE established foundations for patterns of cross-cultural mobility and transmission which culminated in the following periods of the Sakas and Kuṣānas.

\section{Saka Migrants and Mediators between Central Asia and South Asia}

As Indo-Greek power waned, various groups of Sakas established control of important nodes on networks of long-distance routes used for migrations, trade, and cultural transmission between Central Asia, the Iranian borderlands, and the northwestern Indian subcontinent. ${ }^{128}$ Their domination of overland routes corresponds to a critical period of heightened patronage and growth of Buddhist institutions in the first century $\mathrm{BCE}$ and first century $\mathrm{CE}$. The profound impact of the Sakas in South Asia is gaining greater recognition, although many previous scholars regarded the Sakas (sometimes called Indo-Scythians) as mere imitators of their Indo-Greek predecessors. For example, W.W. Tarn opined that the "Sacas simply stepped into the shoes of the Greeks" (1984 [1951]: 323). Subsequent Kuṣāna dominion over a more extensive empire extending from Bactria to northeastern India has overshadowed Saka precedents. Finally, the conflation of Sakas (Śakas) with other immigrant goups (including the Indo-Greek yavanas and Iranian pahlavas) has obscured their position. Brahmanical xenologies integrate these powerful but impure mleccha rulers into the varna hierarchy as degraded Kșatriyas. ${ }^{129}$ Nevertheless, the establishment of continous Indian historical eras which are still in use, the Azes

Iranian, Hellenistic, Central Asian, and local motifs and narratives with Indian Buddhist conventions.

${ }^{128}$ For a more detailed treatment of Śaka and Kuṣanna migration routes, see Neelis, Jason. 2007. "Passages to India: Śaka and Kușāna Migrations in Historical Contexts." In Srinivasan 2007: 55-94. This section is a synopsis of this longer article, but focuses on the relevance of these migrations for patterns of Buddhist transmission.

${ }_{129}$ Pimary sources include Mānavadharmaśāstra 10.44 (Olivelle 2004: 183), Mahābhārata 3.186.26-33 (Buitenen, J.A.B. van, trans. 1973. The Mahābhārata. Chicago: University of Chicago Press, vol. 3, 586), and Patañjali's Mahābhāssya 2.4.10 (discussed by Bronkhorst 2007: 357, n. 2). Traditional "xenologies" involving Sakas, Yavanas, and other mlecchas are examined by Halbfass, Wilhelm. 1988. India and Europe: An Essay in Understanding. Albany: SUNY Press, 172-196 (esp. 176, 181) and Parasher-Sen, Aloka. 1991. Mlecchas in Early India: A Study in Attitudes towards Outsiders up to AD 600. Delhi: Munshiram Manoharlal, 222-261 (esp. 228-232 for Śakas). 
(Vikrama) era of 58 BCE and the Śaka era of 78 CE, were originally tied to the reigns of Saka rulers, whose chronologies are reviewed below. In addition to linguistic borrowings of Iranian loanwords into Sanskrit and Prakrit languages, the initial use of Sanskrit in official inscriptions and the adoption of poetic conventions (kāvya) in epigraphic eulogies (praśastis) are connected with Saka centers in Mathura and Gujarat during the first two centuries CE. ${ }^{130}$ The active role of Sakas as patrons of Buddhist literature, art and archeology is apparent in early Buddhist manuscripts from Gandhāra, pre-Kușāṇa sculptures from Mathura, and Kharoșthī and Brāhmī inscriptions from northwestern and western regions of South Asia, but they also supported other religious groups as well. ${ }^{131}$ Sakas and other Iranian and Central Asian immigrants were not merely passive converts to Buddhism, but played active roles as mediators for the trans-cultural flow of Buddhism beyond India.

\section{Saka migrations to South Asia}

Saka immigrants, who began to arrive in South Asia around the beginning of the first century BCE, belonged to separate branches of nomadic and sedentary groups that inhabited areas of Central Asia extending from the Pontic steppes north of the Black Sea to western Mongolia. Peoples known as Sakas in Iranian and Kharoșțī inscriptions, Sakas in Sanskrit, and Scythians in western classical sources are broadly associated with material cultures and artistic styles classified as the "Scythian triad" (consisting of bronze and iron weapons, horse-

${ }_{130}$ Damsteegt 1978: 204-216; Sheldon Pollock comments: “The radical reinvention of Sanskrit culture seems to have occurred-at least, it is here that we can actually watch it occurring-precisely where one might expect it, in a social world where the presuppositions and conventions of the vaidika culture were weakest: among newly immigrant peoples from the far northwest of the subcontinent (and ultimately from Iran and Central Asia), most importantly the Sakas (the so-called Indo-Scythians), especially a branch of the Sakas known as the Western Kṣatrapas, and the Kuṣanasas" (2006: 67). Buddhist (hybrid) Sanskrit inscriptions and literature are discussed in Chapter 1 pp. $44-54$.

${ }_{131}$ Fussman, Gérard. 1980. "Nouvelles inscriptions śaka: ère d'Eucratide, ère d'Azès, ère Vikrama, ère de Kaniska." Bulletin de l'Ecole française d'Extrême-Orient (BEFEO) 67, 1-43; Fussman, Gérard. 1984. "Nouvelles inscriptions śaka II." BEFEO 73, 31-46; Fussman, Gérard. 1985. "Nouvelles inscriptions śaka (III-IV).” BEFEO 74, 35-42, 47-51. Quintanilla 2007: 192-218; Salomon 1999a: 180-181. 
riding gear, and the so-called animal style). ${ }^{132}$ However, these features were shared by a wide range of Eurasian nomads and are not as clearly apparent in South Asia as in Central Asian burial mounds (kurgans). Before the period of migration to South Asia, three distinct groups of Sakas appear in Achaemenid monumental art and Old Persian inscriptions issued during the reign of Darius I (522-486 BCE):

1) Sakas "who are across the sea" (paradraya) in areas north of the Black Sea are mentioned only in the Naqš-i Rustam inscription, but Herodotus (4.1-162) provides many details about this group of Scythians in his account of the Darius I's campaign against them (ca. 513 BCE). ${ }^{133}$

2) Sakas "wearing the pointed cap" (tigraxauda) correspond with the Sakas or Scythians with "pointed helmets" (Greek: orthokorybantioi) listed by Herodotus (3.92) in the tenth satrapy of Media. In addition to the Naqš-i Rustam inscription, an inscription of Darius at Susa and an inscription of Xerxes from Persepolis refer to this group of Sakas. ${ }^{134}$

3) "Hauma-drinking" (haumavarga) Sakas appear together with the previous group in Old Persian inscriptions and are referred to as Amyrgian Scythians by Herodotus (7.64). ${ }^{135}$ They originally inhabited regions around the Syr Darya (Jaxartes River) in the Ferghana and Alai valleys of western Central Asia, but also settled in the Helmand valley and southeastern Iran (Seistan). ${ }^{136}$ Since this region around the Hamun Lake "is a land where the steppe and the sown are intermingled and nomads are on all sides of the lake which is large in winter while almost vanishing in the late summer" (Frye

${ }_{132}$ The Scythian triad and Central Asian burial practices are discussed by Di Cosmo 2002: 32-42, Jettmar, Karl. 1967. Art of the Steppes. New York: Crown Publishers, 195-7, and Pavlinskaya, Larisa. 1989. "The Scythians and Sakians, Eighth to Third Centuries BC.” In Nomads of Eurasia, ed. Vladimir Basilov. Los Angeles; Seattle: University of Washington, 19-31. Vogelsang 1992: 14 refers to a somewhat different 'triad' of a short sword, trilobal arrowhead, and Animal Style.

133 Briant 2002: 141-143; Kent 1953: 138.

134 Briant 2002: 173; Kent 1953: 141, 151, 186.

135 Kent 1953: 211-212.

136 P'iankov, L.V. 1994 (1996). "The Ethnic History of the Sakas.” Bulletin of the Asia Institute 8, 37-38 summarizes arguments for localizing the Amyrgians in Ferghana. Lamotte 1988 [1958]: 448 localizes this group of Sakas in Drangiāna in southeastern Iran. 
1963: 72), different groups of Sakas may have temporarily settled there in periodic seasonal migrations. ${ }^{137}$

In other Old Persian inscriptions of Darius at Behistun, Persepolis, and the Susa foundation charter, the Sakas are listed immediately after the satrapy of Gandhāra. ${ }^{138}$ W.J. Vogelsang (1992: 304-315) argues that the Sakas who infiltrated eastern Iran from areas to the north during the first half of the first millennium BCE played major roles in the establishement and maintenance of Achaemenid power. According to Vogelsang, Saka migrations to the Iranian plateau and onwards to the Near East or to the Indian subcontinent can be viewed as a recurring pattern in which nomadic migrants from Central Asia initially disrupted settled life, but eventually “.... were adopted within local structures, and either disappeared from view as a distinct ethnic unity, or turned into the new ruling class of the sedentary people, often mingling with the old group of the autochthonous population" (1992: 305). This characterization aids in understanding patterns of migration of exogenous Sakas to northwestern India towards the end of the first millennium BCE, although it is not necessarily the case that all of these groups came to South Asia from eastern Iran.

Chinese historical annals (Shi ji and Han shu) refer to Saka and Kuṣana migrations from the Western Region (Xiyu) of China in Central Asia during the second century BCE. ${ }^{139}$ According to the Han shu (96A.10b, 96B.1b, 61.4b), westward Yuezhi migrations forced the Sai

${ }^{137}$ Frye, Richard. 1963. Heritage of Persia. Cleveland: World Pub. Co.

138 Briant 2002: 173; Vogelsang 1992: 97.

139 Relevant sources compiled in the first century BCE and first century CE are translated by Hill, John E. 2009. Through the Jade Gate to Rome: A study of the silk routes during the Later Han Dynasty 1st to 2nd centuries CE: an annotated translation of the chronicle on the 'Western Regions' in the Hou Hanshu. Charleston, South Carolina: BookSurge Publishing; Hulsewé, A.F.P. and Michael Loewe. 1979. China in Central Asia: The Early Stage: 125 BC-AD 23: An Annotated Translation of Chapters 61 and 96 of the History of the Former Han Dynasty. Leiden: Brill; Thierry, François. 2005. "Yuezhi et Kouchans: Pièges et dangers des sources chinoises." In Bopearachchi and Boussac 2005: 421-539; Zürcher, Erik. 1968. "The Yüeh-chih and Kanișka in the Chinese Sources." In Papers on the Date of Kanişa, ed. A.L. Basham Leiden: Brill, 346-390. Useful guides to the secondary literature are available in Benjamin, Craig. 2000. "The Yuezhi and their Neighbours: Evidence for the Yuezhi in Chinese Sources c. 220-c. 25 BCE." In Realms of the Silk Roads, Ancient and Modern eds. David Christian and Craig Benjamin. Turnhout, Belgium: Brepols, 105-159 and Benjamin, Craig. 2007. The Yuezhi: Origins, Migration and the Conquest of Northern Bactria. Turnhout: Brepols, 52-58. 
to migrate south from areas around the Ili Basin (in modern Kyrghizstan). While the Chinese character transliterated as Sai or Se (pronounced ${ }^{*} \mathrm{~s} ə \mathrm{k} / \mathrm{s}$ g/ $/ \mathrm{seg}$ ) corresponds closely enough to Iranian Saka, Gāndhārī Saga, and Sanskrit Saka, distinctions between the Sakas and other groups are not always clear (as is also the case with Iranian and western classical sources describing Central Asian nomadic movements).${ }^{140}$ Geographical details about Saka migrations beyond the Western Region (Xiyu) are somewhat vague, but the Chinese sources nevertheless indicate that at least one branch of Sakas began to move into the northwestern Indian subcontinent without passing through the Iranian plateau. A passage in the Han shu (96B.1b) specifies that the Sai crossed the "hanging passage" (xuan $d u$ ), located between Shatial and Swat in the gorges of the upper Indus River in modern Pakistan. ${ }^{141}$ Han shu (96A.10b) also indicates that the Sakas eventually conquered Jibin, a territory commonly associated with Kashmir or Kapiśa (Begram in Afghanistan), but here perhaps referring to Gandhāra. ${ }^{142}$

During the final two centuries BCE, three separate groups of Sakas migrated to South Asia via overland routes from southeastern Iran, Bactria, and the Tarim Basin. ${ }^{143}$ Despite topographical difficulties of the proposed routes from eastern Central Asia across the Pamir and Karakorum mountains to Swat and Gandhāra, artifacts from the Pamir region and bronze objects with Scythian stylistic affinities from mountain valleys in northern Pakistan and the late survival of

${ }^{140}$ Hulsewé (1979: 104, fn. 210) transliterates Sai while Thierry (2005: 451, fn. 39) uses $\mathrm{Se}$. Gérard Fussman cautions that Chinese sources do not clearly distinguish the Sai from the Yuezhi, which in his view are "... shifting confederations of tribes without any linguistic, ethnic (i.e. racial) and probably cultural, unity" (Fussman, Gérard. 1996. "Southern Bactria and Northern India before Islam: A Review of Archaeological Reports." Journal of the American Oriental Society 116, 252).

${ }^{141}$ For localizations of the "Hanging Passage" see Stein, Marc Aurel. 1942. "From Swat to the Gorges of the Indus." Geographical Journal 100.2, 49-56 and Jettmar, Karl. 1987a. “The 'Suspended Crossing'-Where and Why?” In Pollet 1987: 95-101. Benjamin 2007: 107-109 refers to earlier theories of Chavannes and more recent investigators such as Tsuchiya who prefer to associate $x u a n d u$ with the Khunjerab or Mingteke passes that connect Tashkurgan in Xinjiang with the Hunza and Gilgit valleys in northern Pakistan, but localizations identified by Jettmar and Stein are more accurate.

${ }_{142}$ Hulsewé 1979: 105-6. Geographical references to Jibin are discussed in Routes of Buddhist Missionaries from Gandhāra, Swat, and Kashmir in Chapter 4 pp. 250-252.

${ }^{143}$ Fussman 1994a: 32; Neelis 2007: 61-63; Senior, Robert. 2001. Indo-Scythian Coins and History. Lancaster, Pennsylvania: Classical Numismatic Group, vol. 1, 12-13. 
'animal style' features in petroglyphs provide evidence of Saka migrations through northern Pakistan. ${ }^{144}$ Another closely related branch of Sakas may have migrated to the northwestern frontiers of South after crossing the Hindu Kush following conflicts with the Yuezhi and Bactrian Greeks in Bactria during a period of instability in the second century BCE. ${ }^{145}$ Strabo (11.8.2) and Justin (41) attribute the decline of the Bactrian Greek kingdoms to various groups of nomads, including Sacarauloi/Saraucae, with whom the Sakas have been identified. ${ }^{146}$ Although Strabo and other classical authors were unclear about distinctions between various groups of nomads, Konow's remark that "Scythian pressure on the Greek empire in Bactria... seems to coincide with the Indian conquests" (1929: xxii) suggests a scenario in which migratory movements of Sakas and other Central Asians forced Bactrian Greek rulers such as Demetrius and Agathokles to extend their dominions to areas south of the Hindu Kush beginning in the early second century BCE. Since Indo-Greek kings appear to have remained in control of Kapiśa during the second century BCE, a Saka military conquest does not appear to have been likely, but a series of nomadic movements may have been partially responsible for the displacement of Greek rulers first from Bactria and again from Gandhāra, Taxila and the Punjab in the middle of the first century BCE.${ }^{147} \mathrm{~A}$ third wave of Sakas migrated to the western borderlands of South Asia from Seistan in southeastern Iran and Arachosia in southern Afghanistan after a series of conflicts with the Arsacid dynasty of Parthia between 130-80

${ }^{144}$ Dani, Ahmad Hasan. 1989. History of Northern Areas of Pakistan. 2nd ed. Islamabad: National Institute of Historical and Cultural Research, 119; Fussman, Gérard. 1978. "Inscriptions de Gilgit." Bulletin de l'École française d'Extrême-Orient 65, 3-4; Jettmar, Karl. 1991. "The Art of the Northern Nomads in the Upper Indus Valley." South Asian Studies 7, 5; Litvinskyj, Boris. 1993. "Pamir und Gilgit-Kulturhistorische Verbindungen." In Antiquities of Northern Pakistan, ed. Karl Jettmar, et al. Mainz: P. von Zabern, vol. 2, 147; Narain 1957: 135-138; Neelis 2007: 64-69; and Senior 2001: 9. This evidence invalidates Tarn's objection that "no horde with its flocks and herds could ever have crossed the Hanging Pass" (1984 [1951]: 277-8).

145 Tarn 1984 [1951]: 274-299 (chapter VII: The Nomad Conquest of Bactria).

146 Strabo (11.8.2) [based on Apollodorus] refers to the Asioi, Pasianoi, Tocharoi, and Sacarauloi and Justin (41) [based on Pompeius Trogus] refers to the Saraucae and Asiani. The implications of these passages are discussed by Konow 1929: xxi-xxii; Lamotte 1988 [1958]: 450, Narain 1957: 131-134, Senior 2001: 10, and Tarn 1984 [1951]: 284-295.

${ }_{147}$ Tarn's statement that "The beginning of the end for all Greek kingdoms in India was the Saca conquests" (1984 [1951]: 320) assumes that political and cultural shifts necessarily result from military conquests. 
BCE. ${ }^{148}$ From areas of the lower Indus valley known as Sakadvipa or Saakadvīpa ("Śaka continent") in Sanskrit Purānas, this group of Sakas expanded to the Saurāstrtra peninsula of Gujarat and into the western hinterlands of the Indian subcontinent, where the Kșaharāta and Kārdamaka lines of Western Kṣatrapas continued to rule until the end of the fourth century CE.

\section{Saka Rulers in the Northwest}

Numismatic sequences and dated inscriptions are the primary sources for reconstructing chronological frameworks for the dynastic history of Saka rulers in the northwestern and western Indian subcontinent in the first century BCE and eary centuries CE. Greek and Kharosthì coin legends indicate that Maues (or Moa in Kharoșthī) was the first Śaka ruler to declare himself "king of kings" (Greek: BA $\Sigma \mathrm{I} \Lambda \mathrm{E} \Omega \Sigma \mathrm{BA} \Sigma \mathrm{I} \Lambda \mathrm{E} \Omega \mathrm{N} /$ Kharoșthī: rajatiraja) in areas of Gandhāra, Swat, and Taxila in the early first century BCE. ${ }^{149}$ Since his coins are more commonly found in areas of northwestern Pakistan rather than in regions around Kabul or in southeastern Afghanistan, he and his predescessors probably followed routes from the north across the Hindu Kush, Pamir, or possibly the Karakorum mountains rather than migrating from southeastern Iran, Afghanistan, and the lower Indus, as sometimes suggested. ${ }^{150}$

${ }^{148}$ Justin (42.1-2) provides an account of relationships with the Sakas during the reigns of Phraates II (who died in 138 BCE during a campaign against the Sakas) and Mithridates II (123-88 BCE), who reached an accommodation with the Sakas (Konow 1929: xxxvii-xxxix; Lamotte 1988: 451-2, Narain 1957: 140-141, Senior 2001: 11-12, Tarn 1984 [1951]: 320).

149 Maues' coinage is treated by Bopearachchi, Osmund. 1999. "Recent Coin Hoard Evidence on Pre-Kushana Chronology." In Alram and Klimburg-Salter 1999: 124126; Jenkins, G.K. 1955. "Indo-Scythic mints." Journal of the Numismatic Society of India 17, 1-26; Konow 1929: xxix-xxxi; Rapson, E.J. 1922. "The Scythian and Parthian Invaders." In Cambridge History of India, vol. 1, ed. E.J. Rapson. Cambridge: Cambidge University Press, 513; and Senior 2001: 1.25-38. Senior's estimate (2001: 26) of Maues' reign from c. 95/85-60 BCE seems plausible.

${ }_{150}$ Mitchener, Michael. 1976. Indo-Greek and Indo-Scythian Coinage. London: Hawkins Publications, vol. 5: Establishment of the Scythians in Afghanistan and Pakistan, $457 \mathrm{ff}$. [Maps 40-42] proposes that Maues expanded his domain from bases in the Kurram valley northwards to Taxila and Gandhāra, while Tarn (1984 [1950]: 321-323) argues that Maues conquered Taxila by sailing upriver on the Indus from southern Pakistan. In contrast, the hypothesis of Bivar, A.D.H. 1984. "Maues at Taxila: Problems of his Arrival-Route and Political Allegiance." Journal of Central Asia 7.1, 14 that Maues or his predecessors migrated from areas in the north (Hazara and Kashmir) to Gandhara and Taxila in the south is also supported by Narain 1957: 145 ff., and Senior 2001: 29-34. 
In addition to issues of coins that reflect his major position as a powerful regional ruler in the Northwest, a Kharoșthi inscription recording the establishment of Buddhist relics in Taxila dated in year 78 "of Mahārāja Moga the Great" (maharayasa mahamtasa mogasa) indicates that Saka kṣatrapas ("Satraps") acknowedged his importance by using a continuous era named after him, although this inscription is the single attestation of such a reckoning system. ${ }^{151}$ While Maues himself is not directly connected with material evidence of Buddhist patronage, he appears to have initiated a decentralized administrative network of Saka mahākșatrapas, kșatrapas and loosely affiliated subordinates who were avid Buddhist donors. ${ }^{152}$

The most prominent successor of Maues was Azes (Aya in Kharoșțī), who also declared himself "King of Kings" on widespread and voluminous issues of coins following the decline of Indo-Greek rulers, from whom he adopted depictions of Hellenistic deities. ${ }^{153}$ Since Azes initially issued coins jointly with Spalirises, an Indo-Parthian official, he appears to have expanded his dominion to Taxila and other areas of northwestern Pakistan from a base in the region of Arachosia in southeastern Afghanistan rather than directly inheriting the regions previously ruled by Maues. ${ }^{154}$ Azes' likely successors (Azilises and

151 The copper plate Kharoșthī inscription of Patika is edited by Konow 1929: 23-29, no. 13, pl. 5.1 (= CKI 46: http://www.ebmp.org/a_inscription.php?catid=CKI0046), but an identification of the era of year 78 remains disputed. Falk, Harry. 2002. "Frühe Zeitrechnung in Indien." In Vom Herrscher zur Dynastie: zum Wesen kontinuierlicher Zeitrechnung in Antike und Gegenwart, ed. Harry Falk. Bremen: Hempen, 87-88 and Robert Senior 2001: 25 argue that Maues initiated his own era, but other scholars (Tarn 1984 [1951]: 494-502, Fussman 1980: 35 ff., Salomon 1998: 181, 2005: 372) have suggested identifications with other historical eras beginning in dates corresponding to 155 BCE (“Old Śaka” era), 172 BCE ( ${ }^{\star}$ Eucratides era), and 185 BCE (Yavana era). However, as observed by Glass, Andrew. 2007b. "The Chronology of Kharoșthī Inscriptions: A reassessment in light of recent discoveries.” Gandhäran Studies 1, 61-76, these solutions result in dates for Patika and his father, ksatrapa Liaka Kusulaka, that are too early for them to also appear in Kharoșthî inscriptions on the Mathura lion capital.

${ }^{152}$ Salomon, Richard. 1974. "The Kṣatrapas and Mahākșatrapas of India." Wiener Zeitschrift für die Kunde Südasiens 18, 5-25 concludes that these titles attested in Indian coins and inscriptions denote regional subordinates and semi-independent or independent rulers depending on the political context.

${ }_{153}$ Mitchener 1976: vol. 6 (Dynasty of Azes), 481-504; Rosenfield, John M. 1967. The Dynastic Arts of the Kushans. California studies in the History of Art, 6. Berkeley: University of California Press, 127, pl. XIV, coins 269-272; Senior 2001.

${ }^{154}$ Bopearachchi and Pieper 1998: 212, 260, pl. 51, coin 246; Bopearachchi and Aman ur Rahman 1995: 168-169, coins 702-703; Rosenfield 1967: 127; Senior 2001, $1.42-43$. 
Azes II) continued to produce numerous coins, including very common types with a figure on horseback holding a spear or whip. ${ }^{155}$ Azes is also credited (perhaps in hindsight) with initiating a dynastic era beginning in $58 \mathrm{BCE}$ which later became identified with the so-called Vikrama era still used in South Asia. ${ }^{156}$ Since this important era (which no longer bears his name) was adopted by later regional rulers who acknowledged the authority of the dynastic lineage of Azes in their inscriptions and coins, his impact on this period of South Asian history deserves greater emphasis. Robert Senior links Azes with "unification of the Punjab and a great increase of wealth, evidenced by his huge output of coinage" as well as "a revolution in religious ideas brought about by the cultural mix resultant from his sitting at the hub of the Silk route" (2001: 65). Such an assessment of Azes' legacy may be exaggerated by a narrow emphasis on numismatic sources, since Azes, like Maues, is not directly connected to patronage of religious institutions and is not mentioned in literary sources. Nevertheless, the consolidation of Saka power after Azes began to rule in 58 BCE by a confederation of regional rulers who established control of major routes connecting Gandhāra to Mathura had significant implications for political, economic, and religious history.

\section{Buddhist Patronage by the Apracas and Odis}

Regional Saka subordinates, allies, and officials supported Buddhist institutions by donating relics, building stūpas, and giving donations to monastic communities in their domains. Members of the Apraca

155 Although most other numismatic specialists maintain that the "spear versus whip" criterion for distinguishing coins of Azes I from those of Azes II "holds reasonably well for separating earlier and later Azes' coins" (Mitchener 1976: 6.481), Senior 2001: 63, 71, 83 argues that Azilises' coins follow those of Maues and precede issues of Azes and dismisses the distinction between Azes I and II by regarding later coins of Azes as posthumous issues. While the relative chronological sequence remains disputed (and it is beyond my scope to resolve numismatic debates), it is interesting to note that horseriders with whips also appear in petroglyphs from various sites (Hodar, Gichi Nala, Chilas, Thalpan, and Hunza-Haldeikish) in northern Pakistan, but it is not very clear that Azes' coinage was the source of this imagery.

156 Salomon 1998: 182 briefly explains the use of the Azes/Vikrama era in Indian inscriptions. Falk 2002: 85-87 observes that this era first attested 63 years after Azes began to reign in the Indravarman casket corresponding to 5/6 CE may have been a "creation in hindsight" (Schöpfung im Nachhinein). The date in this inscription (CKI 242: http://www.ebmp.org/a_inscription.php?catid=CKI0242) is discussed by Salomon, Richard. 1982. "The 'Avaca' inscription and the origin of the Vikrama era." Journal of the American Oriental Society 102, 59-68. 
family in the northwestern borderlands of Pakistan and Afghanistan made numerous Buddhist donations recorded in Kharoșthī inscriptions dated in the era of Azes. ${ }^{157}$ Although most of these inscriptions lack specific provenance, the domain of the Aparacas was probably centered in Bajaur and extended to Swat, Gandhāra, Taxila, and parts of eastern Afghanistan in the last half of the first century BCE and the early decades of the first century CE. Since the discovery of an inscribed reliquary casket from Shinkot in Bajaur donated by the Apraca king Vijayamitra (who evidently founded the dynasty), other inscriptions record donations of relics by at least four generations of kings, queens, and court officials. ${ }^{158}$ Apraca kings known from Kharoșthī inscriptions, coins, and seals included Indravasu, Viṣnuvarman (perhaps identical to Viśpavarman), and Indravarman, but the dynastic genealogy remains uncertain. ${ }^{159}$ Another important member of the Apraca lineage was the "general" (stratega) Aśpavarman, who appears as a character in a Buddhist avadāna preserved in first-century Kharoșthī manuscript fragments and whose name is inscribed on a silver saucer found at Sirkap in Taxila. ${ }^{160}$ Since Aśpavarman's coins overlap with late or

${ }^{157}$ For Kharoșthī inscriptions of the Apracas and Odis with references to additional publications, see Salomon 2005a: 385 and Salomon, Richard. 2007. "Dynastic and Institutional Connections in the Pre- and Early Kușāna Periods." In Srinivasan 2007: 267-285. Senior 2001: 1.89-94, 2.136-143 treats Apraca coins. Rahman, Abdur. 1999. "The Role of the Udis and Aprācas in the Spread of Buddhism: A lost chapter of the History of Gandhāra." Lahore Museum Bulletin 12, 3-18 is a very brief overview. Srivastava, Prashant. 2007. The Apracharajas: A history based on coins and inscriptions. Delhi: Agam Kala Prakashan synthesizes most (but not all) of these epigraphic and numismatic sources. Callieri, Pierfrancesco. 2002. "Il periodo dei Saka e dei Parti: le dinastie di Apraca e di Oḍi ed il loro support al Budhismo." In Callieri, Pierfrancesco and Anna Filigenzi, eds. Il maestro di Saidu Sharif: alle origine dell' arte del Gandhara. Roma: IsIAO, 57-61 re-examines the evidence or Buddhist patronage by the Sakas, Parthians, and the Apracas and Odi kings, their regional allies in Bajaur and Swat.

${ }_{158}$ Majumdar, N.G. 1937a. "The Bajaur Casket of the Reign of Menander." Epigraphia Indica 24, 1-8; Konow, Sten. 1947. "Note on the Bajaur Inscription of Menandros.” Epigraphia Indica 27, 52-58; Fussman 1993a: 95-111; CKI 176: http:// www.ebmp.org/a_inscription.php?catid=CKI0176 (see note 113).

159 Apraca genealogies proposed by Falk, Harry. 1998. "Notes on Some Apraca Dedicatory Texts." Berliner Indologische Studien 11/12, 107; Salomon, Richard. 1996b. "An Inscribed Silver Buddhist Reliquary of the Time of King Kharaosta and Prince Indravarman." Journal of the American Oriental Society 116, 450; Senior 2001: 1.90, and Srivastava 2007: 139 differ considerably.

${ }^{160}$ Lenz, Timothy. 2010. Gandhäran Avadānas. GBT 6. Seattle; London: University of Washington Press, 85-93 (Avadāna 8); Salomon 1999a: 145-150; Marshall 1951, 1.188, 2.613 (= CKI 190: http://www.ebmp.org/a_inscription.php?catid=CKI0190). 
posthumous issues of Azes (II) and the Indo-Parthian ruler Gondophares (see below), he probably flourished from ca. 20-50 CE. ${ }^{161}$

Kharoșthi inscriptions indicate significant relationships between the Apracas, Oḍi kings, contemporary Saka kṣatrapas, the early Kuṣananas, and other local dynasties during a politically turbulent period from the end of the first century BCE to the middle of the first century CE. A silver drinking vessel with an animal-style ibex figure formerly belonging to the "Yagu king" (yaguraño) Kharayosta (or Kharaosta) that was rededicated as a Buddhist reliquary by Indravarman (Aśpavarman's father) may indicate that this object was given to the Apracas as a gift in exchange for some form of tribute or assistance. ${ }^{162}$ The Apracas were also connected by marital alliance with the Odi kings in the Swat valley, since a royal relative and officer named Suhasoma in a Budddhist reliquary inscription of Senavarman (Fig. 2.2: Reliquary Stūpa of Senavarman, the King of Oḍi) was married to Vasavadattā, according to a Kharoșthī inscription recording her donation of a waterpot. ${ }^{163}$ Vasavadattā, the donor of the waterpot, may be identified with the sister of the Apraca prince Indravarma, since she is mentioned in a Kharoșţi reliquary casket inscription. ${ }^{164}$ Since Senavarman's inscription mentioning Suhasoma also refers to Sadașkaṇa, a son of the first Kuṣanna ruler Kujula Kadphises, the role of the Apracas and Odi rulers as powerful regional Buddhist patrons can be synchronized with the early Kușanas during a period of dynamic religious activity and political fluctuations at the beginning of the first century CE. ${ }^{165}$

161 Senior 2001: 92-94.

162 This interpretation of CKI 21 (http://www.ebmp.org/a_inscription.php?catid= CKI0241) is suggested by Salomon 1996b: 442-443.

163 Salomon 1999a: 152-155, 198-199 (British Library pot A, inscription $2=$ CKI 369: http://www.ebmp.org/a_inscription.php?catid=CKI0369); Salomon 2007: 276277. Links proposed by Salomon between Suhasoma in the Senavarma inscription (CKI 249) and Vasavadattā, the wife of Suhasoma (CKI 369) and the sister of Apraca prince Indravarman in a reliquary casket inscription (CKI 242 "Avaca Casket 1"), have been disputed by Harry Falk in his review of Salomon 1999a in Journal of Asian Studies 59 (2000), 210-211.

${ }_{164}$ CKI 242 (Avaca Casket 1): http://www.ebmp.org/a_inscription.php?catid= CKI0242 was first published by Bailey, Harold. 1978. "Two Kharoṣthī casket inscriptions from Avaca." Journal of the Royal Asiatic Society, 3-13.

${ }^{165}$ Lines 8g-9b of the Senavarma Inscription(CKI 249: http://depts.washington. edu/ebmp/inscriptions.php) link Suhasoma and with Sadaṣkana: maharaja-rayatiraraya Kuyula-Kataphsa-putro Sadașano devaputro sadha anakaena Suhasomena așmakareṇa sayuga-savalavahaṇa sadha guśurakehi ca puyita "Sadașkaṇa, son of the 


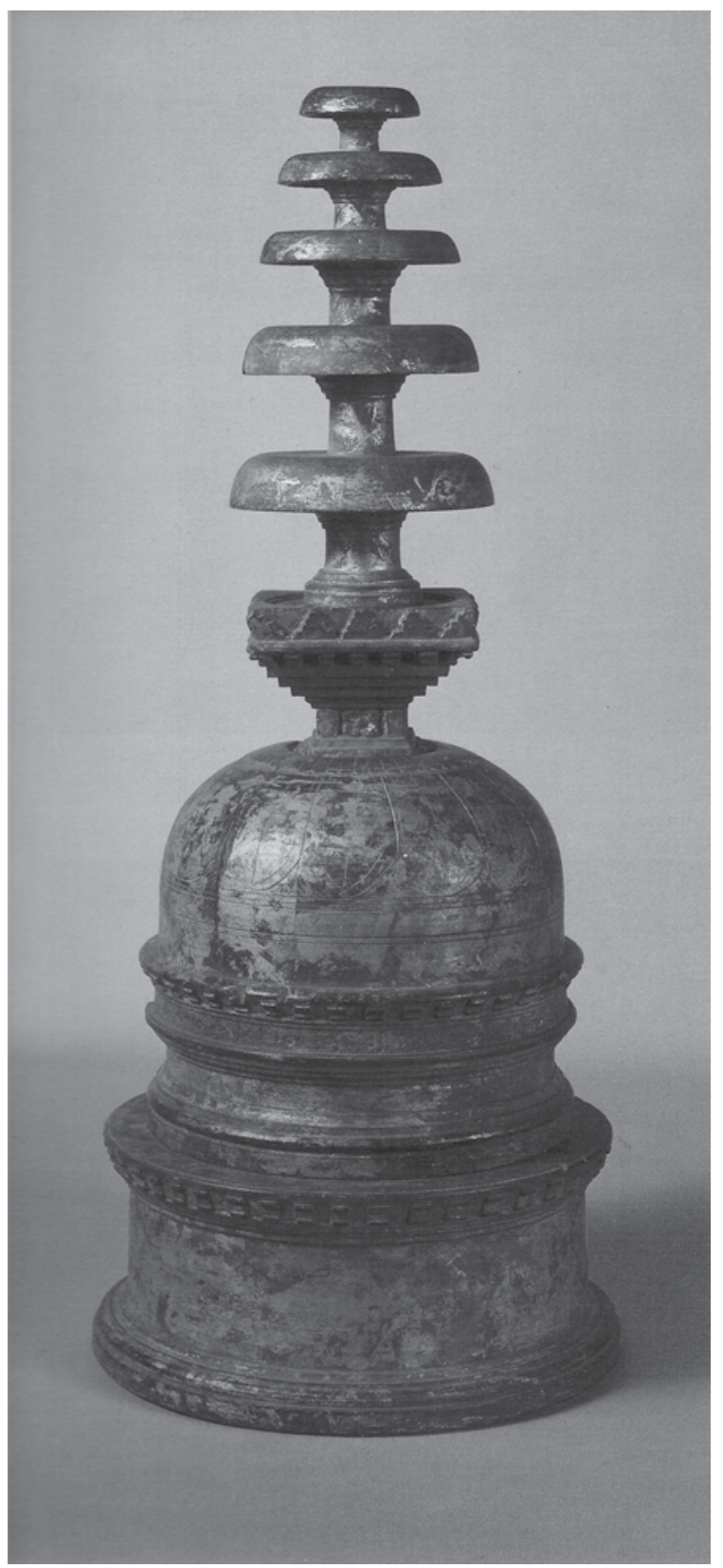

Fig. 2.2: Reliquary Stūpa of Senavarman, King of Oḍi (Source: Czuma and Morris 1985: 165 , no. 82) 


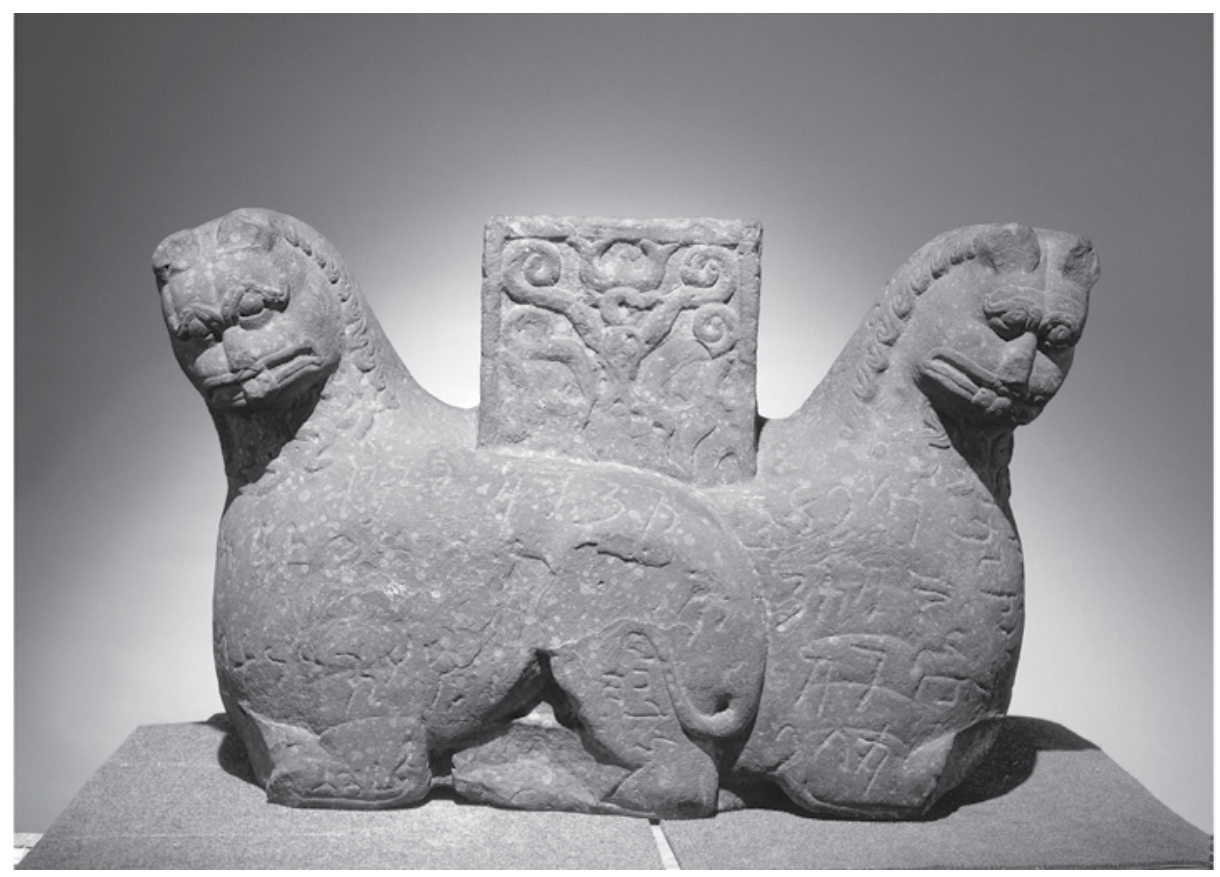

Fig. 2.3: Mathura Lion Capital (๑Trustees of the British Museum)

\section{Mathura Kṣatrapas and Mahākșatrapas}

Kșatrapas and Mahākșatrapas reigning in Mathura extended Saka administration and religious patronage from the northwestern borderlands to an important cultural and commercial center in the GangaYamuna doāb by the late first century BCE. Kharoșthī inscriptions

gods, son of the Great King, King over Kings, Kuyula Kataphsa (Kujula Kadphises), with [his] royal kinsman Suhasoma the aśmanakara (officer), with [his] mounts, with [his] forces and vehicles, with [his] guśuraka and sturaka nobles, is honored" (Salomon 1986: 271). The reading and interpretation of this Kharoșthi inscription (the longest discovered to date) first published by Bailey, Harold. 1980. "A Kharoștrī Inscription of Senavarma, King of Odi." Journal of the Royal Asiatic Society (1980), 21-29 has been significantly improved by the studies of Fussman, Gérard. 1982. "Documents épigraphiques kouchans (III): L'inscription Kharosțīi de Senavarma, roi d'Oḍi: Une nouvelle lecture." Bulletin de l'École Française d'Extrême-Orient 71, 1-46 and Hinüber 2003. Kharoșțī inscriptions of Senavarma's father Ajitasena (CKI 334: http://www.ebmp.org/a_inscription.php?catid=CKI0334) and his brother Varmasena (CKI 401: http://www.ebmp.org/a_inscription.php?catid=CKI0401) are published by Fussman, Gérard. 1986a. "Documents épigraphiques kouchans IV: Ajitasena, père de Senavarma." Bulletin de l'École Française d'Extrême-Orient 75, 1-14 + pls. 1-6 and Salomon, Richard. 2003b. "Three Kharoșthī Reliquary Inscriptions in the Institute of Silk Road Studies.” Silk Road Art and Archaeology 9, 39-51, 63-64. 
on a lion capital from Mathura provide keys to understanding links between various Saka families which ruled Taxila and Mathura. ${ }^{166}$ Since its discovery in 1869 by Bhagvanlal Indraji, epigraphists have struggled to read and interpret the inscriptions written on all surfaces of the sculpture (on its top, back, sides, front, and bottom). A relatively long passage written on top and on back of a rectangular block joining the adorsed lions commemorates the installation of Buddhist relics and donation of a stūpa and monastery to a Sarvāstivādin monastic community by the "Chief Queen" (agramaheși) of Mahäkșatrapa Rajula. Although the phrasing is ambiguous, her name may be understood as a compound, Ayasia Kamuia, or as Ayasia, the daughter (dhitra) of the Kamu[ia]. She was apparently the daughter of Kharaosta, whose name appears twice in the Mathura lion capital inscriptions with the title of "heir apparent" (yuvaraña and yuvaraya in Gāndhārī correspond to Sanskrit yuvarāja). Since Kharayosta (a variant of Kharaosta) is identified as a Mahäkșatrapa's son in a Kharoșthī inscription on the silver goblet rededicated as a Buddhist reliquary by the Apraca prince Indravarman, the Mathura lion capital inscriptions indicate kinship connections between the family of Mathura Kșatrapas and Saka lineages in the Northwest. ${ }^{167}$

Another Mathura lion capital inscription refers to Mahäkșatrapa Kusula Patika, who can be identified with the donor (mahādānapati) of Buddhist relics named Patika, the son of Liaka Kusulaka, the Kṣatrapa of Cukhsa, according to a Kharoșți inscription from

${ }^{166}$ Konow 1929: 30-49, no. 15, pls. VI-IX; Sircar 1965: 114-119, no. 24, pls XVIIXXII; Thomas, F.W. 1907-8. “The Inscriptions on the Mathura Lion-Capital." Epigraphia Indica 9, 135-147; CKI 48 (http://www.ebmp.org/a_inscription.php?catid=CKI0048). Although Konow attempts to read and interpret the haphazardly written inscriptions on the lion capital as a single epigraphic record, Sircar and Thomas split the inscriptions into separate groups. The Kharosthi i characters vary in size, but do not appear to have been written by separate hands at different times. John Rosenfield suggested that "... a ceremonial gathering at Mathurā of a large number of Śaka princes" (1967: 134) may have served as a context for writing these records, which resemble informal graffiti.

${ }_{167}$ Salomon 1996b: 424 (Inscription II: mahakṣatrapa-putrasa [ya]guraṃna khara[yosta]sa... [= CKI 241 (http://www.ebmp.org/a_inscription.php?catid=CKI0241). Since Kharayosta has the title of Yabgu-king (yaguramña) in this inscription and the title of heir-apparent (yuvaraya) in the Mathura lion capital inscriptions, it is likely that the Mathura inscriptions were written before he was elevated to the position of Yabgu-king. Yabgu, a Central Asian title corresponding to Chinese xihou, was adopted in Kusānạa coin legends (Hulsewé 1979: 121-123, Rosenfield 1967: 11, Thierry 2005: 462-469, 498). Kssatrapa Kharaosta is known as the "son of Arta" and as the father of Hajatria in Greek and Kharoṣthī coin legends (Senior 2001: 98-100). 
Taxila. ${ }^{168}$ The appearance of the title and name of Mahāksatrapa Rajula's son Kșatrapa Șudasa in the lion capital inscriptions demonstrates that they were written before he inherited the title of Mahākșatrapa, as Śộasa is known in Brāhmī inscriptions from Mathura, including a Jain ayavati plaque inscription of a female donor named Amohini dated in year $72 .{ }^{169}$ If this date is reckoned according to the Azes/ Vikrama era of 57-58 BCE, a correspondence with 14-15 CE provides a terminus ante quem for the Mathura lion capital inscriptions as well as the period when Saka historical figures such as Mahäkșatrapa Patika and Yuvarāja Kharaosta were in power. Kharoșthī inscriptions written on the bottom surface of the Mathura lion capital call for the honor (puyae for Sanskrit püjāyai) of the donation to extend to "all Buddhas, the Dharma, and the Sangha" and to "all of Sakastan." The somewhat unusual use of the formula with Sakastana may reflect some conception of a Saka domain in the northwestern Indian subcontinent. By establishing themselves as powerful rulers and administrators in Mathura, Taxila, and the Punjab, the Sakas controlled a network of routes that connected the northwestern frontiers with the Indian heartland.

\section{Indo-Parthians: Mahārāja Gondophares or the Gondopharids?}

By the middle of the first century CE, Saka Kșatrapas and Mahäkșatrapas in the Northwest evidently served under the nominal authority of Indo-Parthian rulers related to Mahārāja Gondophares. However, the interpretation of numismatic and epigraphic sources for the reign of Gondophares is complicated by the "homonymy problem" (Alram 1999, 37, fn. 123) of several kings with this name or title meaning "winner of glory' during the late first century BCE and early first century CE. ${ }^{170}$

168 Konow 1929: 23-29, no. 13, pl. V.1; Sircar 1965: 124-125, no. 27; CKI 46 (http:// www.ebmp.org/a_inscription.php?catid=CKI0046). See note 151 for references to discussions of the date of this inscription in year 78 of Maues.

${ }^{169}$ Quintanilla 2007: 168-172, 275-276; Sircar 1965: 120-121, no. 25, pl. XXIII. An alternative reading of the first figure in the date as 40 rather than 70 is supported by Senior 2001: 100 on the basis of his proposed numismatic chronology for the coins of Rajuvula (Rajula), but the arguments of Sircar 1965: 125 n. 3 and Quintanilla 2007: 275-6 for a reading of 72 based on epigraphic and art historical evidence are more convincing.

${ }^{170}$ Senior argues that 'Gondophares' is in reality a title (Vindapharna-Old Persian for 'winner of glory')" (2001: 108) adopted by several successors to an original Gaondophares I, who should be dated before c. 20 BCE. B.N. Puri. 1994. "The Sakas 
Table 2.2: Saka Networks in South Asia

\begin{tabular}{|c|c|c|}
\hline Northwest and Taxila & $\begin{array}{l}\text { Mathura Lion Capital } \\
\text { inscriptions (MLCI) }\end{array}$ & Western India \\
\hline $\begin{array}{l}\text { Moga/Moa (Maues) } \\
\text { "king of kings" } \\
\text { Aya (Azes) Era of } 58 \text { BCE } \\
\text { "king of kings" } \\
\text { Azilises } \\
\text { Azes II }\end{array}$ & $\begin{array}{l}\text { Ayasia (kamuia) } \\
\text { agramahiși (primary } \\
\text { queen), daughter of } \\
\text { Kharaosta }\end{array}$ & $\begin{array}{l}\text { Kșhaharata Kṣatrapas: } \\
\text { Bhūmaka } \\
\text { Nahapāna } \\
\text { Dakhamitrā, daughter of } \\
\text { Nahapāna } \\
\text { Ușavadata, husband of } \\
\text { Dakhamitrā }\end{array}$ \\
\hline $\begin{array}{l}\text { Taxila Mahākșatrapas: } \\
\text { Liaka Kusulaka } \\
\text { kșatrapa of Cukhsa, } \\
\text { father of Patika } \\
\text { Kusulaa Patika } \\
\text { (Maues Year 78) } \\
\text { mahākșatrapa in MLCI } \\
\text { Arța mahākṣatrapa, } \\
\text { father of Kharaosta } \\
\text { Kharaosta yuvarāja in } \\
\text { MLCI Hajatria, son of } \\
\text { Kharaosta in coin legends } \\
\text { Jihoniga (Zeionises) } \\
\text { mahākșatrapa, precedes } \\
\text { Kușāṇas }\end{array}$ & $\begin{array}{l}\text { Suḍasa (Azes year } 72 \text { ) } \\
\text { ksatrapa, son of Rajula } \\
\text { Abuhola mother of } \\
\text { Ayasia } \\
\text { Nada Diaka daughter } \\
\text { of Ayasia } \\
\text { Piśpasi mother of } \\
\text { Rajula } \\
\text { Ha... and Hana brother } \\
\text { and niece of Ayasia }\end{array}$ & $\begin{array}{l}\text { Kardamaka Kṣatrapas: } \\
\text { Caștana } \\
\text { (Śaka era of } 78 \mathrm{CE} \text { ) } \\
\text { Rudradāman Caștana's } \\
\text { grandson } \\
\text { (Śaka year } 72 \text { ) } \\
\text { (line continues in Ujjayinī } \\
\text { and Gujarat until ca. } 400 \mathrm{CE} \text { ) }\end{array}$ \\
\hline
\end{tabular}

Gondophares/Guduphara has been identified with King Gudnafar in the Christian apocryphal account of the visit of St. Thomas to India, but these late hagiographical sources do not necessarily provide a reliable basis for clarifying the rather complicated political history of the northwestern Indian subcontinent during the early decades of the first century. ${ }^{171}$ The legacy of Gondophares and his successors as powerful

and Indo-Parthians" (Chapter 8 in Harmatta 1994) adopts the argument that the 'Winner of Glory' title "became a sort of family name for many subsequent members of the family" (200). However, Senior's challenge to the general consensus for dating Gondophares I from c. 19-46+ CE has not received much support (Srivastava 2007: 85-92).

171 According to Fussman, Gérard. 1998. L'inscription de Rabatak et l'origine de l'ère Śaka," Journal Asiatique 286, 624-625, the hagiographical sources only indicate 
rulers who expanded Indo-Parthian dominion from Arachosia (southeastern Afghanistan) to Gandhāra, Taxila, Jammu, and the western Punjab is primarily reflected in the production and distribution of coins produced in different mints. ${ }^{172}$ The single epigraphic attestation for the reign of Gondophares is a Kharoșthi inscription reportedly from Shahbazgarhi or the Takht-i Bahi Buddhist monastery in the Mardan district of Northwestern Pakistan dated in the twenty-sixth regnal year of Mahārāja Gudavhara (maharayasa gudavharasa) and in year 103 of an unspecified era. ${ }^{173}$ If the date in year 103 is calculated according to the Azes era of 58/7 BCE, the period of Gondophares' reign apparently extended from c. 19 CE to at least 45-46 CE, but it is not certain that Guduvhara refers to Gondophares himself or to a successor ruling in his name. ${ }^{174}$ Since Gondophares and other members of his family probably seem to have ruled "... by co-operating with powerful forces on the ground and by absorbing them into [their] sphere[s] of influence" through "... a system of absorption allowing local rulers to keep their independence” (Senior 2001: 110), nominally subordinate local rulers (such as the Apraca general Aśpavarman) had significant roles. Although chronological details remain disputed and the role of the Gondopharid dynasty in political history before the advent of the Kușananas is still not clearly understood, Indo-Parthian hegemony in the Northwest in the middle of the first century CE corresponded with "a period of great prosperity and cultural achievement" (Rosenfield 1967: 129).

that an Indo-Parthian ruler with this name was still known in Syria after c. 250 CE, but do not provide evidence that St. Thomas actually met him or that he controlled Taxila.

172 Alram 1999, 37-44; Bopearachchi, 1993, 59-60; Bopearachchi and Pieper 1998, 219-223; Bopearachchi 1999, 135-136; Mitchener 1976, 5.393-394, 8.697-719; Senior 2001, 1.108-128, 2.148-158.

${ }_{173}$ Konow 1929: 57-62, no. 20, pl. XII.1; Sircar 1965: 125-126, no. 28; CKI 53 (http://www.ebmp.org/a_inscription.php?catid=CKI0053). Sadakata, Akira. 1996. "Quelques inscriptions kharoșthī provenant du marché aux antiquités de Peshawar." Journal Asiatique 284.2, 308-311, (pls. 4-5) published a Kharosțī inscription dated in Azes year 98 (equivalent to c. $41 \mathrm{CE}$ ) during the reign of Abdagases (Avakaśa), a nephew of Gondophares (Guphara), but its authenticity is doubted by Senior 2001: 125 and Salomon 2005a: 369, fn. 19.

174 Senior 2001: 125 proposes that Mahārāja Guduvhara is to be identified to Sases, a descendant of Gondophares who issued coins with legends similar to the titles used in the coins of Gondophares I, but the Kharosthin inscription provides no indication to confirm this hypothesis. 


\section{Kṣaharāta and Kärdamaka Kșatrapas in Western India}

The Kṣaharāta and Kārdamaka lines of Saka rulers, commonly known as the Western Kṣatrapas, contended for power with the Sātavāhana dynasty from the first century CE. ${ }^{175}$ These two groups of Sakas probably came from the lower Indus region of Sind after migrating from southeastern Iran (Seistan) in the first century BCE. ${ }^{176}$ The term Kṣaharāta appears in inscriptions from Taxila and Mathura and on coins issued by Saka rulers in Sindh and Saurāsțra (the Kathiawar peninsula of modern Gujarat). ${ }^{177}$ Although the relationship with these Kṣaharātas is not very clear, Bhūmaka and his son Nahapāna issued coins as Kṣaharāta Kṣatrapas in western India. ${ }^{178}$ Brāhmī donative inscriptions in Buddhist caves at Nasik, Junnar, and Karle in the Western Ghats by Nahapāna's daughter Dakhamitrā and her husband Ușavadāta are dated in years 41-6 of an unspecified era. ${ }^{179}$ The chronology of Nahapāna's rule hinges on whether these dates refer to his regnal era or to the Śaka era beginning in $78 \mathrm{CE}$, which would result in dates corresponding to c. 119-124 CE. ${ }^{180}$ If years 41-46 instead refer to Nahapāna's regnal years, his apparently long reign can be situated in the mid-first century $\mathrm{CE}$, which would permit an identification with Manbanos, the ruler of Barygaza (modern Broach in Gujarat) in the Periplus Maris Erythraei, a koinē Greek navigational text dated

175 Mirashi, Vasudev Vishnu. 1981. The History and Inscriptions of the Sätavāhanas and the Western Kshatrapas. 2 vols. Bombay: Maharashtra state Board for Literature and Culture; Sircar, Dineshchandra. 1969. Ancient Malwa and the Vikramāditya Tradition. Delhi: Munshiram Manoharlal; and Shrava, Satya. 1947. The Sakas in India. Lahore: Vedic Research Institute (Reprint, New Delhi: Pranava Prakashan, 1981) treat literary and epigraphic sources for the Western Kșatrapas in detail. The numismatic studies of Mitchener 1976: 811-852 (vol. 9, chapters 26-27) and Senior 2001: 129-138 present conflicting views on chronological and historical issues.

176 See p. 115, note 148 .

177 Konow 1929: 24-25; Lüders 1961: 157-158 (\$ 118); Mitchener 1976: 811, 819822.

${ }_{178}$ Mirashi 1981: 1.278-9; Mitchiner 1976: 816-824; Senior 2001: 1.135-6, 2.194-6.

179 Mirashi 1981: 2.95-114; Sircar 1965: 164-173, nos. 58-62.

180 Sircar 1965: 164, fn. 1; Mirashi 1981: 1.100-108 assign these dates to the Saka era. Fynes, R.C.C. 1995. "Religious Patronage of the Sātavāhana Dynasty." South Asian Studies 11, 43-50 supports an identification with regnal years of Nahapāna, corresponding to a period between 66-71 CE. Senior 2001: 132 reckons the years according to the Azes/Vikrama era of 58/7 BCE, resulting in c. 17-12/11 BCE, but placing Nahapāna before the Common Era creates insurmountable problems of relative chronology. 
to c. 40-70 CE. ${ }^{181}$ While secure dates for Nahapāna's period are elusive, overstrikes of his coins by the Sātavāhana ruler Gautamīputra Sātakarni, who is praised for destroying the Śakas, Yavanas, and Pahlavas and for "exterminating the race of the Kșaharātas" in an inscription of his descendant Vāsișthīputra Pulumāvi, indicate that the Kșaharāta Kșatrapas in western India were defeated by the Sātavāhanas. ${ }^{182}$ Jain commentaries referring to a conflict between Nahavāna of Bharukaccha (Broach) and the Sālavāhana (Sātavāhana) rulers of Paiṭhāna (the Sātavāhana capital at Pratișțāna) lend support to the numismatic and epigraphic evidence. ${ }^{183}$ Quasi-historical memories of ongoing conflicts between the Sakas and Sātavāhanas in western India are also reflected in the Kälakācāryakathānaka, a medieval Jain hagiographic narrative which connects the origins of the Azes/Vikrama era of 57/8 BCE and the Saka era of $78 \mathrm{CE}$ with the arrival of Sakas in Ujjayini after they crossed the Indus and conquered Saurāstra. ${ }^{184}$ The struggle between the Sātavāhanas and the Sakas for control of seaports and routes across the Western Ghats to the Indian hinterland was likely to have been motivated by the lucrative trade in a variety of commodities that circulated in maritime commerce between India and Egypt during this period. ${ }^{185}$

A separate branch of Western Kșatrapas apparently called Kārdamakas succeeded the Kṣaharāta Kṣatrapas and continued to rule in Gujarat, Ujjayinī, and parts of western India until $415 \mathrm{CE}$. The origins of this family are uncertain, but a reference to a Kardamaga king who was reborn as a pig as a result of selfishness in Kharoșți manuscript fragments suggests links with Sakas in the Northwest. ${ }^{186}$

181 Casson, Lionel. 1989. The Periplus Maris Erythraei: Text with introduction, translation and commentary. Princeton: Princeton University Press, 77, 197-198, §41.14.2. The identification of Nahapāna with Manbanos is not accepted by Fussman, Gérard. 1991. "Le Périple et l'histoire politique de l'Inde." Journal Asiatique 279, 33, who disagrees that Nahapāna could have been ruling between c. 40-70 CE.

${ }_{182}$ Nāsik cave inscription of Vāsiśțhipputra Pulumāvi: Mirashi 1981: 1.31-35, 2.41-49 (no. 18, 1l. 5-6) and Sircar 1965: 203-207 (no. 86); overstrikes of Nahapāna's coins are discussed and illustrated in Senior 2001: 1.135, 2.197; also see Fynes 1995: 44, Raychaudhuri 1923: 261, Sircar 1969: 81.

183 Shrava 1947: 62; Sircar 1969: 81.

184 Konow 1929: xxvi-xxvii; Mitchener 1976: 806-7; Sircar 1969: 106-148.

185 See Seaports and Maritime Routes across the Indian Ocean in Chapter 3 pp. 217-226.

${ }^{186}$ Neelis, Jason. 2008. "Historical and Geographical Contexts for Avadānas in Kharosthī Manuscripts.” In Gombrich and Scherrer-Schaub 2008: 160-161. Raychaudhuri, H.C. 1933. "The Kārddamaka Kings.” Indian Historical Quarterly 9.1, 37-39 
The earliest attested figure in this line of Saka Kṣatrapas was Caștana, the son of Ysāmotika (or Zāmotika), who issued inscriptions dated in years 6, 11, and 52 of the Saka era of 78 CE, an astronomical era perhaps connected with the beginning of Castana's rule. ${ }^{187}$ The dates in these inscriptions indicate that Castana had an unusually long reign of 52 years (until at least $130 \mathrm{CE}$ ). While D.C. Sircar and V.V. Mirashi maintain that Caștana was appointed Kuṣanna viceroy after Nahapāna’s death "with instructions to recover the lost areas of the satrapy from the Sātavāhanas" (Sircar 1969: 86), this reconstruction is largely based on the identity of the Śaka era with a later era initiated by Kanișka and the possibility that an image of Caștana appears in a Kușanna dynastic shrine outside of Mathura. ${ }^{188}$ The expansion of the dominion of Caștana and his descendants to Ujjayini and other areas of western India does not indicate that they served as Kușanna subordinates, but instead acted as independent regional rulers who filled a void after the downfall of the Kṣaharātas and a temporary decline of the Sātavāhanas in the middle of the second century CE. ${ }^{189}$

analyzes Indian literary references that suggest connections to a Karddama River in Persia (commentary on Arthaśástra 2.11) or to a royal lineage of Kṣatriyas traced back to Kārddameya (Rāmāyaṇa, Uttarakāṇ̣a, 100.19-20), but Shrava 1947: 68 contends that Kardamaka refers to the Kardama area near modern Siddhapur in Gujarat.

187 Mirashi 1981, 2.115-9, nos. 45-9, 153-6, no. 63 and Sircar 1965, 173-175, nos. 63-66. Mirashi, Sircar, and Raychaudhuri 1923: 266 deny that the Saka era of 78 was initiated by Castana, while Fynes claims that Castana"s accession date "is almost certainly marked by the commencement of the Saka era in AD 78" (1995: 44). Falk 2002: 94 suggests that the beginning of the Śaka era may reflect the beginning of Castana's rule of Ujjayini on an auspicious date, since the first day of Caitra (April), $78 \mathrm{CE}$ corresponds with the conjunction of the sun, moon, and Jupiter in Ares. The longevity of this era may be linked to its usefulness in casting horoscopes.

${ }_{188}$ Falk, Harry. 2001. "The yuga of Sphujiddhvaja and the era of the Kusânanas." Silk Road Art and Archaeology 7, 121-136; 2002: 91-95, has called attention to the fact that the Saka and Kanișka eras are treated as separate reckoning systems in the Yavanajätaka. Rosenfield 1967: 145-146 (fig. 3) provisionally labels an image from the Māt devakula as "the Caśțana statue" but acknowledges that Lüders (1961: 145$147, \$ 100$ ) reads mastana rather than șastana, which is very difficult to reconcile with Caștana's name in Brāhmī inscriptions and coins of the Western Kṣatrapas. For further details about the dating of the Kanișka era, see Early Kușāna Genealogy and Chronology pp. 133-137.

189 Ptolemy's Geography (7.1.63) (translated by McCrindle, J.W. 1885. Ancient India as described by Ptolemy. Calcutta: Thacker, Spink, \& co, 152-155), which was written c. $140 \mathrm{CE}$, refers to the capital (Greek basileion) of Tiastanos (=Caștana) at Ozene (Sanskrit Ujjayinī, modern Ujjain). For references and further discussion, see Eggermont, P.H.L. 1966. "The Murundas and the Ancient Trade-Route from Taxila to Ujjain." Journal of the Economic and Social History of the Orient 9.3, 264-265; Rosenfield 1967: 132; Sircar 1969: 87. 
A Sanskrit inscription praising Caștana's grandson Rudradāman clearly reflects the historical and cultural impact of the Western Kșatrapas. The inscription dated in 150 CE (Śaka year 72) commemorate repairs to an embankment on Lake Sudarśana at Junagadh, where the Girnar version of Aśoka's Major Rock Edicts was inscribed approximately four centuries earlier. ${ }^{190}$ The composition of this eulogy (praśasti) of Rudradāman's exploits in ornate classical Sanskrit rather than Prakrit was a significant innovation in Indian cultural history. ${ }^{191}$ Mahākșatrapa Rudradāman is praised as a skilled and learned overlord of territories extending from the lower Indus (Sindhu-Sauvira) to coastal areas just to the north of modern Mumbai (Aparānta, with its capital at Sopāra). According to the claims in the inscription, he twice conquered the Sātavāhana ruler (Sātakarṇi), who is described as "Master of the Southern Route" (dakșināpatha-pati). Despite the agonistic relationship with the Sātavāhanas, a Sanskrit inscription recording a donation of a water cistern in a Buddhist cave at Kanheri (within the urban area of Mumbai) refers to a marriage alliance between the Kārdamakas and the Sātavāhanas. ${ }^{192}$ A Sātavāhana queen who donated the water cistern was a Kārdamaka descendant and the daughter of Mahākșatrapa Ru-, probably to be identified with Rudradāman or another Western Kṣatrapa. ${ }^{193}$ The Kārdamakas consolidated their

${ }^{190}$ Kielhorn, Franz. 1905. "Junagadh Rock Inscription of Rudradaman; the Year 72.” Epigraphia Indica 8, 36-49; Mirashi 1981: 2. 121-130 (no. 51); Sircar 1965: 175-80 (no. 67). Falk 2006: 118-120 (Fig. 6 is a very clear photograph of part of the Rudradāman Sanskrit inscription), 287-288 (Girnar dam) examines the Aśokan edicts and the site of the dam built by Rudradāman. A later inscription issued during the time of Skandagupta is discussed later in this chapter under Shifting Networks of Political Power and Institutional Patronage during the Gupta Period, p. 155.

191 Comments on the Junagadh inscription of Rudradāman by Pollock 2006: 67-73 highlight its significance as a turning point in Sanskrit literary culture, but his contention that a "desacralization of Sanskrit" (70) was intitiated by the Sakas "in the interests of a new cultural politics" (73) seems hyperbolic, since earlier trends towards Sanskritization are evident in religious donations from Mathura.

${ }^{192}$ James Burgess and Bühler, Georg. 1883. Report on the Elura cave temples and the Brahmanical and Jaina caves in western India. Archaeological Survey of Western India 5. London: Trübner [reprint, 1970]), 78, no. 11, pl. LI. Also see Gokhale, Shobhana. 1991. Kanheri Inscriptions. Pune: Deccan College Post Graduate and Research Institute, 62; Lüders 1973 [1912]: 103 (no. 994); Mirashi 1981: 2.68-69 (no. 25).

${ }^{193}$ Bühler, Georg. 1883. "On the Relationship between the Andhras and the Western Kshatrapas." Indian Antiquary 12, 272-274 noted the marital link between this family of Western Kṣatrapas and the Sātavāhanas. The Kārddamaka royal lineage (kārddamakarājavamiśa) is only referred to in this inscription. 
position as a regional power through marital ties with the Sātavāhanas as well as other dynasties in the Indian subcontinent.

The Kārdamaka lineage of Western Kșatrapas continued to rule areas of western India from their bases in Ujjayini and the Kathiawar peninsula until the end of the fourth century CE. ${ }^{194}$ In addition to the marriage between the Kārdamaka princess and the Sātavāhanas discussed in the previous paragraph, the Western Kșatrapas also established marital alliances with the Licchavis of Vaiśāli in the Buddhist heartland and the Ikṣvākus in the Krishna-Godāvarī delta in the eastern Deccan, where the queens belonging to this dynasty made Buddhist donations at Nāgārjunakoṇ̣a. ${ }^{195}$ This regional dynasty of Kārdamakas issued inscriptions, coins, and seals (including a monastic sealing of the "Mahārāja Rudrasena vihära") ${ }^{196}$ until the period of the impe-

${ }_{194}$ Mirashi 1981: 1.68-86; Raychaudhuri 1923: 266-270; Sircar, Dineshchandra. 1968. "The Saka Satraps of Western India." Chapter 13 in The Age of Imperial Unity. The History and culture of the Indian people, vol. 2, ed. Ramesh Chandra Majumdar. Mumbai: Bharatiya Vidya Bhavan, 178-190; Tripathi 1942: 217-219.

${ }_{195}$ A link between the Western Ksatrapas and Licchavis is suggested by discoveries of clay seals of Prabhudamā, a queen (mahādevī) who was the daughter of Mahākșatrapa Rudrasimha, who ruled until $197 \mathrm{CE}$, and sister of Rudrasena I, who ruled for a period of 20 years from ca. 199-220 (Mirashi 1981: 1.77; Sircar 1968: 187). A marriage alliance between the Western Kṣatrapas and the Ikșvāku dynasty is attested by a memorial pillar inscription from the time of King Rudrapurusadatta (ca. 295 to 315-325 CE) at Nāgārjunakoṇda (Sircar, Dineshchandra and K.G. Krishnan. 1960. "Two Inscriptions from Nāgārjunakoṇ̣a.” Epigraphia Indica 34, 20-22). Rudradhara-bhațtārikā, one of the wives of the Ikșvāku King Virapurusadatta, is identified as the daughter of the Mahārāja of Ujjayin̄i (Ujanikā-mahār<āja>bālikā) in a Buddhist inscription at Nāgārjunikoṇda: Vogel, J.P. 1929/1930. "Prakrit Inscriptions from a Buddhist Site at Nagarjunikonda." Epigraphia Indica 20, 4-5, 19 (Āyaka-pillar inscription B 5); Sircar 1965: 231 (No. 98.2). Sircar 1968: 189 links Rudradhara-bhațāarakā with Rudrasena II, whose coins bear Śaka era dates between years 177-199, corresponding to 255-277 CE. For Buddhist donations by Ikșvāku queens, see Sircar 1965: 236-240 (nos. 102-104) and Vogel, J.P. 1930. "Additional Prakrit Inscriptions from Nagarjunikonda." Epigraphia Indica 21, 61-71. A very early copper-plate grant by the Ikșvāku king Ehavala Cāntamūla (ca. 270-294 CE) to a Buddhist community at Pithuṇ̣a has recently been published by Falk, Harry. 1999/2000. "The Pạtagaṇ̣igūdem copperplate grant of the Ikșvāku king Ehavala Cāntamūla." Silk Road Art and Archaeology 6, 275-283 and N.S. Ramachandra Murthy. 1999. "Pātaganḍigūdem plates of Ehavala Chāntamūla." Journal of the Epigraphical Society of India 25, 114-123. Also see Sircar, Dineshchandra. 1946. "Eastern Deccan." Chapter 4 in The Vākātaka-Gupta Age (Circa 200-550 AD), eds. Anant Sadashiv Altekar and Ramesh Chandra Majumdar. Banaras: Motilal Banarsidass, 64-92 for a treatment of Ikșvāku political history and Stone, Elizabeth Rosen. 1994. The Buddhist art of Nāgärjunakonda. Delhi: Motilal Banarsidass Publishers for art history.

${ }^{196}$ Mirashi 1981: 2.140-141 (no. 58). 
rial Guptas, when they lost control of ancient Mālava and Saurāșțra. ${ }^{197}$ As regional counterparts, rivals, and successors to the Kușānas and the Sātavāhanas, the Western Kṣatrapas and Ikṣvākus controlled an important network between coastal ports for long-distance maritime trade and hinterland nodes in western and eastern India with thriving Buddhist communities in the second and third centuries CE.

\section{Saka Summary}

By establishing themselves as powerful sovereigns at critical nodes in western and northwestern India, the Sakas of Ujjayinī, Mathura, and Taxila controlled important routes belonging to overland and maritime trade networks. Although their role in social, religious, and cultural transformations in this dynamic period of South Asian history has not (until recently) received as much attention as earlier Hellenistic or later Kuṣanna impacts, various donors connected with Saka courts directly contributed to the growth of Buddhist religious institutions. The establishment of relics in stuppas and gifts to Buddhist monasteries by Mahākșatrapa Patika in Taxila, the Apraca Prince Indravarman and his wife Uttarā, King Senavarman in Oḍi, Queen Ayasia in Mathura, and the Western Kṣatrapas are widely attested in Kharoșthi and Brāhmī inscriptions. References to Mahākșatrapa Jihonika, Stratega Aśpavarman, the Kardamaga King, and other Sakas in Gāndhārī avadānas acknowledges and reflects their supporting roles in "the great flowering of Gandhāran Buddhism" (Salomon 1999a: 180). The Sakas, like the Sātavāhanas and other dynasties with whom they competed, conformed to the traditional role of Indian rulers as donors to multiple groups without necessarily adopting an exclusive religious identity. ${ }^{198}$ Perhaps their adoption of Indian patterns of rulership, appropriation of South Asian religious symbolism on issues of coins, and use of Gāndhārī, other regional Prakrit languages, and Sanskrit in inscriptions facilitated their gradual acceptance as Kṣatriya rulers. However, a distinctively Saka cultural identity is difficult to recognize in literary sources that tend to reflect the ideological values and anachronistic

${ }_{197}$ Mitchener 1976, 9.827-829; Rosenfield 1967: 133; Sircar 1969: 87-105; Tripathi 1942: 218-219.

198 Fynes 1991; Marshall 1951: 1.57-58. 
historical memories of much later periods. Nevertheless, recent discoveries of manuscripts and inscriptions support Sten Konow's characterization of the Sakas as "the great intermediators" (1929: xxvi) who imported Iranian, Hellenistic, and Central Asian elements into South Asia and exported Indian religious and cultural ideals to Central Asia with the transmission of Buddhism.

\section{Dynamics of Mobility during the Kușāna Period}

Kușāna control of a network of routes between western Central Asia and the northern Indian subcontinent accelerated patterns of cross-cultural exchange, long-distance trade, and religious transmission from the first to third centuries CE. The Kuṣannas belonged to a branch of the Yuezhi (as their ancestors are known in Chinese sources), which had migrated from eastern Central Asia to Bactria under pressure from other nomadic groups during the second century BCE. ${ }^{199}$ The early Kusaananas followed similar routes as the Indo-Greeks and Sakas into the northwestern borderlands of South Asia. ${ }^{200}$ Kujüla Kadphises, who established the Kușanna line of emperors, expanded his domain across the Hindu Kush to Swat, Gandhära, and Taxila by the middle of the first century $\mathrm{CE}$, apparently overlapping with contemporary Gondopharid rulers (discussed previously). By the time of his grandson Kanișka (whose second century CE date is discussed below), the Kuṣana realm extended beyond the northwestern urban centers of Taxila and Mathura to the traditional capitals of the 'great countries' (mahājanapadas) of Kosala, Vatsa, Magadha, and Anga in northeastern India, according to a Bactrian inscription from Rabatak in northeastern Afghanistan. ${ }^{201}$ The list of of these four cities was prob-

\footnotetext{
199 Annotated translations of primary Chinese historical sources (Han Shu 96A and Shi ji 123) by Hill 2009, Hulsewé 1979, Thierry 2005, and Zürcher 1968 are referred to in note 139. Also see Benjamin 2007 for a synthesis of Chinese literary sources, archaeological evidence, and western classical sources for the Yuezhi migration to Bactria.

${ }^{200}$ Neelis 2007: 79-91 gives an expanded treatment of Kuṣāna migrations, genealogy, and chronology in South Asia. See the previous subchapters for nomadic movements and the downfall of the Indo-Greeks.

${ }^{201}$ The Rabatak inscription claims that Kaniṣka captured the cities of Sāketa [ancient Śrāvastī] (sagedo), Kauśāmbī (Kōzambo), Pātaliputra [modern Patna] (Palabotro), and Śrī Campā (Ziri Tambo). The inscription was first published by Joe Cribb and Nicholas Sims-Williams. 1995-1996. “A New Bactrian Inscription of Kanishka the Great.” Silk
} 
ably intended to reinforce claims that Kanișka "submitted all India to his will" (Sims-Williams 2004: 56), since "he who controlled these four janapada controlled India down to the Bay of Bengal" (Fussman 1998: 602). By administering a network from the Oxus basin to the Ganges delta, the Kușannas effectively unified major nodes of the northern routes known as the Uttarāpatha. ${ }^{202}$ Kusānana administration of this artery of commercial and cultural exchanges facilitated long-distance movement of merchants and missionaries between South Asia, Central Asia, and East Asia.

\section{Early Kuṣāna Genealogy and Chronology}

Recent scholarly advances have helped to resolve (or at least clarify) longstanding disputes about early Kușāna history, genealogy and chronology. Chinese historical annals indicate that the Yuezhi predecessors of the Kușananas originally inhabited the region between the Qilian and Tien Shan mountains before conflicts with the Xiongnu forced them to gradually migrate westwards across the Tarim Basin to the Ili River Basin at the beginning of the Han period from c. 207-162 BCE. ${ }^{203}$ By c. 128 BCE (after the downfall of Bactrian Greek kingdoms), Yuezhi migrants were settled north of the Oxus River on the border of

Road Art and Archaeology 4, 75-142. A translation by Mukherjee, B.N. 1995 (1999). "The Great Kushāna Testament." Indian Museum Bulletin 30, 1-106 is less reliable. Fussman 1998: 571-651 makes extensive comments on the chronological implications. Now see Sims-Williams, Nicholas. 2004 (2008). "The Bactrian Inscription of Rabatak: A New Reading." Bulletin of the Asia Institute 18, 53-68. The identification of the first two cities in the Bactrian list at the end of line 4 and beginning of line $5(+++$ adrago and $\bar{o} z o p o$, following the latest reading of Sims-Williams) remain uncertain.

${ }^{202}$ See Chapter 3: Trade Networks in Ancient South Asia-Northern Route (Uttarāpatha) pp. 186-204.

${ }^{203}$ According to Thierry's analysis (2005: 448, 490-491 [texts 3-4]) of relevant passages in Han shu 96A and Shi ji 123, the original homeland of the Yuezhi should be localized in territories to the west of Dunhuang. Also see Benjamin 2007: 45-97 (who accepts the standard localization of the Yuezhi homeland in Gansu) and Liu, Xinru. 2001. "Migration and Settlement of the Yuezhi-Kushan: Interaction and Interdependence of Nomadic and Sedentary Societies," Journal of World History 12.2, 268, who refers to Lin, Meicun. 1995. The Western Region of the Han-Tang Dynasties and the Chinese Civilization [in Chinese: Han Tang xiyu yu Zhongguo wen ming. Beijing: Wen wu chu ban she], $64 \mathrm{ff}$. For comments on complex intertextual relationships between Han Shu 61 and 96 and Shi ji 123, described by Zürcher as "probably a patchwork made up of fragments of Han shu 61 and 96" (1968: 358), also see M.A.N. Loewe's introduction to Hulsewé (1979: 13-25), Fussman 1998: 631 ff., and Thierry 2005: 427428, who rejects the previous hypotheses of Zürcher and Loewe that Shi ji 123 was reconstructed from Han shu 61. 
Bactria (designated as Daxia in Chinese sources) when the Han emissary Zhang Qian arrived on a diplomatic mission seeking an alliance against the Xiongnu. ${ }^{204}$ According to some of these sources, the Yuezhi realm was divided into five separate districts (yabgus), which were eventually unified by the Yabgu of Guishang named Qiujiuque, who can be identified with Kujūla Kadphises, the putative founder of the Kuṣana dynasty. ${ }^{205}$

Over his very long career (he lived past 80 years of age) Kujūla Kadphises crossed the Hindu Kush and conquered neighboring territories of the Indo-Parthians, the Kabul valley, Pușkalāvatī, and Gandhāra. ${ }^{206}$ As he acquired power in these areas, Kujūla Kadphises assumed the titles of "Kușana Yabgu steadfast in dharma" (kuṣana yavugasa dhramațidasa) and "Great King, King of Kings" (maharaja rajatiraja) in Kharoșthi legends on coins. ${ }^{207}$ His coins are patterned after the posthumous issues of Hermaios, the last Indo-Greek ruler of the Kabul valley, and the bull and lion coin-types of Jihoniga, a Saka Mahāksatrapa in the Punjab between ca. 30-40 CE. ${ }^{208}$ Royal portraits of Kujūla Kadphises adopted from gold coins of the Roman emperor Augustus (31 BCE-14 CE) provide a general terminus post quem. ${ }^{209}$ It is not possible to fix an absolute chronology for Kujüla Kadphises based on Chinese literary references or numismatic sources, but a reference to his son Sadașkaṇa in the Kharoṣțhī reliquary inscription of Senavarman pro-

204 Benjamin 2007: 189-209, Thierry 2005: 453-459.

${ }^{205}$ The five districts (Chinese $x i$ hou corresponds to yabgu) are referred to in Han shu 96 A (but not in Shi ji 123) and in Hou Han shu 118.9a (History of the Later Han compiled by Fan Ye [398-446 CE] based on General Ban Yong's report on the Western Regions prior to 125 CE (Thierry 2005: 492-493, text 7; Zürcher 1968: 367). Grenet, Frantz. 2006. "Nouvelles données sur la Localisation des cinq Yabghus des Yuezhi." Journal Asiatique 294.2, 325-341 convincingly argues that the five districts were located north of the Oxus River in an arc from the Gui (Wakhsh) valley (with a headquarters at Hucao perhaps localized at Takht-i Sangin) to Termez.

206 Identification of places conquered by Quijiuque/Kujūla in Hou Han shu 118.9a remain uncertain, but Fussman's explanation (1998: 637-638) that the general order in which these territories are listed (Gaofu/Kabul_Puda/Puṣkalāvatī_Jibin/Gandhāra) reflects the sequence of Kusānana conquests seems plausible.

${ }_{207}$ Bopearachchi and Rahman 1995, 37-44; for other examples, see Errington and Cribb 1992, 66, no. 34, 81, no. 75; Mitchiner 1976, 8.681-682, Type 1044-1045; and Rosenfield 1967, 12, Type I, coins 1,2,3.

${ }^{208}$ MacDowall, David W. 1973. "The Azes Hoard from Shaikhan-Dheri: Fresh Evidence for the Context of Jihonika." In South Asian Archaeology 1971, ed. Normand Hammond. Park Ridge, NJ: Noyes Press, 225, pl. 16.2, a,b (also see Mitchiner 1976, 8.690, Type 1055; Rosenfield 1967, 15, Type 4, coin 15).

${ }^{209}$ Errington and Cribb 1992, 66-68, no. 35; Mitchiner 1976, 8.688, Type 1053; Rosenfield 1967, 13-14, Type II, coins 4,5. 
vides a synchronism with the Apracas in the early-mid first century CE. ${ }^{210}$ However, if Kujūla Kadphises was acknowledged as a powerful Kusānana sovereign by subordinate rulers of the Oḍi dynasty in the Swat valley sometime during the first half of the first century CE (as indicated in the Senavarman inscription), his reign would have overlapped with the Indo-Parthian overlord Gondophares (ruling from ca. 20-46 CE). ${ }^{211}$ This quandary has raised questions about relationships between the Gondopharids and the early Kusānanas, since epigraphic and numismatic evidence indicates that both lines exerted considerable influence during the middle decades of the first century CE, with the Kușannas eventually dominating.

The Bactrian inscription at a sanctuary (bagolaggo) in Rabatak (northern Afghanistan) with images of Iranian gods and goddesses constructed during the first year of the reign of Kanișka has clarified the genealogical succession of three generations of Kuṣana rulers following Kujūla Kadphises. ${ }^{212}$ In the passage: "for King Kujula Kadphises (his) great grandfather, and for King Vima Taktu (his) grandfather, and for King Vima Kadphises (his) father, and also for himself, King Kanishka" (Cribb and Sims-Williams 1995/6: 80), Joe Cribb identifies Vima Taktu with a Kușana ruler who issued numerous coins with the title of 'Soter Megas' ("Great Savior"). ${ }^{213}$ Extensive distribution of this ruler's coins reflects an extension of Kușāna hegemony from northern

${ }^{210}$ See Buddhist Patronage by the Apracas and Odis (pp. 117-120) for a discussion of the synchronism proposed by Salomon (1999a: 141-149; 2007: 276-277) based on the marital link between the Apraca princess Vasavadattā and the Oḍi courtier Suhasoma attested in Kharosthī inscriptions (CKI nos. 242, 249, and 369).

211 The chronology of Gondophares based on references in Christian apocryphal literature and a Kharosthī inscription reportedly from Takht-i Bahi (CKI 53) is detailed in Indo-Parthians: Mahārāja Gondophares or the Gondopharids? (pp. 123-125)

${ }^{212}$ See note 201 for complete references.

${ }^{213}$ Fussman 1998: 604 and Mukherjee 1995 [1999]: 10 question Sims-Williams' reading of the name of Vima Taktu in line 13, but the alternative of Sadașana proposed by Mukherjee is not tenable. According to Sims-Williams, Vima Takto's name is legible in the opening lines of the Bactrian version of the Dasht-i Nawur inscriptions, and "Vima Taktu is the only reading which fits the traces of the king's name in both the Rabatak and Dasht-i Nawur inscriptions" (2004 [2008]: 65). A Brāhmī inscription on the base of a statue of a seated Kușāna ruler at Măt read as 1. mahārājo rājātirājo devaputro 2. Kușānapu[t]r[o șā]hi [Vema] Ta[kșu]masya by Lüders (1961: 135, \$98) may correspond with Vima Taktu in the Rabatak inscription. MacDowall, David. 1968. "Soter Megas, the King of Kings, the Kushāna." Journal of the Numismatic Society of India 30, 28-48 proposed that a "nameless king" intervened between Kujula Kadphises and Vima Kadphises before the discovery of the Rabatak inscription. 
Afghanistan to northern India as far east as Banares during his reign in the late first century CE. Vima Kadphises, who is clearly identified as Kanișka's father in the Rabatak inscription but whose name is not really legible in other epigraphic sources, ${ }^{214}$ issued the first Kuṣāna gold coins and adopted grandiloquent titles such as "King of Kings" in Greek coin legends, and "Great King, King of Kings, Lord (King) of All the World, Great Lord (King), Savior" in Kharoșțī. ${ }^{215}$ The style of depicting Vima Kadphises in a standing pose making an offering at a small altar mostly found on his copper coins is adopted in images on coins of later Kuṣanna emperors as well as royal statues in shrines at Surkh Kotal in Afghanistan and Māt across the Yamuna River from Mathura and in petroglyphs from Shatial and Khalatse on the upper Indus River. ${ }^{216}$

An absolute date for the beginning of a continuous era initiated by Kanișka is disputed, but recent findings have raised significant doubts about an identification of the Kanișka era with the Śaka era of 78 CE. ${ }^{217}$ A formula for calculating the difference between the Śaka and "Koṣāna" eras in the Yavanajātaka (79.15), an astronomical treatise written by Sphujidhvaja in $269 \mathrm{CE}$, clearly distinguishes between "the number of years that have passed of the Koșānas" (koșannagatābdasaṃkhyā) and the "the time of the Sakas (i.e., the year in the Śaka era)" (kālah śakānām $)^{218}$ The formula apparently indicates that 149 years sepa-

${ }^{214}$ Konow (1929, 79-81, no. XXIX, pl. XV.2) tentatively reads Uvima Kavthisa in a Kharoșthī inscription at Khalatse (CKI 62: http://www.ebmp.org/a_inscription. php?catid=C̈KI0062), but Sircar 1965: 134, no. 35 and Fussman 1998: 625-626 express doubts about an identification with Vima Kadphises.

${ }^{215}$ Errington and Cribb 1992: 85, no. 88; Rosenfield 1967: 22-26, coins 17-29.

216 Rosenfield 1967: 26, 144ff., figs. 2-3, 119-120; Bandini-König and Fussman 1997: 9-10, pl. 1, nos. 17:40, 34:161, and 14:3; a similar petroglyph at Khalatse on the Upper Indus River is illustrated by Tucci, Giuseppe. 1958. "Preliminary Report on an Archaeological Survey in Swat." East and West 9, 294, fig. 8 and Orofino, Giacomella. 1990. "A Note on Some Tibetan Petroglyphs of the Ladakh Area." East and West 40, 196, fig. 33.

${ }_{217}$ The issue of dating the Kaniska era has been the subject of significant scholarly debate: Basham 1968; Rosenfield 1967: 253-258 [Appendix 1: "The Era of Kanișka”; Zwalf 1996: 1.357-358 [Appendix 1: "A note on ancient eras"]; Falk 2001 and Falk 2002: 95-97. Fussman 1998: 641 and Senior 2001: 1.130 still favor an initial date for the Kanișka era in 78 CE, maintaining the hypothesis that the Western Kșatrapas were subordinate to the Kușannas and adopted the reckoning system from their overlords.

${ }^{218}$ The interpretation of verse 79.15 in the last chapter of the text by Pingree, David. 1978. The Yavanajātaka of Sphujidhvaja. 2 vols. Cambridge/London: Harvard University Press, 2.187 is contested by Falk 2001: 121-136; 2002: 91-97. Falk reads and translates verse 79.15 as gatena sādhyardhaśatena yuktyā vyekena koșānagatābdasaṃkhyāl kālaḥ śakānām pariśodhya tasmād atītam anyad yugavarșayātāḥ // "The elapsed years 
rate the two eras, but Harry Falk (2001: 130) calculates $127 \mathrm{CE}$ as the beginning of the Koṣanna era (which is assumed to be equivalent to the Kanișka era) by subtracting 100 from 149 years and by adding 49 to 78 CE. Falk's proposal that one hundred years must be omitted from the formula seems likely, since there are very strong arguments for the omission of numerals for hundreds in inscribed sculptures and other inscriptions with dates in the Kanișka era. ${ }^{219}$ Although Sphujidhvaja and other astrologers were not aware that $127 \mathrm{CE}$ (rather than 227 $\mathrm{CE})$ was the initial date of the historical Koṣanna/Kaniṣka era, Falk's proposed resolution to longstanding debates over a separate Kanișka era coheres quite well with current understanding of early Kuṣāna dynastic history. However, the solution remains hypothetical until an inscription dated in both the Saka and Kanișka eras confirms Falk's interpretation of the formula in the Yavanajätaka.

\section{Paradigms of Patronage under Kanișka and Huvișka}

Buddhist literary traditions liken the Kuṣāna emperor Kaniṣka to a second Aśoka, but epigraphic and numismatic evidence indicates that he probably supported multiple religious communities. Evidence for Kanișka's patronage of Buddhist institutions is primarily based on accounts of Chinese Buddhist visitors as well as Sarvāstivādin and

of the Kusânas in combination with 149 (change into) the time of the Sakas. Subtracting from this (Śaka time [plus 56]) the elapsed (yuga, i.e. 165 years) (produces) the elapsed years of the second yuga" (2001: 127). Depending on Utpala's commentary on Bṛhajjätaka 7.9, Pingree translates: "(If one takes) the number of years of the Koșānas which have passed and adds 149, then, subtracting from this number the year in the Saka era, (one obtains a year in which) another yuga ended" (Falk 2001: 122). Both Pingree and Falk regard the Śaka and Koṣāna (Kuṣāna) eras as separate reckoning systems, but Falk proposes that the purpose of the formula is to synchronize the two reckoning systems in order to calculate the number of years that had elapsed since an astronomical yuga of 165 years began when the sun and moon enter Ares in conjunction at sunrise on meșasamkrānti (in 22 and $187 \mathrm{CE}$ ).

${ }^{219}$ Lohuizen De Leeuw, Johanna E. Van 1949. The "Scythian" Period: An approach to the History, Art, Epigraphy and Palaeography of North India from the 1st Century BC to the 3rd Century AD. Leiden: Brill [reprint, Delhi: Munshiram Manoharlal, 1995], 235-262 and Lohuizen De Leeuw, Johanna E. Van 1986. "The second century of the Kaniska era." South Asian Studies 2, 1-9 proposed that the numerals for hundreds were omitted from many Kanișka era dates. Falk, Harry. 2004. "The Kanișka era in Gupta records." Silk Road Art and Archaeology 10, 167-176 proposes that Kanișka era dates with omitted hundreds are also found in some Gupta inscriptions. Patterns of either very low or high numbers suggest that hundreds are omitted from Kanișka era dates in Kharoșțī graffiti from northern Pakistan. 
Mahāyāna texts preserved in Chinese, Tibetan, Central Asian, and Iranian languages rather than contemporary Indian Buddhist texts and inscriptions. Faxian and Xuanzang as well as later Chinese pilgrims and Al-Bīrūnī credit Kanișka with the construction of the monumental Shāh-jī-kì Ḍherī stūpa in Purușapura (modern Peshawar). ${ }^{220}$ A copper casket found at this site and inscribed with a Kharoșthī inscription was once believed to have been a Buddhist reliquary donated by Kaniṣka, but is now recognized as a "perfume box" given by two administrative superintendents of the "fire-room" in "[Mahärā]ja Kanișka's monastery" ([mahara]jasa kanișkasa vihare) in the city of Kanișkapura. ${ }^{221}$ While this epigraphic evidence links Kanișka with a major monastery in Peshawar, Buddhist imagery on Kanișka's coins is relatively limited, since Iranian, Hellenistic, and Indian deities are more frequently depicted. ${ }^{222}$ As Ellen Raven remarks:

Buddha's image was not employed before Kaniṣka on Kușāna coins, and never again after him. The Buddha is just one of a wide range of deities, from the pantheons of Iran, the Hellenistic world, Rome, and India, selected to express the king's concern for material abundance and prosperity of his realm, military triumph, legitimacy of his rule, and divine sanction for his kingship. ${ }^{223}$

Buddhist narratives with Kanișka as a prominent figure have been composed in or translated into Chinese, Tibetan, Central Asian, and Iranian languages, but he is not mentioned in Pāli literature or in Sanskrit purānas. ${ }^{224}$ A connection between Kaniṣka and the convening of a

${ }^{220}$ Kuwayama, Shoshin. 1997. The Main Stūpa of Shāh-jī-kī-Dherì: A Chronological Outlook. Kyoto: Inst. for Research in Humanities re-examines the archaeological context, while Rosenfield 1967: 34-36 discusses the literary sources.

${ }^{221}$ Errington and Cribb 1992: 196-197; Fussman1987: 77-82; Konow 1929: 135-7; Luczanits 2008: 190; Rosenfield 1967: 260-262: CKI 145 (with further references).

${ }^{222}$ Religious iconography of Kușāna coins is discussed by Rosenfield 1967: 72-103 and Cribb, Joe. 2008. "The Pantheon of the Kusānạa Kings." In Luczanits 2008: 122125 (also see 145-153, nos. 77-100). For specifically Buddhist images on coins of Kanișka, see Errington and Cribb 1992: 199-201, nos. 197-199; Cribb, Joe. 1999/2000. "Kanishka's Buddha image coins revisited." Silk Road Art and Archaeology 6, 151-189; Göbl, Robert. 1987. “Die Buddha-Darstellungen in der Münzpragung der Kušān.” In Orientalia Iosephi Tucci Memoriae Dicata, eds. G. Gnoli and L. Lanciotti. Rome: Istituto italiano per il Medio ed Estremo Oriente, 535-538; Raven, Ellen. 2006. "Design Diversity in Kanișka's Buddha Coins.” In Behrendt and Brancaccio 2006: 286-302.

${ }^{223}$ Raven 2006: 287.

${ }^{224}$ Rājataranginī 1.168-172 (Kalhana's 11th century Sanskrit chronicle of Kashmir) refers to the founding of towns and Buddhist shrines and monasteries in Kashmir by Hușka, Jușka, and Kanișka 150 years after the Buddha's Nirvāna, which may reflect local historical memories of Kuṣana patronage posterior to the time of Aśoka (Stein, 
Buddhist council in Kashmir, Gandhāra, or Jalandhar (in the Punjab) which supposedly led to the writing of Sarvāstivādin Abhidharma texts on copper plates is probably a "pious fabrication" (Rosenfield 1967: 32) modeled on Theravāda accounts of a third council in Pātaliputra sponsored by Aśoka. Chinese and Tibetan Buddhist traditions also portray Kanișka as a literary patron of Aśvaghoșa, the author of the Buddhacarita and Saundarananda, and claim that Mātṛceta wrote a "letter to Mahārāja Kaṇika" (Mahārājakaṇikalekha) to instruct him in Buddhist principles. ${ }^{225}$ Buddhist claims that Kaniska was a sympathetic lay devotee and a Buddhist monarch probably have more to do with hagiographic topoi associating him with Aśoka than with his direct and certainly not exclusive patronage of Buddhist institutions.

As concrete evidence does not confirm that Kanișka was a Buddhist convert like Aśoka, historians of this period theorize that his suport of Buddhism was due to a political need to promote his status as a cakravartin by making donations to diverse groups in the expanding Kuṣanạa domain. ${ }^{226}$ Although he acknowledges that Kusānāā rulers and officials under Kanișka sponsored a variety of religious institutions (including Buddhist stūpas), Xavier Tremblay contends that the Kuṣannas were

Marc Aurel, trans. 1900. Kalhana's Rājataraniginī, a chronicle of the kings of Kásmìr. London: A. Constable, vol. 1, 30-31.

${ }^{225}$ Rosenfield 1967: 30-34 refers to other literary figures ("theologians" is somewhat misleading, since their topics extended beyond theological concerns to philosophy, doxography, biography, and monastic law) such as Vasumitra, Pārśva, Samgharakșa, Dharmatrāta, and indirectly Nāgārjuna, since the Suhrllekha attributed to him was probably the model for Mătrceta's Kanikalekha. As Rosenfield emphasizes, “... these associations can not be taken at face value, for in the pious, pseudo-historical records of the faith, the names of great kings were often linked with those of great writers" (1967: 30).

${ }^{226}$ Rosenfield 1967: 29-30 (“...Kanishka's patronage of the faith must have been essentially politic... Kanishka may well have been, like Constantine, attracted by a variety of religions and guided as much by the exigencies of politics as by his won spritual needs"). Verardi, Giovanni. 1983. "The Kusāna Emperors as Cakravartins. Dynastic Arts and Cults in India and Central Asia: History of a Theory, Clarifications, and Refutations." East and West 33, 225-294 argues against Rosenfield's thesis of a distinctive dynastic cult of the Kusānas, but maintains that their patronage of Buddhists, Brahmans, Jains, and other religious groups was due to their need to represent themselves as cakravartins in order to address "...the problem of their own legitimation on Indian soil" (1983: 268). Chattopadhyay, Bhaskar. 1975. Kushāna State and Indian Society: A Study in Post-Mauryan Polity \& Society. Calcutta: Punthi Pustak, 179 and Sircar, Dineschandra. 1971b. Some Problems Concerning the Kușannas. Dharwar: Kannada Research Institute, 3 agree that a "catholic religious policy" (Sircar 1971b: 3) was favored, although Chattopadhyay argues in favor of syncretism and against eclecticism. 
Mazdeans and rhetorically asks: "Must then the whole of Budhist lore around Kanișka (none of which is earlier than the fifth century) be a pious fake?" (2007: 87) ${ }^{227}$ Such a question rests on an assumption that Kaniṣka and other Kuṣāna emperors sublimated their own individual religious identities in order to govern a vast domain encompassing diverse religious cultures between the Oxus basin in ancient Bactria and the Ganga-Yamuna doāb in northern India. However, as Gérard Fussman (among others) has pointed out, acceptance of the Buddha's teachings (Dharma) did not require lay devotees to give up their own Hindu, Iranian, indigenous, or other religious beliefs and practices. ${ }^{228}$ Although he did not necessarily favor Buddhists over other Indian or Iranian religious groups, under his aegis conditions of material prosperity fostered an increase in the production of Buddhist art and literature, and it is not accidental that the Senior collection of Kharoșthi manuscripts was deposited in a stūpa inside a pot inscribed with a date in the twelfth year of his reign (ca. $140 \mathrm{CE}$ ). ${ }^{229}$

Buddhist inscriptions, manuscripts and archaeological remains clearly indicate significant growth of monastic institutions and attest the emergence of the Mahāyanna movement during the long reign of Huvișka. Since the dated inscriptions of Kanișka end in year 23 of his era (corresponding to ca. 150-151 CE if the era began in $127 \mathrm{CE}$ ) and the dated inscriptions of Huviṣka begin in year 26 (ca. 153-154 CE), Huvișka's immediate succession is somewhat uncertain. The tremendous output of gold coins and inscriptions dated between years 26 and 64 (until ca. $191 \mathrm{CE}$ ) indicate that Huvișka ruled for at least 35 years during a prosperous phase of South Asian cultural and economic history. ${ }^{230}$ A Mathura Brāhmī inscription from the time of Huviṣka's

227 Tremblay, Xavier. "The Spread of Buddhism in Serindia-Buddhism among Iranians, Tocharians, and Turks before the 13th century." In Heirman and Bumbacher 2007: 75-129, esp. 82-88.

228 Fussman 1994a: 25, 42.

229 Allon 2007 in Glass 2007a: 3-4; Salomon 2003c: 74-77, figs. 1-2.

${ }^{230}$ Rosenfield observes that "The numismatic and epigraphic traces [of Huvișka's rule] are the most copious of any Kushan prince" (1967: 59) and calls the gold coins issued by Huvișka a "veritable shower of gold" (1967: 60). His suggestion (based on the predominance of Iranian deities represented on Huvișka's coins) that "the tastes and interests of the Kushan princes were somewhat at variance with that of their subjects, as might be expected in a feudal social order imposed by foreign invaders" (1967: 73) neglects an "in-built conservatism" (Errington and Cribb 1992: 51) in numismatic designs, which do not necessarily reflect personal convictions or religious identities of rulers. 
successor Vāsudeva (dated in year 77, corresponding to ca. $204 \mathrm{CE}$ ) refers to "the monastery of the mahārāja rājātirāja devaputra Hūvīṣka" (Lüders 1961: 68, §31). This epigraphic evidence to Huviṣka’s monastery at Jamalpur mound in Mathura parallels epigraphic and literary references to Kanișka's monastery in Peshawar. As during the time of Kaniṣka, Kuṣāna subordinate officials who recorded donations to numerous religious groups in inscriptions sometimes shared their religious merit with their overlord, Huvișka. For example, the "principal lot” (agrabhaga) of merit is assigned to Mahārāja Rājātirāja Huviṣka in a reliquary vase inscription from Wardak in central Afghanistan dated in year 51 (ca. $178 \mathrm{CE}$ ). ${ }^{231}$ Nascent Indian Mahāyāna traditions are attested in a Mathura Brāhmī inscription on the pedestal of "an image of the Blessed One, the Buddha Amitābha" (Schopen 1987b: 111) dated at or near the beginning of Huvișka's reign (year 26). ${ }^{232}$ Huvișka was portrayed as a Mahāyāna follower "who has set forth on the (Great) Vehicle" (Salomon 2002b: 256) in a version of an avadāna narrative preserved in fourth century Buddhist Sanskrit manuscript fragments in the Schøyen collection. ${ }^{233}$ A literary parallel to a similar story set in Huvișka's court is preserved in the Chinese translation of the Kalpanāmanditikā or Sutrālarikāra (Dazhuanyan lun jing). ${ }^{234}$ However, Prasenajit of Kosala rather than Huvișka is the king in a shorter version in the ${ }^{\star}$ Samyuktaratnapitakasūtra or ${ }^{\star} K s ̦ u d r a k a p i t a k a$ (Za bao zang jing). ${ }^{235}$ The Mathura inscription and the narrative with

${ }^{231}$ CKI 159 (http://www.ebmp.org/a_inscription.php?catid=CKI0159); Errington and Cribb 1992: 174-175; Konow 1929: 165-170. Another recently published inscription from Wardak on another vase dated in the same year and day records a relic donation by the daughter of the donor of the first vase, but does not include Huvișka among the recipients who share the merit (Falk, Harry. 2008. "Another reliquary vase from Wardak and consecrating fire rites in Gandhāra." In Religion and Art: New issues in Indian iconography and iconology, ed. Claudine Bautze-Picron. London: British association for South Asian Studies, 63-80; CKI 509: http://www.ebmp.org/a_inscription.php?catid=CKI0509).

${ }_{232}$ Schopen, Gregory. 1987b. "The inscription on the Kusān image of Amitābha and the character of the early Mahāyāna in India." Journal of the International Association of Buddhist Studies 10, 99-133 (-Schopen 2005: 247-277 [chapter 8]). The image labeled in the inscription is no longer extant, except for the feet.

${ }^{233}$ Salomon, Richard. 2002b. "A Sanskrit Fragment Mentioning King Huvișka as a Follower of the Mahāyāna.” In Buddhist Manuscripts 2, ed. Braarvig 2002: 255-267.

${ }^{234}$ Huber, Édouard, trans. 1908. Sûtrâlamkâra [attributed to Aśvaghoṣa, translated into Chinese by Kumārajīva]. Paris: E. Leroux, 423-426, no. 73. Sanskrit fragments of this narrative in the source text, Kalpanāmanditikā Drștântapanikti of Kumāralāta, are no longer preserved.

${ }^{235}$ Translated by Willemen 1994: 94-96. 
Huviṣka as a Mahāyāna follower do not prove that he played a role in the promotion of Mahāyāna, but do seem to indicate that "the time of Huvișka was a pivotal one in the development of the Mahāyāna" (Salomon 2002b: 261).

\section{Vicissitudes of the Later Kuṣānas}

Following the period of Huviṣka, the dynastic fortunes of the Kuṣannas gradually declined during the reign of Vāsudeva and his successors in the third century CE. Brāhmī inscriptions dated in Kanișka era years from 64 or 67 (ca. 191-194 CE) to 98 (ca. 225-6 CE) demonstrate that Vāsudeva ruled for at least thirty years. His apparently Vaiṣnava proper name and his coins with images of Siva (Ooesho) standing in front of Nandin (his bull vāhana) reflect a trend towards greater Indianization. ${ }^{236}$ The territory controlled by Vāsudeva may have been reduced to regions of North India and parts of the Punjab, since he is not mentioned in inscriptions from the Northwest, and the burial of his coins around Taxila suggests a crisis. ${ }^{237}$ According to Rosenfield (1967: 104-105), at least two other Kusānạa rulers were named Vāsudeva, but it is not necessary to add more Vāsudevas to the Kuṣāna genealogy if the Kanișka era begins in $127 \mathrm{CE}$ rather than $78 \mathrm{CE}$. A later Kuṣāna ruler named Kaniṣka (II) who copied Vāsudeva's coin types appears to have directly succeeded Vāsudeva after the first century of the Kanișka era (ca. $227 \mathrm{CE}$ ).

Brāhmī inscriptions from Mathura and Sãñcī dated in years 24 and 28 during the reign of an otherwise unknown Kușanna ruler named Vāsiṣka probably belong to the second century of the Kaniṣka era (with corresponding dates in 251-2 and 255-6 CE). ${ }^{238}$ A Kharoșthī

${ }_{236}$ Rosenfield 1967: 104; Sircar, Dineschandra. 1971c. "Vāsudeva-Krsṣna and Nārāyaṇa in Early Vaiṣnavism." In Studies in the Religious Life of Ancient and Medieval India. Delhi: Motilal Banarsidass, 16-38, states that Vàsudeva's name “...indicates the Bhāgavata leanings of the later Kuṣannas who had an important gubernatorial centre at Mathurā" (22). However, the Śiva and Bull motif on his coins (which appeared earlier on the coins of Wima Kadphises) indicates that Vāsudeva's religious identity was not exclusively Vaiṣnava.

${ }^{237}$ Rosenfield 1967: 105.

${ }^{238}$ A Brāhmī inscription on an inscribed pillar ( $\left.y \bar{u} p a\right)$ from Iśapur near Mathura is dated in the 24th year "of the reign of mahārāja rājātirāja devaputra șāhi Vāsiṣka" (Lüders 1961: 125-6 [\$94]), and another Brāhmī inscription on a fragment of a seated Buddha probably from Jamalpur mound in Mathura is dated in year 28, but the reading of Vāsiṣka's name is uncertain (Lüders 1961: 63 [\$28]). A Brāhmī inscription on the 
inscription found at Ārā near Attock on the Indus River in northwest Pakistan refers to a son of Vāsiṣka (Vazeșka) named Kaniṣka (III) ruling with full imperial titles in year 41 (ca. $268 \mathrm{CE}$ ), which seems to indicate that the Kusānanas were still acknowledged as powerful rulers in this region. ${ }^{239}$ While scholars have suggested that Vāsișka and a nephew named Kanișka vied with Huvișka, it seems more likely that the numerals for hundreds have been omitted from the Kanișka era dates in inscriptions of Vāsiṣka and his son named Kaniṣka (III), whose reigns fall in middle to end of the third century CE. ${ }^{240}$ Thus, they probably came into conflict with Shapur I, the Sasanian ruler of Iran from 241-271 CE, who claimed to have conquered part of the Kuṣāna realm possibly as far as Peshawar by ca. 260 CE. ${ }^{241}$ Kushano-Sasanian rulers continued to produce Kușanạa-type coins until the fourth century period of the Sasanian ruler Shapur II (309-379 CE). The political history of the former territories of the Kușannas in the northwestern borderlands from the late third to early fourth century $\mathrm{CE}$ is almost as opaque as the end of Kusāna rule in Mathura and the Ganga-Yamuna doāb, which is likewise "lost in the general obscurity which hovers over North Indian history in the later third century" (Rosenfield 1967: 115).

base of a Bodhisattva image donated to a shrine at Sāñcī commemorating Siddhārtha's first meditation under the Jambu-tree is is also dated in the 28th year of ( ${ }^{*}$ mahäräja) rājātirāja ( ${ }^{\star}$ deva)putra șāhi Vās $\left({ }^{*}\right.$ )ṣka (Lüders 1912: no. 161; Majumdar 1940: 1.385; Sircar 1965: 150, no. 48; Willis, Michael. 1999/2000. "The Sānchī Bodhisattva dated Kuṣan̄a year 28." Silk Road Art and Archaeology 6, 269-273). Rosenfield comments: "on complex stylistic grounds this statue must be attributed to a much later period" (1967: 57) and he assigns it to "Images dated in a second Kushan era" with hundreds omitted (1967: 272).

239 Konow 1929: 162-165; CKI 158: maharajasa rajatirajasa devaputrasa [ka]i[ $[s a]$ rasa Vazeșkaputrasa Kanișkasa sambatsarae ekacapar[i]- [śa]ï sam 20201.

240 Rosenfield 1967: 57-60; Harmatta, János, et al. 1994. "Religions in the Kushan Empire." In Harmatta, ed. 1994 posits a "triple kingship" (323) after Kanișka I when Vāsișka, Huvișka, and Kaniṣka II all ruled in year 30 of the Kanișka era, but a Bactrian inscription at Airtam and the Kamra Kharosthi inscription (CKI 158, cited in the previous note) do not support this speculative reconstruction.

${ }^{241}$ Rosenfield 1967: 116-117; Dani, A.H. and B.A. Litvinsky. 1996. "The KushanoSasanian Kingdom.” In History of Civilizations of Central Asia. Vol. III: The crossroads of civilizations: AD 250 to 750, ed. B.A. Litvinsky, et al. Paris: Unesco, 103-118, esp. 104. The claim that the Sasanians caused the downfall of the Kușannas depends on an identification of Purușapura with Puškabūr in the Pahlavi version of the Kaaba-iZardusht inscription at Naqsh-i-Rustam. 


\section{Kuṣāna Conclusions}

From about the second half of the first century CE to the middle of the third century CE, the Kușannas maintained control over important nodes on a network of overland routes connecting Bactria in western Central Asia with the heartland of northern India. A chain of cities from Termez in the Oxus valley to Begram in the Hindu Kush, Peshawar in Gandhāra, Taxila in the Potwar plateau of the Punjab, and Mathura on the Yamuna River linked the multicultural empire of the Kusaananas to the Northern Route (uttarāpatha). Although the Kuṣannas did not directly administer western Indian ports ruled by the Western Kșatrapas or the so-called silk routes in the Tarim Basin, it is likely that alliances with regional rulers allowed the Kusaannas to act as intermediaries between trans-Asian overland and maritime networks. ${ }^{242}$ Kuṣāna power was linked to long-distance trade in luxury items such as silk from China, jade from Khotan, lapis lazuli from northeastern Afghanistan, and other precious commodities which appear in lists of the "seven jewels" (saptaratna) in Buddhist texts. ${ }^{243}$ The stability of overland commercial routes controlled by the Kusaananas helped to generate material surpluses used to support religious institutions, which received ample donations recorded in Kharosțhī, Brāhmī, and Bactrian inscriptions. Kuṣanna emperors such as Kaniṣka and Huviṣka are credited with the construction of stüpas and monasteries in Peshawar and Mathura and appear in narratives as exemplary rulers comparable to Aśoka and Prasenajit, but their direct role in the growth of Buddhist monasticism was probably less significant than local officials and lay donors whose offerings of relics, images, and other meritorious gifts helped to establish and maintain residential communities of monks and nuns. Kuṣanna facilitation of commercial exchanges, dynamic mobility, and cross-cultural contact between South Asia and Central

${ }^{242}$ Kușanna military and diplomatic involvement in the local affairs of Kashgar detailed in Hou Han shu 77.4a-7a and 118.13b seems to have been temporary. For further discussion of the issue of the extent of Kusanna diplomatic, military, and commercial influence, see Brough, John. 1965. "Comments on Third-century Shan-shan and the History of Buddhism." Bulletin of the School of Oriental and African Studies 28, 582-612, esp. 589; Hitch, Douglas. 1988. "Kushan Tarim Domination." Central Asiatic Journal 32, 170-192, esp. 182-183; Neelis 2007: 90-91; Rosenfield 1967: 43; Thierry 2005: 480-482; Zürcher 1968: 352-353, 369-370.

${ }^{243}$ Liu 1988/2009 and 1998 proposes that the development of a Buddhist commercial ethos was result of Kuṣāna period prosperity. 
Table 2.3: Kuṣāṇa Rulers and Dates

\begin{tabular}{lll}
\hline \multicolumn{1}{c}{ Kuṣāṇa Rulers: } & \multicolumn{1}{c}{ Kaniṣka era dates } & \multicolumn{1}{c}{ CE } \\
\hline Kujula Kadphises & NA & early-mid 1st century \\
Vima Taktu (Soter Megas) & NA & mid-late 1st century \\
Vima Kadphises & NA & late 1st century \\
Kanișka & $1-23$ & $127-$ ca. 150 \\
Huvișka & $26-64$ & ca. 153-191 \\
Vāsudeva & $64 / 7-98$ & ca. 191/194-225 \\
Kanișka II & {$[1] 05-[1] 17$} & ca. 232-244 \\
Vāsișka & {$[1] 24-[1] 28$} & ca. 251-255 \\
Kanișka III & {$[1] 41$} & ca. 268 \\
\hline
\end{tabular}

Asia was a significant catalyst for the expansion of Buddhist networks during this crucial period in the first three centuries CE.

\section{Shifting Networks of Political Power and Institutional Patronage during the Gupta Period}

Following the Kușanana period, Buddhist institutions successfully adapted to economic and political transitions, despite commonplace assertions that "Buddhism in Gupta India was losing out to Brahmanism" (Liu 1988: 128). A brief interlude of perhaps less than 50 years, sometimes referred to as a "Dark Interval" (Tripathi 1942: 234-236), between the post-Kuṣana phase in the late third century and the beginning of the Gupta period in 319 CE was marked by the ascendance of various regional powers, such as the Western Kṣatrapas, Ikșvākus, and Vākāțakas. ${ }^{244}$ Epigraphic records of permanent endowments (akșayanivi $\bar{l}$ ), gifts of landed property, and interest-earning donations that enabled monasteries to reduce thier dependence on individual donations attest to the persisting strength and accelerating growth of Buddhist institutions. ${ }^{245}$ Buddhist art and architecture at Bodh Gaya,

${ }^{244}$ The cultural impact and patronage patterns of the Western Ksatrapas and Ikșvākus are discussed earlier in this chapter (Kșaharāta and Kärdamaka Kșatrapas in Western India, note 195 for the Ikșvākus), and the Vākāțaka patterns of institutional support are treated in the following subchapter (Vākātaka Networks of Religious Patronage).

${ }^{245}$ Schopen 1994c ("Doing Business for the Lord”): 533-534 (= 2004: 52-53) points out that aksayanivi $\bar{i}$ grants dating from as early as the 1st-2nd centuries CE before the Gupta period in Andhra, Kānheri, and Mathura were widespread instruments for 
flourishing Buddhist and Jain ateliers at Mathura, and numerous high quality Buddhist sculptures with Gupta period inscriptions from Sarnath reflect an acceleration rather than slackening of artistic production at Buddhist shrines in north India. ${ }^{246}$ Although it is beyond the scope of the overview in this chapter to address internal developments within Buddhist traditions, Gregory Schopen has persuasively demonstrated that epigraphic formulae referring to monks as Śäkyabhikșus, textual production of Mahāyāna sūtras, and doctrinal elaborations associated with prominent figures mark the institutionalization of Mahāyāna during the Gupta period. ${ }^{247}$ Historians such as Ramashankar Tripathi argue that the "catholicity of the age" (1942: 274) and the "beneficient rule of Gupta emperors who were men of catholic culture" (277) was responsible for the vitality of Buddhist literary and visual culture. While some Gupta subordinates acted as Buddhist donors, the Guptas themselves generally drew on Vaiṣnava imagery and language to portray themselves as "supreme devotees" (paramabhägavatas), perhaps in a conscious effort to legitimate themselves as supreme rulers. ${ }^{248}$ The impact of this official propaganda appears to have been limited to dynastic temples, such as those at Udayagiri, and does not seem to have adversely affected Buddhist communities, since Buddhist monuments located within walking distance at Sãñcī continued to prosper. Therefore, the pattern is one of increased Buddhist artistic and literary output, which was probably stimulated by a competitive religious atmosphere.

supporting a variety of religious institutions. Also see Maity, Sachindra Kumar. 1970 [1957]. Economic Life in Northern India in the Gupta Period (Cir. AD 300-550). Delhi: Motilal Banarsidass, 36-42.

${ }^{246}$ Williams, Joanna. 1982. The Art of Gupta India: Empire and province. Princeton: Princeton University Press, 28-33 (Mathura in early Gupta period), 148-150 (Sarnath), 150-151 (granite railing additions at Bodh Gaya during the late Gupta period).

${ }^{247}$ Schopen 1979: 15 (= 2005: 238); Schopen 2000b. "The Mahāyāna and the Middle Period in Indian Buddhism: Through a Chinese Looking-glass." Eastern Buddhist n.s. 32.2, 1-25 (= Schopen 2005: 3-24).

${ }^{248}$ Willis, Michael D. 2009. The Archaeology of Hindu Ritual: Temples and the Establishment of the Gods. Cambridge: Cambridge University Press makes an impressive case for a strong link between Hindu, specifically Vaiṣnava, religious architecture and Gupta imperial patronage based on an in depth analysis of the archaeological site of Udayagiri and an extensive treatment of Gupta inscriptions and related literary texts. 


\section{Vākāțaka Networks of Religious Patronage}

The Eastern and Western Vākātakas dominated the northern Deccan from the late third to fifth centuries and effectively controlled overland networks across India. ${ }^{249}$ Recent excavations of an Eastern Vākāțaka temple complex at Mansar near Rāmagiri in Maharashtra and ongoing research in the Buddhist caves at Ajanțā patronized by the Western Vākātakas have reaffirmed their cultural and religious significance. ${ }^{250}$ The historical and geographical origins of the early Vākātaka kings remain obscure, but a relationship with Nàga rulers who succeeded the Kuṣannas in Mathura and Vidiśā is indicated by epigraphic references to the marriage between the daughter of Bhavanāga, the Bhāraśiva king of Padmāvatī (identified with Pawāyā about 125 miles south of Mathurā in Madhya Pradesh) and Gautamiputra, the son of Pravarasena I, a "Vākāțaka emperor" (saṃrād-vākāṭaka) from ca. 275-335 CE. ${ }^{251}$ After Pravarasena's reign, the Vākātaka genealogy split into two separate lines of the Eastern Vākātakas ruling in Nandivardhana (in ancient Vidarbha outside of modern Nagpur) and the Western Vākāțakas in Vatsagulma (modern Basim further to the southwest). ${ }^{252}$ By the end

${ }^{249}$ Contributions by Bakker, Hans. 1997. The Vākātakas: An Essay in Hindu Iconology and Art. Groningen: Egbert Forsten and Bakker, Hans, ed. 2004. The Vākātaka Heritage: Indian culture at the crossroads. Groningen: Egbert Forsten, as well as Shastri, Ajay Mitra. 1992. The Age of the Vākätakas. New Delhi: Harman Publishing House, and Shastri, Ajay Mitra. 1997. Vākāttakas: Sources and History. New Delhi: Aryan Books International have significantly clarified and expanded the scope of earlier historical studies by Altekar, A.S. 1946. "The Vākātakas." Chapter 5 in Majumdar and Altekar 1946: 86-115 and Yazdani, Ghulam, ed. 1960. The Early History of the Deccan. London: Oxford University Press, vol. 1, 149-200 (Part 3 by A.S. Altekar). Since the publication of Mirashi, V.V. 1963. Inscriptions of the Vākattakas. Corpus Inscriptionum Indicarum, 5. Ootacamund: Archaeological Survey of India, the number of known Vākātaka inscriptions has more than doubled (Bakker 1997: 2).

250 Bakker, Hans, ed. 2008. Mansar: The Discovery of Pravareśvara and Pravarapura Temple and Residence of the Vākātaka King Pravarasena II. Groningen: Library of the University of Groningen [e-book available online: http://mansar.eldoc.ub.rug .nl/]; Schlingloff 1987 Spink, Walter M. 2005. Ajanta: history and development. Leiden: Brill, 5 vols.

${ }^{251}$ Altekar 1946: 90-94; Bakker 1997: 9-10; Mirashi 1963: xix-xx, 13-14; Raychaudhuri 1923: 255-256; Sircar 1965: 442-449 (no. 62). Also see Williams 1982: 16-21 for an assessment of Nāga history and art as a possible prelude to Gupta monumental Hindu art and architecture.

${ }^{252}$ Bakker 1997: 168 (Appendix II) and Mirashi 1963: v-vi provide genealogical charts of separate Vākāțaka lineages, but Mirashi cautions that "The Vākātaka chronology is still more or less conjectural" (v). Although many scholars view the Eastern Vākattakas as the "main branch" or interpret the predominance of one line over the 
of the fourth century, the Eastern Vākātakas had become allies with the Guptas through a marriage between Rudrasena II (a grandson of Gautamīputra) and Prabhāvatī Guptā, the daughter of Candragupta II (reigning ca. 376-415) and Kuberanāgā (who belonged to one of the Nāga families). Following her husband's death in $405 \mathrm{CE}$, Prabhāvatī Guptā reigned as a powerful dowager queen and continued to exercise significant influence over her sons Dāmodarasena (reigning ca. 415422) and Pravaresena II (422-457), who shifted his royal residence to Pravarapura (modern Mansar) and constructed an impressive temple to Śiva named Pravareśvara. ${ }^{253}$

In apparent contrast to the Eastern Vākātakas, who depicted themselves as devotees of Viṣnu and Siva in their inscriptions and established a network of Hindu temples and shrines around Rāmagiri, the Western Vākātakas are directly linked with elaborate Buddhist cave complexes at Ajanțā and Ghațotkaca during the reign of Hariṣeṇa at the end of the fifth century (ca. 460-478). ${ }^{254}$ While some caves at Ajanțā were excavated as early as the first or second centuries BCE (nos. 9, 10, 12), praśasti inscriptions indicate that Harișeṇa's minister Varāhadeva was the donor of the Ghatotkaca cave and Ajanțā cave 16, while a local ruler who was subservient to Harișeṇa donated Ajaṇtā caves 17 and 19. ${ }^{255}$ Buddhist paintings and architecture in the Ajaṇtā caves not only serve as valuable art historical evidence, but also reflect the cir-

other in different periods, Kulke, Hermann. 2004. "Some Thoughts on State and State Formation under the Eastern Vākāțakas." In Bakker 2004: 1-9 comments on Vākāțaka historiography and argues that "The inscriptions of both so-called branches of the Vākātakas thus neither contain any hint at a united dynasty nor at the quest for some kind of superiority by one of the two branches" (2004:3).

${ }^{253}$ Prabhāvatī Guptā's role as a patroness of royal Vaiṣnava ideology and symbolism is emphasized by Bakker, Hans. 1992. "Memorials, Temples, Gods, and Kings: An attempt to unravel the symbolic texture of Vākātaka kingship." In Ritual, State and History in South Asia: Essays in Honour of J.C. Heesterman, ed. A.W. Van Den Hoek, et al. Leiden: Brill, 7-19. See Bakker 2004: 71-85 and 2008 (including appendix 1 with Vākāțaka and Gupta comparative chronology) for Pravarasena’s establishment of Pravarapura and the temple of Pravareśvara at Mansar.

${ }^{254}$ Spink 2005: vol. 2, 3-8, 174-196 limits the period of construction and painting of the later Ajantā caves to a "Short Chronology" of ca. 462-480, when a crisis following the death of Harisena lead to "breakdown of patronage." However, Williams 1982: 181-187, von Stietencron (in Bakker 2004: 107-108), and other scholars (including Schlingloff and Zin, see note 264 below) hold that a longer range must have been necessary. Bakker 1997: 41 points out that the Buddhist caves were not dedicated by Harișena himself, and probably continued to be excavated after the Aśmakas had gained control of the area from the Western Vākătakas.

${ }^{255}$ Mirashi 1963: 103-129 (nos. 25-27). Also see Wood, Leela Aditi. 2004. "The Ajanta Cave 17 Inscription as a Preface to the Local King's Vihāra: History, Religious 
culation of both mainstream and Mahāyāna texts (such as Āryaśūra's Jātakamālā and probably the Saddharmapundarīkā-sütra) as well as widespread symbols such as the "Wheel of existence" (bhavacakra). ${ }^{256}$ Hans Bakker suggests that control of an important north-south trade route through Ajaṇțā connecting Ujjayinī to Pratișthāna stimulated Buddhist donations by Western Vākāțaka courtiers, while Eastern Vākātaka donations of land grants to Brahman communities and temples can be attributed to a prosperous rural agrarian economy. ${ }^{257}$ Bakker's hypothesis of a correlation between the growth of a significant Buddhist complex at Ajanțā and a network of overland trade routes belonging to the Daksingapatha corresponds well to the general pattern in which Buddhist shrines and monasteries are located on or near major trade networks. ${ }^{258}$ However, a strict dichotomy between urban patronage of Buddhists and rural support for Brahmans would be misleading, since many important Buddhist shrines (like Ajanțā) are found far away from cities.

\section{Gupta 'Golden Age’ Reappraised}

A persistent historiographical dichotomy between the 'Golden Age' of imperial Gupta rulers who are portrayed as quasi-nationalist supporters of "vigorous Brahmanic revival and restoration" (Bhandarkar 1920: 51) and a decline of Buddhist institutions with the withdrawal of

Story and Homology." In Bakker 2004: 109-132 and Cohen, Richard. 2006. “Ajanta's Inscriptions." Appendix to Spink 2005: vol. 2, 273-339.

${ }^{256}$ Relationships between textual sources and Buddhist narratives depicted in Ajaṇtā paintings have been masterfully treated by Dieter Schlingloff and Monika Zin in numerous articles collected (in English translation) in Schlingloff 1987. Schlingloff, Dieter. 2000. Erzählende Wandmalereien: Handbuch der Malereien 1. 3 vols. Wiesbaden: Harrassowitz and Zin, Monika. 2003. Devotionale und ornamentale Malerei: Ajanta, Handbuch der Malereien 2. 2 vols. Wiesbaden: Harrassowitz are authoritative guides. Also see Schopen 2005: 278-298 and Teiser 2006: 76-103 for studies of individual paintings.

${ }^{257}$ Bakkker 1997: 44-45. According to Bakker 2004: v, one main north-south itinerary from Prayāga (Allahabad) at the Ganga-Yamuna confluence to Pratișthāna (Paithan) on the upper Godavari River passed through the Western Vākātaka kingdom, while another north-south route from Kauśāmbī to the lower Krishna-Godavari delta (formerly the domain of the Ikșvākus) passed through the capital of the Eastern Vākattakas. East-west routes through the territories of the Eastern and Western Vākāțakas from Dakșiṇa Kośala (modern Chattisgarh) to western coastal ports at Sopara and Kalyan bisected the north-south arteries.

${ }^{258}$ Routes and nodes of this network are investigated in more detail in the subchapter on the Southern Route (Daksināpatha) in Chapter 3 (pp. 205-217). 
foreign support does not withstand scrutiny. ${ }^{259}$ Claims that "Brahmanical Hinduism became dominant all over India, and other religious systems were more or less neglected" (Chatterjee 2005: 199) are typically followed by retractions (“... but Buddhism retained its hold in many centres”), since Buddhist material and cultural contributions as well as internal developments during this period are difficult to overlook. ${ }^{260}$ Michael Willis traces the modern construction of a Gupta 'Golden Age' to Vincent Smith, for whom "...the reign of a great monarch in a golden age would have to have been long, happy and glorious" (2005: 142-143). ${ }^{261}$ Romila Thapar has questioned "...the notion of a uniformly Golden Age that encompasses an entire society" (2003: 280) and argues that "the Gupta period is the threshold to a marked mutation of north Indian society during the late-first millennium AD rather than a revival or renaissance" (2003: 282). ${ }^{262}$ The Guptas appropriated precedents set by earlier Indian rulers by revising and reinventing the past, so that their dynastic names, titles, inscriptions, and dating systems can seem like "a historical palimpsest" (Thapar 2003: 283).

259 Bhandarkar, Ramkrishna Gopal. 1920 [1897]. A Peep into the Early History of India: From the foundation of the Maurya Dynasty to the downfall of the imperial Gupta Dynasty (322 BC-circa 500 AD). Bombay: D.B. Taraporevala, quoted in Bhandarkar, Devadatta Ramakrishna, Bahadurchand Chhabra and Govind Awamirao Gai, eds. 1981. Inscriptions of the Early Gupta Kings, Corpus Inscriptionum Indicarum 3. New Delhi: Archaeological Survey of India, p. 122. La Vallée Poussin, Louis de. 1935. Dynasties et Histoire de l'Inde depuis Kanishka jusqu'aux invasions musulmanes. Paris: Boccard refers to juxtapositions between the "National" character of the Gupta period and the foreign character of the earlier period by R.G. Bhandarkar, A.B. Keith, and Vincent Smith (1935: 30). Gérard Fussman observes that "proclamations of admiration" for the Guptas are often based on sentiments associating Indian nationalism with Hinduism, the view that Gupta royal patronage was responsible for a peak in the quality of Indian art and Sanskrit literature, and overly literal interpretations of eulogistic praśasti inscriptions (Fussman, Gérard. 2006-2007. "Les Guptas et le nationalisme indien.” Annuaire de la Collége de France, 2006-7, p. 696). ${ }_{260}$ Chatterjee, Asim Kumar. 2005. A Comprehensive History of Buddhism. Kolkata: Punthi Pustak.

${ }^{261}$ Willis, Michael. 2005. "Late Gupta History: Inscriptions, Coins and Historical Ideology." Journal of the Royal Asiatic Society 3rd series, 15.2, 131-150.

262 Ali, Daud. 2004. Courtly Culture and Political Life in Early Medieval India. Cambridge: Cambridge University Press also highlights the significance of the "VākātakaGupta imperial formation" as the beginning of a "400-year period (c. 350-750 CE) which saw the development, crystallization, and proliferation of a common political culture throughout all major regions of the subcontinent" (2004: 20). 
Gupta origins are uncertain, but a marriage between Candragupta I and Kumāradevī, a Licchavī princess in Magadha, where Buddhist institutions maintained a very strong presence, probably allowed them to initially consolidate their power in northeastern India. ${ }^{263}$ Since this region (ancient Magadha) was also the homeland of the Mauryas, the personal name of Candragupta may deliberately recall this earlier line of rulers founded by a figure with an identical name. The Guptas emulated the Kușannas by giving the imperial title of Mahärājādhirāja to Candragupta and successive Gupta rulers and by striking coins based on Kușaña models. ${ }^{264}$ The Guptas continued to use the Kaniṣka era (with hundreds omitted) in inscriptions dated "in the continuous year" (kālānuvartamāna-samvatsare) along with a "victorious royal year" (vijayaräjya-samvvatsare) of the Gupta era beginning in $319 \mathrm{CE} .{ }^{265}$ Since the Gupta era was not used until the time of Candragupta II, who began ruling sometime before $388 \mathrm{CE}$, Candragupta I and his successor Samudragupta are somewhat arbitrarily assigned reigns of 20 to 25 years. ${ }^{266}$

${ }^{263}$ Bhandarkar et al. 1981 suggests that since Kumāradevī was apparently the Licchavī ruler's only child, "she naturally succeeded him to his kingdom and administered it along with her husband" (1981: 6). A link with the Licchavīs is clear from the Allahabad pillar inscription, which indicates that Samudragupta was the 'daughter's son of the Licchavi, born from mahādevī Kumāradevì' (1. 29: licchavi-dauhitrasya mahādevyām Kumāradevyām=utphannasya).

${ }^{264}$ Candragupta is titled Mahārājādhirāja in Samudragupta's Allahabad pillar inscription (Fleet 1888: 16), but in the Gupta genealogy of Prabhāvatī Guptā's Poona and Roddhapur copper-plate inscriptions (Mirashi 1963: 7-8 (no. 2), 36-37 (No. 8)) Candragupta has the same title of Mahārāja as Ghatotkaca, the "first king of the Guptas" (Guptādirāja/ Guptānam=ādirājo). See Raven, Ellen. 1994. Gupta gold coins with a Garuda-banner, Samudragupta-Skandagupta. Gonda indological studies, v. 1. Groningen: Egbert Forsten, 25-33 for a detailed discussion of typologial links between Gupta and Kuṣāna coins.

${ }^{265}$ Falk 2004: 167-176; Salomon 1998a: 186 (\$5.5.1.6: “Gupta-Valabhī era of AD 319"); and Schmiedchen, Annette and Fred Vierkus. 2002. "Die Ären der Guptas und ihren Nachfolger: Politische Kultur, Regionalgeschichte und Zeitrechnung im alten und früh-mittelalterlichen Indien." In Falk 2002: 106-137. Schmiedchen and Virkus point out that the initial use of the newly created Gupta era in Mathura during the reign of Candragupta II was an aspect of self-representation that helped to intensify their imperial image in an impotant metropolitan area formerly dominated by the Kuṣānas and Śakas (2002: 111).

266 Following Falk 2004: 169-172, the date of the Mathura pillar inscription of year 61 "in the continuous year" is calculated from $327 \mathrm{CE}$ rather than $319 \mathrm{CE}$. 
The commemoration of Samudragupta's exploits in a classical Sanskrit inscription written on an Aśokan pillar at the confluence of the Ganga and Yamuna rivers marks an important juncture in South Asian political and cultural history. ${ }^{267}$ Thapar remarks that "It is curious that he should have chosen this pillar, carrying the pillar edicts of Ashoka, suggesting either that he was claiming some historical continuity or, if the earlier inscriptions could stil be read, that he was taking a contrary stand to the views of Ashoka" (2003: 283). Although the first four lines (two verses) of the inscription are damaged, the genealogy of early Gupta rulers near the end of the inscription specifies that Mahārājas (Śrī)Gupta and Ghațotkaca and Mahārājādhirāja Candragupta preceded Samudragupta. The epigraphic eulogy (praśasti) in praise of Samudragupta's military expeditions and personal qualities was composed by a court poet named Harișena. ${ }^{268}$ This ornate composition of mixed prose and verse is regarded as an impressive example of the campu style of Sanskrit poetry (kāvya) and represents a significant transition from Prakrit to Sanskrit in royal inscriptions, since "From this point on, all the inscriptions of the Guptas and their neighbors an feudatories in northern India were written in correct classical Sanskrit" (Salomon 1998a: 92). ${ }^{269}$ Daud Ali (2004: 83) argues that ubiquitous references to 'fame' (kìrti, yaśas) in this inscription of Samudragupta and thousands of other praśastis show that building a reputation was probably an important motivating factor.

Caution is necessary in interpreting the claims of conquest attributed to Samudragupta, however, since the "the conventional bombast and rhetorical exaggeration of the praśasti style" (Salomon 1998a: 229) was not intended to serve as an objective account of historically verifiable events. Thus, Harișena's claims that Samudragupta increased his glory by "capturing and then liberating" twelve southern kings of Dakșināpatha and "violently exterminating" eight kings of Āryāvarta in a 'conquest of the directions' (digvijaya) can not be accepted at face value, since his military expeditions were probably limited to

${ }^{267}$ Fleet 1888: 1-17 (no. 1); Sircar 1965: 262-268 (no. 2).

268 Ali 2004: 46 comments that Harișena was awarded the titles of 'officer for peace and war' (sandhivigrahika), 'princely counselor' (kumārāmātya), and 'great leader of the forces' (mahādandanāyaka) for assuming various service functions in the royal household, and was probably treated on a level similar to military retainers and vassals (2004: 46). Richard Salomon remarks that "...the composition of such panegyrics was perhaps more a labor of daily bread than of love" (1998a: 236).

${ }^{269}$ See also Salomon 1998: 110-113 for further discussion of epigraphic praśastis. 
regions directly to the south and east of the Narmada River valley not controlled by the Vākātakas and to territories adjacent to the GangaYamuna doāb. ${ }^{270}$ References to Kușāna successors in the Northwest as Daivaputra-Ṣāhi-Ṣāhānu-Ṣāhis and to the Western Kṣatrapas (probably) as Śaka-Murundias together with the Simhalas "and all the other island-dwellers" (sarvva-dvīpa-vāsibhir-) more likely reflects a vague awareness of distant rulers and peoples than submission to Samudragupta.

Samudragupta issued a series of gold coins with the emblem of Garuda (the mount, or vāhana, of Viṣnu) and another series of coins and seals commemorating the performance of a horse sacrifice (aśvamedha). ${ }^{271}$ Later Gupta inscriptions of Kumāragupta issued in year 96 (415/6 CE) and of Skandagupta (reigning ca. 456-467) refer to Samudragupta as "the restorer of the Aśvamedha sacrifice that had long been in abeyance" (Fleet 1888: 44, 51). ${ }^{272}$ While numismatic and epigraphic evidence reflects the religious proclivities of Samudragupta and the Gupta dynasty, R.C. Majumdar's statement that "there can be hardly any doubt that his reign marked a distinct revival of the old glory and influence of the Brahmanical religion which had suffered decline since Aśoka made Buddhism the dominant religion of India" (1954: 15) pushes this evidence too far, since his impact on religious beliefs and practices beyond the royal court was relatively limited.

After Samudragupta's reign, there was a succession dispute between Rāmagupta and Candragupta II, who eventually consolidated Gupta dominion. Jain image inscriptions from Vidiśā referring to Mahārājādhirāja Rāmagupta and gold coins issued by Kācagupta

${ }^{270}$ Fleet 1888: 12-13 (lines 19-21). For efforts to localize the rulers who are said to have been conquered, see Bhandarkar, Chhabra and Gai 1981: 12-25 and Sircar 1965: 265. Following La Vallée Poussin 1935: 45, it is necessary to read between the lines of fantastic formulae which "give an aspect of vassality to their diplomatic relations," since the foreign countries were completely independent.

271 Raven 1994 thoroughly examines Gupta gold goins with the "Garuda-Banner" issued by rulers form the Samudragupta to Skandagupta and discusses epigraphic references and images on royal seals and Gupta period art, concluding that "...the valiant king of birds, Garuda Vainateya, is the perfect representative of Gupta kingship, might and glory" (1994: 196), and symbolizes a bond between Gupta kings and Vāsudeva/ Vișnu. Lindquist, Steven. 2003. "Enigmatic Numismatics: Kings, Horses, and the Aśvamedha Coin-type." South Asian Studies 19, 105-112 argues that the images of the horse and Śrī on the Aśvamedha coins of Kumāragupta I and Samudragupta fulfill narrative and representational purposes, since the king can be identified with the horse and the queen with Śrī.

272 Bhandarkar, Chhabra and Gai 1981:35-42, Sircar 1965: 275. 
(probably identical to Rāmagupta) lend credence to Sanskrit and Arabic literary references to a struggle between Rāmagupta (Rawwāl in Arabic) and Candragupta (Barkamāris) in which Candragupta killed Rāmagupta and took his wife Dhruvadevī after Rāmagupta was defeated by the Sakas (Western Kșatrapas). ${ }^{273}$ As Michael Willis remarks, rivalry for the Gupta throne was fiercely contested:

Each king was forced to engage in a vigorous struggle for political, military and ritual supremacy. The system was sufficiently precarious and predatory that the king's attempt to create a working circle of power could come unraveled at any moment (2005: 144).

Rāmagupta's "circle of power" appears to have been restricted to the Mālava region around Vidiśā and it is uncertain that he ruled for very long (ca. $375-380$ is a very rough estimate).

Candragupta II succeeded in expanding the Gupta domain during a long reign of over thirty years (ca. 380-415). His own marriage with Kuberanāgā, a Bhāraśiva Nāga princess, and the marriage between their daughter Prabhāvatī Guptā and the Eastern Vākāṭaka ruler Rudrasena II cemented alliances with important allies in northern and central India. ${ }^{274}$ His conquest of the Western Kṣatrapas in Ujjayinī and Gujarat at the beginning of the fifth century (ca. 409/10 CE) was a signal event, since the Guptas now controlled important links between overland networks and ports in western India. ${ }^{275}$ Legends associating Vikramāditya (an epithet of Candragupta II) with the establishment of the Azes (so-called "Vikrama") era of 58 BCE anachronistically recall his campaigns against the Western Kșatrapas. ${ }^{276}$ By building monuments for worshipping Viṣnu in the form of Nārāyaṇa, Varāha

${ }^{273}$ Bhandarkar et al. 1981: 46-52 provide a detailed account of the inscriptions, coins, and versions in literary sources, including Viśākhadatta's Devīcandraguptam (lost but fragments preserved in Nätyadarpana), Bāṇa's Harșacarita, Bhoja's Śrngāaraprakāśa, Rājaśekhara's Kāvyamimāmsāa, and the Majmālut-Tawārikh. Majumdar 1962: 17-18 (with further references) and Tripathi 1942: 248-249 doubt the veracity of the Rāmagupta 'romance.' However, Bakker, Hans. 2006. "A Theatre of Broken Dreams: Vidiśa in the Days of Gupta Hegemany.” In Interrogating History: Essays for Hermann Kulke, eds. Martin Brandtner and Shishir Kumay Parda, Delhi: Manohar, 165-187, esp. 166-170, assesses the literary sources, epigraphic references in later Rāsțtrakūṭa praśasti inscriptions, and coinage of Rāmagupta and Candragupta II to demonstrate how Candragupta II consolidated political power through matrimonial alliances following a successful coup d'état.

${ }^{274}$ La Vallée Poussin 1935: 47.

${ }^{275}$ La Vallée Poussin 1935: 48, Bhandarkar et al. 1961: 53-54, Sircar 1965: 282 (no. 13: inscription on silver coins of Candragupta in Gupta year 90+ $x=409 / 10+$ ), Tripathi 1942: 250-251.

276 Salomon 1982: 65-68; Salomon 1998: 182; Sircar 1969: 165-166. 
(boar) and Narasiṃha (man-lion) at Udayagiri outside of Vidiśā, Candragupta II explicitly identified himself as a "supreme devotee" (paramabhāgavata). ${ }^{277}$ However, a donation by Amrakārdava at the nearby site of Sāñci stūpa 1 during the reign of Candragupta II shows that patronage of Buddhist communities by members of the Gupta court continued. ${ }^{278}$

After a period of relative stability during the first half of the fifth century, the strength of the Gupta dynasty declined precipitously as a result of internal turmoil, external threats, and the growing autonomy of regional subordinates. Kumāragupta I, a son of Candragupta II and Dhruvadevī, ruled for at least thirty years from ca. 415-447. ${ }^{279}$ Inscriptions issued during his reign are mostly Brahmanical donations, although a few Jain and Buddhist inscriptions are attested. ${ }^{280}$ After Kumāragupta, there was another succession dispute between his brother Ghatotkacagupta and his bastard son, Skandagupta. ${ }^{281}$ At Junagadh, on the same rock inscribed with the Girnar version of Aśoka's major rock edicts and Rudradāman's praśasti inscription of $150 \mathrm{CE}$, an elaborate Sanskrit inscription records the construction of a temple to Viṣnu and repairs to the dam on Sudarśana lake between 455-458 CE by a local subordinate of Skandagupta named Cakrapālita, whose father Parṇadatta had been appointed governor of Saurāsțra. ${ }^{282}$ Another private donor of five Jain images at the village of Kakubha (modern Kahāum in Gorakhpur district in northeastern Uttar Pradesh) in 460 CE effusively praised Skandagupta:

Lord over a hundred kings, who is like Śakra (Indra), whose audience hall is fanned by the breeze from the bowing of the heads of hundreds of kings, who was born in the lineage of the Guptas, whose glory has spread afar, and who prospers above all others. ${ }^{283}$

277 Williams 1982: 40-55; Willis 2009.

${ }^{278}$ Fleet 1888: 29-34 (no. 5); Williams 1982: 37.

279 Dates for Kumāragupta I are fixed by the Bilsad pillar inscription of Gupta year 96 (415-416 CE) and the Dāmodarpur copper-plates of Gupta year 128 (447 CE) (Willis 2005: 136).

${ }^{280}$ Fleet 1888: 39-47 (nos. 8-11); Sircar 1965: 285-295; Bhandarkar et al. 1981: 77-78 refer to Buddhist and Jain donations.

${ }^{281}$ Bakker 1997: 25-29; Bakker 2006: 178-179; Willis 2005: 136. In later Gupta genealogies, Purugupta is listed as Kumāragupta's successor.

${ }^{282}$ Fleet 1888: 56-65, no. 14; Sircar 1965: 307-316. The appointment of Parnadatta and his son Cakrapālita as hereditary Gupta regional administrators apparently resulted from a practice of "appointing protectors (or 'mini-Guptas': goptrnn) in all countries" (sarvveșu deśeșu vidhāya goptṛn, line 6, verse 7).

${ }^{283}$ Translation by Salomon (1998a: 275) of the Kahāum Pillar Inscription (Fleet 1888: 65-68, no. 15; Sircar 1965: 316-317). 
In the Bhitari stone pillar inscription, Skandagupta claimed to have restored the fortunes of his faltering dynasty by conquering the Hūnas. ${ }^{284}$ Skandagupta was followed by a quick succession of Gupta rulers: Narasiṃhagupta, Kumāragupta II, and Budhagupta within a single decade (468-476/7 CE). ${ }^{285}$ Seals of Budhagupta and Viṣnugupta from Nālandā provide evidence for the establishment of this important center of monastic scholarship in the Gupta heartland. ${ }^{286}$ Vainyagupta himself acted as a Buddhist donor in the Gunaighar Copper-Plate inscription of $507 \mathrm{CE}$ from the Comilla district in modern Bangladesh, but this is the only example of direct Gupta patronage and belongs to the latest phase of Gupta dynastic history. ${ }^{287}$ The limited distribution of inscriptions and seals of Vainyagupta and Viṣnugupta seem to indicate that a short-lived Gupta resurgence at the beginning of the sixth century was restricted to Bihar and Bengal. The Guptas relied on a network of allies to establish and maintain control of critical regions, but their former regional subordinates asserted themselves and groups of outsiders, particularly the Hūnas, filled the void as Gupta power declined.

Table 2.4: Vākāṭaka-Gupta Genealogy and Chronology ${ }^{288}$

\begin{tabular}{|c|c|c|}
\hline Eastern Vākāṭakas & Western Vākāṭakas & Guptas \\
\hline \multicolumn{2}{|c|}{ Vindhyaśakti (c. 250) } & Ghațotkaca (c. 300-319) \\
\hline \multirow{2}{*}{\multicolumn{2}{|c|}{$\begin{array}{c}\text { Pravarasena I (c. 275-335) } \\
\text { Gautamīputra }^{290}\end{array}$}} & Candragupta I \\
\hline & & \\
\hline $\begin{array}{l}\text { Rudrasena I } \\
\text { (c. 335-360) }\end{array}$ & Sarvasena I (c. 330-355) & $\begin{array}{l}\text { Samudragupta } \\
\text { (c. 350-375) }\end{array}$ \\
\hline
\end{tabular}

${ }^{284}$ Fleet 1988: 52-56, no. 13; Sircar 1965: 321-324. Bhitarī may have been an imperial mausoleum for the Guptas (Bhandarkar et al 1981: 83). Huns (Sanskrit Hūnas) are discussed in more detail in Kidāras and Huns in Northwestern Indian subcontinent.

${ }^{285}$ The chronology of later Gupta rulers is uncertain, but the genealogy and dates presented in Table-follow Willis 2005, wose reconstruction differs from Bhandarkar et al. 1981: 84-89 (who place Narasimphagupta last in a series of four brothers beginning with Vainyagupta).

286 Sircar 1965: 339-340.

287 Sircar 1965: 340-345.

${ }^{288}$ Based on Bakker 1997: 168-171 (Appendices II-III); Bakker 2008; Willis 2005: 135, fig. 1 .

${ }^{289}$ Marriage with Kumāradevī (Licchavī princess).

${ }^{290}$ Marriage with daughter of Bhavanāga (Bhāraśiva ruler). 
Table 2.4 (cont.)

\begin{tabular}{|c|c|c|}
\hline Eastern Vākāṭakas & Western Vākāṭakas & Guptas \\
\hline $\begin{array}{l}\text { Prrthvīsena I } \\
\text { (c. 360-395) }\end{array}$ & $\begin{array}{l}\text { Vindhyaśakti II } \\
\text { (c. } 360-400)\end{array}$ & Rāmagupta (c. 375) ${ }^{291}$ \\
\hline $\begin{array}{l}\text { Rudrasena } \mathrm{II}^{293} \\
\text { (c. 395-405) }\end{array}$ & $\begin{array}{l}\text { Pravarasena II } \\
\text { (c. } 400-415)\end{array}$ & $\begin{array}{l}\text { Candragupta II (c. 375/ } \\
380-415)^{292}\end{array}$ \\
\hline $\begin{array}{l}\text { Divākarasena } \\
\text { (before c. 419) }\end{array}$ & Unknown & $\begin{array}{l}\text { Kumāragupta I } \\
\text { (c. 415-447) }\end{array}$ \\
\hline $\begin{array}{l}\text { Dāmodarasena } \\
\text { (c. 415-422) }\end{array}$ & & Purugupta ${ }^{294}$ \\
\hline $\begin{array}{l}\text { Pravarasena II } \\
\text { (c. } 422-457)\end{array}$ & & $\begin{array}{l}\text { Ghațotkacagupta } \\
(\text { c. } 448-455)^{295}\end{array}$ \\
\hline \multirow[t]{2}{*}{$\begin{array}{l}\text { Narendrasena } \\
\text { (c. 457-475) }\end{array}$} & $\begin{array}{l}\text { Devasena } \\
\text { (c. } 450-460)\end{array}$ & Skandagupta (c. 456-467) \\
\hline & Harișeṇa (c. 460-478) & $\begin{array}{l}\text { Narasimuagupta } \\
\text { (c. } 467-474 \text { ?) }\end{array}$ \\
\hline \multirow[t]{4}{*}{$\begin{array}{l}\text { Pṛthvīsena II } \\
\text { (c. 475-495) }\end{array}$} & & $\begin{array}{l}\text { Kumāragupta II } \\
\text { (c. } 474 ?-476)\end{array}$ \\
\hline & & Budhagupta (c. 477-488) \\
\hline & & Vainyagupta (c. 508) \\
\hline & & Viṣṇugupta (c. 515?) \\
\hline
\end{tabular}

Cross-cultural Transmission between South Asia and Central Asia, ca. 500-1000 CE

Competition for economic, political, and religious power affected patterns of cross-cultural contact and exchanges between South Asia and Central Asia during a period of instability after the downfall of the Guptas in the middle of the first millennium CE. Local and regional

\footnotetext{
${ }^{291}$ Perhaps identified with Kācagupta (immediate successor of Samudragupta), first husband of Dhruvadevi in Devīcandraguptam.

${ }^{292}$ Marriage with Kuberanāgā (Bhāraśiva Nāga princess).

${ }^{293}$ Mariage with Prabhāvatī Guptā (daughter of Candragupta II), who continued to rule from c. 405-419.

${ }^{294}$ Son of Kumāragupta, did not rule.

${ }^{295}$ Perhaps married to Atibhāvatì (his niece), the daughter of Prabhāvatī Guptā and Rudrasena II (Bakker 1997: 17).
} 
polities emerged, solidified, and expanded their domains in the Indian subcontinent while acting as patrons of competing Buddhist, Saiva, Vaișnava, and other religious movements. Ronald Davidson links the "early medieval vitality" of Indian religions, literature, and art to "the valorization of regional identity" and a "discourse of divine power" whereby "the gods became kings even as the kings became gods" (2003: 74). ${ }^{296}$ The systematic use of imperial metaphors of divine apotheosis in public inscriptions and literary texts composed in the courts of rulers who aspired to fulfill the cakravartin ideal of universal overlordship provides a political-historical context for the development of a "mature synthesis of esoteric Buddhism" (Davidson 2002: 114 ) and the monastic institutionalization of Saiva Tantrism, both of which provided rival rituals of consecration (abhiseka), powerful texts and formulas (mantras), and religious ideologies to confer royal legitimacy. ${ }^{297}$ Volatile political alliances, changing military alignments, and fluctuating migration patterns did not result in insular stagnation, but often caused shifts in transregional routes for commercial exchanges and religious transmission. Contemporary sources from this period, including the accounts of Chinese travelers, inscriptions of visitors to Indian Buddhist centers, and material artifacts found far way from their original contexts, attest significant mobility via overland and maritime itineraries. The emergence of new trade networks and merchant communities (such as the Sogdians in Central Asia) and macroregional conflicts between Indian, Chinese, Central Asian, Tibetan, and Arab forces had major impacts on cultural transmission, sometimes prompting the creation of new ties and in other cases constraining access. The re-emergence of the northwestern borderlands as a contact zone between South Asia and Central Asia deserves special emphasis, since Buddhist literary and material cultures flourished at nodes for long-distance trade and political administration loosely con-

296 Davidson, Ronald M. 2002. Indian Esoteric Buddhism: A Social History of the Tantric Movement. New York: Columbia University Press.

${ }^{297}$ Sanderson, Alexis. 2009. "The Śaiva Age: The Rise and Dominance of Śaivism during the Early Medieval Period." In Genesis and Development of Tantrism. Shingo Einoo, ed. Tōkyō: Sankibō Busshorin, 41-350 provides a detailed survey of royal patronage of Buddhism (pp. 70-116), but argues that Śaivism absorbed or provided the models for Buddhist Tantrism (252). His claim that the repertoire of Saiva rituals and theory promoted economic, policial, and social processes that encouraged "intellectual and aesthetic vigour" (253, n. 590) applies equally well to a Buddhist impetus. 
trolled by a network of rulers affiliated with the Kidara and Alchon Huns or local dynasties like the Palola Șāhis of Gilgit.

\section{Kidāras and Huns in the Northwestern Indian Subcontinent}

Like their Saka and Kușāna predecessors, the Kidāra and Alchon Huns migrated to the Indo-Iranian borderlands from Central Asia as a result of Xiongnu nomadic expansion. Although relationships between Hunnic groups known as the Hūnas in Indian sources (and Chionites or Hephthalites in western sources) remain unclear due to conflicting reports about their origins and identities, they filled a significant gap by asserting control of areas between the eastern frontier of the Sasanians and the northwestern borderlands of the Guptas and their allies beginning in the fifth century CE. ${ }^{298}$ Based primarily on analysis of coins and seals, a group identified as the Kidāras emerged as autonomous rulers of large areas between Gandhāra and western Central Asia in the fifth century (ca. 430-477). ${ }^{299}$ Chinese sources based on the report of Dong Wan's mission to the Western Regions in 437 CE affiliate the Kidaras (Juduoluo) with the Yuezhi (rather than the Xiongnu), but the testimony attributed to him may have been copied from or harmonized with later historical texts. ${ }^{300}$ The Kidāras portray themselves as "restorers of the previous order" (Grenet 2002:

${ }^{298}$ La Vaissière, Étienne de. 2003 (2007). "Is There a 'Nationality of the Hephtalites'?” Bulletin of the Asia Institute 17, 119-132.

${ }^{299}$ Grenet, Frantz. 2002. "Regional Interaction in Central Asia and Northwest India in the Kidarite and Hephthalite periods." Proceedings of the British Academy 116, 203224. Grenet's dates are adopted, although the chronological range for the Kidaras is highly uncertain, since the Chionites with whom they are sometimes identified are assigned to a period beginning in the fourth century immediately after the Sasanians lost control of Bactria in the mid-370's during the rule of Shapur II (Grenet 2002: 206). La Vaissière's hypothesis that “... all the nomadic kingdoms that flourished in Bactria between the middle of the fourth century and the middle of the sixth century can trace their origin back to a single episode of massive migration in the second half of the fourth century (circa 350-370), and not to a whole set of successive migrations" (2003 [2007]: 122) alleviates problematic associations between the Chionites and Kidāras, while leaving a significant lag before the Kidāras emerged as regional political power.

${ }_{300}$ Passages referring to the Yuezhi affiliation of the Kidāras and Hephtalites in Wei $s h u$ ("History of the Wei") chapter 102,8b (p. 2278), Bei shi ("History of the Northern Dynasties") chapter 97.11b (pp. 3230-31), Zhoushou chapter 50 (p. 918), and Suishu chapter 83 (p. 1854) indicate that in the sixth century when the textual passages were redacted, the origins of the groups which occupied the former territory of the Kusaanas were no longer clearly understood (La Vaissière 2003 [2007]: 120). 
206-7) of the Kușananas or Kushano-Sassanians by adopting the title of Kidāra kușāna șăhi on Brāhmī coin legends. However, the title of Kidāra kușāna șāhi does not necessarily indicate that the Kidāras were related to the Kuṣannas, but ruled the former Kusānạa territory. ${ }^{301}$ Keeping these caveats in mind, Shōshin Kuwayama reconstructs a scenario in which the Kidāras migrated to northwestern Pakistan after gaining control of five kingdoms north of Gandhāra and established a capital at Purușapura (moden Peshawar) based on passages in the Weishu:

The king of Da Yuezhi called Jiduoluo (Kidara), brave and fierce, eventually dispatched his troops southward and invaded North India (present-day Pakistan), crossing the great mountains to subjugate the five kingdoms which were located to the north of Gandhāra. ${ }^{302}$

Brief Chinese references to Kidāra rulers coupled with distribution of their coin-types on both sides of the Hindu Kush from northern Gandhāra, Swat and Bannu (in present-day Northwest Pakistan) to Samarkand in ancient Sogdia have resulted in different interpretations of their relationships with regional contemporaries. Since Kidāra coins fit into a continuous series with those issued by their Kushano-Sasanian predecessors, Robert Göbl (1967) views the Kidāras as erstwhile regional allies of the Sasanians against the Alchon Huns. Adopting the perspective of the Chinese accounts, Kuwayama $(1989,1992)$ also holds that the Kidāras were opponents of a subsequent 'wave' of Xiongnu invaders who drove them out of Bactria (which Kuwayama refers to as Tokharistan) and into the northwestern frontiers of South Asia. Frantz Grenet (2002) questions the loyalty of the Kidaras to the Sasanians, since they "cashed in on the military threat they exercised against Iran" (2002: 209) by exacting tribute from Sasanian rulers such as Yazdigird II. While acknowledging a long struggle between

301 Göbl, Robert. 1967. Dokumente zur Geschichte der iranischen Hunnen in Baktrien und Indien. Wiesbaden: Harrassowitz, vol. 2, 53.

302 Translated by Kuwayama, Shoshin. 1992. "The Hephthalites in Tokharistan and Gandhara" (parts 1-2). Lahore Museum Bulletin 5.1-2, 19 (= Kuwayama 1989. "The Hephthalites in Tokharistan and Northwest India." Zinbun, Annals of the Institute for Research in the Humanities, Kyoto University 24, 25-77 and Kuwayama, Shōshin. 2002. Across the Hindukush of the First Millennium: A collection of the papers. Kyoto: Inst. for Research in Humanities, Kyoto Univ.). According to Kuwayama, the five kingdoms to the north of Gandhāra included Yarkand, Tashkurgan, Wakhan, Chitral, and possibly Swat, although Grenet (2002: 207, n. 6) suggests that Kapisa should be added to the list. For a translation of the same passage, see Zürcher 1968: 373 and comments by Zeimal, E.V. 1996. "The Kidarite Kingdom in Central Asia." In Litvinsky, ed. 1996: 122. 
the Kidāras and Hephthalites (identified with the Alchon Huns) for control of Bactria and Sogdia, Grenet draws attention to evidence for coexistence between the last Kidāras and the first Hephthalites who seem to have been on "hunting terms" (2002: 212) in depictions on two Gandhāran silver bowls found in Swat and in Chilek, north of the Sogdian capital in Samarkand. Grenet surmises that the Kidaras (and the Alchon Huns who later supplanted them) "... sought to control the mountainous nexus of trade routes linking Bactria, India, China, and Sogdiana" (2002: 207). The expansion of the Kidāra and Hephthalite Huns to Sogdia entailed a process of "Bactrianisation" (Grenet 2002: 208) whereby Indian cultural elements (including Buddhist elements) were introduced to some areas of western Central Asia which had not been exposed to the initial phases of long-distance transmission in earlier periods.

By acting as political and cultural mediators between India, Iran, and Central Asia, the Alchon Huns (identifiable with the Indian Hūnas, Chinese Yida or Yada, and Hephthalites in Western historical sources) aided the development of overland trade and expansion of Buddhist networks in the fifth and sixth centuries, despite their exaggerated reputation as oppressive barbarians in Chinese and Sanskrit literary sources. While the Alchon Huns had much in common with the Kidāras (including similar origins in mass migrations from Central Asia to Bactria in the fourth century), they consciously distinguished themselves by abandoning Kuṣanna titles, using Bactrian and Brāhmī instead of Pahlavi on coin and seal legends, and developing distinctive styles of ornamentation and portraiture (particularly their artificially deformed craniums or "steeple heads"). ${ }^{303}$ They played a prominent role in Central Asian geopolitics in the fifth and sixth centuries by engaging in conflicts and enacting alliances with a series of Sasanian rulers (helping Peroz rise to power between 459-484 and sheltering Kawad I between 484-488), and expanding their dominion west to the Merv oasis (probably during the reign of Kavad I) and north to

303 Alram, Michael. 2003 (2007). "Three Hunnic Bullae from Northwest India." Bulletin of the Asia Institute 17, 179; Göbl 1967: 2.232 ff.; Grenet 2002: 210; Callieri, Pierfrancisco. 1997. Seals and Sealings from the North-West of the Indian Subcontinent and Afghanistan (4th Century BC-11th Century AD): Local, Indian, Sasanian, GraecoPersian, Sogdian, Roman. Naples: Istituto universitario orientale, Istituto italiano per l'Africa e l'Oriente, 229-231 (Class IV); Callieri, Pierfrancisco. 1999. "Huns in Afghanistan and the North-west of the Indian Subcontinent: The Glyptic Evidence." In Alram and Klimburg-Salter, eds. 1999: 282-285 (Class D). 
Sogdia (by $509 \mathrm{CE}$ ). ${ }^{304}$ The Alchon Huns began to exchange diplomatic missions with the Chinese court in $457 \mathrm{CE}$ after consolidating their stronghold in eastern Bactria, eventually took control of routes across the Hindu Kush away from the Kidāras, established themselves as overlords of northwestern India, and directly contributed to the downfall of the Guptas, whose position in central India eroded as the Hūnas (whom Skandagupta claimed to have defeated) made significant inroads as far as modern Gujarat and Madhya Pradesh. ${ }^{305}$

The Alchon Huns appear in several inscriptions, including two Buddhist donations that demonstrate religious patronage of monasteries in northern Afghanistan and Pakistan. The recent publication of a Sanskrit inscription on a thin copper scroll belonging to the Schøyen collection provides valuable information about the identities of Alchon Huns who are named in a list of secondary donors who received credit for the erection of a relic stuppa. ${ }^{306}$ If Gudrun Melzer's identification of year 68 as a Laukika era date corresponding to $492 / 3 \mathrm{CE}$ is correct, this inscription supplies a fixed point in the chronology of the Alchon

304 Bivar, ADH. 2004. "Hephthalites." In Encyclopedia Iranica Online, available at http://www.iranica.com/newsite/; Grenet 2002: 212-213, 220-221; Kuwayama 1992: 3 (part 2); La Vaissière, Étienne de. 2005 [2002]. Sogdian Traders: A history. Leiden: Brill, 110-111. Earlier treatments include Christensen, Arthur. 1936. L'Iran sous les Sassanides. Copenhague: Levin \& Munksgaard, 288 ff.; Ghirshman, Roman. 1948. Les Chionites-Hepthalites. Cairo: Institut francais d'archeologie orientale, 82-114 and McGovern, William Montgmery. 1939. The Early Empires of Central Asia: A Study of the Scythians and the Huns and the part they played in world history. Chapel Hill: University of North Carolina Press, 410-419, 454-457.

${ }_{305}$ On the Chinese missions, see Grenet 2002: 210-211; Kuwayama 1992: 4 (part 2); and La Vaissière 2003 (2007): $122 \mathrm{ff}$. Based primarily on numismatic analysis, Göbl 1967: 2.60 ff. identifies approximate dates or "Zeithorizonte" for the initial accession to power ("Annahme der Krone") of the Alchon Huns under Khingila around 450 CE, the conquest of Taxila (ca. 460), and appropriating Indic styles following conflicts with the Guptas in 470/480 (after the death of Skandagupta). For the impact of the Hūnas in Indian history, see Biswas, Atreyi. 1973. The Political History of the Hūnas in India. New Delhi: Munshiram Mahoharlal and Thakur, Upendra. 1967. The Hünas in India. Varanasi: Chowkhamba Sanskrit Series Office, whose synthesis of Indian epigraphic, numismatic, and literary evidence leads him to remark that "the Hūnas also issued forth like the lava of the erupting volcano, blasted the political horizon and soon receded to obscurity" (1967: 70). Tripathi fixes a terminus post quem of 484-5 CE (Mahārāja Maitrigupta's inscription of Gupta year 165 at Eran, edited by Fleet 1888: 88-90), after which "The Hūna hordes now poured into India like swarms of locusts in terrific numbers, and caused the downfall of the Gupta empire" (1942: 280).

${ }^{306}$ Melzer, Gudrun. 2006. "A Copper Scroll Inscription from the Time of the Alchon Huns.” In Buddhist Manuscripts 3, Braarvig, Jens, ed. Oslo: Hermes, 251-278. 
Huns. ${ }^{307}$ Khingila (with the title of mahāṣāhi) and Toramāna (titled devarāja), who were already well-known historical figures (but apparently not father and son, as previously supposed), are listed together with male and female contemporaries: Mehama (like Khingila, a mahạșāhi during whose reign the donation was made), Javūkha (a mahārāja who was the son of Sādavìkha), a queen, and two "mistresses of the great monastery" (mahāvihārasvāminī) named Arccavāmanā and Sāsā. ${ }^{308}$ The primary purpose of this long and ornate inscription is to record the establishment of a reliquary stūpa (tathägatacaityo dhātugarbha) by the 'master of a great monastery' (mahāvihārasvāmin), whose official title of Tälagānika-Devaputrașāhi may indicate that he belonged to the ruling family of the Tālagān region east of Kunduz in northern Afghanistan, which was the geographical heartland of the Alchon Huns. ${ }^{309}$ At the beginning of the inscription, an extensive quotation from a Mahāyāna sūtra (Śrimatībrāhmaṇi pariprcchōa) about the teaching of dependent arising by the Buddha to the Brahmin woman Śrimatī is followed by the introductory verses to Nāgārjuna's Mūlamadhyamakakārika. Melzer (2006: 252) suggests that these citation may indicate the use of Pratityasamutpāda texts in consecration rituals. The invocation of passages from Mahāyāna sūtras and the concluding seven verses composed in classical Sanskrit meters show that monasteries supported by the Alchon Huns in a region "adorned with stūpas resembling a multitude of autumn clouds" (Melzer 2006: 277) were linked to Buddhist scholastic and literary networks.

The Alchon Hun rulers Toramāna and Javūkha are also associated with the donation of a monastery in another Buddhist inscription from Kura in the Salt Range in the western Punjab. ${ }^{310}$ The primary

307 Melzer 2006: 263-4 considers other possibilities, including the Gupta era of $319 / 20 \mathrm{CE}$, the Kaniska era (with hundreds omitted) beginning in 127/8 CE, and the era of the Tochi Valley inscriptions of $223 \mathrm{CE}$, but her arguments in favor of the Laukika/Saptarși era (later used by the Palola Șāhis of Gilgit, as discussed in the following subchapter) are convincing.

308 Melzer 2006: 257-262 discusses the historical context of these rulers, whose names and titles are attested in lines 37-39 of the inscription's donative formula (274).

${ }^{309}$ Melzer 2006: 256; Grenet 2002: 210 suggests that eastern Bactria may have been the original base of the Hephthalites, and argues that the later Hephthalites continued to control the area around Surkh Kotal in the Surkh-ab valley on the route between Kunduz and Kabul.

310 Bühler, Georg. 1892. "The New Inscription of Toramana Shaha." Epigraphia Indica 1, 238-241; Sircar 1965: 422-424 (no. 56); Tsukamoto 1996: 976-978. 
donor named Roța-siddhavriddhi, a 'master of the monastery' who was the son of Rota-jayavrddhi, a 'master of many monasteries' (anekaviharrasvāmino), extended the merit of the donation to his own brothers, wives, sisters, sons, and daughters and to all of the queens, princes, and princesses of Mahārāja Toramāṇa and Șāha Javūkha (written Jaūvkha), and expressed the wish that his religious offering (deyadharma) be used for the "attainment of supreme knowledge by all beings." ${ }^{111}$ The names and titles of the Masters of the Monastery, whose "special prosperity" (visessa-vrddhi) was "praised and honored by the lord of Naścīra” (Bühler 1892: 241), corroborates Gregory Schopen's hypothesis that some Buddhist monasteries were privately owned and inherited by prosperous families responsible for their maintenance and supervision. ${ }^{312}$ The last line of the inscription seems to have been intentionally defaced, and the designation of the Mahissāsakas (ācārya mahiśs [äsakānām $]$ ) as recipients of the donation may have been forged. ${ }^{313}$ Although this area has not been carefully surveyed for Buddhist and other archaeological remains, the significance of a monastery located at Kura is probably related to efforts by Hun rulers such as Toramāna (and his son Mihirakula) to maintain access to the "salt road" between Kashmir and the Salt Range. ${ }^{314}$

311 Since the copper scroll inscription (Melzer 2006) clearly differentiates Toramāna from Javūkha, earlier interpretations of Jaūvkha or Jaūvla (as read by Bühler in line 10) as an epithet of Toramāna should be discarded, although the relationship between Javūkha and Toramāna remains unclear. Epigraphic parallels for this donative formula are compiled by Schopen 1979: 5-9 (-2005: 227-231), who argues that this standardized formula does not necessarily indicate Mahāyāna affiliation.

${ }^{312}$ Schopen, Gregory. 1996b. "The lay ownership of monasteries and the role of the monk in Mūlasarvāstivādin monasticism." Journal of the International Association of Buddhist Studies 19.1, 81-126 (= Schopen 2004: 219-259) provides other epigraphic references to the possession of monasteries by lay donors, including vihärasvämins.

${ }^{313}$ Salomon, Richard. 2009. "The Fine Art of Forgery in India." In Écrire et transmettre en Inde Classique. Gérard Colas and Gerdi Gerschheimer, eds. Études Thématiques 23. Paris: École française d'Extrême-Orient, 117-118.

${ }^{314}$ Kuwayama 1992: 6-7 (part 1) connects the importance of the salt trade between Kashmir and the Punjab to the location of the military camp of the Hephthalite ruler near Jhelum. With the assistance of Mohammad Usman, I was able to visit the site ("Kutte Mar") in 1996, and although few surface remains were visible there, numerous other archaeological sites in this part of the Salt Range may belong to this historical period. I have found my unpublished notes ("Ancient Remains in the Salt Range") online at various websites, including: http://www.reference.com/browse/Salt+Range. For references to articles by Michael Meister and Pakistani scholars on Hindu temples from the 6th to 11th centuries in the Salt Range and along the Indus River, see: http:// www.arthistory.upenn.edu/meister/pakistan.html, including Meister, Michael. 2010. Temples of the Indus: Studies in the Hindu Architecture of Ancient Pakistan. Leiden: 
Other epigraphic records of religious donations made by local subordinates of Toramāna demonstrate that Hūna rule in India did not necessarily alter patterns of non-Buddhist patronage. An inscription written on a colossal red sandstone sculpture of the boar avatära of Viṣnu as Varāha at Eran (ancient Airikiṇa) in western Madhya Pradesh clearly indicates that a family of local Brahmin Mahärājas who had ruled under the Guptas until at least 484-5 CE switched their allegiance to Mahārājādhirāja Toramāna within the first year of his Indian conquests. ${ }^{315}$ This expression of obeisance by a local feudatory named Dhanyavișnu who had a Vaiṣnava temple constructed at this site shows that the Hūna domain extended deep into the former territory of the Guptas, but does not really support Upendra Thakur's Hinduization argument that the "culturally weak" victors (the Hūnas) "succumbed to the overwhelming cultural superiority of the vanquished and gradually forgot all about their earlier faiths and beliefs" (1967: 260). The adoption of Vaișnava symbols such as the conch and the appearance of Lakșmī on some coins issued by Toramāna hardly "point to his strong leanings to the Brāhmanic religion" or "mark his emergence as a convert to Hinduism" (Thakur 167: 261), since other issues with fire altars and polyvalent disks (cakras) circulated more widely.

A copper-plate inscription dated in the third year of Toramanna's reign found near Sañjeli in Gujarat records donations of commodities by local and long-distance merchants to a Vaișnava temple of the deity Jayasvāmin. ${ }^{316}$ The temple was built by Virăḍhyika, the queen-mother of Mahārāja Bhūta, a regional overlord (vișayapati) subservient to Toramāna, who is given Gupta imperial titles (Paramabhatțāraka Mahārājādhirāja). As Ranabir Chakravarti notes, donations to this

Brill; Meister, Michael. 1996. "Temples Along the Indus." Expedition 38.3, 41-54; Meister, Michael. 2000b. "Chronology of Temples in the Salt Range, Pakistan." In South Asian Archaeology 1997, ed. Maurizio Taddei and Giuseppe De Marco. Rome: Istituto Italiano per l'Africa e l'Oriente, 2000, 1321-39; and Meister, Michael with Abdur Rehman and Farid Khan. 2000a. "Discovery of a New Temple on the Indus." Expedition 42.1, 37-46.

${ }_{315}$ Fleet 1888: 158-161, no. 36, pl. 23A; Sircar 1965: 420-422, no. 55.

316 Chakravarti, Ranabir. 2008. "Three Copper Plates of the Sixth Century AD: Glimpses of Socio-Economic and Cultural Life in Western India." In South Asian Archaeology 1999, ed. Ellen Raven. Groningen: E. Forsten, 395-399; Mehta, Ramanlal Nagarji, and A.M. Thakkar. 1978. M.S. University Copper Plates of the time of Toramana. Maharaja Sayajirao University archaeology series, no. 14. Vadodara: Dept. of Archaeology \& Ancient History, Faculty of Arts, M.S. University of Baroda; Ramesh, K.V. 1973-5. "Three Early Charters from Sanjeli in Gujarat." Epigraphia Indica 40: $175-186$. 
temple by a mercantile organization (vaniggrāma) of local and longdistance merchants who came from Kanauj, Ujjayinī, and Mathura indicate that the district headquarters of Vadrapāli "...can be viewed as a nodal point in the overland supra-local trade network" (2008: $397)$ and "...combined religio-cultural activities with administrative functions and commercial transactions" (2008: 398). The construction and repair of a sun temple not very far way at Mandasor (Daśapura) in the neighboring region of Mālava by a guild of silk weavers demonstrates that commercial patronage of non-Buddhist temples sustained religious establishments during a period of considerable dynastic flux in the fifth and sixth centuries as the Hūnas contended with Guptas and emergent regional rulers for control of pivotal links between the Indian hinterland and the western coast. ${ }^{317}$

Literary traditions associate Toramānaa's son Mihirakula with religious oppression and the downfall of Hūna power in India, but the evidence from epigraphy and archaeology is ambiguous. In an inscription dated in Mihirakula's fifteenth regnal year, a local donor of a sun temple in Gwalior praises Toramāna and Mihirakula as powerful sovereigns, indicating that the hegemony of the Hunas continued to be acknowledged in areas of north-central India during the earlymid sixth century. ${ }^{318}$ However, the Aulikara rulers of Daśapura in the Mālava region resisted Hūna domination, according to the Rīsthal inscription of Prakāśadharman, who made grandiose claims of defeating Toramāna in battle, using the tusks of his vanquished elephants to make ivory seats for ascetics and dedicating the females of his harem to the temple of Lord Vṛsabhadhvaja (Śiva). ${ }^{319}$ In two sand-

317 Fleet 1888: 79-88, no. 18, pl. 11; Sircar 1965: 299-304, no. 24.

318 Fleet 1888: 161-164, no. 37, pl. 22B; Sircar 1965: 424-426, no. 57. Sircar 1965: 424 gives c. 515-545 CE as an approximate range for Mihirakula's reign, but the claim by the contemporary Aulikara ruler Yaśodharman to have made Mihirakula subservient in his undated Mandasor stone pillar inscriptions (Fleet 1888: 142-150, nos. 33-34, pl. 26B-C; Sircar 1965: 418-420, no. 54) aids in fixing a date for Mihirakula, since another inscription from Mandasor was issued while Yaśodharman was ruling in Mālava year 589, corresponding to 532 CE (Fleet 1888: 150-158, no. 35, pl. 22; Sircar 1965: 411-417, no. 53).

319 Salomon, Richard. 1989. "New Inscriptional Evidence for the History of the Aulikaras of Mandasor." Indo-Iranian Journal 32, 1-36, lines 12-14, vv. 16-18. The Rīsthal inscription is dated in 515 CE (Mālava year 572). Salomon points out that this date does not mark a terminus ante quem for the reign of Toramānā, since "the rhetorical claim of his submission to the Aulikara king proves nothing more than that the two came into conflict, and that Prakāsadharman was not conquered by the Hun" (1989: 27). 
stone pillar inscriptions, ${ }^{320}$ Yaśodharman, who apparently succeeded Prakāśadharman, also claims to have subjugated Mihirakula, "whose forehead was pained through being bent low down by the strength of [Yaśodharman's] arm in obeisance" (Fleet 1888: 148). In this praśasti to Yaśodharman's superiority over Mihirakula, the poet Vāsula remarks that Mihirakula did not render homage to anyone else except Śiva (Sthānu), which leads some historians (such as D.C. Sircar) to suggest that Mihirakula was indeed a Saiva ruler, ${ }^{321}$ although it seems more likely that this convention is more directly related to the importance of Siva as the family deity (istadevatā) of this branch of the Aulikaras.

Mihirakula is depicted as a violent tyrant and as a persecutor of Buddhists in the accounts of Chinese visitors to South Asia, but his rule in Gandhāra, the Punjab, and Kashmir does not appear to have had a negative impact on the growth of Buddhist monasteries. Song Yun, an official Wei envoy, visited the court of the Hephthalite (Heda) ruler in eastern Afghanistan in $519 \mathrm{CE}$ with Huisheng and continued traveling to Swat and Gandhāra in $520 \mathrm{CE}^{322}$ In contrast to the ruler of Swat, who is depicted as a diligent Buddhist vegetarian, Song Yun described the Hephthalite ruler of Gandhāra as a bloodthirsty enemy of Buddhists:

The nature of the king is violent and cruel, very often conducting massacres. He does not believe in the Buddhist faith, but well worships their own heathen gods. As all the inhabitants in the country are Brahmans who respect Buddhism by much reading the sutras, so it is deeply against their wishes that they suddenly have such a king. ${ }^{323}$

In contrast to John Marshall (1951: 1.76-7) and other historians (cited by Kuwayama 2002: 108) who claim that the Hephthalites destroyed Buddhist monasteries in Taxila and elsewhere, Kuwayama emphasizes that "no statement is made in any paragraph proving that the

${ }^{320}$ Fleet 1888: 142-150, nos. 33-34, pl. 26B-C; Sircar 1965: 418-420, no. 54.

${ }^{321}$ Sircar 1965: 419, n. 4 states unequivocally that Mihirakula was a devotee of Śiva. From a numismatic perspective, Grenet observes, “This ruler's own religious sympathies are expressed by the Shivaite trident and bull symbols prominently displayed on his coins" (2002: 211).

${ }_{322}$ There is no specific reference to Mihirakula in Song Yun's Luoyang Qielan ji (translated by Beal 1884: c; Chavannes, Édouard. 1903. "Voyage de Song Yun dans l'Udyāna et le Gandhara (518-522 p.C)." Bulletin de l'École française d'Extrême-Orient 3, 379-440; and Jenner, W.J.F. 1981. Memories of Loyang: Yang Hsüan-chih and the lost capital (493-534). Oxford: Clarendon Press, 265.

${ }^{323}$ Translated by Kuwayama 1992: 4 / 2002: 103, 109. 
Hephthalite king killed Buddhist monks or destroyed Buddhism in Gandhāra" (1992: 4 / 2002: 110). He cautions that Chinese Buddhist monks were especially concerned with "extinction of the True Law" and attributed persecution of Buddhism in Gandhāra to Mihirakula because he was a known historical figure associated with cruelty. ${ }^{324}$ Kuwayama's criticism may be applied to Xuanzang's recapitulation of Mihirakula's attempt to persecute Buddhists when he ruled Sākala (modern Sialkot in the Punjab) "several hundred years ago" (Li 1996: 114). Xuanzang described Mihirakula as "a man of talent and intelligence with a bold and furious nature" (Li 1996: 114) who ordered the destruction of Buddhism and expulsion of monks after a royal servant (rather than a learned monk) was appointed as his Buddhist preceptor. The narrative of Mihirakula's alleged persecution of Buddhism is linked with a story of his capture by King Balāditya of Magadha, whose mother spared Mihirakula from capital punishment. While it is tempting to identify Balāditya with a later Gupta ruler (such as Narasiṃha Balāditya), Balāditya was a common epithet and the story as well as Mihirakula's subsequent campaigns against Gandhāra from a base in Kashmir appear to be anachronistic. Although Mihirakula is described in the Rājataraniginī as a "royal Vetāla (vampire) day and night surrounded by thousands of murdered human beings" (Stein 1900: i.291), a major Buddhist shrine at Harwan was built during this period of Hephthalite rule. ${ }^{325}$ Despite a reputation for cruelty in several literary sources, Mihirakula and his Hūna predecessors may be compared to other "foreign successors [who] legitimated their presence in the same way that the new Indian dynasties clung to some Gupta formulae" (Williams 1982: 102). The Hūnas were probably expelled from central India by the middle of the sixth century, but continued to be perceived as foreign threats to north India from the Punjab, Kashmir and the northwestern frontiers. ${ }^{326}$

\footnotetext{
${ }^{324}$ Kuwayama 2002: 109.

325 Stein remarks that the "legendary anecdotes... reproduce faithfully the popular tradition regarding the king such as had developed in Kaśmir within a century of his death" (1900: 1.78). Kak, Ram Chandra. 1933. Ancient Monuments of Kashmir. London: India Society [reprint, New Delhi: Sagar publications, 1971] and Paul, Pran Gopal. 1986. Early Sculpture of Kashmir. Leiden: Sneldruk Enschede, 39 ff. describe the Buddhist remains at Harwan.

326 Thakur 1967: 140-163 discusses additional Buddhist (Āryamañjuśrīmūlakalpa) and Jain references to the Hūnas and Mihirakula, as well as references to the domain of King Gollas west of the Indus River in the account of Kosmos Indikopleustes (Topographia Christiana), an Alexandrian merchant who visited western India around
} 
In the aftermath of the Hūnas' departure from North India, regional dynasties contended for imperial power, but Hūna rule in pockets of the northwestern frontier continued to have a significant impact on patterns of Buddhist transmission between South Asia and Central Asia. Frantz Grenet argues that "a second Buddhist conquest of Central Asia" during the Hephthalite period was "more far-reaching than the first one in the Kushan period" (2002: 213). In support of this assertion, he refers to Pierfrancisco Callieri's identification of an early sixth-century soapstone statuette of a female playing a harp imported from Gandhara or Kashmir to Merv, where it was deposited in a stūpa with a reliquary, Brāhmī manuscript fragments, and other small figurines. ${ }^{327}$ Although an earlier stüpa may have been established in Merv sometime prior to this period, material evidence of contact between Buddhist cultures in northwestern India and western Central Asia supports Callieri's hypothesis that "the westward expansion of Budhism may therefore have profited from the temporary political subjugation of Margiana" (1996: 399) by the Hephthalites in the fifth and sixth centuries.

The Hephthalites also had an impact on the establishment of a triangular network for long-distance trade dominated by Sogdian merchants. ${ }^{328}$ Over 600 Sogdian graffiti and Bactrian inscriptions in the

530 CE. Schwartzberg, Joseph. 1992 [1978]. Historical Atlas of South Asia. Chicago: University of Chicago Press proposes that the Hūnas were assimilated into Indian society while continuing to wage wars against the Maukharis and other post-Gupta rulers of north India. The Hūnas were stereotyped as enemies to be conquered in the northern direction in epigraphic praśastis and Sanskrit literary epitomes of heroic conquests, according to Pollock 2006: 244 (referring to an inscription written during the reign of Nārāyanapāla, 875-932 CE, extolling anachronistic conquests of Hūnas by his Pāla predecessors).

${ }^{327}$ Pierfrancisco Callieri. 1996. "Hephthalites in Margiana? New Evidence from the Buddhist Relics in Merv." In La Persia e l'Asia centrale da Alessandro al X secolo. Rome: Accademia Nazionale de Lincei, 391-400, figs. 4-5. Frumkin, Grégoire. 1970. Archaeology in Soviet Central Asia. Leiden: Brill, 147-149, figs. 36-38 illustrates and briefly describes the vessel which contained these artifacts. La Vaissière concurs with Callieri in noting that "Buddhism did not spread to Merv before the 4th century, and not during the 2nd century as was previously thought" (2005: 77-78). A similar figure of a woman playing a harp on a chlorite mirror handle from Afghanistan is illustrated and discussed by Ghose, Madhuvanti. 2003 (2007). "The Impact of the Hun Invasions." Bulletin of the Asia Institute 17, 148-9, fig. 4.

${ }^{328}$ Sims-Williams, Nicholas. 1996. "The Sogdian Merchants in India and China." In Cina e Iran: Da Alessandro Magno alla Dinastia Tang. Alfredo Cadonna and Lionello Lanciotti, eds. Firenze, Italy: Leo S. Olschki, 45-67; La Vaissière, Étienne de. 2004. "The rise of Sogdian Merchants and the Role of the Huns: The Historical Importance of the Sogdian Ancient Letters." In The Silk Road: Trade, travel, war and faith. Susan 
Upper Indus valley, particularly at Shatial, indicate that long-distance commerce flourished while the Hephthalites controlled adjoining regions. ${ }^{329}$ Étienne de La Vaissière points out that the frequent appearance of the ethnonym Hun $(x w n)$ in these inscriptions "... is historically inconceivable before a conquest of Sogdiana by the Huns, followed by a period of calm and fusion beween the Sogdian population and the nomadic invaders" (2005: 81-82). ${ }^{330}$ Kuwayama attempts to attribute shifts in trade and pilgrimage routes between South Asia and Central Asia to changes in the political landscape with the rise and fall of the Hephthalites. ${ }^{331}$ Between 550-560 CE, the Hephthalites lost control of western Central Asia and Tokharistan (northern Afghanistan) to Turkish chieftains allied with the Sasanians. ${ }^{332}$ Afterwards, the sphere of Hephthalite rule was confined to the Surkhab valley (the middle course of the Kunduz River in northeastern Afghanistan), although they maintained a network of castles on routes to Bamiyan and an affiliated dynasty of Nezak Shahs held power in the Kabul valley until their defeat by the Arab general Qutaiba in 709-710. ${ }^{333}$ Following the decline of these Hephthalite successors, other local and regional dynasties emerged at important nodes in exchange networks and acted as Buddhist patrons and agents of transmission.

Whitfield, ed. London: British Library, states: “the Huns' invasions in Central Asia gave way to the sole domination of the Sogdians on the caravan routes of Central Asia" (23).

329 Sims-Williams, Nicholas. 1989-1992. Sogdian and other Inscriptions of the Upper Indus I, II. Corpus Inscriptionum Iranicarum v. 3, part 2. London: SOAS; BandiniKönig and Fussman 1997 [MANP 2].

330 "Hun" (Sogdian $x w n$ ) is well attested as a component of names in at least 15 Sogdian inscriptions from the Upper Indus (Sims-Williams 1989-92: 2.80 [glossary]). La Vaissière 2005: 82-83, 87, 108 proposes that an absence of Hun patronyms may indicate that Sogdian merchants ceased to use routes through the Upper Indus when the Hephthalites split the Kidāra kingdom in the first half of the 5th century, but such a short chronology for the Sogdian presence in the Upper Indus region is unlikely.

${ }^{331}$ Kuwayama ties a "drastic change" $(2002: 149,194)$ in the itineraries of Chinese pilgrims and Indian monks from earlier routes through the Karakorum and eastern Hindu Kush to later patterns of travel through the western Hindu Kush (particularly Bamiyan) to the decline of the Hephthalites around $550 \mathrm{CE}$. However, Brāhmī and Proto-Saaradā inscriptions from the Upper Indus demonstrate continuous movement through the 7 th century instead of a disruption in the 6th century. The epigraphic evidence from northern Pakistan is treated in greater detail in Chapter 5: Capillary Routes in the Upper Indus.

${ }^{332}$ Grenet 2002: 213, 221; Kuwayama 2002: 210.

${ }^{333}$ Grenet 2002: 214-218; Kuwayama 2002: 194-199, 211-221. 


\section{Palola Șāhis of Gilgit: Élite Patrons in a Buddhist Enclave}

The Palola Șāhis, a local dynasty of rulers in Gilgit from the late sixth to early eighth century CE, supported the production of Buddhist Sanskrit manuscripts and bronze sculptures at an important administrative and cultural hub in a network of deep valleys in the Karakorum mountains. Manuscript colophons, stone inscriptions, and inscribed bronze sculptures serve as primary sources for Oskar von Hinüber's reconstruction of the chronology and genealogy of this family of Buddhist patrons. ${ }^{334}$ A collection of manuscripts discovered in 1931 west of Gilgit near the village of Naupur in the Kargah valley clearly demonstrates that local Buddhist literary culture flourished during this period. The extensive range of Buddhists texts, including 532 folios of the Mülasarvāstivāda-vinaya, represented in the Gilgit manuscripts seems likely to have belonged to a monastic library, despite arguments to the contrary by Gérard Fussman and Gregory Schopen based on an absence of architectural evidence of monastic structures. ${ }^{335}$ Although absolute dates for the manuscripts can not be determined, Hinüber proposes a terminus ante quem around $630 \mathrm{CE}$ based on the use of the so-called Round Brāhmī script before its replacement by ProtoSāradā. ${ }^{336}$

${ }^{334}$ Hinüber, Oskar von. 2004. Die Palola Șāhis: ihre Steininschriften, Inschriften auf Bronzen, Handschriftenkolophone und Schutzzauber: Materialien zur Geschichte von Gilgit und Chilas. ANP 5. Mainz: Philipp von Zabern.

${ }_{335}$ Fussman, Gérard. 2004. "Dans quel type de bâtiment furent trouvés les manuscrits de Gilgit." Journal Asiatique 292, 101-150 dismisses earlier identifications of the quadrangular tower that contained the manuscrips as a "hollow stūpa" belonging to a royal monastery and instead suggests that it was the dwelling or chapel of an individual eremitic Buddhist teacher (äcärya) or a lineage of teachers. Schopen, Gregory. 2009. "On the Absence of Urtexts and Otiose Ācāryas: Buildings, Books, and Lay Buddhist Ritual at Gilgit." In Colas and Gerschheimer, eds. 2009: 189-219 rejects Fussman's theory that this building served as a residence and chapel for Buddhist monks who performed protective or healing rituals, and instead conjectures "... that it was a kind of sacred workshop, a combination of genizah and scriptorium, where old, unusable, or returned manuscripts (i.e., those with donor colophons or donors' names in them) were kept, along with some master-copies, and where new manuscripts were manufactured and were for sale (i.e., those without donor-colophons or donors' names in them)" (2009: 203). Manuscripts and other materials were excavated by Kaul Shastri, Madhusudan. 1939. "Report on the Gilgit Excavation in 1938." Quarterly Journal of the Mythic Society 30.1, 1-12 + pls. 1407-1434. Another substantial collection of 454 folios of a Sanskrit Dìrghāgama manuscript was reportedly recovered from the site in 1998 (Fussman 2004: 104, n. 8).

${ }^{336}$ In support of ca. $630 \mathrm{CE}$ for the transition from Round Brāhmī to Proto-Saāradā, Hinüber refers to the colophon of a Samghàta-sūtra Proto-Śāradā manuscript dated in year three (samvatsare tritiye 3) of an unspecified era (2004: 25-26, no. 10), which 
Names of early Palola Șāhi rulers, family members, and court officials appear among the lists of donors in colophons of Buddhist manuscripts and dhäranīs (brief textual formulae conferring protection and other benefits). ${ }^{337}$ Three rulers, Vajrāditya-nandin, Vikramādityanandin, and Surendravikramāditya-nandin, are listed along with their wives among the donors of Mahāyāna sūtras in formulae beginning with the phrase: "this religious offering" (deyadharmo yam or devadharmo yam). ${ }^{338}$ Various forms of the name of the Palola Șāhi successor Navasurendrāditya-nandin is written in three Mahāmāyūri fragments and incorporated into copies of the Vimaloṣnișa dhärañ. ${ }^{339}$ As co-donors who received religious merit for their sponsorship of Buddhist manuscripts labeled as "religious offerings" and as donors whose names have been inserted into dhāranīs, Navasurendra, his Palola Șāhi predecessors, their wives, and courtiers participated in the Mahāyāna 'Cult of the Book' in which devotees worship the Buddha's dharmakāya by following exhortations to have many of the sūtras preserved in the Gilgit Sanskrit manuscripts written down.

Navasurendra has full imperial titles in a Sanskrit stone inscription at Hatun in the Ishkoman valley written in the Proto-Śāradā script and dated in year 47 of the Laukika era, corresponding to $671 \mathrm{CE} .{ }^{340}$

would correspond to $627 / 8 \mathrm{CE}$ if calculated according to the same century of the Laukika era as the Hatun inscription of year 47 (671 CE) and the Dainyor inscription of year 62 (687 CE). Hinüber's terminology is adopted here, although "Round Brāhmī" is also referred to as "calligraphic ornate script" or "Gilgit/Bāmiyān Type I," which is distinguished from "Gilgit/Bāmiyān Type II" (Proto-Śāradā) by changes in writing the character for ya. Sander, Lore. 1989. "Remarks on the Formal Brāhmì of Gilgit, Bāmiyān and Khotan.” In Jettmar, ed. 1989 [ANP 1]: 107-130 comments on the paleography.

${ }_{337}$ Hinüber 2004: 12-27, 77-83 supercedes earlier studies by Hinüber, Oskar von. 1979. Die Erforschung der Gilgit-Handschriften. Nachrichten der Akademie der Wissenschaften in Göttingen. Philologisch-historische Klasse I, no. 12. Göttingen: Vandenhoeck \& Ruprecht, 329-360; Hinüber, Oskar von. 1980. "Die Kolophone der Gilgit-Handschriften.” Studien zur Indologie und Iranistik 5-6, 49-82; Hinüber, Oskar von. 1981. "Namen in Schutzzaubern aus Gilgit." Studien zur Indologie und Iranistik 7, 163-170; and Hinüber, Oskar von. 1983b. "Die Bedeutung des Handschriften-fundes bei Gilgit." In Zeitschrift der Deutschen Morgenländischen Gesellschaft, Supplement 5. XXI Deutscher Orientalistentag, March 24-29, 1980. Wiesbaden: Franz Steiner, $47-66$.

${ }^{338}$ Hinüber 2004: 86-89, nos. 6-9.

339 Kaul Shastri 1939: 8-9; Hinüber 1981: 167; Hinüber 2004: 12-16, 89-90, nos. 1-4; Schopen, Gregory. 1985b. "The Bodhigarbhālañkāralakṣa and Vimaloṣnịṣa Dhāraṇīs in Indian Inscriptions. Two Sources for the Practice of Buddhism in Medieval India." Wiener Zeitschrift für die Kunde Südasiens 29, 141-145 (= Schopen 2005: 332-336).

${ }_{340}$ Chakravarti, N.P. 1953. "Hatun Rock Inscription of Patola-deva." Epigraphia Indica 38: 226-231; Fussman, Gérard. 1993b. "Chilas, Hatun et les bronzes boud- 
The inscription records the excavation of an irrigation canal and the founding of a town by Makara Simgha, an official under the Palola Șāhis who simultaneously held the titles of Great Treasurer, Supreme Minister, Great Chief of the Feudatories, and Military Commander of Gilgit. ${ }^{341}$ Another damaged Sanskrit inscription at Dainyor, near the confluence of the Gilgit and Hunza rivers, with the name of his succesor, Jayamangalavikramāditya-nandin and dated in Laukika era year 62 corresponding to $687 \mathrm{CE}$, may have recorded a land grant, but the details remain uncertain. ${ }^{342}$ The distribution of graffiti inscriptions with names of people with Palola titles or ethnonyms located near the confluence of the Gilgit and Indus rivers at Alam Bridge and at various sites in the Chilas plain of the Upper Indus suggests that the Palola Sāhis exerted considerable influence in the Gilgit valley and surrounding areas of northern Pakistan in the seventh century. ${ }^{343}$

Numerous bronze sculptures inscribed with names of Palola Șāhi queens, kings, and family members with dates in the seventh and eighth century attest to their direct patronage of a local atelier. ${ }^{344}$ The earliest inscriptions record donations of an image of the Buddhist goddess Prajñāpāramitā holding a manuscript (labeled as a Perfection of Wisdom text) by Mangalahamsikā, the Chief Queen of Vajrādityanandin, who belongs to the early seventh century [Fig. 2.4]. ${ }^{345}$ The pedestals

dhiques du Cachemire." In Jettmar, ed. 1993 [ANP 2]: 4-19; Hinüber 2004: 48-52, no. 22, ills. 18-19; Stein, Marc Aurel. 1944. "Archaeological Notes from the Hindukush Region.” Journal of the Royal Asiatic Society, 5-14. His titles are: Paramabhatțāraka Mahārājādhirāja Parameśvara Pațola Deva Șāhi.

${ }^{341}$ These titles contain the earliest reference to the toponym of Gilgit (Giligittā) and Makara Simgha is described as Kāñjuti (Kañudīya), an ethnonym still applied to Burushos, as recognized by Stein 1944: 9 and Fussman 1993b: 14, n. 6. Fussman 1993b: 15 comments that Iranian sarāmgha (Persian sarhanga/ Middle Iranian srhng "hero") demonstrates local adoption of non-Indian titles.

342 Hinüber 2004: 52-57, no. 23, ills. 20-23.

${ }^{343}$ Hinüber 1989a: 64-65, no. 64, pl. 131; Hinüber 2004: 46-47, 57-62, nos. 18-21, $24-29$.

${ }^{344}$ Fussman 1993b: 39-47, pls. 30-31; Hinüber 2004: 28-42, 190, nos. 11-16, Addendum; Hinüber, Oskar von. 2007. "Three New Bronzes from Gilgit. "Annual Report of the International Research Institute for Advanced Buddhology at Soka University 10. 39-44; Hinüber, Oskar von. 2009. "More on Gilgit Bronzes and some Additions to 'Die Palola Șahis.'” Annual Report of the International Research Institute for Advanced Buddhology at Soka University 12, 3-6.

${ }^{345}$ Hinüber 2007 has published donative inscriptions of Mangalahamsikā (not included in Hinüber 2004). The copper alloy sculpture (41 cm in height) of Prajñāpāramitā is illustrated in Sotheby's auction catalog of Indian and Southeast Asian Art (1 April, 2005: 60, no. 5) and another pedestal inscription recording a donation by Queen Mangalahasrikā (identical with Mangalahamsikā) together with Śrī Paṭoladeva Șāha Vajrādityandin, Torabhațārikā, and the treasurer Raṇādhira is in the collection 


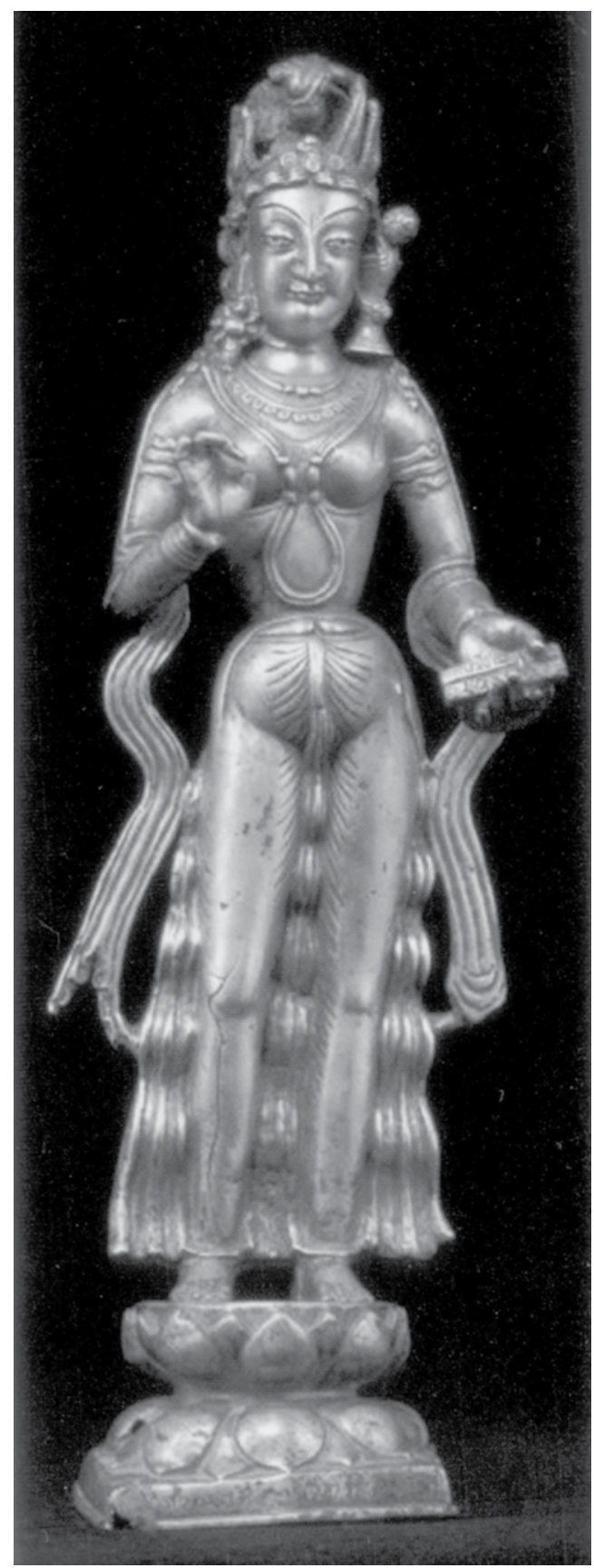

Figure 2.4: Bronze image of Prajñāpāramitā, donated by Mañgalahamsikā, Chief Queen of Vajrādityanandin (Source: Hinüber 2007, plate 1) 
of small bronze images of the Buddha are inscribed with the name of Surendrādityanandin and dated during the reign of Navasurendra in 645-645 CE. ${ }^{346}$ Jayamangalavikramāditya-nandin, the Palola Ṣāhi ruler known from the Dainyor inscription of $687 \mathrm{CE}$, donated a very large bronze sculpture of a seated Buddha dated in 706/7 (Laukika year 82) and another standing Buddha along with his wives, children and courtiers. ${ }^{377}$ His successor, Nandivikramāditya-nandin, donated two exquisite bronze images dated in 714 and 715 CE (Laukika years 90 and 91). ${ }^{348}$ In the earlier image, a jeweled Buddha acknowledges the patronage of this Palola Șāhi ruler by placing one hand on his head while holding a manuscript in the other hand. In the second image, the ruler himself holds a manuscript, perhaps reflecting the role of his family in Buddhist literary production. Another ornate bronze sculpture dated just one week prior to Nandivikramāditya-nandin's inscribed bronze of $714 \mathrm{CE}$ was a gift of the princess Devaśri and her husband, the treasurer Samkarasena, who are depicted in postures of reverence kneeling on lotuses and holding wreaths and incensers at the base of the sculpture. ${ }^{349}$ These dated bronze images donated by Palola Șāhi rulers and their families belong to a larger group of Buddhist bronze images that were produced by a local atelier of artists whose output demonstrates important links between the stylistic heritages of Gandhāra and Swat and traditions of Buddhist art in Kashmir and Tibet.

of the Rubin Museum of Art (New York). Earlier forms of tripartite $y a$ and the later Proto-Sāradā form both appear in the latter inscription. Paramadevi Maṃgalahasirika and Śrī Pațoladeva Șăhi Vajrādityanandi are listed as co-donors in a colophon preserved on a single folio of an unknown text (Hinüber 2004: 24-25, no. 9).

${ }^{346}$ Hinüber 2004: 190, pl. 36 notes that the $14.3 \mathrm{~cm}$ Buddha of Surendrādityanandin was brought from Tibet to the Qing/Manchu court, and is now included in the Collection of the Treasues of the Palace Museum in Beijing, China. The Buddha of Laukika year $20+$ (the inscription on the pedestal is broken after the numeral 20) was donated by Varșa, the son of a treasurer, during the reign of Navasurendra, who is known from dhäranīs and the Hatun inscription of $671 \mathrm{CE}$ (Laukika year 47).

347 Hinüber 2004: 31-38, nos. 12-13. These sculptures now in the Jhokang Palace in Lhasa and Tsaparang were probably brought to Tibet following the downfall of the Palola Șāhis during the period when Gilgit and surrounding valleys in northern Pakistan were occupied by a Tibetan military force between 720-745 CE.

${ }^{348}$ Fussman 1993b: 40-43, pl. 30; Hinüber 2004: 38-42, nos. 14, 16, pls. 5, 7; Paul 1986: 202-218.

${ }_{349}$ Fussman 1993b: 43-7, pl. 31; Hinüber 2004: 39-40, no. 15, pl. 6; Paul 1986: 219-243. 
Shortly after the heyday of Buddhist patronage by the Palola Șāhis in the beginning of the eighth century, their realm became a key battleground in the struggle between the Tibetan and Chinese empires for control of long-distance routes through the high mountain borderlands. After Little Bolor (presumably controlled by the Palola Șāhis) made an alliance with Tang China in 717 CE to deter growing Tibetan influence in the Karakorum and Pamir mountains, Tibetan forces occupied the region in 722 and $737 .{ }^{350}$ Huizhao (Hye Ch'o), a Korean monk who traveled from Kashmir to Bolor, reported that Greater Bolor was controlled by Tibetans and Lesser Bolor was under Chinese dominion before $727 \mathrm{CE}$ :

Greater Bolor was originally the place where the king of Lesser Bolor resided. It was because the Tibetans have come that he fled and shifted his residence to Lesser Bolor. The chiefs and common people remained and did not come. ${ }^{351}$

In $747 \mathrm{CE}$ a Chinese expedition of 10,000 men led by the Korean general Gao Xianzhi crossed the Pamirs and defeated a Tibetan garrison in the Wakhan valley of present-day northeastern Afghanistan. ${ }^{352}$ The Chinese force reached Gilgit through the Yasin valley and subsequently conquered the capital of Baltistan (Great Bolor), located at present-day Katsura near Skardu, in $753 .{ }^{353}$ As a result of the intense conflict between Tibet and China for control of this strategic region in the middle of the eighth century, the Palola Șāhi dynasty disappeared, but religious and cultural exchanges between this region, Central Asia, and the Tibetan plateau are likely to have intensified. ${ }^{354}$

\footnotetext{
${ }^{350}$ Beckwith, Chistopher. 1987. The Tibetan Empire in Central Asia: A History of the Struggle for Great Power among Tibetans, Turks, Arabs, and Chinese during the Early Middle Ages. Princeton: Princeton University Press, 95-116; Hinüber 2004: 97-98; Jettmar, Karl. 1993. "The Patolas, their Governors and their Successors." In Jettmar, ed. 1993 [ANP 2]: 84.

${ }^{351}$ Yang Han-sung, et al. (translator). 1985. The Hye-Ch'o Diary: Memoir of the pilgrimage to the five regions of India. Berkerly: Asian humanities press, 48.

352 Beckwith 1987: 131 ff.; Stein, Marc Aurel. 1922. "A Chinese Expedition across the Pamirs and Hindukush, AD 747." Geographical Journal 59, 122-131.

${ }^{353}$ Stein 1922: 112ff.; Jettmar 1993: 84-91.

${ }_{354}$ Bru-za (or 'Bru-zha/Drusha), corresponding to Little Bo-lu-luo in Chinese sources and Bolor in Arabic and Persian sources, is related to the ethnonym Burusho and the Burushaski language still spoken in Hunza, Nagar, and Yasin (Beckwith 1987: 116, fn. 44). Padmasambhava's links with Swat (Uḍdiyāna) and the foreign origins of the Bon religion in Bru-za (Gilgit region) are probably literary tropes. Nevertheless, Stein, R.A. 1972 [1962]. Tibetan Civilization. Stanford: Stanford University Press, observed: "one cannot but be struck by the stress both Buddhist and Bonpo tradition lays on
} 
Table 2.5: Genealogy and Chronology of the Palola Șāhi Dynasty ${ }^{355}$

\begin{tabular}{ll}
\hline Ruler: & Date: (Laukika year in parentheses) \\
\hline Vajrāditya-nandin & ca. $585-605$ \\
Vikramāditya-nandin & ca. $605-625$ \\
Surendravikramāditya-nandin & ca. $625-644 / 655$ \\
Navasurendrāditya-nandin & ca. $644 / 655-685$ \\
Jayamañgalavikramāditya-nandin (I) & ca. $685-710$ \\
Nandivikramāditya-nandin & ca. $710-715$ \\
Surendrāditya & ca. $715 / 720-?$
\end{tabular}

The singular patronage of Buddhist literature and art by the Palola Șāhis in Gilgit contrasts with complex patterns of support for religious institutions affiliated with multiple traditions by their northwestern neighbors and North Indian contemporaries. The survival of at least eight Buddhist monasteries in Gilgit long after the period of the Palola Saahis is attested in a Khotanese Saka account of an itinerary from the Tarim Basin (via Gilgit) to Kashmir during the reign of Abhimanyugupta (958-972 CE). ${ }^{356}$ However, the number of small monasteries in Gilgit and other places along the route through the Upper Indus region pales in comparison to countless small monasteries and a large monastery with a dharmarāja stūpa and five hundred rock cells in Kashmir. While overlapping with the period of the Palola Șanhis, the Kārkotas (ca. 625-855/6 CE) ruling in Kashmir identified themselves as Vaiṣnavas, but continued to establish and support numerous Buddhist establishments against the backdrop of a flourishing Śaiva literary culture. ${ }^{357}$ For example, in the Räjatarangiṇi, Kalhana refers to King

Bon's foreign origins, which it locates to the south-west of Tibet where India meets the fringes of Iran" (1972: [2]35).

355 Adapted from Hinüber 2004: 99.

356 Bailey, Harold W. 1936. "An Itinerary in Khotanese Śaka." Acta Orientalia 14, 261-262; Hinüber 2004: 74-76; Skjærvø, Prods O. 2002. Khotanese manuscripts from Chinese Turkestan in the British Library: a complete catalogue with texts and translations. Corpus inscriptionum Iranicarum, 6. London: British Library, 524-6 (IOL Khot. S. 21).

${ }^{357}$ The account of the Karkoța dynasty of Kashmir in Kalhana's Räjataranigini (Book 4) is analyzed and translated by Stein 1900: 1.87-97, 120-185. Inden, Ronald. 2000. "Imperial Purānas: Kashmir as a Vaiṣnava Center of the Words." In Inden, Ronald B., et al. 2000. Querying the Medieval: Texts and the history of practices in South Asia. Oxford: Oxford University Press, 29-98 and Sanderson 2009: 60-61, 73, 298-300 offer very different interpretations of the religious history of Kashmir under the Kārkotasas based on the perspectives of their respective foci on Vaiṣnava purānas 
Lalitāditya Muktāpịda's construction of Vaiṣnava temples and Buddhist monasteries, which shared the same complexes at Huskapura and his royal capital at Parihāsapura:

At Huskapura this noble-minded king built the splendid [shrine of Viṣnu] Muktasvāmin and a large Vihära with a Stüpa. (4.18) 358

At Parihāsapura ("which mocked the residence of Indra"):

That king, who was free from passions, built the ever-rich Rajjavihära [royal monastery] with a large quadrangle (catuhśālā), a large Caitya, and a large Jina [Buddha image]. (4.200)

Into the image of Muktākeśava [Viṣnu] he put 84,000 tolakas of gold. (4.201).

And collecting as many thousands of of palas of silver, that pure-minded [king] made the famous [statue of] Parihāsakeśava [Viṣnu image]. (4.202)

With just as many prasthas of copper he made the glorious [statue of] the 'Great Buddha' (Brhadbuddha) which reached up to the sky. (4.203) 359

Although he does not refer to the Palola Șāhis, Kalhana describes relationships between the rulers of Kashmir and the Hindu Șāhis, who ruled from a capital at Udabhāndapura (modern Hund) at an important crossing of the Indus River located to the north of the modern bridge at Attock from 870-871 until 1026 CE. ${ }^{360}$ From their base, the Hindu Șāhis occupied a primary hub on routes between South Asia and Central Asia, maintained fortresses at Barikot and Udegram in the Swat valley, embellished Hindu stone temples in the Salt Range, and presumably supported local Buddhist communities until Bhimapāla, the last Hindu Șāhi, was killed in battle against the Ghaznavids.

(Viṣnudharmottara purāṇa and Nīlamata purāṇa "dialogically" studied by Inden) and Kashmir Śaiva āgama literature (mastered by Sanderson).

${ }_{358}$ Translated by Stein 1900: 1.140, who identifies this monastery with the Wukong's Moung-ti Vihära.

359 Translated by Stein 1900: 1.142, who also provides an archealogical description of the site in an appendix (2.300-303, Note F).

${ }^{360}$ Rājataranginin 5.152-155 (Stein 1900: 1.99-100, 206, 2.336-339 [Note J: The Saahi of Udabhānḍa]. For a detailed historical treatment of the Hindu Saahis, see Rehman, Abdur. 1979. The last two dynasties of the Sahis: an analysis of their history, archaeology, coinage, and palaeography. Islamabad: Centre for the Study of the Civilizations of Central Asia, Quaid-i-Azam University. Thapar 2002: 415-417 and Tripathi 1942: 339-349 provide brief but useful overviews of political history in the Northwest and Kashmir, but do not refer to the Palola Șāhis of Gilgit. 
Several northern Indian contemporaries of the Palola Șāhis remained major patrons of Buddhist institutions, but rulers who identified themselves as Buddhists generally tended to dominate peripheral border regions in the eastern subcontinent. Inscriptions issued by the Maitrakas of Valabhī, who succeeded the Guptas and Hūnas in Gujarat from the sixth to the eighth century, demonstrate complex patterns of religious patronage. The Maitrakas typically referred to themselves as Śaivas (parama-māheśvaras), but approximately a quarter of their inscriptions record donations to Buddhists (including a famous monasic center at Valabhī). ${ }^{361}$ In the account of his visit to Buddhist sites in North India, Xuanzang portrays King Harșavardhana of Kanyākubjā (Kanauj) as a major Buddhist patron and convert who was targeted by "heretics" in a failed assassination attempt, but Harșavardhana's own inscriptions and Bāna's poetic account of his deeds in the Harșacarita depict him as a Saiva. ${ }^{362}$ After his death in 647/8 CE, the Pālas of Bihar and Bengal (ca. 750-1200), who struggled with the Pratihāras of western India and the Rāsțrakūțas of the Deccan for control of the Ganga-Yamuna heartland, explicitly identified themselves as Buddhists (parama-saugata) and were responsible for constructing and expanding many of the great Buddhist monasteries in eastern India. ${ }^{363}$ However, their support for Buddhist institutions hardly precluded patronage of Saiva temples and monasteries, which flourished in a competitive religio-political environment of appropriation and mutual exchange of rituals, iconography, and esoteric ideologies. The Bhaumakaras in Orissa (ca. 736-950) and the Candras in southeast Bengal (ca. 850-1050) followed the Pāla lead in adopting Buddhist epithets while supporting a variety of religious institutions. Buddhist institutions continued to feature prominently in South Asian intellectual and cultural life, particularly in northwestern and northeastern borderland areas which served as bases for expansion across the Himalayas to Tibet and via maritime networks to Southeast Asia.

${ }^{361}$ Sanderson 2009: 72-73; Schmiedchen, Annette. 1993. "Einige Besonderheiten der buddhistischen Schenkungsinschriften unter den Maitrakas." Beiträge des SüdasienInstituts der Humboldt-Universität zu Berlin 1 ("Maitraka-Studien”), 83-108.

${ }^{362} \mathrm{Li}$, Rongxi (trans.). 1996: 141-150.

363 Davidson 2002: 51-62; Sanderson 2009: 80-117; Thapar 2003: 409-411; Tripathi 1942: 354-363. 


\section{Conclusions}

This overview of ancient and early medieval South Asian historical contexts provides a framework for understanding diachronic processes in the formation and expansion of the early Buddhist sangha across regional and cultural horizons, with a general emphasis on the northwestern frontiers of the Indian subcontinent from the time of Aśoka to ca. $750 \mathrm{CE}$. Having completed a whirlwind tour of over a thousand years of South Asian Buddhist history, a pause to reconsider the questions posed at the beginning of this chapter highlights significant patterns.

Passages from inscriptions and texts reveal that much was at stake in shaping Buddhist religious identities through the development of narratives about the historical Buddha (whose parinirvanna probably dates between 400-370 BCE), previous Buddhas, their prior lifetimes, and early followers. By drawing connections between these figures and places in particular chronological frameworks of the past, present and future, hagiographical narratives illustrate core doctrinal beliefs, situate authoritative discourses understood as buddhavacana, establish institutional precedents, justify ritual practices, and promote exchanges of material donations for religious merit. These versions of Buddhist history had important ramifications for building networks of patrons (including but not restricted to powerful rulers and wealthy merchants) and transferring real and imagined religious topologies linked with the Buddha to locations outside of his original homeland, particularly to prosperous cities and agricultural areas.

Interreligious contacts, intrareligious debates, and encounters with exogenous groups played significant roles in shaping and changing Buddhist practices and ideologies. The emergence of Buddhist traditions of renunciation and the elaboration of doctrines of karmic retribution resulted from competitive dialogues with other śramana movements (such as the Jains and Ājivikas) and later Vedic traditions undergoing processes of reformulation. Internal contestation of monastic vinaya regulations and disputed interpretations of which teachings to attribute to the Buddha caused divisions in the saingh (sanghabheda). Alternative goals and practices sytematized (to varying extents) in texts and images associated with "vehicles" (Mahāyāna and Vajrayāna) developed in response to internal and external challenges. Intercultural exchanges with migrating groups, especially in 
the borderland regions of the northwestern Indian subcontinent, had definite impacts on Buddhist material culture, as reflected in syntheses of Indian, Iranian, Hellenistic, and local features in art and architecture. Indo-Iranians, Indo-Greeks, Sakas, Kuṣānasas, and Huns who established various degrees of control over routes connecting Central Asia to South Asia greatly enhanced patterns of cross-cultural contact. Inscriptions recording donations by rulers, family members, and officials associated with these social outsiders demonstrate that their contributions to the expansion and consolidation of Buddhist institutions also aided their assimilation by providing cultural legitimation. Politial and religious dynamics were closely intertwined with social and economic changes, since Buddhist monasteries were often clustered near hubs of commerce and administration on long-distance regional routes which Indian and non-Indian rulers vied to dominate.

Religious economies of exchange based on the awarding of merit for material support of Buddhist monks and nuns had important historical ramifications within and outside of South Asia. The literary legacy of the Mauryan emperor Aśoka as a cakravartin who donated generously and exclusively to the sangha provided an exemplary model for later Buddhist rulers. However, his edicts endorsing (mostly) nonviolent victory by imperial dharma and promoting donations to other śramanas and brahmins were less univalent. Whether or not the Buddhist model of Aśoka was in fact emulated by later rulers (such as Menander and Kanișka), the normative ideal of generous patronage to Buddhist and other religious institutions required basic conditions of commercial or agricultural prosperity, which in turn depended on local, regional, and long-distance economic networks. Changing patterns of patronage and exchange affected the religious economy, since dynastic turmoil, abandonment of old routes and the development of new networks, and a general shift toward permanent endowments by merchant guilds and land grants by rulers had significant implications for the fortunes of Buddhist monasteries. Thus, paths for Buddhist transmission did not remain stable or fixed, but adapted to fluctuating economic and political conditions. 
Jason Neelis - 978-90-04-19458-8 Downloaded from Brill.com $04 / 26 / 2023$ 11:30:22AM via free access 


\section{CHAPTER THREE}

\section{TRADE NETWORKS IN ANCIENT SOUTH ASIA}

The survey of ancient and early medieval South Asian history in the preceding chapter amply demonstrates that establishing and maintaining control of trade networks and arteries of cross-cultural religious transmission was a significant impetus for political dynamics. Based on this diachronic foundation, our attention now shifts to a synchronic exploration of specific route systems in the Indian subcontinent. This treatment of transregional networks emphasizes religious and cultural geography more than economic patterns, since available literary, epigraphic, numismatic, and archaeological sources do not permit a quantitative assessment of early trade. ${ }^{1}$ The aim of retracing routes and identifying nodes is to understand how trade networks shaped patterns of Buddhist transmission and how Buddhist ideologies provided an impetus to cross-cultural mobility and material exchanges. Trade can be broadly understood as a form of exchange involving the movement of commodities with fluctuating values conditioned by a wide range of economic, environmental, geographical, social, cultural, and religious factors. Combining Karl Polanyi's general definition of trade as "the mutual appropriative movement of goods between hands" (1957: 266) with Neville Morley's sense of trade as the "movement of goods across different sorts of boundaries" (2007: 11) as starting points, this examination is more concerned with exchanges across relatively long distances and interconnections between regional nodes than with local distribution and exchange networks. ${ }^{2}$ Rather than focusing on

${ }^{1}$ Chattopadhyaya, Brajadulal. Studying Early India: Archaeology, texts, and historical issues. New Delhi: Permanent Black, 2003, 217-231 (= Chattopadhyaya, Brajadulal. 1988-89. "Trends of Research on Ancient Indian Economic History." Journal of Ancient Indian History 18: 109-131) remarks that "...quantification in any meaningful sense is not possible in ancient Indian economic history" (2003 [1988-1989]: 218). Neville Morley makes similar observations in regard to western classical antiquity: "[W]e simply lack the detailed evidence for changes in supply, demand and price of any good, let alone the market as a whole, to construct a sufficiently detailed model of the ancient economy for the application of economic analysis" (2007: 15).

${ }^{2}$ Following Morley (2007: 11), it must be acknowledged that short and long distances are somewhat arbitrarily distinguished according to political and ecological considerations. 
local contexts for the establishment and institutional growth of individual Buddhist stūpas and monasteries, this study of long-distance trade patterns seeks to clarify connections between clusters of sites within larger interregional frameworks. Since distance affects the value of both economic and religious goods, traders who acquire and carry goods between destinations can be compared with religious specialists, as they also:

... obtain materials from outside and bring them home under circumstances in which the act of moving from a locus outside to a cultural setting inside effects a symbolically significant transformation, sometimes of form, always of meaning. (Helms 1993: 105). ${ }^{3}$

The designations applied to routes used by merchants and religious travelers refer not only to their itineraries, but also to geographical regions with flexible boundaries and polyvalent socio-religious connotations. Encounters, contacts, and exchanges along these overland and maritime routes contributed to changing definitions of insiders and outsiders, demarcating norms of purity and pollution, and contrasting Buddhist and orthodox Brahminical xenologies. Patterns of religious mobility can be retraced by mapping trade networks and surveying commercial nodes.

The broad geographical and chronological scope of this chapter encompasses interregional networks that connected the overland arteries of South Asian with maritime routes across the Indian Ocean from the sixth/fifth century BCE to the end of first millennium CE. The journey commences on the Northern Route (Uttarāpatha) in the Buddhist heartland of Magadha in northeastern India and proceeds as far as the Indus River, pausing at Taxila, since regional networks of the northwestern frontiers of South Asia are examined in more detail in the following chapters. Links between the Ganga-Yamuna doāb in North India and the Deccan plateau in central and southern India are explored by following the Southern Route (Dakșinappatha),

${ }^{3}$ Mary Helms' $(1988,1993)$ emphasis on relationships between distance and the valuation of knowledge and material commodities can be compared with observations by Karl Polanyi about trade as a "method of acquiring goods that are not available on the spot" (1975: 133) and Arjun Appadurai on the role of merchants who bridge gaps between consumers' and producers' knowledge of supply and demand (1986: 42). Building on Appadurai and Helms, Graham Parker refers to specific examples of ways in which Indian commodities imported to Rome belonged to "... a system of value where geographical distance brings social prestige...” (2008: 168). 


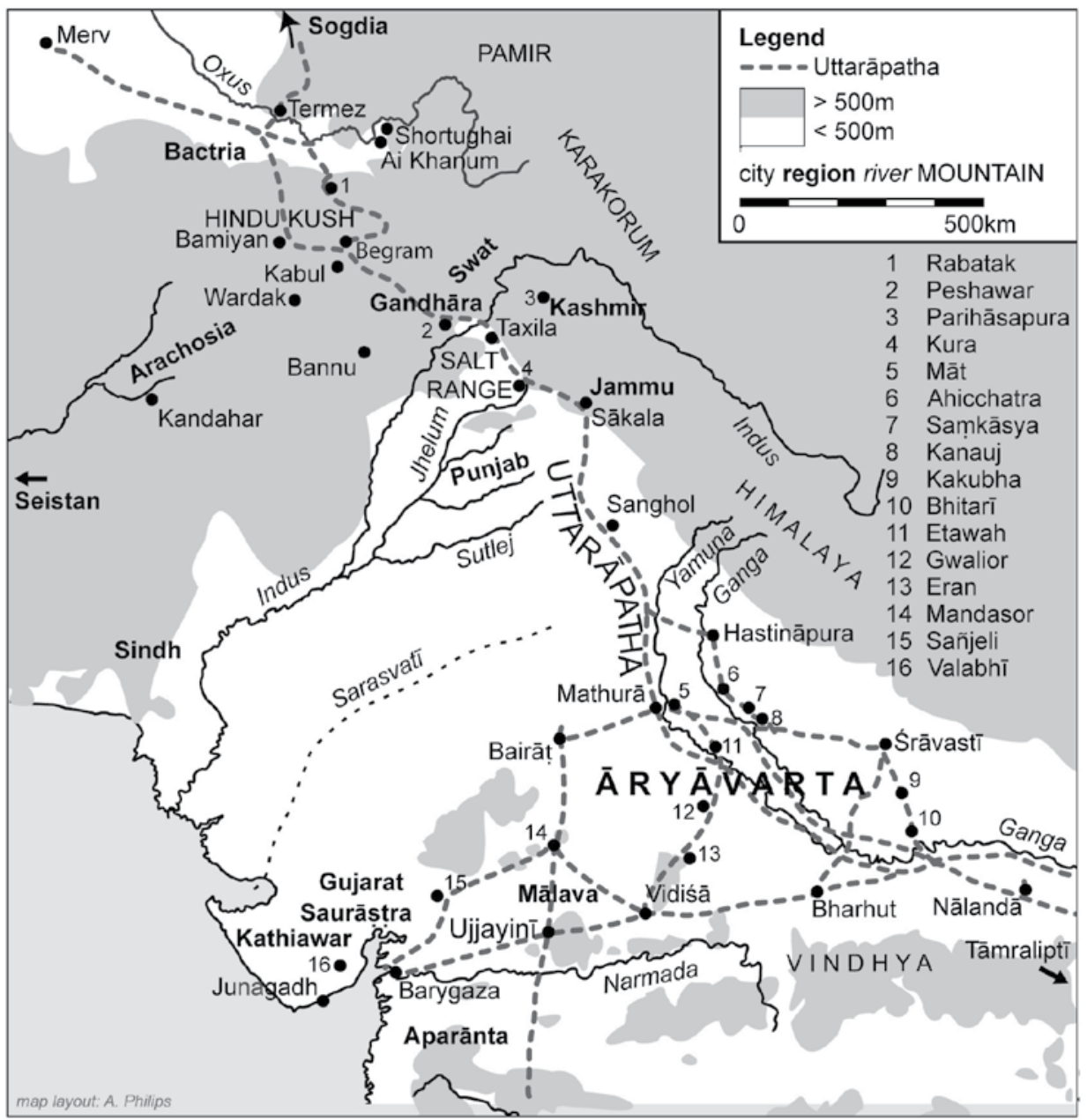

Map 3.1: Routes and Nodes of the Uttarāpatha (Sources: Chakrabarti 2001, 2005, 2007; Errington and Cribb 1992; Lahiri 1992; Schwartzberg 1992)

with a focus on the distribution of Buddhist monasteries and shrines (caityas). In the final section, Seaports and Maritime Routes, connections are drawn between the overland networks of the Indian hinterland and long-distance trade and cultural exchanges across the Indian Ocean. While it is possible to show that these overland and maritime routes belonged to "a world of networks and connections" (Morley 2007: 96), there were limits to the success of Buddhist transmission. 


\section{Northern Route (Uttarāpatha)}

The Uttarāpatha (literally the "Northern Route") was the main artery of commercial and cultural exchange between the northwestern borderlands of South Asia and the Ganga-Yamuna doāb in northern India. Rather than a single road, the Uttaräpatha was a network of constantly shifting itineraries consisting of "multiple feeder routes...intertwined with the major axis" (Lahiri 1992: 401). ${ }^{4}$ Uttarāpatha commonly designates the "North Country" or "Northern Region," encompassing territories from the Gangetic basin in northern India to Mathura, Taxila, and Bactria in northern Afghanistan and western Central Asia. Fluid literary and epigraphic references to the Uttaräpatha as a general geographical term for 'The North' overlap with its more specific and probably more original etymological meaning as the Northern Route. Textual associations of the Uttarapatha with long-distance travel and trade in a northern or northwestern direction correspond fairly well with the "archaeological reality" (Lahiri 1992: 370) of transregional contact and intercultural relationships with inhabitants of the northwestern frontier. Archaeological evidence from the middle of the first millennium BCE amply demonstrates long-distance connections and continuities in material culture throughout the northern Indian subcontinent.

The development of arterial networks for the dissemination of material culture and commodities through interregional trade exchanges was closely linked with the growth of cities in the northern subcontinent. A characteristic feature of this cultural assemblage was Northern Black Polished (NBP) ware pottery beginning around 550-400 BCE and continuing until about 100 BCE. ${ }^{5}$ Nonlocal materials including lapis lazuli from Badakhshan (northeastern Afghanistan), sandstone from Mathura, and precious stones such as topaz and amethyst provide evidence for the transport of certain raw materials over long dis-

${ }^{4}$ Lahiri, Nayanjot. 1992. The Archaeology of Indian Trade Routes up to c. 200 BC: Resource use, resource access and lines of communication. Delhi: Oxford University Press.

${ }^{5}$ Issues of urbanization and the dating and distribution of NBP are discussed in more detail in Initial Phases of the Establishment of Buddhist Communities in Early India (Chapter 2 p. 74). Sharma, Ram Sharan. 1983. Material Culture and Social Formations in Ancient India. New Delhi: Macmillan, proposes that the appearance of NBP was an outcome of the use of iron tools, which were responsible for creating an agricultural surplus and thus "prepared the ground for the rise of urban settlements in northeastern India around 600 B.C." (1983: 123). However, Chakrabarti 1995: 169 argues against an overemphasis on the role of iron technology. 
tances. ${ }^{6}$ Trans-regional movement of materials via trade routes appears to have been related to interlinked processes of urbanization and consolidation of political power in early historic South Asia. According to Georg Erdösy, Kauśāmbī and Rājag̣̣ha were distinguished from smaller settlements by functioning as nodes for the "procurement, processing and exchange of raw materials absent in the alluvial plains" (1995: 82) before ca. $600 \mathrm{BCE}$. In the ensuing period from ca. $550 \mathrm{BCE}$ to 250 $\mathrm{BCE}$, the transition to urbanized city states (janapadas) was connected to population growth, cultivation of forest lands, long-distance trade, introduction of a monetary economy, and the development of writing systems. ${ }^{7}$ Archaeological evidence confirms "a broad but indistinct picture of a network of trade routes connecting sites in ancient South Asia" (Heitzman 1984: 122), which is mirrored in Buddhist and other literary references to the Uttaräpatha.

The network of roads called the "Northern Route" connotes a loosely defined northerly region with polyvalent associations depending on geographical contexts and orientation in Indian texts and inscriptions. ${ }^{8}$ The earliest literary reference to this term as a trade route is probably the grammarian Pānini's brief allusion to goods which have been "brought via the Northern Route" (Uttarapathenāhrtam) as an example in Asțädhyāyi 5.1.77, which probably belongs to the fifth century BCE. ${ }^{9}$ Although the Northern Route is not explicitly mentioned

${ }^{6}$ Lahiri 1992: 268-323 contrasts raw materials from within sub-regions of northern India with those imported from other sub-regions, in order to demonstrate that "certain artefacts of specifically non-local origin found in the archaeological repertoires of the sites along this axis also help in amplifying the nature of movement along this route" (1992: 371).

7 Erdosy 1995: 99.

${ }^{8}$ Chandra, Moti. 1977 [1966]. Trade and Trade Routes in Ancient India. New Delhi: Abhinav Publications. (Originally published as Sārthavāha [Prācīna Bhārata kī Patha-paddhati] (in Hindi). Patna: Bihāra-Rāștrabhāṣā-Parișad, 1966), 48-89 provides a useful survey of literary references to the Uttaräpatha. Also see Joshi, Nilakanth Purushottam. 1967. Life in Ancient Uttaräpatha: Material civilisation of northern India from c. 200 B.C. to c. 300 A.D. as revealed by the sculptures, terracottas, and coins. Varanasi: Hindu Vishvavidyalaya Nepal Raja Sanskrit series for an assessment of material evidence. I address epigraphic and textual meanings of the 'Northern Route' in forthcoming articles: "Overland Shortcuts for the Transmission of Buddhism." In Highways, Byways, and Road Systems in the Pre-Modern World, ed. John Bodel, Sue Alcock and Richard Talbert (Malden, MA: Blackwell/Oxford); and "Polyvalent Perceptions of the Uttarappatha: Archaeological sources, epigraphic references, and literary demarcations." In Revisiting Early India through Epigraphy and other Texts, ed. Suchandra Ghosh, et al. Calcutta.

${ }_{9}$ For this passage demonstrating the application of $-k a$ suffixes, see Böhtlingk, Otto (editor and translator). 1886. Pānini's Grammatik. Leipzig: Haessel (reprints, 
in inscriptions of Aśoka, the distribution of his rock edicts at junctions of trade routes and in the border areas of the Mauryan empire demonstrate an extensive administrative system in the middle of the third century BCE [Map 2.2: Distribution of Aśokan inscriptions]. ${ }^{10}$ Passages in rock edicts and pillar inscriptions demonstrate that facilities for long-distance travelers were constructed on this imperial road network. In the second major rock edict, Aśoka ordered wells excavated and trees planted for both humans and animals on long-distance routes. ${ }^{11}$ An expanded version of this order is recorded in a version of his seventh pillar edict inscribed on a pillar brought to Delhi from Toprā in Haryana by Fīrūz Shāh Tughluq around 1368 CE:

On the roads I have had banyan trees planted, which will provide shade for animals and men. I have had mango groves planted and I have had wells dug and rest houses built every nine miles. And I have had many watering places made here and there for the use of beasts and men. (Thapar 1961 [1997]: 265) 12 $^{12}$

Hildesheim: Georg Olms, 1964 and Delhi: Motilal Banarsidass, 1998), 229 and Vasu, Śríśa Chandra (editor and translator). 1891-1898. The Ashtádhyáyí of Pánini. Allahabad, Indian Press (reprint, Delhi: Motilal Banarsidass, 1962), who translates: “The affix thañ comes, after the word 'uttarapatha' in the third case of construction, in the sense of 'who passes by that way' and 'what is conveyed by that way"' (1962 [1891]: 2.878). The passage is also discussed by Agrawala, V.S. 1963. India as Known to Pānini: A study of the cultural material in the Ashțādhyāyin. Varanasi: Prithvi Prakashan, 244-5, Lahiri 1992: 369, and Chandra 1977: 53. Although Pānini is usually dated between ca. 500-400 BCE, Bronkhorst 2007: 177-206 argues for a later date in or after the middle of the fourth century BCE, rejecting the consensus view that Pạnini's Asțādhyāyì necessarily postdates Late Vedic texts such as the Rgveda Prātiśäkhya and Nirukta.

${ }^{10}$ See Legacy of the Mauryans: Aśoka as Dharmarāja in Chapter 2 pp. 78-94, esp. $81 \mathrm{ff}$. Fussman observes that the Major Rock Edicts issued 12-13 years after Aśoka's consecration "are all posted near road junctions and important sites and on the perimeter of Empire, often even on the frontier" (1987-88: 68). Thapar 2003: 196 proposes a "hub model" with metropolitan Magadha at the central core, but Fussman (1987b: 66-7, Figs. 3-4) suggests alternative patterns of regional transmission from centers at Taxila, Ujjayinī and Suvarnagiri. Falk also notes that Major Rock Edicts are generally located at important crossings, in border areas, and near ancient city sites (2006: 111), but offers an alternative explanation for the location of sixteen Minor Rock Edicts at places associated with pilgrimages (yātras), fairs (melās), gatherings (samājas), and other local cultic activities (2006: 55-58). Thapar 1961: 228-238 (Appendix III “The Geographical Locations of the Edicts") is a useful treatment of the religious, economic, and administrative significance of the placement of Aśokan inscriptions on travel routes, at religious centers, and near cities. Also see Allchin 1995: 198-200, fig. 10.2, Allchin, F.A. and K.R. Norman 1985. "Guide to the Aśokan Inscriptions." South Asian Studies 1: 43-50, Lahiri 1992: 379; and Salomon 1998: 133-140.

${ }^{11}$ Hultszch 1925: 4; Thapar 1961: 251.

12 Although Hultszch $(135$, n. 2) translates nimsi[d ha]ya as "flights of steps (for descending into the water)" Thapar's translation as "rest houses" is supported by parallels noted by Bühler (cited by Hultszch) for nișidiyā in the Nāgārjunī Hill cave 
The epigraphic evidence of Aśoka's inscriptions clearly indicates that roads were maintained in order to facilitate long-distance travel, both by his administrative agents and armies, but also probably by merchants and Buddhist monks who circulated between urban centers and religious sites associated with the Buddha's life and significant early monasteries. This network was also used for military and political expansion by other northern Indian dynasties and by groups of foreign rulers from the Northwest such as the Indo-Greeks, Sakas, and Kușānas.

Descriptions of a route from the northwestern frontier to the mouth of the Ganges in Western classical literature provide further evidence of a major route across ancient northern India. ${ }^{13}$ Megasthenes' report of a royal road with pillars to mark distances and junctions is quoted by Strabo (Geography 15.1.11, 15.1.50) and probably served as a partial source for a detailed account by Pliny the Elder (23/4-79 CE) in Natural History (6.62.1-6.62.4). ${ }^{14}$ Pliny the Elder seems to have followed Megasthenes in noting that markers along the route indicated distances and junctions with other routes and that officers were in charge of maintaining roads, but he also included contemporary first century CE sources of information about stations on the main artery from Puṣkalāvatī to Pāțaliputra:

1. Peucolatis (Sanskrit Puṣkalāvatīi, identified with modern Charsada)

2. Hydaspes (Jhelum) River

3. Hypasis (Beas) River

4. Sydrus (Sutlej) River

5. Yamuna River

inscriptions and nisidiyā in the Hāthigumphā inscription of Khāravela. See Falk 2006: 215-219 for traditions about Fìrūz Shāh's installation of the pillar in the Firoz Shah Kotla after transporting it from Toprā (original location uncertain).

${ }_{13}$ Rawlinson, H.G. 1926 [1916]. Intercourse between India and the Western World, from the earliest times to the fall of Rome. 2nd ed. Cambridge: University Press 42-3, 64-5; Warmington, E.H. 1928. The Commerce between the Roman Empire and India. Cambridge: University Press, 31, fn. 84.

${ }^{14}$ McCrindle 1877: 50 (Megasthenes Fragment 4 referring to a royal road 10,000 stadia in length), 86 (Megasthenes Fragment 34 with details about roads constructed with pillars every 10 stadia to show "byways and distances"). Eggermont 1966: 277 argues that Megasthenes was used as a source by Pliny the Elder in combination with a longer list of cities similar to those found in Ptolemy's Geography (7.1.42 ff.), a 2nd century CE Greek work. For Ptolemy's list, see McCrindle, J.W. (translator). Ancient India as described by Ptolemy. Calcutta: Thacker, Spink \& Co. 1885: 152-155; Renou, Louis (editor and translator). 1925. La géographie de Ptolémée. L'Inde. (vii, 1-4). Paris: É. Champion; and Sircar 1967a: 121-143. Parker discusses the use of Megasthenes as a source by later western classical authors (2008: 42-48) and the account of India in Pliny's Natural History (2008: 78-80), which has a complicated history of excerpting and anthologizing in the process of textual transmission. 
6. Ganges River

7. Rhodopha (identification uncertain)

8. Callinipaza (Kanyākubjā or Kanauj?)

9. Confluence of the Ganges and Yamuna

10. Palibothra (ancient Pāțaliputra, modern Patna)

11. Mouth of the Ganges

In outlining these overland itineraries in South Asia, Megasthenes, Strabo, Ptolemy, and Pliny the Elder may have been influenced by the model of an Achaemenid Royal Road developed by earlier writers such as Ctesias and Herodotus. ${ }^{15}$ Nevertheless, descriptions of a main road through the northern Indian subcontinent in western classical sources provide some hints about the location of the Northern Route, although the arteries, places, and peoples broadly associated with the Uttarāpatha fluctuated considerably in Indian literary sources.

Sanskrit epics use Uttarāpatha (or Udīcyapatha) as a geographical term for the northwestern borderlands of the "Âryan heartland" (Āryāvarta). The Mahābhārata and Rāmāyana contain many episodes of travel, pilgrimage, and conquest in northern India, but do not refer to the Uttarāpatha as "a grand trunk route uniting diverse sections of the subcontinent" (Lahiri 1992: 369). The North is conventionally included in 'conquests of directions' (digvijaya) in which kings claim to have subjugated the borderlands of their realms by conquering adversaries in all cardinal directions. Such claims of conquest, symbolically re-enacted in the Vedic rājasūya ceremony of royal consecration, were necessary to justify applying the imperial title of cakravartin to rulers whose domains (cakravarti-ksetra) extended to the northern direction of the Uttarāpatha. ${ }^{16}$ Arjuna's northern conquests before Yudhișthira's consecration in the Mahäbhärata (2.23ff.) incorporate mundane victories over various groups of northwestern inhabitants, including the Daradas and Kāmbojas (2.24.24), with encounters with otherworldly beings such as the Kimpurusas (2.25.1-5) before he was turned back by the gatekeepers of Uttarakuru (2.25.10-14).$^{17}$ Thus, in the epic worldview, the Uttarapatha encompasses both geographical locations inhabited by known groups and a mythical place with imagined beings.

\footnotetext{
15 See Chapter 2 subchapter: Iranian Contacts in the Northwest pp. 96-98.

16 Buitenen 1973: 1.18. Sircar defines cakravartin as "a ruler, the wheels of whose chariot move everywhere without obstruction” (1971a: 4).

17 Buitenen 1975: 2.76-85.
} 
Kālidāsa applies the model of directional conquest in his poetic eulogy of an expedition to the northern direction by Raghu, the legendary forefather of Rāma, in the Raghuvamśs (4.66 ff). Raghu's digvijaya reached the banks of Sindhu (Indus River) (4.67), or the Vañkū/Vańkșū (Oxus/Amu Darya) in important manuscript variants. ${ }^{18}$ In praising Raghu's victory over the Hūnas, whose wives he taught to blush (4.68), and his defeat of the Kāmboja princes, which resulted in rewards of tremendous amounts of gold and many fine horses (4.69-70), Kālidāsa reflects challenges to Gupta hegemony posed by the Hūnas in the fifth century and alludes to cultural motifs of wealth and horses associated with the North (Kubera's direction). The countries, rulers, and semimythical beings in the northwestern frontiers conquered by Arjuna in the Mahäbhärata and by Raghu in the Raghuvamśa epitomize claims of universal conquest in epigraphic eulogies (praśastis).

The claim by the eastern Indian Mahāmeghavāhana ruler Khāravela to have "terrified the kings of the Uttaräpatha" in an inscription at Hāthìgumphā, which probably belongs to the late first century BCE, indicates that the location of Uttarapatha was understood in geographical relation to his own domain. ${ }^{19}$ Although the identity of the northern kings is unclear due to the poor condition of the inscription, the glorification of Khāravela's campaigns against Magadha suggests that Uttarāpatha probably refers to the middle Ganges-Yamuna valley. In epigraphic eulogies of the Cālukyas and their feudatories, Pulakeśin II (died $642 \mathrm{CE}$ ) is praised for defeating Harșavardhana, the "master of all of Uttarāpatha" (sakalottarāpatheśvara). ${ }^{20}$ In the Harșacarita, a long poetic composition about Harșa’s deeds by his court poet Bāna,

${ }_{18}$ Sircar 1971a: 7; Upadhyaya, Bhagwat Saran. 1968. India in Kālidāsa. Delhi: S. Chand, 20-22.

19 The relevant passage: vitāsayati utarāpadha-rājāno is clearly read by Jayaswal, K.P. and R.D. Banerji. 1929-30. "The Hathigumpha Inscription of Kharavela." Epigraphia Indica 20: 88, l. 11 and Sircar 1965: 217, 220 n. 3, no. 91. On palaeographic grounds, Sircar dates the Hāthīgumphā inscription of Khāravela "about the end of the first century B.C." (1965: 213 n.1), whereas Jayaswal and Banerji prefer to date the inscription in the early to mid-second century BCE based partly on an uncertain identification of the Indo-Greek ruler Demetrios. The reference to Satakarni (an unspecified Sātavāhana ruler) suggests a date around the beginning of the Common Era.

${ }^{20}$ Sircar, Dineschandra. 1957. "Amudalapadu Plates of Vikramaditya I, Year 5." Epigraphia Indica 32: 176, Sircar 1983: 451-456 (Vakkaleri Copper-plate inscription of Kirtivarman II, Saka year 679, 757 A.D., line 9. Tripathi comments that the epithet sakalottaräpathanātha in Cālukya inscriptions "... was often used in a vague and loose way, and did not necessarily connote the whole of the region from the Himalayas to the Vindhya ranges" (1942: 298). 
his older brother Rājyavardhana campaigned against the Hūnas in Uttārapatha, which probably refers in this context to the Punjab or Kashmir. ${ }^{21}$ In the Rājataraingiñ $\bar{\imath}(5.215-216)$, Kalhana refers to an expedition to Uttarāpatha by Śankaravarman, who died in $902 \mathrm{CE}$ before returning to Kashmir:

Roused to anger by this [event], the king set out on an expedition himself, and after destroying Vīrānaka, proceeded full of lust [for conquest] towards the northern region (uttaräpatha).

When he had conquered numerous territories on the banks of the Indus (Sindhu), and had received the homage of [their] terror-stricken kings, he turned back from that [region]. ${ }^{22}$

This expedition by Śankaravarman appears to foreshadow hostilities between the rulers of Kashmir and the Hindu Șāhis, whose capital at Udabhāndapura (modern Hund) was vanquished by his successor. ${ }^{23}$ Therefore, the reference to Uttarāpatha in the Rajjatarangini $\bar{\imath}$ is somewhat ambiguous, since it could refer to territories northwest of Kashmir in the Upper Indus region or to areas closer to the Hindu Șāhi capital located further south. Although Kashmir is often considered part of the Uttarāpatha along with Gandhāra and other northwestern regions, the account of Śankaravarman's expedition in the Rājataraingin ì distinguishes Kashmir from its neighbors.

A ninth century inscription found near Nalanda records the life journey of a Buddhist monk from the Northwest to Buddhist shrines and monasteries in northeastern India. ${ }^{24}$ His birthplace in Nagarāhāra (modern Jalalabad in eastern Afghanistan) is praised as "an ornament to Uttaräpatha" (Kielhorn 1888: 311-2). He traveled from the Kaniṣka monastery in modern Peshawar to Bodh Gaya and was appointed to supervise a monastery in Nalanda. The inscription commemorates the erection of an edifice for a vajrāsana during the reign of the Pāla ruler

${ }^{21}$ Kane, P.V. (ed.). 1918. The Harshacarita of Bānabhațta (Text of Uchchvāsas I-VIII). Bombay: Nirnayasagara Press (Reprint, Delhi: Motilal Banarsidass, 1986), 74, 438.

22 Stein 1900: 1.214-15. Stein identifies Vìränaka with the village of Viran on the Jhelum River at and points out that it was on the frontier between Kashmir and the Khaśa kingdom (perhaps identifiable with Khaśarājya in Brāhmī inscription no. 5:2-5 at Shatial).

${ }^{23}$ The conflict between the Kashmir rulers and the Hindu Șāhis is briefly discussed in Chapter 2 pp. $178 \mathrm{ff}$.

24 Kielhorn, Franz. 1888. A Buddhist Stone-Inscription from Ghosrawa. Indian Antiquary 18: 307-312. 
Devapāla (ca. 821-860 CE). In this record, Uttarāpatha refers to the northwestern heartland of ancient Gandhāra, which remained a major Buddhist cultural center since monks like Vīradeva continued to travel from there to northeastern India as late as the ninth century CE.

The literary and epigraphic references discussed above show that the geographical position of the Northern Route fluctuated according to the viewpoints of particular sources. By excluding the borderlands of the Uttarāpatha from the "Heartland of the Āryas" (Āryāvarta) where proper Brahmans could best maintain their purity, orthodox Brahminical perspectives reflect a major shift in cultural topology away from the Northwest to the Ganga-Yamuna basin of northern India. In order to understand how this shift was related to normative processes of Brahmanical self-definition in contradistinction to impure outsiders, it is necessary to briefly recapitulate dynamic patterns of ideological marginalization in which the northwestern regions that once figured prominently in older worldviews came to be regarded as "outside of Dharma" (dharmabāhya). In earlier periods, the Punjab was evidently a central region of vedic culture, since the Rgvedic hymns (mantras) frequently refer to the Indus (Sindhu) and the 'Seven Sindhus' of the Punjab, whereas the Ganga and Yamuna rivers are mentioned only in the Nādi Sükta (Rgveda 10.75.5), which is considered to be relatively late. ${ }^{25}$ Passages mentioning other rivers, including the Kabul (Kubhā) and Swat (Suvāstu) rivers, indicate that the geographical horizons of the Rgveda extended to areas now located in northwestern Pakistan and Afghanistan. ${ }^{26}$ The earlier Upanișads were probably composed in the

25 Kāne, P.V. 1968 [1930-1962]. History of Dharmaśāstra (ancient and medioval religious and civil law in India). Poona: Bhandarkar Oriental Research Institute, vol. 2, part 1, 12 compiles references to the Sindhu (Indus River) 2.15.6, 5.53.9, 4.30.12, 8.20.25; 'Seven Sindhus' 2.12.12, 4.28.1, 8.24.27, 10.43.3; Paruṣnī (Ravi River) 4.22.2, 5.52.9; Vipāś (Beas River) 3.33.1, 4.30.12; Śutudrī (Sutlej River) 3.33.1, 10.75.5; Vitastā (Jhelum River) 10.75.5; Asiknī (Chenab River) 7.20.25, 10.75.5. The Ganga $(6.45 .31,10.75 .5)$ and Yamuna $(5.52 .17,10.75 .5)$ rivers probably belonged to the eastern periphery, since they are mentioned infrequently outside of the the Nādi sūkta (Rgveda (10.75.5). Witzel, Michael. 1987. "On the Localisation of Vedic Texts and Schools (Materials on the Vedic Śakhas 7).” In Pollet, ed. 1987: 175-176 comments on the geographical horizons of the Rgveda based on environmental and hydrographic references.

${ }^{26}$ Kubhā (Kabul River) 5.53.9, 10.76.6; Suvāstu (Swat River) 8.19.37. Falk, Harry. 1997. “The Purpose of Rgvedic Ritual.” In Witzel, Michael, ed. 1997. Inside the Texts, Beyond the Texts: New approaches to the study of the Vedas. Cambridge: Harvard University Dept. of Sanskrit and Indian Studies, suggests that the Helmand valley in Seistan (southeastern Afghanistan) may have been the home of the "proto-Rgvedc 
kingdoms of Kuru-Pañcāla and Kosala-Videha in the Ganga-Yamuna plains rather than in the Punjab or northwestern regions, while the geographical range of the later Upanișads extends from the upper Indus to the lower Ganges and from the Himalaya to the Vindhya mountain ranges. ${ }^{27}$ Thus, by the late vedic period in the middle of the first millennium BCE, a shift from the Indus and the Punjab to the Ganga-Yamuna doāb is perceptible in the expanded geographical scope of the Upanișads, which included areas of northern India not mentioned in earlier vedic samhitas.

The reorientation in religious and cultural topologies towards the Ganga-Yamuna doāb led Brahminical authorities on the Dharmasūtras and Dharmaśāstras to consider the Northwest, like Magadha in the Northeast, to be outside of Āryāvarta.$^{28}$ Rather than locating Āryāvarta in a specific geographical region, some of these authorities considered the upholding of orthodoxy and orthopraxy to be most important criterion for defining Āryāvarta. However, according to the views of other authorities cited in Baudhāyana Dharmasütra (1.2.9), Āryāvarta begins "east of where the Sarasvatī disappears" (Olivelle 1999: 134), thus effectively excluding the Punjab, the Indus River valley, and the northwestern borderlands. Opinions referred to in this passage and other Dharmasūtras either more narrowly restrict Āryāvarta to the region between the Ganges and Yamuna (1.2.10) or broaden its range to include any area between the Himalayas and the Vindhyas where the black antelope wanders (1.2.12). Later Dharma texts attempt to reconcile the flexible boundaries of Äryāvarta with notions of the 'Middle Region' (Madhyadeśa) where Brahmanical norms prevail. For example, Mānava Dharmaśästra (2.21) adopts the definition of Āryāvarta as the country between the Himalayas and Vindhyas, which encompasses the Middle Region between the confluence of the Ganges and Yamuna rivers in the East to the place of disappearance (of the Sarasvatī River) in

Aryans" (86), since economic and ecological conditions would have been suitable for sedentary pastoralism.

27 Olivelle 1996: xxxvii-xxxix.

${ }^{28}$ The position of Magadha outside of Āryāvarta is discussed in Initial Phases of the Establishment of Buddhist Communities in Early India (in Chapter 2 pp. 76 ff.). Olivelle 1999: xxxiii dates discussion of Āryāvarta in the Dharmasūtras of Baudhāyana and Vasisțha between the middle of the 2nd century BCE and the first century CE. Links between Patañjali's definition of Āryāvarta in Mahābhāsya 12.4.1and the boundaries of Madhyadeśa in Manu's Dharmaśāstra 2.21-22 are discussed by Bronkorst 2007: $1-2$. 
the West. ${ }^{29}$ In cosmographic sections of Sanskrit purānas, Āryāvarta is divided into central (Madhyadeśa), western (Aparānta or Paścāddeśa), eastern (Prācya or Pūrvadeśa), and northern (Udīcya or Uttarāpatha) regions. ${ }^{30}$ Purānic "lists of peoples" inhabiting Uttarāpatha or Udīcya refer to the Kāmbojas and Daradas together with Gāndhārans, Kashmiris, and other groups which can be localized in a geographical range extending from Rajasthan and Punjab to Afghanistan, Iran, and Central Asia. ${ }^{31}$ These references suggest that the heterogenous population of the northwestern frontiers were suspected of not correctly maintaining traditional customs and practices.

Heterodox beliefs and practices attributed to regional inhabitants who were associated with ritually impure "foreigners" (mlecchas) contributed to the marginalization of the Uttarāpatha. Sanskrit passages often contrast the borderlands of the Uttarapatha with the heartland of Āryāvarta. According to Baudhāyana Dharmasūtra 1.2.4, peculiar practices of northerners include "selling wool, drinking rum, trafficking in animals with teeth in both jaws, making a living as a soldier, and traveling by sea" (Olivelle 1999: 134). In the Mahābhārata, Karṇa rebukes Salya, the leader of the Madras in the Punjab, whose subjects are criticized for being "devoid of virtue" (dharmabāhya) since they engaged in antinomian practices:

8.30.15. They are devoid of virtue after drinking alcohol distilled from grain and molasses, eating beef with garlic, and pancakes, flesh, and figs. 8.30.16. Wearing garlands and smeared with ointment, intoxicated and banished outside the city walls, they laugh, sing and dance with women. 8.30.17. Excessively drunk, they call out to one another with various crude and crazy songs similar to the noises of monkeys. (8.30.15-17)

${ }_{29}$ Mānava Dharmaśāstra 2.21: Himavad-vindhyayor madhyam yat prāg vinaśanād api pratyag eva prayāgāc ca madhyadeśah prakīrtitah (translated by Olivelle 2004: 24). Sircar 1967: 16, n. 58 discusses references to the "disappearance" (vinaśana / adarśana) of the Sarasvatì localized near Kurukșetra in late vedic sources (Pañcavimśa Brāhmana 15.10.6; Jaiminìya Upanișad Brāhmaña 4.26) and in the Mahäbhārata (3.82.111). Sircar observes that Buddhist authors extended the boundaries of Madhyadeśa further eastwards to Kajangala (Rajmahal in eastern Bihar) and Pundravardhana (modern Mahasthan in West Bengal) "in their eagerness to include the land of the Buddha's birth and activities" (1967a:17), while medieval authors such as Rājaśekhara refer to Vārānasī (Banares) as the eastern boundary of Madhyadeśa.

${ }^{30}$ Ali, S. Muzafer. 1966. The Geography of the Puranas. New Delhi: People's Pub. House, 112-175; Sircar 1967a: 69-83; Sircar 1971a: 29.

31 Ali 1966: 138-43; Sircar 1967a: 73-76; Sircar 1971a: 32-36. 
Such passages lead Klaus Karttunen to note "... the general unorthodox character of the Northwesterners, who practice an orgiastic religion, are barbarians with no Brahmans among them and are originally thought to be degraded Kșatriyas" (1989: 202). ${ }^{32}$

Indian and non-Indic literary sources share common topoi about a wonderland of marvelous but difficult-to-attain riches and fabulous people in the distant impenetrable mountains in the northern territories on the mysterious periphery of the Indian subcontinent. Stories of gold-digging ants reported by Herodotus (3.102) may have been adopted from Indian sources, since the Mahäbhärata (2.48.4) and a Pāli commentary by Buddhaghosa (Manorathapūrañi 2.239.21) also connect ants with gold. ${ }^{33}$ A "Kingdom of Women" (Strìrājya) located in the mythical land of Uttarakuru in other Sanskrit sources is associated with the production of gold in Xuanzang's account and in Tibetan versions of the Inquiry of Vimalaprabha the heroine was a descendant of the female progenitor of the "Gold Race" (suvarnagotra). ${ }^{34}$ The fantastic legends set in the Northwest may have had some foundation, since Al-Bīrūnī (973-1048 CE) refers to gold mines in the Dardar country on the upper Indus River, where Soniwal prospectors still pan for gold, in his work on mineralogy. ${ }^{35}$ The Kürmavibhäga ("Division of Globe") in the fourteenth chapter of the Bṛhat Samhitā by

${ }^{32}$ Fussman dismisses characterizations of the impure practices of the people of this region in normative Sanskrit texts, since on the basis of these texts the majority of the Indian population would be assigned degraded status, except for orthodox Brahmans living in Madhyadeśa, "la seule Inde qui vaille" (1994a: 17, fn. 5).

${ }_{33}$ Wirth, Gerhard and Oskar von Hinüber, eds. and trans. 1985. Der Alexanderzug; Indische Geschichte: Griechisch und Deutsch. München: Artemis, 1123-1124; Buitenen 1975: 118; Karttunen 1989: 171-6.

${ }^{34}$ Sircar 1971a: $261 \mathrm{fn} .1$ refers to passages in the Skanda Purāna, Rājataranigin̄i (4.173-4), Mahābhārata, and Bṛhatsaṃhitā. Beal 1884: 1.198-199 and Li 1996: 134 translate passages about the "country of Suvarnagotra" which "produces gold of the best quality" located to the south of Khotan in the Great Snowy Mountains. Thomas, Frederick William, trans. 1963. Tibetan Literary Texts and Documents concerning Chinese Turkestan. London: Royal Asiatic Society, part 1, 137-258 translates and comments on the Inquiry of Vimalaprabhā. This source is also discussed by Jettmar, Karl. 1975. Die Religionen des Hindukusch. Stuttgart: W. Kohlhammer, 299-312, Jettmar 1993: 107-110 (= Jettmar 2002: 148-152), and Uray, G. 1979. "The Old Tibetan Sources of the History of Central Asia up to 751 A.D.: A Survey." In Harmatta, J., ed. 1979. Prolegomena to the Sources on the History of Pre-Islamic Central Asia. Budapest: Akadémiai Kiadó, 288-289.

${ }_{35}$ Bīrūnī, Abu-'r-Raiḥān Muhammad Ibn-Ahmmad al-. 1989. The Book most Comprehensive in Knowledge on Precious Stones: Al-Beruni's book on mineralogy. Kitāb al-jamāhir fì márifat al-jawāhir, translated by and Hakīm Muhammad Sậìd. Islamabad: Pakistan Hijra Council, 204. 
Varāhamihira illustrates the topos of situating 'fabulous peoples' in all directions, including fantastic dog-headed people who live in the northern direction. ${ }^{36}$ However, Varāhamihira places other groups that can be reliably located in the northern and northwestern regions in the South and Southwest instead. ${ }^{37}$ Such motifs of immense material wealth located in a region populated by outsiders whose lifestyles deviated from the social and religious norms of the Middle Country of Āryāvarta may have provided additional incentives for commercial and religious mobility, especially perhaps for itinerant traders and other groups (such as Buddhist mendicants) who were not constrained by Brahmanical prohibitions against encounters with impure 'others.'

\section{Routes and Nodes of the Uttarāpatha}

While the location and significance of the Northern Route shifts according to the geographical and cultural perspectives of literary and epigraphical sources, archaeological materials clearly demonstrate that a network of arterial routes through the northern Indian subcontinent was used for transregional interactions. An overview of major arteries and nodes belonging to this network illustrates connections between northeastern and northwestern nodes, with an emphasis on links between the cities of Mathura and Taxila. Since these arteries were interconnected, travelers were able to choose different itineraries depending on their purposes and conditions along the overland routes, which were probably linked with navigable rivers in earlier periods. The Uttarapatha split into at least three branches along an axis from the northeastern to northwestern Indian subcontinent, with numerous North-South and East-West transversal connections:

1. The northernmost route followed the foothills of the Himalayas through ancient Hastināpura, Ahicchatra, Śrāvastī, and Vaiśālì to the ancient capital of Magadha at Rajjagṛha (modern Rajgir in south Bihar). ${ }^{38}$ This artery continued from Rajgir to Campā (5 km west of modern Bhagalpur) and through the lower Ganges to the port of

36 Karttunen 1989: 185; Sircar 1971a: 69.

37 Karttunen 1989: 195, n. 10.

38 Chandra [1966] 1977: 77; Schwartzberg 1978: 19, pl. III.b.5. 
Tamralipti in the Bengal delta. ${ }^{39}$ According to Dilip Chakrabarti (1995: 212), Rajgir was a terminal point for trade routes linking the middle Ganges with the Chotanagpur plateau, which was rich in material resources, and routes to Paithan on the Godavari River. This itinerary seems to have been most widely used during the early historical period and during the lifetime of the historical Buddha.

2. A middle route in the Ganges-Yamuna doāb passed through Saṃkāsya (Pāli Saṃkassa), Kauśāmbì (near the confluence of the two rivers at Prayāga), Banaras (ancient Kāśi, modern Vārānasī), and Pătaliputra (modern Patna). ${ }^{40}$ Many nodes on this route were also popular destinations during the early historical period and continued to be prominent in post-Mauryan periods.

3. A more southerly route followed the Yamuna River through Mathura to Kauśāmbī, where it joined the middle route along the Ganges River. ${ }^{41}$ This route was probably more widely used during the first to third centuries $\mathrm{CE}$ than in earlier periods due to the growing importance of Mathura as a political and commercial center of the Sakas and Kuṣānas.

\section{Mathura}

Mathura linked East-West itineraries of the Northern Route to NorthSouth feeder routes of the Southern Route (Dakșināpatha). In an article on trade routes through Mathura from the post-Mauryan period to the Kușana period, Shiva G. Bajpai comments on the significance of Mathura's geographical position:

Situated at the western periphery of the Gangā plain on the crossroads of the principal geo-political and cultural divisions of India, the city commanded the gateway to the rich alluvial Ganga plain, to central and southern India, and to the flourishing ports on the western seaboard. It traditionally had served as the focus for the ethnic migrations from the north-west and as a conduit for their further movements to the south and west. (1989: 46) ${ }^{42}$

\footnotetext{
${ }^{39}$ Chakrabarti, Dilip K. 2001. Archaeological Geography of the Ganga Plain: The lower and the middle Ganga. New Delhi: Permanent Black, 60-190, 283.

${ }^{40}$ Chakrabarti 1995: 191-201, 209-212; Chakrabarti, Dilip K. 2007. Archaeological Geography of the Ganga Plain: The upper Ganga (Oudh, Rohilkhand, and the Doab). New Delhi: Munshiram Manoharlal Publishers, 58-88; Heitzman 2009: 193-196; Motichandra 1977: 77; Schwartzberg 1978: 19, pl. III.b.5.

${ }^{41}$ Chakrabarti 2001: 264-265; Chakrabarti 2007: 89-119; Chandra [1966] 1977: 7; Schwartzberg 1978: 24, pl. III.C.5.

${ }^{42}$ Bajpai, Shiva G. 1989. "Mathurā: Trade Routes, Commerce, and Communication Patterns, from the Post-Mauryan Period to the End of the Kuṣanna Period." In
} 
Mathura was located at the nexus of routes between the Punjab and Yamuna River valley and was directly linked to the three branches of the Uttarappatha. Another conjectural route from Mathura led to the western region of Aparānta, probably via Bairāt, and continued through modern Rajasthan southwards to the Saurāșțra peninsula in Gujarat, where Aśokan rock edicts and Sanskrit inscriptions of the Western Kṣatrapa ruler Rudradāman (ca. $150 \mathrm{CE}$ ) and the Gupta emperor Skandagupta are inscribed at Girnar. ${ }^{43}$ Feeder routes going directly south from Mathura via Vidiśā and Ujjayinī to the Southern Route and the port of Bharukaccha connected overland routes through northern and northwestern India with maritime routes to ports on the west coast. ${ }^{44}$ Since the area around Mathura was not optimal for agriculture, the prosperity of the city was due to its location at the crossroads of several trans-Indian trade routes, which enabled Mathura to become "a great clearing house of commodities" (Sharma 1989: 32) ${ }^{45}$

Long-distance trade contributed to the cosmopolitan environment of Mathura, where religious and artistic traditions flourished with the patronage of wealthy donors and powerful rulers. During the early historical period, Mathura and the neighboring city of Kṛnnapura (perhaps located downstream from Mathura at Bateshwar) were the centers of the Surrasena janapada.$^{46}$ During the Saka and Kuṣanna periods, Mathura was one of the most important administrative, commercial, religious, and artistic urban centers in northern India. ${ }^{47}$ Mathura's emergence as a major metropolis may also be attributed to military and political factors, including its role as a base for Indo-Greek expansion from the Northwest into the Ganga-Yamuna valleys and diplomatic and cultural ties between the Kssatrapa rulers of Mathura and the Saka

Srinivasan, Doris Meth (editor) 1989. Mathurā: The Cultural Heritage. New Delhi: American Institute of Indian Studies, 46-58.

${ }^{43}$ Bajpai 1989: 47; Chakrabarti 2007: 215-216; Schwartzberg 1978: 19, pl. III.B.5A. See Chapter 2 subsections on the Mauryans, Sakas, and Guptas for further discussion of the historical and religious significance of these inscriptions.

${ }^{44}$ Bajpai 1989: 48; Schwartzberg 1978: 24, pl. III.C.5.

45 Sharma, R.S. 1989. "Trends in the Economic History of Mathurā (c. 300 B.C.A.D. 300).” In Srinivasan 1989: 32-38.

${ }^{46}$ Chakrabarti 2007: 204-205 identifies modern Bateshwar with Chrysobera (Krṣnapura), which is referred to by Megasthenes as one of the two big cities of the Saurasenoi, along with Methora (Mathura). Radiocarbon dates from excavations at Sonkh, about $25 \mathrm{~km}$ southwest of Mathura, indicate that settlement there does not precede 800 BCE, according to Härtel, Herbert. 1993. Excavations at Sonkh: 2500 years of a town in Mathura District. Berlin: D. Reimer, 85.

47 Chakrabarti 1995: 295-296; Chattopadhyaya, Barjadulal 1989. "Mathurā from the Śnnga to the Kuṣāna Period: An Historical Outline.” In Srinivasan 1989: 23. 
Ksatrapas of Punjab, Taxila, Gandhāra, and Bajaur. ${ }^{48}$ Mathura also played a significant role in the administration of the Kușanna empire, which "further helped transform Mathura into a base for absorption of men and ideas from outside its orbit" (Chattopadhyaya 1989: 24). The devakula shrine at Māt across the Yamuna River from Mathura epitomizes the mixture of Central Asian, Hellenistic, and Iranian architectural and monumental statuary with Indian politico-religious conceptions of the emperor as a cakravartin who governs through the fortune of patron gods and goddesses. ${ }^{49}$ It is not surprising that the Kuṣannas chose this location for such a shrine, since Mathura was also a significant center for many Indian religious traditions, including Jainism, Buddhism, Vaiṣnavism, and devotion to Nāgas, Yakṣas, and other local deities. The impact of Mathuran art on the development of iconographic, stylistic and technical conventions for a wide range of religious imagery extended throughout northern India and probably into the Northwest. ${ }^{50}$

\section{Uttarāpatha in the Punjab}

From Mathura the Northern Route continued through the Punjab via several possible itineraries. Excavations at Sanghol in Indian Punjab between Chandigarh and Ludhiana have revealed an impressive Buddhist sacred complex with Kuṣanna period sculptures and architectural elements from Mathura. ${ }^{51}$ Another significant node on the Uttarāpatha was the city of Sankala, the capital of King Milinda (Menander) in the Milindapañha and later Mihirakula, according to Xuanzang. ${ }^{52}$ The

\footnotetext{
48 Chattopadhyaya 1989: 21; Salomon 1996: 439-443. See Chapter 2: Mathura Kșatrapas and Mahākssatrapas pp. 121-123.

${ }^{49}$ Fussman, Gérard. 1989b. "The Māt devakula: A New Approach to its Understanding." In Srinivasan 1989: 193-9, Rosenfield 1967: 140-163.; and Verardi 1983: 225-237 offer vastly different interpretations of the Mathura devakula in relation to the bagolango shrine with images and Bactrian inscriptions of Kușana rulers at Surkh Kotal in Afghanistan. At issue is whether or not this structure was really a dynastic temple.

${ }^{50}$ Czuma and Morris 1985: 7-17; Quintanilla 2007; Lohuizen De Leeuw 1949.

${ }^{51}$ Gupta, Swarajya Prakash. 1985. Kushāna Sculptures from Sanghol, 1st-2nd century A.D.: A recent discovery. New Delhi: National Museum; Ray, Himanshu Prabha, ed. 2010. Sanghol and the Archaeology of Punjab. New Delhi: Aryan Books International.

${ }^{52}$ Saakala (Pali Sāgala) may be identified either with modern Sangla near Faisalabad or with Sialkot across the border from Jammu in Pakistani Punjab. Although Sialkot is now a larger city than Sangla, Fussman 1993a: 83 supports the localization of Saakala/ Sāgala in modern Sangla because the modern name Sangla is more likely to have been derived from Sāgala than Siāl(koț). In the Mahābhärata (2.32.14) and Pali jātakas,
} 
immense stūpa at Mānikyāla, which is clearly visible from the Grand Trunk Road southeast of Rawalpindi, probably marked an important stage on the Uttarapatha close to Taxila. ${ }^{53}$ At a place about two days journey away from Taxila, Faxian describes a large stūpa commemorating Prince Mahāsattva's sacrifice of his own body in the Vyāghrījātaka, which may be identified with the Mānikyāla stūpa. ${ }^{54}$ Deposits of coins in reliquaries excavated by General Ventura in 1830 indicate that the stuppa continued to be venerated from the time of its initial establishment during the reign of Huviska in the second century CE until at least the early eighth century when it was substantially renovated. ${ }^{55}$

\section{Taxila}

The metropolis of Taxila was a major destination for military invaders, merchant caravans, students, teachers, and pilgrims coming to and from India on the Northern Route. ${ }^{56}$ Taxila emerged as the main center for political control and military administration in the northern Punjab beginning in the Achaemenid period due to its strategic location at the hub of routes from Gandhāra and Central Asia, northern India and the Punjab, and the upper Indus and Kashmir, but the

Śakala is the capital of the Madra country (Chakraborti 1966: 167-9; Law 1932: 53-4). In Xuanzang's account (Taishō 51, no. 2087, 888-889), Sākala is located in the Țakka country (Beal 1884: 1.172; Li 1996: 113-118).

53 Dar, Saifur Rahman. 1970. "Excavation at Manikyala-1968.” Pakistan Archaeology 7, 6-22 + pls. IV-VII.

${ }^{54}$ Legge 1886: 32 and Li 2002: 170 translate Faxian's account of his visit to the "place where the Buddha once gave his body to feed a starving tigress" (Taishō 51, no. 2085, 858b). Xuanzang (Taishō 51, no. 2087, 885c, translated by Beal 1884: 1.145-6 and Li 1996: 99-100) also describes a massive stone stūpa associated with the story of Prince Mahāsattva's bodily sacrifice but his localization of this narrative at "a great rocky pass" (Li 1996: 99) can not be reconciled with the topography of the area around Mānikyāla. Since Xuanzang continues his journey to Uraśā (Hazara) and Kashmir, the location of this shrine may be located elsewhere in northern Pakistan, but the geographical information seems to be confused.

${ }_{55}$ Errington and Cribb 1992: 45, 183-185, nos. 181-185.

${ }^{56}$ For archaeological evidence of long-distance trade between Taxila, India, and Central Asia, see Allchin 1995: 14-15, Callieri, Pierfrancisco. 1995. “ The North-West of the Indian Subcontinent in the Indo-Greek Period: the Archaeological Evidence.” In Invernizzi, Antonio, ed. 1995. In the Land of the Gryphons: Papers on Central Asian archaeology in antiquity. Firenze: Le lettere. 298-299, Fussman, Gérard. 1993c. "Taxila: The Central Asian Connection.” In Spodek, Howard and Doris Meth Srinivasan, eds. 1993. Urban Form and Meaning in South Asia: The Shaping of Cities from Prehistoric to Precolonial Times. Washington: National Gallery of Art, 86-7, and Marshall 1951: 1.11. On the toponym of Taxila, see Salomon, Richard. 2005b. "The Name of Taxila: Greek $T \alpha \xi_{1} \lambda \alpha$, Gāndhārī Takṣaïla, Sanskrit Takṣaśilā, Pali Takkasilā." East and West 55: 265-278. 
growth of Taxila during subsequent periods can be attributed to a wide variety of factors. ${ }^{57}$ Literary references to merchants who traveled in caravans between northern India and Taxila underscore the role of Taxila as a commercial entrepot for long-distance trade between India and Central Asia. ${ }^{58}$ The concentration of wealth in the city was likely to have attracted teachers and students, since Taxila is identified as a center for learning in Buddhist Jatakas. ${ }^{59}$ Buddhist stories about the decapitation of the head of a bodhisattva and the blinding of Aśoka's son Kuñāla encouraged pilgrims such as Faxian and Xuanzang to visit stūpas in and around Taxila where these narratives were localized. Archaeological and literary sources confirm Taxila's eminence as the most important political, economic, cultural, and religious center in the Northwest.

Several routes converged with the Uttaräpatha at Taxila, according to John Marshall, who led the excavations of sites around Taxila from 1913-1934. ${ }^{60} \mathrm{He}$ identified three main routes coming from western Asia through Bactria, from northeastern India, and from Kashmir. Since the hills to the North and the Salt Range to the South are more difficult to traverse than the Potwar plateau, Gérard Fussman observes that "Taxila is located on the shortest possible way from the Doab to Central Asia if you want to travel on a flat and well-watered road" (1993c: 84). Other routes branching off from the Uttarāpatha at Taxila lead north towards Mansehra, where another set of Aśokan rock edicts in Kharoșthī marked an important junction of routes to Kashmir (following the Jhelum valley), Chilas (via the Kagan valley and Babusar Pass, which is only open during the summer months), and through the Indus River gorge (following the same path as the Karakorum Highway). ${ }^{61}$ The location of Taxila at the "main gate to India" (Chakraborti 1966: 159) on a network of routes connected to Central Asia, Iran and the western China was largely responsible for its development into a political, economic and cultural hub of the Uttarāpatha.

57 Fussman 1993c: 87.

58 Chakraborti 1966: 159, Lahiri 1992: 370 and Chandra [1966] 1977: 12.

59 Law 1932: 53.

60 Marshall 1951: 1, 1.

61 Allchin 1995: 15; Dani, Ahmad Hasan. 1986. The Historic City of Taxila. Tokyo, Japan: Centre for East Asian Cultural Studies, 17; Falk 2006: 129; Fussman 1993c: 86. 
The concentration of urban settlements and monasteries at Taxila demonstrates close relations between residents of the city and the Buddhist institutions which flourished on the outskirts. Excavations at Taxila have revealed that several sites were occupied during various stages:

1. Hathial ridge: early settlements from about $2500-500$ BCE. ${ }^{62}$

2. Bhir mound: Taxila's "oldest townlike settlement" (Fussman 1993c: 88), during Achaemenid, Mauryan and early Indo-Greek periods from ca. 425 BCE-mid-second century BCE. ${ }^{63}$

3. Sirkap: between Hathiāl and Kacchā Koț, an urban center laid out in a grid pattern and fortified in the last decades of the first century BCE, which declined during the second century CE. ${ }^{64}$

4. Sirsukh: a mostly unexcavated rectangular area of settlement north of Sirkap established during the Kușāna period.

Buddhist stūpas and monasteries are clustered around the urban settlements of Taxila, including Dharmarājikā (the core of the stūpa was probably constructed during the reign of Aśoka in the third century BCE), Kālawān (the largest Buddhist sacred complex at Taxila after Dharmarājikā), and Jauliāñ (constructed between the second to fifth centuries CE). ${ }^{65}$ As the most significant regional center of administration, trade, and Buddhist monasticism in the northwestern Indian subcontinent, Taxila's sphere of influence extended across the Indus

62 Allchin 1995: 125-7, fig. 8.2; Dani 1986: 20-39.

${ }^{63}$ Allchin 1995: 127, fig. 8.2, Callieri 1995: 297; Dani 1986: 81-88; Erdösy, Georg. 1990. "Taxila: Political History and Urban Structure." In Maurizio Taddei, and Pierfrancesco Callieri, eds. 1990. South Asian Archaeology, 1987. Rome: Istituto italiano per il Medio ed Estremo Oriente, 665; Marshall 1951: 1.87-111.

${ }^{64}$ Marshall's (1951: 1.112-216) interpretation and dating of the phases for the construction of the structures at Sirkap remain controversial; for alternative interpretations of the stratigraphy and chronology, see Behrendt, Kurt. 2004. The Buddhist Architecture of Gandhära. Leiden: Brill, 255-260 (Appendix A), who proposes that Sirkap belongs to a phase from ca. 200 BCE to the middle to late first century CE; Callieri 1995: 294 ff., Dani 1986: 88 ff., Fussman 1993c: 88 ff., and Kuwayama, Shoshin. 2007. "Kañjur Ashlar and Diaper Masonry. Two Building Phases in Taxila of the First Century A.D." In Srinivasan 2007: 201-231, who concludes: "This time frame, the latter half of the first century B.C. and the early half of the first century A.D. may roughly correspond to the entire city life inside the city walls of Sirkap" (2007: 226).

${ }^{65}$ Behrendt 2004: 40-45 (doubting the Mauryan origins of the Dharmarājikā stūpa), 77-96 (for the initial phases of Kālawān, Jauliāñ, and other Buddhist complexes), 135-174 (for later phases); recent finds from excavations of mural paintings from stūpa and monastery complexes from the 2nd-5th centuries CE are announced by Ashraf Khan, Muhammad and Mahmood-ul-Hasan. 2008. "A New Discovery in the Taxila Valley: Archaeological Excavations at the Buddhist Monastery of Jinan Wali Dheri." In Luczanits 2008: 302-307. 


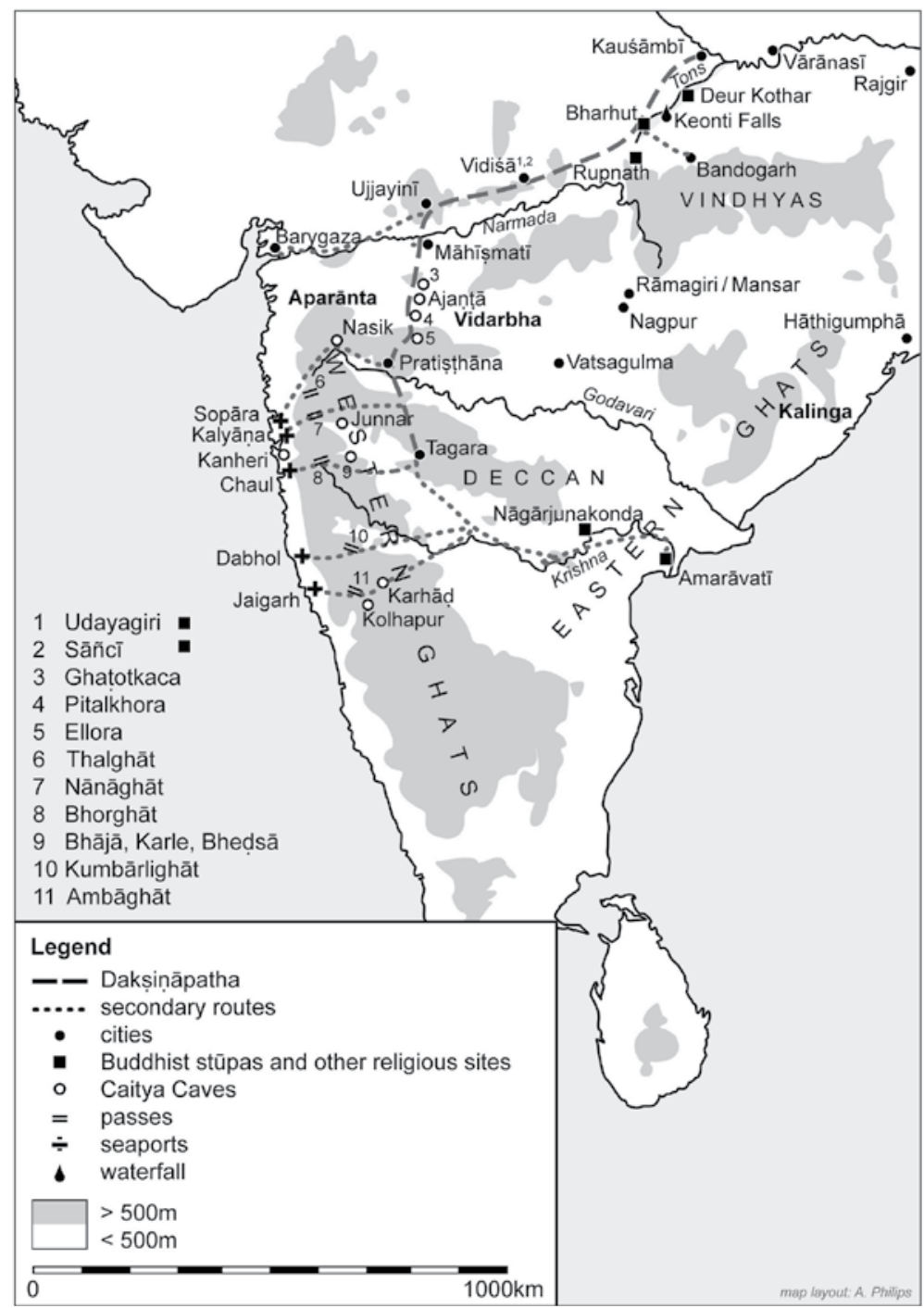

Map 3.2: Routes and Nodes of Dakșinapatha (Sources: Chakrabarti 2005; Dehejia 1972; Lahiri 1992; Ray 1986; Schwartzberg 1992)

River to Gandhāra. Extensions of the Northern Route westward to Gandhära and northward to the upper Indus are treated in the following chapters, which demonstrate that Taxila was a major hub rather than a terminus of the Uttarapatha. 


\section{Southern Route (Dakṣināpatha)}

The Daksināpatha (literally "Southern Route") connecting the GangesYamuna valley with the west coast via the Deccan plateau was the southern Indian counterpart to the Uttaräpatha. The Southern Route encompasses a transregional network of interconnected routes in southern India, but also refers generally to areas of the Deccan peninsula ostensibly separated from Äryāvarta by the Vindhya range of hills and the Narmada River. ${ }^{66}$ Numerous feeder routes branching off from "nodal points" (Chakrabarti 2005: 21) at Mathura, Etawah, Kauśāmbī, Vārānasīi, and Rajgir connected the Southern Route with the Northern Route. ${ }^{67}$ This transregional network allowed raw materials such as iron, copper, and precious stones from the Deccan peninsula to be transported overland to the Ganges valley and provided an outlet for products from northern and northwestern India to seaports on the Indian Ocean. The Southern Route integrated the interior of the Indian subcontinent into broader patterns of long-distance commercial and cultural exchanges, as indicated by discoveries of Roman coin hoards and Egyptian and Mediterranean artifacts in western and southern India after the first century CE.

Archaeological and epigraphic sources expose significant material connections, long-distance trade contacts, and patterns of Buddhist transmission between northern and southern India. The distribution of NBP, Black and Red Ware, and other characteristic northern Indian pottery types in central India at Vidiśā and Ujjayinī and in the Deccan plateau indicates pervasive links in the last centuries of the first millennium BCE. ${ }^{68}$ The expansion of Red Polished Ware (RPW), which originated in Gujarat, and northwestern types of elite pottery to the Deccan peninsula provides a general guideline for assessing the relative strength of interregional commercial and religious exchanges in subsequent periods. ${ }^{69}$ The distribution of third century BCE Aśokan

${ }^{66}$ Sircar 1967a: 69, 79-80, 103; Sircar 1971a: 14-15, 29.

${ }^{67}$ Chakrabarti, Dilip K. 2005. The Archaeology of the Deccan Routes: The ancient routes from the Ganga plain to the Deccan. New Delhi: Munshiram Manoharlal Publishers.

${ }_{68}$ Allchin 1995: 136-140; Chakrabarti 1995: 221-230; Lahiri 1992: 383.

${ }^{69}$ According to Liu (1988: 29-30, maps 3-4, appendices II-IV) ceramic distribution indicates basic exchange patterns, the movement of commodities, and the economic framework for the use of money. Heitzman observed that "[Buddhist] Monastic site 
inscriptions indicates that the Mauryan network extended from administrative centers in northern and central India to key areas of the Deccan peninsula. A Minor Pillar Edict at Sãñii and Minor Rock Edicts at Rupnath and Panguraria in the Narmada valley belong to the intermediate zone between the Northern and Southern Routes, while Major Rock Edicts at the seaport of Sopara on the West coast, and Dhauli and Jaugada in ancient Kalinga (modern Orissa) on the East coast show that the Mauryan empire stretched from coast to coast across the Deccan peninsula. ${ }^{70}$ Major Rock Edicts at Sannati and Erragudi and Minor Rock Edicts in neighboring districts of Andhra Pradesh and Karnataka were clustered around Suvarṇagiri ('gold mountain') in areas with ancient gold and diamond mines. ${ }^{71}$

In the post-Mauryan period during the last two centuries BCE, Brāhmī inscriptions from Vidiśā, Bharhut, and Sãñcī in central India provide further epigraphical evidence for the development of networks for transregional movement. Antialkidas, an Indo-Greek Mahärāja in the late second century BCE, sent Heliodōros as his ambassador from Taxila to the court of Kāsíputra Bhāgabhadra, who probably controlled access to the Southern Route from Vidiśā (Fig. 2.1: Heliodoros Pillar). ${ }^{72}$ Buddhist donative inscriptions from Bharhut show that donors came from Pāṭalipura, Kauśāmbī, Vidiśā, Nāsik, Karhāẹ, and other cities in northern and central India. ${ }^{73}$ Among over 800 inscriptions at Sāñcī, toponyms indicate that many donors came from the nearby city of

distribution intersected completely that of Red Polished Ware, and overlapped the distribution of Rouletted Ware in Andhra Pradesh" (1984: 131).

${ }^{70}$ Falk 2006: 89-90, 109-110 (Panguraria), 93-94 (Rupnath), 203-205 (Sāñcī), 113-115 (Dhaulī), 121-123 (Jaugaḍa).

${ }^{71}$ The Brahmagiri and Siddapura inscriptions begin by addressing the Mahāmātras "from Suvarnagiri" (suvamnagirite), which may be identified with Kanakagiri south of Maski in an area which "abounds in ancient gold-workings" according to H. Krishna Sastri (Hultszch 1925: 177, fn. 5). It is probably not coincidental that the minor rock edict at Maski was found by a British gold-mining engineer (Falk 2006: 81; Hultszch 1925: xxv). Lahiri comments, "That Andhra Pradesh was extremely strategic in the administration of the Mauryan empire is clearly suggested not only by the presence of Aśokan edicts in the Kurnool district... but also by the archaeological evidence at Veerapuram, in the same district, of a mint with the authority to issue Mauryan currency" (1992: 388).

${ }^{72}$ Salomon 1998a: 141, 265-7, fig. 12; Sircar 1965: 88-9. The religious significance of the pillar inscription of Heliodōros is discussed in Hellenistic Interactions in Chapter 2 pp. $98-109$.

${ }_{73}$ Lüders 1963: 6-10 compiles and identifies toponyms in Bhārhut inscriptions. Lahiri 1992: 384-5 and Hawkes 2009: 162 comment on "movement along these routes" connecting Bharhut to the donors' places of origin. 
Vidiśā and adjacent regions of central India, but other toponyms and personal names show that visitors also traveled from locations on the Southern Route and from Gandhāra and Kāmboja in the Northwest. ${ }^{74}$ Thus, toponyms in Buddhist donative inscriptions illustrate of longdistance travel and religious mobility between northwestern and central India and the Deccan plateau in the first-second centuries BCE.

Construction of Buddhist monasteries clustered on trade routes from the West coast to the interior of the Deccan peninsula in modern Maharashtra and Andhra Pradesh drastically accelerated during the Sàtavāhana period from the end of the first century BCE until about the middle of the second century CE. ${ }^{75}$ Pratisțhāna (modern Paithan in Maharashtra) was the major inland center of the Southern Route and the capital of the Sātavāhana dynasty, which struggled with the Western Ksatrapas and other regional powers to control routes across the Deccan plateau between seaports on the western coast and the KrishnaGodavari river valleys. ${ }^{76}$ The Sātavāhanas, Western Kṣatrapas, and other regional rulers, as well as merchants and other donors (including monks and nuns) donated the resources to excavate and maintain over 900 rock-cut caves which mostly functioned as Buddhist shrines (caityas) at Ajaṇțā, Nāsik, Junnar, Bhājā, Kārle, Kāṇherī, Kolhāpur, etc. ${ }^{77}$ Many Brāhmī donative inscriptions which explicitly refer to merchants and artisans who belonged to guilds record mercantile patronage of shrines located on capillary routes connecting the Southern Route to seaports across the Western Ghats. ${ }^{78}$ Rulers frequently

${ }^{74}$ N.G. Majumdar (in Marshall, Foucher, and Majumdar 1940) 1940: 1.299-300, xxx-xxxii reads inscriptions of donors from Gandhāra (no. 702), and Kāmboja (nos. 169 and 601).

75 The chronology of the Sātavāhana period remains "one of the most hotly debated problems in the field of ancient Indian history" (Fynes 1995: 43-4). Some authorities tentatively place the origins of the Sātavāhanas in the late second century BCE (Dehejia, Vidya. 1972. Early Buddhist Rock Temples: A chronological study. London: Thames and Hudson, 19) or early first century BCE (Ray, Himanshu Prabha. 1986. Monastery and Guild: Commerce under the Sātavāhanas. Delhi: Oxford University Press, 50).

${ }^{76}$ Conflicts between the Sātavāhanas and Western Kșatrapas are treated in more detail in the subchapter on Kșaharāta and Kärdamaka Kșatrapas in Western India in Chapter 2 pp. 126-131.

${ }_{77}$ Chakrabarti 1995: 315; Dehejia 1972; Lahiri 1992: 386-7; Lamotte 1988 [1958]: 504-515; Liu 1988: 124-127; Ray 1986: 183 ff.; Ray 1994: 138-40, fig. 17.

${ }^{78}$ Lüders 1912: 101-139, nos. 984-1199 lists over 200 Brāhmī inscriptions from caves in western India from periods before $400 \mathrm{CE}$, but many inscriptions from later periods are not included in the list. Burgess, James, and Bhagvanlal Indraji. 1881. Inscriptions from the Cave Temples of Western India. Bombay: Government Central Press, 27-38 and Senart, Émil. 1902. "Inscriptions in the Caves at Karle." Epigraphia Indica 7, 47-74 
distributed their patronage broadly to Buddhist, Jain, and Hindu establishments by endowing shrines, temples and caves with revenue from taxes on villages and land grants. ${ }^{79}$ For example, an inscription from a cave at Nānāghāt with labeled images of members of the Sātavāhana dynasty commemorated the performance of vedic sacrifices sponsored by Queen Nāganikā and praised the king (who was probably deceased, and whose name is lost in the inscription) with the epithet of "lord of Daksināpatha." ${ }^{80}$ Claims by the Western Kșatrapas and the Guptas to have conquered the "Kings of Daksinapatha" underscore the value of dominating the Southern Route. ${ }^{81}$

In Indian literature Daksinapatha not only designated the network of trade and travel routes between the Ganges-Yamuna valley and the Deccan plateau, but more generally refers to the "southern region" separated from northern India by the Narmada River, just as Uttarāpatha refers to the "northern region." The Arthaśästra attributed to Kauṭilya contrasts the Northern Route (referred to as Haimavatamärga rather

treat inscriptions at Kārle; Senart, Émil. 1905. "Inscriptions in the Caves at Nasik." Epigraphia Indica 8, 59-96 reads inscriptions at Nāsik; Burgess and Indraji 1881: 41-56 edit inscriptions at Junnar, for Nānāghāt see Burgess and Bühler 1883: 59-74, and for Kāṇherī see Burgess and Bühler 1883: 74-87, Burgess and Indraji 1881: 56-66, and Gokhale 1991. See also Dehejia 1972 for a synthesis of inscriptions, art and architecture of early Buddhist caityas in western India, as well as Chakravarti 1987: 193; Liu 1988: 125; and Ray 1986: 111-2, 193 for religious, social, and economic dimensions.

79 Fynes 1995: 44-6.

${ }^{80}$ Although the inscription is damaged, the reading of this epithet is fairly certain since Burgess and Bühler 1883: 60 reads Dakhi[nāpa]tha[patino] and Sircar 1965: 193, no. 82 , 1. 2 reads Dakhi<napa* ${ }^{*}$ thapati- (also see Lüders 1912: 121, no. 1112). The layout of the cave with images of Sătavāhana rulers and their family members has been compared to the Kuṣana devakula at Maṭ near Mathurā (Rosenfield 1967: 152-3; Verardi 1983: 244-50), but Fynes points out that "the Nānāghāt cave was not a shrine to the dead, since the inscription suggests that several members of the Sātavāhana dynasty, including the queen who sponsored the sacrifices commemorated in the inscription, were still alive at the time it was engraved" (1995: 45). The conclusion by Verardi 1983: 149 and Fynes 1995: 45 that this site served as a rest house for travelers crossing the pass corresponds well with other evidence for transregional mobility along these capillary routes that connected the Deccan hinterland with the western coast. The date of the inscriptions is discussed by Fynes 1995: 44 (between ca. 25 BCE and $10 \mathrm{CE}$ ), Dehejia 1972: 19 and Ray 1986: 36-7 (70-60 BCE).

${ }^{81}$ The epithet of "Master of the Southern Route" belongs to a Sātavāhana ruler who was defeated twice by the Western Kṣatrapa ruler Rudradāman, according to his Sanskrit inscription at Junagadh in 150 CE (Kielhorn 1905: 44, 47; Sircar 1965: 178), which also indicates a marriage alliance between the two regional powers. For Samudragupta's claim to have captured and liberated twelve "kings of Daksināpatha" (Bhandarkar 1981: 12-25, 217; Fleet 1888: 12-13, Sircar 1965: 265), see Gupta 'Golden Age' Reappraised in Chapter 2 pp. 149-157. 
than Uttarāpatha) used for trade in horses, hides, and furs, with the more profitable Southern Route:

[T] he commodities of conch-shells, diamonds, rubies, pearls and gold are more plentiful on the southern route (daksinappathe). Even in the case of the route to the south, the trade-route (vanikpatha) with many mines, with commodities of high value, with well-secured movements, or requiring little expenditure an exertion, is preferable, or one with commodities of small value, with an extensive scope (for sale). (7.12.24-5, translated by Kangle 1969: 2.360) ${ }^{82}$

This passage indicates that the Daksinappatha was used as a trade route for lucrative commodities. A likely itinerary is outlined in the Pārāyana-vagga of the Sutta-nipāta, which refers to the northward journey of Bāvarî̀s sixteen Brahmin disciples from his retreat on the Godavari River:

... [1010] they all set out towards the North, [1011] firstly to Patițthāna of Alaka, then to Māhissatī, and to Ujjenī, Gonaddhā, Vedisā, (the place) called Vanasa, [1012] and to Kosambì too, to Sāketa, and Sāvatthī, best of cities... (Norman, trans. 1985: 161).

On the basis of this episode, G.P. Malalasekera suggests that "[i]t is possible that Dakkhinapatha was originally the name of the road which led southwards... and that later the road lent its name to the whole region through which it passed" (1937-8: 1.1050-1051). A reference to "the Southern Route in the south" (dakșine dakșinapatham) in the Nala episode of the Mahäbhärata (3.58.22) seems to reflect literary perceptions of Dakșinapatha as both an actual "southern route" and the southern region. In the Rāmāyana, the exile of Rāma, Sìtā and Lakṣmana from the north (Ayodhyā) to the south (Daṇ̣akāranya, Kiṣkindha and Lankā) has been interpreted as a reflection of Brahmanical expansion to the Deccan plateau, although identifying the

\footnotetext{
${ }^{82}$ Lahiri's comment that "our analysis of the archaeological evidence, in this regard, does not show any significant movement of raw materials from the Deccan towards north India" (1992: 384) needs clarification. Discrepancies between literary sources and archaeological evidence are not surprising, but the absence of items referred to in the Arthaśästra in northern Indian excavations in levels before 200 BCE (the terminus of Lahiri's investigation) does not invalidate general patterns of exchange between northern and southern India. Moreover, despite the traditional attribution of the authorship of the text to the Mauryan minister Kauțilya, the Arthaśästra primarily belongs to the third century $\mathrm{CE}$, although some passages like the one quoted here may preserve earlier textual strata (the issue of its date is discussed in Legacy of the Mauryans: Aśoka as Dharmarāja pp. 78-80, fn. 42). This passage is also discussed by Chakrabarti 2005: 7, Chakraborti 1966: 30 and Chandra [1966] 1977: 78.
} 


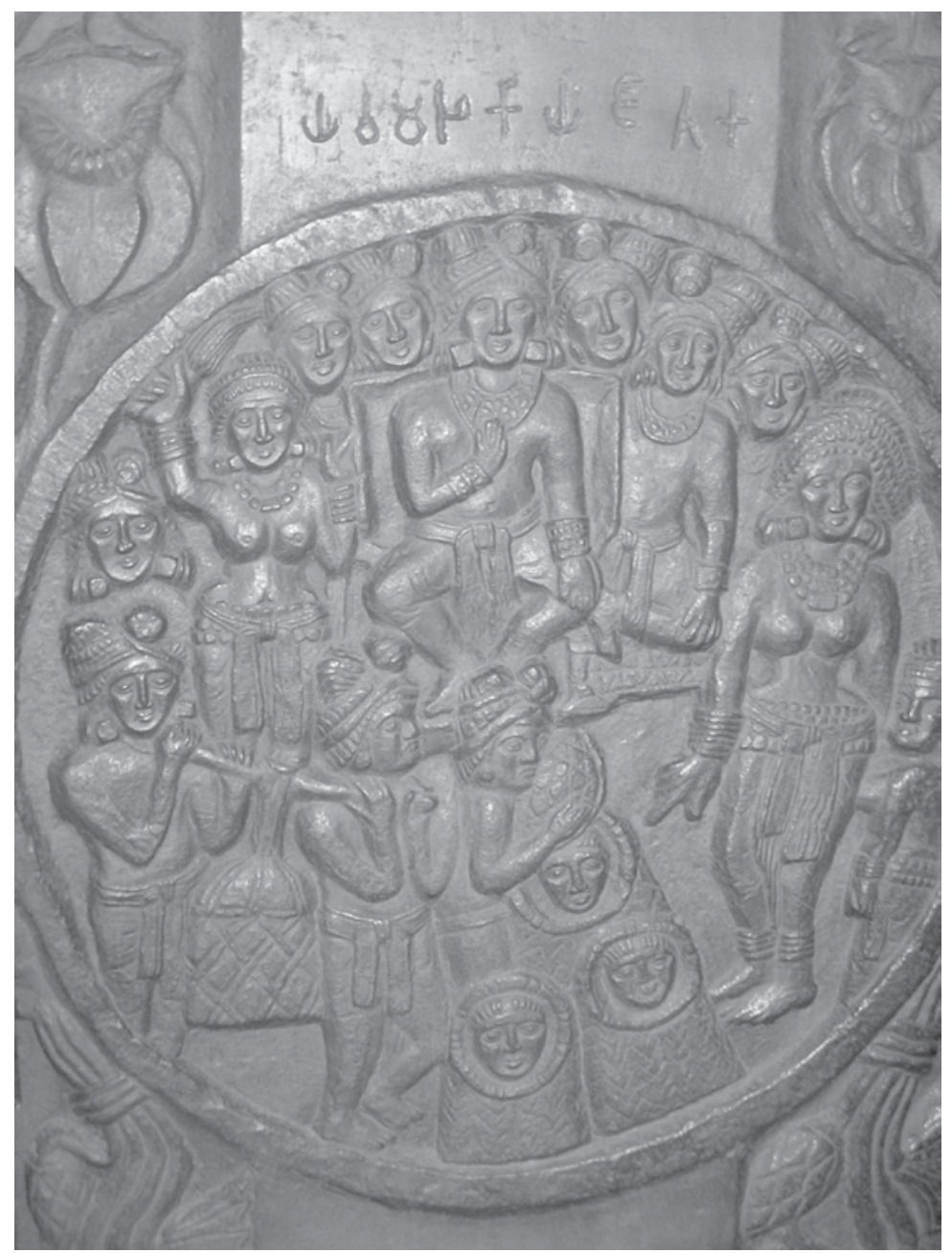

Fig. 3.1: Bharhut Pillar depicting a scene from the Mahaumagga Jātaka, Indian Museum, Kolkata (author's photo). The inscription labeling the image as an illustration of the yava majhakiyam jätakam refers to events in the narrative that took place at Yavamajhakiya, a set of four market-towns outside the gates of Mithilā.

imagined literary landscape with geographical locations is problematic. ${ }^{83}$ Kālidāsa's vivid description in the Meghadūta of the cloud-messenger's

${ }^{83}$ Schwartzberg 1978: 13, pl. III.A.1 ("India as revealed in the Rāmāyaṇa") gives two itineraries for the path of Rāma's exile "according to modern reinterpretation of the epic" in which Kiṣkindha and Lankā are located in the upper Narmada valley, and 
journey from Ràmagiri (Ramtek, north of modern Nagpur) in the Deccan plateau across the Vindhya range (v. 19) through Vidiśā (v. 24) and Ujjayinī (v. 27) to the Yakṣa's home at Alakā near Kailāsa in the Himalayas represents an idealized journey from southern to northern India. Purānic lists of inhabitants of Dakșinappatha or Dākșinātya include the Pulindas of the Vindhya region, the Kalingas of modern Orissa, Mahārāștras in the West, and Pānḍas, Keralas, and Colas in the far South..$^{84}$ The use of Daksinappatha as a geographical term for the southern region of India is reflected in the Periplus Maris Erythraei: "Thus the region is called Dachinabades, for the word for south in their language is dachanos" (Casson 1989: 83, §51). Lahiri’s conclusion that Brahmanical and Buddhist traditions depict the Daksinapatha as a "vehicle of cultural symbiosis involving the Gangetic plains and central India" (1992: 401) may stretch the literary evidence too far, but there is little doubt that this transregional network facilitated crosscultural contact between the inland routes of the Deccan plateau and maritime routes across the Indian Ocean.

\section{Routes and Nodes of the Dakṣināpatha}

\section{Bharhut}

Although very little remains at its original site in the Tons River valley in northeastern Madhya Pradesh, Bharhut was a major Buddhist stūpa complex with Brāhmī inscriptions and sculptures from the late second and first century BCE (figs. 1.3 and 3.1) ${ }^{85}$ The location of Bharhut on an intermediate route between the Uttaräpatha and the Daksinapatha across the Vindhya Hills on the Rewa-Panna plateau leads Jason Hawkes

\footnotetext{
"according to traditional interpretation of the epic" in which Lankā is identified with modern Sri Lanka. Similar reservations apply to Arjuna's pilgrimage to the "fords on the southern ocean" in Mahäbhärata 1.208-9 (Buitenen 1973: 402-4).

${ }^{84}$ Sircar 1967: 79-80, 103; 1971: 38-40.

${ }_{85}$ Most of the sculptures and inscriptions from Bharhut were removed to the Indian Museum in Calcutta and the Allahabad Museum during the nineteenth century (Cunningham, Alexander. 1879. The Stupa of Bharhut: A Buddhist monument ornamented with numerous sculptures illustrative of Buddhist Legend and History in the third century B.C. London: W.H. Allen). Lüders 1963 edits and reads Brāhmī inscriptions from Bhārhut. Brancaccio, Pia. 2005. "The Making of a Life: Re-reading Bhārhut Sculpture." South Asian Studies 21, 47-52 and Hawkes, Jason. 2008. "Bharhut: A Reassessment." South Asian Studies 24, 1-14 offer important revisions of the art historical and archaeological evidence. Hawkes 2009: 146-174 surveys the geographical and archaeological context of the site, with particular attention to local support networks.
} 
(2009: 161) to suggest that the site was consciously selected by the monastic community due to its proximity to an important route for interregional travel, since there are no significant urban centers nearby. Hawkes' observation that “...trade was probably one of the main causative factors in the development of the area" (2009: 168) of Bharhut is quite plausible, considering its nodal position in a network of regional routes between Kauśāmbī, Vārānasī and other cities in the Ganges-Yamuna plains and the Narmada valley ${ }^{86}$ Travelers coming from the northeast could reach Bharhut after ascending the Vindhya escarpment either at Deur Kothar, where stüpas and rock shelters have recently been excavated downstream the Tons River from Bharhut, or at Baldaha Ghat near the waterfalls of Keonti (Kevatikund), where caves with rock carvings of Buddhist stūpas were described by Alexander Cunningham in $1885 .{ }^{87}$ Different feeder routes from Bharhut to the Deccan led southeast to Bandogarh, where about twenty Prakrit and Sanskrit cave inscriptions record donations by merchants, traders, and other donors from as far away as Mathura (without noting the recipients of their gifts) and to the southwest through Rupnath, the site of an Aśokan Minor Rock Edict. ${ }^{88}$ Thus, archaeological and epigraphical sources demonstrate that ancient travelers could cross the Vindhyas by using several possible intra- and interregional itineraries.

\section{Vidiśá and Sāññ}

Vidiśā, one of the largest urban centers outside of the Ganges basin in the Mauryan and post-Mauryan periods, supported adjacent Buddhist stūpa and monastic complexes in the hills around Sãñcī, as well as numerous non-Buddhist shrines and monuments, including impe-

\footnotetext{
${ }^{86}$ Chakrabarti 2005: 77-89 discusses Bharhut's importance in the early historic period as a connecting point in alignments of routes between the Yamuna and Narmada valleys and via the Balaghat gap in the Satpara range to the Wainganga valley routes in ancient Vidarbha in central India to Orissa and Andhra.

${ }^{87}$ Chakrabarti 2005: 73-76, map 10; Hawkes 2009: 169.

${ }^{88}$ Inscriptions from Bandogarh first published by Chakravarti, N.P. 1955. "Brāhmī Inscriptions from Bandogarh." Epigraphia Indica 31, 167-186 are discussed by Chakravarti, Ranabir. 1995. "Merchants and Other Donors at Ancient Bandogarh." South Asian Studies 11, 33-41 and Chakrabarti 2005: 80-83. For the Aśokan Minor Rock edict at Rūpnāth, see Falk 2006: 93-94; Hultszch 1925: xxiii, 166-9; Thapar 1961: 234-235. The site is now associated with Śiva and the exile of Rāma, Sìtā and Lakșmaṇa.
} 
rial Gupta temples at Udayagiri. ${ }^{89}$ Vidiśá's importance as the primary religious, commercial, and administrative node can be attributed to its "central position" (Rapson 1922: 471) on long-distance east-west routes between the Ganga-Yamuna basin, the Narmada valley, and ports on the west coast and on north-south routes between the Uttarāpatha and Daksinapatha..$^{90}$ As noted in lists of Indian rivers, cities and people in Ptolemy's Geography, Kognabanda, likely to be a Greek equivalent to Kākanādaboṭa (as Sāñcī is called in Brāhmī inscriptions), is located on a trade route which branched off from the Yamuna valley to follow the Betwa River. ${ }^{91}$ As at Bharhut, donors names and toponyms in more than 800 Brāhmī inscriptions indicate that the 'catchment area' of potential patrons extended far beyond Vidiśa to Ujjayiṇi in the Chambal valley of western India, Māhiṣmatī on the Narmada River, and Pratișthāna in the Deccan plateau. ${ }^{92}$ Other important epigraphic records from Sãñcĩ include an Aśokan pillar inscription and reliquary inscriptions commemorating prominent early Buddhist saints such as Mahāmaudgalyāyana and Saariputra. ${ }^{93}$ The monumental architecture of stūpas, gateways, railings, and sculptures at Sāñci and nearby sites of Sonārī, Satdhāra, Bhojpur, and Andher show that these Buddhist com-

${ }^{89}$ Excavations at Sāñcī are published by Marshall, Foucher and Majumdar 1940 (3 vols.). Significant re-interpretations of the religious significance and environmental contexts are presented in contributions to Dehejia 1996 and Willis 2000 and in a recent study by Shaw, Julia. 2007. Buddhist Landscapes in Central India: Sanchi Hill and archaeologies of religious and social change, $c$. third century BC to fifth century $A D$. London: British Association for South Asian Studies, The British Academy. For the archaeology of Vidiśā, a large site of over 240 hectares surrounded by a mud rampart, see Allchin 1995: 136, 207, fig. 10.5, 248-250, fig. 11.22 and Shaw 2007: 21-22, 39, 83-85. Literary references are compiled by Chakraborti 1966: 192-5, Lamotte 1958 [1988]: 326-8 and Law, Bimala Churn. 1954. Historical Geography of Ancient India. Paris: Société Asiatique de Paris, 336-340. Willis 2009 is an in-depth study of the Udayagiri temples supported by the imperial Guptas.

${ }_{90}$ According to Kālidāsa's Mālavikāgnimitra composed many centuries later during the Gupta period, the Śungas shifted their capital from Pātaliputra to Vidiśā, where the family had previously served as feudatories of the Mauryas.

${ }_{91}$ Marshall and Foucher 1940: 1.12. Eggermont 1966: 263, fn. 2 notes that variants of Kognabanda cited by Renou 1925: 23, n. 7 include Kognandaua, Kognabara, Kognadaba, and Kognandaba. Kākaṇāva, Kākaṇāya, and other variants appear in Brāhmī inscriptions from Sāñcì.

${ }_{92}$ Majumdar 1940 (in Marshall, et al. 1940) identifies toponyms corresponding to Mahīṣmati (Mahīsati: nos. 213, 251-6, 274-6, 413), Pratișțāna (Pațithāna: nos. 214, $229,546,608,717$ ), and Ujjayinī (Ujeni: 59 occurences). See note 74 for references to long-distance travelers from Gandhāra and Kāmboja in Sãñcī Brāhmī inscriptions. Shaw 2007: 51 refers to an overemphasis on the local patronage networks, since Vidiśā (Vidisā) appears in only 16 inscriptions.

${ }^{93}$ Majumdar 1940: 1.289-96; Willis 2000: 12-26. 
plexes were important residential monasteries and pilgrimage places. Recent studies of a broad range of religious sites around Sāñcī, Vidiśā, and Udayagiri have shown that the development of rudimentary rockshelters from prehistoric to medieval periods, Buddhist hillltop stūpas and monasteries, Näga and Yakșa shrines, and Vaiṣnava temples were linked to complex local and interregional patronage networks, which connected religious institutions and ritual centers with the construction of irrigation systems, dams, and other waterworks. ${ }^{94}$

\section{Ujjayin̄̄}

Another major node of intraregional and long-distance trade was the city of Ujjayini (modern Ujjain), the administrative capital of the central Indian janapada of Avanti. Ujjayini was surrounded by a moat with a mud rampart that was probably constructed between the sixth to fourth centuries BCE. ${ }^{95}$ According to some Buddhist literary traditions, Aśoka served as the Mauryan "viceroy" in Ujjayini during the first quarter of the third century BCE before his consecration as emperor, and separate Aśokan rock edicts at Dhauli and Jaugaḍa specify that officers (mahāmātras) were to be despatched from Ujjayinī and Taxila every three years in order to monitor other administrators. ${ }^{96}$ Like Taxila, Ujjayinī earned a formidable reputation in Indian literature as a prosperous regional metropolis famous for learned scholars who benefited from the generous patronage of wealthy merchants and powerful rulers. ${ }^{97}$ In the Meghadūta (v. 27), Kālidāsa has the cloud-messenger make a detour from his northward route in order to view "the roofs of Ujjayinī's white mansions" (Nathan 1976: 33). ${ }^{98}$ The Periplus Maris Erythraei explicitly refers to the role of Ujjayini in long-distance trade between the port of Bharukaccha and the Indian hinterland:

${ }_{94}$ Shaw 2007 and Willis 2009 exemplify different approaches to interpreting Buddhist and Hindu archaeological remains in this region, since Shaw decries "...the narrow framework of reference through which archaeological material has been used by text-based scholars of Buddhist history" (without specific reference to the scholarship being criticized), while Willis attempts to integrate the art historical, architectural, and epigraphical evidence from a specific site (Udayagiri) with broader patterns of Gupta period literature, numismatics, and political and religious history.

95 Allchin 1995: 134-6, fig. 8.7.

${ }_{96}$ Hultzsch 1925: 97; Lamotte 1988 [1958]: 325.

97 Chakraborti 1966: 195-198; Law, Bimala Churn. 1944. Ujjayinī in Ancient India. [Gwalior]: Archaeological Dept., Gwalior Government, 28 ff.; Liu 1988: 32-3.

${ }_{98}$ Nathan, Leonard, translator. 1976. The Transport of Love = The Meghadūta of Kālidāsa. Berkeley: University of California Press. 
There is in this region towards the east a city called Ozéné [Ujjayinī], the former seat of the royal court, from which everything that contributes to the region's prosperity, including what contributes to trade with us, is brought down to Barygaza [Bharukaccha]. ( $\$ 48$, Casson 1989: 81)

The same passage also indicates that "nard that comes by way of Proklais" (Puskalāvatī) and "nard that comes through the adjacent part of Skythia, and costus and bdellium" were transported from the Northwest through Ujjayini to Bharukaccha. ${ }^{99}$ Routes from Ujjayinī led north towards Mathurā and crossed the Narmada River to the south at Māhișmatī before continuing to Pratișthāna or west to the port city of Bharukaccha (modern Broach) near the river's mouth.

\section{Pratișthāna and other Cities of Dakșināpatha}

The Daksināpatha proper began south of Ujjayini at the traditional crossing point (tìrtha) of the Narmada River at Māhișmatī, identified with modern Māndhātā in Madhya Pradesh. ${ }^{100}$ Routes between Māhiṣmatī and Pratișthāna passed Buddhist, Jain and Hindu cave sites at Ajanțā, Pitalkhorā and Ellora, where early caitya caves were excavated in the first century $\mathrm{BCE}$ and continued throughout the middle to late first millennium CE, including a heightened phase with support from Western Vākātaka feudatories in the late fifth century CE. ${ }^{101}$ From the Sātavāhana capital at Pratișthāna (modern Paithan in Maharashtra), routes through passes of the Western Ghats lined with rock-cut shrines connected the Deccan plateau to ports on the west coast. ${ }^{102}$ Other routes to the southeast via the Godavari valley and Tagara (identified with modern Ter) linked the western Deccan with Buddhist centers such as Nāgārjunakoṇda and Amarāvatī in the Krishna River valley in Andhra Pradesh. ${ }^{103}$ The Periplus Maris Erythraei

\footnotetext{
99 Eggermont 1966: 257-9.

100 Law, Bimala Churn 1955. "Māhiṣmatī in Ancient India." Journal of Indian History 33, $313 \mathrm{ff}$. cites epigraphic and literary references to Māhiṣmatī, which was associated with the Haihaya dynasty of the Mahäbhärata and became the center of the Kalacuri dynasty in the post-Gupta period. Schwartzberg 1978: 26, pl. III.D.2b provides a map of the extent of the Kalacuri territory with a core area centered around Māhișmatī.

${ }_{101}$ Dehejia 1972: 155-158; Lamotte 1988 [1958]: 506-7; Ray 1986: 66. See Vākāṭaka Networks of Religious Patronage in Chapter 2 pp. 147-149, for further discussion of the Ajantāa caves.

102 Dehejia 1972: 17-18; Ray 1986: 21, 54.

${ }^{103}$ Chakraborti 1966: 200-207; Ray 1994: map 18.
} 
emphasizes the importance of Pratișthāna (Paithana) and Tagara on inland trade networks of the Dakșinappatha (Dachinabades):

Of the trading centers in the region of Dachinabades, two are the most outstanding: Paithana, twenty days' travel to the south from Barygaza; and, from Paithana, about ten days to the east, another very large city, Tagara. From these there is brought to Barygaza, by conveyance in wagons over very great roadless stretches, from Paithana large quantities of onyx, and from Tagara large quantities of cloth of ordinary quality, all kinds of garments, garments of molochinon, and certain other merchandise from the coastal parts that finds a market locally there. ( $\$ 51$, Casson 1989: 83)

Long-distance trade in the types of items outlined in the Periplus Maris Erythraei allowed the Sātavāhanas, Western Kṣatrapas and subsequent local and regional rulers of the Southern Route to patronize religious establishments clustered on routes through the Western Ghats.

\section{Buddhist Caityas in Western India}

The location of Buddhist caityas (rock-cut caves with cells for monks and nuns, sculptures, and stūpas) in the Western Ghats and near seaports on the west coast testifies to interconnections between longdistance trade, patronage by various groups (including merchants), and religious transmission. As D.D. Kosambi observed, "Their sites were chosen at the junction of primitive tracks, which became crossroads on the major trade routes" (1960: 137). ${ }^{104}$ Selective links between cave sites (caityas), passes (ghäts) and seaports are summarized in the accompanying Table: ${ }^{105}$

Table 3.1: Caityas, Ghäts and Seaports in Western India

\begin{tabular}{lll}
\hline Caityas & Ghāts & Seaports \\
\hline Nāsik & Pimpri, Thalghāt & Sopāra, Kalyāṇa \\
Junnar & Nānāghāt & Sopāra, Kalyạna \\
Kārle, Bhẹ̣sāa, Bhājā & Bhorghāt & Chaul \\
Karhạ̣ & Ambāghāt, Kumbārlighāt & Dabhol, Jaigarh \\
\hline
\end{tabular}

104 Kosambi, D.D. 1960. “At the Crossroads: Mother Goddess Cult-sites in Ancient India." Journal of the Royal Asiatic Society 1-2, 17-31 (part 1), 3-4, 135-144 (part 2).

105 Useful maps of Buddhist caves in western India are available in publications by Dehejia 1972: 12 (with comments on pp. 30-31); Margabandhu, C. 1965. "Trade contacts between Western India and the Graeco-Roman World in the early centuries of the Christian Era." Journal of the Economic and Social History of the Orient 8.3, 317, Ray 1986: 54 (= Ray 1994b: 139, fig. 17) and Schwartzberg 1978: 22, pl. III.C.3. 
Most of these caityas were excavated during the peak of long-distance maritime trade between western India and Egypt and Rome during the first to fourth centuries CE, when the Sātavāhanas and Western Kșatrapas vied for control of the inland routes. However, merchants, artisans, male householders, female donors, and monks and nuns made significantly more donations than royal patrons to residential Buddhist monasteries. ${ }^{106}$ While most donations were made by local inhabitants, inscriptions record many gifts by donors who had traveled long distances across the western Deccan to caityas located on the coast (such as Kānherī) or near passes through the Western Ghats. ${ }^{107}$ According to D.D. Kosambi, the fortunes of the Buddhist monasteries clustered on trade routes fluctuated with changing economic patterns:

...the monasteries remained tied to the specialized and concentrated "luxury" trade of which we read in the Periplus. This trade died out, to be replaced by general and simpler barter with settled villages. The monasteries, having fulfilled their economic and religious function, disappeared too. (1960: 138)

Kosambi also proposed that many Buddhist monasteries may have established near junctions of trade routes in order to supplant blood sacrifices to local mother goddesses at important crossroads. ${ }^{108}$ After long-distance trade declined and the Buddhist monks and nuns who benefited from donations of economic surpluses abandoned the caves, the worship of mother goddesses such as Yamāì, Veher-āì and Mānamoḍi (or Ambikā) re-emerged at sites like Bheḍsā, Kārle and Junnar, where they are still venerated by local communities.

\section{Seaports and Maritime Routes across the Indian Ocean}

By linking South Asian overland networks with maritime routes across the Indian Ocean, coastal seaports offered outlets for commodities

106 Kosambi's assertion that "royal support was comparatively slight" (1975 [1956]: 271) is supported by Dehejia 1992: 35-45.

107 Dehejia 1972: 142 compiles a list of cave sites with donations by inhabitants of distant places and observes that "...the architects and sculptors of the western caves, along with the merchants and traders, traveled widely" (1972: 140).

${ }_{108}$ Kosambi supports this hypothesis with Sanskrit and Pali literary references to sacrifices at crossroads, contemporary field research on the popular worship of mother goddesses in Maharashtra, and concentrations of microliths at sites associated with the cult and Buddhist monasteries, but admits "in all these places it is difficult to prove the existence of the cult before the monasteries were carved out" (1960: 136). 


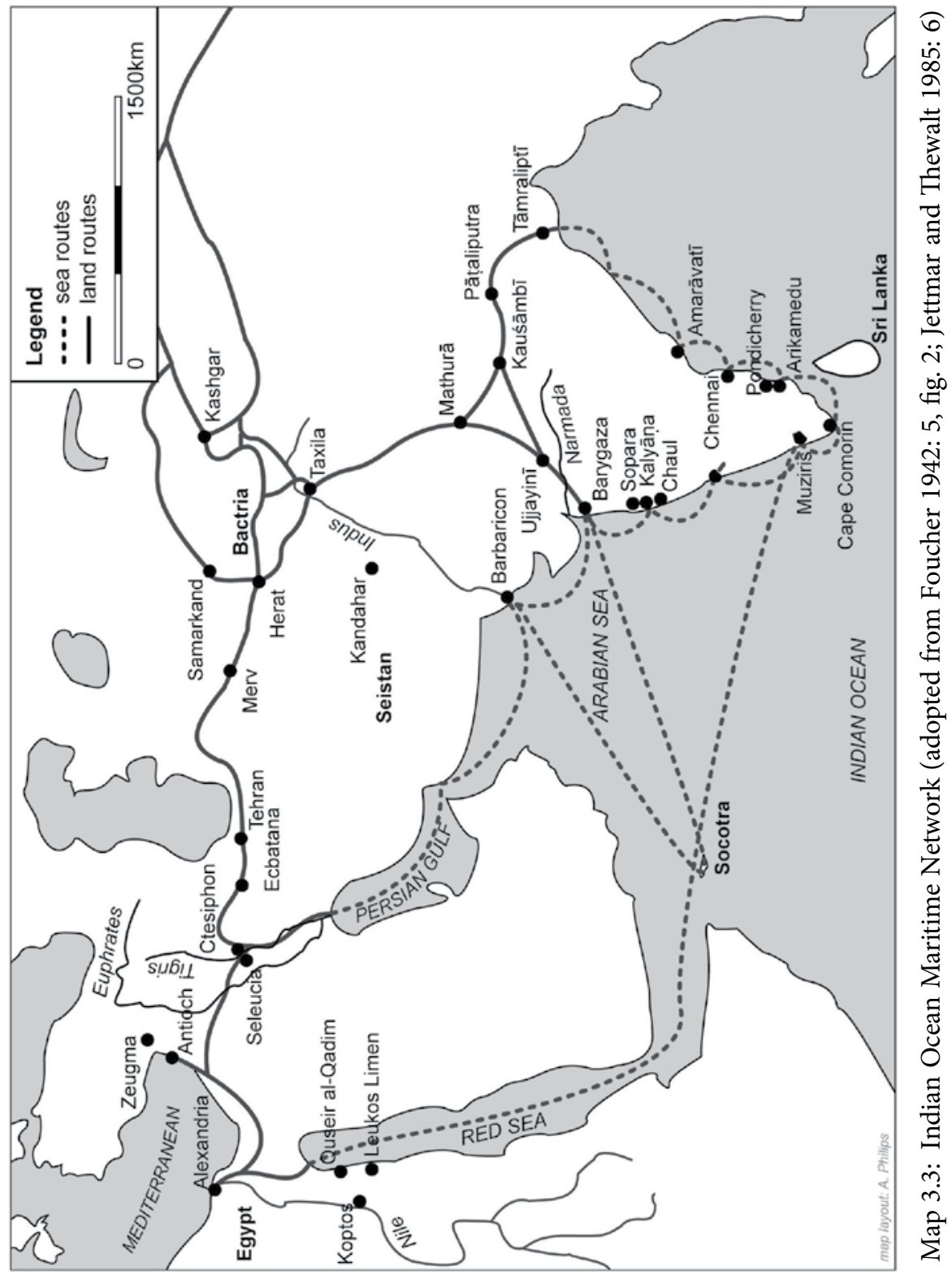


from the Indian subcontinent and opened up possibilities for longdistance cross-cultural contact. Recent archaeological excavations of seaports on the Red Sea and Indian coastline, inscriptions of Indian merchants in Egypt and Socotra, Greek papyrii records of commercial transactions involving Indian goods, and Roman coin hoards in India and Sri Lanka show that information from western classical literary sources about maritime trade between India and the western world had significant material basis. According to Strabo and other classical authors, Eudoxus of Cyzicus was the first Greek sailor to cross the Arabian Sea from Egypt to India using the monsoon winds guided by a shipwrecked Indian pilot during the reign of Ptolemy VIII Euergetes II (ca. 120 BCE). ${ }^{109}$ Other accounts, such as the Periplus Maris Erythraei (\$57), credit a sailor named Hippalos with the discovery of the monsoon winds, but such "foundation myths" (Parker 2008: 194) raise suspicions due to literary parallels with stories about low-prestige merchants and other wayward adventurers (like Odysseus) in Greek novels. It was only after the Ptolemaic period (ending in $31 \mathrm{BCE}$ ) that direct long-distance maritime trade between Egyptian seaports on the Red Sea and western Indian seaports accelerated. The koine Greek text of the Periplus Maris Erythraei preserves many specific details about maritime itineraries, seaports and inland emporia, and commodities traded between India, Egypt and the Mediterranean during the first century CE. ${ }^{110}$

Material evidence from archaeological excavations in Egypt and India and discoveries of imported items from India in the Mediterranean and from the Roman world in India attest long-distance trade contacts in the early centuries CE. Excavations in Egypt at Quseir alQadim (perhaps the port of Myos Hormos) and ruins of wateringplaces (hydreumata) on ancient roads to Koptos on the Nile River have demonstrated that goods were transported across the desert from coastal seaports to the Nile River. ${ }^{111}$ Luxury items from India, China, Persia, and Arabia were then shipped on to Rome and other

${ }^{109}$ Karttunen 1997a: 329-331; Parker 2008: 193; Rawlinson 1916: 96-99 discuss the sources for Strabo 2.3.4-6.

110 Casson 1989 is an accessible translation and commentary. Parker 2008: 98-100 refers to the periplus genre in western classical literary contexts as a "paradigm for chorography" and discusses its date (40-70 CE) and value for understanding Roman long-distance trade and Indian trade (172 ff.). Its value as a source for Indian history is discussed in Kṣaharāta and Kärdamaka Kșatrapas in Western India in Chapter 2 pp. 126 ff. fn. 181.

111 Casson 1989: 13-4; Sidebotham, Steven. 1986. Roman Economic Policy in the Erythra Thalassa, 30 B.C.-A.D. 217. Leiden: E.J. Brill, 48-71. 
parts of the Mediterranean from Alexandria. An ivory statuette of an Indian female figure manufactured in the Deccan plateau and found at Pompeii is an example of the type of artifact that reached the Mediterranean through long-distance trade, although other perishable imports are not preserved. ${ }^{112}$ Items imported from the Red Sea and Mediterranean to Indian coastal and inland trade centers included rouletted ware, Megarian or Samian ware, amphorae, bronze statuettes, terracotta lamps, glass beads, and other objects which were also manufactured in imitation of foreign prototypes between the first and fourth centuries CE. ${ }^{113}$ In exchange for luxury items such as beryl and other precious stones, imported Roman gold and silver coins, which are found mostly in southern Indian hoards, were often melted for their metal content, but terracotta bullae imitations of coin images of Roman emperors found at Ter suggest that flourishing maritime trade stimulated Indian interest in foreign items. ${ }^{114}$

Epigraphic records of Indian traders in Egypt and Socotra and a maritime loan written on the so-called Muziris papyrus provide further documentation of long-distance commercial interactions described in the Periplus. Prakrit and Tamil inscriptions found in Egypt and Tamil literary sources referring to yavana ships, bodyguards, and artisans demonstrate the involvement of South Indian sailors and merchants in maritime trade. ${ }^{115} \mathrm{~A}$ second century CE papyrus fragment recording an agreement between a South Indian merchant and an Egyptian agent gives a detailed account of arrangements to transport large quantities

112 Brancaccio, Pia. 2007. "Close Encounters: Multicultural Systems in Ancient India." In Srinivasan 2007: 387-388; Karttunen, Klaus. 1997b. "Wooden Tables with Ivory Legs." In Allchin and Allchin 1997: 2.557-562; Mehendale, Sanjyot. 1993. "The Ivory Statuette from Bokardan and Its Connection to the Ivory Statuettes from Pompei and Ter." In South Asian Archooology 1991, edited by Gail, Adelbert, Gerd J.R. Mevissen, and Britta Zehmke. Stuttgart: F. Steiner, 529-538; Parker 2008: 162, fig. 10.

113 Margabandhu 1965: 318 ff.; Ray 1994: 48-76; Singh, Ajoy Kumar. 1988. IndoRoman Trade. New Delhi, India: Commonwealth Publishers; Tomber, Roberta. 2008. Indo-Roman Trade: From pots to pepper. London: Duckworth; Tomber, Roberta, Lucy Blue, and Shinu Abraham, eds. 2010. Migration, Trade and Peoples. Part 1: Indian Ocean Commerce and the Archaeology of Western India. London: The British Association for South Asian Studies.

114 Brancaccio 2007: 388-393, figs. 14.3-4; Karttunen 1997a: 332-3; Raschke, Manfred. 1978. New Studies in Roman Commerce with the East. Berlin / New York: W. de Gruyter, 665 ff.; Ray 1994: 76, 79-82, fig. 10.

${ }^{115}$ Karttunen 1997a: 320; Ray 1994: 84; Salomon, Richard. 1991. "Epigraphic Remains of Indian Traders in Egypt". Journal of the American Oriental Society. 111.4, 731-736; Salomon, Richard. 1993. "Addenda to "Epigraphic Remains of Indian Traders in Egypt." Journal of the American Oriental Society. 113.4, 593. 
of nard, ivory, and textiles from Muziris to the port of Myos Hormos on the Red Sea and across the desert to Koptos and then down the Nile River to Alexandria. ${ }^{116}$ Merchants from other areas of the western and northwestern Indian subcontinent also wrote Brāhmī and Kharoșthī graffiti in caves on the island of Socotra, near the coast of Yemen, which was an important node in the maritime network. ${ }^{117}$

A partial list of the major ancient Indian seaports described in the Periplus Maris Erythraei includes:

1. Barbaricon (\$38-9) was a port at the mouth of the Indus River near the "metropolis of Scythia" named Minnagara, where "all the cargoes are taken up the river to the king" (Casson 1989: 75). ${ }^{118}$ Barbaricon imported clothing, multicolored textiles, peridot or topaz (chrysolithon, "golden stone"), coral, storax, frankincense, glassware, silverware, money, and a limited amount of wine; in return, it exported costus, ${ }^{119}$ lykion, ${ }^{120}$ bdellium, ${ }^{121}$ nard, ${ }^{122}$

116 Casson, Lionel. 1986. "P. Vindob G 40822 and the Shipping of Goods from India." Bulletin of the American Society of Papyrologists 23.3-4, 73-79; Harrauer, Hermann and Pieter J. Sijpesteijn 1986. "Ein neues Dokument zu Roms Indienhandel, P. Vindob. G 40822." Anzeiger der Österreichischen Akademie der Wissenschaften, philosophischhistorische Klasse 122, 124-155; Morley 2007: 42; Parker 2008: 173-174. For the location and significance of Muziris in the Periplus Maris Erythraei, see no. 4 below.

117 Strauch, Ingo and Michael D. Bukharin. 2004. "Indian Inscriptions from the Cave Hoq on Suquțrā (Yemen).” Annali Istituto universitario orientale (Naples, Italy) 64, 12i-138.

${ }_{118}$ Neither Barbaricon nor Minnagara have been conclusively identified due to the shifting delta of the lower Indus River, but Barbaricon can probably be localized at or new Barbhore in Sindh in southern Pakistan. The statement that "the throne is in the hands of the Parthians, who are constantly chasing each other off it" (Casson 1989: 75) may refer to the political situation in this region during the middle to late first century CE, perhaps following the reign of Gondophares. See Chapter 2, subchapter: Indo-Parthians: Mahārāja Gondophares of the Gondopharids? (pp. 123-125) for a brief overview of chonological and historical issues.

119 Costus corresponds to Sanskrit kuștha, a medicinal herb from the Kashmir valley (Casson 1989: 191; Rawlinson 1916: 124-5; Warmington 1928: 197-8).

${ }_{120}$ According to Rawlinson 1916: 125 and Warmington 1928: 205, lykion (or lycium) was a medicine (a yellowish dye used as an astringent) and cosmetic extracted from the western Himalayan barberry. Casson (1989: 192-3) seems to prefer an identification of lykion with extract from the wood of Acacia catechu grown throughout India and Burma.

${ }^{121}$ Bdellium is gum resin from the gugul tree (Balsamodendron mukul) grown in western India and Pakistan which is very closely related to myrrh (Balsamodendron myrrha) (Casson 1989: 185; Warmington 1928: 201).

${ }_{122}$ Nard corresponds to Sanskrit nalada (Nardostachys jatamansi), a plant belonging to the Valerian class used for making expensive fragrant oils (Rawlinson 1916: 126; Warmington 1928: 195). Despite some problems with the reading of the text (Casson 1989: 262-3), a northwestern origin for these items is clear. 
turquoise, ${ }^{123}$ lapis lazuli, ${ }^{124}$ indigo ${ }^{125}$ and Chinese pelts, cloth, and yarn (silk). Since most of the exported commodities were brought down the Indus River from or through the mountain areas of northern Pakistan, Afghanistan and Kashmir, Barbaricon functioned as a major outlet for long-distance trade items from the Northwest.

2. Barygaza $(\$ 41-51)$ is identified with Bharukaccha (Sanskrit Bhrgukaccha), modern Broach in Gujarat, near the mouth of the Narmada River. Casson points out that "Barygaza is far and away the most important of the foreign ports mentioned in the Periplus Maris Erythraei, occurring in nineteen of the sixty-six chapters" (1989: 200). Literary references to Bharukaccha in Pāli and Sanskrit Buddhist literature also indicate that it was an important seaport with links to cities in northern India. ${ }^{126}$ According to Periplus Maris Erythraei $\$ 41$, the coastal region around the gulf of Barygaza (Gulf of Khambhat/Cambay) was "the beginning both of Manbanos's realm and of all India" (Casson 1989: 77). Since Manbanos may be identified with Nahapāna, the Periplus Maris Erythraei shows that the Kșaharāta line of Western Kșatrapas controlled the region around Barygaza in the middle of the first century CE. ${ }^{127}$ In contrast to Barbaricon, Barygaza was not only an important port, but also functioned as an industrial center for the manufacture and distribution of a wider variety of commodities. ${ }^{128}$ Imports to Barygaza listed in the Periplus Maris Erythraei (\$49) included wine, coral, copper, tin, lead, peridot or topaz, many types of clothing, storax, yellow sweet clover, raw glass, realgar, sulphide of antimony, gold and silver Roman coins, silverware, musicians, and "beautiful girls for concubinage" (Casson 1989: 81). The items listed for export were very similar to those traded in Barbaricon: nard, cos-

${ }^{123}$ Turqoise ("blue-green stone") may have come from mines near Nishapur in northeastern Iran (Casson 1989: 194).

${ }^{124}$ Lapis lazuli probably came from Badakhshan in northeastern Afghanistan (Casson 1989: 194), although other sources of lapis lazuli have been found in Baluchistan near the borders of Pakistan, Afghanistan and Iran.

${ }^{125}$ Indigo ("Indian black") was used in Roman paintings and as a pharmaceutical (Casson 1989: 194-5; Warmington 1928: 204-5).

${ }_{126}$ Chakraborti 1966: 92 ff.; Gokhale, B.G. 1987. "Bharukaccha/Barygaza.” In Pollet, ed. 1987: 68-70; Law 1932: 56-7; Law 1954: 277-9; Ray 1986: 57 ff. cite references in and Pāli and Sanskrit texts.

127 The issue of dates and identification of Nahapāna with Manbanos is treated in Ksaharāta and Kärdamaka Kṣatrapas in Western India, pp. $126 \mathrm{ff}$.

${ }_{128}$ Casson 1989: 22; Chakraborti 1966: 95-6. 
tus, bdellium, lykion, and Chinese cloth (silk), but in addition ivory, onyx, agate, cotton cloth, molochinon cloth, and long pepper.

3. Ports enumerated in the Periplus Maris Erythraei (\$52-3) south of Barygaza in the vicinity of modern Bombay include Suppara, corresponding to Sopāra (Sanskrit Śurpāraka), Kalliena (Sanskrit Kalyāna), and Semylla, identified with Chaul. The Periplus Maris Erythraei provides specific information about political dynamics in Kalliena, where:

.... in the time of the elder Saraganos was a port of trade where everything went according to law. [Sc. It is no longer] for, after Sandanes occupied it, there has been much hindrance [sc. to trade]. For the Greek ships that by chance come into these places are brought under guard to Barygaza." (Casson 1989: 83)

The "elder Saraganos" may refer to Sātakarni, perhaps the father of Gautamiputra Sātakarṇi, and Sandanes may have been a local Western Kșatrapa official under Nahapāna who disrupted Sātavāhana control of Kalliena and other ports in this area of the coast by re-routing foreign ships which were bound for Barygaza. Apparently, the Western Kșatrapas and Sātavāhanas, as well as the dynasties which followed them in western India, continued to struggle for control of seaports used in the lucrative maritime trade described in the Periplus Maris Erythraei.

4. Muziris, probably located at Pattanam near the mouth of the Periyar River in Kerala, was the most significant port south of modern Mumbai described in the Periplus Maris Erythraei (\$53-4). ${ }^{129}$ According to the text, "Muziris, in the same kingdom [of Keprobotos, Sanskrit Keralaputra], owes its prosperity to the shipping from Ariake [region around Barygaza] that comes there as well as to Greek shipping" (Casson 1989: 84-5). The primary export of this region was pepper, but pearls, ivory, Chinese cloth (silk), Gangetic nard, malabothron (cinnamon), transparent gems, diamonds, sapphires, and tortoise shell also appear in the list of items in Periplus Maris Erythraei \$56. The testimony of the Periplus Maris Erythraei agrees with Indian archaeological and literary evidence which associates southern India with jewel mining and maritime trade.

129 Selvakumar, V., K.P. Shajan, and Roberta Tomber. 2010. "Archaeological Investigations at Pattanam, Kerala: New evidence for the location of ancient Muziris." In Tomber, et al. 2010: 29-41. For locations of other ports, see Appendix 5: India's West Coast, from Bombay to Cape Comorin in Casson 1989: 294-299, fig. 17, table 1. 
5. Podukê, briefly mentioned in Periplus Maris Erythraei \$60, is identified with Pondicherry, the former French colony south of Chennai on the southeast coast of Tamil Nadu. ${ }^{130}$ Excavations at Arikamedu, the site of the ancient port about two miles south of Pondicherry, have resulted in discoveries of imported Roman Arretine ware, amphorae, glass, and other archaeological materials which demonstrate sustained economic and cultural contact with western trade from the first century CE to ca. 200 CE. ${ }^{131}$ According to the Periplus Maris Erythraei, local boats sailed up and down the eastern coast and around Cape Comorin to the western coast to carry out indirect maritime trade, which was probably more common than direct trade with foreign merchants at these ports. Since the Periplus Maris Erythraei provides much less information about the east coast than the west coast, western seafaring merchants seem to have circumnavigated India very rarely. ${ }^{132}$

Overland routes between India and the West were not as popular as maritime routes for long-distance trade. Isidore of Charax described overland trade routes from Mesopotamia to Kandahar in the "Parthian Stations" (Stathmoi Parthikoi) written in Greek around the beginning of the first century CE. ${ }^{133}$ The account of the itinerary begins at the crossing of the Euphrates River at Zeugma, which was directly connected with Antioch, and lists stages and distances of the journey to Seleucia on the Tigris River $(\$ 1)$, near the Parthian winter capital at Ctesiphon. From Seleucia or Ctesiphon, travelers proceeded across the Iranian plateau to the Parthian summer capital at Ecbatana (\$6), and onward to the city of Rhaga in Media (near modern Tehran) and the Caspian Gates (\$7). The route continued eastward to Antiochia in Margiana ( $\$ 14$, modern Merv in Turkmenistan), where it was linked with routes to Sogdia, Bactria and the Oxus valley. However, the route described by Isidore of Charax branched off southwards from Margiana to Alexandria of the Arii ( $\$ 15$, modern Herat in western Afghanistan), Sacastana ( $\$ 18$, Seistan), and the metropolis of Arachosia at Alexandropolis $(\$ 19$, modern Kandahar in southeastern Afghanistan), where the account ends with the state-

130 Casson 1989: 89, 228.

131 For excavations at Arikamedu, see Allchin 1995: 147-50, figs. 8.12-5; Begley, Vimala. 1996. The Ancient Port of Arikamedu: New excavations and researches, 19891992. Pondichéry: École française d'Extrême-Orient; Casson 1989: 228-9; Karttunen 1997a: 334-5; Parker 2008: 175-176; Ray 1994: 69-76; Sidebotham 1986: 22, fn. 26 (with further references to earlier publications by Mortimer Wheeler).

132 Karttunen 1997a: 334-5.

133 Schoff, Wilfred H., trans. 1914. Parthian Stations by Isidore of Charax: An account of the overland trade route between the Levant and India in the first century B.C. Philadelphia: Commercial Museum. 
ment: "As far as this place the land is under the rule of the Parthians" (Schoff 1914: 9). From Kandahar, which was a significant urban center and node for long-distance trade between South Asia and Iran since pre-Achaemenid times, routes to the northeast led to Gandhāra and Taxila, while a southeastern route led to the lower Indus. ${ }^{134}$ Rather than following the route to Kandahar described in the Parthian Stations, at least one Macedonian merchant (who may have lived in Syria) named Maes Titianus traveled from Bactria through the mountain countries of the Comedi and Sakas (Sacae) to a place called the "Stone Tower" (probably modern Tashkurgan in Xinjiang) in order to meet Chinese silk traders. ${ }^{135}$ Although Strabo $(2.1 .15,17 ; 11.5 .8,11.7 .3)$ and Pliny (6.19.52) refer to another route for Indian merchandise from Bactria through the Oxus valley to the Caspian Sea, these reports are suspect due to western authors' lack of familiarity with the geography of Central Asia. Compared with the knowledge of maritime routes in classical sources, "much less is known of land-trade, though occasional glimpses of evidence show that caravans were traveling and dogs barking, even if only a few echoes reach us" (Karttunen 1997a: 348).

From this broad survey of links between transregional South Asian networks and maritime and overland routes to the West, it is tempting to suggest that the Indian subcontinent played a major role in the 'world system' of international commerce with the Roman empire during the early centuries CE. The maritime network detailed in the Periplus Maris Erythraei, excavations of ancient ports such as Arikamedu in southern India and Leukos Limen in Egypt, and literary and epigraphic references outlined in this section seem to validate Pliny the Elder's moral outrage over the cost of long-distance trade in luxury items from India, China and Arabia:

And by the lowest reckoning India, China and that peninsula [Arabia] take from our empire 100 million sestertii each year. That is the sum which our luxuries and our own women cost us. For what fraction of these imports, I ask, gets to the gods or to the lower world? (Natural History 12.84; Sidebotham 1986: 36) 136 $^{13}$

${ }^{134}$ See Allchin 1995: 127-30, figs. 8.3-4 and Ball, Warwick, and Jean Claude Gardin, eds. 1982. Archaeological gazetteer of Afghanistan = Catalogue des sites archéologiques d'Afghanistan. Paris: Editions Recherche sur les civilizations, vol. 1, 145-7, no. 522 for excavations at Kandahar. Karttunen 1997a: 337 and Warmington 1928: 21 refer to routes from Kandahar to the Indian subcontinent.

${ }_{135}$ Charlesworth, Martin Percival. 1926. Trade-Routes and Commerce of the Roman Empire. 2nd ed. Cambridge: Cambridge University Press, 103.

136 Morley 2007: 39 and Parker 2008: 184 translate and discuss the significance of Pliny the Elder's statement. Morley uses this passage to question misleading 
Steven Sidebotham warns that "we must use these citations cautiously" (1986: 36) since the volume of long-distance trade cannot be reliably determined on the basis of this passage. Nevertheless, Lionel Casson calculated that the aggregate value of the cargo of a fully loaded large ship capable of carrying 500 tons of the types of Indian commodities described in the second century Muziris papyrus (P. Vindob G 40822) would have been about 20,000 talents. ${ }^{137}$ This estimate would support the contention by E.H. Warmington, H.G. Rawlinson and other scholars that an "adverse balance" of trade favored India. According to Warmington:

...the Empire taken as one unit was often unable to offer to foreign regions in general and to oriental nations in particular sufficient products of its own to balance the articles imported from them in large quantities, and the result of this was the draining away from the Empire of precious metals in the form of coined money without any adequate return. (1928: 273)

Warmington's observation that "The 'drain' to the East has continued therefore for nearly 2000 years" (ibid., 312) has recently been echoed by Andre Gunder Frank, who emphasizes the dominance of Asia in the global economy between 1400-1800, when gold and silver imported from American colonies enabled Europe, "which remained a marginal player in the world economy with a perpetual deficit" (1998: 75), to import commodities from Asia without offering much in return besides specie. Judging from the items described in the Periplus Maris Erythraei, it is likely that similar exports of gold and silver coinage were necessary to balance imports from India.

distinctions between "luxuries" and staples in the ancient economy (2007: 40-43) and provides other examples of "elite disdain for 'trade"” (2007: 83). Parker comments that "Moral rectitude again emerges as the all-important lens through which Pliny visualizes the issues at hand" (2008: 184) and acknowledges that the "suspiciously rounded" figures justify suspicions that "Pliny himself may have been lying with statistics, using them to reinforce points motivated by concerns with morality" (189), but still finds the estimate "within the limits of credibility" (186).

${ }_{137}$ Casson, Lionel. 1988. "Rome's Maritime Trade with the Far East." American Neptune 48.3, 152. Parker observes that the goods in the Muziris papyrus valued at 1,145 talents and 2,852 drachmae would have amounted to 7 million sestertii, suggesting that Pliny's estimates of an annual drain of between $50-100$ million sestertii ".... are still within the bounds of the possible" (2008: 186). 


\section{Conclusions}

The exploration of arterial networks known as the Northern Route (Uttarāpatha) and Southern Route (Dakșināpatha) in this chapter has established guidelines for investigating paths for transregional movement within and beyond the Indian subcontinent. Archaeological patterns, inscriptions, and literary references show that these constantly shifting routes were used for intra- and interregional travel by various classes of merchants, rulers, administrators, armies, and monks, nuns and pilgrims. Evidence of trade and other economic activities involving the transportation of material commodities frequently indicates broader patterns of cultural exchange and social transformation, including interrelationships between urbanization and religious expansion. Long-distance networks certainly incorporated regional and local networks of individual macro-regions (janapadas), cities, and shrines. While it is useful to identify distinctive features of local cultures through analysis of small-scale exchanges of ordinary goods and catchment zones for religious patronage, this study has drawn attention to interactions between nodes, regions, and micro-networks in order to highlight mobility between distant regions and contacts between ancient South Asia and the outside world.

References to Uttaräpatha and Dakinäpatha in texts and inscriptions apparently indicate that the names of these arterial networks of transregional routes were appropriated as geographical/cultural terms for distinguishing the 'Middle Country' of Āryāvarta or Madhyadeśa from the northwestern and southern regions of the Indian subcontinent. Orthodox Brahmanical tendencies to view the inhabitants of peripheral borderlands as impure are related to the presence of foreigners who migrated to and ruled the Northwest and coastal seaports (including Barbaricon and Barygaza in the Periplus Maris Erythraei). The qualitative impact of transcultural exchanges resulting from the movement of people and materials via overland and maritime networks varies enormously depending on conditions for selective appropriation and re-contextualization. ${ }^{138}$ Aside from ephemeral adoption of figurines of exotic animals and some devotional items, mutual impacts

${ }_{138}$ These terms are adopted from Pia Brancaccio, who observes that "Foreign models were selectively appropriated and recontextualized when they seemed familiar to the indigenous background" (2007: 392). 
of maritime trade across the Indian Ocean are difficult to discern in western and southern India. In contrast, longstanding patterns of interaction between the Ganges basin and the Northwest contributed to a major shift in cultural geography from the Punjab to the GangesYamuna doāb by the mid-late centuries BCE and provided pathways for the transmission of Buddhism and other śramana movements that originated in Magadha to Mathura and Taxila beginning in the Mauryan period. Networks of exchange between the plains of North India and the Deccan plateau likewise facilitated the establishment of stuppas, caityas, and residential monasteries at significant transit points and hubs of the Southern Route at Bharhut, Vidiśā, Ujjayinī, the Western Ghats, and the Krishna-Godavari river valleys. The successful transplantation of Buddhism was not simply an outcome of long-distance trade, but required other conditions for the sangha to flourish. By looking more carefully at the Indo-Iranian borderlands of Gandhāra in the next chapter, such conditions for the regional proliferation of Buddhist material and literary culture in the fertile environment of the northwestern frontier will be clarified. 


\section{OLD ROADS IN THE NORTHWESTERN BORDERLANDS}

Ancient Gandhāra was a pivotal contact zone for movement into and out of South Asia. Migrations of Greeks, Sakas, Kușānas and Huns enriched the political and cultural history of this fertile region, which served as a launching pad for Buddhist transmission across the Hindu Kush and Karakorum mountains. As at other major South Asian nodes (such as Taxila, the northwestern metropolis located across the Indus River from Gandhāra proper), material surpluses generated by agriculture and trade permitted Buddhist complexes with stüpas and monasteries to proliferate in Gandhāra and neighboring regions. Although Gandhāra was geographically distant from Sākyamuni Buddha's homeland in Magadha, the localization of his relics and narratives of his former lives contributed to a strong and enduring Buddhist presence during the first millennium CE. Gandhäran Buddhist art and archaeology, inscriptions and coins, and new discoveries of several collections of Gāndhārī manuscripts from the first few centuries $\mathrm{CE}$ amply demonstrate this region's rich material and literary culture. These sources, along with the accounts of Chinese pilgrims who visited regional shrines and monasteries between the fifth and seventh centuries CE, provide different viewpoints on Gandhāran Buddhism. The regional 'transplantation' of Buddhism in Gandhāra and its successful movement across mountain passes raise interesting and longstanding questions about the character of Gandhäran Buddhism and the impetus it gave to transmission beyond the frontiers of the Indian subcontinent. ${ }^{1}$ Which Gandhāran religious, cultural, economic, and political features have had discernible impacts on Buddhist literary texts, artistic motifs, devotional practices, and monastic architecture and institutions? To what extent are dynamic syntheses of hybrid indigenous, Indian, Iranian, and exogenous elements resulting from contacts and

${ }^{1}$ As a transplant requires suitable soil and other conditions to grow and flourish, whereas it is not necessary for an implant to adjust to a different environment, "transplantation" is preferable to the "implantation of Buddhism" discussed by Lamotte 1988: 333 [1958: 365] and elaborated by Fussman 1994a. 


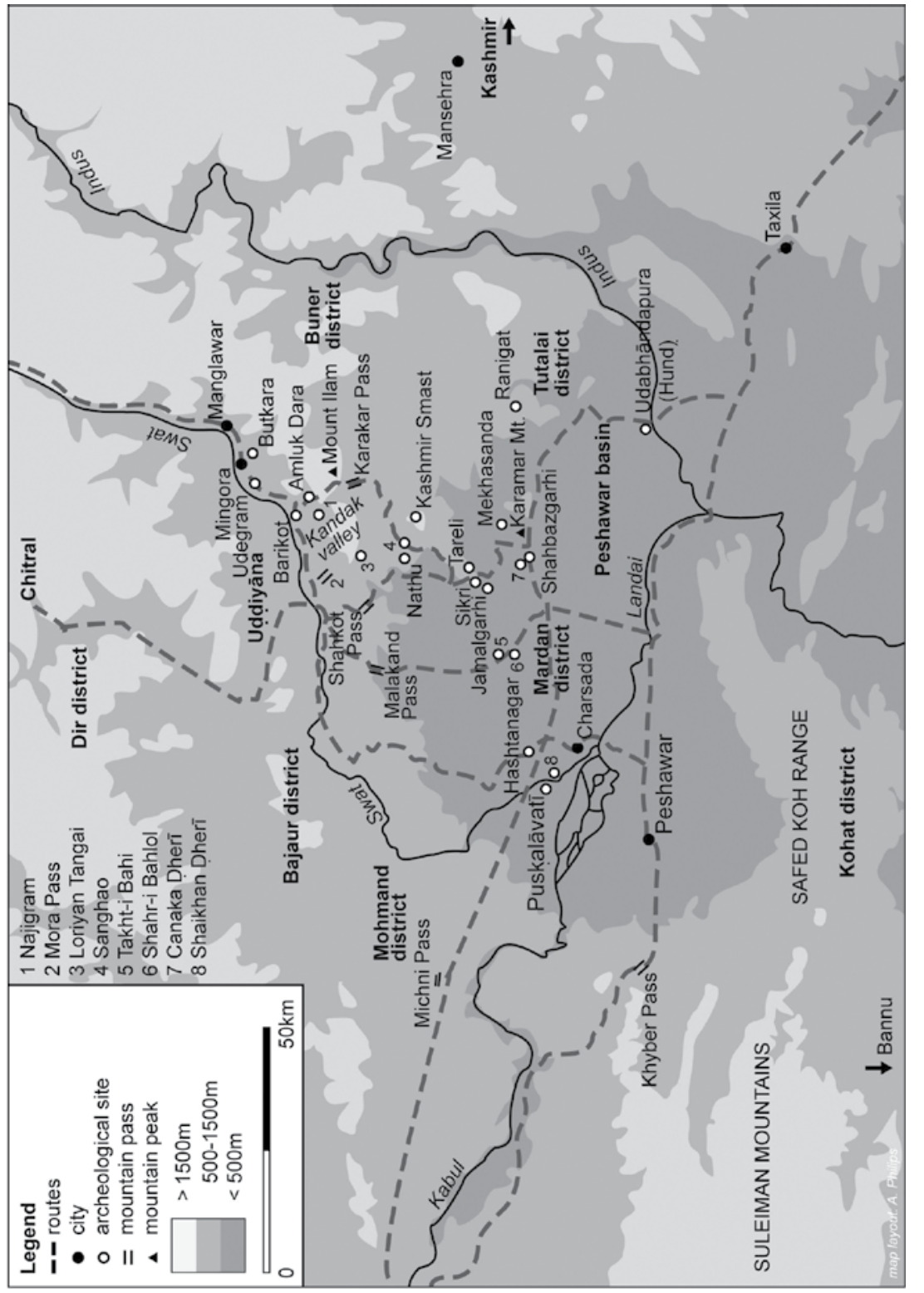

.

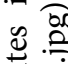
क 정 . 응 巡

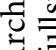
$4 \frac{1}{5}$

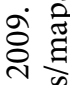
घ่ 등 중 콕 50 $\exists \stackrel{\Xi}{*}$ $\Xi \frac{\pi}{4}$ 空 등 రृ (ํ. อี สี ) 茫 选 乙 च्己 $\infty$ वृ 乙 컹 츌 주 클 สี กิ 붐듬 సิำ 
exchange with transregional migrants assimilated with Buddhist traditions? How was it possible for the Buddhist sangha to thrive for so long in this regional borderland, and why did Gandhāran Buddhism have such an extensive influence on early patterns of transmission in Central Asia and China? In order to address these questions, environmental, political, and economic conditions for settlement patterns and the institutional expansion of Buddhist shrines and monasteries are surveyed, along with relevant Gandhāran material sources. Nodes and networks for cultural and religious transmission between Gandhāra, Uḍ̣̣iyāna (Swat valley), and Bactria (northern Afghanistan and the Oxus basin) are delineated. These connections permit us to retrace the overland itineraries of South Asian Buddhist missionaries to Central Asia and East Asia and to locate Buddhist shrines and monastic communities reported by visitors such as Faxian, Song Yun, and Xuanzang. This examination of 'Old Roads' for religious mobility concludes with an assessment of how Gandhāran Buddhists 'imagined a place for Buddhism' and made it their own through processes of social, cultural, and literary 'domestication,' particularly by situating jātakas, avadānas and other previous-birth narratives in the northwestern frontier milieu. ${ }^{2}$ Rather than importing Buddhist traditions without modification from Indian Buddhist centers, Buddhists selectively appropriated and transformed religious media to localize the Buddha's presence and to turn the Dharmacakra from the regional hub of Gandhāra.

\section{Environmental Conditions for Buddhist Transmission in Gandhāra}

Just as religious and social conditions in ancient Magadha proved ideal for the emergence of the Buddhist saingha, the geographical, economic, and political environment of Gandhāra was optimal for Buddhist traditions imported from northern India to grow and expand in new directions. Before mapping regional routes in the northwestern borderlands, it is necessary to demarcate topographical features and the broader cultural extent of Gandhära in order to discern significant

2 The phrase 'imagining a place for Buddhism' is borrowed from Monius, Anne E. 2001. Imagining a Place for Buddhism: Literary culture and religious community in Tamil-speaking South India. Oxford: Oxford University Press. The cultural and literary domestication of Gandhāran Buddhism is discussed at the end of this chapter. 
patterns in the distribution of Buddhist establishments. The "center of gravity" (Foucher 1905: 1.13) of Gandhāra was located in the Peshawar basin around the confluence of the Kabul and Swat rivers, which join to form the Landai tributary of the Indus River. ${ }^{3}$ While the Indus River marks the eastern boundary of Gandhāra proper, the Suleiman Mountains form a permeable western boundary interspersed with numerous passes (besides the famous Khyber Pass). ${ }^{4}$ The Safed Koh range separates the Peshawar valley from the Kohat district to the south in the North-West Frontier Province (NWFP) of Pakistan. Passes leading to the Mohmand and Bajaur districts in the northwest and the lower Swat valley and Buner district in the north and northeast intersect an arc of hills on the northern rim of the Peshawar basin. The rich alluvial land watered by drainage from the surrounding mountain valleys along with seasonal monsoon rains has long sustained "substantial agriculture and urban centres, and the entire region forms a transit zone between the highland massif of Central Asia and the Indian plains" (Zwalf 1996: 14).

Gandhāra was located on an extension of east-west arterial routes of the Uttarāpatha as well as northern and southern regional feeder routes. While the Gandhäran core area can be narrowly defined as the Peshawar basin, the amorphous cultural influence of "Greater Gandhāra" (Salomon 1999: 3) extended across the Indus River to Taxila ( $30 \mathrm{~km}$ east of the Indus) and westwards into modern Afghanistan following the Kabul River upstream to Jalalabad and Kabul, as well as the Bamiyan valley. ${ }^{5}$ Areas to the north of Gandhära, such as

${ }^{3}$ For the hydrography of Gandhāra, see Foucher 1942: 1.51-52 ("La rivière maîtresse"), Fussman 1994a: 18; Jansen, Michael. 2008. "The Cultural Geography of Gandhara.” In Luczanits 2008: 28; and Zwalf 1996: 14.

${ }^{4}$ Dar, Saifur Rahman. 2007. "Pathways Between Gandhāra and North India during the Second Century B.C.-Second Century A.D." In Srinivasan 2007: 24-54 correlates nineteenth-century geographical descriptions of routes and mountain passes in the northwestern frontier of British India with archaeological discoveries from ancient Gandhāra.

${ }^{5}$ Although Takkasilā (Taxila) (treated in greater depth in Chapter 3: Taxila, pp. 201-204) is referred to as the capital of the Gandhāra mahājanapada in Pāli literature (Dietz 2007: 49; Law 1932: 49-50), a late passage in the Rāmāyana (7.101.11) distinguishes between the capital of the Gandhāra visaya at Pușkalāvatī (modern Charsada) and the capital of the Gandharva deśa at Taksaśila (Taxila) (Jansen 2008: 27). Fussman criticizes the inclusion of Taxila in Gandhāra "par abus de langage" (1994a: 18, n. 6), but admits that Taxila participated in Gandhāran culture. While some authors add the Bamiyan valley "to the west of the core region" (Jansen 2008: 27) and areas of Bactria north of the Hindu Kush to 'Greater Gandhāra,' more restrictive 
the Swat, Bajaur, Buner, Dir, Chitral, and the upper Indus, Gilgit, and Hunza valleys also maintained varying levels of cultural, commercial and religious contact with Gandhāra, yet remained distinct regions. Bannu, Kohat, and the Kurram valley located directly to the south of the Peshawar basin can also be included within the broader orbit of Gandhāra, but Kandahar and other areas of southeastern Afghanistan and neighboring areas of Baluchistan in southwestern Pakistan may be excluded. In this chapter, networks that connected the core areas of ancient Gandhāra with Swat and Bajaur to the north and with ancient Bactria across the Hindu Kush further to the northwest are discussed in more depth than links with Taxila (already treated in chapter 3 ) and the upper Indus (the focus of chapter 5).

The growth of Buddhism in Gandhāra benefited from political and social factors, including royal patronage and urbanization. Since Gandhāra and the lower Indus River valley were Achaemenid provinces until Alexander of Macedon's attempted conquest in 327-6 BCE, the northwestern borderlands played important roles in the formation of early western classical ideas about Indian politics and life. ${ }^{6}$ During the reign of Aśoka (ca. 272-232 BCE), Major Rock Edicts inscribed in Kharoșthī at Shahbazgarhi and Mansehra signaled that these northwestern frontier regions belonged to the Mauryan empire. ${ }^{7}$ The initial foundations of Dharmaräjika stūpas at Taxila and at Butkara I in the Swat valley probably date to the Mauryan period, although Aśokan Buddhist inscriptions are not found at these early monuments. ${ }^{8}$ While Buddhist missionaries may have reached Gandhāra earlier than the

definitions limit its extent to the valley of the Kabul River and its tributaries in northeastern Afghanistan.

${ }^{6}$ See Chapter 2: Iranian Contacts in the Northwest and Hellenistic Interactions, pp. 96-109. Gandhāra and the western borderlands were the primary contact zones between the Hellenistic and Indian worlds before Alexander's campaign.

7 See Chapter 2: Legacy of the Mauryans: Aśoka as Dharmarāja, pp. 78-94 and Falk 2006: 127-129 (Mansehra), 132-135 (Shahbazgarhi) for Aśokan edicts in Kharoșthī. Falk 2006: 241-253 points out that the Aramaic inscriptions from sites around Jalalabad (Laghman and Pul-i Darunta) mention Aśoka (King Priyadarśin) as ruler, but seem to report legal verdicts instead of recording Aśokan edicts.

${ }^{8}$ Fussman 1994a: 19 and Behrendt 2004: 40 express skepticism about the attribution of these stūpas to Aśoka and argue for later dates in the second century BCE rather than the Mauryan period. While Aśokan inscriptions "do not directly address the introduction of Buddhism into Gandhara" (Behrendt, Kurt. 2007. The Art of Gandhāra in the Metropolitan Museum of Art. New York: Metropolitan Museum of Art, 21), a Mauryan imperial presence in the Northwest firmly attested by Aśokan edicts at Mansehra and Shahbazgarhi supports the consensus view that the foundations for these two stüpas can be reasonably dated in the third century BCE. 
time of Aśoka, the official introduction of Buddhism was apparently linked with imperial support, and it is only significantly later in the first century BCE and first century CE that Buddhist stūpas and monasteries begin to proliferate when the Sakas and their subordinates exerted control over routes and territories between Gandhāra and Mathura.

Settlement patterns indicate that agricultural surpluses fueled the growth of Gandhāran urban centers such as Puṣkalāvatī, the ancient capital of Gandhāra near modern Charsada. ${ }^{9}$ Other important cities with very early archaeological layers ranging from prehistoric to IndoGreek periods include Barikot, Udegram, and Mingora in the Swat valley, Puruṣapura (modern Peshawar), and Udabhaṇdapura (modern Hund) at an important crossing of the Indus River. ${ }^{10}$ Recent surveys of the Peshawar basin by Ihsan Ali and other Pakistani archaeologists have revealed that the first century $\mathrm{BCE}$ and first century $\mathrm{CE}$ were periods of intensive growth of urban and suburban centers. ${ }^{11}$ Although there is relatively little archaeological evidence for Buddhist shrines

9 Sanskrit Puskkalāvatī (or Puṣkarāvatī) "lotus town," is identified with the Bālā Hișsār mound, which was excavated by Mortimer Wheeler (Wheeler, Mortimer. 1962. Chärsada: A metropolis of the North-West Frontier, being a report on excavations of 1958. Oxford: Oxford University Press for the Government of Pakistan and the British Academy). Wheeler "suggested" that the site was occupied between the sixth to first or second century BCE (Callieri 1995: 299), but it could be dated much earlier according to Stacul, Giorgio. 1990. "On Chārsada and Beyond: What is Wrong with Sir Mortimer?” In Taddei and Callieri, eds. 1990: 605-610 (cited by Karttunen 1997a: 50). Marshall, John H. and Jean-Philippe Vogel 1904. "Excavations at Charsada."Annual Report of the Archaeological Survey of India for the Year 1902-1903. Calcutta: Superintendent of Government Printing, 141-184 report on earlier excavations and Taj Ali, et al. 1997-1998. "Preliminary Report of Two Seasons of Archaeological Excavations at the Bala Hissar of Charsadda, NWFP, Pakistan." Ancient Pakistan 12, 1-34 reports on more recent excavations. Also see comments by Foucher, Alfred. 1901. "Notes sur la géographie ancienne du Gandhâra." Bulletin de l'École française d'Extrême-Orient 1, 331-340; Foucher 1931. "De Kāpiśi à Pushkarāvatī." Bulletin of the School of Oriental Studies 6.2, 341-8; and Foucher 1942: 1.41-5, 1.155-158 for geographical and historical comments. Settlement at the neighboring site of Shaikhān Ḍherī can be dated to the Indo-Greek period beginning in the third and second centuries BCE on the basis of coins of Indo-Greek rulers and classical double-moulded terracotta figures (Callieri 1995: 299-300; Dani, Ahmad Hasan. 1965-1966. "Shaikhan Dheri excavation (1963 \& 1964 seasons)." Ancient Pakistan 2, 17-214.

${ }^{10}$ Callieri, Pierfrancesco. 2008. "The Archaeological Basis." In Luczanits 2008: 58-63.

${ }_{11}$ Ali, Ihsan. 1994. "Settlement History of Charsada District." Ancient Pakistan 9, 1-164; Ali, Ihsan. 2003. "Early Settlements, Irrigation, and Trade Routes in Peshawar Plain, Pakistan.” Frontier Archaeology 1 (cited by Callieri 2008: 58); Ali, Taj. 2001. "Archaeological Survey of District Mardan in the North-West Frontier Province of Pakistan." Ancient Pakistan 14, 55-172. 
within these cities during the early pre-Kușanna periods, the proliferation of stüpas and monasteries located outside of cities, close to transit routes, or on hillsides above fertile agricultural zones demonstrates that regional Buddhist expansion was intrinsically linked to conditions of urban and agricultural prosperity. ${ }^{12}$

The distribution of Buddhist archaeological sites in Gandhāra and adjacent regions of the Northwest reveals connections between monastic networks and interregional itineraries through river valleys and across mountain passes. Alfred Foucher, the "father of Gandhāra studies" (Zwalf 1996: 74), proposed three stages for the "propagation of Buddhism" in Gandhāra and Bactria from ca. 250 BCE to $150 \mathrm{CE}$ :

1) Buddhist institutions expanded from northern India to the plains of Gandhāra between 250-150 BCE with the initial patronage of Aśoka.

2) Piedmont areas bordering the southern Hindu Kush and Himalayas gradually converted to Buddhism by the end of the first century $\mathrm{CE}$ at the time of the Kușananas.

3) After a "long interval of time had separated the evangelization of the mountains from that of the plains" (Foucher 1942-1947: 2.279), Buddhism crossed the Hindu Kush to the Oxus valley. ${ }^{13}$

Gérard Fussman also discusses a "relatively coherent (and possibly illusory) tableau" (1994a: 20) reflected by archaeology and epigraphy in which the first monasteries and dharmaräjika stūpas were established near cities at the end of the third century BCE, followed by progressive expansion into mountain areas from the second century BCE, and considerably more success at the beginning in the first century. These general models for understanding the growth of monasteries and paths of transmission in the context of regional topography tend to reify models of gradual diffusion from the Peshawar basin to the surrounding hillsides and over mountain passes without adequately accounting for the contemporaneous foundations of early stüpas at

12 Callieri, Pierfrancesco. 2006. "Buddhist Presence in the Urban Settlements of Swāt, Second Century BCE to Fourth Century CE.” In Behrendt and Brancaccio 2006: $60-82$.

${ }^{13}$ I reconsider the stages proposed by Foucher in Neelis, Jason. 2002 [2006]. " $L a$ Vieille Route Reconsidered: Alternative Paths for Early Transmission of Buddhism Beyond the Borderlands of South Asia." Bulletin of the Asia Institute 16, 146-147. 
Taxila and Butkara. Foucher's observation that dozens of Gandhāran Buddhist monasteries are "threaded like pearls of a necklace" (1942: 1.156) along sinuous routes and often mark the openings of the principal passes between Gandhāra and Uḍdịāna (Swat) draws attention to systemic connections between the construction of Buddhist shrines and travel routes, as was sometimes the case also for medieval Christian monasteries. ${ }^{14}$ Other possible reasons for "siting" Buddhist monasteries in pleasant garden-like surroundings, in idyllic locations suitable for meditation, or on promontories suitable for defensive purposes are not to be excluded. ${ }^{15}$ While acknowledging that different types of Gandhāran stūpas and monasteries were accommodated to the local landscape for various reasons, it is still useful to quickly revisit Foucher's early division of Buddhist archaeological remains in Gandhāra situated along "two concentric lines of ruins" (1905: 1.11-12), with sites on hills near cities of the Peshawar plain belonging to the inner band and those located further away on routes through the mountains between Gandhāra and Swat on the outer band.

Archaeological sites of Buddhist stuppas and monasteries in the Peshawar basin belonging to the inner radius tend to be located within or just outside of urban settlement areas. Stüpas and monasteries were rarely built inside of cities, but Buddhist sculptures excavated from the Bālā Hișsāā mound at Charsada (ancient Puṣkalāvatī) and a large stūpa-like structure in the adjacent city of Shaikhan Dheri probably dating from the second to fourth centuries CE are notable exceptions. ${ }^{16}$ The area of the "eight cities" (Sanskrit Aștanagara / modern Hashtanagar) near the confluence of the Kabul and Swat rivers (upstream from Charsada) has also been a very productive region for Buddhist mate-

${ }^{14}$ Marc Bloch's comments (1961 [1949]: 1.63) about the location of medieval European monasteries in proximity to trade routes may be applicable to the distribution of Gandhāran Buddhist monasteries.

${ }^{15}$ Schopen, Gregory. 2006. "The Buddhist 'Monastery' and the Indian Garden: Aesthetics, Assimilations, and the Siting of Monastic Establishments." Journal of the American Oriental Society 126.4: 487-505 draws attention to aesthetic considerations in the selection of locations for Indian Buddhist monasteries. Jansen 2008: 29 suggests that the stüpa and monastery at Nimogram on a high ridge above a side valley in Swat may have been due to the suitability of this spot for meditation, but does not exclude the possibility that such sites were chosen because they could be protected. Shaw 2007: 143 also suggests that that the "fortress-like aspect" of some towered platforms on hilltops around Sãñci could indicate that these sites were selected for monastic inhabitation because of their suitability for defense and surveillance.

${ }^{16}$ Callieri 2006: 76-77; Callieri 2008: 58-59, fig. 1. 
rial remains, but it is likely that extensive monastic sites have not been preserved because stone structures have been reused for modern buildings or lie buried beneath agricultural fields and settlements. ${ }^{17}$ Another major urban Buddhist complex was the "Kanișka vihära" and monumental stūpa at the site of Shāh-jī-kī Dherī in the city of Peshawar (ancient Purusapura), which is referred to in Faxian's account as "over four hundered feet high... decorated with various kinds of ornaments... [and] the most splendid in all of Jambudvipa" (Li 2002: 170-171)..$^{18}$ While recent excavations at Gor Khuttree in the center of Peshawar indicate that ancient Purușapura was occupied as early as the fourth century BCE, the Buddhist site at Shāh-jī-kī Ḍherī is likely to belong to Kanișka's period (after ca. $127 \mathrm{CE}$ ) or slightly later. Ancient Varușapura (probably localized at Shahr-i Bahlol) was another major ancient city in Gandhāra where extensive Buddhist structural remains and sculptures have been found since the nineteenth century, but the site is not well preserved due to continued occupation. ${ }^{19}$ However, the impressive remains of a large Buddhist shrine and monastic complex that may have housed approximately 250-350 monks at its peak are preserved at Takht-i Bahi on a ridge a few kilometers north of Shahr-i Bahlol. ${ }^{20}$ Significant archaeological remains of stüpas and monasteries located on ridges and hilltops overlooking the Peshawar plain directly to the east and northeast of Takht-Bahi include Jamalgarhi, Sikri, and Tareli. ${ }^{21}$ Other hilltop stūpas and monasteries at Mekhasanda and Canaka Ḍheri belonging to Foucher's inner concentric circle are

17 Behrendt 2004: 24, 176 plausibly suggests that the relative paucity of Buddhist archaeological remains in urban centers in the plains of the Peshawar Basin compared with better preserved complexes in the foothills may be attributed to modern population and development pressure.

${ }_{18}$ Kuwayama 1997 discusses the archaeological remains of the stüpa and monastery at Shāh-jī-kī Dherī in significant depth. Xuanzang also describes the shrine and neighboring monastery, along with narratives associating the construction of this complex with Kanișka (translated by Li 1996: 70-76). The so-called Kanișa reliquary inscription (CKI 145) is discussed in Chapter 2, subchapter Paradigms of Patronage under Kaniṣka and Huvișka, pp. 137-142.

19 Errington, Elizabeth. 1993. "In search of $P a$-lu-sha, a city of the central Gandhara plain." Bulletin of the Asia Institute 7, 55-66 localizes Varușapura (Pa-lu-sha in Chinese accounts of a shrine commemorating the Viśvantara narrative) at Shahr-i Bahlol.

${ }^{20}$ Behrendt 2004: 181-190, figs. 44-53 provides a recent overview of excavations at Takht-i Bahi since the nineteenth century.

${ }^{21}$ Behrendt 2004: 191-199, figs. 61-63 (Jamalgarhi), 68-77 (Tareli), 90-91 (Sikri) re-assesses the architectural and sculptural evidence from Tareli and Jamalgarhi, and estimates that the peak monastic populations may have been over 200 at Tareli and 
clustered on a spur of the Karamar mountain above Shahbazgarhi (where a set of Aśokan major rock edicts are inscribed). ${ }^{22}$ While the dating of these Buddhist monastic sites largely based on discoveries of coins, stylistic analysis of sculptures, and structural comparisons with Buddhist monasteries in Taxila and Swat remains open to dispute, their distribution can be explained by the ready availability of economic surpluses generated by prosperous urban settlements (ancient Purușapura, Puṣkalāvatī, Varușapura, and important crossroads at Shahbazgarhi) and the agricultural production of the rich Peshawar plain.

The outer band of the concentric line of Buddhist monasteries ringing the Peshawar Basin closely corresponds to transit points over mountain passes leading to Swat, Bajaur, Buner, and the upper Kabul River valley. For example, the so-called Shpola stūpa and the related monastic site of Ali Masjid just below the Khyber Pass leading to Jalalabad in eastern Afghanistan have received considerable attention because they are located on the primary modern route. ${ }^{23}$ Noting that many other Buddhist monasteries in the outer band mark the opening ("debouche") of principal passes between ancient Gandhāra and Uḍ̣iyana, Foucher commented that "... the route would become the unique reason for sanctuaries" (1942: 1.157). ${ }^{24}$ While the Malakand Pass is the main modern passageway between the Peshawar basin and the lower Swat valley, the routes through the Shahkot, Mora, and Karakar passes were lined with archaeological remains of Buddhist monasteries at sites such as Loriyan Tangai, Sanghao, and Nathu. ${ }^{25}$ Materials found at Kashmir Smast demonstrate that religious establishments on these transregional lines of communication were not exclusively Buddhist monasteries. ${ }^{26}$ Another important Buddhist monastic at Ranigat is located on a steep mountainside in the Tutalai district in the northeastern Peshawar basin. ${ }^{27}$ The distribution of Buddhist and other religious monasteries on transit routes through mountain passes between

about 100 at Jamalgarhi based on the number of cells built around the main courtyards and scattered among "mountain vihäras" on the hillsides.

${ }_{22}$ Behrendt 2004: 177-180, figs. 64-67 (Mekhasanda).

${ }^{23}$ Foucher 1942: 1.156, 159, n. 28; Luczanits 2008: 47, fig. 3.

24 "Parfois même, comme dans le cas extrême de Bâmiyân, la route sera l'unique raison d'être des sanctuaries." (Foucher 1942: 1.157)

${ }^{25}$ Zwalf 1996: 14, 18, n. 35.

${ }^{26}$ Nasim Khan, M. 2006. Treasures from Kashmir Smast: The earliest Śaiva monastic establishment. Peshawar: Dept. of Archaeology, University of Peshawar.

${ }^{27}$ Behrendt 2004: 97-99, figs. 78-82; Odani, Nakao. 2000. "New Discoveries from the Excavations at Rānigāt, Pakistan.” In Taddei, Maurizio and Giuseppe De 
Gandhāra, Swat, and Buner, indicates that some religious communities were not directly dependent on urban patronage or local agriculture, but benefited from their position within interregional networks used by traders, pilgrims, and other travelers.

\section{Gandhäran Material and Literary Cultures}

Archaeological excavations of Buddhist stūpas and monasteries as well as discoveries of Buddhist art, inscriptions, coins, and manuscripts amply testify to high levels of cultural production in Gandhāra and neighboring regions of the northwestern Indian subcontinent. The innovative adoption of local, Indian, Iranian, Hellenistic, and Central Asian features in Gandhāran Buddhist sculptures continues to attract the interest of art historians and contemporary museum audiences. According to Wladimir Zwalf:

The huge quantity of surviving sculpture and large number of sites reflect a powerful religious motivation in a region which, for some of the duration of the style, formed part of a large empire and possessed the commercial importance and consequent wealth for generous endowments. (1996: 20)

Foucher's masterly L'art gréco-bouddhique du Gandhāra (3 vols., 19051951) remains a major touchstone for studies of Gandhāran Buddhist art. His debate with A.K. Coomaraswamy concerning the primacy of foreign Hellenistic influences versus indigenous Indian sources for anthropomorphic depictions of the Buddha still resonates as a "confrontation of colonizer and colonized" (Abe 1995: 82) ${ }^{28}$ Among art historians who have reconsidered the role of Gandhäran artists in the

\footnotetext{
Marco, eds. 2000. South Asian archaeology, 1997. Rome: Istituto italiano per l'Africa e l'Oriente, vol. 2, 831-841.

${ }^{28}$ Foucher, Alfred. 1917. "The Greek Origin of the Buddha Image." In Foucher, The Beginnings of Buddhist Art and other Essays in Indian and Central-Asian Archaeology. Paris: P. Geuthner; [reprint, Varanasi/Delhi: Indological Book House, 1972), 111-137; Coomaraswamy, Ananda Kentish. 1927. "The Origin of the Buddha Image." The Art Bulletin 11, 287-329. Commenting on Foucher's penchant for finding Greek origins in the style of Gandharan Buddhist art, Abe makes an interesting point: "Foucher was in his own way attempting to enhance the standing of Gandharan art by incorporating Graeco-Buddhist art into the universal history of World Art" (1995: 80). Also see Chapter 2: Hellenistic Interactions, pp. 98-109, especially notes 121-127, for the problem of determining the chronology and extent of Greek influence on Gandhäran Budddhist art.
} 
formation of the Buddha image and the significance of western Hellenistic influences in Gandhāran Buddhist art, Maurizio Taddei's contributions are particularly noteworthy:

We cannot of course content ourselves with a bare description of convergency or derivation phenomena in iconography and style. Nor can we accept facts as mere links in a chain of stylistic evolution under the impact of a foreign artisitic culture: this would amount to admitting that Gandhāra was either a sort of cultural vacuum into which anything could be poured (just for the look of things) or a Hellenized province the inhabitants of which-though Buddhists! - regarded the Mediterranean countries as their fatherland. (2003 [1969]: 1.155-156) $)^{29}$

While Foucher recognized the importance of Gandhāra as a significant zone of contact and cultural transmission between India, Iran, Central Asia, and the Hellenistic world, his emphasis on foreign influence tends to diminish Gandhāran impacts, since he tended to regard ancient Gandhāra, Bactria, and Uḍ̣iyāna as transit zones between the great civilizations of Europe and Asia. ${ }^{30}$ The prominent role played by Gandhära in the development and elaboration of Buddhist artistic styles, architectural features, and the production, standardization, and transmission of texts written in Gāndhārī was connected to the position of this region on trade routes between ancient India, Iran and Central Asia, but it was hardly a "cultural vacuum" where these cultures just crossed paths.

Epigraphic and numismatic sources provide valuable evidence of intrareligious developments and interreligious dynamics in ancient Gandhāra. Kharoșthī inscriptions that record donations to Buddhist communities by male and female lay patrons, local and regional rulers, and monks and nuns supply concrete data for studying onomastic patterns, religious and political titles, and chronologies for regional

29 Original publication: "Harpocrates-Brahmā-Maitreya: A tentative interpretation of a Gandharan relief from Swāt." Dialoghi di Archeologica 3, 364-390. In "Some Reflections on the Formation of the Buddha Image" (2003: 2.593-607), Taddei asks "What is wrong with Foucher?" (596) in order to "...underscore the fact that some of the premises are simply wrong" (597). He concludes that "Gandharan artists introduced a technique of narration which is neither fully Indian not fully Hellenistic, though it was later widespread both in the Christian West and the Buddhist East; now we see that they introduced an image of the Enlightened One which is neither fully Indian nor fully Hellenistic; it was something new" (605).

${ }^{30}$ Foucher 1942-1947: 2.368-371 (“Orient et Occident”); Olivier-Utard 2003 [1997]: 76 comments that Foucher's views on Gandhāra and Afghanistan were conditioned by geographical and political outlooks of the early twentieth century. 
history and art. ${ }^{31}$ Monastic affiliations of recipients of gifts reflect the geographical distribution and relative influence of various Buddhist ordination lineages. ${ }^{32}$ Coin hoards from Gandhāra help to reconstruct relative chronologies of local, regional, and imperial dynasties and shed light on cultural and religious symbol systems, since Indian, Iranian, and Greek and Roman gods and goddesses depicted and labeled on coins illustrate cross-cultural "transformation of image and symbol" (Errington and Cribb 1992). ${ }^{33}$

Recent acquisitions within the last fifteen years of diverse collections of Kharosthin manuscripts belonging mostly to periods from the first to third century CE scholarly have broadened scholarly understanding of the scope of Buddhist literature in Gāndhārī. ${ }^{34}$ Along with an incomplete scroll of a Gāndhārī version of the Dharmapada recovered in the 1890 s near Khotan, ${ }^{35}$ " ...these fragments are likely to be the oldest Buddhist manuscripts, as well as the oldest Indian manuscripts, known to date" (Salomon 1999a: Xv). Five more important collections of Kharoșthī manuscripts are now accessible:

${ }^{31}$ See Chapter 1: Buddhist Inscriptions: Epigraphic Markers of Transmission, pp. 48-54, especially note 53, for relevant information about Kharoșthī inscriptions, as well as references to important publications by Fussman 1989a and Konow 1929. Fussman 1987a discusses the implications of dated Kharosthin inscriptions for a relative chronology of Gandhāran art. Glass analyzes the dating formulae of Kharoșthī inscriptions, which "provide the bedrock upon which much of the early history of Gandhāra is built" (2007b: 76).

32 Dietz 2007: 62, depending on Fussman 1994a: 20-21 refers to Buddhist schools in Kharosthī inscriptions, which can be correlated with the CKI database with reference to findspots (if known) in order of numerical citations: 8 Sarvāstivādins (CKI 48: Mathura, 145: Peshawar Shah-ji-ki Dheri, 148: Zeda, 153: Kurram, 165: Tor Dherai, 161: Taxila Kalawan, 223: Haḍ̣a, 361: British Library pot), 5 Kāśyapīyas (CKI 66, 223: Taxila, 67: Bedadi, 127: Palatu Dheri, 257: Satruleka reliquary), 3 Dharmaguptakas (CKI 116: Jamalgarhi, 182: Qunduz, 362: British Library pot), 2 Mahāsāṇghikas (CKI 48: Mathura, 159: Wardak), and 1 Mahís̄āsaka (CKI 331: Priavaśa requary). For epigraphic references to Buddhist schools elsewhere in India, see Bareau, André. 1955. Les sectes bouddhiques du Petit Véhicule. Saigon: Ecole française d'Extrême-Orient, 36, Lamotte 1988 [1958], 523-529, and Shastri 1965: $67 \mathrm{ff}$.

${ }_{33}$ Alram and Klimburg-Salter 1999: vii; Bopearachchi and Pieper 1998: 183-187; Cribb 2008 in Luczanits 2008: 64-69, 122-125; MacDowall 2007b.

${ }^{34}$ Gāndhārī manuscripts are introduced in Chapter 1: Panorama of Buddhist Literature, pp. 41-48, especially note 126 . The most recent overview of new finds is published by Allon, Mark. 2008. "Recent Discoveries of Buddhist Manuscripts from Afghanistan and Pakistan and their Significance." In Art, Architecture and Religion Along the Silk Roads, ed. Ken Parry. Turnhout: Brepols, 153-178. Comparisons of the manuscript collections by Strauch 2008: 112-115 are especially helpful.

${ }^{35}$ Brough 1962. 
1. British Library collection of twenty-nine birch bark scrolls with twenty-three texts. ${ }^{36}$

2. Senior collection of twenty-four birch bark scrolls with approximately 41 texts. $^{37}$

3. Schøyen collection with approximately 250 small palm-leaf fragments of Gāndhārī/Kharoșthī texts reportedly from Bamiyan. ${ }^{38}$

4. Bajaur collection found in the Bajaur district of NWFP in Pakistan with ca. 19 birch bark scrolls written by 18 different scribes. ${ }^{39}$

5. "Split Collection" 40

In addition to these manuscript collections, Kharoșthī fragments from Kucha in the northern Tarim Basin, a scroll recently acquired by the Library of Congress, and strips of a scroll in the University of Washington Library confirm that Gandhāran literary cultures produced an extensive range of Buddhist textual genres which probably belonged to multiple mainstream schools rather than a particular "canon," as suggested by Ingo Strauch's analysis of vinaya fragments belonging to the Bajaur collection and Richard Salomon's edition of versions of the Anavatapta-gāth $\bar{a}$ in the British Library and Senior collections. ${ }^{41}$ Studies of these texts have produced new insights into the use of Gāndhārī as a Buddhist literary language and have raised interesting questions about the types of texts produced and circulated in monasteries when Gandhāra emerged as a "center of Buddhist intellectual activity" (Salo-

${ }^{36}$ Salomon 1999a gives an overview of the British Library collection. Texts belonging to this collection have been edited in the Gandhāran Buddhist Texts (GBT) series: Salomon 2000 (GBT 1) and Salomon 2008a (GBT 5), Allon 2001 (GBT 2), Lenz 2003 (GBT 3), and Lenz 2006 (GBT 6).

37 Salomon 2003c; Allon 2007 in Glass 2007a: 3-25; Allon 2008: 163-167.

38 Allon, Mark and Richard Salomon 2000. "Kharosthī fragments of a Gāndhārī version of the Mahäparinirvānasūtra." In Braarvig, ed. 2000: 243-273. Allon 2008: 168-170.

39 Earlier reports by Nasim Khan and Sohail Khan 2004 [2006] and Nasim Khan 2008 are superseded by Strauch 2007-2008 and Strauch 2008: $115 \mathrm{ff}$.

${ }^{40}$ Strauch 2008: 112, n.8.

${ }^{41}$ In Strauch's opinion, “... in the early stage of Buddhist literature which we are dealing with the boundaries of recensions must not coincide with sectarian boundaries, a later definition of a recension in terms of a school affiliation does not automatically imply the sectarian affiliation of the text at the time of its composition" (2008: 115). According to Salomon, "... the different versions of a text such as the AG [Anavatapta-gäthä] should not necessarily be considered as exclusively or even primarily sectarian in character" but "this is not to say that school affiliations are irrelevant or meaningless for the issue at hand here, namely an understanding of the history of the AG and its versions" (2008a: 14). 
mon 1999: 178) in the first three centuries CE, including some early Mahāyāna sūtras. ${ }^{42}$

The employment of various media to transmit the Buddha's teachings in written and visual forms raises several questions about relationships between the regional literary and material cultures during the first centuries CE. The material and historical contexts gleaned from inscriptions and coins have aided in the interpretation of manuscript fragments, but it remains to be seen if advances in textual studies of the manuscripts help to clarify issues in Gandhāran art and archaeology. While material evidence indicates unique hybrid regional features characteristic of a borderland environment, the extent to which Gandhāran Buddhist literary texts are culturally distant or relatively close to Indian Buddhist traditions varies significantly, and depends on the relationship of particular texts to versions in other Buddhist languages. While some narrative texts, commentaries, and scholastic treatises in the British Library are clearly original compositions without direct literary parallels, other texts may have been translated, transposed, or transformed versions of texts similar but not identical to versions preserved in Pāli and Sanskrit, or another hypothetical Buddhist Middle Indic dialect. Further comparative work on recentlydiscovered Kharoșthi manuscripts may help to support if not prove the 'Gāndhārī hypothesis' of a link with early Chinese translations of Buddhist texts. ${ }^{43}$ What these textual and other artifacts reveal about the role of Gandhāra as a contact zone between South Asia and Central Asia remains open to speculation, but a full synthesis of archaeological, art historical, epigraphic, numismatic, and manuscript sources is beyond the scope of this investigation of routes for religious transmission in Gandhāra.

${ }^{42}$ Allon, Mark and Richard Salomon. 2010. "New Evidence for the Mahāyāna in Early Gandhāra." Eastern Buddhist 41.1:1-22 discuss Kharoșthī fragments of the Bhadrakalpika-sūtra, Bodhisattvapitaka-sūtra, and Sarvapunyasamuccayasamādhisütra in the Schøyen collection, and Strauch 1998: 123-125 presents the preliminary results of an examination of a Gāndhārī text resembling the Akșobhyavyūha-sūtra, the longest text in the Bajaur collection preserved in ca. 640 lines, which is an "independent source of the early variety of 'Pure Land' Buddhism which centers around the Buddha Aksobhya and his Abhirati Buddha field" (125).

${ }^{43}$ Boucher 1998 critically examines the evidence for this hypothesis with regard to Dharmarakșa's Chinese translation of the Saddharma-pundarika sütra, which is not (so far) attested among Kharoșthī manuscript discoveries. 


\section{Gandhäran Nodes and Networks}

Multiple nodes of Buddhist transmission within Gandhāra belonged to a complex network with many itineraries for connecting the cosmopolitan frontier with the major arteries of South and Central Asia. Feeder routes north of Gandhāra led to Swat, Buner, Bajaur, Chitral, and the valleys of the upper Indus and Gilgit rivers, where capillary networks across the Karakorum range provided direct inks to the southern silk routes of the Tarim Basin. ${ }^{44}$ Other paths leading south from Gandhāra criss-crossed the foothills and passes through the Suleiman mountains to reach Kandahar in southeastern Afghanistan (ancient Alexandria in Arachosia), and yet other itineraries connected Gandhāra with the southern Punjab and the lower Indus valley. In the Gandhāran core area of the Peshawar basin, the ancient urban center of Puṣkalāvatī (near modern Charsada) probably functioned as an entrepôt for commercial traffic with Nagarāhāra and the upper Kabul valley (in eastern Afghanistan) via the Michni Pass or other passageways through the territories of modern Mohmand or Bajaur territories rather than the Khyber Pass, which is now the primary artery. Although the archaeological foundations are significantly earlier, by the Kuṣanna period Puruṣapura (Peshawar) had become a major hub for exchanges between Gandhāra, Nagarahāra, and regions south of the Hindu Kush when itineraries on the southern side of the Kabul valley were more widely utilized. Other urban centers of ancient Gandhāra, such as Varusapura near Takht-i Bahi and Shahbazgarhi in the district of modern Mardan, occupied nodal positions where east-west arteries through the Peshawar basin intersected with multiple north-south feeder routes from Uḍ̣iyāna (Swat). Udabhandiapura (modern Hund), an extensive archaeological site in the eastern Peshawar plain which served as the later capital of the Hindu Șāhis, was located at the most important crossing of the Indus River for interregional connections with Taxila and the Punjab.

${ }^{44}$ Capillary routes in northern Pakistan and the silk routes in eastern Central Asia are detailed in chapters 5-6. 


\section{Uddiyana in the Swat Valley}

Gandhāran Buddhists evidently maintained close connections with counterparts in the Swat valley of ancient Uḍdiyāna, a famous region with an especially rich archaeological, artistic, epigraphic, and literary heritage with seemingly innumerable remains of Buddhist stūpas, monasteries, and rock carvings. Since the 1950s, Italian and Pakistani archaeologists have surveyed and excavated major Buddhist sites in the lower Swat valley, including stüpas and monasteries clustered around Butkara and Barikot. ${ }^{45}$ Their surveys indicate that Buddhist monasteries concentrated on communication routes and connected with hydraulic systems were integrated into the prosperous mercantile and agricultural economy of the Swat valley. Based on the distribution of over 120 monasteries, a "radial model" in which Buddhist sites radiated outward from the older center at Butkara to inner valleys on the slopes of Mount Ilam above the modern cities of Mingora and Manglawar can be distinguished from a polygonal "multiradial settlement typology" in which the Buddhist monastic network expanded into the Karakar, Najigram, and Kandak valleys south of Barikot. ${ }^{46}$ Along the "ancient communications route" (Olivieri 2008: 294) leading to the Karakar Pass, monastic complexes are generally situated above the alluvial fan of fertile agricultural land and many of the most important sites, such as Tokar Dara, Najigram, and Tokdara are connected with dams and irrigation structures, while other more remote sites such as Amluk-dara and Abbasaheb-china are built near water sources (springs and lakes) close to the head of the valley. The possibility of a Buddhist monastic role in the management of water resources and control of important road networks between the first and fourth centuries $\mathrm{CE}$ when most of the monasteries in the side valleys were

${ }^{45}$ Useful guides to surveys and excavations in the Swat valley include Ashraf Khan, Muhammad Ashraf. 1993. Buddhist Shrines in Swat. Saidu Sharif: Archaeological Museum; Faccenna, Domenico. 1964. A Guide to the Excavations in Swat (Pakistan) 1956-1962. Roma: [Scuolo Grafica Salesiana]; and Tucci 1958. Faccenna and his collaborators have published detailed excavation reports on Buddhist sites at Butkara I (1980-1981), Saidu Sharif (1989-1995), and Panr (1993) in IsMEO Reports and Memoirs. Excavations of Barikot directed by Pierfrancesco Callieri $(2006,2007)$ are ongoing.

46 Olivieri, Luca Maria. 2008. "The Swat Case Study: Barikot and its Environs." In Luczanits 2008: 294-295; Olivieri, Luca Maria, et al. 2006. "Archaeology and Settlement History in a Test Area of the Swat Valley, Preliminary Report on the AMSV Project (1st Phase)." East and West 56, 73-150. 
constructed may justify Luca Maria Olivieri's strong hypothesis that "The economy of the Buddhist foundations doubtlessly favored, and even conditioned, the growth, development, and decadence of BKG [Barikot]" (2008: 297). The "silent presence" of "mountain people" is reflected in rock paintings, petroglyphs and shelters that may belong to a "local religious substratum" (Filigenzi 2008: 300-301). ${ }^{47}$

\section{Old Roads Across the Hindu Kush (Map 4.2: Archaeological Sites in Afghanistan)}

An extension of the Uttarapatha called the "ancient route" (vieille route) by Foucher connected Gandhāra and Taxila with Bactria, thus linking South Asia with the overland network of the "silk routes" in western Central Asia. ${ }^{48}$ Extrapolating from literary sources, archaeological discoveries, and art historical analysis, Foucher contended that this "Old Road" across the Hindu Kush of Afghanistan was the primary artery for foreign invasions into northwestern India and the movement of Buddhism beyond the Indian subcontinent to Central Asia. In his description of the Old Road through the Hindu Kush of Afghanistan, Foucher acknowledged that this "grande-route" was not the only route between western Central Asia and the Indian subcontinent:

We do not pretend that the route which we will describe was the only one possible or the only one that existed: we only say that it was once the overland 'highway' between the West and the interior of the [Indian] peninsula...(1942: 1.3 $)^{49}$

\section{Nagarahāra}

Reliquaries and other artifacts from stūpas and monasteries clustered around Haḍda near modern Jalalabad in Nangarhar district (ancient Nagarahāra) show that this area was an important center of artistic

\footnotetext{
${ }^{47}$ Filigenzi, Anna. 2008. "Buddhist Art in its Social Context." In Luczanits 2008: 298-301.

${ }^{48}$ The publication of La vieille route de l'Inde de Bactres à Taxila (Memoires de la Délégation archéologique française en Afghanistan I-II, Paris: Les éditions d'art et d'histoire, 1942-1947) was the culmination of Foucher's scholarly 'labor of love' for Gandhāra and Bactria.

49 "[N]ous ne prétendons nullement que le route que nous allons décrire soit la seule possible ni la seule existente: nous disons seulement qu'elle a été jadis la 'granderoute' terrestre entre l'Occident et l'intérieur de la péninsule...” (1942: 1.3).
} 


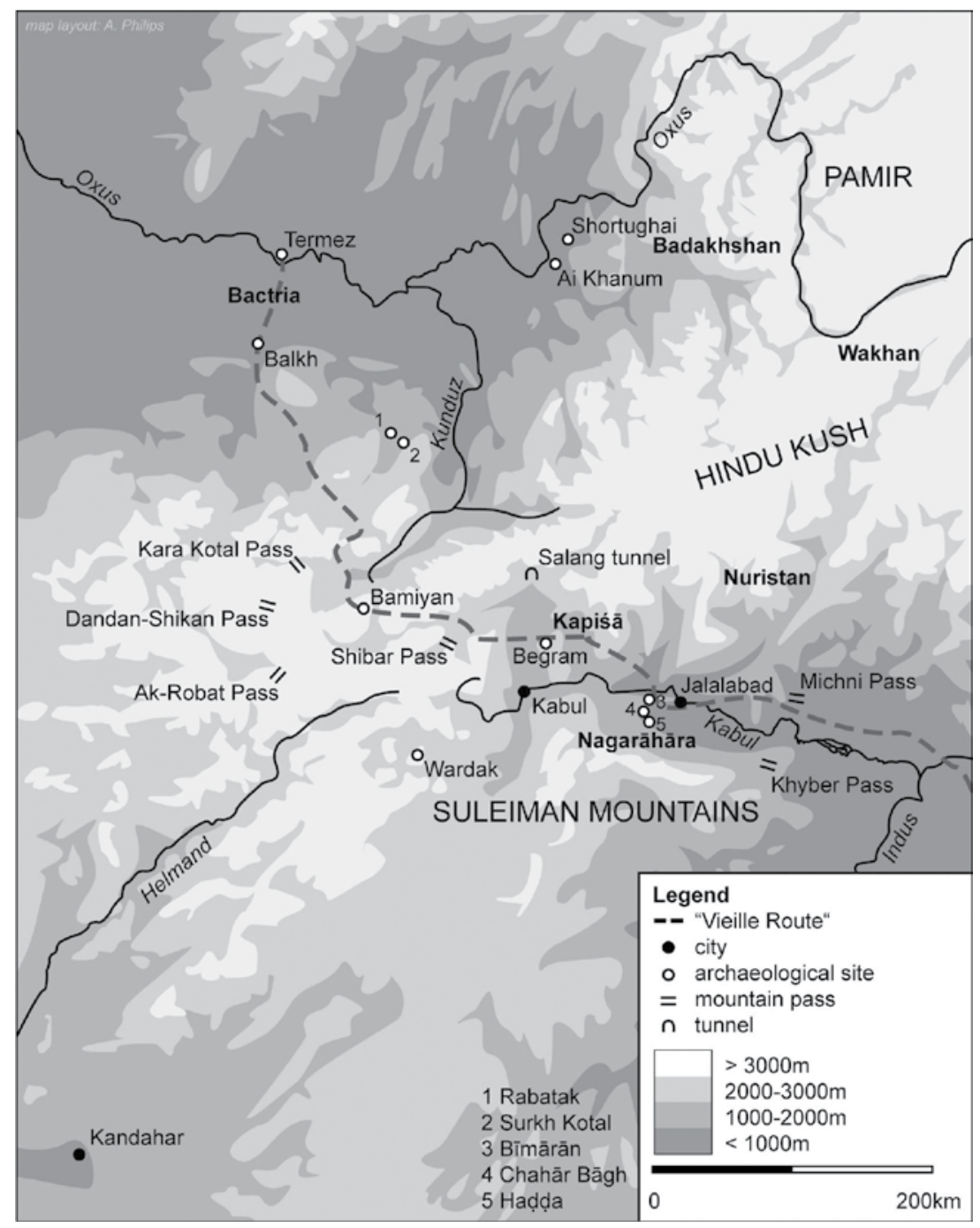

Map 4.2: Archaeological Sites in Afghanistan (Sources: Foucher 1942: 12, 21 , 39 [figs. 4, 6, 8]; Ball and Gardin 1982) 
and textual production with immediate ties to Gandhāra. ${ }^{50}$ Buddhist stūpas and monasteries at Bīmārān, Chahār Bāgh, and Haḍda were already recognized as major sources of coins deposited in reliquaries as well as Buddhist sculptures before preliminary surveys by Foucher and subsequent French Archaeological Mission (DAFA) excavations undertaken at sites around Haḍda. ${ }^{51}$ In a survey of the British Library collection of first century Gāndhārī Buddhist manuscripts, Richard Salomon notes that similar birch-bark scrolls were reported at Haḍda and other Buddhist sites around Jalalabad by earlier explorers and excavators. ${ }^{52}$ Unfortunately, the provenance of many of the artistic and literary materials suspected to have originated in eastern Afghanistan is insecure.

\section{Kapiśa}

Abundant finds of ancient coins and numerous archeological remains of Buddhist stūpas attest to the commercial and cultural significance of the plateau of modern Begram (ancient Kapiśa). ${ }^{53}$ Ivory sculptures imported from western India, Roman glassware, and Chinese lacquer were among the spectacular discoveries of DAFA excavations between 1937-1946. ${ }^{54}$ The results of French excavations of Begram support Foucher's assertion that “...it commanded the main routes between India and High Asia" (1942: 1.139), although Sanjyot Mehendale disputes the characterization of the findspot as a Kușanna royal palace and instead proposes that the materials belonged to a commercial storeroom. ${ }^{55}$ Begram was a major node for interregional trade and tribute

50 Foucher 1942: 1.34-35, 148-154.

51 Ball and Gardin 1982: 1.116-118; Barthoux, Jules. 1933. Les Fouilles de Hadda. 2 vols. . Memoires de la Délégation archéologique française en Afghanistan 4. Paris : Les éditions d'art et d'histoire (translated by Miller, Bruce L., Nilofaur Moaven Fatemi, and Azizeh Azodi. 2000. The Hadda Excavations. Bangkok: SDI Publications).

52 Salomon 1999a: 59-68.

53 Ball and Gardin 1982: 1.55-57; Foucher 1942: 1.28-31, 138-144.

54 Hackin, Joseph. 1939. Recherches archéologiques à Begram. 2 vols. Memoires de la Délégation archéologique française en Afghanistan 9. Paris: Les Éditions d'art et d'histoire; Hackin, Joseph. 1954. Nouvelles recherches archéologiques à Begram, ancienne Kâpicî, 1939-1940; rencontre de trois civilisations, Inde, Grèce, Chine. MDAFA 11. Paris: Impr. nationale; Meunié, J. 1942. Shotorak. MDAFA 10. Paris: Les Éditions d'art et d'histoire; Ghirshman, Roman. 1946. Bégram: recherches archéologiques et historiques sur les Kouchans. MDAFA 12. Cairo: Institut français d'archéologie orientale.

55 Mehendale, Sanjyot. 1997. Begram: New Perspectives on the Ivory and Bone Carvings. Berkeley, CA: University of California Ph.D. dissertation; Mehendale, Sanjyot. 2008. "Begram, at the Heart of the Silk Roads." In Hiebert and Cambon 2008: 131-143. 
networks, which played a critical role in the expansion of Buddhist institutions at courtly levels.

\section{Bamiyan}

The route to Bamiyan in central Afghanistan was "the true highway of another time" (Foucher 1942: 1.25). Due to its location in a valley connecting the Oxus and Indus watersheds via the Kara Kotal, Dandan-Shikan, Ak-Robat, and Shibar passes across the western Hindu Kush, Bamiyan was a particularly important place for traders and other travelers to halt for provisions. ${ }^{56}$ According to Xuanzang, who visited Bamiyan in $629 \mathrm{CE}$, "When merchants coming and going happen to witness visions of heavenly deities, whether as good omens or as predictions of disaster, they worship the deities to pray for blessedness" (Li 1996: 38). ${ }^{57}$ Perhaps the devotional need to make religious offerings before attempting or immediately after completing difficult journeys over dangerous mountain passes stimulated the growth of Bamiyan. ${ }^{58}$ Buddhist manuscript fragments from Bamiyan demonstrate that both artistic and literary cultures flourished there for several centuries, beginning in the second or third century CE. ${ }^{59}$ Xuanzang's visit provides a terminus ante quem in the early seventh century for the worship of the colossal standing Buddhas (demolished in 2001) and a Mahāparinirvāṇa Buddha, which is now being excavated by Zemary-

${ }^{56}$ Ball and Gardin 1982: 49-51 (no. 100: Bāmiyān); Foucher 1942: 1.129-137; Godard, André, Y. Godard, Joseph Hackin, and Paul Pelliot. 1928. Les antiquités bouddhiques de Bāmiyān. MDAFA 2. Paris: G. van Oest; Hackin, Joseph, and Jean Carl. 1933. Nouvelles recherches archéologiques à Bāmiyān. MDAFA 3. Paris: G. van Oest. Klimburg-Salter, Deborah. 1989. The Kingdom of Bāmiyān : Buddhist Art and Culture of the Hindu Kush. Naples: Istituto universitario orientale, Dipartimento di studi asiatici; Rome: Istituto italiano per il Medio ed Estremo Oriente.

${ }^{57}$ Taishō 51, no. 2087, fascicle 1, 873b is also translated by Beal 1884: 1.50 and Kuwayama, Shoshin. 1987. "Literary Evidence for Dating the Colossi in Bāmiyān.” In Gnoli and Lanciotti 1987: 2.724 (= Kuwayama 2002: 154).

${ }^{58}$ Such a possibility suggested by Foucher 1942: 1.132-133 is also accepted by Klimburg-Salter 1989: 123, 136, although she attributes the construction of the monumental complex at Bamiyan to Western Turkic patronage at the beginning of the seventh century, since patronage by merchants and pilgrims would not have been sufficient to build the massive sculptures.

${ }_{59}$ Braarvig 2000: xiii and Braarvig 2006: vol. 3, pls. I-II (Photographs of the possible place of origin of Buddhist manuscripts in the Schøyen Collection). Excavations of Buddhist caves at Bamiyan by French archeologists in the 1930s and by Japanese archeologists as recently as 2003 have found very similar fragments of seventh century Buddhist Sanskrit manuscripts (Lévi, Sylvain. 1932. "Note sur les manuscripts provenant de Bāmiyān (Afghanistan), et de Gilgit (Cachemire)." Journal Asiatique $220,1-45)$. 
alai Tarzi and other DAFA archaeologists. ${ }^{60}$ Based on a shift in Chinese pilgrimage routes, Shoshin Kuwayama links Buddhist activities at Bamiyan to a period of commercial prosperity beginning in the middle of the sixth century. ${ }^{61}$ Although the regional political history remains obscure, the nodal position of Bamiyan within a network of routes across the Hindu Kush attracted patrons, pilgrims, and merchants.

\section{Bactria}

The "vieille route" traced by Alfred Foucher extended to Bactria, a major node for transregional overland trade located between the southern bank of the Oxus River and the Hindu Kush. Bactria is linked to Margiana (Merv) in the west, to Termez, Payon Kourgan and via the "Iron Gates" to the Sogdian emporium near Samarkand in the north, and across valleys in Badakhshan, Wakhan and the Pamir mountains to the Tarim Basin in eastern Central Asia. ${ }^{62}$ The proverbial "thousand cities of Bactria" referred to by Strabo (15.686) and Justin (41.1.8, 4.5) indicate that this region was known for its prosperity, which resulted from its central position on trade routes between northwestern India, Iran, Central Asia, and western China, and its fertility, which was largely due to a vast irrigation system in existence since the second millennium BCE. ${ }^{63}$ According to Strabo (relying on Apollodorus of Artemita):

${ }^{60}$ Results of the ongoing excavations were discussed by Buffler, Eléonore. 2009. "Spreading of some Buddhist Architectural Designs between Afghanistan and China: The Case of the Cruciform Stupa" in a paper presented at the Buddhism Across Asia conference in Singapore (17 February, 2009). Numismatic evidence of Kushano-Sasanian coins found at the site may suggest that the main stūpa belongs to a period before the Kidāras and Alchon Huns controlled routes through the Hindu Kush beginning in the fifth century.

${ }^{61}$ Kuwayama 2002: 159, map 17 ("Bamiyan and its Buddhist Activities"). Kuwayama's assertion that earlier routes between Central Asia and Gandhara through the Karakorum and eastern Hindu Kush were "completely discarded" (1987: 725) is directly contradicted by the evidence of Buddhist inscriptions and petroglyphs from the upper Indus region discussed in Chapter 5.

${ }_{62}$ Foucher 1942: 1.7, fig. 2; Leriche, P., Sh. Pidaev, K. Abdullaev, and P. Gentelle. 1997. "Bilan de campagne 1997 de la MAFOuz de Bactriane." Bulletin of the Asia Institute 11, 17-52.

${ }_{63}$ References to the "thousand cities of Bactria" are discussed by Tarn 1951: 118124 and Karttunen 1997a: 271. Foucher observes that population density is noted in all of the ancient sources, but "Ne cherchez pas ailleurs que dans ces centaines de petites bourgades rurales les 'milles villes' de Justin" (1942: 15). Tarn attributes the "thousand cities" to the rise in status of "serf villages" and claims that "the evolution of the serf village into the organized and quasi-autonomous township was the most important work done by the Greeks in Asia" (1951: 124). Karttunen disputes Tarn's assertions 
The Greeks who caused Bactria to revolt [from the Seleukids] grew so powerful on account of the fertility of the country that they became masters, not only of Ariana, but also of India (11.11.1, translation by Jones 1917-1933: 5.279). ${ }^{64}$

Foucher referred to a "Bactrian Mirage" because he was unable to identify Hellenistic layers during his excavations at Balkh. Although he did not find what he expected in Balkh, the survival of a Hellenistic outpost at Ai Khanum, which is not located on the main artery of the Old Road, essentially confirms some aspects of his hypothesis of Greek cultural impact in ancient Bactria. ${ }^{65}$

\section{Routes of Buddhist Missionaries and Pilgrims to and from Gandhära}

Many if not most eminent Indian Buddhist monks in Chinese hagiographies compiled by Sengyou (c. 515), Huijiao (c. 530), and Daoxuan (664) either came from the northwestern frontiers of South Asia or traveled through this region on their overland journeys to Central Asia and China. ${ }^{66}$ Several figures are associated with the region of Jibin, which is often translated as Kashmir and sometimes as Kapiśa (located near Begram), but the term often refers more generally to the northwestern regions of South Asia, including areas of modern northern Pakistan. While literary accounts specify that monks from Jibin such as Buddhayaśas, Dharmayaśas, Dharmamitra, Vimalākșa, and Punyatara traveled overland to Chinese centers via the Tarim Basin, other eminent figures including Buddhabhadra, Gunavarman and Buddhajiva followed circuitous maritime itineraries. Several sixth

by pointing out that archaeological excavations at Ai Khanum, Surkh Kotal and other sites in Afghanistan conducted in the second half of the twentieth century after Tarn had proposed his hypothesis have demonstrated that the "thousand cities of Bactria" preceded the period of the Bactrian Greeks.

${ }^{64}$ Jones, Horace Leonard (translator, based on an unfinished version by J.R. Sitlington Sterrett). 1917-1933. The geography of Strabo. The Loeb classical library. London: W. Heinemann.

${ }_{65}$ Archaeological excavations at Ai Khanum are discussed in Chapter 2, subchapter: Hellenistic Interactions, with reference to publications by Bernard (1967, 1973-1992, 1982, 1994a-b, 2008).

${ }_{66}$ Bagchi, Prabodh Chandra. 1927-1938. Le canon bouddhique en Chine; les traducteurs et les traductions. 2 vols. Sino-Indica; publications de l'Université de Calcutta. Paris: P. Geuthner; Shih, Robert, trans. 1968. Biographies des moines éminents de Houei-Kiao. Kao seng tchouan. Louvain: Institut orientaliste, Bibliothèque de l'Université; Zürcher 1999: 30-32. 
century Indian monks (Narendrayaśas, Vinītaruci, and Vimokṣasena) came from Uḍdiyāna in the Swat valley.

Some hagiographical accounts provide interesting details about the long-distance journeys of eminent monks who traveled through northwestern India to Central Asia and China. For example, a Gandhāran monk named Jinagupta from ancient Peshawar (Purușapura) traveled through Afghanistan (Kapiśa) and the Pamir range to Tashkurgan, via the southern Tarim Basin to Khotan, and through the Gansu corridor to Xian. ${ }^{67} \mathrm{~A}$ western Indian monk named Dharmagupta also traveled though Afghanistan (Kapiśa), across the Hindu Kush, and via Tashkurgan, Kashgar, and Kucha to Xian and Loyang. ${ }^{68}$ Dharmakșema, a master of protective spells (dhāranīs) from the "Middle Country" (Madhyadeśa), studied in Jibin before going to Kucha and the court of the Northern Liang ruler at Lanzhou, where he was murdered in $433 .{ }^{69}$ Based on his survey of biographies of Buddhist monks who came to China during this period, Kuwayama observes:

... most of the eminent translators of Buddhist texts in China were closely related to Ji-bin in the point that they studied the Buddhist philosophy there, whether they may have been natives of Ji-bin or not. It is also likely that those intending to proceed from Ji-bin to China inevitably took the routes leading to Kashgar and farther to Qyzyl [near Kucha]. (1987: 707)

Other Buddhists from China and Central Asia came to the northwestern Indian subcontinent to study for extended periods. Probably the most famous of them was Kumārajīva (344-413 CE), who traveled from Kucha to Jibin with his mother when he was eight or nine years old, and after three years returned via Kashgar to Kucha. ${ }^{70}$

Accounts of Chinese pilgrims supply geographical details and information about Buddhist communities and shrines on long-distance routes used by other Buddhist travelers as well as merchants, diplomatic missions and sometimes soldiers who traveled to and from South Asia. The famous Chinese traveler Faxian described numerous shrines in Uḍ̣̣iyāna and Gandhāra around 400 CE. ${ }^{71}$ Zhemong and

${ }^{67}$ Bagchi 1927: 276-9, 1938: 446-57.

${ }^{68}$ Bagchi 1938: 464-467.

69 Bagchi 1927: 212-223; Zürcher 1999: 42-43.

${ }^{70}$ Bagchi 1927: 1.178 ff.; 1981: 42-4; Kuwayama 1987: 706.

${ }^{71}$ Faxian's sojourn in the Northwest is commented upon by Deeg, Max. 2005. Das Gaoseng-Faxian-Zhuan als religionsgeschichtliche Quelle: der älteste Bericht eines 
other fifth century Chinese pilgrims traveled via similar routes to worship the relic of the Buddha's bowl at Nagarahāra, but many details of their itineraries between Central Asia and northwestern India remain unclear. ${ }^{72}$ In the beginning of the sixth century, Song Yun and Huisheng travelled through the southern Tarim Basin to Tashkurgan, crossed the Pamir mountains to northeastern Afghanistan, and continued via Chitral to the Swat valley. Xuanzang provides a detailed report of his journey from China to India from 627-645, although his information about Buddhist communities in the northwestern frontiers is sometimes based on secondhand reports rather than firsthand observations. Zürcher cautioned that Chinese pilgrims, Indian missionaries and translators memorialized in hagiographies represent only "the tiny tip of the iceberg, the élite of scholar monks" (1999: 18) and suggested that many more anonymous foreign monks fulfilled roles as thaumaturges, meditation teachers, and ordination experts (1999: 52-7). Like the more famous figures whose long-distance journeys are sometimes outlined in religious biographies, these itinerant monks followed overland networks which connected the Tarim Basin to the northwestern frontiers of South Asia. While Chinese hagiographies about the travels of the great monks typically focus on Buddhist relics, previous-birth stories, images, and festivals localized at shrines and monasteries, similar itineraries between the northwestern Indian subcontinent and the Western Regions of China were followed by merchants with worldly goals of journeying for material profit.

\section{Domestication of Gandhāran Buddhism}

From the perspectives of local devotees and Chinese pilgrims who visited regional Buddhist shrines between the 5th-7th century, Gandhāra, Uḍ̣iyāna, and Bamiyan were central hubs rather than marginal peripheries of the Buddhist world. The Chinese accounts reflect processes of "domestication" whereby local Buddhist inhabitants adopted previous lives of Buddhas and Bodhisattvas and relics of Saakyamuni Buddha to local settings in the regional landscape of the northwestern border-

chinesischen buddhistischen Pilgermönchs über seine Reise nach Indien mit Übersetzung des Textes. Wiesbaden: Harrassowitz.

${ }^{72}$ Kuwayama 1987: 711-13; Shih 1968: 144-145. 
lands. ${ }^{73}$ Depictions of hagiographical events in the life of Saakyamuni and narratives of his previous lives have served as useful sources for interpreting Gandharan Buddhist art and identifying archaeological sites of stüpas and monasteries. Although the historical Buddha clearly did not visit this region during his lifetime, the Mülasarvāstivādin Vinaya includes apocryphal stories about Sākyamuni's "conquest of dharma" (dharmavijaya) in Gandhāra, Kashmir, and other northern regions where, accompanied by Vajrapāni, he subjugated local Yakșas and Nāgas. ${ }^{74}$ Literary sources regard a disciple of Ananda named Madhyantika (Majjhantika in Pāli) as the earliest Buddhist missionary to Kashmir, the Indus Valley, and Gandhāra. ${ }^{75}$ Although these accounts and narratives of the Buddha's previous lives, his conquests, and Madhyantika's mission to Gandhāra are objectively dismissed as ahistorical imaginings, they reflect Buddhist strategies to establish a locative connection between Gandhāra and Bodhisattvas, Saakyamuni Buddha, and prominent figures within the Buddhist tradition belonging to various past periods.

Abbreviated summaries of avadāna and pürvayoga stories about Gandhāran historical figures from the first century CE also reflect the domestication of Buddhist narratives in Gandhāra in Kharoșthī

${ }^{73}$ Lewis, Todd. 1993. "Newar-Tibetan Trade and the Domestication of the Siṃhalasārthabāhu Avadāna" History of Religions 33.2: 135-160 proposes that "domestication" is a "universal process in the successful missionary adaptation of Buddhism in venues throughout Asia" (1993: 135). This "dialectical historical process by which a religious tradition is adapted to a region or ethnic group's socioeconomic and cultural life" (Lewis 2000: 3-4) overlaps somewhat with a more general model of "domestication of the saingha" elaborated by Strenski, Ivan. 1983. "On Generalized Exchange and the Domestication of the Sangha." Man n.s. 18.3, 463-477. Strenski views domestication as an early and ongoing maintenance of residential, ritual, social, political, and economic relationships between the sangha and society through symbolic and material exchanges, although he criticizes a "romantic vein" (1983: 464) which links domestication to the decline of a 'pure' saingha of world renouncers. Strenski's criticism is directed at Carrithers, Michael. 1979. "The Modern Ascetics of Lanka and the Pattern of Change in Buddhism.” Man n.s. 14.2: 294-310, who juxtaposes eremitic forest-dwelling ideals of 'pure' renunciation to the practices of town- or village-dwelling monks who interact with society by serving as preachers and literary specialists.

${ }_{74}$ Lamotte 1988: 679, n. 67 [1958: 752-3]; Przyluski, Jean. 1914. "Le nord-ouest de l'Inde dans le Vinaya des Mūla-Sarvāstivāda et les texts apparentés." Journal Asiatique 11 ser., vol. 4: 493-568.

${ }^{75}$ Fussman 1994a: 44, n. 162 refers to literary accounts in the Mūlasarvāstivādavinaya, Divyāvadāna, and Avadāna-Kalpalatā as "pious fictions" which are not specific to Gandhāra. 
manuscript fragments. ${ }^{76}$ Not surprisingly, Saka characters play important roles in many of these narratives. For example, Aśpavarman, a member of the Apraca dynasty who is attested in first century CE coins and an inscribed silver saucer from Taxila, helps to make arrangements for sheltering monks during the rainy season with a character named Zadamitra. ${ }^{77}$ In the following avadāna, Zadamitra vows to obtain individual enlightenment after discussing the disappearance of the true law with a monk. ${ }^{78}$ Timothy Lenz (2003: 182-191) relates this avadāna to a pürvayoga story set in Taxila summarizing a dialogue between a Saka and a monk about the disappearance of the "True Dharma" (saddharma), which concludes with the Saka making a vow to become an Arhat. The favorable depictions of Zadamitra and the Saka as aspiring devotees of Buddhism in these Gāndhārī narratives present an interesting contrast to other Buddhist ex eventu prophecies associating the disappearance of the Dharma with an invasion of Kauśāmbī in northern India by foreign kings, including Sakas, Parthians, and Greeks. ${ }^{79}$ Another very fragmentary story explicitly set in Gandhāra (gadharami) involves a 'Great Satrap' (Mahakșatra $\left({ }^{*} p a\right)$ ) named Jihoniga, who is also known from first century CE coins and an inscribed vessel from Taxila. ${ }^{80}$ Although these original compositions of avadāna and pürvayoga story summaries with contemporary historical figures present interpretive difficulties due to the lack of direct literary parallels, the incorporation of these characters into Buddhist narratives was likely intended to acknowledge their religious patronage and to appeal to a regional audience.

Étienne Lamotte dismissed the value of these types of narratives for illuminating local traditions, since in his view the domestication of legendary stories merely reflects a process in which pan-Indian Buddhist narratives have lost their original local associations in processes of oral and written transmission when they become linked with places outside of the Buddha's homeland:

\footnotetext{
${ }^{76}$ Neelis, Jason. 2008. "Historical and Geographical Contexts for Avadānas in Kharoșthī Manuscripts." In Gombrich and Scherrer-Schaub 2008: 151-167.

77 Salomon 1999a: 145-149; Lenz 2010: 85-93.

${ }^{78}$ Lenz 2003: 203-208, Appendix 3: Avadāna of Zadamitra; Lenz 2010: 82-89.

79 Nattier 1991: 127.

${ }^{80}$ Lenz 2010: 95-98; Salomon 1999a: 141-145 (Frag. 2.1r is reproduced on the cover of Salomon 1999a).
} 
The stories, tales, legends and fables, undergoing a perpetual interchange of ideas, were conveyed from one end of the world to the other and, if they ever had any local characteristics which might betray their origin, they soon eliminated them and acquired a universal aspect which made them to the taste and within the reach of everybody. (1988: 442 [1958: $487])^{81}$

Gérard Fussman also argues that Gandhāran Buddhism was no different in terms of ideology from Gangetic Buddhism. ${ }^{82}$ While Gandhāran Buddhists certainly sought to link their own traditions to the Indian Buddhist homeland, it was also necessary to compose new stories and adapt other narratives to local settings in order to attract potential patrons, including Sakas, Kuṣānas, and Huns.

\section{Conclusion}

Gandhāran Buddhist manuscripts, inscriptions, art, and architecture clearly reflect the cosmopolitan culture of the frontiers between ancient India, Iran and Central Asia. Gandhāran Buddhism blended South Asian and exogenous features from the cultural environment of the northwestern frontier. The long period of rapprochement with peoples and cultures foreign to South Asia probably strengthened the appeal of Gandhāran Buddhism in adjacent regions of Bactria and the Tarim Basin. As the primary zone of contact and encounter between India and the outside world, Gandhāra provided a springboard for the transmission of Buddhism beyond South Asia.

\footnotetext{
${ }^{81}$ Lamotte elsewhere comments that "Alongside Vārānasī...Gandhāra was the only one to play the game-somewhat puerile, but profitable to the places of pilgrimage-of the acclimatization of the legends" (1988: 335 [1958: 367]).

82 “...sur le plan idéologique, le bouddhisme du Gandhāra ne se distingue en rien du bouddhisme gangétique" (Fussman 1994: 43).
} 


\section{CHAPTER FIVE}

\section{CAPILLARY ROUTES OF THE UPPER INDUS}

While the Old Road across the Hindu Kush in Afghanistan connected Taxila to Bactria and western Central Asia, an alternative network of intertwined passageways through deep river valleys and high mountain passes in the upper Indus region of northern Pakistan directly linked major arteries of the Northern Route of the Indian subcontinent with branches of the silk routes in the Tarim Basin of eastern Central Asia. Capillary routes following the Indus, Gilgit, and Hunza rivers and side valleys across passes through the western Himalaya, Karakorum, and Pamir provided paths for long-distance trade and cross-cultural transmission between transregional overland arteries at a "Crossroads of Asia." 1 Before the construction of airports, jeep roads and the Karakorum Highway (KKH) between Pakistan and China, capillary networks gave ancient travelers many choices of north-south and east-west itineraries. Modern routes followed by the KKH through northern Pakistan and the Salang tunnel north of Kabul across the Hindu Kush in Afghanistan have eclipsed the ancient pathways through mountain valleys and passes, but travelers who wrote their names in graffiti inscriptions and drew images on rocks at river crossings and wayside shrines were not restricted to staying on major highways. ${ }^{2}$ As Marc Bloch remarked in regard to medieval Europe: "Traffic, in short, was not canalized in a few great arteries; it spread

1 "Crossroads of Asia" broadly encompasses the modern Northern Areas of Pakistan, although the phrase also applies to the Tarim Basin of Xinjiang in western China, borderland areas of northern Afghanistan and northwestern Pakistan, and western Central Asian republics of Kirghizstan, Tajikistan, and Uzbekistan. Errington and Cribb extend the concept of "Crossroads of Asia" to parts of India and Iran: "For us the Crossroads of Asia is a broad concept, centrally focused on Afghanistan, but also including the southern Central Asian republics of Turkmenistan, Uzbekistan, and Tadzhikistan, to the north; eastern Iran, or Khorasan to the west, and the northwestern parts of Pakistan and India to the east and south" (1992: 1). Owen Lattimore includes Mongolia, Xinjiang, and other areas of eastern Central Asia in the "Inland Crossroads of Asia" (Lattimore, Owen. 1962. Studies in Frontier History: Collected Papers, 1928-1958. London: Oxford University Press, 119-133).

${ }^{2}$ Foucher 1942: 1.22-24. 
capriciously through a multitude of little blood vessels" (1961 [1949]: 1.64). Bloch's comments on medieval European roads are relevant to trans-Asian routes:

It is in the nature of good roads to create a vacuum around them-to their own profit. In the feudal age, when all roads were bad, scarcely any of them was capable of monopolizing the traffic in this way. (Bloch 1961 [1949]: 1. 63)

Instead of following a single main route, "...the traveler had almost always the choice of several itineraries, of which none was absolutely obligatory" (Bloch 1961 [1949]: 1.64). Rather than functioning like interstate highways in the United States or the Autobahn in Germany, which create vacuums by monopolizing traffic, multiple itineraries allowed merchants, monks, pilgrims, and other ancient travelers to choose from interconnected passageways. Their decisions depended on many factors, including the seasonal condition of mountain passes and river fords, the availability of provisions, animals, and porters, as well as political stability, security, and sometimes the location of religious shrines along the way. ${ }^{3}$ Topographical imperatives were often decisive in choosing routes through the high mountain desert environment, where travel from one point to another in a straight line was not possible. Since crossing the high mountains was difficult for large groups of traders in caravans, capillary networks were probably used for a smaller scale of trade than the bulk trade of the main arteries.

Indian, Iranian, Chinese, and Tibetan inscriptions and petroglyphs lining the interconnected pathways belong to travelers and residents from a wide range of cultural and linguistic backgrounds and show that this region was definitely not a "cul de sac" (Fussman 1986c: 56-58; 1993b: 1). ${ }^{4}$ The written and visual records, as well as stray archaeological finds, the testimony of Chinese pilgrims and other literary references, and evidence of Buddhist manuscripts and sculptures found near Gilgit demonstrate significant patterns of cross-cultural movement. Capillary routes through this high-altitude transit zone between South and Central Asia were used for migrations across the mountains, long-distance trade in valued commodities and cultural expansion. Multidirectional flows of travelers bringing trade goods

\footnotetext{
${ }^{3}$ Fussman, Gérard. 1986c. "La route oubliée entre l'Inde et la Chine." L’histoire 93, 60 .

${ }^{4}$ Fussman, Gérard. 1993b. "Chilas, Hatun et les bronzes bouddhiques du Cachemire.” In Jettmar, ed. 1993 [ANP 2]: 1.
} 


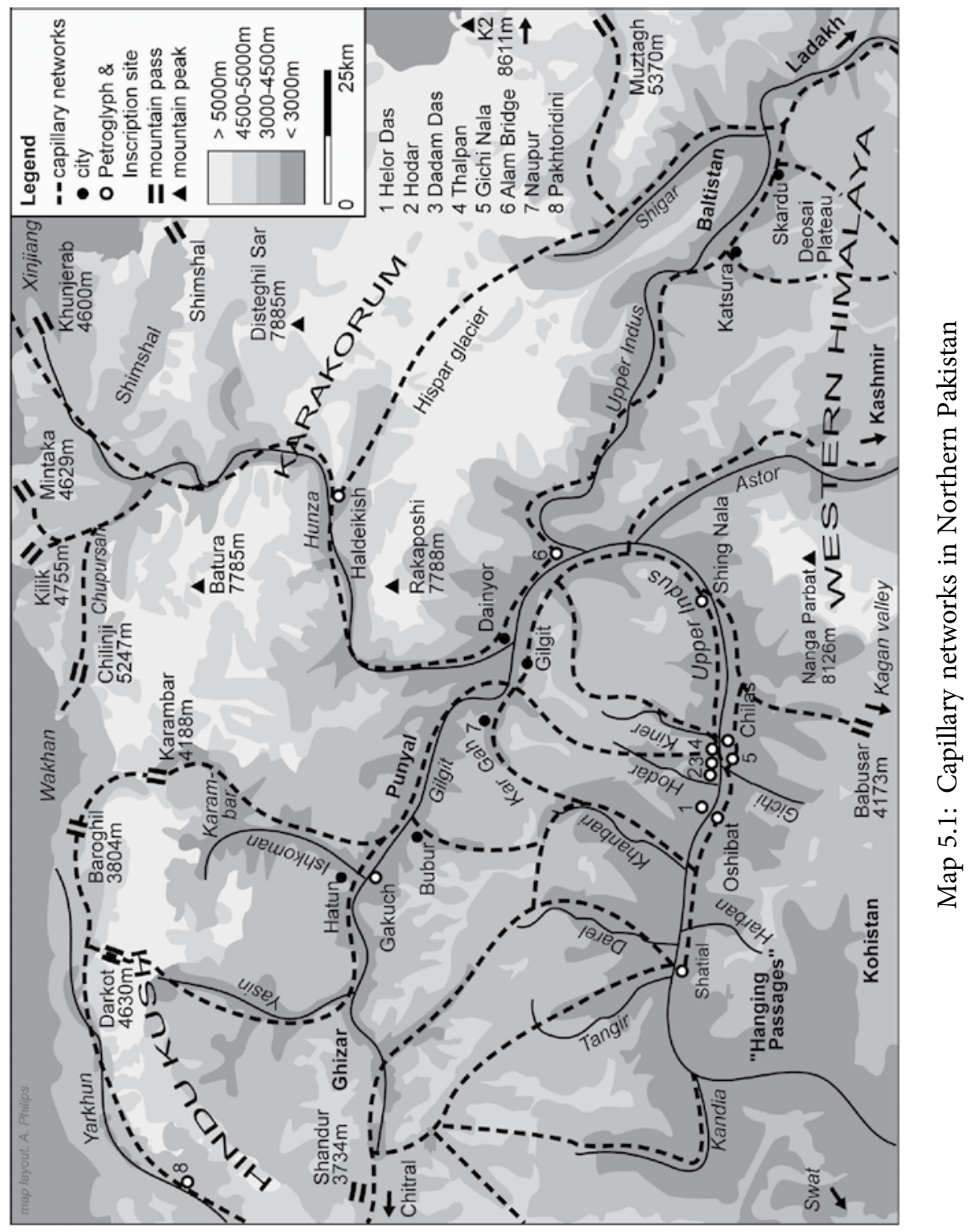


and materials as well as religious texts and images to and from many points via interconnected capillary routes in the upper Indus region supports a model of long-distance transmission rather than unidirectional diffusion along a major artery.

Capillary networks in northern Pakistan (Map 5.1) belonged to larger networks of trans-Asian trade routes, and played a crucial role in linking the major overland arteries of South Asia with the silk routes of Central Asia and China. While earlier chapters gave broad overviews of South Asian networks, this chapter focuses on the role of a particular transit zone in Buddhist transmission beyond the Indian subcontinent. In the first part of the chapter (Geography, Economy, and Capillary Routes in a High-Altitude Environment), geographical and economic features are given a detailed treatment in order to explain links between transregional and intraregional networks. The second part of the chapter (Graffiti, Petroglyphs, and Pilgrims) examines epigraphic records and visual markers in correlation with literary accounts of Chinese pilgrims, Arabic and Persian sources, and a Khotanese Saka itinerary. These combined sources illustrate Manifestations of Buddhist Presence at individual nodes in the upper Indus, Gilgit and Hunza valleys. The implications of this evidence for understanding patterns of long-distance Buddhist transmission at élite and subélite levels are discussed in the chapter conclusions.

\section{Geography, Economy, and Capillary Routes in a High-Altitude Environment}

Deep river valleys and high passes in the mountain desert environment played determining roles in the formation of capillary networks that linked this border region to ancient Gandhāra, Swat, Kashmir, and the Tarim Basin. The Karakorum, Hindu Kush, and western Himalayan mountain ranges converge in this area, where many of the world's tallest mountains are concentrated, including K2 $(8611 \mathrm{~m})$, Nanga Parbat (8126 m), Rakaposhi (7788 m), and Batura (7785 m). The stark difference in altitude between the summit of Nanga Parbat $(8126 \mathrm{~m})$ and the bottom of the Indus gorge (ca. $1300 \mathrm{~m})$ indicates " $\mathrm{a}$ very young uplift" (Gansser 1964: 66) in terms of geological time. ${ }^{5}$ Glaciers cover over a quarter of the Karakorum mountain range, which is

\footnotetext{
${ }^{5}$ Gansser, Augusto. 1964. Geology of the Himalayas. London: Interscience Publishers.
} 
a larger percentage than any other region outside of the polar ice caps. ${ }^{6}$ Due to the very arid climate of the valley floors (Gilgit, for example, only receives an average of $134 \mathrm{~mm}$ of rainfall per year), sustainable agriculture in the high mountain desert environment relies on glaciers to supply water for irrigation. While the gradual advance of glaciers down the slopes of the mountains often block roads, retreating glaciers can open new routes. The geological dynamism and vertical landscape presented special challenges for habitation and long-distance trade and travel, but the geographical barriers were not insurmountable.

Many valuable commodities, especially precious stones and metals, either originated in or were transported through the mountains of northern Pakistan. ${ }^{7}$ Several gemstones incorporated into the saptaratna classification are found in the upper Indus region and adjacent areas of Chitral, Swat and Kohistan. Emeralds, yellow-green epidote, green actinolite (which includes the jade mineral nephrite), green serpentinite, pink to fine red rubies, and variously colored spinels are associated with the Indus suture zone running through Hunza and Gilgit to Swat. ${ }^{8}$ In fact, ruby deposits in the rocks at Haldeikish almost led to the destruction of the graffiti and petroglyphs. ${ }^{9}$ Gemstones associated with pegmatite deposits in areas between Gilgit and Skardu and in the Hindu Kush near Chitral include a blue variety of beryl, many types of multicolored tourmalines, topaz, feldspar (moonstone), and quartz. ${ }^{10}$ Many types of crystal, a favorite material for reliquaries and carved geese (hamsa), are also found in northern Pakistan. ${ }^{11}$ The main sources for lapis lazuli were located in the valley of the Kokcha River in Badakhshan (northeastern Afghanistan), which was linked to the upper Indus region via Chitral.

${ }^{6}$ Gansser 1964: 29; Kreutzmann, Hermann. 1993. "Challenge and Response in the Karakoram: Socioeconomic Transformation in Hunza, Northern Areas, Pakistan.” Mountain Research and Development 13.1, 22; Miller, Keith. 1982. Continents in collision. London: G. Philip, 6-7.

7 Kazmi, Ali H. 1995. “Gemstones.” In Bender, F.K and H.A. Raza, eds. Geology of Pakistan. Berlin: Gebrüder Borntraeger, calls northern Pakistan as "... a paradise, not only for gemstones and gem connoisseurs, but also for rock-hounds and collectors of mineral specimens" (1995: 290).

${ }^{8}$ Kazmi 1995: 282-7.

9 Dani, Ahmad Hasan. 1985. “The Sacred Rock of Hunza." Journal of Central Asia $8.2,7$.

${ }_{10}$ Kazmi 1995: 287-8.

${ }^{11}$ Kazmi 1995: 289; a crystal goose (hamsa) is "the symbol of the wandering soul and the promulgation of the Buddhist doctrine to all realms" (Errington 1998: 86). 
River Valleys and Mountain Passes in Northern Pakistan

The Upper Indus, Gilgit, and Hunza rivers and their affluents form natural passageways through alluvial canyons in the narrow valleys between the high mountain ranges. However, as water levels increase due to melting snow during the summer (mid-May to mid-October), the swollen torrents of these rivers become treacherous to cross. ${ }^{12}$ Since the rivers are much easier to ford after water levels recede, the period from October to January was probably the time of maximum mobility in the upper Indus region. ${ }^{13}$ If conditions were unsuitable for crossing turbulent rivers or snowbound passes, travelers had to delay crossing the rivers and mountain passes until conditions became relatively safe. Many concentrations of inscriptions and rock drawings mark important junctions where travelers may have been temporarily forced to stop while waiting for the right conditions to proceed onwards. In connection with the location of Buddhist petroglyphs and inscriptions at a crossing of the Indus River near Chilas, Aurel Stein observed:

The possibility of risks run at these crossings, when the Indus in the early spring and summer carries down its mighty floods, might also have served to stimulate such acts of devotion or gratitude. (1944: 22) $)^{14}$

Karl Jettmar, who followed in Stein's footsteps but was able to explore sites in the region more thoroughly, also suggested that dangerous river crossings motivated travelers to make images and write graffiti:

In olden times as well as up to the twentieth century this was a maneuver of considerable risk. You prayed before you started and you offered thankful gifts when you had succeeded. (1979: 920)

Jettmar proposed that "the valleys on both sides of the Indus must have been a series of seasonal 'waiting rooms' for travelers" (1989: xxvii).

\footnotetext{
${ }^{12}$ Jettmar, Karl. 1979. "Rock-carvings and Stray Finds in the Mountains of North Pakistan: Archaeology before Excavation." In Taddei, Maurizio, ed. South Asian Archaeology 1977. Naples: Istituto universitario orientale, 2.920; Jettmar 1987a: 97-8 [2002: 177]; Jettmar 1989: xxvi; Jettmar. 1994. "Prähistorische Wanderrouten in den zentralasiatischen Hochgebirgen: Voraussetzungen und frühe Nachweise." Studien zur Indologie und Iranistik 19, 160. Foucher 1942: 1.22 makes a similar point about crossing the Qunduz River, which sometimes required a long detour because it could not be crossed in all seasons.

13 Jettmar 1994: 172.

${ }^{14}$ Stein, Aurel. 1944. "Archaeological Notes from the Hindukush Region." Journal of the Royal Asiatic Society, 8-24.
} 
Travelers from Gandhāra, Swat, and Kashmir could take several routes to the upper Indus transit zone, depending on the time of year and local conditions. Very difficult routes through the deep gorges of the Indus River now followed by the $\mathrm{KKH}$ in the Kohistan district of NWFP are described by Chinese pilgrims as the "Hanging Passages." 15 This was the most direct way from the upper Indus to the Swat valley, but long-distance traders probably followed less dangerous routes which were open during restricted periods. ${ }^{16}$ A route from Mansehra which passes through the Kagan Valley and over the Babusar Pass to Chilas is only open during the summer because accumulations of snow prevent passage during other seasons. Therefore, travelers coming from the upper Indus had to wait until May or June to use this route, while travelers coming from Mansehra, Kashmir, or points further to the South (such as Taxila) needed to begin their journeys by August. ${ }^{17}$

During his expeditions to eastern Central Asia in the early twentieth century, Aurel Stein explored routes through the upper Indus region used by earlier Chinese pilgrims. ${ }^{18}$ On his first expedition from Kashmir to Central Asia in 1900, Stein followed the 'Gilgit Transport Road' through the Astor valley, which was built in 1890-92 to supply British military campaigns in Gilgit, Chitral and Hunza. Although he commented that this route "... is marked out by nature as the most accessible line of communication from Kashmir to the Dard territories northward" (1907: 1.1), he later realized that other routes between Kashmir and Chilas were more practical than the difficult route of the

${ }^{15}$ Jettmar locates the "Hanging Passages" between Sazin and Jalkot, where "the dangerous part of the journey came to an end" (1987a: 99).

16 Klimburg, Max. 1982. "The Setting: The Western Trans-Himalayan Crossroads." In Klimburg-Salter, Deborah, ed. The Silk Route and the Diamond Path: Esoteric Buddhist Art on the Trans-Himalayan Trade Routes. Los Angeles: UCLA Arts Council comments: "Merchants often had to choose longer, easier routes for the sake of their heavily loaded pack animals. Pilgrims could take shorter, more difficult routes or visit sacred places irrespective of additional travel hardships" (1982: 34).

17 Jettmar 1987a: 98.

18 Stein, Marc Aurel. 1907. Ancient Khotan: Detailed report of archaeological explorations in Chinese Turkestan. Oxford: Clarendon Press, 1.1-4; Stein, Aurel. 1921. Serindia: Detailed report of explorations in Central Asia and westernmost China carried out and described under the orders of H.M. Indian government. Oxford: Clarendon Press, 1.34-59; Stein, Aurel. 1928. Innermost Asia: Detailed report of explorations in Central Asia, Kan-su, and Eastern Irān. Oxford: Clarendon, 1.1-46, Stein 1922; Stein 1942. 
Gilgit Road, which lacked grazing areas for laden animals. ${ }^{19}$ Several capillary routes between Kashmir and Baltistan cross the high-altitude Deosai plateau, and it is possible to reach Ladakh by following the Indus River. ${ }^{20}$

Traditional connections between Kashmir, Gilgit, Baltistan, and Ladakh continued to be used in the late nineteenth and early twentieth century, but are now blocked by border disputes between India and Pakistan. Traditional caravan routes from Khotan and Yarkand in the southern Tarim Basin crossed the Karakorum (5575 m) and Muztagh $(5370 \mathrm{~m})$ passes in the eastern Karakorum range to Ladakh and Baltistan. While these routes across the Karakorum Pass continued to be used until the third quarter of the nineteenth century, at least four other passes over 5000 meters had to be crossed, and the journey over several barren stretches took about a month to complete in one direction. ${ }^{21}$ Since the eastern Karakorum routes were extremely difficult, routes further to the west through the Pamir range were more likely choices.

Pamir routes were "the safest and quickest way across the stupendous mountain barriers between Central Asia and India" (Klimburg 1982: 33). According to Klimburg, "Probably the most important among the ancient trails from the Pamirs down into Gandhāra followed the Chitral Valley" (1982: 28). Song Yun and Huisheng probably followed these routes on their journey between Chitral (She-mi), Swat (Wu-chang), and Gandhāra around 519-20 CE.22 A route through the Yarkhun valley in the eastern Hindu Kush of present-day northeastern Afghanistan and the Chitral Valley in northwestern Pakistan provided connections to the capillary network of the upper Indus region. The main route to Chitral follows the Kunar River (lower Yarkhun River) from Jalalabad (ancient Nagarahāra) through Nuristan in eastern Afghanistan. Several routes converge in Chitral, including a route

19 Stein 1928: 1.4-5; Lorimer, Emily O. 1939. Language Hunting in the Karakoram. London: Allen \& Unwin describes the immense difficulty of crossing these passes on the Gilgit Transport Road in a snowstorm at the end of the summer.

${ }^{20}$ Drew, Frederic. 1875. The Jummoo and Kashmir Territories. A geographical account. London: E. Stanford, 530-31.

${ }^{21}$ Klimburg 1982: 36; Kreutzmann, Hermann. 1996. Ethnizität im Entwicklungsprozess: die Wakhi in Hochasien. Berlin: D. Reimer, 87, Abb. 12; Rizvi, Janet. 1999. Trans-Himalayan Caravans: Merchant princes and peasant traders in Ladakh. New Delhi: Oxford University Press, 27-9.

${ }^{22}$ Beal 1884: Xc-xciii, Chavannes 1903: 400 ff., Jenner 1981: 259-61. 
from Swat and Dir over Lowari Pass (ca. $3118 \mathrm{~m}$ ) and a route to the north over Dorah Pass (ca. $4554 \mathrm{~m}$ ) continues to Badakhshan. Other passes provide connections to the Wakhan or Ab-i-Panja valley, one of the sources of the Oxus River (Amu Darya) which flows through western Central Asia. ${ }^{23}$ The Baroghil Pass (ca. 3804 m) links the Wakhan valley to the upper valley of the Yarkhun River, and the Darkot Pass (ca. $4630 \mathrm{~m}$ ) connects the upper Yarkhun valley with the upper Yasin valley. ${ }^{24}$ The headwaters of the Yarkhun valley are joined via the Karambar Pass (ca. $4188 \mathrm{~m}$ ) with the Karambar valley, which feeds into the Ishkoman River near Imit. ${ }^{25}$ The Karambar valley is connected with the Wakhan valley via the Khora Bhurt Pass $(4630 \mathrm{~m})$ and with the Chupursan valley via the Chilinji Pass $(5247 \mathrm{~m}) .{ }^{26}$ The interlinked network of high mountain passes was intermittently used by various travelers, merchants, pilgrims, and semi-permanent resident communities for crossing the permeable frontiers between Central Asia and South Asia.

Capillary routes through the Yasin and Ishkoman valleys linked Gilgit to the Wakhan valley in northeastern Afghanistan. Although petroglyphs have been discovered in the Ishkoman valley near Imit, the paucity of Buddhist rock drawings and visitors' inscriptions suggests that routes through these valleys were not as popular as routes through Hunza-Haldeikish, Gilgit-Alam Bridge, and the upper Indus during the first millennium CE. ${ }^{27}$ Nevertheless, epigraphic and archaeological evidence from sites such as Hatun (five km north of the confluence of the Ishkoman and Gilgit rivers), Gakuch (across the Gilgit River from the mouth of the Ishkoman Valley), and Bubur (on the northern bank of the Gilgit River in Punyal) show that this part of the Gilgit valley was included in the domain of the Palola Saahis during the seventh

${ }^{23}$ Klimburg 1982: 26, Map 2.

${ }^{24}$ Kreutzmann1996: 265, fig. 42; Stein 1928: 1.45-7, figs. 43, 48.

25 Stein 1928: 48-50, figs. 47, 49-50.

${ }^{26}$ Stein 1928: 1.50 ff., figs. 51-2, 57, 61. According to Stein, "It is only for a few weeks in the early spring and autumn that it is possible to follow the route leading up the Karambar valley to the north and across the Khora-bohrt pass (about 15,000 feet) to the Afghan Pamirs. Even then it is far from easy" (1928: 1.48-9).

${ }^{27}$ Hallier, Ulrich. 1991. "Petroglyphen in Nordpakistan." Antike Welt 22, 8 ff.; Tsuchiya, Haruko. 1999. "Tracing Ancient Routes in Northern Pakistan. Field Research 1991-1996 (Preliminary Report)." In Alram and Klimburg-Salter, eds. 1999: 368-371. A single exception is a petroglyph of a stūpa and a Tibetan inscription found by Stein (1928: 1.46, fig. 46) on his journey through the Yasin Valley to Darkot Pass in 1913. 
century and was probably significant in the Tibetan-Chinese conflict in the middle of the eighth century. ${ }^{28}$

Numerous capillary routes link the upper Indus valley with Gilgit, which still serves as the administrative and commercial hub for the Northern Areas. During the summer, interconnected routes through side valleys of the Gilgit and Indus rivers allowed ancient travelers to bypass dangerous river crossings. Paths through the Kar Gah and Shingai Gah valleys, located west of Gilgit near Naupur, lead over the main ridge of mountains to watersheds of the Kiner Gah and Hodar Gah valleys and to petroglyph and graffiti complexes at Thalpan and Hodar on the northern bank of the upper Indus River. ${ }^{29}$ The Kar Gah headwaters are connected with the wide valley of the Khanbari Gah, which flows into the upper Indus downstream from Thor and Oshibat. ${ }^{30}$ Affluents of the Gilgit/Ghizer River provide possible connections with the Tangir and Darel valleys, which join the Upper Indus near Shatial. ${ }^{31}$ A seasonal route through Mastuj connects Chitral to Gilgit over the Shandur (ca. $3734 \mathrm{~m}$ ) and Chamarkhan (4334 m) passes. Stein noticed rock drawings of stūpas with Brāhmī inscriptions at Pakhtoridini and near the village of Charrun between Mastuj and Chitral along this route. ${ }^{32}$ Another feeder route from the South over the Kachikani Pass (ca. $4766 \mathrm{~m}$ ) directly connects the upper Swat Valley to the Gilgit River. ${ }^{33}$ Thus, a network of river valleys and mountain passes through the Pamir and Hindu Kush connect Chitral with Gilgit, Badakhshan, Swat, and ancient Gandhāra.

In addition to these capillary routes through mountain valleys, a major route follows the Gilgit River downstream to its confluence with the Indus River near Alam Bridge, where Kharoșthī and Brāhmī graffiti along with some petroglyphs mark an important crossing. This complex is located at a junction of regional routes connecting Gilgit

\footnotetext{
${ }^{28}$ Chapter 2, subchapter: Palola Șāhis of Gilgit: Élite Patrons in a Buddhist Enclave, especially pp. $176 \mathrm{ff}$.

${ }^{29}$ Connections between these valleys are clearly visible in the NASA Landsat image in the map of "Rock Carvings and Inscriptions along the Karakorum Highway" in Jettmar, ed.:1989 [ANP 1]. The colossal image of a Buddha carved from a rock cliff overlooking the Kar Gah valley indicates the importance of routes through these valleys.

30 Tsuchiya 1999: 379, map 3.

${ }^{31}$ Tsuchiya 1999: 359-61, 380-82, maps 4-6.

32 Stein 1921: 1.37-41, figs. 5-6.

${ }_{33}$ Klimburg 1982: 26, map 2.
} 
with Baltistan through deep gorges of the Indus River (still used as the main road to Skardu) and with Kashmir across the Deosai plateau or through the Astor valley. Visitors to this complex who were traveling on routes between Hunza, Gilgit, Baltistan, and the upper Indus probably arrived during the late autumn, winter, or early spring, when rivers could be crossed safely and temperatures on the valley floor are bearable. This micro-network of intra-regional capillary routes between neighboring valleys was used for intra- and interregional travel and trade.

Hunza-Haldeikish is the northernmost major site of graffiti and petroglyphs. West of Hunza is the Ishkoman valley of the Ghizar district, and southeast of Hunza is the Shigar valley of Baltistan. Nager is located directly across from Hunza on the southern and eastern side of the Hunza river. To the south, the KKH connects Hunza with Gilgit and extends to the north through Sost via the Khunjerab pass (ca. 4600 meters) to Tashkurgan. From the Wakhan valley, the Irshad Unwin Pass (ca. $4926 \mathrm{~m}$ ) is connected to the headwaters of the Chupursan valley, which joins the upper Hunza River. ${ }^{34}$ The Mintaka (ca. $4629 \mathrm{~m}$ ) and Kilik (ca. $4755 \mathrm{~m}$ ) passes also provide access from the Misgar valley of northern Hunza to the Taghdumbash Pamir area of southwestern Xinjiang. ${ }^{35}$ In addition to routes over the Mintaka, Kilik, and Khunjerab passes and through the Chupursan valley which closely follow affluents of the upper Hunza River, paths over the Shimshal pass and a difficult trek over the Hispar glacier to Baltistan may have also served as minor feeder routes to the Hunza valley during various periods. Although the reputation of Hunzakuts (residents of Hunza) as infamous raiders of caravans discouraged travelers from passing through the valley in pre-colonial periods, Haldeikish graffiti show that these routes were widely used in the early- to midfirst millennium CE. Because of its strategic location on trans-Asian routes crossing the Karakorum mountains, Hunza is not an isolated and remote utopia impervious to change, but an important crossroads affected by outside influences throughout its history. Capillary routes through the Hunza Valley must have always been difficult due to constantly shifting glaciers, avalanches and landslides, steep paths through

\footnotetext{
${ }^{34}$ Stein 1928: 1.51-2.

${ }^{35}$ Stein observed that the Kilik and Mintaka passes "can be crossed, even with laden animals, during the greater part of the year" (1907: 1.21).
} 
narrow canyons, and swollen rivers and streams during periods of snowmelt. Although the Hunza route was an important capillary through the Northern Areas, it was not the only possibility nor was it always the most practical choice. Capillary routes across the Karakorum and Pamir ranges provided relatively quick and direct connections between the long-distance trade routes of the northwestern Indian subcontinent and Central Asia. Despite the difficulties of these routes over the Pamirs to northern Pakistan, "A shortcut between Central and South Asia was possible, partly compensating for the dangers and strains" (Jettmar 1989: xxvii).

\section{Graffiti, Petroglyphs, and Pilgrims}

About 5000 graffiti and over 30,000 petroglyphs written and abraded onto rocks along capillary routes in the upper Indus region demonstrate remarkable mobility across the high mountain terrain. Visitors and local residents created designs and wrote brief inscriptions by abrading (rather than incising) the dark surfaces of rocks with pointed stones or metal implements. The dark patina, called "desert varnish," is formed by a combination of the autochthonous process of iron and manganese leaching from the interior to the surface of the rocks over thousands of years to develop a smooth coat and the allochthonous action of windblown sand and dust in the arid mountain desert environment which creates a shiny exterior polish. ${ }^{36}$ As in Native American petroglyphs, the repatination of the lighter lines of drawings and inscriptions preserves a contrast with the older desert varnish. This process of repatination can sometimes indicate the relative chronology of petroglyphs and inscriptions, but rates of repatination of desert varnish vary widely from place to place and even from rock to rock depending on geology and orientation to the sun. Jettmar, relying on his own experience with prehistoric carvings, estimated that full repatination of petroglyphs takes three or four millennia, but this figure depends on exposure to the sun as well as the quality of the rocks. ${ }^{37}$

${ }^{36}$ Whalley, W.B. 1983. "Desert Varnish.” In Goudie, Andrew, and Kenneth Pye, eds. 1983. Chemical Sediments and Geomorphology: Precipitates and residua in the near-surface environment. London: Academic Press, 217.

${ }^{37}$ Jettmar 1989: xvi. 
Ghulam Muhammad published the first account of petroglyphs and inscriptions carved on stones on the banks of the Indus River. ${ }^{38}$ In 1942 Aurel Stein examined groups of inscriptions and petroglyphs near Chilas which had not been noticed by British officials who, with the exception of John Biddulph and D.H.L. Lorimer, had little interest in the antiquities of the Gilgit district. ${ }^{39}$ Subsequent explorations of the upper Indus valley confirmed that these earlier discoveries were "the tip of an iceberg." ${ }^{40}$ After the completion of the Karakorum Highway (KKH) connecting Pakistan and China in 1979, Karl Jettmar and Ahmad Hasan Dani initiated efforts to document rock drawings and inscriptions in the Northern Areas of Pakistan. ${ }^{41}$ Studies of selected inscriptions and petroglyphs, including analysis of their historical, religious, and artistic significance, have been published in volumes of Antiquities of Northern Pakistan. ${ }^{42}$ Nine volumes of Materialien zur Archäologie der Nordgebiete Pakistans (MANP) published to date thoroughly document petroglyphs and graffiti at Oshibat, Shatial, Hodar, Shing Nala and Gichi Nala, Dadam Das, and Chilas Bridge / Thalpan. ${ }^{43}$ These publications supply crucial data for examining the nature of long-distance trade and religious transmission in northern Pakistan.

Brāhmī, Kharoșțī, Sogdian, Bactrian, Chinese, Tibetan, and Hebrew inscriptions provide concrete evidence for cross-cultural contact, religious dynamics, and linguistic change. Travelers and local residents

${ }^{38}$ Ghulam Muhammad. 1905. Festivals and Folklore of Gilgit. Memoirs of the Asiatic Society of Bengal, Vol. 1, Nr. 7. Calcutta: Asiatic Society [reprint: 1980. Festivals and Folklore of Gilgit. Islamabad: National Institute of Folk Heritage], 32-34.

39 Stein 1944: 16-24.

${ }^{40}$ Jettmar 1979: 920-22; Klimburg 1982: 30.

${ }^{41}$ For a bibliography of initial publications, see Jettmar 1989: vi-x.

42 The first two volumes of Antiquities of Northern Pakistan (abbreviated as ANP) are edited by Jettmar (1989-93) in collaboration with König, Thewalt and Bemmann, and the third volume is edited by Fussman and Jettmar (1994). The fourth volume on Sazin, a fortified village in Indus-Kohistan is authored by Peter Alford Andrews and Karl Jettmar. The fifth volume by Oskar von Hinüber (2004) is devoted to sources for studying the Palola Șāhis.

${ }_{43}$ Oshibat (MANP 1): Bandini-Konig, Ditte and Martin Bemmann. 1994. Die Felsbildstation Oshibat. Mainz am Rhein: P. von Zabern; Shatial (MANP 2): Bandini-Konig and Fussman 1997; Hodar (MANP 3): Bandini-König, Ditte. 1999. Die Felsbildstation Hodar. Mainz am Rhein: P. von Zabern; Shing Nala and Gichi Nala (MANP 4): Bandini-König, Ditte, and Oskar von Hinüber. 2001. Die Felsbildstationen Shing Nala und Gichi Nala. Mainz am Rhein: P. von Zabern; Dadam Das (MANP 5): Bemmann, Martin. 2005. Die Felsbildstation Dadam Das. Mainz am Rhein: P. von Zabern; Chilas and Thalpan (MANP 6-9): Bandini-König, Ditte. 2003-. Die Felsbildstation von Thalpan. Mainz am Rhein: P. von Zabern, 4 vols. to date. 
recorded their own names, often along with the names of their fathers, in formulaic graffiti. Onomastic patterns in Kharoșthī and Brāhmī inscriptions reveal a mixture of Indian, Iranian and indigenous proper names reflecting the cultural diversity of travelers and residents who wrote graffiti and drew petroglyphs. Formulae of arrival with various expressions for " $x$ arrived (here)" explicitly refer to travel, with records of visitors from as far away as Mathura. ${ }^{44}$ Unlike donative inscriptions at Bharhut, Sāñcī, and caityas in western India with numerous references to merchants and traders, graffiti from northern Pakistan rarely include titles specifying the visitors' occupations. Consequently, very few travelers are explicitly designated as merchants, apart from vanij (van̄in) (Oshibat 82:2) and sārthavāha (sarthavahasya) (Shatial 39:23). ${ }^{45}$

About 600 Sogdian, Bactrian and Iranian inscriptions provide strong evidence for the use of long-distance routes through the upper Indus between the third to seventh centuries ${ }^{46}$ Although occupational titles rarely appear in Sogdian graffiti in northern Pakistan, toponyms and personal names derived from places near Samarkand and ethnonyms connected with China and Kucha suggest that many of these travelers were merchants involved in long-distance trade between Sogdia, northern Pakistan, the Tarim Basin, and China.${ }^{47}$ Sogdian inscriptions have also been found in Ladakh, including a record dated in year 210 (perhaps corresponding to 841/2 CE) of "Caitra of Samarkand, together with the [Buddhist] monk Nōsh-farn, sent as messengers to the Qaghan of Tibet" (Sims-Williams 1993: 158-9, no. 2, pls. 2-6). ${ }^{48}$ Sogdian travelers who reached Ladakh and Tibet probably followed routes along the upper Indus through northern Pakistan. Epigraphic evidence of Sogdian and other Iranian inscriptions found along the

${ }^{44}$ A Brāhmī inscription from Hunza-Haldeikish records that "Balamitra of Mathurā arrived" (Neelis, Jason. 2000. "Kharoșțhī and Brāhmī Inscriptions from Hunza-Haldeikish: Sources for the Study of Long-Distance Trade and Transmission of Buddhism." In Taddei and De Marco 2000: 2.912-913, fig.7, no. I.A.B3 corresponds to Dani 1985: 40-41, Brāhmī no. 4, whose reading can be corrected from mayūro to mathūro).

${ }^{45}$ Hinüber 1989a: 46, no. 28, pl. 71.

46 Sims-Williams 1989-92; Sims-Williams, Nicholas. 1997. “Zu den Iranischen Inschriften." In Bandini-König and Fussman 1997: 62-72.

${ }^{47}$ Sims-Williams 1989-92: 2.29-36, 1996: 54-5; Yoshida, Yutaka. 1993. Review of Sims-Williams 1989-1992 in Indo-Iranian Journal 36, 255.

${ }^{48}$ Sims-Williams, Nicholas. 1993. "The Sogdian Inscriptions of Ladakh.” Appendix to Jettmar, ed. 1993 [ANP2]: 151-163. 
upper Indus (especially at Shatial), Ladakh, and Hunza-Haldeikish validates Sims-Williams' hypothesis that Sogdians "were engaged in the trade between India and Sogdiana and in that between India and China" along a triangular network of trade routes "with India, China, and Sogdiana as its three corners" (1996: 56). ${ }^{49}$

Chinese, Tibetan and Hebrew inscriptions in the Northern Areas also demonstrate long-distance diplomatic, cultural and trade relations. The Chinese inscription of " $[\mathrm{Gu}]$ Wei-long, envoy of Great Wei, now dispatched to Mi-mi" (Ma Yong 1989: 144, pl. 217) records the visit by an official envoy of the Northern Wei dynasty to Hunza-Haldeikish while traveling to the Sogdian center of Maymurgh around $451 \mathrm{CE} .{ }^{50}$ Tibetan inscriptions in Gakuch, Baltistan, Ladakh, and Hunza-Haldeikish show that Tibetan influence extended westwards to the upper Indus, Hunza, Gilgit, and Yasin valleys. ${ }^{51} \mathrm{~A}$ set of Hebrew inscriptions at the "Campsite" complex on the upper Indus River between Chilas and Oshibat records the names of Jewish merchants who may have replaced Sogdians as long-distance trading partners with Hindu merchants in Kashmir in the ninth century. ${ }^{52}$

Petroglyphs from prehistoric periods to the present time represent a wide spectrum of styles, motifs and images ranging from very common simplified drawings of mountain goats (caprini) to skillful renderings of Buddhist stuppas, portraits, and narratives. Each site has its own distinctive characteristics-concentrations of zoomorphic petroglyphs may indicate hunting grounds or trails into the mountains where game was available, while drawings and inscriptions at complexes located near settlements were more likely to have been produced by local inhabitants than visitors. Indian, Iranian, and indigenous elements adopted in petroglyphs indicate patterns of religious and cultural transmission. Buddhist and non-Buddhist petroglyphs

${ }^{49}$ La Vaissiére 2002 [2005] is a detailed study of the Sogdian trading network. For historical relations between Sogdian traders and Hephthalites in the northwestern frontiers of South Asia, refer to chapter 2, subchapter: Kidāras and Huns in the Northwestern Indian Subcontinent, pp. 159-170, especially 169-170.

${ }^{50}$ Ma Yong. 1989. The Chinese Inscription of the Da Wei Envoy of the Sacred Rock of Hunza. In Jettmar, ed. 1989 (ANP 1): 139-157.

${ }^{51}$ Jettmar, Karl and Klaus Sagaster with Loden Sherab Dagyab. 1993. Ein Tibetisches Heiligtum in Punyal. In Jettmar, ed. 1993 (ANP 2): 123-139; Jettmar, Karl. 1990. "Exploration in Baltistan." In Taddei and Callieri 1990: 801-813 (= Jettmar 2002: 182-188); Orofino 1990.

${ }_{52}$ Jettmar, Karl with Theodore Kwasman. 1987b. "Hebrew Inscriptions in the Western Himalayas.” In Gnoli and Lanciotti 1987: 668-9. 
(which are in fact the majority) exhibit hybrid features that sometimes deviate from standard iconographic repertoires of South Asian art. For example, unusual drawings of Harìtī and images of Vāsudeva-Kṛṣna and Baladeva-Balarāma labeled with relatively early Kharoșthī inscriptions at the site of Chilas II are quite distinctive, and shed light on the multiple religious proclivities of visitors, who were not exclusively Buddhist. ${ }^{53}$ (Fig. 5.1)

Although Buddhist images are less numerous than other types of drawings at most sites, they provided locative focii for Buddhist veneration at outdoor shrines, attracted travelers and local devotees who added their names in proximity to the drawings, and indicate routes of transmission. Such "relics of instruction" (uddeśika dhātu) in the form of drawings of stuppas, Buddhas, Bodhisattvas, and narrative scenes established a Buddhist presence in areas without the resources (at least initially) to support residential monastic communities. In lieu of building monasteries and constructing stūpas with "bodily relics" (śarīra) or "relics of use" (pāribhogika dhātu), itinerant monks, artists, and local donors drew Buddhist images on rocks and recorded their donations of "religious offerings" (devadharma) with inscriptions. The drawings concentrated at dangerous river crossings or in way stations below mountain passes attracted traders, travelers, and local devotees who wrote their names in proximity to the images at wayside shrines (caityas). Gifts of rudimentary stūpa images and more elaborate petroglyphs generated merit and expanded opportunities for worshipping and remembering the Buddha. Petroglyphs of ornate stūpas, jātakas, scenes from the life of the Buddha, and images of various bodhisattvas correspond more closely to Buddhist architectural and iconographical patterns. The standardization of Buddhist images in some rock drawings was probably due to closer contact with other Buddhist artistic traditions than was previously the case in earlier stages of longdistance transmission.

Literary accounts of Chinese pilgrims corroborate epigraphic and petroglyphic evidence for trans-regional movement to and from South Asia on these particular capillary routes from the fourth to eighth centuries. Faxian vividly described many details of his route across

${ }^{53}$ Fussman, Gérard. 1989c. "Les inscriptions Kharoșthī de la plaine de Chilas." In Jettmar, ed. 1989 (ANP 1), 3-5, no. 1,2 (rama[kri]sa), pl. 4; 10-11, no. 3,3 (hariti prațakasa), pls. 10, 12; 15-16, nos. 7,3 (valadebo), 7,6 (vasudevo), pl. 18 (= fig. 5.1). 


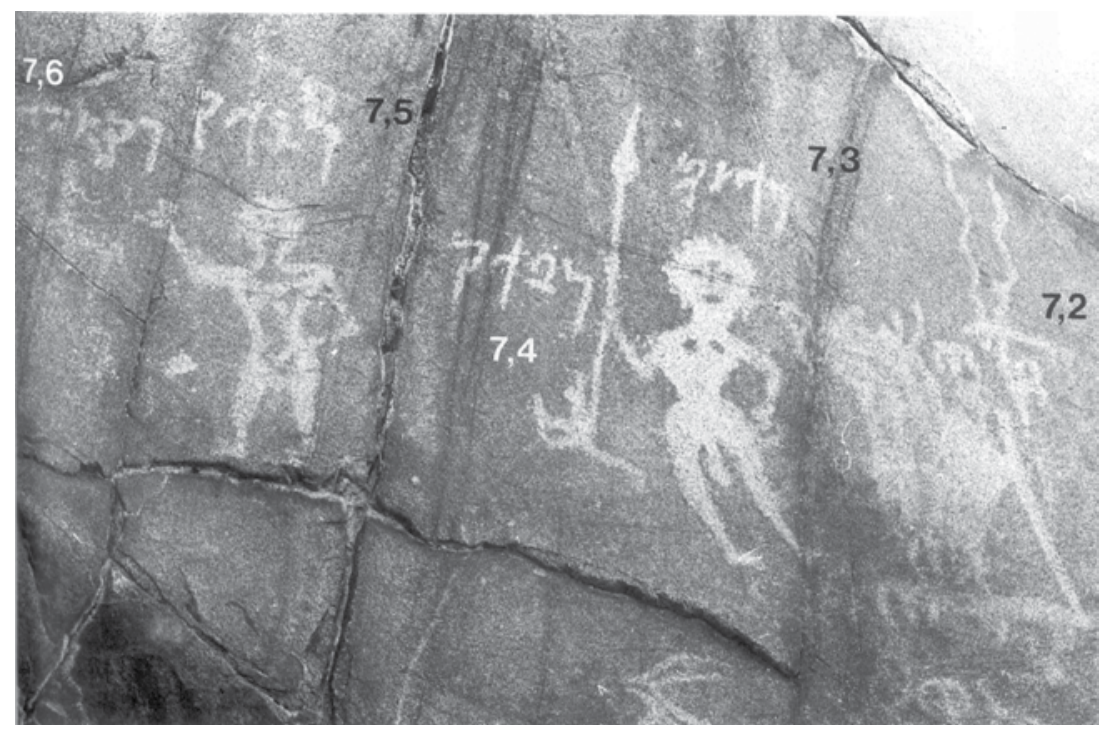

Fig. 5.1: Petroglyphs of Vāsudeva-Kṛṣna and Baladeva-Balarāma at Chilas II (Source: ANP 1, plate 18)

the "Onion" (Cong-lin) mountains between Khotan and Swat around $403 \mathrm{CE}$, but the precise path of this stretch of his itinerary remains uncertain. After leaving Khotan, he visited the mountain kingdom of Jiecha, "in the midst of the Onion range" (Legge 1886: 23), possibly located at Tashkurgan in southwestern Xinjiang, close to Skardu in Baltistan, or in Ladakh. ${ }^{54}$ After crossing the Onion mountains, Faxian visited Tuo-li, where a large wooden image of Maitreya was venerated by neighboring kings. ${ }^{55}$ Archaeological remains of such a shrine have not been found, but Tuo-li may have been located in a valley of an

\footnotetext{
${ }^{54}$ Tashkurgan is generally accepted as the location of Jiecha (Kuwayama 1987: 711), but locations in Baltistan (Deeg, Max. 2000. "On the localisation of Faxian's kingdom of Jiecha." In Taddei and De Marco 2000: 877-888) and Ladakh (Legge 1886: 18, n. 2; 22, n. 3) correspond more closely to the report that Faxian and his fellow travelers "went westwards [from Jiecha] towards North India, and after being on the way for a month, they succeeded in getting across and through the range of the Onion mountains" (Legge 1886: 24). While travelers could proceed to the West from Tashkurgan to Wakhan, in other Chinese sources Tashkurgan is named Khe-ban-tuo/ Han-ban-tuo (corresponding to Kharvandan in Sogdian), which makes an identification between Jie-cha and Tashkurgan unlikely.

${ }_{55}$ Legge 1886: 24-5; Li 2002: 168.
} 
upper Indus tributary between Shatial and Chilas. From Tuo-li, Faxian traversed the difficult "Hanging Passage" (xuan $d u$ ):

From here they traveled southwest along the mountain range for fifteen days on a difficult path that was full of obstacles. The crags rose to a formidable height and there was nothing bu precipitous rocks towering high in the mountains. One would feel dizzy when looking down from above, and there was no foothold for proceeding along the way. Below flowed a river called the Indus. The ancients had hewn a stairway-like path out of the rocks that has seven hundred steps. After climbing the stairway, the party crossed the river by walking carefully over a rope suspension bridge. The banks of the river were nearly eighty paces apart. (translated by Li 1996: 168$)^{56}$

Zhimeng, another Chinese Buddhist pilgrim who left Chang-an (modern Xian) in $404 \mathrm{CE}$, followed roughly the same route as Faxian from Khotan though Ji-sha (Jie-cha in Faxian's account) to Bo-lun. ${ }^{57}$ There, nine of the fourteen monks accompanying Zhimeng turned back to China and the Indian monk who was probably their guide died of fatigue..$^{58}$ After crossing the "Snowy mountains" (Himalaya) and the Indus River, Zhimeng reached Jibin (probably Gandhāra rather than Kashmir). Other Chinese monks named Dharmavikrama and Hui-lan also journeyed from China to Jibin, probably through Bolor, the upper Indus, the Hanging Passages, Swat, and Gandhāra, to worship the relic of the Buddha's bowl at Nagarahāra in the fifth century. ${ }^{59}$

The journey of Song Yun and Huisheng followed similar routes from the southern Tarim Basin to Swat and Gandhära between 518$522 \mathrm{CE}$. Although he probably did not visit Bo-lu-le east of Chitral, Song Yun described the direct route from Swat in terms similar to Faxian's description:

One has to cross iron-chain bridges across bottomless chasms; there is nothing to hold on to, and at any moment one may suddenly fall 10,000

${ }^{56}$ Xuan $d u$ can be localized in the gorge of the Indus river between Sazin and Besham in Kohistan, as recognized by Stein 1942: 54-55 and Jettmar 1987a: 95-101 (= 2002: 174-181).

${ }^{57}$ Kuwayama cautions that Hui-jao, who edited Zhi-meng's biography, “...was quite careless of precise locations of North Indian kingdoms, or had little knowledge about Indian geography..." (1987: 711, n. 27). Nevertheless, the geographical position of Bo-lun between Jisha/Jiecha and Jibin is consistent with other accounts.

${ }^{58}$ Bagchi, Prabodh Chandra. 1981. India and China: A Thousand Years of Cultural Relations. 2nd rev. ed. Calcutta: Saraswat Library, 84.

${ }^{59}$ Kuwayama 1987: 712-3. 
fathoms. This is why travelers abandon their journeys at the sight of it. (Jenner 1981: 261)

According to Kuwayama (1987: 718, 721), later Chinese pilgrims followed routes further west towards Bactria and away from the infamous "Hanging Passage" in subsequent periods.

Xuanzang probably did not pass through the upper Indus region during his travels in Central Asia and India from 627-645 CE, but he described the route from Swat to the Indus River:

The roads are craggy and steep; the mountains and the valleys are dark and gloomy. Sometimes we have to cross by ropes, sometimes by iron chains stretched (across the gorges). There are foot-bridges (or covered ways) suspended in the air, and flying bridges across the chasms, with wooden steps let into the ground for climbing the steep embankments. (Beal 1884: 1.133)

Xuanzang also provided detailed information about the Maitreya image in Da-li-luo, where, according to his sources, gold and turmeric were found and where the former capital of Uḍdiyana was located. A route led from Da-li-luo along the Indus River to Bo-lu-luo in the middle of the Snowy Mountains, which could be reached "by the help of flying bridges and footways made of wood across the chasms and precipices" (Beal 1884: 134-5). According to Xuanzang, Bo-lu-luo was long from east to west, narrow from north to south, rich in gold, silver, wheat, pulse (lentils), and other supplies, continually cold, and inhabited by rough people who spoke a somewhat different language written in similar letters to those used in India. The secondhand nature of this information is probably the reason why Xuanzang does not refer to the Palola Saahi rulers of this region, whose support of Buddhist scholarship in the seventh century was contemporary with Xuanzang's visit to Swat.

Huizhao, a Korean monk who visited India around 723-727 CE, traveled from Kashmir to Bolor, which at that time was divided into Greater Bolor (fifteen days' journey northeast of Kashmir) controlled by Tibetans, and Lesser Bolor (seven days' journey northwest of Kashmir) under Chinese dominion. Huizhao's account includes some information about the customs, dress and hairstyles of the local inhabitants of Lesser Bolor. He also referred to poor economic conditions:

The poor are many and the rich are few. The valleys are narrow and cultivable lands are limited. The mountains are withered and sterile, with no trees or grass. (Yang 1985: 48) 
Huizhao's account of impoverishment contrasts sharply with the information in Xuanzang's report from about one century earlier. While some elements may be exaggerated (e.g. "no trees or grass"), the region of Lesser Bolor may have indeed experienced economic and military catastrophes leading to the downfall of the Palola Șanhis during the eighth century.

Persian and Arabic texts supply details about the routes followed by merchants traveling between Central Asia and Northwest India. Hudüd al- 'Álam ("Regions of the World"), a Persian geography written in 982 $\mathrm{CE}$, contains information about routes connecting western Central Asia with Kashmir through the present Northern Areas of Pakistan. Merchants and other travelers followed routes from the Oxus River through Badakhshan and the Wakhan corridor to Bolor in northern Pakistan. ${ }^{60}$ The description of Bolor (Persian Bulür, corresponding to Chinese Bo-lu-luo), where "there is no salt but that imported from Kashmir” (Minorsky 1937: 121, \$26.19), occurs between Samarqandāq (probably Sarhad in Wakhan) and Andrās (tentatively identified with Dras, about $100 \mathrm{~km}$ east of Srinagar on the route between Kashmir and Ladakh). ${ }^{61}$ As in later Chinese sources, Bolor proper is distinguished from "Bolorian Tibet" (Baltistan), where "[t]he people are chiefly merchants" (ibid., 93, \$11.2). The itinerary in the Hudüd al-'Ālam outlines stages of an west-east network of routes which were probably used by earlier Sogdian merchants whose names are preserved in upper Indus graffiti of the third to seventh centuries.

Al-Bīrūni (973-1048 CE) refers to a route between the northwestern frontier of Kashmir and the upper Indus valley which was very similar to those itineraries outlined in $H u d \bar{u} d$ al-' $\bar{A} l a m$. Following his discussion of the people, cities, and rivers of Kashmir, Al-Bīrūnī notes:

Leaving the ravine by which you enter Kashmir and entering the plateau, then you have for a march of two more days on your left the mountains of Bolor and Shamilān... Their towns are Gilgit, Aswira, and Shiltās...(Sachau 1888: 1.207) ${ }^{62}$

${ }^{60}$ Minorsky, Vladimir; trans. 1937. Hudūd al-'Ālam = "The regions of the world": a Persian geography, 372 AH-982 AD London: Luzac, 261, map iv.

${ }_{61}$ Minorsky 1937: 369-70.

62 Sachau, Carl Eduard, trans. 1888. Alberuni's India: An account of the religion, philosophy, literature, geography, chronology, astronomy, customs, laws, and astrology of India about $A D$ 1030. 2 vols, London: Trübner. 
In this passage, Aswira can be identified with Astor, and Shiltās corresponds to modern Chilas. ${ }^{63}$ The "mountains of Bolor and Shamilān" indicate the Karakorum, western Himālaya (including Nanga Parbat), and Deosai plateau in Baltistan. The route described by Al-Bīrūnī was the primary entryway to Kashmir through the valley of the Jhelum River, which could be reached from the Northern Areas through the Kagan valley and Babusar Pass above Chilas.

A Khotanese Saka itinerary was probably the most popular northsouth route between the Tarim Basin, Gilgit, Chilas, and Kashmir during the tenth century, but it may have been used widely for several centuries before and after this period. ${ }^{64}$ Although many places have not been identified, a significant segment of the route passed through the Ishkoman, Gilgit and upper Indus valleys. ${ }^{65}$ The text refers to an important ford of the Gilgit River at Bubur (Baubuera) in modern Punyal. The "king's abode" was in the "great city" of Gilgit (Gïdagitti), where eight stone samghārāmas indicate that Buddhism was still flourishing. ${ }^{66}$ Chilas (Śilathasa/Śĭdathasi) is referred to as another "great city" on the Indus River south of Gilgit. From Chilas, the Mangalacakra bridge could be reached after a journey of eight days, probably via the Babusar Pass and Kagan Valley. From "the first Indian city towards Kashmir" (Bailey 1936: 262) located at the bridge near the confluence of the Kishanganga and Jhelum rivers (close to Muzaffarabad), the itinerary describes places along the Jhelum River on the route to Baramula (Varnavalā) in Kashmir.

${ }^{63}$ Bailey 1936: 262; Stein 1900: 2.363; Jettmar, Karl. 1980. Bolor \& Dardistan. Islamabad: National Institute of Folk Heritage, 22.

${ }^{64}$ Bailey 1936: 258-267 (= Bailey, H.W. 1981. Opera Minora: Articles on Iranian Studies. Shiraz, 287-298); Skjaervø 2002: 524-6. References to surviving Buddhist monasteries along the route described in this itinerary are examined in Chapter 2, subchapter: Palola Șāhis: Élite Patrons in a Buddhist Enclave, p. 177.

${ }^{65}$ According to Bailey (1936: 260, citing Morgenstierne), the "Blue River" may be identified with the Ishkoman River (Burushaski șiqam means "blue"), the Sina is the Gilgit River (ibid., 261), and the "Golden River" is the Indus (262). Tucci comments that Golden River "is here certainly not a mere poetical attribute" (1977: 19, fn. 17), since this region is associated with gold in other literary traditions.

${ }^{66}$ Bailey 1936: 262. 


\section{Enigma of an Absence of Archaeological Evidence and Manifestations of Buddhist Presence}

In contrast to the rich corpus of petroglyphs and inscriptions and interesting literary references to the upper Indus region, very little archaeological evidence is available to corroborate the use of this network of capillary routes for long-distance trade and religious transmission. Aside from stray finds, the archaeological record for this region is very poor because systematic surveys and excavations have not been undertaken. Nevertheless, among the most notable discoveries are items which may have been imported during Saka migrations, including a bronze rhyton and another bronze vessel from the Ishkoman valley, a bronze plaque from the Kandia valley, and a large golden ring discovered near Pattan in the Kohistan district of the Indus valley ${ }^{67}$ The paucity of other items imported through long-distance trade exchanges may also be due to the tendency of artifacts to be found at opposite ends of trade route terminals rather than in transit zones. The absence of archaeological remains of urban centers on routes through the mountain valleys of northern Pakistan does not necessarily indicate that traders bypassed this region in the first millennium CE, but instead probably relates to the inability of the physical environment to support large populations in cities. Judging from the meager archaeological remains of stuppas and monasteries in northern Pakistan, the establishment of large-scale Buddhist institutions in northern Pakistan did not take place before the middle to late first millennium CE.

The following overview begins downriver on the upper Indus at Shatial and ends at Haldeikish in the Hunza valley. Rather than a comprehensive survey, the focus of this tour is on inscriptions and rock drawings that demonstrate a Buddhist presence. Along the way, other important sites of possible Buddhist stūpa sites and shrines are noted. The largest concentrations of Buddhist petroglyphs in northern Pakistan are located south of Hunza-Haldeikish and Alam Bridge in the upper Indus valley between Chilas and Shatial.

${ }^{67}$ Dani, Ahmad Hasan. 1998. "Origin of the Dardic Culture: a new discovery in the Northern Areas of Pakistan." Journal of Central Asia 21.1, 158-170; Jettmar 1991; Litvinsky 1993 [ANP 2]; Neelis 2007: 64-66; Rehman, Saeed ur. 1990. Unique Find of Gold Ornaments from Pattan/Kohistan.” Journal of Central Asia 13.1, 5-17, pls. I-XV; Stein 1944: 14-16. 


\section{Shatial}

Over one thousand inscriptions and seven hundred petroglyphs located at Shatial bridge on the upper Indus River mark an especially significant junction of ancient byways used by long-distance traders and Buddhist missionaries and pilgrims. ${ }^{68}$ Shatial functioned as an important "transit station" (Durchgangsstation) on routes connecting the upper Indus to the Swat valley and Gandhāra via the infamous "Hanging Passages" (xuan $d u$ ). Across the Indus River from Shatial, pathways through the Darel and Tangir valleys lead northwards to Gilgit and Chitral, with further links to Badakhshan and the Oxus watershed in northeastern Afghanistan. Shatial is distinguished from other upper Indus sites by almost six hundred Iranian visitors' inscriptions from the third to seventh centuries CE, which were primarily written by Sogdian visitors. ${ }^{69}$ The longest inscription at Shatial was written by a Sogdian traveler on his way to Tashkurgan in southwestern Xinjiang:

(I), Nanai-vandak, the (son of) Narisaf, came (here) on the tenth (day/ year) and have requested the favor from the soul of the holy place Kărt

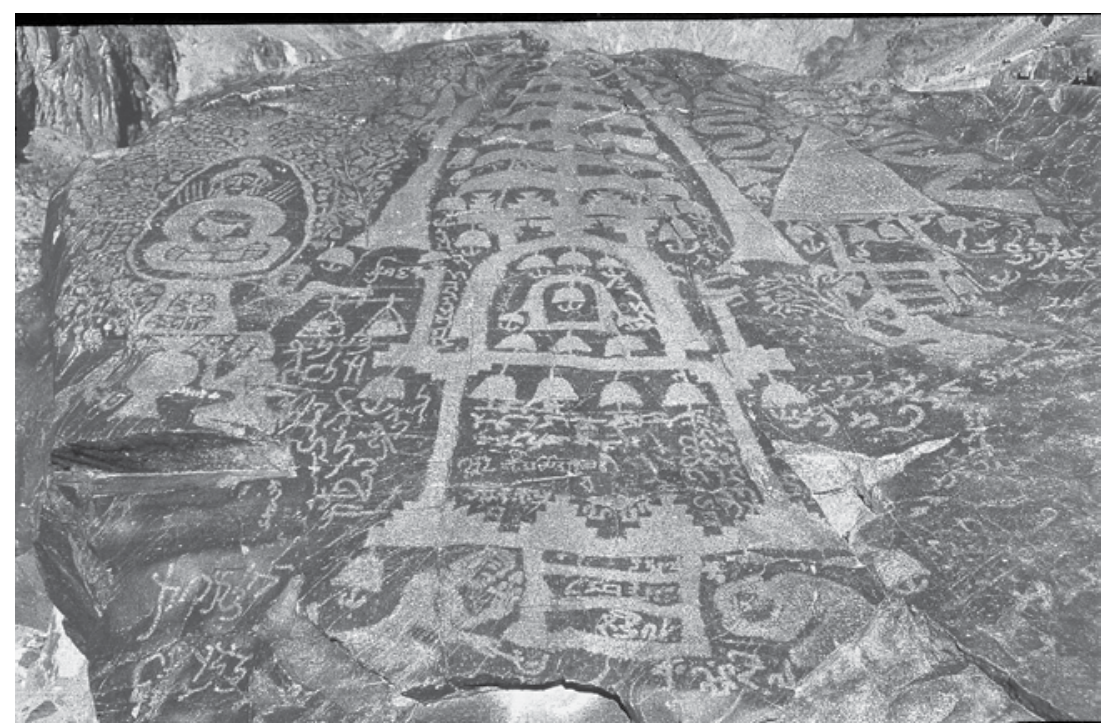

Fig. 5.2: Triptych with a Stūpa and Sibi Jātaka at Shatial (Source: MANP 2, plate $\mathrm{Vb}$ )

${ }^{68}$ Bandini-König and Fussman 1997 (MANP 2).

${ }^{69}$ Sims-Williams 1989-1992; La Vaissière 2005 [2002]: 79-81. 
(that) I reach Kharvandan [Tashkurgan] very fast and see (my) dear brother in good (health). (no. 36:38, Sims-Williams 1989: 23).

Numerous Indian inscriptions written in the Brāhmī (411), Kharoșthī (15), and Proto-Sāradā (7) scripts suggest that South Asian merchants met their Sogdian counterparts at this commercial hub or entrepôt. Drawings of 138 stüpas at Shatial also indicate the religious significance of this waystation, especially to Buddhist visitors. The most impressive Buddhist image at Shatial is a large triptych with an intricate drawing of a stūpa flanked by an illustration of the Sibi Jātaka (in which the king of the Sibis holds a bird which he has saved by cutting off a piece of his own flesh), and an unidentified structure that may represent another Buddhist narrative, with devotees prostrating below. ${ }^{70}$ The depiction of the king of the Sibis as a Buddha deviates from conventional representations. Based on paleographic analysis of Sogdian, Brāhmī, and Kharoșțī graffiti densely written within and around these images, Gérard Fussman dates the drawing to ca. 350 CE. Thus, Shatial served multiple functions as a significant commercial node and as a wayside shrine where the jātaka story of King Sibi's selfless gift of his own flesh may have been localized.

\section{Oshibat and other "crossing stations" of upper Indus}

Several important complexes located upstream from Shatial on the upper Indus are located where tributaries enter the Indus from side valleys or at river crossings where local, regional, and long-distance travelers drew designs and wrote their names while waiting to continue their voyages. A mixture of many types of petroglyphs at the "crossing station" of Oshibat depict animals (especially caprids, since simple drawings of goats or ibexes are by far the

${ }^{70}$ Bandini-König and Fussman 1997: 178-79, Scene 34:A, pl. Vb. Based on palaeographic analysis of graffiti, Fussman (1994b. "Une peinture sur pierre: Le triptyque au stūpa de Shatial." In Fussman and Jettmar, ed. 1994 [ANP 3]: 43) dates the drawing to c. 350-350 CE. The Śibi Jātaka is also illustrated in a set of petroglyphs at Thalpan which includes a depiction of the R̦̣ipañcaka Jātaka (Bandini-König 2003: 118-22, Scenes 30:D, 30:X). Thewalt, Volker. 1983. "Jātaka-Darstellungen bei Chilas und Shatial am Indus." In Snoy, Peter, ed. Ethnologie und Geschichte: Festschrift für Karl Jettmar. Wiesbaden: F. Steiner, 622-634 compares and evaluates petroglyphs of Buddhist Jatakas from the upper Indus in relation to other Indian Buddhist artistic and literary traditions. 


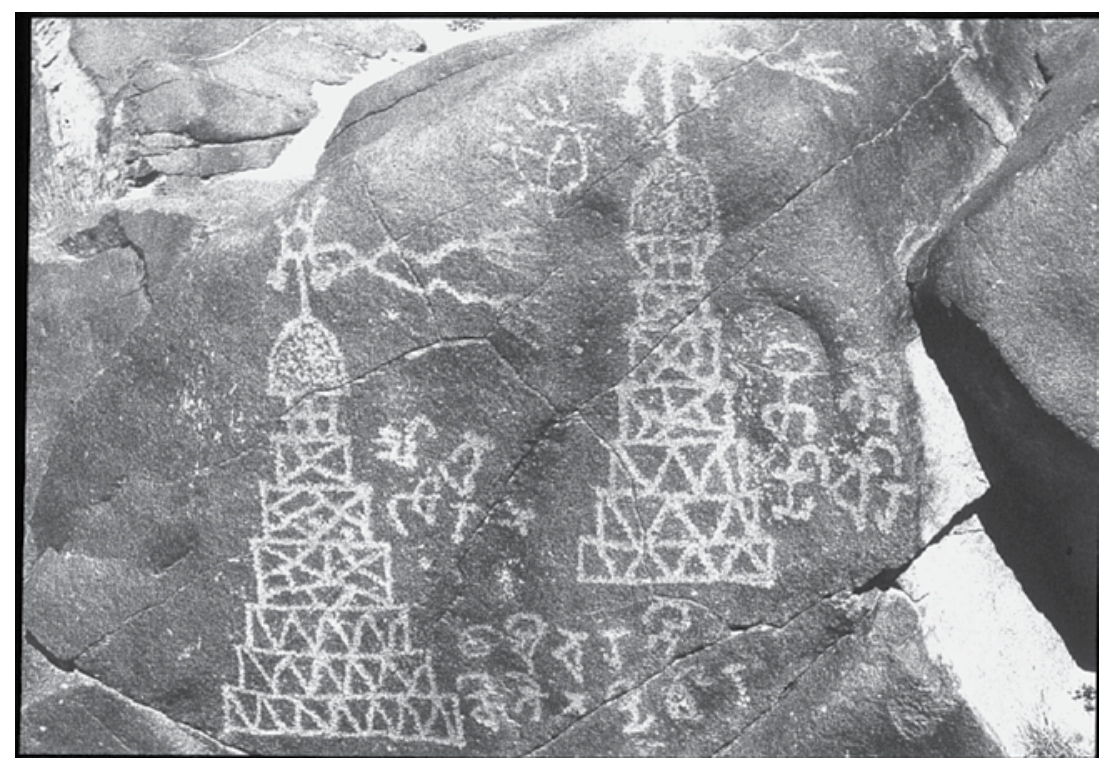

Fig. 5.3: Stūpa petroglyphs donated by Bhita the scribe at Hodar (Source: MANP 3, plate Ia)

most common type of petroglyh in northern Pakistan) with a relatively small proportion of stūpa images (37 drawings are only $4 \%$ of the total). ${ }^{71}$ Numerous Brāhmī inscriptions (230) record Indian, Iranian, and local personal names (with -ott(t)a suffixes), and the names of visitors in some Sogdian inscriptions (26) recur at Shatial and other sites.

The crossing at Oshibat was linked to routes on the other bank of the Indus River, where petroglyphs and inscriptions at Helor Das, Hodar, and Dadam Das were made by local inhabitants as well as transregional traders and travelers. Over 130 drawings of stūpas demonstrate popular Buddhist devotion at Hodar. Brāhmī and Proto-Sāradā donative inscriptions indicate that many drawings were "religious offerings" of local inhabitants, including a scribe (divira) named Bhita, who shared the merit from drawing abstract geometric stūpas with his mother and father. ${ }^{72}$ These transformed images of stūpas with only the most basic features of multiple foundations leading to an apex crowned by a staff,

71 Bandini-König and Bemmann 1994 (MANP 1): 13-14, pls. 24-27.

72 Bandini-König 1999 (MANP 3): nos. 4:1-2, 4:5-8, 6:1-11. 
sometimes in the form of a trident, show that simple drawings provided a focus for veneration and generated merit in essentially the same way as more elaborate petroglyphs. According to Volker Thewalt:

Many of these elaborate rock-carvings must be attributed to highly skilled craftsmen who received their artistic training in the great monasteries of Gandhāra, while others are crude imitations, executed by traveling laymen or the inhabitants of neighboring villages, wishing to gain some spiritual merit by reproducing these sacred monuments. $(1985: 2.782)^{73}$

The popularity of drawing and venerating stuppa images at Hodar contrasts with the relative paucity of Buddhist images at the nearby site of Dadam Das (only 5 stūpa petroglyphs), which seems to have functioned as a prehistoric hunting station and border post for longdistance traders such as Dovala $(37: 10,15,24)$, who wrote his name in Brāhmī and Kharoșthī next to an image of an Iranian fire altar (his name also appears at Shatial 54:24). ${ }^{74}$

Among the petroglyph "stations" located at the mouths of the Harban, Khanbari, Minargah, and Gichi valleys, only the catalog of petroglyphs and inscriptions at Gichi has been published. ${ }^{75}$ This site can be divided between an eastern part with many Buddhist engravings near the remains of a settlement at the mouth of the Gichi stream and a western part with a majority of visitors' inscriptions. Stūpas with anthropomorphic features included among 77 images of stūpas on rocks at Gichi Nala are associated with a local devotee named Sangamitra (nos. 31:1, 3, 4, 5), who seems to have introduced his own unique innovations into the designs (p. 113). Brāhmī inscriptions predominate, aside from a single inscription in Sogdian and an exceptional Hebrew inscription (no. 155:4). There are at least 25 examples of Buddhist dedicatory formulae (with devadharma-, krta, and dharmahetuvarada), and the repetition of the names of some visitors who wrote their names at other sites allows their routes through the upper Indus region to be reconstructed.

73 Thewalt, Volker. 1985. "Rockcarvings and Inscriptions along the Indus: The Buddhist Tradition.” In South Asian Archaeology. 1983, v.2, eds. Janine Schotsmans and Maurizio Taddei. Naples: Instituto universitario orientale.

${ }_{74}^{74}$ Bemmann 2005 (MANP 5): 104-106.

75 Bandini-König and Hinüber 2001 (MANP 4) 161-114; 207-315. A catalog of inscriptions from Basha, Bazeri Das, Chilas IV, V, VI, Harban, Hodar-South, Khanbari, and Minar Gah is published as an appendix to MANP 9: 243-281. 


\section{Chilas-Thalpan}

Proceeding upriver from Shatial on the upper Indus, several graffiti and petroglyph complexes are located at crossing points, but many of the most impressive Buddhist petroglyphs are concentrated near the modern bridge between Chilas and Thalpan. ${ }^{76}$ The earliest petroglyphs of stüpas are found at the complex of Chilas II, where about sixty Kharoșthi $\bar{i}$ graffiti belonging to periods from about the first to third centuries accompany Buddhist and non-Buddhist petroglyphs. ${ }^{77}$ Rock drawings of stūpas at Chilas II typically have only three to five "umbrellas" or "parasols" (chattras) attached to a mast (yaști) above a rectangular harmikā which crowns a cylindrical dome (anda). A contrast between abundant stūpa drawings and the absence of anthropomorphic images of the Buddha at Chilas II leads Martha Carter to conclude that the Buddha icon was not included in "the common repertoire of devotional imagery" (Carter 1993: 363) at this stage in the upper Indus. Iconographic motifs connected with Buddhist, Hindu, and indigenous traditions shed light on the multiple

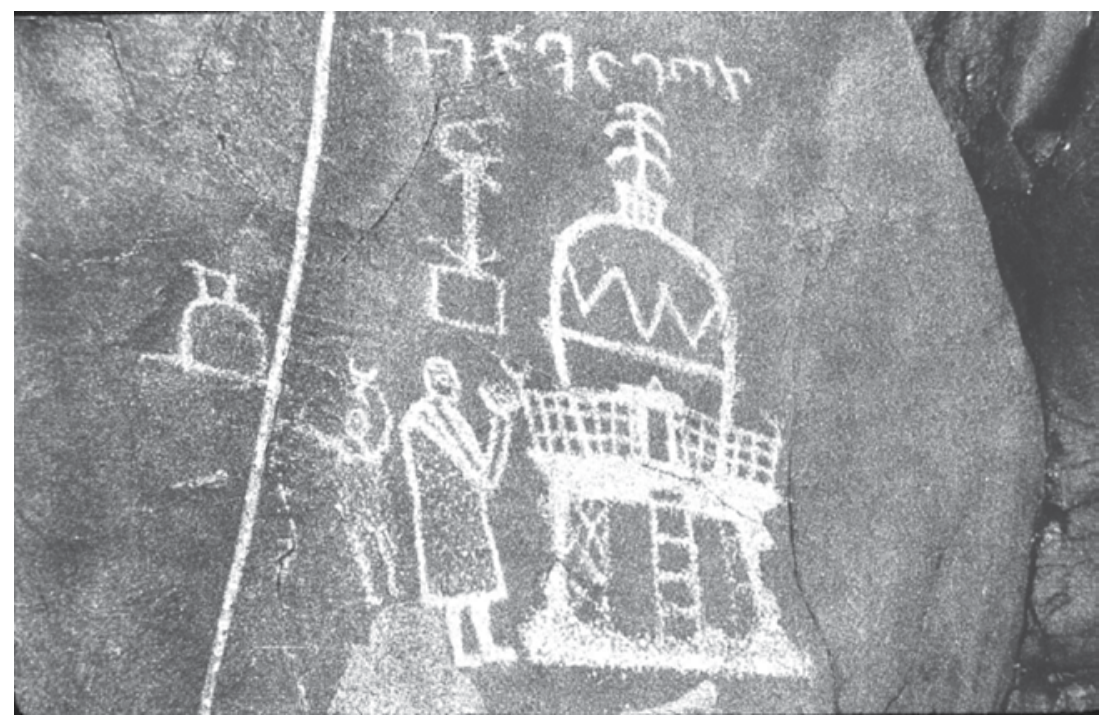

Fig. 5.4: Stūpa veneration at Chilas II (Source: ANP 1, plate 22)

76 Bandini-König 2003- (MANP 6-9).

77 Fussman 1989c [ANP 1]: 1-40. 
religious proclivities of visitors to this encampment, which was apparently not an exclusively Buddhist shrine. (Fig. 5.1)

At sites around Thalpan and Chilas a local patron named Kuberavāhana donated several ornate stūpas as well as visual narratives of Sākyamuni Buddha's religious biography. He is portrayed with his teacher Mitragupta in a detailed drawing of the Vyāghrī Jātaka, a widespread narrative in which a Bodhisattva (labeled Mahāsattva) makes a gift of his own body to save a hungry tigress and her cubs. ${ }^{78}$ Other petroglyphs of the Sibi Jātaka (also illustrated downstream at Shatial) and the Roșipañcaka Jātaka suggest that these narratives may have been linked with local or regional sites. Another prominent local patron named Sinhoța donated "religious offerings" (devadharma) of petroglyphs depicting the Bodhisattvas Avalokiteśvara and Maitreya along with stupa drawings at Chilas bridge. Other inscriptions denote homage to Buddhas and Bodhisattvas associated with the Mahāyāna such as Amitābha, Akșobhya, Prabhūtaratna, and Ratnaśikhin. ${ }^{79}$ The standardization of Buddhist images in rock drawings donated by Kuberavāhana and Sinhoța at Chilas and Thalpan was probably due to close contact with Buddhist artistic traditions in neighboring regions of Swat, Gandhāra, and Kashmir.

\section{Shing Nala}

A shrine at Shing Nala, located approximately thirty $\mathrm{km}$ upstream from Thalpan, has a remarkable concentration of Buddhist petroglyphs, including 156 stuppas (41\% of the total engravings) often recorded as "religious offerings" in Brāhmī donative inscriptions. ${ }^{80}$ Most of the Buddhist images and inscriptions are clustered around a large geological formation that periodically fills with water and serves as a place to rest in the shade of overhanging rocks. Since Shing Nala was not located on a major transit route, Ditte Bandini-König (2001: 57-58) hypothesizes that the localization of a Buddhist shrine was tied

\footnotetext{
${ }^{78}$ The petroglyph of the Vyāghrī Jātaka at Chilas was initially published by Stein 1944: 20-21. Now see Bandini-König 2003: 43-49, Ensemble $30 \alpha$, Scenes 30: A-B, pl. 41, IVa-c, Va for updated readings of Brāhmī inscriptions.

${ }^{79}$ Hinüber 1989b (ANP 1): 101-2.

${ }^{80}$ Bandini-König and Hinüber 2001 (MANP 4): 1-59, 143-206 catalog inscriptions and petroglyphs from Shing Nala.
} 
to the residential retreat of a Buddhist forest monk (aranyavāsin), who attracted visitors for a limited period around $500 \mathrm{CE}$. If this hypothesis is correct, Shing Nala was not a "wayside shrine" per se, but primarily functioned as a pilgrimage place, which became a focus for the devotion of visitors who made their own stūpa designs. Designs of elaborate stuppas with profuse architectural details and decorative elements and other complex Buddhist drawings are relatively scarce outside of Chilas, Thalpan, Shatial, and Shing Nala. Rudimentary images of stüpas with only the most basic features show that patronage was not restricted to élite donors.

\section{Alam Bridge}

Kharoșthī and Brāhmī graffiti written on rocks near the confluence of the upper Indus and Gilgit rivers close to Alam Bridge reflect patterns of long-distance travel. ${ }^{81}$ While there are very few petroglyphs of stupas or other images to indicate that this site functioned as a Buddhist shrine, personal names and titles clearly indicate that many visitors were Buddhist travelers or local devotees. Approximately twenty percent of the personal names in Kharoșthī and Brāhmī graffiti at Alam Bridge are composed of Buddhist naming elements. Examples of Buddhist titles in Brāhmī graffiti include a novice (śrāmaṇera) named Asokakșema, a "Master of Monastic Law" (vinayadhara) named Ratnarakșita, and a "Śākya monk" (śākyabhikșu) named Satyaśreșțhi. Brāhmī graffiti recording the visits of Palolajo Bhikșus were written by Buddhist monks with regional ethnonyms, since Gilgit and the surrounding valleys were ruled by the Palola Șāhis until the early eighth century. ${ }^{82}$ Kharoșthī and Brāhmī graffiti at Alam Bridge serve as valuable written records of the journeys of agents of Buddhist transmission.

${ }^{81}$ Fussman, Gérard. 1978. "Inscriptions de Gilgit." Bulletin de l'École française d'Extrême-Orient 65: 1-64; Humbach, Helmut. 1980a. "Hybrid Sanskrit in the Gilgit Brāhmī Inscriptions." Studien zur Indologie und Iranistik 5/6: 99-121; Humbach, Helmut. 1980b. "Die Kharoșți-Inschriften aus Gilgit.” Münchener Studien zur Sprachwissenschaft 39: 53-58.

${ }_{82}$ Hinüber 2004: 58-59. For more details about the historical context of the Palola Șāhis, refer to Palola Șāhis of Gilgit: Élite Patrons in a Buddhist Enclave in the penultimate subchapter of Chapter 2, pp. 171-177. 


\section{Hunza-Haldeikish}

Inscriptions and petroglyphs at Hadeikish in the Hunza valley mark a significant waystation on the network of capillary routes through the Karakorum mountains. Over one hundred Kharoșțī, Brāhmī, Sogdian, Bactrian, Chinese, and Tibetan inscriptions at Haldeikish provide concrete evidence for the movement of travelers during the first millennium. Haldeikish is predominated by petroglyphs of mountain goats (the name of Haldeikish is derived from haldén, the Burushaski word for a male ibex or a domesticated male goat), which may indicate an ongoing connection with hunting expeditions. Four large rock outcroppings form a conspicuous natural landmark near an important ford across the Hunza River and provide a convenient resting place for visitors who drew zoomorphic designs and abraded graffiti into weathered patches of desert varnish covering the sandstone and shale surfaces. Since graffiti at Haldeikish primarily record the arrival of visitors in epigraphic formulae similar to those used at Alam Bridge and there are very few Buddhist petroglyphs, this site probably functioned as a transit station for long-distance travelers rather than a shrine for local devotees. Nevertheless, Buddhist personal names (appearing in a relatively higher proportion of the Kharosthi inscriptions, which outnumber other inscriptions at this site) indicate that Haldeikish belonged to the capillary network of long-distance routes of Buddhist transmission between South Asia and Central Asia.

\section{Conclusions}

This upper Indus border region of northern Pakistan was a significant transit zone for the initial phases of Buddhist transmission beyond South Asia. The climate and terrain of the high mountain desert environment severely limited agricultural production. Precious gems and metals found throughout the mountains of northern Pakistan probably provided a powerful incentive for undertaking difficult journeys through the mountains, since there is always a demand for such high-value/low-volume commodities. Hunting was evidently a major occupation based on scenes depicted in rock drawings and still has a meaningful role in local traditions in the Northern Areas of Pakistan. However, in contrast to more fertile areas of Gandhära, Swat, and the Kashmir valley, the material resources of this region were not suffi- 
cient to support large residential Buddhist monasteries. Like the Takla Makan desert in Xinjiang (to be explored in the following chapter), the high mountain passes, deep river valleys, and other topographical features of this region were difficult to traverse in certain seasons. Nevertheless, images drawn on rocks located at nodes in networks of capillary routes and inscriptions written by visitors to record their arrival at crossing points clearly indicate that these physical barriers were not impediments to transregional mobility.

Buddhist names written in Kharoșthī and Brāhmī graffiti, various types of stūpa drawings, illustrations of jätakas and other Buddhist biographical narratives, and images of Buddhas and Bodhisattvas reflect different stages in the regional establishment and transmission of Buddhism in the transit zone of northern Pakistan, which was definitely not devoid of a Buddhist presence. "Religious offerings" (devadharma/deyadharma) of Buddhist petroglyphs given to wayside shrines (caityas) localized the presence of the Buddha by acting as visual commemorative relics for local and itinerant devotees to worship in an environment that could not initially sustain permanent stūpas and residential monasteries. Chinese accounts of Faxian and Xuanzang refer to a Buddhist shrine with a colossal wooden image of the future Buddha Maitreya in the upper Indus region. However, its location is unknown, and archaeological evidence of local monasteries mentioned nearby the shrine has not yet been discovered. While Buddhist institutions are very well attested by archaeological remains of stūpas and monasteries in the Swat valley of ancient Uḍdiyāna, socioeconomic conditions in the upper Indus apparently did not support a pattern of monastic settlement before a period of élite patronage by the Palola Șâhi dynasty of Gilgit from the 7th to early 8th century. The enigmatic absence of a Buddhist institutional presence before this period did not mean that Buddhists were missing from the transit zone of the upper Indus. Instead, this overview of Buddhist petroglyphs and inscriptions has demonstrated that traders, itinerant monks, and local patrons began to localize religious topologies and narratives long before élite patronage led to increased levels of Buddhist literary and artistic production in Gilgit. 
Jason Neelis - 978-90-04-19458-8 Downloaded from Brill.com $04 / 26 / 2023$ 11:30:22AM via free access 

ROUTES AND CHINA

Previous chapters have retraced paths of Buddhist expansion along the great arteries of the Northern and Southern Routes of the Indian subcontinent, the Old Road to Bactria, and capillaries through the mountain valleys northern Pakistan. In this chapter, the focus shifts to overland networks for long-distance transmission through the desert oases of Central Asia, which functioned as a critical transit zone for the early movement of Buddhism to China. Southern and northern branches of the so-called silk routes in the Tarim Basin of modern Xinjiang in western China merit special consideration, since an enigmatic absence of Buddhist stuppas and monasteries in the early phases of long-distance transmission raises important questions about the history of Buddhism in Central Asia and China. Why does the earliest archaeological evidence of Buddhist institutions in eastern Central Asia appear to belong to a later period than the first Buddhist communities in Han China? Which economic, environmental, and religious conditions permitted Buddhist literary and artistic cultures to eventually flourish, and how were regional monastic institutions linked to Buddhist nodes elsewhere in Central Asia, South Asia, China, and Tibet? How were Buddhist ideas, images, and other materials transformed in the process of transmission through the transit zone of the Tarim Basin? How does the process of long-distance transmission affect the early development of Chinese Buddhism, and do these initial patterns have longer-term ramifications? Although it is not possible to fully address each of these broad questions, brief descriptions of nodes on the silk route network of the Tarim Basin and a reconsideration of Erik Zürcher's alternative model of long-distance transmission of Buddhism to China will bring dynamic patterns in the historical movement of Buddhism in intermediate zones between India and China into sharp relief. Rather than marginalized transfer points for the passage of Indian missionaries and Chinese pilgrims, Central Asian Buddhist centers developed distinctive religious cultures and played central roles in trans-regional exchanges. 


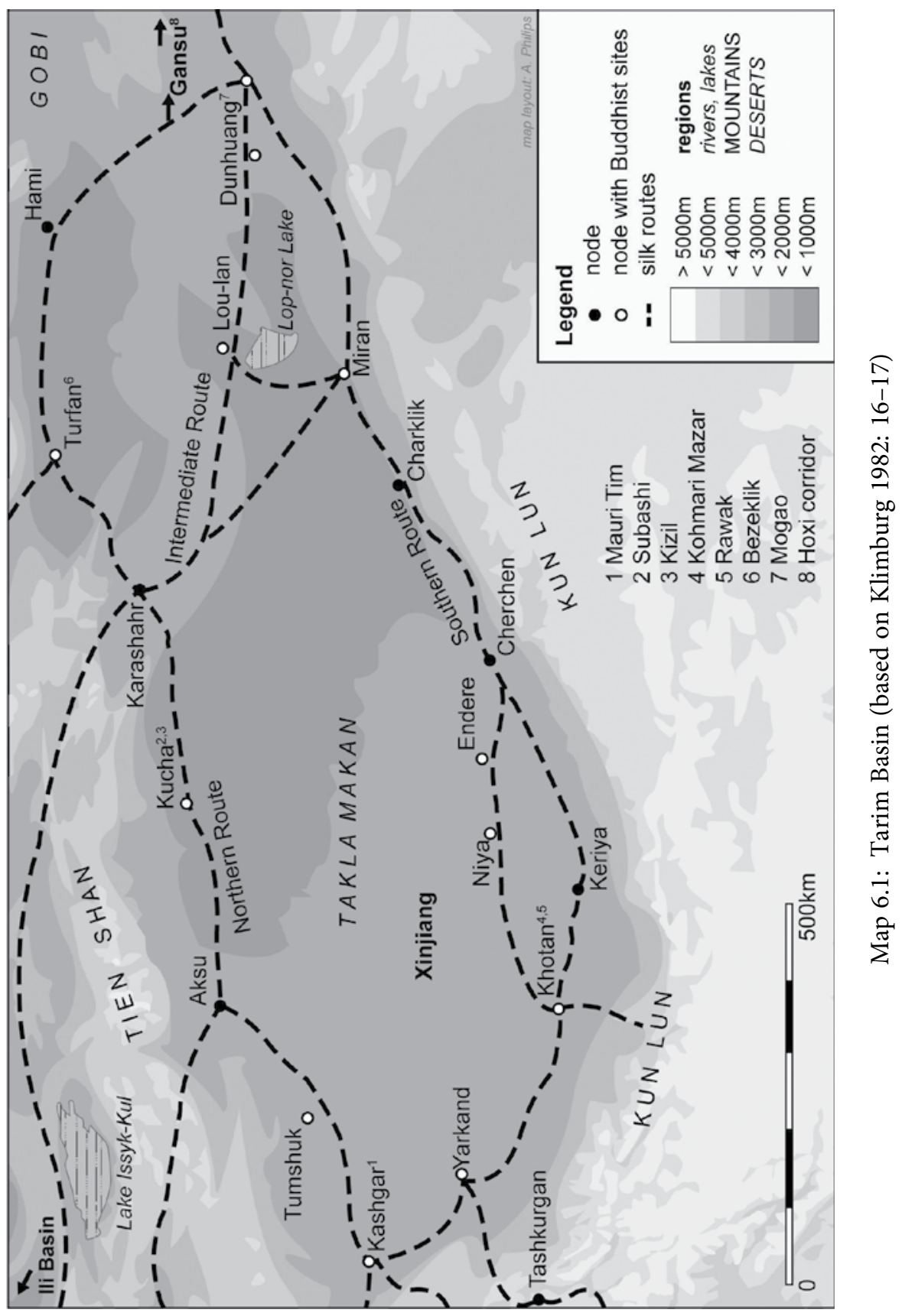




\section{Silk Routes of Eastern Central Asia}

Trans-Asian overland networks termed the "Silk Route" or "Silk Road" (Seidenstraße) by Ferdinand von Richthofen in the late nineteenth century encompassed numerous primary arteries and secondary capillaries used for various commercial and cultural exchanges, including the transmission of Buddhism between Central Asia and East Asia. ${ }^{1}$ While the Silk Road is popularly associated with opulent grandeur and exoticism, silk was only one of many commodities traded on multiple branches of intertwined itineraries. As Xinru Liu remarks,

The Silk Road was not a single route, nor did it remain stable throughout its existence. Depending on variations in environmental, political, and social conditions, the many branches of the Silk Road rose and fell in their frequency of use. $(1998: 2)^{2}$

In the broadest sense, the silk routes extended from Rome to China along parts of the itinerary described in the Parthian Stations by Isidore of Charax. ${ }^{3}$ Western Central Asian routes from Margiana (Merv) reached Termez and Bactria in the Oxus valley, or branched to the north through Bukhara and Samarkand in Sogdia. Routes from Sogdia through the Ferghana valley of the Jaxartes River crossed the Alai range to join other routes from the Oxus valley on the other side of the Pamir mountain range.

This treatment is more specifically concerned with lines of communication between China and a chain of garrisons and agricultural oases in the Tarim Basin of modern Xinjiang. Chinese sources refer to

${ }^{1}$ For a history of the term "Silk Road" see Foltz, Richard. 1999. Religions of the Silk Road: Overland trade and cultural exchange from antiquity to the fifteenth century. New York: St. Martin's Press, 1-2 and Härtel, Herbert, and Marianne Yaldiz. 1982. Along the Ancient Silk Routes: Central Asian art from the West Berlin State Museums. New York: Metropolitan Museum of Art, 15. Since the so-called Silk Road is a misnomer which gives the impression of a single route rather than a network of routes, "silk routes" is adopted as an expression for the multiple itineraries for long-distance travel, trade, and cultural exchange.

${ }^{2}$ Liu, Xinru. 1998. The Silk Road: Overland trade and cultural interactions in Eurasia. Essays on Global and Comparative History. Washington, DC: American Historical Association.

${ }^{3}$ See chapter 3: Seaports and Maritime Routes across the Indian Ocean in Chapter 3 pp. 224-225 for a discussion of the overland network from Zeugma on the Euphrates in present-day Iraq to Kandahar in southeastern Afghanistan described in the Stathmoi Parthikoi (Schoff 1914). 
these frontier borderlands as the "Western Regions" $(X i-y u)$, a general term for all of Central Asia, but more often applied to "eastern Central Asia" instead of "western Central Asia." of the silk routes through eastern Central Asia were connected with South Asia via a network of capillary routes through northern Pakistan, as detailed in the preceding chapter. Like the Northern Route of South Asia, the silk routes connecting China with Central Asia were not well-maintained international highways with fixed unalterable paths, but rather functioned as parallel arteries of commercial exchange, religious transmission, cultural diffusion, and political and military expansion.

Depending on travelers' goals and destinations, at least three fairly well-defined itineraries were used for traveling around the Tarim Basin. Southern, intermediate, and northern branches of the silk routes around the Takla Makan desert connected the western frontiers with the Han Chinese capitals at Ch'ang-an (modern Xi'an) and Loyang. After following the Ho-xi corridor between the Gobi desert and Nanshan mountains through Gansu province to Dunhuang, the silk routes divided into northern, southern and central branches. ${ }^{5}$ The northern route started from the Jade Gate (Yu-men-kuan) outside of Dunhuang and continued to the Turfan oasis, a rich agricultural, commercial, and religious node described in more detail below. The northern route followed the southern foothills of the Tien-shan range from Turfan to Kucha (an urban center with numerous Buddhist caves nearby) and Kashgar, where the southern route reconnected with the northern branch. The southern route began at the Yang-kuan gate outside of Dunhuang and continued to Miran and Niya. The southern route followed the northern foothills of the Kunlun mountains to Khotan,

${ }^{4}$ Eastern Central Asia has also been known as Chinese Turkestan, Eastern Turkestan, Serindia, Kashgaria, and Chinese Tartary (Härtel and Yaldez 1982: 18). Western Central Asia was formerly known as Soviet Turkestan, now divided into the independent countries of Turkmenistan, Uzbekistan, Tajikistan, and Kirghizstan, roughly corresponding to the ancient regions of Sogdia, Bactria and Korezm (Rhie, Marylin M. 1999. Early Buddhist art of China and Central Asia. Leiden: Brill, vol. 1, 7, fn. 2). Transoxonia is another name for western Central Asia west of the Pamirs and between the valleys of the Oxus and Jaxartes rivers.

${ }^{5}$ See maps and decriptions in Härtel and Yaldiz 1982: 15-19; Liu 1988: 42 ff.; Rhie 1999: 159-60, map 4.1. Herrmann, Albert. 1910. Die alten Seidenstrassen zwischen China und Syrien. Abt. 1. Quellen und Forschungen zur alten Geschichte und Geographie, 21 has an excellent map of "Zentralasien zur Zeit der Alten Handelsbeziehungen zwischen China und den Iranisch-Turanischen Ländern." 
Yarkand and Kashgar. An intermediate route from Dunhuang led to the military garrison at Lou-lan on Lop-nor lake, where branches diverged to Miran on the southern route and Karashahr on the northern route.

While routes through eastern Central Asia were used by the Yuezhi and other nomadic groups in earlier periods, Chinese interest in the Western Regions developed in the second century BCE as a result of conflicts between the Former (Western) Han dynasty and the Xiongnu nomadic confederacy. ${ }^{6}$ During the reign of the Han emperor Wudi (141-87 BCE), Zhang Qian was sent as an envoy to the Yuezhi in the Oxus Valley to make an alliance against the Xiongnu. ${ }^{7}$ Although this mission ultimately failed, by 111 BCE the Han dynasty controlled the Gansu corridor to Dunhuang, and shortly thereafter the Great Wall was extended to the Jade Gate and a system of 570 watchtowers was constructed along the routes. ${ }^{8}$ Following the submission of Lou-lan in 109 BCE, Miran in $77 \mathrm{BCE}$, and Turfan (a major base of the Xiongnu) between 90-60 BCE, the Han dynasty established a series of military garrisons and irrigated agricultural oases in eastern Central Asia. ${ }^{9}$ According to the Hou Han shu:

Agricultural garrisons were set up in fertile fields and post stations built along the main highways. Messengers and interpreters travelled without cessation, and barbarian merchants and peddlers came to the border [for trade] everyday. ${ }^{10}$

After Han influence declined in the beginning of the first century CE, Ban Chao re-established temporary Han control over the silk routes through eastern Central Asia while serving as Protector General of the Western Regions from 91-102 CE, but local and regional rulers regained power by the end of the second century CE. ${ }^{11}$ Chinese control of the Western Regions continued to fluctuate, but political instability

${ }^{6}$ For Yuezhi migrations across Central Asia to South Asia under pressure from the Xiongnu, see Chapter 2: Dynamics of Mobility during the Kuṣāna Period pp. 132-145, particularly Early Kușāna Genealogy and Chronology.

${ }^{7}$ Liu 1998: 4; Raschke 1978: 616; Rhie 1999: 7.

${ }^{8}$ Hulsewé, Anthony A.F.P. 1974. "Quelques considérations sur le commerce de la soie au temps de la dynastie des Han." In Mélanges de sinologie offerts à Monsieur Paul Demiéville. Paris: Presses universitaires de France, vol. 2, 123; Raschke 1978: 616, fn. 166.

${ }^{9}$ Hulsewé 1974: 123-4; Rhie 1999: 9-10.

10 Rhie 1999: 10, quoting Cambridge History of China [1986] I, 411, 413.

${ }^{11}$ Raschke 1978: 618-9; Rhie 1999: 11-12. 
did not necessarily hinder travel or trade along the silk routes through eastern Central Asia. ${ }^{12}$

Archaeological and artistic patterns demonstrate significant connections between northwestern South Asia and the southwestern Tarim Basin during the early centuries CE. A brief survey of a few nodes in the Tarim Basin demonstrate intersections between South Asian, Iranian, and Chinese economic and cultural spheres in eastern Central Asia.

\section{Kashgar}

Kashgar, located at the junction of the northern and southern silk routes on the western edge of the Tarim Basin near the base of the Pamirs, was "the main meeting point of most of the main communication routes between China and the centers of western Central Asia" (Rhie 1999: 247). As a prosperous and fertile oasis in a very strategic location, Kashgar became a protectorate of the Former Han empire in the middle of the first century BCE, but control of Kashgar wavered between Yarkand, Khotan and the Later Han administration of Ban Chao during the first century CE (ibid., 248). The Hou Han shu refers to Yuezhi (probably Kușanana) military and political involvement in the dynastic succession of Kashgar between 87-91 CE and 114-119 CE. ${ }^{13}$

Cultural links between Kashgar and the northwestern Indian subcontinent are evident in archaeological remains of five large stüpas with hemispherical domes (andas) on circular or rectangular foundations, which are very similar to architectural patterns of Buddhist sacred centers in Gandhāra, Taxila, and other sites in Swat and Afghanistan. ${ }^{14}$ Petroglyphs of stüpas in the upper Indus, particularly at Chilas and Thalpan, exhibit many of the same features, such as hemispherical or parabolic domes on three or more rectangular foundations, like those of stüpas at Mauri Tim outside of Kashgar, Subashi

12 Hulsewé 1974: 123; Rhie 1999: 161.

13 See Chapter 2: Dynamics of Mobility during the Kuṣāna Period especially Kuṣāna Conclusions, pp. 114 ff., note 242.

14 According to Rhie, the circular base and hemispherical dome of the stuppa at Topa Tim "...generally accord with the early form of Indian stüpa and the earliest form in the Gandhāran region" (1999: 249), while stūpas at Kurghan Tim, Kizil Debe, Khakanning-shahri (Tegurman), and Mauri Tim with square or rectangular bases and hemispherical domes are very similar to stüpas at Taxila, Swat and Afghanistan in the first to third centuries CE (ibid., 250 ff.). 
near Kucha, Niya, Endere, and Lou-lan. ${ }^{15}$ While Marilyn Rhie (1999: 252-3) and Aurel Stein (1921: 1.37-8) liken the stūpa at Mauri Tim to a stuppa drawing from Kara Tepe in Termez and petroglyphs found near Chitral, and draw parallels to developments of stūpa types in Bactria, stūpa designs on rocks in the upper Indus suggest alternative routes for the transmission of stüpa models to eastern Central Asia from Gandhāra, Swat or Kashmir. Foucher's argument that the Old Road was the primary route for the transmission of Buddhism (Foucher 1942: 1.3) seems to underlie theories of an early diffusion of Buddhist elements from western Central Asia across the Tarim Basin of Xinjiang to China favored by Rhie (1999: 427), although she also finds many strong parallels with the art of Swat and Gandhāra.

\section{Khotan}

Coins, manuscripts, and other artifacts reflect economic and religious connections between Gandhāra, Gilgit, and Khotan, the major city of the southern silk route for most of the first millennium in tribute relationships with China. ${ }^{16}$ Bilingual coins of Indo-Scythian (Saka) and Kușana rulers from South Asia and coins issued by Khotanese kings with legends in Chinese and Kharoșthī suggest ties between Khotan and Gandhara via capillary routes across the Karakorum in the first century. ${ }^{17}$ The distribution of bull and camel copper coins of Kujula Kadphises and copper drachmas of Kanișka in Gandhāra, Swat, Kashmir, and Khotan leads David MacDowall to conclude that that "[b]oth denominations must have been the copper currency of the Karakorum country and the upper Indus valleys" (1985: 156) and that "coinage reinforces other evidence of developing links between the Tarim basin and upper Indus" (1985: 157). ${ }^{18}$ Joe Cribb has identified thirteen

\footnotetext{
${ }_{15}$ Maillard, Monique and Robert Jera-Bezard. 1994. "Les stūpas de Kuberavāhana à Chilas et Thalpan.” In Fussman and Jettmar, eds. 1994 (ANP 3): 188.

16 Whitfield 2004: 34-42, 133-168.

${ }_{17}$ Cribb, Joe. 1984-5. "The Sino-Kharosthi Coins of Khotan. Their Attribution and Relevance to Kushan Chronology." The Numismatic Chronicle 144, 129-152; 145, 136-149 (2 parts); MacDowall, David W. 1985. "Numismatic Links Across the Karakorum.” Journal of Central Asia 8.2, 153-157.

${ }_{18}$ MacDowall's conclusion that a "northern route" for the establishment of IndoScythian and Kusānana empires is demonstrated by the names of Maues, Gondophares, and Kuṣanna rulers in Kharosthī inscriptions from the Northern Areas is based on unreliable identifications of these names by Dani 1985. The association between Kanișka and Khotan in later literary sources can not be confirmed.
} 
groups of Sino-Kharoșthi copper coins from Khotan adapted from the copper coins of first and second century CE Saka and Kuṣāna rulers with similar Kharoșthī legends, images of horses and Bactrian camels, and weight standards. ${ }^{19}$ According to Cribb, these Sino-Kharoșthi coins from Khotan provide evidence for a "secondary route" across the Karakorum mountains directly to Gandhāra, since "[i]t is Gandhāran cultural and political influence which is most strongly seen in the coinage of Khotan" (1985: 145).

The distribution of Buddhist manuscripts suggests textual transmission between Gandhāra, Gilgit and Khotan. An incomplete manuscript of a Gāndhārī version of the Dharmapada found in a cave at Kohmārī Mazār near Khotan in 1892 may have been brought from Gandhāra to Khotan sometime after the late first or second century CE. ${ }^{20}$ Close connections between monastic communities in Gilgit and Khotan during the seventh century CE are evident in the preservation of similar Mahāyāna sūtra texts (particularly the Samghāta-sūtra), shared palaeographic affinities and Śaka orthographic features, and Iranian proper names in colophons of Buddhist Sanskrit manuscripts from Gilgit. ${ }^{21}$ Perhaps Khotanese scribes responsible for copying the manuscripts came to Gilgit, where their work was supported by the Palola Sāhis, who were avid Buddhist patrons. ${ }^{22}$ Such relationships between the Palola Șāhis, scribes from Khotan, and resident communities of Buddhist monks reflect strong cultural, religious, political, and, in all likelihood, commercial ties between Gilgit and Khotan.

Many other religious and commercial items were imported to Khotan from the northwestern Indian subcontinent. Small Gandhāran stone sculptures, including an image of emaciated Siddhārtha belong-

19 The dates proposed by Cribb for Sino-Kharosthi coins from Khotan in the first and second century before ca. 132 diverge from the dates between ca. 175-220 CE proposed by Lin Meicun, ca. mid-second century to fourth century suggested by $\mathrm{Ma}$ Yong, the time of Ban Chao (late first century) to third century accepted by Hsia Nai, and the Warring States period according to Enoki Kazuo (Rhie 1999: 339, fn. 31).

${ }^{20}$ It is uncertain whether or not this manuscript edited by John Brough (1962) was actually written in Khotan, since arguments for its local composition based on the scroll format and linguistic features have been disconfirmed by recent discoveries of other Gāndhārī scrolls, including one example of another Dharmapada fragment (Lenz 2003; Salomon 1999: 102, 120, 129-30).

${ }^{21}$ Hinüber 1983b: 59; Hinüber, Oskar von. 1984. "Expansion to the North: Afghanistan and Central Asia." In Bechert, Heinz and Richard Gombrich, eds. The World of Buddhism: Buddhist monks and nuns in society and culture. London: Thames and Hudson, 102; Sander 1999: 98-9.

${ }^{22}$ Hinüber 1983b: 58. 
ing to a portable diptych, steatite fragments of a miniature stūpa, and moulded terracotta figures of Herakles and Serapis with Harpocrates arrived in Khotan via long-distance networks for trade and cultural transmission. ${ }^{23}$ Such images transported to Khotan may reflect a transmission of Gandhāran Buddhist iconography and styles. Fragments of finely woven tabby silk from China reflect long-distance trade or tribute relations with Khotan during the third or early fourth centuries CE. ${ }^{24}$ While Khotan flourished as a regional commercial and religious center of the southwestern Tarim Basin and served as a connecting point between China, India, western Central Asia, and Iran, stūpas and monasteries were not apparently constructed before the third century. Marylin Rhie tentatively concludes that "Buddhist establishments may have been rather well established in Khotan by 200 AD" (1999: 322), but she dates sculptures from the Rawak stüpa located northeast of Khotan in the late third to early fourth centuries CE. Thus, Khotan, which later became a major Buddhist center on the southern silk route, lacks definite archaeological evidence for residential Buddhist monasteries before the late third century.

\section{Oases of Kroraina: Niya, Endere, Miran, Loulan}

Oases located east of Khotan along branches of the southern silk routes in the Tarim Basin functioned as nodes in regional trade networks and as centers for Buddhist art and architecture. Close to one thousand Kharoșthī documents in the Niya Prakrit dialect of Gāndhārī from sites around Niya, Endere, and Loulan provide interesting snapshots of commercial relationships involving administrative officials, local merchants, and Buddhist monks in the southern Tarim Basin during the third to fourth centuries $\mathrm{CE} .{ }^{25}$ Kharoșți continued to be employed

${ }^{23}$ Maillard, Monique. 1975. "À propos de deux statuettes en terre rapportées par la Mission Otani: Serapis et Harpocrates en Asie Centrale.” Journal Asiatique 263, 223-230, figs. 1-2; Härtel and Yaldiz 1982: 61-62; Rhie 1999: 265-66, figs. 4.6a-b, 270-1, fig. 4.9.

${ }^{24}$ Rhie 1999: 276, fig. $4.15 \mathrm{c}$.

${ }^{25}$ Boyer, et al. 1920-29 edited 758 Kharoșthī documents discovered by Aurel Stein, and many are translated by Burrow, T. 1940. A translation of the Kharosthi documents from Chinese Turkestan. London: Royal Asiatic Society. Additional discoveries may increase the number of published and unpublished Kharosthi documents from the southern Tarim Basin to about 1000 (Rhie 1999: 338; Lin 1996 and Salomon 1998a: 159-60 refer to recent publications). Short Kharoșthī inscriptions are also written on the wall paintings at Miran (Boyer, A.M. 1911. "Inscriptions de Miran." Journal 
for writing administrative documents in the southern Tarim Basin until at least $321 \mathrm{CE}$, probably after it had fallen out of general use in Gandhāra. ${ }^{26}$ The period of the Kharoșthi documents in Shan-shan between the third to fourth centuries CE corresponds to the period of transition from Kharoșthī to Brāhmī in graffiti in northern Pakistan. The subsequent decline of the southern silk route kingdom of Shanshan during the late fourth and fifth century led to the extinction of Gāndhārī as a living language. ${ }^{27}$

A recently-discovered Buddhist inscription from Endere, paintings from Miran, and stupas at Lou-lan provide valuable evidence for the history of Buddhism in Central Asia. An epithet of a Kroraina / Shanshan king (probably Aṃgoka) describing him as a Mahāyāna devotee (Mahayana-[sam]prasti[da]șa) in a Kharoșthī inscription from Endere provides epigraphic evidence for Mahāyāna patronage sometime in the middle of the third century. ${ }^{28}$ Exquisite mural paintings of the Buddha and disciples and the Viśvantara Jātaka in shrines III and V at Miran display stylistic similarities with the artistic traditions of northwestern India, but also reflect ties with the art of Iran and western Central Asia in the fourth and fifth centuries. ${ }^{29}$ At least five stupas in the Lou-lan area on the northern shore of lake Lop Nor, including a very large monumental stuppa within the city walls, reflect the roles of Lou-lan as the capital of the Kroraina kingdom, a prosperous commercial center on an intermediate route through the Tarim Basin, and the headquarters of the regional Buddhist sangha. ${ }^{30}$ The economic prosperity of agricultural oases and trading centers on the southern silk route enabled Buddhist communities to establish stūpas in Niya, Endere,

Asiatique 17 (n.s. 10), 413-430, Stein 1921: 1.529-31) and on silk fragments from Miran and Lou-lan (Konow, Sten. 1939. "Notes on the Inscription on the Silk-Strip No. 34:65.” In Bergman, Folke. 1939. Archaeological Researches in Sinkiang, especially the Lop-Nor Region. Stockholm: Bokförlags Aktiebolaget Thule, 231-234; Salomon 1998a: 132, Stein 1921: 1.495).

${ }^{26}$ Brough 1965: 604; Lin 1996. Various propositions for the chronological range of the eastern Central Asian Kharoșthī documents are listed by Rhie (1999: 338, fn. 28 ), from $235 / 6$ to ca. $321 \mathrm{CE}$ promoted by Brough (1965) to alternative dates from 175-359 advocated by Lin based on a new discovery of a Kharoșthi document with a regnal date of the Shan-shan ruler Sulika (ibid., $343 \mathrm{ff}$.).

27 Salomon 2008b.

${ }^{28}$ Salomon, Richard. 1999b (but 2002). "A Stone Inscription in Central Asian Gāndhārī from Endere (Xinjiang).” Bulletin of the Asia Institute 13, 1-13.

${ }^{29}$ Bromberg, Carol Altman. 1991. "An Iranian Gesture at Miran.” Bulletin of the Asia Institute 5, 45-58; Rhie 1999: 385.

${ }^{30}$ Rhie 1999: 385. 
Cherchen, Charklik, and Miran, and the great stūpa in Lou-lan. Just as the architectural forms of these stūpas are very similar to stūpas in Gandhāra and Bactria, Buddhist sculptures from Miran (and from the Rawak stūpa near Khotan) which belong to the fourth-fifth century "maintain considerable links with the art of the greater Gandhāra area, especially with Swat and probably Kashmir" (Rhie 1999: 425).

Political relations between Kroraina and China fluctuated from vigorous Chinese control while Ban Chao was Protector General between 80-104 CE to "virtual independence" (Rhie 1999: 331) from the last quarter of the second century $\mathrm{CE}$ to the third century. ${ }^{31}$ Even during periods in the late second century $\mathrm{CE}$ when China lost control of Shan-shan, luxury commodities from Central Asia continued to be in demand in the Chinese capital at Loyang. ${ }^{32}$ In exchange for luxury items from the Western Regions, Chinese silk was probably used in commercial transactions, since silk was preferred to copper coins as currency. ${ }^{33}$ Silk fragments found at Lou-lan and Niya may have been used in transactions, since the commercial value of silk is featured in Kharoșthī documents. ${ }^{34}$

During the period when the Tibetan empire vied for control of Central Asia with the Chinese and Arabs, cross-cultural contact with Chinese in Dunhuang (controlled by Tibet from 786-848) and with local inhabitants of Khotan and Miran (directly administered by Tibetan garrisons) is reflected in Old Tibetan Annals and Chronicles

${ }^{31}$ Chinese documents found at Lou-lan and Niya with dates between 252-330 CE suggest that Chinese control was re-asserted after the middle of the third century (Rhie 1999: 333-5). Brough (1965: $600 \mathrm{ff.}$ ) proposes that the title of jitu(m)gha (corresponding to Chinese shi-zhong) in Kharoșthi documents indicated the submission of the Shan-shan ruler Amgoka in $263 \mathrm{CE}$ or slightly later. However, he points out that the contrast between numerous Chinese documents found at Lou-lan and relatively few Chinese documents recovered at Niya (especially compared with the large number of Kharoșthi documents) shows that "The position of the Chinese in the two principal towns was obviously very different" (1965: 603), since Lou-lan functioned as a garrison with a significant Chinese administration, while the Chinese presence at Niya was probably restricted to a frontier guard-post or customs checkpoint.

${ }^{32}$ Rhie 1999: 331.

${ }^{33}$ Liu 1988: 71.

${ }^{34}$ Rhie 1999: 422-3, 467. In a list compiled by Raschke 1978: 791, fn. 627 based on Burrow, Thomas. 1937. The Language of the Kharosthi Documents from Chinese Turkestan. Cambridge: Univ. Press, several Kharoșthī documents from Niya (nos. 3, $35,225,345,348,419,489$ ) and Endere (no. 660) refer to transactions and punishments involving rolls of silk (pata). Other documents refer to thefts and gifts of silk items (nos. 149, 318, 345, 353, 566), and one document (no. 35) refers to merchants from China involved in an investigation of a debt of silk. 
in Tibetan Buddhist texts. For example, the Inquiry of Vimalaprabhā (translated from Sanskrit before $812 \mathrm{CE}$ ) is an ex eventu prophecy of relations between the kings of Khotan and Skardu (located in Baltistan in northern Pakistan) and incorporates popular narratives that associate female rulers descended from ogres (rākșasiss) with the production of gold. ${ }^{35}$

\section{Turfan}

Intermediate routes through Karashahr and northern routes through Turfan probably eclipsed the southern route by the fifth century CE. ${ }^{36}$ Many of the most important archaeological sites on the northern silk route are clustered around Kucha and the Turfan oasis. A local dynasty patronized Buddhism in Turfan by the end of the fourth century, and the earliest literary evidence for local Buddhism is a translation by Dharmarakșa dated in 296. ${ }^{37}$ Buddhist manuscripts from monasteries in and around Turfan and cave paintings from Bezeklik provide ample evidence of Buddhism "above the ground" but there is little evidence for Buddhist items in tomb inventories "below the ground" until the sixth century. ${ }^{38}$ Early evidence for Buddhism in Turfan supports Zürcher's hypothesis of long-distance transmission, since "Monasticism seemingly leaped across an underdeveloped Central Asia to the wealthy cities of China, only filtering back to Central Asia when economic conditions allowed it" (Hansen 1998: 38).

\section{Kucha}

Mural paintings in cave monasteries, Buddhist manuscripts, and archaeological remains of stuppas from sites around Kucha in the northwestern Tarim Basin display various continuities with Buddhist

35 The Inquiry of Vimalaprabhā is translated by Thomas 1935: 137-258 and commented upon by Uray 1979: 288-289 (also briefly discussed in Chapter 3, subchapter: Northern Route (Uttaräpatha) p. 196, fn. 34; Jettmar 1975: 299-312; and Jettmar 1993: 107-109. The conflict between Tibetan forces and China for control of Skardu in the eighth century is attested in Tibetan Annals covering the years 721-760 CE (Uray 1979: 282-3; Beckwith 1987). The ramifications of this conflict for the upper Indus region of northern Pakistan are treated in Chapter 2, subchapter: Palola Șāhis.

${ }^{36}$ Rhie 1999: 392.

${ }^{37}$ Hansen, Valerie. 1998. "The Path of Buddhism into China: The view from Turfan." Asia Major (3rd series) 11.2, 40-41.

${ }^{38}$ Hansen 1998: 50. 
artistic and literary cultures. Buddhist paintings from the Kizil caves, the earliest of which may belong to the fourth and fifth centuries, demonstrate stylistic affinities with artistic traditions of Swat, Gandhāra, Sasanian Iran, and China. ${ }^{39}$ On the basis of stylistic features in details of composition and decorative dress in mural paintings, Härtel and Yaldiz adopt the general distinction between "an older, western school (about AD 500-700) around Kucha, and an eastern school of later date (about AD 650-950) in the region of the Turfan oasis" (1982: 47). ${ }^{40}$ Early paintings from the cave monastery of Kizil (outside of Kucha) which preserve stylistic features related to sculptures from Swat and a Buddhist reliquary from Kucha with Gandhāran and Iranian elements demonstrate certain continuities between the art of the western part of the northern silk routes and the artistic traditions of Swat, Gandhāra and Sasanian Iran into the middle of the first millennium CE. ${ }^{41}$ Collections of Buddhist Sanskrit manuscripts (including some Kharoșthi fragments) from the second to sixth centuries suggest links with centers of Sarvāstivādin Buddhist scholasticism in Kashmir, Gandhāra, and possibly Mathura. ${ }^{42}$ Brāhmī was subsequently adopted for writing Buddhist manuscripts and secular documents in vernacular languages of eastern Central Asia such as Tocharian (or Kuchean) and Khotanese Śaka. Graffiti and caravan passes written in Tocharian (or Kuchean) testify to long-distance travel by Buddhist monks and merchants during the seventh century. ${ }^{43}$ Among the archaeological remains at Subashi, the ancient urban center of Kucha, are two large monastery sites with small circular stüpas encased within larger stuppas, which Rhie attempts to date from the second or third centuries

${ }^{39}$ Härtel and Yaldiz 1982: 47, Rhie 2002: 719.

40 This general distinction does not mean that all of the paintings in cave monasteries near Kucha exhibit the same style and belong to the same period between ca. 500-700 CE. Härtel and Yaldiz 1982: 49 point out that the Chinese style of Buddhist painting which was predominant in the Turfan area is also found in paintings at Kumtura near Kucha. According to Bussagli, Mario. 1979 [1963]. Central Asian Painting. Treasures of Asia. Geneva: Skira, "It is generally considered that painting at Kucā began in the fourth century AD and continued, somewhat attenuated, throughout the eighth century, and even beyond" (1979 [1963]: 71).

${ }_{41}$ Bussagli 1979 [1963]: 71-2, 86-7.

42 Sander 1999: $75 \mathrm{ff}$.

${ }^{43}$ Pinault, Georges. 1987. “Épigraphie koutchéenne." In Sites divers de la région de Koutcha: épigraphie Koutchéenne. Paris: Collége de France, Instituts d'Asie, Centre de recherche sur l'Asie Centrale et la Haute Asie, 61-196 + pls. 40-96. 
"if not earlier" (2002: 644), but the arguments for such early dates are inconclusive.

Material remains from sites along the northern and southern silk routes around the Tarim Basin in eastern Central Asia reflect close relations between long-distance trade and patterns of cultural and religious transmission from the northwestern Indian subcontinent and western Central Asia. Since the most direct routes from South Asia to the Tarim Basin passed through the mountains and river valleys of northern Pakistan, this intermediate border region probably played a crucial role in transmitting architectural forms, artistic elements, and South Asian languages written in Kharoșțī and Brāhmī scripts to eastern Central Asia. Branches of the silk routes which extended westward beyond eastern Central Asia to Sogdia and Bactria and southward to Kashmir and Gandhāra via capillary routes in northern Pakistan continued to flourish from the Later Han period in the first centuries CE through the Wei and Tang periods in the middle to end of the first millennium $\mathrm{CE}$, even though the Xiongnu, autonomous local and regional rulers, and Tibetans, Turks, and other foreign powers constantly challenged Chinese control of the Western Regions. Although the routes through modern Gansu to Xinjiang were originally established in order to secure China's western frontiers against nomadic raids, tribute relations involving gift exchanges of rolls of Chinese silk for horses from Ferghana, jade from Khotan, and other luxury commodities eventually led to extensive commercial and cultural contacts between China and Central Asia.

\section{Long-distance Transmission Reconsidered}

The movement of Buddhism across geographical and cultural frontiers between northwestern South Asia and Central Asia was a critical step in the early spread of Buddhism to China. As already discussed, Erik Zürcher emphasized that models for gradual diffusion by "contact expansion" of Buddhist monasteries along trade routes connecting urban centers and agricultural oases do not apply to the earliest stages of the establishment of Buddhism in Xinjiang. ${ }^{44}$ Rather than accepting

${ }^{44}$ Chapter 1: Diffusion vs. Long-Distance Transmission (pp. 4-7) introduces models of long-distance transmission developed by Zürcher in some of his later publications (1990, 1999). 
diffusion-based theories, Zürcher develops an alternative paradigm of "long-distance transmission" for the cross-cultural movement of Buddhism in the "transit zone" of Xinjiang during the first centuries CE. The process of long-distance transmission closely corresponds to the movement of Buddhism through the upper Indus region of northern Pakistan, which also functioned as a transit zone in the periods before Buddhist stūpas and monasteries were established. Inscriptions and rock drawings created by travelers in the early to middle first millennium CE now provide ample evidence for the use of direct routes from Gandhāra, Swat and Kashmir through northern Pakistan to the Tarim Basin. ${ }^{45}$ Networks of capillary routes through northern Pakistan were not the only routes for the transmission of Buddhism to Central Asia and China, but they did serve as critical links for long-distance travel, trade and religious and cultural transmission between Buddhist centers in the Indian subcontinent and southern silk route oases in Xinjiang. However, many scholars still consider indirect routes from Taxila through the Hindu Kush in present-day Afghanistan to the Oxus valley the most likely path for the propagation of Buddhism to western Central Asia, eastern Central Asia and China.

The diffusion of Buddhism by contact expansion was more difficult, if not impossible, in the high mountains of the Himalayas, Hindu Kush, and Karakorum, in the desert of the Tarim Basin, and in other areas which lacked arable land to maintain the local population above subsistence levels. The early transmission of Buddhism from the northwestern Indian subcontinent to Central Asia probably did not result from contact expansion, since surplus resources necessary to support the establishment of Buddhist monastic institutions were not available. For this reason, the desert environment of Serindia (modern Xinjiang) remained devoid of Buddhist monasteries during the Later Han period in the first centuries CE. According to Zürcher, "The unanimous testimony of the archaeological data and the Chinese written sources leads us to conclude that at the time when Buddhism started to settle in China, in the first two centuries of our era, Serindia still was virtually untouched by monastic Buddhism" (1990: 176). Zürcher maintains that the earliest reliable archaeological evidence for the establishment of Buddhist monasteries in the Tarim Basin belongs to periods after

${ }^{45}$ Jettmar, Karl and Volker Thewalt. 1985. Zwischen Gandhāra und den Seidenstrassen: Felsbilder am Karakorum Highway: Entdeckungen deutsch-pakistanischer Expeditionen, 1979-1984. Mainz: P. von Zabern, 10. 
ca. $250 \mathrm{CE}$, about one century later than the first translators of Buddhist texts into Chinese arrived in the Chinese capital of Loyang and nearly two centuries after the first Chinese literary references to Buddhist monks. ${ }^{46}$ However, he acknowledges that "the oases in the Lop Nor region and along the southern branch of the Silk Road present a somewhat different picture" than sites along the northern silk routes, since "the traces of Buddhist activity reach back to a somewhat earlier period" (Zürcher 1990: 173), especially in the Kroraina kingdom between Niya and Lou-lan and in Khotan. ${ }^{47}$ Zürcher adopts a "working hypothesis" that the development of Chinese types of irrigated agricultural colonies (tuntian) in Xinjiang during the second century $\mathrm{CE}$ which led to "explosive population growth... urbanization, a flourishing trade, and the formation of a prosperous urban elite" (1990: 181) created the conditions necessary for monastic Buddhism to flourish in southern silk route centers of Khotan, Miran and Lou-lan by the middle of the third century. Before this period, "Serindia appears to have played the role of a neutral transit zone" (ibid.) in long-distance transmission of Buddhism to the Chinese capital at Loyang.

Zürcher proposes that the "embryonic and archaic phases" (1999: 15) of Buddhism in China during the Later Han period resulted from long-distance transmission rather than contact expansion. Features of Later Han Buddhism directly related to long-distance transmission (in contrast to features which would result from contact expansion) include "extreme hybridization, the diffuse incorporation of disparate elements, no coherent complexes of doctrines or scriptures, but rather a random collection of single translated texts" (Zürcher 1990: 182). Zürcher distinguishes three different "sectors" in the "composite phenomenon" (1990: 159 ff.) of Han Buddhism:

1. Hybrid court Buddhism at the élite level

2. Nucleus of monastic Buddhism centered in the "Church of Loyang"

3. Diffuse adoption of Buddhist elements at the sub-élite level.

${ }^{46}$ Zürcher 1999: 13.

${ }^{47}$ See Khotan subsection earlier in this chapter. 
The first "hard evidence" (ibid.) for the existence of Buddhism at the élite court level is an imperial edict issued in $65 \mathrm{CE}$ which praises Liu Ying, the King of Chu: ${ }^{48}$

The king of Chu recites the subtle words of Huang-lao ${ }^{49}$ and respectfully performs the gentle sacrifices to the Buddha. After three months purification and fasting, he has made a solemn covenant (or: a vow) with the spirits. What dislike or suspicion (from Our part) could there be, that he must repent (of his sins)? Let (the silk which he sent for) redemption be sent back, in order thereby to contribute to the lavish entertainment of the upāsakas and śramanas. (Zürcher 1959: 1.27)

Chinese literary sources of the second century CE such as the "Rhapsody of the Western Capital" refer to Buddhist monks (sangmen), relics (sheli), and "white elephants" (a symbol of the Buddha's conception)..$^{50}$ These references show that some popular aspects of Buddhism were adopted in a hybrid cult associated with court circles, but "there is no suggestion of any kind of monastic organization" (Zürcher 1990: 162).

In contrast, the activities of An Shigao in Loyang beginning before ca. 150 CE herald the entry of "organized monastic Buddhism" (Zürcher 1990: 163). An Shigao and his co-translators were foreign transplants rather than local enthusiasts for hybrid novelties. Not only was there a large chronological gap of several decades between the embryonic hybrid cult and An Shigao's arrival, but "there is no evidence of any connection between this embryonic Buddhism, with its quaint terminology and its puzzling relations with court and courtiers, and the activities initiated by An Shigao" (Zürcher 1991: 283). ${ }^{51}$ Early Chinese translations by An Shigao, Lokakșema, and other Parthian, Sogdian, and foreign translators suggest that the texts were intended for a select group of Chinese lay devotees interested in meditation techniques, breath control, and esoteric traditions, which provided distinct alternatives to traditional Chinese systems of belief and practice. $^{52}$ Since ordination formulae were not translated into Chinese

${ }^{48}$ The kingdom of Chu corresponded to northern Jiangsu province and southern Shandung, and the court was located at Pengcheng (Zürcher 1959: 1.26).

49 "The study and practice of Taoist arts which were supposed to lead to bodily immortality, and which were much en vogue at the imperial court and among the princes around the middle of the first century" (Zürcher 1959: 1.26).

${ }^{50}$ Zürcher 1990: 160-61.

${ }^{51}$ Zürcher, Erik 1991. "A New Look at the Earliest Chinese Buddhist Texts." In Shinohara and Schopen, eds. 1991: 277-304.

${ }^{52}$ Zürcher 1991: 289-91. 
until the third century, most of the early Chinese followers were not monks, but clerks, copyists, traders, and artisans who belonged to a literate intermediate level of society ('gentry'). ${ }^{53}$ Although distinctions between monks and laymen were probably not so important, "the earliest community bears the stamp of authenticity: a nucleus of monks who devote themselves to the practice of the religious life; active in translating, preaching and explication, and supported by a circle of upāsakas" (Zürcher 1990: 163).

The origins of the early foreign translators reflect geographical patterns of the initial long-distance transmission from northwestern South Asia and western Central Asia. Based on the names, ethnonyms, and provenance of the earliest groups of eminent monks preserved in Chinese biographical sources (Gaoseng zhuan and Xu gaoseng zhuan), Zürcher (1999: 29-33) distinguishes four phases of Buddhist propagation between the second to fifth centuries CE:

1. An early phase from ca. 150 to ca. $270 \mathrm{CE}$ of "western Central Asian dominance" by Yuezhi, Parthians and Sogdians during the period of the Kuṣaṇa empire

2. Another phase from ca. 270 to ca. $380 \mathrm{CE}$ marks a decline in the number of foreigners, but the influx of translators from Khotan and Kucha "reflects the beginning of a flourishing monastic Buddhism in the oasis states from the early third century" (1999: 32)

3. A phase of "maximum activity" (ibid.) from ca. 380 to ca. 450 $\mathrm{CE}$ by prominent monks coming from northern India, especially Kashmir

4. A final phase of "modest input" (ibid.) from Buddhist centers in Southeast Asia, especially from Funan in the lower Mekong delta, beginning in the middle of the fifth century.

Famous translators from Xinjiang with foreign backgrounds such as Dharmarakșa (ca. 233-311 CE), a Yuezhi monk from Dunhuang, and Kumārajīva (344-413 CE), a monk of Indian descent from Kucha who studied in Kashgar and Kashmir (Jibin), came to the Chinese Buddhist centers of Ch'ang-an and Loyang after the period of initial long-

${ }^{53}$ Zürcher 1991: 286. 
distance transmission. ${ }^{54}$ Although traditional biographies claim that Dharmarakșa and Kumārajiva came from the Tarim Basin in the third and fourth centuries, there is surprisingly little archaeological evidence for Buddhist monasticism in eastern Central Asia prior to periods when they began their extraordinary careers as prolific translators of Mahāyāna sūtras and other Buddhist texts from Indic languages into Chinese.

At the beginning of the fifth century, "a highly standardized homogenous scriptural language" (Zürcher 1999: 25) for Chinese translations of Buddhist texts was developed by Kumārajīva and his collaborators, whose translation projects were patronized by the court rather than private devotees. In the oral/aural/written translation process, an "international translation committee" (Boucher 1998: 498) of Chinese and Central Asian students, monks and scribes often assisted the foreign masters, who usually do not seem to have been able to write Chinese (with the exception of Kumārajīva). ${ }^{55}$ In Zürcher's opinion, "the role these foreign masters played in the actual formation of Chinese Buddhism appears to be less decisive and less substantial than we would assume it to be at first sight" (1999: 58) since they only supplied the "raw materials" of written or memorized texts, while Chinese assistants and Central Asian intermediaries did the real work of reinterpreting and reformulating the translations.

While Chinese Buddhist literary sources preserve more information about "high-class translators" (Zürcher 1999: 5) who received official patronage and élite scholar-monks who belonged to "the tiny tip of the iceberg" (ibid., 18), many anonymous foreign monks (huseng) were responsible for the transmission of Buddhism at sub-élite levels. These foreign monks (whose biographies are rare) fulfilled numerous roles as magicians, miracle-workers, faith healers, meditation experts, ordination experts, and authenticators of relics (ibid., 5, 19, 53). They were involved in the ongoing "diffuse and unsystematic adoption of Buddhist elements" (ibid., 19) and promoted the veneration of images of the Buddha, six-tusked elephants, and auspicious relics which were associated with the afterlife in popular beliefs and practices. Such foreign monks also produced "anonymous translations" (shiyi) which

${ }^{54}$ Bagchi 1927: 1.179-180; 1981: 43; Kuwayama 1987: 706.

55 Zürcher 1999: 47-52. 
represent "a 'special' layer in early Chinese Buddhism, a type of Buddhism that is less sophisticated, less scholastic and more laity-oriented than the level represented by foreign masters who are known by name" (ibid., 24). ${ }^{56}$ According to Zürcher, "The vast majority consists of free (and sometimes drastically shortened) versions of sütras taken from the Ágamas, or narratives of the Jätaka and Avadāna type, which suggests a public of lay readers satisfied with simple, edifying stories" (ibid., 22). Similar genres of Buddhist literature are well represented in an early collection of Kharoșthi manuscripts in the British Library. ${ }^{57}$

\section{Conclusions}

During the early phases of Buddhism in China in the Later Han period, the first Iranian and western Central Asian foreign monks and translators were active in Loyang about a century before residential monasteries were established in the Tarim Basin. The paucity of archaeological evidence in the transit zone of Xinjiang does not corroborate a pattern of diffusion by contact expansion from monastery to monastery following major trade routes. Élite centers of Buddhist literary and artistic production only develop later when sufficient economic surpluses are available for making donations to support year-round monastic institutions. However, such a network of monasteries was not necessary for sub-élite agents of Buddhist transmission who crossed formidable boundaries in the mountainous northwestern frontiers of South Asia and the Takla Makan desert in eastern Central Asia, but who remain largely anonymous in literary traditions.

These concluding observations are not intended to reify a false or misleading dichotomy between contact expansion at élite levels of eminent monks and nuns eulogized in official hagiographies and long-distance transmission at the sub-élite levels of itinerant Buddhist merchants, wonder-workers, and spell-casters. Certainly there was considerable overlap, since prominent foreign translators were actively

${ }^{56}$ Zürcher 1999: 24 notes that about 100 "anonymous translations" are preserved in the Taishō canon, but observes that the number should be much larger, since many of the later attributions to early non-anonymous translators are unreliable (ibid., fn. 15). More than 317 anonymous texts (about twice the number attributed to specific translators) are listed by Dao'an (314-385 CE) in Zongli zhongjing mulu, but $90 \%$ of these have been lost (ibid., 20-21).

${ }^{57}$ Lenz 2003; Lenz 2010; Salomon 1999: 24-6, 30-39. 
engaged in long-distance transmission and everyday monks and nuns clearly benefited from the trickle-down effects of "high level patronage" of monastic centers. Nevertheless, Zürcher's heuristic distinction between patterns of contact expansion and long-distance transmission is useful for generating alternative paradigms to the spread of Buddhism by diffusion. 
Jason Neelis - 978-90-04-19458-8 Downloaded from Brill.com $04 / 26 / 2023$ 11:30:22AM via free access 


\section{CONCLUSION: ALTERNATIVE PATHS AND PARADIGMS OF BUDDHIST TRANSMISSION}

After setting out to retrace paths of Buddhist transmission, what conclusions can we draw at the end of the journey? Patterns of Buddhist transmission overlap with cultural and commercial exchanges due to symbiotic relationships between monastic communities and donor networks in a "moral economy" of merit. Buddhist literary texts employ economic metaphors to encourage donors, including merchants, to make "religious offerings" (deyadharma) of material gifts for the "gift of dharma" (dharmadāna). As the establishment of stūpas and residential monasteries required material resources, donations of surplus wealth sustained the growth of the Buddhist saigha. Many examples from Buddhist manuscripts, inscriptions, and archaeological artifacts examined in the previous chapters illustrate economic, social, and political catalysts for the formation and expansion of the Buddhist saigha from the time of the Buddha in the fifth century BCE to the end of the first millennium CE. As the saigha consolidated its position within and outside of ancient India, Buddhist monks and nuns frequently participated in social and economic dynamics, despite ascetic ideals of withdrawal. Considerable literary, epigraphic, and archaeological evidence demonstrates that Buddhist institutions played key roles in political legitimation, management of hydraulic systems, and development of interregional road networks for long-distance trade. Routes for commercial exchanges of high-value commodities and cross-cultural interactions have served as conduits for transregional Buddhist mobility, which fluctuated with changing economic and political conditions. An ability to change with shifting conditions of material support and to appeal to wide audiences was a very significant factor in successful Buddhist transmission.

Rather than viewing the spread of Buddhism as a process of gradual diffusion from one point to another along major trade routes, applying a paradigm of "long-distance transmission" to transit zones between South Asia and Central Asia helps to explain uneven flows of Buddhist monks, nuns, and other missionary agents through intertwined 
arteries and capillaries that connected multiple nodes of Buddhist literary and material culture within political and economic networks controlled by local rulers, regional administrators, and guilds of merchants and craftsmen. While theories of point-to-point diffusion can account for the gradual spread of static forms of Buddhism between closely connected centers on established major routes, other models provide better explanations for irregular patterns of movement with rapid accelerations and sudden halts, local changes in religious practices and ideologies, and distinctive features of regional Buddhist cultures. The model of long-distance transmission proposed by Erik Zürcher in his later articles to explain anomalous features of early Chinese Buddhism as an alternative paradigm to diffusion by "contact expansion" can be extended more broadly to transit zones in South Asia to clarify different chronological stages and institutional levels of Buddhist movement.

Long-distance networks of the "Northern Route" (uttarāpatha) and the "Southern Route" (dakșinapatha) incorporated regional and local micro-networks of individual regions, cities, and shrines, and were linked to overland and maritime routes that connected the Indian subcontinent with the Red Sea and Mediterranean. Literary and epigraphic references and archaeological patterns of distribution of commodities and cultural artifacts point towards significant mobility between distant nodes, complex interactions, and different levels of economic, cultural, and religious exchange. While the northwestern and southern frontiers tend to be viewed as "outside of dharma" (dharmabāhya) due to contact with impure foreigners from orthodox Brahmanical perspectives, Buddhist attitudes are more inclusive, probably in no small part because many of these outsiders were important donors. Ancient Gandhāra (in the northwestern borderlands on the frontier between modern Northwest Pakistan and northeastern Afghanistan) was an especially pivotal and prosperous contact zone between South Asia and Central Asia. Archaeological remains of stūpas and monasteries, distinctive artistic traditions, Kharoșțī donative inscriptions, and Gāndhāri manuscripts from the first centuries $\mathrm{CE}$ amply reflect the deep impact of Buddhism. Regional traditions of Gandhāran Buddhism synthesized indigenous and exogenous features from the cultural milieu of the borderland environment and successfully domesticated stories connected with the Buddha and his previous births. Extensive contacts helped to open paths for the transmission of Buddhism beyond South Asia to Bactria in the Oxus valley of western Central Asia and with the Tarim Basin in eastern Central Asia. 
Interconnected capillary routes through the deep valleys of the upper Indus River and across high Karakorum mountain passes in northern Pakistan directly linked Gandhāra, Swat, and Kashmir with arterial branches of the so-called silk routes in the Tarim Basin of modern Xinjiang. Petroglyphs and inscriptions from prehistoric to relatively recent periods mirror the multicultural backgrounds of visitors and local inhabitants who drew designs and wrote names on rocks lining these routes. However, architectural remains of stüpas and residential monasteries are not clearly attested before a period of heightened patronage by the Palola Șāhi dynasty of Gilgit in the seventh century. The late establishment of formal Buddhist institutions in this transit zone between more fertile areas of the Swat valley, Kashmir and desert oases such as Khotan in the southern Tarim Basin can be attributed to the difficulties of generating adequate surpluses to support residential communities of monks and nuns in the high-mountain environment. The Tarim Basin also functioned as a critical transit zone for the initial stages of long-distance transmission of Buddhism to China. While hybrid Buddhist rituals were performed in court circles at Pengcheng in the first century $\mathrm{CE}$ and foreign Buddhists began translating texts into Chinese at the Han capital in Loyang in the second century CE, the first Buddhist archaeological evidence in the transit zone of Xinjiang can not be reliably dated before the third century CE. As Zürcher has argued, the relatively late appearance of stupas or monasteries in the Tarim Basin indicates that early Central Asian and Chinese Buddhist traditions resulted from more complex processes of transplantation, transmission, and transformation than diffusion by contact expansion.

Catalysts for the Formation and Expansion of the Buddhist Sangha

This particular case study of early patterns of Buddhist transmission highlights the significance of interreligious exchanges and trade networks as dynamic catalysts for the establishment and growth of Buddhist institutions far outside of the homeland of the historical Buddha. Contacts with other religious groups and exogenous migrants to South Asia contributed several important dimensions to Buddhist ideologies, practices, and identities during the initial phases of the emergence of Buddhism in the fifth century BCE and subsequent periods of expansion throughout and beyond the Indian subcontinent. Buddhist traditions arose from interreligious contexts of intense competition between śramaṇas (including Ājivika and Jain forerunners) and Brahmins who 
formulated responses reflected in late Vedic texts (particularly the early Upanișads) within and outside of ancient Magadha. Efforts to define Buddhist doctrinal positions in deliberate contradistinction to the views of contemporary rivals in the middle of the first millennium $\mathrm{BCE}$ resulted in alternative karma theories, dependent arising, no-self, and other ideological hallmarks of mainstream Buddhism. Shortly after the emergence of the Buddhist sangha as a distinct śramana movement, intrareligious contestation led to splits within the community (sanghabheda) and eventually to separate ordination lineages, different vinaya codes, separate textual classifications and rescensions (which were not necessarily tied to scholastic divisions), and diverse paths (mārgas) and vehicles (yānas) of practice leading to various religious goals of nirvāna, pure land rebirth, and Buddha-hood. Such internal developments within the Buddhist sangha were directly and indirectly stimulated by external contacts with śramana and Brahmin religious competitors and also by cross-cultural encounters with Iranians, IndoGreeks, Sakas, Kușannas, and Huns who were assimilated into the social and political milieu of the northwestern borderlands in the late centuries BCE and early centuries CE. Sustained interactions with these "outsiders" (insofar as xenologies were constructed by orthodox Brahmins in Äryāvarta) had significant ramifications and longstanding impacts on Buddhist material culture and transmission beyond South Asia, particularly in regional Buddhist literary and artistic traditions of Gandhāra, Swat, and Afghanistan. While the degree of hybrid cosmopolitanism is more apparent in sculptures produced by Gandhāran ateliers than in Gāndhārī Buddhist manuscripts (which nevertheless exhibit distinctive regional features of language and genre), the flexibility of Buddhist traditions to adapt to internal and external changes is rooted in a very early history of transcultural exchange.

The consolidation of patronage networks provided a critical impetus for the expansion of Buddhist communities within political domains and across cultural boundaries. The Mauryan emperor Aśoka is adopted as a paradigmatic patron and ideal Buddhist ruler, but the epigraphic records preserved in his mid-third century BCE edicts do not corroborate Buddhist literary hagiographies in which he is portrayed as an exclusive Buddhist supporter. Instead, his inscriptions clearly demonstrate that he advocated generosity to all śramanas and Brahmins and that he made donations of caves to the Ājivikas. While Aśoka identified himself as an upāsaka, made pilgrimages to Buddhist shrines, and addressed inscriptions to Buddhist communities at Sarnath, Kośāmbī, 
Sãñcī, and Bhairat, the growth of Buddhist institutions during his reign can not be attributed to his propagation of Buddhism as an official state religion, but to political, administrative, and economic conditions that facilitated expansion throughout the Mauryan empire (and possibly beyond its boundaries to Sri Lanka, according to accounts in Pāli vamsas). Buddhist missionaries used the example of Aśoka to appeal to other rulers and powerful patrons, although religious patronage and identity was not necessarily exclusive to particular traditions. Erik Zürcher asserted that "There can be no doubt that from the earliest times Buddhism has been a missionary religion par excellence" (1999: 6). However, it is not necessary to assume that Buddhist monks and nuns had similar ideological justifications, used the same methods, or sought identical results as modern missionaries. Mandates to "wander the path" in order to "teach the dharma" (Mahàvagga 1.11.1) compelled Buddhist monks and nuns to propagate the Buddha's teachings by reciting and interpreting texts, to establish the presence of the Buddha in stupas, and to expand opportunities for followers to accumulate merit, but they were not exclusively intent on religious conversion. These intrinsic motivations provided strong structural incentives for religious mobility and institutional expansion of the sangha across political, cultural, and linguistic boundaries. An essential aspect of the process of crossing boundaries between South Asia and Central Asia was the establishment of Buddhist communities in prosperous regions of the northwestern borderlands, where material support was available for constructing stūpas and building residential monasteries. Initially, dharmarājika stūpas were built at important administrative nodes at Taxila and in the Swat valley as early as the Mauryan period, but other nodes such as Bamiyan, Gilgit, and Khotan later emerged as prominent centers of Buddhist literary and cultural production when socio-economic conditions for élite patronage "ripened." However, conditions for these centers to become "hubs" for multiradial shrines and monasteries were uneven, and links with patronage by ruling authorities are unclear in some cases (i.e. Bamiyan). The early phases of long-distance transmission through transit zones of the upper Indus in northern Pakistan and the Tarim Basin in Xinjiang did not depend on high-level patronage for the establishment of permanent stüpas and residential monasteries, since itinerant monks and merchants marked their passages at wayside shrines with images and inscriptions.

This study has emphasized the central importance of trade as a particularly important economic catalyst for Buddhist transmission and 
institutional expansion. Historical patterns of Buddhist expansion were not exclusively determined by economic conditions, but an investigation of trade networks contributes another dimension to typologies of religious transfer, communication, and mobility. As elaborated in the introduction and borne out with concrete examples in the following chapters, the growth of the Buddhist saigha and trade networks were mutually imbricated in two major ways:

1. Various classes of merchants played significant roles as patrons of monastic communities and agents of transmission by donating material goods in exchange for religious merit, which functioned as an incentive to accumulate wealth and tied the saigha to networks of social support. Buddhism was and is not a "trading religion" in the strict sense that traders, merchants, financiers, and bankers were its only supporters, but epithets of the Buddha as such "caravanleader" (sārthavāha), Avadāna and Jätaka narratives of his previous lives as a maritime merchant or overland trader, and the worship of Bodhisattvas such as Avalokiteśvara who are invoked as protectors of merchants in distress indicate Buddhist efforts to make special appeals to affinities with these groups of potential patrons. Epigraphic attestations of donations by merchants and archaeological distribution of stuppas and monasteries near junctions of trade routes through passes of the Western Ghats and Hindu Kush, at maritime seaports on the Indian Ocean, and urban centers such as Mathura, Taxila, and Peshawar that functioned as administrative, commercial, and religious nodes amply demonstrate a strong nexus between Buddhist institutions and economic networks.

2. Buddhist monastic institutions participated in commercial exchanges and economic transactions despite ideals of ascetic withdrawal, renunciation of material wealth, and normative principles forbidding individual monks and nuns from handling money and buying and selling. It is necessary to read between the lines of normative vinaya prescriptions against the accumulation of property by monks and nuns to find numerous exceptions allowing the monastic community (the corporate saingha) to own and distribute a wide range of properties (including landed estates and slaves), accumulate capital from permanent endowments, and lend money on interest through networks of intermediate agents and managers. Furthermore, donative inscriptions of gifts by monks and nuns at Bhārhut, Sāñcī, and other Buddhist sites demonstrate that they 
continued to have private property and were not completely dependent on lay patronage for support. Vinaya rules setting conditions for traveling with and seeking donations from merchant caravans and narratives about monks who participated in trade missions and traders who visited monasteries along their routes reflect deep connections between mobile monastic and merchant communities.

Thus, the religious economy of the Buddhist saingha and more general economic patterns were intertwined and paths for Buddhist transmission and commercial exchange often overlapped due to the embedded nature of religion and economy in social and cultural networks.

\section{Changing Paradigms for Buddhist Transmission within and beyond South Asia}

In order to explain why Buddhist transmission was successful in the South Asian homeland of the historical Buddha and his followers as well as in the distant northwestern borderlands and the transit zones of Central Asia, a counterintuitive question may be posed: how did the Buddhist sangha make itself attractive to diverse audiences of patrons, devotees, and monastic recruits? The worthiness of the saingha as a fruitful "field of merit" for donations to ripen and bring higher rewards than the initial material gift was ostensibly based on a formal separation from the social economy. However, strong evidence for interrelated Buddhist and economic networks synthesized in this treatment of patterns of long-distance transmission and trade indicates that such a separation was more doctrinal than actual. Politically powerful patrons who gained social legitimacy as rulers and commercial constituencies whose donations led to greater rewards were not the only audiences that were receptive to Buddhist appeals, but their support was highly instrumental in the institutional growth of the sangha. Although social, political, and economic catalysts for Buddhist transmission have been emphasized in this book, numerous other religious "attractors", including ideologies, devotional rituals, and meditative practices, also stimulated Buddhist expansion by drawing adherents with wide-ranging interests and levels of commitment. For example, the doctrine of selflessness (anätman) could be deployed as a semantic incentive to make generous donations, since avarice entailed karmic punishments of rebirth as a pig, hungry ghost, or consignment to 
hellish states. Opportunities to earn merit through devotional worship of stūpas and images was and continues to be a central concern of both élite and non-élite practitioners. The production of merit through meditation has traditionally been associated with monastic specialists, who developed paths of practice and thought for attaining religious goals of awakening, release from the cycle of worldly rebirth, and transcendence of mundane patterns of cognition. To posit that one of these examples is necessarily more internal, intrinsic, or "endogenous" as a motivation for attraction to the sarigha than so-called "exogenous" factors is to prioritize a particular location for Buddhist traditions in the realm of philosophical thought, ritual practice, or meditative techniques. Rather than constructing a dichotomy between internal religious causes and external social conditions or reifying a 'protestant' hierarchy of primary ideological beliefs over secondary vulgarizations, it would be more fruitful to develop integrative models in which attractors and catalysts are correlated in a dynamic system of Buddhist formation, transmission, and transformation.

Flexible processes of "locativization" and translation certainly contributed to Buddhist transmission outside of South Asia. The transposition of religious topologies to locations outside of the Buddhist heartland was facilitated by portable relics and images that established a locative focus for the Buddha's presence. If material surpluses were not immediately sufficient to build monumental stüpas for the Buddha's physical relics, devotees could worship "commemorative" relics of images of the Buddha, Bodhisattvas, or stūpa drawings or establish caityas for venerating the "dharma body" (dharmakayy) of the Buddha in written texts and other materials. Worship of texts was privileged as a direct connection with the Buddha's presence, particularly according to Mahāyāna viewpoints that regarded the Buddha's dharmakāya as superior to his corporeal forms. Translations of Buddhist texts reflect cross-cultural movement across linguistic boundaries, and careful analysis of the distribution of manuscripts, variant readings, and different recensions can provide clues to links between Buddhist literary centers. While studies in the transmission of textual traditions have helped to clarify the literary history of monastic ordination lineages, the intellectual history of prominent ideas, and the relative chronological development of Buddhist genres, much work remains to be done to incorporate this work into a comprehensive understanding of broader patterns of Buddhist transmission. 
Following multiple paths of transmission between South Asia and Central Asia has illuminated dynamic interactions between regional cultures in the northwestern borderlands with the aim of providing alternative perspectives on the history of Buddhism and the history of religions. Rather than reinforcing a dialectic opposition between Indian Buddhism and Chinese Buddhism by rehashing outdated arguments over an Indianizing Buddhist religious conquest beyond the frontiers of South Asia or a Chinese transformation or Sinification of Buddhism, this investigation shows that the hypothesis of Buddhism as a monolithic unchanging religion must be reconfigured. A relational network approach to long-distance transmission challenges assumptions about a straightforward diffusion of Buddhism from India via Central Asia to China. Multidirectional movement by agents of Buddhist transmission (monks, nuns, pilgrims, missionaries, merchants, and migrants) who selectively left traces of their journeys in literary texts, inscriptions, and material artifacts indicates more complex patterns of transmission than an oversimplified flow of influence in a single direction along a fixed route. As they consolidated multifaceted links between religious, economic, and political nodes along multiple lines of communication, they formed their own parallel exchange networks, thus enhancing possibilities for cross-cultural contact and transfer. The consolidation of Buddhist networks of religious mobility greatly enhanced the pace and process of transmission, which proceeded in variable stages depending on local, regional, and transregional contingencies (including socio-political stability or instability, environmental and economic conditions of sufficient material surpluses, and shifts in patronage patterns). It remains to be seen if trade networks played comparative roles as catalysts for long-distance transmission in other Buddhist geographical and historical contexts that were beyond the scope of this inquiry: Sri Lanka and Southeast Asia (where the role of maritime networks may have been analogous to the overland networks examined here), Tibet and Himalayan regions where itinerant trading communities continued to migrate across mountain routes until recently, and East Asia (only early Chinese Buddhism has received brief attention, but patterns of expansion to Korea and Japan need reconsideration). The comparative relevance of situating mutually embedded religious, economic, political, and social networks in historical contexts will continue to illuminate interactive patterns and dynamics in the history of religions. 
Jason Neelis - 978-90-04-19458-8 Downloaded from Brill.com $04 / 26 / 2023$ 11:30:22AM via free access 


\section{BIBLIOGRAPHY}

Abe, Stanley. 2005. Ordinary Images. Chicago: University of Chicago Press.

- 2002. Inside the Wonder House: Buddhist Art and the West. In Curators of the Buddha: The study of Buddhism under colonialism, ed. Donald S. Lopez, 63-106. Chicago: University of Chicago.

Agrawala, Vasudeva Sharana. 1963. India as Known to Pānini; A study of the cultural material in the Ashțādhyāyī. Radha Kumud Mookerji endowment lectures 1952. Varanasi: Prithvi Prakashan.

Ali, Daud. 2004. Courtly Culture and Political Life in Early Medieval India. Cambridge studies in Indian history and society, 10. Cambridge, UK; New York: Cambridge University Press.

Ali, Ihsan. 1994. Settlement History of Charsada District. Ancient Pakistan 9: 1-164.

—. 2003. Early Settlements, Irrigation, and Trade Routes in Peshawar Plain, Pakistan. Frontier Archaeology 1.

Ali, S. Muzafer. 1966. The Geography of the Puranas. New Delhi: People's Publishing House.

Ali, Taj. 1997. Preliminary Report of Two Seasons of Archaeological Excavations at the Bala Hissar of Charsadda, NWFP, Pakistan. Ancient Pakistan 12: 1-34.

- 2001. Archaeological Survey of District Mardan in the North-West Frontier Province of Pakistan. Ancient Pakistan 12: 55-172.

Allchin, F. Raymond. 1995. The Archaeology of Early Historic South Asia: The emergence of cities and states. Cambridge; New York: Cambridge University Press.

Allchin, F. Raymond, and Bridget Allchin, eds. 1997. South Asian Archaeology, 1995. New Delhi: Published for the Ancient India and Iran Trust, Cambridge by Science Publishers, U.S.A. and Oxford \& IBH.

Allchin, F. Raymond, and K.R. Norman. 1985. Guide to the Aśokan Inscriptions. South Asian Studies 1: 43-50.

Allievi, Stefano, and Jørgen S. Nielsen, eds. 2003. Muslim Networks and Transnational Communities in and across Europe. Muslim Minorities 1. Leiden; Boston: Brill.

Allon, Mark. 2001. Three Gāndhārī Ekottarīkāgama-type sutras: British Library Kharoșthī fragments 12 and 14. Gandhāran Buddhist Texts 2. Seattle: University of Washington Press.

—. 2007. Introduction: The Senior Manuscripts. In Andrew Glass, Four Gāndhārī Samyuktāgama sutras: Senior Kharoșthī fragment 5, 3-25. Gandhāran Buddhist Texts 4. Seattle: University of Washington Press.

- 2008. Recent Discoveries of Buddhist Manuscripts from Afghanistan and Pakistan and their Significance. In Art, Architecture and Religion: Along the silk roads, ed. Kenneth Parry, 153-178. Silk Road Studies 12. Turnhout, Belgium: Brepols.

Allon, Mark and Richard Salomon. 2000. Kharoșțhī Fragments of a Gāndhārī Version of the Mahāparinirvānasūtra. In Buddhist Manuscripts 1, ed. Jens Braarvig, 243-73. Manuscripts in the Schøyen Collection 1. Oslo: Hermes Academic Publishing.

— . 2010. New Evidence for the Mahāyāna in Early Gandhāra. Eastern Buddhist 41.1: 1-22.

Allon, Mark, Richard Salomon, Geraldine Jacobsen, and Ugo Zoppi. 2006. Radiocarbon Dating of Kharoșțī Fragments from the Schøyen and Senior Manuscript Collections. In Buddhist Manuscripts 3, ed. Jens Braarvig, 279-292. Manuscripts in the Schøyen Collection 7. Oslo: Hermes Pub. 
Almond, Philip C. 1988. The British Discovery of Buddhism. Cambridge; New York: Cambridge University Press.

Alram, Michael. 2003 (2007). Three Hunnic Bullae from Northwest India. Bulletin of the Asia Institute 17: 177-184.

Alram, Michael, and Deborah E. Klimburg-Salter, eds. 1999. Coins, Art, and Chronology: Essays on pre-Islamic history of the Indo-Iranian borderlands. Beiträge zur Kultur- und Geistesgeschichte Asiens 31. Wien: Österreichischen Akademie der Wissenschaften.

Altekar, Anant Sadashiv. 1946. The Vākāțakas. In The Vākāțaka Gupta age, circa 200550 A.D., eds. Ramesh Chandra Majumdar and Anant Sadashiv Altekar, 86-115. Delhi: Motilal Banarsidass.

Andersen, Paul Kent. 1990. Studies in the Minor Rock Edicts of Asoka. Freiburg: Hedwig Falk.

Appadurai, Arjun, ed. 1986. The Social Life of Things: Commodities in cultural perspective. Cambridge; New York: Cambridge University Press.

Ashraf Khan, Muhammad. 1993. Buddhist Shrines in Swat. Saidu Sharif: Archaeological Museum.

Ashraf Khan, Muhammad, and Mahmood-ul- Hasan. 2008. A New Discovery in the Taxila Valley: Archaeological Excavations at the Buddhist Monastery of Jinan Wali Dheri. In Gandhära: the Buddhist heritage of Pakistan: Legends, monasteries, and paradise, ed. Christian Luczanits, 302-307. Mainz: P. von Zabern.

Bagchi, Prabodh Chandra. 1927-1938. Le canon bouddhique en Chine: Les traducteurs et les traductions. 2 vols. Sino-Indica; publications de l'Université de Calcutta. Paris: P. Geuthner.

- 1981. India and China: A thousand years of cultural relations. 2 nd rev. ed. Calcutta: Saraswat Library.

Bailey, Greg, and Ian W. Mabbett. 2003. The Sociology of Early Buddhism. Cambridge: Cambridge University Press.

Bailey, Harold W. 1936. An Itinerary in Khotanese Śaka. Acta Orientalia 14.4: 258267.

- 1946. Gāndhārī. Bulletin of the School of Oriental and African Studies 11.4: 764797.

- 1978. Two Kharoșthī casket inscriptions from Avaca. Journal of the Royal Asiatic Society: 3-13.

- 1980. A Kharoștrī Inscription of Seṇavarma, King of Oḍi. Journal of the Royal Asiatic Society: 21-29.

- 1981. Opera Minora: Articles on Iranian studies. Ed. M. Nawabi. Shiraz, Iran: Forozangah Publishers.

Baines, John, John Bennet, and Stephen D. Houston, eds. 2008. The Disappearance of Writing Systems: Perspectives on literacy and communication. London; Oakville, CT: Equinox.

Bajpai, Shiva G. 1989. Mathurā: Trade Routes, Commerce, and Communication Patterns, from the Post-Mauryan Period to the End of the Kuṣanna Period. In Mathurā: The Cultural Heritage, ed. Doris Srinivasan, 46-58. New Delhi: Manohar Publications for American Institute of Indian Studies.

Bakker, Hans. 1992. Memorials, Temples, Gods, and Kings: An attempt to unravel the symbolic texture of Vākātaka kingship. In Ritual, State, and History in South Asia: Essays in honour of J.C. Heesterman, ed. A.W. van den Houk, et al., 7-19. Memoirs of the Kern Institute 5. Leiden: Brill.

- 1997. The Vākātakas: An essay in Hindu iconology. Gonda Indological Studies 5. Groningen: E. Forsten.

- 2004. The Vākāṭaka Heritage: Indian culture at the crossroads. In The Vākātaka heritage: Indian culture at the crossroads [Colloquium held at Groningen from 
6 to 8 June, 2002], ed. Hans Bakker. Gonda indological Studies 13. Groningen: E. Forsten.

— 2006. A Theatre of Broken Dreams: Vidiśā in the Days of Gupta Hegemony. In Interrogating History: Essays for Hermann Kulke, eds. Martin Brandtner and Shishir Kumar Panda, 165-187. Delhi: Manohar.

— - ed. 2008. Mansar: the Discovery of Pravareśvara and Pravarapura Temple and Residence of the Vākātaka King Pravarasena II. Groningen: Library of the University of Groningen.

Balagangadhara, S.N. 1994. "The heathen in his blindness": Asia, the West, and the dynamic of religion. Leiden: Brill.

Ball, Warwick, and Jean Claude Gardin, eds. 1982. Archaeological Gazetteer of Afghanistan = Catalogue des sites archéologiques d'Afghanistan. Synthèse (Editions Recherche sur les civilisations), 8. Paris: Editions Recherche sur les civilisations.

Bandini-König, Ditte. 1999. Die Felsbildstation Hodar. Materialien zur Archäologie der Nordgebiete Pakistans 3. Mainz: P. von Zabern.

—. 2003-. Die Felsbildstation Thalpan. 4 vols. Materialien zur Archäologie der Nordgebiete Pakistans 6-9. Mainz: P. von Zabern.

Bandini-König, Ditte, and Martin Bemmann. 1994. Die Felsbildstation Oshibat. Materialien zur Archäologie der Nordgebiete Pakistans 1. Mainz: P. von Zabern.

Bandini-König, Ditte, and Gérard Fussman. 1997. Die Felsbildstation Shatial. Materialien zur Archäologie der Nordgebiete Pakistans 2. Mainz: P. von Zabern.

Bandini-König, Ditte, and Oskar von Hinüber. 2001. Die Felsbildstationen Shing Nala und Gichi Nala. Materialien zur Archäologie der Nordgebiete Pakistans 4. Mainz: P. von Zabern.

Bareau, André. 1955. Les sectes bouddhiques du Petit Véhicule. Publications de l'École française d'Extrême-Orient 38. Saigon: Ecole française d'Extrême-Orient.

—. 1963. Recherches sur la biographie du Buddha dans les Sutrapitaka et les Vinayapitaka anciens. Publications de l'École française d'Extrême-Orient 53. Paris: École française d'Extrême-Orient.

Barrett, Timothy. 2005. History. In Critical Terms for the Study of Buddhism, ed. Donald S. Lopez, 124-142. Chicago: University of Chicago Press.

Barthoux, Jules. 1930. Les fouilles de Hadda. Mémoires de la Délégation archéologique française en Afghanistan 4, 6. Paris: Éditions d'art et d'histoire.

- 2000. The Hadda Excavations. Trans. Bruce L. Miller, Nilofaur Moaven Fatemi, and Azizeh Azodi. Memoirs of the French Archaeological delegation in Afghanistan, 4. Bangkok: SDI Publications.

Basham, A.L. 1979. Sambodhi in Aśoka's 8th Rock Edict. Journal of the International Association of Buddhist Studies 2: 81-83.

_ - ed. 1968. Papers on the Date of Kaniska. Oriental monograph series 4. Leiden: Brill.

Basilov, Vladimir N., ed. 1989. Nomads of Eurasia. Los Angeles, Calif.; Seattle, Wash.: Natural History Museum of Los Angeles County; Distributed by University of Washington Press.

Baums, Stefan, and Andrew Glass. In Progress. Catalog of Kharoșthī Inscriptions [CKI]. http://www.ebmp.org/a_inscriptions.php.

Beal, Samuel, trans. 1884. Si-yu-ki. Buddhist Records of the Western World. Trübner's oriental series. London: Kegan Paul, Trench, Trübner.

Bechert, Heinz. 1989. The Problem of the Determination of the Date of the Historical Buddha. Wiener Zeitschrift für die Kunde Südasiens 33: 93-120.

— - ed. 1980. Die Sprache der ältesten buddhistischen Uberlieferung = The language of the earliest Buddhist tradition. Symposien zur Buddhismusforschung 2. Abhandlungen der Akademie der Wissenschaften in Göttingen, philologisch-historische Klasse, 3rd series, Nr. 117. Göttingen: Vandenhoeck \& Ruprecht. 
ed. 1991. The Dating of the historical Buddha = Die Datierung des historischen Buddha. Abhandlungen der Akademie der Wissenschaften in Göttingen, philologischhistoriche Klasse, 3rd series, Nr. 189, 194. Göttingen: Vandenhoeck \& Ruprecht. Bechert, Heinz, and Richard Gombrich, eds. 1984. The World of Buddhism: Buddhist monks and nuns in society and culture. London: Thames and Hudson.

Beckwith, Christopher I. 1987. The Tibetan Empire in Central Asia: A history of the struggle for great power among Tibetans, Turks, Arabs, and Chinese during the early Middle Ages. Princeton, N.J.: Princeton University Press.

Begley, Vimala. 1996. The Ancient Port of Arikamedu: New excavations and researches, 1989-1992. Publications de l'Ecole française d'Extrême-Orient, Mémoires archéologiques 22. Pondichéry: Centre d'histoire et d'archéologie, École française d'Extrême-Orient.

Behrendt, Kurt A. 2004. The Buddhist Architecture of Gandhära. Handbuch der Orientalistik. Zweite Abteilung, Indien, 17. Leiden; Boston: Brill.

- 2007. The Art of Gandhāra in the Metropolitan Museum of Art. New York; New Haven: Metropolitan Museum of Art; Yale University Press.

Behrendt, Kurt A., and Pia Brancaccio, eds. 2006. Gandhāran Buddhism: Archaeology, art, and texts. Asian Religions and Society series. Vancouver: UBC Press.

Bell, Alexander Peter. 2000. Didactic Narration: Jätaka iconography in Dunhuang with a catalogue of jätaka representations in China. Münster: Lit.

Bemmann, Martin. 2005. Die Felsbildstation Dadam Das. Materialien zur Archäologie der Nordgebiete Pakistans 5. Mainz: P. von Zabern.

Benavides, Gustavo. 2005. Economy. In Critical Terms for the Study of Buddhism, ed. Donald S. Lopez, 77-102. Chicago: University of Chicago Press.

Bender, F., and Hilal A. Raza, eds. 1995. Geology of Pakistan. Beiträge zur regionalen Geologie der Erde 25. Berlin: Gebrüder Borntraeger.

Benjamin, Craig. 2000. The Yuezhi and their Neighbours: Evidence for the Yuezhi in Chinese Sources c. 220-c. 25 BCE. In Realms of the Silk Roads, Ancient and Modern, eds. David Christian and Craig Benjamin, 105-159. Silk Road Studies 4. Turnhout, Belgium: Brepols.

. 2007. The Yuezhi: Origin, migration and the conquest of northern Bactria. Silk Road Studies 14. Turnhout, Belgium: Brepols.

Bentor, Yael. 1995. On the Indian Origins of the Tibetan Practice of Depositing Relics and Dhâranîs in Stûpas and Images. Journal of the American Oriental Society 115.2: 248-261.

Bergman, Folke. 1939. Archaeological Researches in Sinkiang, especially the Lopnor region, Reports from the scientific expedition to the north-western provinces of China under the leadership of Dr. Sven Hedin. The Sino-Swedish expedition. Publication 7. VII. Archaeology, 1. Stockholm: Bokförlags aktiebolaget Thule.

Berkwitz, Stephen C., Juliane Schober, and Claudia Brown, eds. 2009. Buddhist Manuscript Cultures: Knowledge, ritual, and art. Milton Park, Abingdon, Oxon; New York, NY: Routledge.

Bernard, Paul. 1967. Aï Khanum on the Oxus: A Hellenistic city in central Asia. Albert Reckitt archaeological lecture 1967. London: Oxford University Press.

—. 1973-. Fouilles d'Aï Khanoum. 8 vols. Mémoires de la Délégation archéologique française en Afghanistan 21, 26-31, 33. Paris: Klincksieck.

- 1982. An Ancient Greek City in Central Asia. Scientific American 246: 148159.

- 1994a. The Seleucids in Central Asia. In History of Civilizations of Central Asia, ed. János Harmatta, vol. 2: 88-97. Paris: Unesco.

- 1994b. The Greek Kingdoms of Central Asia. In History of Civilizations of Central Asia, ed. János Harmatta, vol. 2: 98-129. Paris: UNESCO.

—. 2008. The Greek Colony at Aï Khanum and Hellenism in Central Asia. In Afghanistan: Hidden treasures from the National Museum, Kabul, eds. Fredrik T. Hiebert and Pierre Cambon, 81-129. Washington, D.C.: National Geographic. 
Bernard, Paul, Georges-Jean Pinault, and Georges Rougemont. 2004. Deux nouvelles inscriptions grecques de l'Asie centrale. Journal des savants: 227-356.

Bernhard, Franz, ed. 1965. Udānavarga. Sanskrittexte aus den Turfanfunden 10. Göttingen: Vandenhoeck \& Ruprecht.

Bhandarkar, Devadatta Ramakrishna, Bahadur Chand Chhabra, and Govind Swamirao Gai, eds. 1981. Inscriptions of the Early Gupta kings. Rev. ed. Corpus Inscriptionum Indicarum 3. New Delhi: Archaeological Survey of India.

Bhandarkar, Ramkrishna Gopal. 1920. A Peep into the Early History of India from the Foundation of the Maurya Dynasty to the Downfall of the Imperial Gupta Dynasty. (322 B.C.-Circa 500 A.D.). Bombay: D.B. Taraporevala Sons, and Co.

Biardeau, Madeleine. 2002. Le Mahābhārata: Un récit fondateur du brahmanisme et con interprétation. 2 vols. Paris: Éditions du Seuil.

Binsbergen, Wim M.J. van, and Peter Geschiere, eds. 2005. Commodification: Things, agency, and identities (The social life of things revisited). Münster: Lit.

Biruni, Muhammad ibn Ahmad Abu al-Rihan al-. 1888. Alberuni's India: An account of the religion, philosophy, literature, geography, chronology, astronomy, customs, laws and astrology of India about A.D. 1030. Trans. Carl Eduard Sachau. London: Trübner.

- 1989. The Book most Comprehensive in Knowledge on Precious Stones: Al-Beruni's book on mineralogy. Trans. Hakim Muhammad Sa id. One hundred great books of Islamic civilisation 66. Islamabad: Pakistan Hijra Council.

Biswas, Atreyi. 1973. The Political History of the Hūnas in India. New Delhi: Munshiram Manoharlal Publishers.

Bivar, A.D.H. 1984. Maues at Taxila: Problems of his Arrival-Route and Political Allegiance. Journal of Central Asia 7.1: 5-15.

- 2004. Hephthalites. In Encyclopedia Iranica Online. Available at http://www. iranica.com/newsite/.

Blaut, James M. 1993. The Colonizer's Model of the World: Geographical diffusionism and Eurocentric history. New York: Guilford Press.

Bloch, Jules. 1950. Les inscriptions d'Asoka. Collection Émile Senart 8. Paris: Les Belles Lettres.

Bloch, Marc L. 1939-1949. La société féodale. 2 vols. Paris: A. Michel.

- 1961. Feudal society. Trans. L.A. Manyon. 2 vols. Chicago: University of Chicago Press.

Bodhi, Bhikkhu, trans. 2000. The Connected Discourses of the Buddha: A new translation of the Samyutta Nikāya. Somerville, MA: Wisdom Publications.

Böhtlingk, Otto, ed. 1887. Pânini's Grammatik. Leipzig: Haessel.

Bongard-Levin, Grigorii Maksimovich. 1998. Ancient Indian History and Civilization. 2nd ed. Delhi: Ajanta.

Bopearachchi, Osmund. 1990. Ménandre Sôter, un roi Indo-grec. Observations chronologiques et géographiques. Studia Iranica 19: 39-85.

—. 1991. Monnaies gréco-bactriennes et indo-grecques: catalogue raisonné. Paris: Bibliothèque nationale.

- 1993. Indo-Greek, Indo-Scythian and Indo-Parthian Coins in the Smithsonian Institution. Washington: National Numismatic Collection, Smithsonian Institution.

—. 1998. Foreign Powers in Ancient Northern India from the Bactrian Greeks until the time of the Early Kushans. In Osmund Bopearachchi and Wilfried Pieper, Ancient Indian Coins, 177-273. Indicopleustoi 2. Turnhout, Belgium: Brepols.

— 1999. Recent Coin Hoard Evidence on Pre-Kushana Chronology. In Coins, Art, and Chronology: Essays on pre-Islamic history of the Indo-Iranian borderlands, eds. Michael Alram and Deborah Klimburg-Salter, 99-149. Beiträge zur Kultur- und Geistesgeschichte Asiens 31. Wien: Österreichischen Akademie der Wissenschaften.

Bopearachchi, Osmund, and Aman Ur Rahman. 1995. Pre-Kushana coins in Pakistan. Karachi (Pakistan): Mughal Print. \& packaging (Pvt) Ltd. 
Bopearachchi, Osmund, and Wilfried Pieper. 1998. Ancient Indian coins. Indicopleustoi, 2. Turnhout, Belgium: Brepols.

Bopearachchi, Osmund, and Marie-Françoise Boussac, eds. 2005. Afghanistan, ancien carrefour entre l'Est et l'Ouest: actes du colloque international au Musée archéologique Henri-Prades-Lattes du 5 au 7 mai 2003. Indicopleustoi, 3. Turnhout, Belgium: Brepols.

Boucher, Daniel. 1991. The Pratityasamutpàda and Its Role in the Medieval Cult of the Relics. Journal of the International Association of Buddhist Studies 14: 1-27.

— 1998. Gāndhārī and the Early Chinese Buddhist Translations Reconsidered: The Case of the Saddharmapundarikasütra. Journal of the American Oriental Society 118.4: 471-506.

Boyer, Auguste M. 1911. Inscriptions de Miran. Journal Asiatique 17: 413-430.

Boyer, Auguste M., E.J. Rapson, E. Senart, and Peter Scott Noble. 1920-1929. Kharosthī Inscriptions discovered by Sir Aurel Stein in Chinese Turkestan. 3 vols. Oxford: Clarendon Press.

Braarvig, Jens, ed. 2000-2006. Buddhist Manuscripts. 3 vols. Manuscripts in the Schøyen Collection. Oslo: Hermes Publ.

Brancaccio, Pia. 2005. The Making of a Life: Re-reading Bhārhut Sculpture. South Asian Studies 21: 47-52.

- 2007. Close Encounters: Multicultural Systems in Ancient India. In On the cusp of an era: art in the pre-Kușāna world, ed. Doris Srinivasan, 385-397. Brill's Inner Asian Library 18. Leiden: Brill.

Brandtner, Martin and Shishir Kumar Panda, eds. Interrogating History: Essays for Hermann Kulke. New Delhi: Manohar.

Briant, Pierre. 1996. Histoire de l'Empire perse: de Cyrus à Alexandre. Paris: Fayard.

- 2002. From Cyrus to Alexander : a history of the Persian Empire. Trans. Peter T. Daniels. Winona Lake, IN: Eisenbraun.

Bromberg, Carol A. 1991. An Iranian Gesture at Miran. Bulletin of the Asia Institute 5: 45-58.

Bronkhorst, Johannes. 2004. Hinduism and Buddhism. In Encyclopedia of Buddhism, ed. Robert Buswell, vol. 1: 328-332. New York: Macmillan Reference, USA.

- 2007. Greater Magadha: Studies in the culture of early India. Handbuch der Orientalistik. Zweite Abteilung, Indien 19. Leiden; Boston: Brill.

Brough, John. 1954. The Language of the Buddhist Sanskrit Texts. Bulletin of the School of Oriental and African Studies 16.2: 351-375.

—. 1962. The Gāndhārī Dharmapada. London Oriental Series 7. London; New York: Oxford University Press.

- 1965. Comments on Third-century Shan-shan and the History of Buddhism. Bulletin of the School of Oriental and African Studies 28.3: 582-612.

- 1980. Sakāya niruttiyā: cauld kale het. In Die Sprache der ältesten buddhistischen Überlieferung = The language of the earliest Buddhist tradition, ed. Heinz Bechert. Symposien zur Buddhismusforschung, 2; Abhandlungen der Akademie der Wissenschaften in Göttingen, philologisch-historische Klasse, 3rd series, Nr. 117. Göttingen: Vandenhoeck \& Ruprecht.

- 1996. Collected Papers. Eds. Minoru Hara and J.C. Wright. London: School of Oriental and African Studies, University of London.

Brown, Robert L. 1986. Recent Stūpa Literature: A Review Article. Journal of Asian History 20: 215-232.

- 1996. The Dvāravatī Wheels of the law and the Indianization of South East Asia. Studies in Asian Art and Archaeology 18. Leiden; New York: Brill.

- 1998. The Miraculous Buddha Image: Portrait, God, or Object? In Images, Miracles, and Authority in Asian Religious Traditions, ed. Richard H. Davis, 37-54. Boulder, Colo.: Westview Press. 
- 2006. The Nature and Use of the Bodily Relics of the Buddha in Gandhära. In Gandhäran Buddhism: Archaeology, art, and texts, ed. Kurt Behrendt and Pia Brancaccio, 182-209. Vancouver: UBC Press.

Bruce, Rodney. 2002. The Poverty of Economism or the Social Limits on Maximizing. In Sacred Markets, Sacred Canopies: Essays on religious markets and religious pluralism, ed. Ted G. Jelen, 167-185. Lanham, Md.: Rowman \& Littlefield Publishers.

Buffler, Eléonore. Forthcoming. Spreading of some Buddhist Architectural Designs between Afghanistan and China: The Case of the Cruciform Stupa. Buddhism Across Asia conference paper, presented in Singapore, February 2009.

Bühler, Georg. 1883. On the Relationship between the Andhras and the Western Kshatrapas. Indian Antiquary 12: 272-274.

- 1892. The New Inscription of Toramana Shaha. Epigraphia Indica 1: 238-241.

Buitenen, J.A.B. van, trans. 1973. The Mahäbhärata. 3 vols. Chicago: University of Chicago Press.

Burgess, James, and Bhagvanlal Indraji. 1881. Inscriptions from the Cave Temples of Western India. Archaeological survey of western India Reports, Old Series 10. Bombay: Government Central Press.

Burgess, James, and Georg Bühler. 1883. Report on the Elura Cave Temples and the Brahmanical and Jaina Caves in western India completing the results of the fifth, sixth, and seventh seasons' operations of the Archoological survey, 1877-78, 1878-79, 1879-80. Supplementary to the volume on "The cave temples of India." Archæological survey of Western India. New Imperial series 5. London: Trübner \& Co.

Burkert, Walter. 1977. Griechische Religion der archaischen und klassischen Epoche. Die Religionen der Menschheit 15. Stuttgart; Berlin; Köln; Mainz: Kohlhammer.

—. 1985. Greek Religion. Trans. John Raffan. Cambridge, Mass.: Harvard University Press.

Burnouf, Eugène. 1844. Introduction à l'histoire du buddhisme indien. Paris: Imprimerie royale.

- 2010. Introduction to the history of Indian Buddhism. Trans. Katia Buffetrille and Donald S. Lopez, Jr. Buddhism and Modernity. Chicago; London: University of Chicago Press.

Burrow, T. 1937. The Language of the Kharosthi Documents from Chinese Turkestan. Cambridge: Cambridge University Press.

- 1940. A Translation of the Kharoșthi Documents from Chinese Turkestan. London: Royal Asiatic Society.

Bussagli, Mario. 1979. Central Asian Painting. Treasures of Asia. Geneva; New York: Skira; Rizzoli.

Buswell, Robert E., ed. 2004. Encyclopedia of Buddhism. 2 vols. New York: Macmillan Reference, USA.

Buswell, Robert E., and Robert M. Gimello, eds. 1992. Paths to Liberation: The Mārga and its transformations in Buddhist thought. Honolulu: University of Hawaii Press.

Cadonna, Alfredo, and Lionello Lanciotti, eds. 1996. Cina e Iran: da Alessandro Magno alla dinastia Tang. Orientalia Venetiana 5. Firenze: L.S. Olshki.

Caillat, Colette, ed. 1989. Dialectes dans les littératures indo-aryennes: actes du colloque international. Publications de l'Institut de civilisation indienne 55. Paris: Collège de France, Institut de civilisation indienne: Diffusion de Boccard.

Callieri, Pierfrancesco. 1995. The North-West of the Indian Subcontinent in the Indo-Greek Period: the Archaeological Evidence. In In the Land of the Gryphons: Papers on Central Asian archaeology in antiquity, ed. Antomio Invernizzi, 293-308. Monografie di Mesopotamia 5. Firenze: La Lettere.

. 1996. Hephthalites in Margiana? New Evidence from the Buddhist Relics in Merv. In La Persia e l'Asia centrale da Alessandro al X secolo, 391-400. Atti dei convegni Lincei, 127. Rome: Academia Nazionale dei Lincei. 
1997. Seals and Sealings from the North-west of the Indian Subcontinent and Afghanistan (4th century B.C.-11th century A.D.): Local, Indian, Sasanian, GraecoPersian, Sogdian, Roman. Naples: Istituto universitario orientale, Istituto italiano per l'Africa e l'Oriente.

. 1999. Huns in Afghanistan and the North-west of the Indian Subcontinent: The Glyptic Evidence. In Coins, Art, and Chronology: Essays on pre-Islamic history of the Indo-Iranian borderlands, ed. Michael Alram and Deborah E. Klimburg-Salter, 277291. Beiträge zur Kultur- und Geistesgeschichte Asien 31. Vienna: Österreichischen Akademie der Wissenschaften.

— 2002. Il periodo dei Saka e dei Parti: le dinastie di Apraca e di Oḍi ed il loro support al Budhismo. In Il maestro di Saidu Sharif: alle origine dell' arte del Gandhara, eds. Pierfrancesco Callieri and Anna Fligenzi, 57-61. Rome: IsIAO.

—. 2006. Buddhist Presence in the Urban Settlements of Swàt, Second Century BCE to Fourth Century CE. In Gandhāran Buddhism: Archaeology, art, and texts, ed. Kurt Behrendt and Pia Brancaccio, 60-82. Vancouver: UBC Press.

- 2007. Barikot, an Indo-Greek Urban Center in Gandhāra. In On the cusp of an era: art in the pre-Kușāna world, ed. Doris Srinivasan, 133-164. Brill's Inner Asian Library 18. Leiden: Brill.

- 2008. The Archaeological Basis. In Gandhara, the Buddhist heritage of Pakistan: Legends, monasteries, and paradise, ed. Christian Luczanits, 58-63. Mainz: P. von Zabern.

Callieri, Pierfrancesco and Anna Filigenzi, eds. 2002. Il maestro di Saidu Sharif: alle origine dell' arte del Gandhara. Rome: IsIAO.

Cardona, George, and Dhanesh Jain, eds. 2003. The Indo-Aryan Languages. Routledge Language Family series. London; New York: Routledge.

Carrithers, Michael. 1979. The Modern Ascetics of Lanka and the Pattern of Change in Buddhism. Man 14.2: 294-310.

Carter, Martha. 1993. Petroglyphs at Chilas II: Evidence for a Pre-iconic Phase of Buddhist Art in Gandhara. In South Asian Archoeology 1991, eds. Adalbert J. Gail, Gerd J.R. Mevissen, and Britta Zehmke, 349-366. Stuttgart: F. Steiner.

Casson, Lionel. 1986. P. Vindob G 40822 and the Shipping of Goods from India. Bulletin of the American Society of Papyrologists 23.3-4: 73-79.

- 1988. Rome's Maritime Trade with the Far East. American Neptune 48.3: 149153.

- 1989. The Periplus Maris Erythraei: Text with introduction, translation, and commentary. Princeton, N.J.: Princeton University Press.

Chakrabarti, Dilip K. 1995. The Archaeology of Ancient Indian Cities. Delhi: Oxford University Press.

- 2001. Archaeological Geography of the Ganga Plain: The lower and the middle Ganga. New Delhi; Bangalore: Permanent Black; Distributed by Orient Longman.

- 2005. The Archaeology of the Deccan Routes: The ancient routes from the Ganga plain to the Deccan. New Delhi: Munshiram Manoharlal.

. 2007. Archaeological Geography of the Ganga Plain: The upper Ganga (Oudh, Rohilkhand, and the Doab). New Delhi: Munshiram Manoharlal.

Chakraborti, Haripada. 1966. Trade and Commerce of Ancient India, c. 200 B.C.-c. 650 A.D. Calcutta: Academic Publishers.

Chakravarti, N.P. 1955. Brāhmī Inscriptions from Bandogarh. Epigraphia Indica 31: 167-186.

Chakravarti, Ranabir. 1995. Merchants and Other Donors at Ancient Bandogarh. South Asian Studies 11: 33-41.

- 2008. Three Copper Plates of the Sixth Century AD: Glimpses of Socio-Economic and Cultural Life in Western India. In South Asian Archaeology 1999, ed. Ellen Raven, 395-399. Gonda Indological Studies 15. Groningen: E. Forsten.

Chakravarti, Uma. 1987. The Social Dimensions of Early Buddhism. Delhi; New York: Oxford University Press. 
Chalmers, Robert, trans. 1895. The Jätaka or stories of the Buddha's former births. 6 vols. Cambridge: Cambridge University Press.

Champion, Timothy C., ed. 1989. Centre and Periphery: Comparative studies in archaeology. One world archaeology 11. London; Boston: Unwin Hyman.

Chandra, Moti. 1966. Sārthavāha: prācīna Bhārata kī patha-paddhati. Patna, Bihar: Bihāra-Rāṣtrabhāṣa-Pariṣad.

—. 1977. Trade and Trade Routes in Ancient India. New Delhi: Abhinav Publications.

Charlesworth, Martin Percival. 1926. Trade-Routes and Commerce of the Roman Empire: With notes on the agricultural resources, mineral wealth, of each province. 2nd ed. Cambridge: Cambridge University Press.

Chatterjee, Asim Kumar. 2005. A Comprehensive History of Indian Buddhism. Kolkata, India: Punthi Pustak.

Chattopadhyay, Bhaskar. 1975. Kushāna State and Indian Society: A study in postMauryan polity \& society. Calcutta: Punthi Pustak.

Chattopadhyaya, Brajadulal. 1988-1989. Trends of Research on Ancient Indian Economic History. Journal of Ancient Indian History 18: 109-131.

— 1989. Mathurā from the Sunga to the Kușāna Period: An Historical Outline. In Mathurā: The Cultural Heritage, ed. Doris Srinivasan, 19-28. New Delhi: Manohar Publications for American Institute of Indian Studies.

- 1994. The Making of Early Medieval India. Delhi; New York: Oxford University Press.

- 2003. Studying Early India: Archaeology, texts, and historical issues. Delhi; Bangalore: Permanent Black; Distributed by Orient Longman.

Chavannes, Édouard, trans. 1903. Voyage de Song Yun dans l'Udyana et le Gandhara (518-522 p.C). Bulletin de l'École française d'Extrême-Orient 3: 379-440.

Chavannes, Édouard, and Sylvain Lévi. 1895. L'itinéraire d'Ou-k'ong (751-90). Journal Asiatique 6 n.s. 9: 341-384.

Christensen, Arthur. 1936. L'Iran sous les Sassanides. Annales du Musée Guimet. Bibliothèque d'études 48. Copenhague: Levin \& Munksgaard.

Christian, David, and Craig Benjamin, eds. 2000. Realms of the Silk Roads, Ancient and Modern. Proceedings from the Third Conference of the Australasian Society for Inner Asian Studies (A.S.I.A.S.), Macquarie University, September 18-20, 1998. Silk Road Studies 4. Turnhout, Belgium: Brepols.

Cohen, Richard S. 2006. Ajanta's Inscriptions. In Walter Spink, Ajanta: history and development, vol. 2: 273-339. Handbuch der Orientalistik, Section 2, India 18. Leiden; Boston: Brill.

Colas, Gérard, and Gerdi Gerscheimer, eds. 2009. Écrire et transmettre en Inde classique. Etudes thématiques 23. Paris: Ecole française d'Extrême-Orient.

Cooke, Miriam, and Bruce B. Lawrence, eds. 2005. Muslim Networks from Hajj to Hip Hop. Chapel Hill: University of North Carolina Press.

Coomaraswamy, Ananda Kentish. 1927. The Origin of the Buddha Image. The Art Bulletin 11: 287-329.

Cowell, Edward B., and Robert Alexander Neil, eds. 1886. The Divyâvadâna, a collection of early Buddhist legends. Cambridge: Cambridge University Press.

Cribb, Joe. 1984-1985. The Sino-Kharosthì Coins of Khotan. Their Attribution and Relevance to Kushan Chronology. Numismatic Chronicle 144, 145: 129-152, 136-149.

—. 1999/2000. Kanishka's Buddha image coins revisited. Silk Road Art and Archaeology 6: 151-189.

- 2005. The Greek kingdom of Bactria, its coinage and its collapse. In Afghanistan: Ancien carrefour entre l'est et l'ouest, eds. Osmund Bopearachchi and MarieFrançoise Boussac, 207-225. Turnhout, Belgium: Brepols.

— . 2008. The Pantheon of the Kușāna Kings. In Gandhāra, the Buddhist heritage of Pakistan: Legends, monasteries, and paradise, ed. Christian Luczanits, 122-125. Mainz: P. von Zabern. 
Cribb, Joe, and Nicholas Sims-Wiliams. 1995/1996. A New Bactrian Inscription of Kanishka the Great. Silk Road Art and Archaeology 4: 75-142.

Cunningham, Alexander. 1879. The Stūpa of Bharhut: A Buddhist monument ornamented with numerous sculptures illustrative of Buddhist Legend and History in the third century B.C. London: W.H. Allen.

Curtin, Philip D. 1984. Cross-cultural Trade in World History. Studies in comparative world history. Cambridge; New York: Cambridge University Press.

Czuma, Stanislaw J., and Rekha Morris. 1985. Kushan Sculpture: Images from early India. Cleveland, Ohio: Cleveland Museum of Art in cooperation with Indiana University Press.

Dallapiccola, Anna L., and Stephanie Zingel-Avé Lallemant, eds. 1980. The Stūpa: its religious, historical and architectural significance. Beiträge zur Südasien-Forschung 55. Wiesbaden: Franz Steiner.

Damsteegt, Theo. 1978. Epigraphical Hybrid Sanskrit: Its rise, spread, characteristics and relationship to Buddhist Hybrid Sanskrit. Orientalia Rheno-Traiectina 23. Leiden: Brill.

Dani, Ahmad Hasan. 1963. Indian Palaeography. Oxford: Clarendon Press. 2nd rev. ed. New Delhi: Munshiram Manoharlal.

- 1965. Shaikhan Dheri excavation (1963 \& 1964 seasons). Ancient Pakistan 2: $17-214$.

- 1985. Sacred Rock of Hunza. Journal of Central Asia 8.2: 5-124.

- 1986. The historic city of Taxila. Tokyo, Japan: Centre for East Asian Cultural Studies.

- 1989. History of Northern Areas of Pakistan. Historical studies (Pakistan) series, 5. Islamabad: National Institute of Historical and Cultural Research.

- 1998. Origin of the Dardic Culture: A new discovery in the Northern Areas of Pakistan. Journal of Central Asia 21.1: 153-185.

Dani, Ahmad Hasan, and Boris A. Litvinsky. 1996. The Kushano-Sasanian Kingdom. In History of Civilizations of Central Asia: The Crossroads of Civilizations A.D. 250 to 750, ed. Boris A. Litvinsky, vol. 3: 103-118. Paris: UNESCO.

Dani, Ahmad Hasan, V.M. Masson, J. Harmatta, Baij Nath Puri, G. F. Etemadi, Boris A. Litvinsky, Guangda Zhang, et al. 1992-2005. History of Civilizations of Central Asia. 6 vols. Paris: Unesco.

Daniels, Peter T., and William Bright, eds. 1996. The World's Writing Systems. New York: Oxford University Press.

Dar, Saifur Rahman. 1970. Excavation at Manikyala-1968. Pakistan Archaeology 7: 6-22.

- 2007. Pathways between Gandhāra and North India during the Second Century BC-Second Century AD. In On the Cusp of an Era: Art in the pre-Kușanna world, ed. Drois Srinivasan, 29-54. Brill's Inner Asian Library 18. Leiden; Boston: Brill.

Davidson, Ronald M. 2002. Indian Esoteric Buddhism: A social history of the Tantric movement. New York: Columbia University Press.

Davis, Richard H., ed. 1998. Images, Miracles, and Authority in Asian Religious Traditions. Boulder, Colo.: Westview Press.

De Marco, Giuseppe. The Stūpa as a Funerary Monument: New Iconographical Evidence. East and West 37: 191-246.

Deeg, Max. 2000. On the Localisation of Faxian's Kingdom of Jiecha. In South Asian Archaeology 1997, eds. Maurizio Taddei and Giuseppe De Marco, vol. 2: 877-888. Serie orientale Roma 90. Rome: Istituto italiano per il Medio ed Estremo Oriente.

—. 2005. Das Gaoseng-Faxian-Zhuan als religionsgeschichtliche Quelle: der älteste Bericht eines chinesischen buddhistischen Pilgermönchs über seine Reise nach Indien mit Ubersetzung des Textes. Studies in Oriental Religions 52. Wiesbaden: Harrassowitz.

Degener, Almuth. 2002. The Nuristani languages. Proceedings of the British Academy 116: $103-118$. 
Dehejia, Vidya. 1972. Early Buddhist Rock Temples: A chronological study. Studies in Ancient Art and Archaeology. London: Thames and Hudson.

— 1992. The Collective and Popular Basis of Early Buddhist Patronage: Sacred Monuments, 100 BC-AD 250. In The Powers of Art: Patronage in Indian Culture, ed. Barbara Stoler Miller, 35-45. Delhi; New York: Oxford University Press.

—, ed. 1996. Unseen Presence: The Buddha and Sanchi. Mumbai: Marg Publications.

Demiéville, Paul. 1924. Les versions chinoises du Milindapañha. Bulletin de l'École Française d'Extrême Orient 24: 1-264.

—. 1966. Mélanges de sinologie offerts à Monsieur Paul Demiéville. Bibliothèque de l'Institut des hautes études chinoises, 20. Paris: Presses universitaires de France.

Demoto Hahn, Mitsuyo. 2006. Fragments of the Avadānaśataka. In Buddhist manuscripts, ed. Jens Braarvig, vol. 3: 207-244. Manuscripts in the Schøyen Collection 7. Oslo: Hermes Pub.

Derris, Karen, and Natalie Gummer, eds. 2007. Defining Buddhism(s): a reader. Critical Categories in the Study of Religion. London; Oakville, CT: Equinox Pub.

Di Cosmo, Nicola. 2002. Ancient China and its Enemies: The rise of nomadic power in East Asian history. Cambridge; New York: Cambridge University Press.

Dietz, Siglinde. 2007. Buddhism in Gandhāra. In The Spread of Buddhism, eds. Ann Heirman and Stephan Peter Bumbacher, 49-74. Handbuch der Orientalistik 16. Leiden: Brill.

Drew, Frederic. 1875. The Jummoo and Kashmir Territories: A geographical account. London: E. Stanford.

Drewes, David. 2007. Revisiting the phrase 'sa prthvīpradeśaś caityabhūto bhavet' and the Mahāyāna Cult of the Book. Indo-Iranian Journal 50: 101-143.

Durkin, Desmon, et al., eds. 2004. Turfan Revisited: The first century of research into the arts and cultures of the Silk Road. Monographien zur indischen Archäologie, Kunst und Philologie 17. Berlin: Reimer.

Edgerton, Franklin. 1953. Buddhist Hybrid Sanskrit Grammar and Dictionary. 2 vols. William Dwight Whitney linguistic series. New Haven: Yale University Press.

Eggermont, P.H.L. 1966. The Murundas and the Ancient Trade-Route from Taxila to Ujjain. Journal of the Economic and Social History of the Orient 9.3: 257-296.

Einoo, Shingo, ed. 2009. Genesis and Development of Tantrism. Institute of Oriental Culture special series 23. Tokyo: Sankibo Busshorin.

Eliade, Mircea, and Charles J. Adams, eds. 1987. The Encyclopedia of Religion. 16 vols. New York: Macmillan.

Emirbayer, Mustafa, and Jeff Goodwin. 1994. Network Analysis, Culture, and the Problem of Agency. The American Journal of Sociology 99.6: 1411-1454.

Erdösy, Georg. 1987. Early Historic Cities of Northern India. South Asian Studies 3: $1-23$.

- 1990. Taxila: Political History and Urban Structure. In South Asian Archaeology, 1987, eds. Maurizio Taddei and Pierfrancesco Callieri, vol. 2: 657-674. Rome: Istituto italiano per il Medio ed Estremo Oriente.

- 1995. City States of North India and Pakistan at the Time of the Buddha. In The Archaeology of Early Historic South Asia, ed. F. Raymond Allchin, 99-122. Cambridge: Cambridge University Press.

Errington, Elizabeth. 1993. In search of Pa-lu-sha, a city of the central Gandhara plain. Bulletin of the Asia Institute 7: 55-66.

- 1998. Gandhara Stūpa Deposits. Arts of Asia. 28.2: 80-87.

Errington, Elizabeth, and Joe Cribb. 1992. The Crossroads of Asia: Transformation in image and symbol in the art of ancient Afghanistan and Pakistan. Cambridge: Ancient India and Iran Trust.

Faccenna, Domenico. 1964. A Guide to the Excavations in Swat (Pakistan) 1956-1962. Rome: Scuolo Grafica Salesiana. 
Falk, Harry. 1993. Schrift im alten Indien: ein Forschungsbericht mit Anmerkungen. ScriptOralia, 56. Tübingen: G. Narr.

- 1997. The Purpose of Rgvedic Ritual. In Inside the texts, beyond the texts: new approaches to the study of the Vedas, ed. Michael Witzel, 69-88. Harvard Oriental Series, Opera Minora 2. Cambridge, Mass.: Harvard University Dept. of Sanskrit and Indian Studies.

- 1998. Notes on Some Apraca Dedicatory Texts. Berliner Indologische Studien 11/12: 85-108.

—. 1999. The Pāṭagaṇ̣igūḍem copper-plate grant of the Ikṣvāku king Ehavala Cāntamūla. Silk Road Art and Archaeology 6: 275-283.

- 2001. The yuga of Sphujiddhvaja and the era of the Kuṣânas. Silk Road Art and Archaeology 7: 121-136.

—. 2002. Frühe Zeitrechnung in Indien. In Vom Herrscher zur Dynastie: zum Wesen kontinuierlicher Zeitrechnung in Antike und Gegenwart, ed. Harry Falk, 77-105. Vergleichende Studien zu Antike und Orient 1. Bremen: Hempen.

- 2004. The Kaniṣka era in Gupta records. Silk Road Art and Archaeology 10: $167-176$.

—. 2005. The Introduction of Stūpa-worship in Bajaur. In Afghanistan: Ancien carrefour entre l'est et l'ouest, ed. Osmund Bopearachchi and Marie-Françoise Boussac, 347-358. Turnhout, Belgium: Brepols.

- 2006. Aśokan Sites and Artefacts: A source-book with bibliography. Monographien zur indischen Archäologie, Kunst und Philologie18. Mainz: P. von Zabern.

- 2008. Another Reliquary Vase from Wardak and Consecrating Fire Rites in Gandhāra. In Religion and Art: New issues in Indian iconography and iconology, ed. Claudine Picron, vol 1: 63-80. London: British Association for South Asian Studies.

Falk, Nancy Auer. 1990. Exemplary Donors of the Pāli Tradition. In Ethics, Wealth, and Salvation: A study in Buddhist social ethics, eds. Russell F. Sizemore and Donald Swearer, 124-143. Studies in Comparative Religion. Columbia, SC: University of South Carolina Press.

Feer, Léon, trans. 1891. Avadâna-çataka: cent légendes bouddhiques: la centaine d'Avadânas, commençant par Pûrna (Pûrnamukha-avadâna-çataka): traduite du Sanskrit, avec une introduction analytique, notes linguistiques et explicatives et trois index. Annales du Musée Guimet. Bibliothèque de vulgarisation. Paris: E. Leroux.

Fick, Richard. 1897. Die sociale gliederung im nordöstlichen Indien zu Buddha's zeit, mit besonderer berücksichtigung der kastenfrage, vornehmlich auf grund der Jâtaka dargestellt. Kiel: C.F. Haeseler.

- 1972. The Social Organisation in North-east India in Buddha's Time. Trans. SisiraKumara Maitra. Varanasi: Indological Book House.

Filigenzi, Anna. 2008. Buddhist Art in its Social Context. In Gandhara, the Buddhist Heritage of Pakistan: Legends, monasteries, and paradise, ed. Christian Luczanits, 298-301. Mainz: P. von Zabern.

Fitzgerald, James L., trans. 2004. The Mahabharata. Vol. 7, Book 11, The book of women. Book 12, The book of peace, part one. Chicago: University of Chicago Press.

Fleet, John Faithful, ed. 1888. Inscriptions of the Early Gupta Kings and their Successors. Corpus Inscriptionum Indicarum 3. Calcutta: Superintendent of Government Printing, India.

Fleming, David. 1993. Where was Achaemenid India? Bulletin of the Asia Institute 7: 67-72.

Foltz, Richard. 1999. Religions of the Silk Road: Overland trade and cultural exchange from antiquity to the fifteenth century. New York: St. Martin's Press.

Foucher, Alfred. 1901. Notes sur la géographie ancienne du Gandhâra. Bulletin de l'École française d'Extrême-Orient 1: 322-369. 
—.1905-1951. L'art gréco-bouddhique du Gandhâra; étude sur les origines de l'influence classique dans l'art bouddhique de l'Inde et de l'Extrême-Orient. 3 vols. Publications de l'École française d'Extrême-Orient, 5-6. Paris: E. Leroux.

- 1915. Notes on the Ancient Geography of Gandhära: A commentary on a chapter of Hiuan Tsang. Trans. Harold Hargreaves. Calcutta: Superintendent of Government Printing, India.

- 1917. The Greek Origin of the Buddha Image. In Alfred Foucher, The Beginnings of Buddhist Art, and other essays in Indian and Central-Asian archoeology, 111-137. Paris: P. Geuthner.

—. 1931. De Kāpiśi à Pushkarāvatī. Bulletin of the School of Oriental Studies 6.2: 341-348.

- 1942-1947. La vieille route de l'Inde de Bactres à Taxila. 2 vols. Mémoires de la Délégation archéologique française en Afghanistan 1. Paris: Les Éditions d'art et d'histoire.

Foulk, T. Griffith. 2007. The Spead of Chan (Zen) Buddhism. In The spread of Buddhism, eds. Ann Heirman and Stephan Peter Bumbacher, 433-456. Handbuch der Orientalistik 16. Leiden: Brill.

Francfort, Henri-Paul. 1989. Fouilles de Shortughaï: recherches sur l'Asie centrale protohistorique. Mémoires de la Mission archéologique française en Asie centrale 2. Paris: Diffusion de Boccard.

Frank, Andre Gunder. 1998. ReOrient: Global economy in the Asian Age. Berkeley: University of California Press.

Friedrich-Silber, Ilana. 1995. Virtuosity, Charisma, and Social Order: A comparative sociological study of monasticism in Theravada Buddhism and medieval Catholicism. Cambridge cultural social studies. Cambridge; New York: Cambridge University Press.

Frumkin, Grégoire. 1970. Archaeology in Soviet Central Asia. Handbuch der Orientalistik 7, Kunst und Archäologie 3. Leiden: Brill.

Frye, Richard Nelson. 1963. The Heritage of Persia. The World Histories of Civilization. Cleveland: World Pub. Co.

Fussman, Gérard. 1978. Inscriptions de Gilgit. Bulletin de l'École française d'ExtrêmeOrient 65: 1-64.

— 1980. Nouvelles inscriptions śaka: ère d'Eucratide, ère d'Azès, ère Vikrama, ère de Kaniska. Bulletin de l'École française d'Extrême-Orient 67: 1-43.

- 1982. Documents épigraphiques kouchans (III): L'inscription Kharosthī de Senavarma, roi d'Oḍi: une nouvelle lecture. Bulletin de l'École française d'Extrême-Orient 71: $1-46$.

—. 1984. Nouvelles inscriptions śaka II. Bulletin de l'École française d'Extrême-Orient 73: 31-46.

- 1985. Nouvelles inscriptions śaka (III-IV). Bulletin de l'École française d'ExtrêmeOrient 74: 35-42, 47-51.

— 1986a. Documents épigraphiques kouchans IV: Ajitasena, père de Senavarma. Bulletin de l'École française d'Extrême-Orient 75: 1-14.

— 1986b. Symbolisms of the Buddhist Stūpa. Journal of the International Association of Buddhist Studies 9.2: 37-53.

—. 1986c. La route oubliée entre l'Inde et la Chine. L'histoire 93: 50-60.

- 1987a. Numismatic and Epigraphic Evidence for the Chronology of Early Gandharan Art. In Investigating Indian Art, eds. Marianne Yaldiz and Wibke Lobo, 67-88. Berlin: Museum für Indische Kunst.

- 1987b. Central and Provincial Administration in Ancient India: The Problem of the Mauryan Empire. Indian Historical Review 14.1-2: 43-72.

- 1987-1988. Les populations de l'Inde ancienne, d'après les texts. Annuaire $d u$ Collége de France, 579-585. Paris: Histoire du monde indien. 
1989a. Gāndhārī écrite, Gāndhārī parlée. In Dialectes dans les littératures indoaryennes, ed. Colette Caillat, 433- 501. Publications de l'Institut de civilisation indienne 55. Paris: Collège de France, Institut de civilisation indienne: Diffusion de Boccard.

— 1989b. The Māt devakula: A new Approach to its understanding. In Mathurā: the cultural heritage, ed. Doris Srinivasan, 193-199. New Delhi: Manohar Publications for American Institute of Indian Studies.

- 1989c. Les inscriptions Kharoșthī de la plaine de Chilas. In Antiquities of Northern Pakistan: reports and studies, ed. Karl Jettmar, vol. 1: 1-40. Mainz: P. von Zabern.

— 1991. Le Périple et l'histoire politique de l'Inde. Journal Asiatique 279: 31-38.

_. 1993a. L'Indo-grec Ménandre ou Paul Demiéville revisité. Journal Asiatique 231: 61-138.

- 1993b. Chilas, Hatun et les bronzes bouddhiques du Cachemire. In Antiquities of Northern Pakistan, ed. Karl Jettmar, vol. 2: 1-60. Mainz: Philipp von Zabern.

- 1993c. Taxila: The Central Asian Connection.” In Urban Form and Meaning in South Asia: The Shaping of Cities from Prehistoric to Precolonial Times, eds. Howard Spodek and Doris Srinivasan, 83-100. Studies in the History of Art 31. Washington / Hanover / London: National Gallery of Art.

—. 1994a. Upāya-kauśalya: L'implantation du bouddhisme au Gandhāra. In Bouddhisme et cultures locales: Quelques cas de réciproques adaptations, eds. Fukui Fumimasa and Gérard Fussman, 17-51. Etudes thématiques 2. Paris: École française d'Extrême-Orient.

— 1994b. Une peinture sur pierre: Le triptyque au stūpa de Shatial. In Antiquities of Northern Pakistan, eds. Gérard Fussman and Karl Jettmar, vol. 3: 1-55. Mainz: P. von Zabern.

- 1996. Southern Bactria and Northern India before Islam: A Review of Archaeological Reports. Journal of the American Oriental Society. 116.2: 243-259.

. 1998. L'inscription de Rabatak et l'origine de l'ère Saka. Journal Asiatique 286: 571-651.

- 2004. Dans quel type de bâtiment furent trouvés les manuscrits de Gilgit? Journal Asiatique 292: 101-150.

- 2006. Les Guptas et le nationalisme indien. Annuaire de la Collège de France, 695-713. Paris: Histoire du monde indien.

Fynes, R.C.C. 1995. Religious Patronage of the Sātavāhana Dynasty. South Asian Studies 11: 43-50.

Gail, Adalbert J., Gerd J.R. Mevissen, and Britta Zehmke, eds. 1993. South Asian Archoology 1991: Proceedings of the Eleventh International Conference of the Association of South Asian Archoeologists in Western Europe, held in Berlin, 1-5 July 1991. Stuttgart: F. Steiner.

Gansser, Augusto. 1964. Geology of the Himalayas. London; New York: Interscience Publishers.

Germano, David, and Kevin. Trainor, eds. 2004. Embodying the Dharma: Buddhist relic veneration in Asia. Albany, N.Y.: State University of New York Press.

Gernet, Jacques. 1956. Les aspects économiques du bouddhisme dans la société chinoise $d u V^{e}$ au $X^{e}$ siècle. Publications de l'École française d'Extrême-Orient 39. Saigon: École française d'Extrême-Orient.

- 1995. Buddhism in Chinese Society: An economic history from the fifth to the tenth centuries. Trans. Franciscus Verellen. Studies in Asian Culture. New York: Columbia University Press.

Ghirshman, Roman. 1946. Bégram: recherches archéologiques et historiques sur les Kouchans. Mémoires de la délégation archéologique française en Afghanistan 12. Cairo: Institut français d'archéologie orientale.

— 1948. Les Chionites-Hephtalites. Mémoires de l'Institut français d'archéologie orientale du Caire 80; Mémoires de la Délégation archéologique française en Afghanistan 13. Cairo: Institut francais d'archéologie orientale. 
Ghose, Madhuvanti. 2003 (2007). The Impact of the Hun Invasions. Bulletin of the Asia Institute 17: 145-158.

Ghosh, Suchandra. 2007. Understanding Transitions at the Crossroads of Asia: c. mid second century BCE to c. third century CE Studies in History 23.2: 289-310.

- Forthcoming. In Search of Hellenism at Ai Khanum and Kandahar. In Revisiting Early India through Epigraphy and Other Texts: Essays in memory of D.C. Sircar, ed. Suchandra Ghosh, et al. Calcutta.

Ghulam Muhammad. 1905. Festivals and Folklore of Gilgit. Memoirs of the Asiatic Society of Bengal, Vol. 1, Nr. 7. Calcutta: Asiatic Society. Reprint, Islamabad: National Institute of Folk Heritage, 1980.

Glass, Andrew. 2004. Kharoșţī Manuscripts: A Window on Gandhāran Buddhism. Nagoya Studies in Indian Culture and Buddhism: Saṃbhāṣā 24: 129-152.

—. 2007a. Four Gāndhārī Samyuktāgama sutras: Senior Kharoșthī fragment 5. Gandhāran Buddhist Texts 4. Seattle: University of Washington Press.

—. 2007b. The Chronology of Kharoșthi Inscriptions: A reassessment in light of recent discoveries. Gandhäran Studies 1: 61-76.

Gnoli, Gherardo, and Lionello Lanciotti, eds. 1985-1988. Orientalia Iosephi Tucci memoriae dicata. 3 vols. Serie orientale Roma 56. Rome: Istituto italiano per il Medio ed Estremo Oriente.

Göbl, Robert. 1967. Dokumente zur Geschichte der iranischen Hunnen in Baktrien und Indien. 4 vols. Wiesbaden: Harrassowitz.

—. 1987. Die Buddha-Darstellungen in der Münzpragung der Kušān. In Orientalia Iosephi Tucci memoriae dicata, eds. Gherardo Gnoli and Lionello Lanciotti, vol. 2: 535-538. Serie orientale Roma 56. Rome: Istituto italiano per il Medio ed Estremo Oriente.

Godard, André, Y. Godard, Joseph Hackin, and Paul Pelliot. 1928. Les antiquités bouddhiques de Bamiyan. Mémoires de la délégation archéologique française en Afghanistan 2. Paris; Bruxelles: G. van Oest.

Gokhale, Balkrishna Govind. 1977. The Merchant in Ancient India. Journal of the American Oriental Society 97.2: 125-130.

- 1987. Bharukaccha/Barygaza. In India and the ancient world: history trade, and culture before A.D. 650, ed. Gilbert Pollet, 67-79. Orientalia Lovaniensia analecta 25. Leuven: Departement Oriëntalistiek.

Gokhale, Shobhana. 1991. Kanheri inscriptions. Pune, India: Deccan College Post Graduate and Research Institute.

Gombrich, Richard F. 2006. Theravāda Buddhism: A social history from ancient Benares to modern Colombo. 2nd ed. The Library of Religious Beliefs and Practices. London; New York: Routledge.

Gombrich, Richard F., and Cristina A. Scherrer-Schaub, eds. 2008. Buddhist studies. Papers of the 12th World Sanskrit Conference, vol. 8. Delhi: Motilal Banarsidass Publishers.

Goudie, Andrew, and Kenneth Pye, eds. 1983. Chemical Sediments and Geomorphology: Precipitates and residua in the near-surface environment. London; New York: Academic Press.

Granoff, Phyllis. 1998. Maitreya's Jewelled World: Some Remarks on Gems and Visions in Buddhist Texts. Journal of Indian Philosophy 26.4: 347-371.

- 2005. The Gift of the Two Merchants: Defining the Buddhist Community through Story. East and West 55: 129-138.

Grenet, Frantz. 2002. Regional interaction in Central Asia and Northwest India in the Kidarite and Hephthalite periods. Proceedings of the British Academy 116: 203-224.

—. 2006. Nouvelles données sur la localisation des cinq yabghus des Yuezhi. Journal asiatique 294: 325-341.

Gunawardana, Ranavira. 1979. Robe and Plough: Monasticism and economic interest in early medieval Sri Lanka. Tucson, Arizona: Association for Asian Studies by University of Arizona Press. 
Gupta, Swarajya Prakash. 1985. Kushana sculptures from Sanghol, 1st-2nd century A.D.: A recent discovery. New Delhi: National Museum.

Hackin, Joseph. 1939. Recherches archéologiques à Begram. Mémoires de la Délégation archéologique française en Afghanistan 9. Paris: Les Éditions d'art et d'histoire.

- 1954. Nouvelles recherches archéologiques à Begram, ancienne Kâpicî, 19391940; rencontre de trois civilisations, Inde, Grèce, Chine. Mémoires de la Délégation archéologique française en Afghanistan 11. Paris: Imprimerie nationale.

Hackin, Joseph, and Jean Carl. 1933. Nouvelles recherches archéologiques à Bamiyan. Mémoires de la Délégation archéologique française en Afghanistan 3. Paris: G. van Oest.

Halbfass, Wilhelm. 1988. India and Europe: An essay in understanding. Albany, N.Y.: State University of New York Press.

Hallier, Ulrich. 1991. Petroglyphen in Nordpakistan. Antike Welt 22: 2-20.

Hallisey, Charles. 1995. Roads Taken and Not Taken in the Study of Theravāda Buddhism. In Curators of the Buddha: The Study of Buddhism under Colonialism, ed. Donald S. Lopez, 31-61. Chicago: University of Chicago Press.

- 2007. Roads Taken and Not Taken in the Study of Theravāda Buddhism. In Defining Buddhism(s): a reader, eds. Karen Derris and Natalie Gummer. Critical Categories in the Study of Religion. London: Equinox Pub.

Hammond, Norman, ed. 1973. South Asian Archaeology: Papers from the First International Conference of South Asian Archaeologists held in the University of Cambridge. Park Ridge, N.J.: Noyes Press.

Hansen, Valerie. 1998. The Path of Buddhism into China: The view from Turfan. Asia Major 11.2: 37-66.

Harmatta, János, ed. 1979. Prolegomena to the Sources on the History of Pre-Islamic Central Asia. Collection of the sources for the history of pre-Islamic Central Asia. Budapest: Akadémiai Kiadó.

Harmatta, János (with B.N. Puri, L. Lelekov, D.C. Sircar, and S. Humayun). 1994. Religions in the Kushan Empire. In History of Civilizations of Central Asia, vol. 2: The development of sedentary and nomadic civilizations: 700 B.C. to A.D. 250, ed. János Harmatta, 313-330. Paris: UNESCO.

Harrauer, Hermann, and Pieter J. Sijpesteijn. 1985. Ein neues Dokument zu Roms Indienhandel: P. Vindob. G 40822. Anzeiger der Österreichischen Akademie der Wissenschaften, philosophisch-historische Kl. 122: 124-155.

Harrison, Paul. 2003. Relying on the dharma and not the person: Reflection on authority and Transmission in Buddhism and Buddhist Studies. Journal of the International Association of Buddhist Studies 26.1: 9-24.

Härtel, Herbert. 1993. Excavations at Sonkh: 2500 years of a town in Mathura District. Monographien zur indischen Archäologie, Kunst und Philologie 9. Berlin: D. Reimer.

Härtel, Herbert, and Marianne Yaldiz. 1982. Along the Ancient Silk Routes: Central Asian art from the West Berlin State Museums. New York: Metropolitan Museum of Art.

Hartmann, Jens-Uwe. 2004. Buddhism along the Silk Road: On the Relationship between the Buddhist Sanskrit Texts from Northern Turkestan and those from Afghanistan. In Turfan Revisited: The first century of research into the arts and cultures of the Silk Road, ed. Desmond Durkin, 125-128. Monographien zur indischen Archäologie, Kunst und Philologie 17. Berlin: D. Reimer.

- 2009. From Words to Books: Indian Buddhist manuscripts in the first millennium CE. In Buddhist Manuscript Cultures: Knowledge, ritual, and art, ed. Stephen Berkwitz, et al. Routledge Critical Studies in Buddhism 52. Milton Park, Abingdon, Oxon; New York, NY: Routledge.

Hawkes, Jason. 2008. Bharhut: A Reassessment. South Asian Studies 24: 1-14. 
2009. The Wider Archaeological Contexts of the Buddhist Stūpa Site of Bharhut. In Buddhist Stūpas in South Asia: Recent archaeological, art-historical, and historical perspectives, eds. Jason Hawkes and Akira Shinada, 146-174. SOAS Studies on South Asia. Delhi: Oxford University Press.

Hawkes, Jason, and Akira Shimada, eds. 2009. Buddhist Stūpas in South Asia: Recent archaeological, art-historical, and historical perspectives. SOAS Studies on South Asia. Delhi; Oxford: Oxford University Press.

Hazra, Kanai Lal. 2002. Buddhism and Buddhist Literature in Early Indian Epigraphy. New Delhi: Munshiram Manoharlal.

Heim, Maria. 2004. Theories of the Gift in South Asia: Hindu, Buddhist, and Jain reflections on dāna. New York; London: Routledge.

Heirman, Ann, and Stephan Peter Bumbacher, eds. 2007. The Spread of Buddhism. Handbuch der Orientalistik 16. Leiden; Boston: Brill.

Heitzman, James. 1984. Early Buddhism, Trade and Empire. In Studies in the Archaeology and Palaeoanthropology of South Asia, ed. Kenneth A. R. Kennedy and Gregory L. Possehl, 121-137. New Delhi: Oxford \& IBH : American Institute of Indian Studies.

- 1997. Gifts of Power: Lordship in an early Indian state. Delhi; New York: Oxford University Press.

—. 2009. The Urban Context of Early Buddhist Monuments in South Asia. In Buddhist Stüpas in South Asia: Recent archaeological, art-historical, and historical perspectives, eds. Jason Hawkes and Akira Shimada, 192-215. SOAS Studies on South Asia. New Delhi: Oxford University Press.

Helms, Mary W. 1988. Ulysses' Sail: An ethnographic odyssey of power, knowledge, and geographical distance. Princeton, N.J.: Princeton University Press.

- 1993. Craft and the Kingly Ideal: Art, trade, and power. Austin: University of Texas Press.

Herodotus. 1942. Persian Wars. Trans. George Rawlinson. New York: Random House.

Herrmann, Albert. 1910. Die alten Seidenstrassen zwischen China und Syrien. Quellen und Forschungen zur alten Geschichte und Geographie 21. Berlin: Weidmann.

Hiebert, Fredrik T. and Pierre Cambon, eds. 2008. Afghanistan: Hidden treasures from the National Museum, Kabul. Washington, DC: National Geographic.

Hill, John E. 2009. Through the Jade Gate to Rome: A study of the silk routes during the Later Han Dynasty 1st to 2nd centuries CE: an annotated translation of the chronicle on the 'Western Regions' in the Hou Hanshu. Charleston, SC: BookSurge Publishing.

Hiltbeitel, Alf. 2005. Buddhism and the Mahābhārata: Boundary Dynamics in Textual Practice. In Boundaries, Dynamics and Construction of Traditions in South Asia, ed. Federico Squarcini, 107-131. Kykéion studi e testi, 3. Firenze, Italy; New Delhi, India: Firenze University Press and Munshiram Manoharlal.

Hinüber, Oskar von. 1979. Die Erforschung der Gilgit-Handschriften: Funde buddhistischer Sanskrit-Handschriften, I. Nachrichten der Akademie der Wissenschaften in Göttingen, philologisch-historische Kl. 12. Göttingen: Vandenhoeck \& Ruprecht.

- 1980. Die Kolophone der Gilgit-Handschriften. Studien zur Indologie und Iranistik 5/6: 49-82.

—. 1981. Namen in Schutzzaubern aus Gilgit. Studien zur Indologie und Iranistik 7: $163-170$.

—. 1983a. The Oldest Literary Language of Buddhism. Saeculum 34: 1-9.

— 1983b. Die Bedeutung des Handschriften-fundes bei Gilgit. In Zeitschrift der Deutschen Morgenländischen Gesellschaft, Supplement 5, 47-66. Wiesbaden: Franz Steiner. 
1984. Expansion to the North: Afghanistan and Central Asia. In The World of Buddhism: Buddhist monks and nuns in society and culture, eds. Heinz Bechert and Richard Gombrich, 99-107. London: Thames and Hudson.

- 1989a. Brāhmì Inscriptions on the History and Culture of the Upper Indus Valley. In Antiquities of Northern Pakistan: reports and studies, ed. Karl Jettmar, vol. 1: 41-71. Mainz: P. von Zabern.

— 1989b. Buddhistische Inschriften aus dem Tal des oberen Indus. In Antiquities of Northern Pakistan: reports and studies, ed. Karl Jettmar, vol. 1: 73-106. Mainz: P. von Zabern.

- 1989c. Origin and Varieties of Buddhist Sanskrit. In Dialectes dans les littératures indo-aryennes: actes du colloque international, ed. Colette Caillat, 341-367. Publications de l'Institut de civilisation indienne, 55. Paris: Collège de France, Institut de civilisation indienne.

- 1994. Selected Papers on Pāli Studies. Oxford: Pali Text Society.

_. 1996. A Handbook of Pāli Literature. Indian Philology and South Asian studies, 2. Berlin; New York: Walter de Gruyter.

- 2001. Das ältere Mittelindisch im Uberblick. 2nd rev. ed. Sitzungsberichte / Österreichische Akademie der Wissenschaften, philosophisch-historische Kl.; Veröffentlichungen zu den Sprachen und Kulturen Südasiens. Vienna: Österreichischen Akademie der Wissenschaften.

—. 2003. Beiträge zur Erklärung der Senavarma-Inschrift. Abhandlungen der Geistes- und Sozialwissenschaftlichen Kl., Jahrg. 2003, Nr. 1. Mainz; Stuttgart: Akademie der Wissenschaften und der Literatur; Franz Steiner.

—. 2004. Die Palola Șāhis: Ihre Steinenschriften, Inschriften auf Bronzen, Handschriftenkolophone und Schutzzauber: materialen zur Geschichte von Gilgit und Chilas. Antiquities of Northern Pakistan 5. Mainz: P. von Zabern.

- 2006a. Everyday Life in an Ancient Indian Buddhist Monastery. Annual Report of the International Research Institute for Advanced Buddhology at Soka University 9: $1-31$.

- 2006b. The Cultural Context of the Inscriptions from the Upper Indus. Paper for the 13th World Sanskrit Conference in Edinburgh, Scotland, July 2006.

- 2007. Three New Bronzes from Gilgit. Annual Report of the International Research Institute for Advanced Buddhology at Soka University, 10: 39-44.

—. 2009. More on Gilgit Bronzes and Some Additions to "Die Palola Șāhis." Annual Report of the International Research Institute for Advanced Buddhology at Soka University, 12: 3-6.

Hitch, Douglas. 1988. Kushan Tarim Domination. Central Asiatic Journal 32: 170192.

Hoek, A. W. van den., D.H.A. Kolff, and M.S. Oort, eds. 1992. Ritual, State, and History in South Asia: Essays in honour of J.C. Heesterman. Memoirs of the Kern Institute 5. Leiden; New York: Brill.

Holt, Frank Lee. 1989. Alexander the Great and Bactria: The formation of a Greek frontier in Central Asia. Mnemosyne, bibliotheca classica Batava, Supplementum 104. Leiden; New York: Brill.

- 1999. Thundering Zeus: The making of Hellenistic Bactria. Hellenistic Culture and Society 32. Berkeley: University of California Press.

Horner, I.B., trans. 1938-1966. The Book of the Discipline (Vinaya-pitaka). Sacred Books of the Buddhists, vols. 10-11, 13-14, 20, 25. London: Published for the Pali Text Society by Luzac \& Co.

_. trans. 1963. Milinda's questions. 2 vols. Sacred books of the Buddhists, v. 22-23. London: Luzac.

—. trans. 1974. Vimānavatthu: Stories of the mansions. Sacred Books of the Buddhists, v. 30. London; London, Boston: Pali Text Society; Distributed by Routledge \& K. Paul.

Huber, Édouard, trans. 1908. Sûtrâlamkâra. Paris: E. Leroux. 
Hulsewé, A.F.P. 1966. Quelques considérations sur le commerce de la soie au temps de la dynastie des Han. In Mélanges de sinologie offerts à Monsieur Paul Demiéville, 2:117-135. Bibliothèque de l'Institut des hautes études chinoises 20. Paris: Presses universitaires de France.

Hulsewé, A.F.P., and Michael Loewe. 1979. China in Central Asia: The early stage, 125 B.C.-A.D. 23: an annotated translation of chapters 61 and 96 of the history of the former Han dynasty. Sinica Leidensia 14. Leiden: Brill.

Hulsewé, A.F.P., W.L. Idema, and Erik Zürcher. 1990. Thought and Law in Qin and Han China: Studies dedicated to Anthony Hulsewe on the occasion of his eightieth birthday. Leiden; New York: Brill.

Hultzsch, E., ed. 1925. Inscriptions of Aśoka. Corpus Inscriptionum Indicarum 1. New Delhi: Director General, Archaeological Survey of India.

Humbach, Helmut. 1980a. Hybrid Sanskrit in the Gilgit Brāhmī Inscriptions. Studien zur Indologie und Iranistik 5/6: 99-121.

—. 1980b. Die Kharoșți-Inschriften aus Gilgit. Münchener Studien zur Sprachwissenschaft 39: 53-58.

Inden, Ronald B. 2000. Imperial Purānas: Kashmir as a Vaiṣnava Center of the Words. In Ronald B. Inden, Jonathan S. Walters, and Daud Ali, Querying the Medieval: Texts and the history of practices in South Asia, 29-98. Oxford: Oxford University Press.

Invernizzi, Antonio, ed. 1995. In the Land of the Gryphons: Papers on Central Asian archaeology in antiquity. Monografie di Mesopotamia 5. Firenze: Le lettere.

Jakobsson, Jens. 2009. Who Founded the Indo-Greek Era of 186/5 BCE? Classical Quarterly 59.2: 505-510.

Janes, Dominic. 1998. God and Gold in Late Antiquity. Cambridge; New York: Cambridge University Press.

Jansen, Michael. 2008. The Cultural Geography of Gandhara. In Gandhāra, the Buddhist Heritage of Pakistan: Legends, monasteries, and paradise,ed. Christian Luczanits, 27-35. Mainz: P. von Zabern.

Jayaswal, K.P., and R.D. Banerji. 1929. The Hathigumpha Inscription of Kharavela. Epigraphia Indica 20: 71-89.

Jelen, Ted, ed. 2002. Sacred Markets, Sacred Canopies: Essays on religious markets and religious pluralism. Lanham, Md.: Rowman \& Littlefield Publishers.

Jenkins, G.K. 1955. Indo-Scythic mints. Journal of the Numismatic Society of India 17: 1-26.

Jenner, W.J.F. 1981. Memories of Loyang: Yang Hsüan-chih and the lost capital (493534). Oxford; New York: Clarendon Press; Oxford University Press.

Jettmar, Karl. 1967. Art of the Steppes. New York: Crown Publishers.

—. 1975. Die Religionen des Hindukusch. Die Religionen der Menschheit 4.1. Stuttgart: W. Kohlhammer.

- 1979. Rock-carvings and Stray Finds in the Mountains of North Pakistan: Archaeology before Excavation. In South Asian Archaeology 1977, ed. Maurizio Taddei, vol. 2: 917-926. Naples: Istituto universitario orientale.

—. 1980. Bolor \& Dardistan. Islamabad: National Institute of Folk Heritage.

- 1987a. The 'Suspended Crossing'-Where and Why? In India and the Ancient World, ed. Gilbert Pollet, 95-101. Leuven: Departement Oriëntalistiek.

— 1987b. Hebrew Inscriptions in the Western Himalayas. In Orientalia Iosephi Tucci Memoriae Dicata, eds. Gherardo Gnoli and Lionello Lanciotti, vol. 2: 667670. Serie orientale Roma, v. 56. Rome: Istituto italiano per il Medio ed Estremo Oriente.

- 1990. Exploration in Baltistan. In South Asian Archaeology 1987, eds. Maurizio Taddei and Pierfranceso Callieri, vol. 2: 801-813. Serie orientale Roma 66. Rome: Istituto italiano per il Medio ed Estremo Oriente.

- 1991. The Art of the Northern Nomads in the Upper Indus Valley. South Asian Studies 7: 1-20. 
1993. The Patolas, their Governors and their Successors. In Antiquities of Northern Pakistan, ed. Karl Jettmar, vol. 2: 77-122. Mainz: P. von Zabern.

- 1994. Prähistorische Wanderrouten in den zentralasiatischen Hochgebirgen: Voraussetzungen und frühe Nachweise. Studien zur Indologie und Iranistik 19: 157-172.

- 2002. Beyond the Gorges of the Indus: Archaeology before excavation. Ed. Ellen Kattner. Karachi: Oxford University Press.

Jettmar, Karl, and Volker Thewalt. 1985. Zwischen Gandhära und den Seidenstrassen: Felsbilder am Karakorum Highway: Entdeckungen deutsch-pakistanischer Expeditionen, 1979-1984. Mainz: P. von Zabern (= Between Gandhära and the Silk Roads: Rock-carvings along the Karakorum Highway - Discoveries by German-Pakistani Expeditions. Islamabad: Lok Virsa, 1991).

Jettmar, Karl, Ditte Bandini-König, Volker Thewalt, and Gérard Fussman, eds. 1989-. Antiquities of Northern Pakistan. 5 vols. Mainz: P. von Zabern.

Jettmar, Karl, and Klaus Sagaster with Loden Sherab Dagyab. 1993. Ein Tibetisches Heiligtum in Punyal. In Antiquities of Northern Pakistan, ed. Karl Jettmar, vol. 2: 123-139. Mainz: P. von Zabern.

Jones, Horace Leonard, trans. 1917-1933. The Geography of Strabo. 8 vols. The Loeb Classical Library. London; New York: W. Heinemann; G.P. Putnam's sons.

Jones, J.J., trans. 1949. The Mahāvastu. 3 vols. Sacred books of the Buddhists, 16, 18-19. London: Luzac.

de Jong, J.W. 1987. A Brief History of Buddhist Studies in Europe and America. Bibliotheca Indo-Buddhica 33. Delhi, India: Sri Satguru Publications.

Joshi, Nilakanth Purushottam. 1967. Life in Ancient Uttarāpatha: Material civilisation of northern India from c. 200 B.C. to c. 300 A.D. as revealed by the sculptures, terracottas, and coins. Varanasi: Hindu Vishvavidyalaya Nepal Raja Sanskrit series.

Juo-Hsüeh Bhikkhunī. 2008. Who is Afraid of Gold and Silver? A Study of the Rule against Monetary Gifts in the Various Vinayas. In Buddhist studies, eds. Richard Gombrich and Cristina Scherrer-Schaub, 35-95. Delhi: Motilal Banarsidass.

Kak, Ram Chandra. 1933. Ancient Monuments of Kashmir. London: the India society (Guildford, printed by Billing and sons).

Kane, Panduranga Vamana. ed. 1965. The Harshacarita of Bānabhațta: Text of Uchchhvāsas I-VIII. 2nd ed. Delhi: Motilal Banarsidass.

- 1968. History of Dharmaśästra (Ancient and mediceval religious and civil law). 2nd ed. 5 vols. Government Oriental Series, no. 6. Poona: Bhandarkar Oriental Research Institute.

Kangle, R.P., ed. and trans. 1969. The Kautiliya Arthaśästra. 3 vols. University of Bombay studies, no. 1-2. Bombay: University of Bombay.

Kapstein, Matthew. 2003. The Indian Literary Identity in Tibet. In Literary cultures in history: reconstructions from South Asia, ed. Sheldon Pollock, 747-802. Berkeley: University of California Press.

Karlsson, Klemens. 2000. Face to Face with the Absent Buddha: The formation of Buddhist aniconic art. Acta Universitatis Upsaliensis, Historia Religionum 15. Uppsala, Sweden: Uppsala University Ph.D. dissertation.

Karttunen, Klaus. 1989. India in early Greek literature. Studia Orientalia 65. Helsinki: Finnish Oriental Society.

—. 1997a. India and the Hellenistic world. Studia Orientalia 83. Helsinki: Finnish Oriental Society.

— 1997b. Wooden Tables with Ivory Legs. In South Asian archaeology, 1995, eds. F. Raymon Allchin and Bridget Allchin, vol. 2: 557-562. New Delhi: Science Publishers, U.S.A. and Oxford \& IBH Pub. Co.

Kaul Shastri, Madhusudan. 1939. Report on the Gilgit Excavation in 1938. Quarterly Journal of the Mythic Society 30.1: 1-12. 
Kazmi, Ali H. 1995. Gemstones. In Geology of Pakistan, eds. F. Bender and Hilal A. Raza, 281-290. Beiträge zur regionalen Geologie der Erde 25. Berlin: Gebrüder Borntraeger.

Kennedy, Kenneth A.R., and Gregory Possehl, eds. 1984. Studies in the Archaeology and Palaeo-Anthropology of South Asia. New Delhi: American Institute of Indian Studies.

Kent, Roland G. 1953. Old Persian: Grammar, texts, lexicon. 2nd ed. American Oriental Series, 33. New Haven, Conn.: American Oriental Society.

Kern, Hendrik, trans. 1884. The Saddharma-pundarika or The Lotus of the True Law. The sacred books of the East, 21. Oxford: Clarendon Press. Reprint, New York, NY: Dover, 1963.

Kern, Hendrik, and Bunyiu Nanjio, eds. 1912. Saddharmapundarīka. Bibliotheca Buddhica 10. St. Pétersbourg: Académie Impériale des Sciences.

Kieffer-Pülz, Petra, and Jens-Uwe Hartmann, eds. 1997. Bauddhavidyāsudhākarah: Studies in honour of Heinz Bechert on the occasion of his 65th birthday. Indica et Tibetica 30. Swisttal-Odendorf: Indica et Tibetica.

Kielhorn, Franz. 1888. A Buddhist Stone-Inscription from Ghosrawa. Indian Antiquary 18: 307-312.

—. 1905. Junagadh Rock Inscription of Rudradaman; the Year 72. Epigraphia Indica 8: $36-49$.

Kieschnick, John. 2003. The Impact of Buddhism on Chinese Material Culture. Buddhisms. Princeton: Princeton University Press.

Kirfel, Willibald. 1920. Die kosmographie der Inder, nach den quellen dargestellt. Bonn; Leipzig: K. Schroeder.

Klimburg, Max. 1982. The Setting: The Western Trans-Himalayan Crossroads. In The Silk Route and the Diamond Path: Esoteric Buddhist art on the trans-Himalayan trade routes, ed. Deborah E. Klimburg-Salter, 24-37. Los Angeles: UCLA Arts Council.

Klimburg-Salter, Deborah E., ed. 1982. The Silk Route and the Diamond Path: Esoteric Buddhist art on the trans-Himalayan trade routes. Los Angeles: Published under the sponsorship of the UCLA Art Council.

- 1989. The Kingdom of Bämiyān: Buddhist art and culture of the Hindu Kush. Series maior, Istituto universitario orientale (Naples, Italy). Seminario di studi asiatici 5. Naples; Rome: Istituto universitario orientale, Dipartimento di studi asiatici; Istituto italiano per il Medio ed Estremo Oriente.

Konow, Sten, ed. 1929. Kharoshthi inscriptions, with the exception of those of Aśoka. Corpus Inscriptionum Indicarum, vol. 2, part 1. Calcutta: Government of India Central publication branch.

- 1939. Notes on the Inscription on the Silk-Strip No. 34:65. In Archaeological Researches in Sinkiang, especially the Lopnor region, 231-234. Stockholm: Bokförlags aktiebolaget Thule.

- 1940. A New Charsadda Inscription. In D.R. Bhandarkar Volume, ed. Bimala Churn Law and Devadatta Ramkrishna Bhandarkar, 305-310. Calcutta: Indian Research Institute.

- 1947. Note on the Bajaur Inscription of Menandros. Epigraphia Indica 27: $52-58$.

— 1948. Charsadda Kharoșthī inscription of the year 303. Acta Orientalia 20: 107-119.

Kosambi, D.D. 1960. At the Crossroads: Mother Goddess Cult-Sites in Ancient India: Parts I-II. Journal of the Royal Asiatic Society of Great Britain and Ireland, no. 1/2 (April): 17-31, no. 3/4 (October): 135-144.

Kreutzmann, Hermann. 1993. Challenge and Response in the Karakoram: Socioeconomic Transformation in Hunza, Northern Areas, Pakistan. Mountain Research and Development 13.1: 19-39. 
. 1996. Ethnizität im Entwicklungsprozess: die Wakhi in Hochasien. Berlin: D. Reimer.

Kristiansen, Kristian, and M. J. Rowlands, eds. 1998. Social Transformations in Archaeology: Global and local perspectives. Material Cultures. London; New York: Routledge.

Kubo, Tsugunari, and Akira Yuyama, trans. 1993. The Lotus Sutra, translated from the Chinese of Kumārajīva. BDK English Tripitaka, 13-1. Berkeley, CA: Numata Center for Buddhist Translation and Research.

Kuijp, Leonard van der. 1996. The Tibetan Script and Derivatives. In The world's writing systems, eds. Peter T. Daniels and William Bright, 331-341. New York: Oxford University Press.

Kulke, Hermann. 2004. Some Thoughts on State and State Formation under the Eastern Vākāțakas. In The Vākāțaka Heritage: Indian culture at the crossroads, ed. Hans Bakker, 1-9. Gonda Indological studies 13. Groningen: Egbert Forsten.

Kuwayama, Shoshin. 1987. Literary Evidence for Dating the Colossi in Bāmiyān. In Orientalia Iosephi Tucci memoriae dicata, eds. Gherardo Gnoli and Lionello Lanciotti, vol. 2: 703-727. Serie Orientale Roma 56. Rome: Istituto italiano per il Medio ed Estremo Oriente.

- 1989. The Hephthalites in Tokharistan and Northwest India. Zinbun, Annals of the Institute for Research in the Humanities, Kyoto University 24: 25-77.

- 1992. The Hephthalites in Tokharistan and Gandhara. Lahore Museum Bulletin 5.1-2: 1-24, 1-18.

- 1997. The Main Stūpa of Shāh-jī-kì-Dherì: A chronological outlook. Institute for Research in Humanities, Kyoto University, 1. Kyoto: Inst. for Research in Humanities, Kyoto Univ.

- 2002. Across the Hindukush of the First Millennium: A collection of the papers. Kyoto: Inst. for Research in Humanities, Kyoto Univ.

- 2007. Kañjur Ashlar and Diaper Masonry. Two Building Phases in Taxila of the First Century A.D. In On the Cusp of an Era: art in the pre-Kușāna world, ed. Doris Srinivasan, 201-231. Brill's Inner Asian Library 18. Leiden; Boston: Brill.

La Vaissière, Etienne de. 2002. Histoire des marchands sogdiens. Bibliothèque de l'Institut des hautes études chinoises, 32. Paris: Collège de France, Institut des hautes études chinoise; Boccard.

- 2004. The rise of Sogdian Merchants and the Role of the Huns: The Historical Importance of the Sogdian Ancient Letters. In The Silk Road: Trade, travel, war and faith, ed. Susan Whitfield, 19-23. London: British Library.

- 2005. Sogdian Traders: A history. Trans. James Ward. Handbuch der Orientalistik, section eight, Central Asia 10. Leiden; Boston: Brill.

_ 2003 (2007). Is There a "Nationality of the Hephtalites"? Bulletin of the Asia Institute 17: 119-132.

La Vallée Poussin, Louis de. 1935. Dynasties et histoíre de l'Inde depuis Kanishka jusqu'aux invasions musulmanes. Histoire du monde, 6. Paris: Boccard.

Lahiri, Nayanjot. 1992. The Archaeology of Indian Trade Routes up to c. 200 BC: Resources use, resource access and lines of communication. Delhi; New York: Oxford University Press.

Laidlaw, James. 1995. Riches and Renunciation: Religion, economy, and society among the Jains. Oxford studies in social and cultural anthropology. Oxford; New York: Clarendon; Oxford University Press.

Lamberg-Karlovsky, C.C. 1975. Third Millennium Modes of Exchange and Modes of Production. In Ancient Civilization and Trade, ed. Jeremy A. Sabloff and C.C. Lamberg-Karlovsky, 341-368. Albuquerque: University of New Mexico Press.

Lamotte, Etienne. 1958. Histoire du bouddhisme indien: des origins à l'ère Śaka. Bibliothèque du Muséon, 43. Louvain: Universite de Louvain, Institut Orientaliste. 
1988. History of Indian Buddhism: From the origins to the Saka era. Trans. Sara Webb-Boin. Publications de l'Institut orientaliste de Louvain, 36. Louvain-la-Neuve: Université catholique de Louvain, Institut orientaliste.

Lattimore, Owen. 1962. Studies in Frontier History; Collected papers, 1928-1958. London; New York: Oxford University Press.

Law, Bimala Churn. 1932. Geography of Early Buddhism. London: Kegan Paul, Trench, Trübner \& Co.

—, ed. 1940. D.R. Bhandarkar Volume. Calcutta: Indian Research Institute.

—. 1944. Ujjayinī in Ancient India. Gwalior: Archaeological Dept., Gwalior Government.

- 1954. Historical Geography of Ancient India. Paris: Société Asiatique de Paris.

—. 1955. Māhișmatī in Ancient India. Journal of Indian History 33: 313-320.

Legge, James, trans. 1886. A Record of Buddhistic Kingdoms: Being an account by the Chinese Monk Fa-Hien of his travels in India and Ceylon (A.D. 399-414) in search of the Buddhist Books of Discipline. Oxford: Clarendon Press.

Lenfant, Dominique. 2004. La Perse; l'Inde; autres fragments. Collection des universités de France, v. 435. Paris: Belles lettres.

Lenz, Timothy. 2003. A New Version of the Gāndhārī Dharmapada and a Collection of Previous-birth Stories: British Library Kharoșthī fragments $16+25$. Gandhāran Buddhist Texts 3. Seattle; London: University of Washington Press.

- 2010. Gandhāran Avadānas: British Library Kharosthì fragments 1-3 and 21 and supplementary fragments A-C. Gandhāran Buddhist Texts 6. Seattle; London: University of Washington Press.

Leriche, Pierre, Kazim Abdullaev, and P. Gentelle. 1997. Bilan de campagne 1997 de la MAFOuz de Bactriane. Bulletin of the Asia Institute 11: 17-52.

Lévi, Sylvain. 1932. Note sur les manuscripts provenant de Bāmiyān (Afghanistan) et de Gilgit (Cachemire). Journal Asiatique 220: 1-45.

Lewis, Todd T. 1993. Newar-Tibetan Trade and the Domestication of the "Simhalasārthabāhu Avadāna." History of Religions 33.2: 135-160.

- 1995. Story of Simhala the Caravan Leader. In Religions of India in Practice, ed. Donald S. Lopez, 153-169. Princeton, N.J.: Princeton University Press.

—. 2000. Popular Buddhist texts from Nepal: Narratives and rituals of Newar Buddhism. SUNY series in Buddhist studies. Albany: State University of New York Press.

Li Rongxi, trans. 1996. The Great Tang Dynasty Record of the Western Regions. BDK English Tripitaka, 79. Berkeley, Calif.: Numata Center for Buddhist Translation \& Research.

Li Rongxi and Albert A. Dalia, trans. 2002. Lives of Great Monks and Nuns. BDK English Tripițaka, 76-III-VII. Berkeley, Calif: Numata Center for Buddhist Translation and Research.

Lienhard, Siegfried. 1985. Die Abenteuer des Kaufmanns Simhala: eine Nepalische Bilderrolle aus der Sammlung des Museums für Indische Kunst, Berlin. Publications of the Museum für Indische Kunst Berlin, 7. Berlin: Museum für Indische Kunst.

Lin, Meicun. 1995. Xiyu wen ming: kao gu, min zu, yu yan he zong jiao xin lun. Beijing: Dong fang chu ban she: Jing xiao Xin hua shu dian.

- 1996. Kharosthịi Bibliography: The Collections from China (1897-1993). Central Asiatic Journal 40: 188-220.

- 1998. Han Tang xiyu yu Zhongguo wen ming (The western Region of the HanTang Dynasties and Chinese Civilization). [Beijing]: Wen wu chu ban she.

Lindquist, Steven. 2003. Enigmatic Numismatics: Kings, Horses, and the Aśvamedha Coin-type. South Asian Studies 19: 105-112.

Little, Lester K. 1978. Religious poverty and the profit economy in medieval Europe. Ithaca, NY: Cornell University Press. 
Litvinsky, Boris A. 1993. Pamir und Gilgit - Kulturhistorische Verbindungen. In Antiquities of Northern Pakistan: reports and studies, ed. Karl Jettmar, vol. 2: 141149. Mainz: P. von Zabern.

—, ed. 1996. The crossroads of civilizations A.D. 250 to 750. History of civilizations of Central Asia, vol. 3. Paris: UNESCO.

Liu, Xinru. 1988. Ancient India and Ancient China: Trade and religious exchanges, AD 1-600. Delhi; New York: Oxford University Press.

- 1998. The Silk Road: Overland trade and cultural interactions in Eurasia. Essays on Global and Comparative History. Washington, DC: American Historical Association.

- 2001. Migration and Settlement of the Yuezhi-Kushan: Interaction and Interdependence of Nomadic and Sedentary Societies. Journal of World History 12.2: 261-292.

—. 2009. Buddhist Ideology and the Commercial Ethos in Kuṣāna India. In Buddhist stūpas in South Asia: Recent archaeological, art-historical, and historical perspectives, eds. Jason Hawkes and Akira Shimada, 177-191. SOAS Studies on South Asia. Delhi; Oxford: Oxford University Press.

Lohuizen De Leeuw, Johanna Engelberta van. 1949. The "Scythian" Period, an approach to the history, art, epigraphy and palaeography of North India from the 1st century B.C. to the 3rd century A.D. Leiden: E.J. Brill.

- 1986. The second century of the Kaniska era. South Asian Studies 2: 1-9.

Loimeier, Roman, ed. 2000. Die islamische Welt als Netzwerk: Möglichkeiten und Grenzen des Netzwerkansatzes im islamischen Kontext. Mitteilungen zur Sozial- und Kulturgeschichte der islamischen Welt, 9. Würzburg: Ergon.

Loimeier, Roman, and Stefan Reichmuth. 1996. Zur Dynamik religios-politischer Netzwerke in muslimischen Gesellschaften. Die Welt des Islams n.s. 36.2: 145-185.

Lopez, Donald S., ed. 1995a. Religions of India in Practice. Princeton Readings in Religions. Princeton: Princeton University Press.

- ed. 1995b. Curators of the Buddha: The study of Buddhism under Colonialism. Chicago: University of Chicago Press.

— Chicago: University of Chicago Press.

Lorimer, Emily Overend. 1939. Language Hunting in the Karakoram. London: Allen \& Unwin.

Luczanits, Chistian, ed. 2008. Gandhāra, the Buddhist heritage of Pakistan: Legends, monasteries, and paradise = Gandhāra, das buddhistische Erbe Pakistans : Legenden, Klöster und Paradiese, ed. Dorothee von Drachenfels. [Bonn]: Kunst- und Ausstellungshalle der Bundesrepublik Deutschland; Mainz: P. von Zabern.

Ludden, David. 2003. Presidential Address: Maps in the Mind and the Mobility of Asia. Journal of Asian Studies 62.4: 1057-1078.

Lüders, Heinrich. 1912. A list of Brahmi inscriptions from the earliest times to about A.D. 400. Epigraphia Indica 10: Appendix (reprint: A List of Brāhmī inscriptions from the Earliest Times to about A.D. 400 with the Exeception <sic> of those of Aśoka. Delhi: Indological Book House, 1973).

— ed. 1963. Bharhut inscriptions. Corpus Inscriptionum Indicarum 2.2. Ootacamund: Government Epigraphist for India.

Lüders, Heinrich, and Klaus Ludwig Janert. 1961. Mathurā Inscriptions; Unpublished papers. Abhandlungen der Akademie der Wissenschaften in Göttingen, philologisch-historische Kl. 3. Nr. 47. Göttingen: Vandenhoeck \& Ruprecht.

Lyonnet, Bertille. 1994. Central Asia, the Indo-Aryans and the Iranians: some reassessments from recent archaeological data. In South Asian Archaeology, 1993, ed. Asko Parpola and Petteri Koskikallio, vol. 1: 425-434. Helsinki: Suomalainen Tiedeakatemia. 
Ma Yong. 1989. The Chinese Inscription of the Da Wei Envoy of the Sacred Rock of Hunza. In Antiquities of Northern Pakistan: reports and studies, ed. Karl Jettmar, vol. 1: 139-157. Mainz: P. von Zabern.

MacDowall, David. 1968. Soter Megas, the King of Kings, the Kushāna. Journal of the Numismatic Society of India 30: 28-48.

- 1973. The Azes Hoard from Shaikhan-Dheri: Fresh Evidence for the Context of Jihonika. In South Asian Archaeology: Papers from the First International Conference of South Asian Archaeologists held in the University of Cambridge, ed. Norman Hammond, 215-230. Park Ridge, NJ: Noyes Press.

. 1985. Numismatic Links Across the Karakorum. Journal of Central Asia 8.2: 153-157.

- 2005. The Role of Demetrius in Arachosia and the Kabul Valley. In Afghanistan: Ancien carrefour entre l'est et l'ouest, eds. Osmund Bopearachchi and Marie-Françoise Boussac, 197-206. Turnhout, Belgium: Brepols.

- 2007a. Numismatic Evidence for a Chronological Framework for Pre-Kanișkan Art, from Kalchayan to Gandhāra. In On the Cusp of an Era: Art in the pre-Kușāna world, ed. Doris Srinivasan, 95-117. Brill's Inner Asian library 18. Leiden: Brill.

- 2007b. Coinage from Iran to Gandhāra - with special reference to divinities as coin types. In On the Cusp of an Era: Art in the pre-Kușanna world, ed. Doris Srinivasan, 233-266. Leiden: Brill.

MacQueen, Graeme. 1988. A study of the Sramanyaphala-sutra. Freiburger Beiträge zur Indologie 21. Wiesbaden: O. Harrassowitz.

Maillard, Monique. 1975. À propos de deux statuettes en terre rapportées par la Mission Otani: Serapis et Harpocrates en Asie Centrale. Journal Asiatique 263: 223230.

Maillard, Monique, and Robert Jera-Bezard. 1994. Les stūpas de Kuberavāhana à Chilas et Thalpan. In Antiquities of Northern Pakistan, ed. Gérard Fussman and Karl Jettmar, vol. 3: 173-198. Mainz: P. von Zabern.

Maity, Sachindra Kumar. 1970. Economic Life in Northern India in the Gupta Period, cir. A.D. 300-550. 2nd ed. Delhi: Motilal Banarsidass.

Majumdar, Nani Gopal. 1937a. The Bajaur Casket of the Reign of Menander. Epigraphia Indica 24: 1-8.

- 1937b. Inscriptions on two relic-caskets from Charsadda. Epigraphia Indica 24: $8-10$

- 1940. Inscriptions. In John Hubert Marshall, Alfred Foucher, and Nani Gopal Majumdar, The Monuments of Sāñchī, vol. 1, 263-496. London: Probsthain.

Majumdar, Ramesh Chandra, ed. 1954. The Classical Age. The History and culture of the Indian people, vol. 3. Bombay: Bharatiya Vidya Bhavan.

Majumdar, Ramesh Chandra, and Anant Sadashiv Altekar, eds. 1946. The Vākātaka Gupta Age, circa 200-550 A.D. Delhi: Motilal Banarsidass.

Malalasekera, G.P. 1937-1938. Dictionary of Pali proper names. 2 vols. London: J. Murray.

Mallory, J. K. 2002. Archaeological Models and Asian Indo-Europeans. Proceedings of the British Academy 116: 19-42.

Margabandhu, C. 1965. Trade Contacts between Western India and the Graeco-Roman World in the Early Centuries of the Christian Era. Journal of the Economic and Social History of the Orient 8.3: 316-322.

Marshall, John Hubert. 1951. Taxila, an illustrated account of archaeological excavations carried out at Taxila under the orders of the Government of India between the years 1913 and 1934. 3 vols. Cambridge: Cambridge University Press.

Marshall, John Hubert, and Jean-Philippe Vogel. 1904. Excavations at Charsada. Annual Report of the Archaeological Survey of India for the Year 1902-1903 1: 141-184. 
Marshall, John Hubert, Alfred Foucher, and Nani Gopal Majumdar. 1940. The Monuments of Sāñchī. 3 vols. London: Probsthain.

Masefield, Peter, trans., assisted by N.A. Jayawickrama 1989. Elucidation of the intrinsic meaning so named the Commentary on the Vimāna stories (Paramattha-dīpani nāma Vimānavatthu-atthakathā). Sacred books of the Buddhists, 35. Oxford: Pali Text Society.

Masuzawa, Tomoko. 2005. The Invention of World Religions, or, How European universalism was preserved in the language of pluralism. Chicago: University of Chicago Press.

McCrindle, John Watson, trans. 1877. Ancient India as described by Megasthenês and Arrian; being a translation of the fragments of the Indika of Megasthenes collected by Dr. Schwanbeck, and of the first part of the Indika of Arrian, Calcutta: Thacker, Spink.

- trans. 1885. Ancient India as described by Ptolemy. Calcutta: Thacker, Spink, \& co.

McGovern, William Montgomery. 1939. The Early Empires of Central Asia; a study of the Scythians and the Huns and the part they played in world history, with special reference to the Chinese sources, Chapel Hill: University of North Carolina Press.

Mehendale, Sanjyot. 1993. The Ivory Statuette from Bokardan and Its Connection to the Ivory Statuettes from Pompei and Ter. In South Asian Archooology 1991, eds. Adalbert J. Gail, Gerd J.R. Mevissen, and Britta Zehmke, 529-538. Stuttgart: F. Steiner.

- 1997. Begram: New perspectives on the ivory and bone carvings. Berkeley: University of California-Berkeley Ph.D. dissertation.

- 2008. Begram, at the Heart of the Silk Roads. In Afghanistan: Hidden Treasures from the National Museum, Kabul, eds. Fredrik Hiebert and Pierre Cambon, 131-143. Washington, DC: National Geographic.

Mehta, Ramanlal Nagarji, and A.M. Thakkar. 1978. M.S. University Copper Plates of the Time of Toramana. Maharaja Sayajirao University archaeology series, no. 14. Vadodara: Dept. of Archaeology \& Ancient History, Faculty of Arts, M.S. University of Baroda.

Meister, Michael. 1996. Temples Along the Indus. Expedition: The Magazine of the University of Pennsylvania Museum of Archeology and Anthropology 38.3: 41-54.

- 2000a. Discovery of a New Temple on the Indus. Expedition: The Magazine of the University of Pennsylvania Museum of Archeology and Anthropology 42.1: 37-46.

- 2000b. Chronology of Temples in the Salt Range, Pakistan. In South Asian Archaeology 1997, eds. Maurizio Taddei and Giuseppe De Marco, vol. 2: 1321-1339. Rome: Istituto Italiano per l'Africa e l'Oriente.

- 2010. Temples of the Indus: Studies in the Hindu Architecture of Ancient Pakistan. Brill's Indological Library, 35. Leiden: Brill.

Melzer, Gudrun. 2006. A Copper Scroll Inscription from the Time of the Alchon Huns. In Buddhist manuscripts 3, ed. Jens Braarvig, 251-278. Manuscripts in the Schøyen Collection 7. Oslo: Hermes Pub.

Meunié, J. 1942. Shotorak. Mémoires de la Délégation archéologique française en Afghanistan 10. Paris: Les Éditions d'art et d'histoire.

Miller, Barbara Stoler, ed. 1992. The Powers of Art: Patronage in Indian Culture. Delhi: Oxford University Press.

Miller, Keith. 1982. Continents in Collision. London: G. Philip.

Minorsky, Vladimir, trans. 1937. Hudud al- 'Alam = "The regions of the world": a Persian geography, 372 A.H.-982 A.D. London: Luzac: Printed at the University Press, Oxford for the Trustees of the "E. J.W. Gibb Memorial".

Mirashi, Vasudev Vishnu, ed. 1963. Inscriptions of the Vākātakas. Corpus Inscriptionum Indicarum 5. Ootacamund: Government Epigraphist for India. 
1981. The History and Inscriptions of the Sätavāhanas and the Western Kshatrapas. 2 vols. Bombay: Maharashtra State Board for Literature and Culture.

Mitchiner, Michael. 1975. Indo-Greek and Indo-Scythian coinage. 9 vols. Sanderstead; London: Hawkins Publications; Distributed by Seaby.

Monius, Anne Elizabeth. 2001. Imagining a Place for Buddhism: Literary culture and religious community in Tamil-speaking South India. Oxford; New York: Oxford University Press.

Mookerji, Radhakumud. 1962. Aśoka. Delhi: Motilal Banarsidass.

Morley, Neville. 2007. Trade in Classical Antiquity. Key Themes in Ancient History. Cambridge: Cambridge University Press.

Morrison, Kathleen D. 1995. Trade, Urbanism, and Agricultural Expansion: Buddhist Monastic Institutions and the State in the Early Historic Western Deccan. World Archaeology 27.2: 203-221.

Mukherjee, B.N. 1995. The Great Kushāṇa Testament. Indian Museum Bulletin 30: $1-106$.

Narain, A.K. 1957. The Indo-Greeks. Oxford: Clarendon Press.

Nasim Khan, M. 2006. Treasures from Kashmir Smast: The earliest Saiva monastic establishment. Peshawar: Dept. of Archaeology, University of Peshawar.

-. 2008. Kharosthī Manuscripts from Gandhāra. Peshawar: M. Nasim Khan.

Nasim Khan, M., and M. Sohail Khan. 2004 (2006). Buddhist Kharoșthī manuscripts from Gandhāra: a new discovery. Journal of Humanities and Social Sciences 12: 9-15.

Nathan, Leonard, trans. 1976. The Transport of Love: The Meghadūta of Kālidāsa. Berkeley: University of California Press.

Nattier, Jan. 1991. Once Upon a Future Time: Studies in a Buddhist prophecy of decline. Nanzan studies in Asian religions, 1. Berkeley: Asian Humanities Press.

—. 2008. A Guide to the Earliest Chinese Buddhist Translations: Texts from the Eastern Han (Dung-han) and Three Kingdoms (San-guo) periods. Bibliotheca philologica et philosophica Buddhica, 10. Tokyo: International Research Institute for Advanced Buddhology, Soka Univ.

Neelis, Jason. 2000. Kharoșțī and Brāhmī Inscriptions from Hunza-Haldeikish: Sources for the Study of Long-Distance Trade and Transmission of Buddhism. In South Asian Archaeology, 1997, eds. Maurizio Taddei and Giuseppe De Marco, vol. 2: 903-923. Serie Orientale Roma 90. Rome: Istituto italiano per l'Africa e l'Oriente.

— 2002 (2006). La Vieille Route Reconsidered: Alternative Paths for Early Transmission of Buddhism Beyond the Borderlands of South Asia. Bulletin of the Asia Institute 16: 143-164.

- 2007. Passages to India: Śaka and Kuṣāna Migrations in Historical Contexts. In On the cusp of an era: art in the pre-Kușäna world, ed. Doris Srinivasan, 55-94. Brill's Inner Asian Library, 18. Leiden: Brill.

—. 2008. Historical and Geographical Contexts for Avadānas in Kharoșthī Manuscripts. In Buddhist studies, eds. Richard Gombrich and Cristina A. Scherrer-Schaub, 151-167. Delhi: Motilal Banarsidass.

- Forthcoming a. Overland Shortcuts for the Transmission of Buddhism. In Highways, Byways, and Road Systems in the Pre-Modern World, eds. Susan Alcock, John Bodel, and Richard Talbert. The Ancient World: Comparative Histories. Malden, MA: Blackwell Pub.

—. Forthcoming b. Polyvalent Perceptions of the Uttarapatha in History: Archaeological evidence, epigraphic references, and literary demarcations. In Revisiting Early India through Epigraphy and Other Texts: Essays in memory of D.C.Sircar, ed. Suchandra Ghosh, et al. Calcutta.

Nehru, Lolita. 1989. Origins of the Gandharan style: A study of contributory influences. Delhi; New York: Oxford University Press. 
Nichols, Andrew. 2008. The complete fragments of Ctesias of Cnidus: Translation and commentary with an introduction. Gainesville, FL: University of Florida Ph.D. dissertation.

Norman, K.R. 1983. Pāli literature; including the canonical literature in Prakrit and Sanskrit of all the Hinayana schools of Buddhism. History of Indian literature, vol. 7, fasc. 2. Wiesbaden: O. Harrassowitz.

- trans. 1985. The Rhinoceros Horn and other early Buddhist Poems: The group of discourses (Sutta-Nipāta). Pali Text Society translation series, 44. London; Boston: Pali Text Society; Distributed by Routledge and Kegan Paul.

- trans. 1997a. The Word of the Doctrine (Dhammapada). Pali Text Society translation series, 46. Oxford: Pali Text Society.

— 1997b. A Philological Approach to Buddhism. The Bukkyō Dendō Kyōkai Lectures, 1994; The Buddhist Forum, 5. London: School of Oriental and African Studies, University of London.

Oberlies, Thomas A. 2003. Aśokan Prakrit and Pāli. In The Indo-Aryan languages, eds. George Cardona and Dhanesh Jain, 161-203. Routledge Language Family series. New York: Routledge.

Obeyesekere, Gananath. 2002. Imagining Karma: Ethical transformation in Amerindian, Buddhist, and Greek rebirth. Comparative Studies in Religion and Society, 14. Berkeley: University of California Press.

Odani, Nakao. 2000. New Discoveries from the Excavations at Rānigāt, Pakistan. In South Asian Archaeology, 1997, eds. Maurizio Taddei and Giuseppe De Marco, vol. 2: 831-841. Serie Orientale Roma. Rome: Istituto italiano per l'Africa e l'Orient.

Ohnuma, Reiko. 2005. Gift. In Critical Terms for the Study of Buddhism, ed. Donald S. Lopez, 103-123. Chicago: University of Chicago Press.

- 2007. Head, Eyes, Flesh, and Blood: Giving away the body in Indian Buddhist literature. New York: Columbia University Press.

Oldenberg, Hermann, ed. 1879. The Vinaya pitakam, one of the principle Buddhist holy scriptures in the Pâli language. 5 vols. London: Williams and Norgate.

Olivelle, Patrick, trans. 1996. Upanisads. The World's Classics. Oxford; New York: Oxford University Press.

- trans. 1999. The Dharmasūtras: The law codes of Āpastamba, Gautama, Baudhàyana, and Vasiștha. Oxford; New York: Oxford University Press.

- trans. 2004. The Law Code of Manu. Oxford; New York: Oxford University Press.

- 2005. Dharmasūtra Parallels: Containing the Dharmasūtras of Āpastamba, Gautama, Baudhāyana, and Vasistha. Sources of Ancient Indian Law. Delhi: Motilal Banarsidass.

Olivier-Utard, Françoise. 1997. Politique et archéologie: histoire de la Délégation archéologique française en Afghanistan (1922-1982). Paris: Editions Recherche sur les civilisations.

Olivieri, Luca M. 2008. The Swat Case Study: Barikot and its Environs. In Gandhāra, the Buddhist Heritage of Pakistan: Legends, monasteries, and paradise, ed. Christian Luczanits, 294-297. Mainz: P. von Zabern.

Olivieri, Luca M, Massimo Vidale, Abdul Nasir Khan, Tahir Saeed, Luca Colliva, Riccardo Garbini, Leonardo Langella, Roberto Micheli, and Emanuele Morigi. 2006. Archaeology and Settlement History in a Test Area of the Swat Valley. Preliminary Report on the AMSV Project (1st Phase). East and West. 56.1: 73-150.

Orofino, Giacomella. 1990. A Note on Some Tibetan Petroglyphs of the Ladakh Area. East and West 40: 173-200.

Pāli Canon Online Database. http://www.bodhgayanews.net/pali.htm.

Parasher-Sen, Aloka. 1991. Mlecchas in Early India: A study in attitudes towards outsiders upto $A D$ 600. New Delhi: Munshiram Manoharlal. 
Parker, Grant Richard. 2008. The Making of Roman India. Greek Culture in the Roman world. Cambridge; New York: Cambridge University Press.

Parpola, Asko. 2002. From the dialects of Old Indo-Aryan to Proto-Indo-Aryan and Proto-Iranian. Proceedings of the British Academy 116: 43-102.

Parpola, Asko, and Petteri Koskikallio, eds. 1994. South Asian Archaeology, 1993: proceedings of the twelfth International Conference of the European Association of South Asian Archaeologists held in Helsinki University, 5-9 July 1993. Helsinki: Suomalainen Tiedeakatemia.

Parry, Kenneth, ed. 2008. Art, Architecture and Religion along the Silk Roads. Silk Road Studies 12. Turnhout: Brepols.

Paul, Pran Gopal. 1986. Early Sculpture of Kashmir (before the middle of the eig[h]th century A.D.): An approach to art history and epigraphy of the Jhelum Valley and its peripheral regions. Leiden: Sneldruk Enschede.

Pavlinskaya, Larisa. 1989. The Scythians and Sakians, Eighth to Third Centuries BC. In Nomads of Eurasia, ed. Vladimir N. Basilov, 19-31. Seattle: University of Washington Press.

P'iankov, L.V. 1996. The Ethnic History of the Sakas. Bulletin of the Asia Institute 8: 37-46.

Picron, Claudine, ed. 2008. Religion and Art: New issues in Indian iconography and iconology. Proceedings of the 18th conference of the European Association of South Asian Archaeologists, London, 2005. Vol. 1. London: the British Association for South Asian Studies.

Pinault, Georges-Jean. 1987. Épigraphie koutchéenne. In Chao Huashan, Simone Gaulier, Monique Maillard, and Georges-Jean Pinaut, Sites divers de la région de Koutcha, 61-196. Mission Paul Pelliot. Documents archéologiques 8. Paris: Collège de France, Institut d'Asie, Centre de recherche sur l'Asie centrale et la Haute Asie.

—. 2005. Remarques sur les noms propres d'origine indienne dans le stèle de Sôphytos. In Afghanistan: Ancien carrefour entre l'est et l'ouest, eds. Osmund Bopearachchi and Marie-Françoise Boussac, 137-142. Turnhout, Belgium: Brepols.

Pingree, David, ed. 1978. The Yavanajātaka of Sphujidhvaja. Harvard Oriental series 48. Cambridge: Harvard University Press.

Polanyi, Karl. 1957. The Economy as Instituted Process. In Trade and Market in the Early Empires; Economies in history and theory, eds. Karl Polanyi, C.M. Arensberg, and H.W. Pearson. New York: Free Press.

- 1968. Primitive, Archaic, and Modern Economies: Essays of Karl Polanyi, ed. George Palton. Garden City, N.Y.: Anchor Books.

- 1975. Traders and Trade. In Ancient Civilization and Trade, ed. Jeremy A. Sabloff and C.C. Lamberg-Karlovsky, 133-154. Albuquerque: University of New Mexico Press.

Polanyi, Karl, Conrad Arensberg, and Harry W. Pearson, eds. 1957. Trade and Market in the Early Empires; Economies in history and theory. Glencoe, Ill.; New York: Free Press.

Pollet, Gilbert, ed. 1987. India and the Ancient World: History trade, and culture before A.D. 650. Orientalia Lovaniensia analecta, 25. Leuven: Departement Oriëntalistiek.

Pollock, Sheldon I., ed. 2003. Literary Cultures in History: Reconstructions from South Asia. Berkeley: University of California Press.

- 2006. The Language of the Gods in the World of Men: Sanskrit, culture, and power in premodern India. Berkeley: University of California Press.

Prebish, Charles. 2008. Cooking the Buddhist Books: The implications of the new dating of the Buddha for the history of early Indian Buddhism. Journal of Buddhist Ethics 15: 1-21.

Przyluski, Jean. 1914. Le nord-ouest de l'Inde dans le Vinaya des Mūla-Sarvāstivāda et les texts apparentés. Journal Asiatique 4, ser. 11: 493-568. 
1936. Le partage des reliques du Buddha. Mélange chinois et bouddhiques 4: 341-67.

Pugliese Carratelli, Giovanni, and Giovanni Garbini. 1964. A bilingual Graeco-Aramaic edict by Aśoka: The first Greek inscription discovered in Afghanistan. Serie orientale Roma 29. Roma: Istituto italiano per il Medio ed Estremo Oriente.

Quintanilla, Sonya Rhie. 2007. History of Early Stone Sculpture at Mathura, ca. 150 BCE-100 CE. Studies in Asian Art and Archaeology 25. Leiden; Boston: Brill.

Rahman, Abdur. 1979. The Last Two Dynasties of the Șāhis: An analysis of their history, archaeology, coinage, and palaeography. Islamabad: Centre for the Study of the Civilizations of Central Asia, Quaid-i-Azam University.

- 1999. The Role of the Udis and Aprācas in the Spread of Buddhism: A lost chapter of the History of Gandhāra. Lahore Museum Bulletin 12.1: 13-18.

Ramachandra Murthy, N.S. 1999. Pātaganḍigūẹem plates of Ehavala Chāntamūla. Journal of the Epigraphical Society of India 25: 114-123.

Ramesh, K.V. 1974. Three Early Charters from Sanjeli in Gujarat. Epigraphia Indica 40: $175-186$.

Rapin, Claude. 2005. L'Afghanistan et l'Asie Centrale dans la géographie mythique des historiens d'Alexandre et dans la toponymie des géographes gréco-romains. In Afghanistan: Ancien carrefour entre l'est et l'ouest, eds. Osmund Bopearachchi and Marie-Françoise Boussac, 143-172. Turnhout, Belgium: Brepols.

Rapson, E.J. 1922. The Scythian and Parthian Invaders. In Cambridge History of India, ed. E.J. Rapson, vol. 1: 508-536. Cambridge: Cambridge University Press.

Raschke, Manfred. 1978. New Studies in Roman Commerce with the East. In Aufstieg und Niedergang der römischen Welt: Geschichte und Kultur Roms im Spiegel der neueren Forschung, vol. 2.9.2: 604-1361. Berlin; New York: W. de Gruyter.

Raven, Ellen M. 1994. Gupta Gold Coins with a Garuda-banner, SamudraguptaSkandagupta. 2 vols. Gonda indological studies 1. Groningen, Netherlands: Egbert Forsten.

- 2006. Design Diversity in Kanișka's Buddha Coins. In Gandhāran Buddhism: Archaeology, art, and texts, eds. Kurt Behrendt and Pia Brancaccio, 286-302. Vancouver: UBC Press.

—, ed. 2008. South Asian Archaeology 1999: Proceedings of the Fifteenth International Conference of the European Association of South Asian Archaeologists, held at the Universiteit Leiden, 5-9 July, 1999. Groningen: E. Forsten.

Rawlinson, H.G. 1916. Intercourse between India and the Western World from the earliest times to the fall of Rome. Cambridge: University Press.

Ray, Himanshu Prabha. 1986. Monastery and Guild: Commerce under the Sätavāhanas. Delhi; New York: Oxford University Press.

. 1994. The Winds of Change: Buddhism and the maritime links of early south Asia. Delhi; New York: Oxford University Press.

- 1995. Trade and Contacts. In Recent Perspectives of Early Indian History, ed. Romila Thapar, 142-175. Bombay: Popular Prakashan.

- ed. 2010. Sanghol and the Archaeology of Punjab. New Delhi: Aryan Books International.

Raychaudhuri, Hemchandra. 1923. Political History of Ancient India, from the accession of Parikshit to the extinction of the Gupta dynasty. Calcutta: University of Calcutta.

- 1933. The Kārddamaka Kings. Indian Historical Quarterly 9.1: 37-39.

Reddy, P. Krishna Mohan. 1998. God, Trade and Worship: A Glimpse into the Religion of Early Āndhradeśa. East and West 48: 291-311.

Rehman, Saeed ur. 1990. Unique Find of Gold Ornaments from Pattan/Kohistan. Journal of Central Asia 13.1: 5-17.

- , et al. 1996. Archaeological Reconnaissance in Gandhara. Karachi: Dept. of Archaeology \& Museums, Ministry of Culture and Sports, Govt. of Pakistan. 
Reichmuth, Stefan. 2000. Netzwerk und Weltsystem: Konzepte zur neuzeitlichen 'Islamischen Welt' und ihrer Transformation. Saeculum 51: 267-293.

Renfrew, Colin. 1975. Trade as Action at a Distance: Questions of integration and communication. In Ancient civilization and trade, eds. Jeremy A. Sabloff and C.C. Lamberg-Karlovsky, 3-59. Albuquerque: University of New Mexico Press.

Renfrew, Colin, and Paul G. Bahn. 1991. Archaeology: Theories, methods, and practice. New York: Thames and Hudson.

Renou, Louis, ed. 1925. La géographie de Ptolémée. L’Inde. (vii, 1-4). Paris: É. Champion.

Renou, Louis, and Jean Filliozat, eds. 1947-1953. L'Inde classique; manuel des études indiennes, 2 vols. Bibliothèque scientifique. Paris: Payot.

Rhi, Juhyung. 2005. Images, Relics, and Jewels: The Assimilation of Images in the Buddhist Relic Cult of Gandhara-Or Vice Versa. Artibus Asiae. 65.2: 169-211.

Rhie, Marylin M. 1999-. Early Buddhist Art of China and Central Asia. 2 vols. Handbook of Oriental studies, Section 4, China, 12. Leiden; Boston: Brill.

Rhys-Davids, Thomas William, trans. 1890. The Questions of King Milinda. 2 vols. Sacred books of the east, Vol. 35-36. Oxford: Clarendon Press. Reprint, Delhi: Motilal Banarsidass, 1965.

Rizvi, Janet. 1999. Trans-Himalayan Caravans: Merchant princes and peasant traders in Ladakh. New Delhi; New York: Oxford University Press.

Robertson, Roland. 1987. Economics and Religion. In The Encyclopedia of Religion, ed. Mirceau Eliade and Charles J. Adams, vol. 5: 1-11. New York: Macmillan.

Rosenfield, John M. 1967. The Dynastic Arts of the Kushans. California Studies in the History of Art, 6. Berkeley: University of California Press.

Rotman, Andy. 2003. Monks, Merchants, and a Moral Economy: Visual culture and the practice of faith in the Divyāvadāna. Chicago: University of Chicago Ph.D. dissertation.

— Wisdom Publications.

Rougemont, Georges. 2005. Nouvelles inscriptions grecques de l'Asie centrale. In Afghanistan: Ancien carrefour entre l'est et l'ouest, eds. Osmund Bopearachchi and Marie-Françoise Boussac, 127-136. Turnhout, Belgium: Brepols.

Rowlands, Michael J. 1998. Centre and Periphery: A review of a concept. In Social Transformations in Archaeology: Global and local perspectives, eds. Kristian Kristiansen and Michael J. Rowlands, 219-242. Material Cultures. London: Routledge.

Sabloff, Jeremy A., and C.C. Lamberg-Karlovsky, eds. 1975. Ancient Civilization and Trade. Albuquerque: University of New Mexico Press.

Sachau, Eduard, trans. 1888. Alberuni's India: An account of the religion, philosophy, literature, geography, chronology, astronomy, customs, laws and astrology of India about A.D. 1030. 2 vols. London: Trübner.

Sadakata, Akira. 1996. Quelques inscriptions kharoșthī provenant du marché aux antiquités de Peshawar. Journal Asiatique 284.2: 301-324.

Salomon, Richard. 1974. The Kșatrapas and Mahākșatrapas of India. Wiener Zeitschrift für die Kunde Südasiens 18: 5-25.

. 1982. The "Avaca" inscription and the origin of the Vikrama era. Journal of the American Oriental Society 102.1: 59-68.

- 1986. The Inscription of Senavarma, King of Odi. Indo-Iranian Journal 29.4: 261-293.

- 1989. New Inscriptional Evidence for the History of the Aulikaras of Mandasor. Indo-Iranian Journal 32: 1-36.

. 1991. Epigraphic Remains of Indian Traders in Egypt. Journal of the American Oriental Society 111.4: 731-736.

- 1993. Addenda to "Epigraphic Remains of Indian Traders in Egypt". Journal of the American Oriental Society 113.4: 593. 
1996a. South Asian Writing Systems. In The World's Writing Systems, eds. Peter T. Daniels and William Bright, 371-441. New York: Oxford University Press.

—. 1996b. An Inscribed Silver Buddhist Reliquary of the Time of King Kharaosta and Prince Indravarman. Journal of the American Oriental Society 116.3: 418-452.

— 1997. The Rededication of Buddhist Reliquaries: A Clue to the Interpretation of Problematic Kharoșthī Inscriptions. In South Asian Archaeology, 1995, eds. F. Raymond Allchin and Bridget Allchin, 365-376. New Delhi: Ancient India and Iran Trust, Cambridge by Science Publishers, U.S.A. and Oxford \& IBH Pub. Co.

- 1998a. Indian Epigraphy: A guide to the study of inscriptions in Sanskrit, Prakrit, and the other Indo-Aryan languages. South Asia Research. New York: Oxford University Press.

— 1998b. Kharoșthī Manuscript Fragments in the Pelliot Collection, Bibliothèque Nationale de France. Bulletin d'études indiennes 16: 123-160.

- 1999a. Ancient Buddhist Scrolls from Gandhāra: The British Library Kharoșthī fragments. Seattle, British Library and University of Washington Press.

—.1999b (2002). A Stone Inscription in Central Asian Gāndhārī from Endere (Xinjiang). Bulletin of the Asia Institute 13: 1-13.

-2000. A Gāndhārì version of the Rhinoceros Sutra: British Library Kharoșthī fragment 5B. Gandhāran Buddhist Texts 1. Seattle: University of Washington Press.

— . 2001. Gāndhārī Hybrid Sanskrit. Indo-Iranian Journal 44.3: 241-252.

- 2002a. Gāndhārī and the other Indo-Aryan languages in the light of newlydiscovered Kharoșthī manuscripts. Proceedings of the British Academy 116: 119-134. — 2002b. A Sanskrit Fragment Mentioning King Huvișka as a Follower of the Mahāyāna. In Buddhist Manuscripts 2, ed. Jens Braarvig, 255-267. Manuscripts in the Schøyen Collection 3. Oslo: Hermes Pub.

- 2003a. Writing Systems of the Indo-Aryan Languages. In The Indo-Aryan Languages, eds. George Cardona and Dhanesh Jain, 67-103. Routledge Family Language series. New York: Routledge.

- 2003b. Three Kharoșthī Reliquary Inscriptions in the Institute of Silk Road Studies. Silk Road Art and Archaeology 9: 39-69.

- 2003c. The Senior Manuscripts: Another Collection of Gandhāran Buddhist Scrolls. Journal of the American Oriental Society 123.1: 73-92.

- 2005a. The Indo-Greek Era of 186/5 BC in a Buddhist Reliquary Inscription. In Afghanistan: Ancien carrefour entre l'est et l'ouest, eds. Osmund Bopearachchi and Marie-Françoise Boussac, 359-401. Turnhout, Belgium: Brepols.

—. 2005b. The Name of Taxila: Greek Taxila, Gāndhārī Takṣaila, Sanskrit Takṣaśilā, Pali Takkasilā. East and West 55: 265-278.

- 2006. New manuscript sources for the study of Gandhāran Buddhism. In Gandhäran Buddhism: Archaeology, art, and texts, eds. Kurt Behrendt and Pia Brancaccio, 135-147. Asian Religions and Society series. Vancouver: UBC Press.

- 2007. Dynastic and Institutional Connections in the Pre- and Early Kusāana Periods. In On the Cusp of an Era: Art in the pre-Kușāna world, ed. Doris Srinivasan, 267-285. Leiden: Brill.

- 2008a. Two Gāndhärī manuscripts of the Songs of Lake Anavatapta (Anavataptagāthā): British Library Kharoșthì fragment 1 and Senior Scroll 14. Gandhāran Buddhist Texts 5. Seattle: University of Washington Press.

- 2008b. Whatever Happened to Kharoșthî? The Fate of a Forgotten Indic Script. In The Disappearance of Writing Systems: Perspectives on literacy and communication, eds. John Baines, John Bennet, and Stephen Houston, 139-155. London: Equinox.

- 2009. The Fine Art of Forgery in India. In Écrire et transmettre en Inde Classique, eds. Gérard Colas and Gerdi Gerscheimer, 107-134. Études thématiques 23. Paris: École française d'Extrême-Orient. 
Salomon, Richard, and Gregory Schopen. 1984. The Indravarman (Avaca) Casket Inscription Reconsidered: Further Evidence for Canonical Passages in Buddhist Inscriptions. Journal of the International Association of Buddhist Studies 7: 107-123.

Sander, Lore. 1989. Remarks on the Formal Brāhmī of Gilgit, Bāmiyān and Khotan. In Antiquities of Northern Pakistan: reports and studies, ed. Karl Jettmar, vol. 1: 107-130. Mainz: P. von Zabern.

—. 1999. Early Prakrit and Sanskrit Manuscripts from Xinjiang (second to fifth/ sixth Centuries CE): Paleography, Literary Evidence, and Their Relation to Buddhist Schools. In Erik Zürcher, et al. Collection of Essays 1993: Buddhism across Boundaries, 61-106. Sanchung, Taiwan: Fo Guang Shan Foundation for Buddhist \& Culture Education.

Sanderson, Alexis. 2009. The Śaiva Age: The Rise and Dominance of Śaivism during the Early Medieval Period. In Genesis and development of Tantrism, ed. Shingo Einoo, 41-350. Institute of Oriental Culture Special Series 23. Tokyo: Sankibō Busshorin, Heisei 21.

Sasaki, Shizuka. 1989-1999. Buddhist Sects in the Aśoka Period. Bukkyo Kenkyu 18: 181-202, 21: 157-176, 22: 167-199, 23: 55-100, 24: 165-225, 25: 29-63, 27: 1-55, 28: $1-10$.

Schlingloff, Dieter. 1987. Studies in the Ajanta paintings: Identifications and interpretations. Delhi: Ajanta Publications.

- 2000. Erzählende Wandmalereien: Handbuch der Malereien / Handbook of the paintings. 3 vols. Wiesbaden: Harrassowitz.

Schluchter, Wolfgang, ed. 1984. Max Webers Studie über Hinduismus und Buddhismus: Interpretation und Kritik. Frankfurt am Main: Suhrkamp.

Schmiedchen, Annette. 1993. Einige Besonderheiten der buddhistischen Schenkungsinschriften unter den Maitrakas. Beiträge des Südasien-Instituts der Humboldt-Universität zu Berlin 1: 83-108.

Schmiedchen, Annette, and Fred Virkus. 2002. Die Ären der Guptas und ihren Nachfolger: Politische Kultur, Regionalgeschichte und Zeitrechnung im alten und früh-mittelalterlichen Indien. In Vom Herrscher zur Dynastie: zum Wesen kontinuierlicher Zeitrechnung in Antike und Gegenwart, ed. Harry Falk, 106-137. Vergleichende Studien zu Antike und Orient 1. Bremen: Hempen.

Schoff, Wilfred H., trans. 1914. Parthian Stations by Isidore of Charax: An account of the overland trade route between the Levant and India in the first century B.C. Philadelphia: Commercial Museum (available online at: http://www.parthia.com/doc/ parthian_stations.htm).

Schopen, Gregory. 1975. The Phrase sa prthvippradeśaś caityabhūto bhavet in the Vajracchedikāa: Notes on the Cult of the Book in Mahāyāna. Indo-Iranian Journal 17: 147-181.

- 1979. Mahāyāna in Indian Inscriptions. Indo-Iranian Journal 21: 1-19.

— 1985a. Two Problems in the History of Indian Buddhism: The Layman/Monk Distinction and the Doctrine of the Transference of Merit. Studien zur Indologie und Iranistik 10: 9-47.

- 1985b. The Bodhigarbhālanikāralakṣa and Vimaloṣnịṣa Dhāraṇīs in Indian Inscriptions. Two Sources for the Practice of Buddhism in Medieval India. Wiener Zeitschrift für die Kunde Südasiens 29: 119-149.

- 1987a. Burial Ad Sanctos and the Physical Presence of the Buddha in Early Indian Buddhism: A Study in the Archaeology of Religions. Religion 17: 193-225.

— 1987b. The inscription on the Kușān image of Amitābha and the character of the early Mahāyāna in India. Journal of the International Association of Buddhist Studies 10: 99-133.

—. 1988. On Monks, Nuns and 'Vulgar' Practices: The Introduction of the Image Cult into Indian Buddhism. Artibus Asiae 49.1-2: 153-168. 
. 1991a. Monks and the Relic Cult in the Mahāparinibbāna-sutta: An Old Misunderstanding in Regard to Monastic Buddhism. In From Benares to Beijing: essays on Buddhism and Chinese religion in honour of Prof. Jan Yün-Hua, eds. Koichi Shinohara and Gregory Schopen, 187-201. Oakville, Ontario: Mosaic Press.

- 1991b. Archaeology and Protestant Presuppositions in the Study of Indian Buddhism. History of Religions 31.1: 1-23.

- 1994a. Ritual Rights and Bones of Contention: More on Monastic Funerals and Relics in the Mūlasarvāstivāda-vinaya. Journal of Indian Philosophy 22: 31-80.

- 1994b. Stūpa and Tīrtha: Tibetan Mortuary Practices and an Unrecognized Form of Burial Ad Sanctos at Buddhist Sites in India. In Buddhist Forum, vol. 3: 273-293. London: School of Oriental and African Studies.

- 1994c. Doing Business for the Lord: Lending on Interest and Written Loan Contracts in the Mūlasarvāstivāda-vinaya. Journal of the American Oriental Society 114.4: 527-554.

— 1996a. What's in a Name? The Religious Function of the Early Donative Inscriptions. In Unseen Presence: The Buddha and Sanchi, ed. Vidya Dehejia, 58-73. Mumbai: Marg Publications.

- 1996b. The lay ownership of monasteries and the role of the monk in Mūlasarvāstivādin monasticism. Journal of the International Association of Buddhist Studies 19.1: 81-126.

- 1997a. Bones, Stones, and Buddhist Monks: Collected papers on the archaeology, epigraphy, and texts of monastic Buddhism in India. Studies in the Buddhist traditions. Honolulu: University of Hawai'i Press.

- 1997b. If You Can't Remember, How to Make It Up: Some Monastic Rules for Redacting Canonical Texts. In Bauddhavidyāsudhākarah: Studies in Honour of Heinz Bechert on the Occasion of His 65th Birthday, eds. Petra Kieffer-Pülz and Jens-Uwe Hartmann, 571-582. Indica et Tibetica 30. Swisttal-Odendorf: Indica et Tibetica.

- 1998. Relics. In Critical terms for religious studies, ed. Mark C. Taylor, 256-268. Chicago: University of Chicago Press.

- 2000a. The Good Monk and His Money in a Buddhist Monasticism of 'The Mahāyāna Period. Eastern Buddhist 32.1: 85-105.

- 2000b. The Mahāyāna and the Middle Period in Indian Buddhism: Through a Chinese Looking-glass. Eastern Buddhist 32: 1-25.

— 2001. Dead Monks and Bad Debts: Some Provisions of a Buddhist Monastic Inheritance Law. Indo-Iranian Journal 44: 99-148.

—. 2004. Buddhist Monks and Business Matters: Still more papers on monastic Buddhism in India. Studies in the Buddhist traditions. Honolulu: University of Hawai'i Press.

- 2005. Figments and Fragments of Mahāyāna Buddhism in India: More collected papers. Studies in the Buddhist traditions. Honolulu: University of Hawai'i Press.

. 2006. The Buddhist "Monastery" and the Indian Garden: Aesthetics, Assimilations, and the Siting of Monastic Establishments." Journal of the American Oriental Society 126.4: 487-505.

- 2009. On the Absence of Urtexts and Otiose Ācāryas: Buildings, Books, and Lay Buddhist Ritual at Gilgit. In Écrire et transmettre en Inde classique, eds. Gérard Colas and Gerdi Gerscheimer, 189-219. Etudes thématiques 23. Paris: École française d'Extrême-Orient.

Schotsmans, Janine and Maurizio Taddei, eds. 1985. South Asian Archaeology 1983: Papers from the Seventh International Conference of the Association of South Asian Archaeologists in Western Europe. 2 vols. Series minor, Seminario di studi asiatici. Naples: Istituto universitario orientale.

Schwab, Raymond. 1950. La renaissance orientale. Bibliothèque historique. Paris: Payot. 
1984. Oriental Renaissance: Europe's rediscovery of India and the East, 16801880. Trans. Gene Patterson-Black and Victor Reinking. New York: Columbia University Press.

Schwartzberg, Joseph E. 1992. A Historical atlas of South Asia. 2nd impression. Chicago: University of Chicago Press.

Seldeslachts, Erik. 2007. Greece, the Final Frontier? The Westward Spread of Buddhism. In The Spread of Buddhism, eds. Ann Heirman and Stephan Peter Bumbacher, 131-166. Leiden; Boston: Brill.

Selvakumar, V., K.P. Shajan, and Roberta Tomber. 2010. Archaeological Investigations at Pattanam, Kerala: New evidence for the location of ancient Muziris. In Migration, Trade and Peoples. Part 1: Indian Ocean Commerce and the Archaeology of Western India, eds. Roberta Tomber, Lucy Blue, and Shinu Abraham, 29-41. London: The British Association for South Asian Studies.

Sen, Tansen. 2003. Buddhism, Diplomacy, and Trade: The realignment of Sino-indian relations, 600-1400. Asian Interactions and Comparisons. Honolulu: University of Hawai'i Press.

Senart, Émil, ed. 1882. Le Mahāvastu. 3 vols. Collection d'ouvrages orientaux : 2. Série, 1. Paris: Imprimerie nationale.

—. 1902. Inscriptions in the Caves at Karle. Epigraphia Indica 7: 47-74.

—. 1905. Inscriptions in the Caves at Nasik. Epigraphia Indica 8: 59-96.

Senior, Robert C. 2001. Indo-Scythian Coins and History. 3 vols. Lancaster, Pa.: Classical Numismatic Group.

Sharf, Robert H. 2002. Coming to Terms with Chinese Buddhism: A reading of the treasure store treatise. Studies in East Asian Buddhism, 14. Honolulu: University of Hawai'i Press.

Sharma, Ram Sharan. 1983. Material Culture and Social Formations in Ancient India. New Delhi: Macmillan.

- 1989. Trends in the Economic History of Mathurā (c. 300 BC-AD 300). In Mathurā: The Cultural Heritage, ed. Doris Srinivasan, 32-38. New Delhi: Manohar Publications for American Institute of Indian Studies.

Shastri, Ajay Mitra. 1965. An Outline of Early Buddhism: A historical survey of Buddhology, Buddhist schools \& sanghas mainly based on the study of pre-Gupta inscriptions. Varanasi: Indological Book House.

- 1992. The Age of the Vākāțakas. New Delhi: Harman Pub. House.

—. 1997. Vākātakas: Sources and history. Great Ages of Indian history. New Delhi: Aryan Books International.

Shaw, Julia. 2007. Buddhist Landscapes in Central India: Sanchi Hill and archaeologies of religious and social change, $c$. third century $B C$ to fifth century AD. London: British Association for South Asian Studies, The British Academy.

Shih, Robert, trans. 1968. Biographies des moines éminents de Houei-Kiao. Kao seng tchouan. Bibliothèque du Muséon, v. 54. Louvain: Institut orientaliste, Bibliothèque de l'Université.

Shinohara, Koichi, and Gregory. Schopen, eds. 1991. From Benares to Beijing : essays on Buddhism and Chinese religion in honour of Prof. Jan Yün-Hua. Oakville, Ontario: Mosaic Press.

Shrava, Satya. 1947. The Sakas in India. Lahore: Vedic Research Institute.

Sidebotham, Steven E. 1986. Roman Economic Policy in the Erythra Thalassa 30 B.C.A.D. 217. Mnemosyne, Bibliotheca Classica Batava, 91. Leiden: Brill.

Silk, Jonathan A. 2004. Buddhist Studies. In Encyclopedia of Buddhism, ed. Robert Buswell, vol. 1: 94-101. New York: Macmillan Reference, USA.

- 2008. Managing Monks: Administrators and administrative roles in Indian Buddhist monasticism. Oxford; New York: Oxford University Press. 
Sims-Williams, Nicholas. 1989-1992. Sogdian and other Iranian Inscriptions of the Upper Indus. 2 vols. Corpus Inscriptionum Iranicarum, pt. 2, v. 3, no. 2. London: Published on behalf of Corpus Inscriptionum Iranicarum by School of Oriental and African Studies.

- 1993. The Sogdian Inscriptions of Ladakh. In Antiquities of Northern Pakistan, ed. Karl Jettmar, vol. 2: 151-163. Mainz: P. von Zabern.

- 1996. The Sogdian Merchants in India and China. In Cina e Iran: da Alessandro Magno alla dinastia Tang, eds. Alfredo Cadonna and Lionello Lanciotti, 45-67. Orientalia venetiana 5. Firenze: L.S. Olshki.

— 1997. Zu den Iranischen Inschriften. In Ditte Bandini-König and Gérard Fussman, Die Felsbildstation Shatial, 62-72. MANP 2. Mainz: P. von Zabern.

- ed. 2002. Indo-Iranian Languages and Peoples. Proceedings of the British Academy 116. Oxford: Published for the British Academy by Oxford University Press.

- 2004 (2008). The Bactrian Inscription of Rabatak: A New Reading. Bulletin of the Asia Institute 18: 53-68.

Singh, Ajoy Kumar. 1988. Indo-Roman Trade. New Delhi, India: Commonwealth Publishers.

Sircar, Dineschandra. 1946. Eastern Deccan. In The Vakataka Gupta age, circa 200550 A.D., eds. Ramesh Chandra Majumdar and Anant Sadashiv Altekar, 64-92. Delhi: Motilal Banarsidass.

- 1957. Amudalapadu Plates of Vikramaditya I, Year 5. Epigraphia Indica 32: $175-184$.

- 1965. Select Inscriptions bearing on Indian History and Civilization from the 6th century B.C. to the 6th century A.D. 2nd ed. Vol. 1. Calcutta: University of Calcutta.

-. 1966. Indian Epigraphical Glossary. Delhi: Motilal Banarsidass.

—. 1967a. Cosmography and Geography in Early India Literature. Calcutta: Indian Studies: Past \& Present.

—. 1967b. Inscriptions of Aśoka. Rev. ed. New Delhi: Publications Division, Ministry of Information and Broadcasting, Govt. of India.

- 1968. The Saka Satraps of Western India. In The Age of Imperial Unity, The History and Culture of the Indian People, vol. 2: 178-190. Mumbai: Bharatiya Vidya Bhavan.

- 1969. Ancient Malwa and the Vikramäditya tradition. Carmichael lectures, 1962. Delhi: Munshiram Manoharlal.

. 1971a. Studies in the Geography of Ancient and Medieval India. Delhi: Motilal Banarsidass.

- 1971b. Some Problems concerning the Kușānas. Dharwar: Kannada Research Institute, Karnatak University.

- 1971c. Studies in the Religious Life of Ancient and Medieval India. Delhi: Motilal Banarsidass.

- 1983. Select Inscriptions bearing on Indian History and Civilization: from the sixth to the eighteenth century A.D. Vol. 2. Delhi: Motilal Banarsidass.

Sircar, Dineschandra, and K.G. Krishnan. 1960. Two Inscriptions from Nāgārjunakoṇḍa. Epigraphia Indica 34: 17-22.

Sizemore, Russell F., and Donald K. Swearer, eds. 1990. Ethics, Wealth, and Salvation: A study in Buddhist social ethics. Columbia, SC: University of South Carolina Press.

Skilling, Peter. 2005. Cutting Across Categories: Relics in Pāli Texts, the Bhadrakalpikasūtra, and the Saddharmapundarika-sūtra. Annual Report of the International Research Institute for Advanced Buddhology at Soka University 8: 269-332.

Skjærvø, Prods O. 2002. Khotanese Manuscripts from Chinese Turkestan in the British Library: A complete catalogue with texts and translations. Corpus Inscriptionum Iranicarum, 6. London: British Library. 
Smith, Jonathan Z. 1978. Map is not Territory: Studies in the history of religions. Studies in Judaism in late antiquity, 23. Leiden: Brill.

— 1987. To Take Place: Toward theory in ritual. Chicago studies in the History of Judaism. Chicago: University of Chicago Press.

- 1998. Religion, Religions, Religious. In Critical Terms for Religious Studies, ed. Mark C. Taylor, 269-284. Chicago: University of Chicago Press.

- 2004. Relating Religion: Essays in the study of religion. Chicago: University of Chicago Press.

Smith, Monica L. 1999. The Role of Ordinary Goods in Premodern Exchange. Journal of Archaeological Method and Theory 6.2: 109-135.

- 2002. The Role of Local Trade Networks in the Indian subcontinent during the Early Historic Period. Man and Environment 27.1: 139-151.

- 2005. Networks, Territories, and the Cartography of Ancient States. Annals of the Association of American Geographers 95.4: 832-849.

Snoy, Peter, ed. 1983. Ethnologie und Geschichte: Festschrift für Karl Jettmar. Beiträge zur Südasienforschung, 86. Wiesbaden: F. Steiner.

Speyer, J.S., ed. 1906. Avadānaçataka, a century of edifying tales belonging to the Hìnayāna. Bibliotheca Buddhica, 3. St. Pétersbourg: Commissionnaires de l'Académie Impériale des Sciences.

Spink, Walter M. 2005. Ajanta: History and development. 5 vols. Handbuch der Orientalistik, Section 2: India 18. Leiden; Boston: Brill.

Spodek, Howard, and Doris Srinivasan, eds. 1993. Urban Form and Meaning in South Asia: The shaping of cities from prehistoric to precolonial times. Studies in the history of art (Washington, D.C.), v. 31.; Symposium papers, 15. Washington; Hanover, N.H.: National Gallery of Art; Distributed by the University Press of New England.

Squarcini, Federico, ed. 2005. Boundaries, Dynamics and Construction of Traditions in South Asia. Kykéion studi e testi, 3. Firenze, Italy; New Delhi, India: Firenze University Press; Munshiram Manoharlal.

Srinivasan, Doris, ed. 1989. Mathurā: The cultural heritage. New Delhi: Manohar Publications for American Institute of Indian Studies.

— - ed. 2007. On the Cusp of an Era: Art in the pre-Kusana world. Brill's Inner Asian library, 18. Leiden; Boston: Brill.

Srivastava, Prashant. 2007. The Apracharajas: A history based on coins and inscriptions. Delhi: Agam Kala Prakashan.

Stacul, Giorgio. 1990. On Chārsada and Beyond: What is Wrong with Sir Mortimer? In South Asian Archaeology, 1987, eds. Maurizio Taddei and Pierfrancesco Callieri, vol. 1: 605-610. Serie orientale Roma 66. Rome: Istituto italiano per il Medio ed Estremo Oriente.

Stark, Rodney. 2005. The Victory of Reason: How Christianity led to freedom, capitalism, and Western success. New York: Random House.

Stark, Rodney, and William Sims Bainbridge. 1980. Networks of Faith: Interpersonal Bonds and Recruitment to Cults and Sects. American Journal of Sociology 85.6: 1376-1395.

Stark, Rodney, and Rodney Finke. 2002. Beyond Church and Sect: Dynamics and Stability in Religious Economics. In Sacred Markets, Sacred Canopies: Essays on religious markets and religious pluralism, ed. Ted G. Jelen, 31-62. Lanham, Md.: Rowman \& Littlefield.

Stein, Marc Aurel, trans. 1900. Kalhana's "Räjataranginī": A chronicle of the Kings of Kaśmìr. 2 vols. Westminster: A. Constable.

Stein, Aurel. 1907. Ancient Khotan: Detailed report of archaeological explorations in Chinese Turkestan. 2 vols. Oxford: Clarendon Press.

- 1921. Serindia: Detailed report of explorations in Central Asia and westernmost China carried out and described under the orders of H.M. Indian government. 5 vols. Oxford: Clarendon Press. 
1922. A Chinese Expedition across the Pamirs and Hindukush, AD 747. Geographical Journal 59: 122-131.

- 1928. Innermost Asia: Detailed report of explorations in Central Asia, Kan-su, and Eastern Iran. 2 vols. Oxford: Clarendon.

- 1942. From Swat to the Gorges of the Indus. Geographical Journal 100.2: $49-56$.

- 1944. Archaeological Notes from the Hindukush Region. Journal of the Royal Asiatic Society: 8-24.

Stein, Otto. 1934. Yavanas in early Indian inscriptions. Indian Culture 1: 343-357.

- 1985. Kleine Schriften. Ed. Friedrich Wilhelm. Glasenapp-Stiftung, 25. Stuttgart: Steiner.

Stein, R.A. 1962. La civilisation tibétaine. Collection Sigma, 1. Paris: Dunod.

- 1972. Tibetan civilization. Trans. J.E. Stapleton Driver. Stanford: Stanford University Press.

Stone, Elizabeth Rosen. 1994. The Buddhist art of Nāgārjunakonda. Buddhist traditions, 25. Delhi: Motilal Banarsidass Publishers.

Strauch, Ingo. 2007. The Bajaur collection: A new collection of Kharoșthī manuscripts. A preliminary catalogue and survey. http://www.geschkult.fu-berlin.de/e/indologie/ bajaur/publication/index.html.

- 2008. The Bajaur Collection of Kharoșthī Manuscripts-a preliminary survey. Studien zur Indologie und Iranistik 25: 103-136.

Strauch, Ingo, and Michael D. Bukharin. 2004. Indian Inscriptions from the Cave Hoq on Suquțrā (Yemen). Annali Istituto universitario orientale (Naples, Italy) 64: 121-138.

Strenski, Ivan. 1983. On Generalized Exchange and the Domestication of the Sangha. Man 18.3: 463-477.

Strong, John. 1983. The Legend of King Aśoka: A study and translation of the Aśokāvadāna. Princeton Library of Asian Translations. Princeton, N.J.: Princeton University Press.

- 2001. The Buddha: A short biography. Oxford: Oneworld.

—. 2004a. Relics of the Buddha. Buddhisms. Princeton, N.J.: Princeton University Press.

- 2004b. Aśoka. In Encyclopedia of Buddhism, ed. Robert Buswell, vol. 1, 34-35. New York: Macmillan USA.

Subrahmanyam, B. 1999. Buddhist Relic Caskets in Andhradeśa. Secunderabad: Ananda Buddha Vihara Trust.

Sutton, Nick. 1997. Aśoka and Yudhișthira: A Historical Setting for the Ideological Tensions of the Mahabharata? Religion 27.4: 333-341.

Swearer, Donald K. 2004. Becoming the Buddha: The ritual of image consecration in Thailand. Buddhisms. Princeton, N.J.: Princeton University Press.

Taddei, Maurizio, ed. 1979. South Asian Archaeology 1977: Papers from the fourth International Conference of the Association of South Asian Archaeologists in Western Europe, held in the Istituto universitario orientale, Naples. 2 vols. Series minor (Istituto universitario orientale (Naples, Italy) Seminario di studi asiatici, 6. Naples: Istituto universitario orientale.

- 2003. On Gandhāra: Collected Articles. Eds. Giovanni Verardi and Anna Filigenzi. 2 vols. Collectanea (Naples, Italy), 3. Napoli: M. D’Auria.

Taddei, Maurizio, and Pierfrancesco Callieri, eds. 1990. South Asian Archaeology, 1987: Proceedings of the Ninth International Conference of the Association of South Asian Archaeologists in Western Europe, held in the Fondazione Giorgio Cini, Island of San Giorgio Maggiore, Venice. Serie orientale Roma 66. Rome: Istituto italiano per il Medio ed Estremo Oriente.

Taddei, Maurizio, and Giuseppe De Marco, eds. 2000. South Asian Archaeology, 1997: Proceedings of the Fourteenth International Conference of the European Association 
of South Asian Archaeologists, held in the Istituto italiano per l'Africa e l'Oriente, Palazzo Brancaccio, Rome, 7-14 July 1997. 2 vols. Serie orientale Roma 90. Rome: Istituto italiano per l'Africa e l'Oriente.

Tambiah, Stanley Jeyaraja. 1976. World Conqueror and World Renouncer: A study of Buddhism and polity in Thailand against a historical background. Cambridge studies in social anthropology, 15. Cambridge; New York: Cambridge University Press.

- 1984. The Buddhist Saints of the Forest and the Cult of Amulets: A study in charisma, hagiography, sectarianism, and millennial Buddhism. Cambridge; New York: Cambridge University Press.

Tarn, W.W. 1951. The Greeks in Bactria \& India. 2nd ed. Cambridge: University Press. 3rd ed., Chicago: Ares Pub., 1984.

Tatelman, Joel. 2000. The Glorious Deeds of Pürna: A translation and study of the Pürnāvadāna. Curzon critical studies in Buddhism series. Richmond, Surrey: Curzon.

— - trans. 2005. The Heavenly Exploits: Buddhist biographies from the Divyāvadāna 1. The Clay Sanskrit Library. New York: New York Univ. Press.

Taylor, Mark C., ed. 1998. Critical Terms for Religious Studies. Chicago: University of Chicago Press.

Teiser, Stephen F. 2006. Reinventing the Wheel: Paintings of rebirth in medieval Buddhist temples. Seattle: University of Washington Press.

Thakur, Upendra. 1967. The Hūnas in India. Chowkhamba Sanskrit studies, 58. Varanasi: Chowkhamba Sanskrit Series Office.

Thapar, Romila. 1961. Aśoka and the Decline of the Mauryas. London: Oxford University Press. Rev. ed. with a new afterword, bibliography, and index, Delhi; New York: Oxford University Press, 1997.

—. 1975. Aśokan India and the Gupta Age. In A Cultural history of India, ed. A.L. Basham. Oxford: Clarendon Press.

- 1995. The First Millennium BC in Northern India. In Recent Perspectives of early Indian History, ed. Romila Thapar, 80-141. Bombay: Popular Prakashan.

- 2003. Early India: from the origins to $A D$ 1300. Berkeley: University of California Press.

Thewalt, Volker. 1983. Jātaka-Darstellungen bei Chilas und Shatial am Indus. In Ethnologie und Geschichte: Festschrift für Karl Jettmar, ed. Peter Snoy, 622-634. Beiträge zur Südasienforschung, 86. Wiesbaden: F. Steiner.

- 1985. Rockcarvings and Inscriptions along the Indus: In South Asian Archaeology 1983, eds. Janine Schotsmans and Maurizio Taddei, vol. 2: 779-800. Naples: Istituto universitario orientale.

Thierry, François. 2005. Yuezhi et Kouchans: Pièges et dangers des sources chinoises. In Afghanistan: Ancien carrefour entre l'est et l'ouest, eds. Osmund Bopearachchi and Marie-Françoise Boussac, 421-539. Turnhout, Belgium: Brepols.

Thomas, Frederick William. 1907. The Inscriptions on the Mathura Lion-Capital. Epigraphia Indica 9: 135-147.

_-, trans. 1935. Tibetan Literary Texts and Documents concerning Chinese Turkestan. 4 vols. Oriental Translation Fund. London: Royal Asiatic Society.

Tomber, Roberta. 2008. Indo-Roman Trade: From pots to pepper. Duckworth Debates in Archaeology. London: Duckworth.

Tomber, Roberta, Lucy Blue, and Shinu Abraham, eds. 2010. Migration, Trade and Peoples. Part 1: Indian Ocean Commerce and the Archaeology of Western India. London: The British Association for South Asian Studies.

Trainor, Kevin. 1997. Relics, Ritual, and Representation in Buddhism: Rematerializing the Sri Lankan Theravāda tradition. Cambridge Studies in Religious Traditions, 10. Cambridge, U.K.; New York: Cambridge University Press.

Trautmann, Thomas R. 1971. Kauțilya and the Arthaśästra; A statistical investigation of the authorship and evolution of the text. Leiden: Brill. 
Tremblay, Xavier. 2007. The Spread of Buddhism in Serindia-Buddhism among Iranians, Tocharians, and Turks before the 13th century. In Spread of Buddhism, eds. Ann Heirman and Stephan Peter Bumbacher, 75-129. Leiden: Brill.

Trenckner, V., ed. 1880. The Milindapañho: being dialogues between king Milinda and the buddhist sage Nāgasena. London: Williams Norgate.

Tripathi, Rama Shankar. 1942. History of Ancient India. Delhi: Motilal Banarsidass.

Tsuchiya, Haruko. 1999. Tracing Ancient Routes in Northern Pakistan. Field research (1991-1996) (Preliminary report). In Coins, Art, and Chronology: Essays on preIslamic history of the Indo-Iranian borderlands, eds. Michael Alram and Deborah Klimburg-Salter, 353-390. Beiträge zur Kultur- und Geistesgeschichte Asiens, 31. Vienna: Österreichischen Akademie der Wissenschaften.

Tsukamoto, Keisho. 1996. Indo Bukkyo himei no kenkyu (A Comprehensive Study of Indian Buddhist Inscriptions). 3 vols. Kyoto-shi: Heirakuji Shoten.

Tucci, Giuseppe. 1958. Preliminary Report on an Archaeological Survey in Swat. East and West 9: 279-328.

Tweed, Thomas A. 2002. On Moving Across: Translocative Religion and the Interpreter's Position. Journal of the American Academy of Religion 70: 253-278.

. 2006. Crossing and Dwelling: A theory of religion. Cambridge, Mass.: Harvard University Press.

Upadhyaya, Bhagwat Saran. 1968. India in Kälidāsa. 2nd ed. Delhi: S. Chand.

Uray, G. 1979. The Old Tibetan Sources of the History of Central Asia up to 751 A.D.: A Survey. In Prolegomena to the sources on The history of Pre-Islamic Central Asia, ed. János Harmatta, 275-304. Budapest: Akadémiai Kiadó.

Vásquez, Manuel. 2008. Studying Religion in Motion: A Networks Approach. Method \& Theory in the Study of Religion 20: 151-184.

Vasu, Srisa Chandra, trans. 1891. The Ashtádhyáyí of Pánini. 8 vols. Allahabad: Indian Press.

Verardi, Giovanni. 1983. The Kuṣāna Emperors as Cakravartins. Dynastic Arts and Cults in India and Central Asia: History of a Theory, Clarifications, and Refutations. East and West 33: 225-294.

- 2007. Excavations at Gotihawa and Pipri, Kapilbastu District, Nepal. Roma: IsIAO.

Vogel, Jean Philippe. 1929. Prakrit Inscriptions from a Buddhist Site at Nāgārjunikoṇ̣a. Epigraphia Indica 20: 1-37.

—. 1930. Additional Prakrit Inscriptions from Nāgārjunikoṇḍa. Epigraphia Indica 21: 61-71.

Vogelsang, W.J. 1992. The Rise and Organisation of the Achaemenid Empire: The eastern Iranian evidence. Studies in the History of the Ancient Near East, 3. Leiden; New York: Brill.

Wagle, N.K. 1966. Society at the Time of the Buddha. Bombay: Popular Prakashan.

Walsh, Michael J. 2007. The Economics of Salvation: Toward a Theory of Exchange in Chinese Buddhism. Journal of the American Academy of Religion 75.2: 353-382.

Warmington, Eric Herbert. 1928. The Commerce between the Roman Empire and India. Cambridge: University Press.

Warner, R. Stephen. 2002. More Progress on the New Paradigm. In Sacred Markets, Sacred Canopies: Essays on religious markets and religious pluralism, ed. Ted G. Jelen, 1-30. Lanham, Md.: Rowman \& Littlefield.

Weber, Max. 1921. Hinduismus und Buddhismus. Tübingen: Mohr.

—. 1922. Gesammelte Aufsätze zur Religionssoziologie. Tübingen: Mohr.

- 1958. The Religion of India; The Sociology of Hinduism and Buddhism. Trans. Hans Gerth and Don Martindale. Glencoe, Ill.: Free Press.

- 1996. Gesamtausgabe Die Wirtschaftsethik der Weltreligionen Hinduismus und Buddhismus, 1916-1920. Ed. Helwig Schmidt-Glintzer. Tübingen: Mohr. 
- 2001. The Protestant Ethic and the Spirit of Capitalism. Trans. Stephen Kalberg. 3rd ed. Los Angeles, Calif.: Roxbury Pub. Co.

- 2001. The Protestant Ethic and the Spirit of capitalism. Trans. Talcott Parsons. Routledge classics. London: Routledge.

Whalley, W.B. 1983. Desert Varnish. In Chemical sediments and geomorphology: precipitates and residua in the near-surface environment, eds. Andrew Goudie and Kenneth Pye, 197-226. London: Academic Press.

Wheeler, Mortimer. 1962. Chärsada, a metropolis of the North-west Frontier, being a report on the excavations of 1958. London: Published for the Goverment of Pakistan and the British Academy by the Oxford University Press.

Whitfield, Susan, ed. 2004. The Silk Road: Trade, travel, war and faith. London: British Library.

Widemann, François. 2004. Une confirmation numismatique de l'era yavana de 186/5. Nomismatika Chronika 23: 37-45.

Wijayaratna, Môhan. 1983. Le moine bouddhiste selon les texts du Theravāda. Paris: Éditions du Cerf.

- 1990. Buddhist Monastic Life according to the texts of the Theravāda tradition. Trans. Claude Grangier and Steven Collins. Cambridge; New York: Cambridge University Press.

Willemen, Charles, trans. 1994. The Storehouse of Sundry Valuables. BDK English Tripitaka, 10-I. Berkeley: Numata Center for Buddhist Translation \& Research.

Williams, Joanna Gottfried. 1982. The Art of Gupta India: Empire and province. Princeton, N.J.: Princeton University Press.

Willis, Michael D. 1999. The Sānchī Bodhisattva dated Kuṣāna year 28. Silk Road Art and Archaeology 6: 269-273.

- 2000. Buddhist Reliquaries from Ancient India. London: Published for the Trustees of the British Museum by British Museum Press.

- 2005. Later Gupta History: Inscriptions, Coins and Historical Ideology. Journal of the Royal Asiatic Society 15.2: 131-150.

- 2009. The Archaeology of Hindu Ritual: Temples and the establishment of the gods. Cambridge; New York: Cambridge University Press.

Wirth, Gerhard and Oskar von Hinüber, trans. 1985. Der Alexanderzug; Indische Geschichte: Griechisch und deutsch. Sammlung Tusculum. München: Artemis.

Witzel, Michael. 1987. On the Localisation of Vedic Texts and Schools (Materials on the Vedic Śakhas 7). In India and the Ancient World: History, Trade and Culture before A.D. 650, ed. Gilbert Pollet, 173-213. Orientalia Lovaniensia analecta, 25. Leuven: Departement Oriëntalistiek.

— - ed. 1997. Inside the Texts, Beyond the Texts: New approaches to the study of the Vedas. Proceedings of the International Vedic Workshop, Harvard University, June 1989. Harvard oriental series, Opera minora, v. 2. Cambridge, Mass.: Harvard University Dept. of Sanskrit and Indian Studies.

Wood, Leela Aditi. 2004. The Ajanta Cave 17 Inscription as a Preface to the Local King's Vihāra: History, Religious Story and Homology. In The Vākātaka Heritage: Indian culture at the crossroads, ed. Hans Bakker, 109-132. Groningen: E. Forsten.

Yaldiz, Marianne and Wibke Lobo, eds. 1987. Investigating Indian Art: Proceedings of a Symposium on the Development of Early Buddhist and Hindu iconography. Veröffentlichungen des Museums für Indische Kunst Berlin 8. Berlin: Museum für Indische Kunst.

Yang, Han-sung, trans. 1985. The Hye-Ch'o Diary: Memoir of the pilgrimage to the five regions of India. Religions of Asia series, vol. 2. Berkeley: Asian Humanities Press.

Yazdani, Ghulam, ed. 1961. The Early History of the Deccan. 2 vols. London; New York: Published under the authority of the Government of Andhra Pradesh by Oxford University Press. 
Yuyama, Akira. 2000. Eugène Burnouf: The background to his research into the Lotus Sutra. Bibliotheca philologica et philosophica buddhica, 3. Tokyo: International Research Institute for Advanced Buddhology.

Zeimal, E.V. 1996. The Kidarite kingdom in Central Asia. In History of Civilizations of Central Asia, ed. Boris A. Litvinsky, vol. 3: 119-133. Paris: UNESCO.

Zin, Monika. 2003. Devotionale und ornamentale Malerei: Ajanta, Handbuch der Malereien 2. 2 vols. Wiesbaden: Harrassowitz.

Zürcher, Erik. 1959. The Buddhist Conquest of China: The spread and adaption of Buddhism in early medieval China. 2 vols. Sinica Leidensia 11. Leiden: Brill.

- 1962. Buddhism: Its origin and spread in words, maps, and pictures. New York: St Martin's Press.

- 1968. The Yüeh-chih and Kanișka in the Chinese Sources. In Papers on the Date of Kaniskka, ed. A.L. Basham, 346-390. Oriental monograph series 4. Leiden: Brill.

- 1987. Buddhist Missions. In The Encyclopedia of religion, eds. Mirceau Eliade, and Charles J. Adams, vol. 9: 570-573. New York: Macmillan.

- 1990. Han Buddhism and the Western Region. In Thought and Law in Qin and Han China: Studies dedicated to Anthony Hulsewé on the occasion of his eightieth birthday, 158-182. Sinica Leidensia 24. Leiden, New York: Brill.

- 1991. A New Look at the Earliest Chinese Buddhist Texts. In From Benares to Beijing: Essays on Buddhism and Chinese religion in honour of Prof. Jan Yün-Hua, eds. Koichi Shinohara and Gregory Schopen, 277-304. Oakville, Ontario: Mosaic Press.

- 1999. Buddhism Across Boundaries: The Foreign Input. In Erik Zürcher, et al, Collection of Essays 1993: Buddhism across Boundaries: Chinese Buddhism and the Western Regions, 1-60. Sanchung, Taiwan: Fo Guang Shan Foundation for Buddhist \& Culture Education.

Zwalf, Wladimir. 1996. A Catalogue of the Gandhära Sculpture in the British Museum. 2 vols. London: British Museum. 


\section{INDEX}

Achaemenids $108,96-98,101 \mathrm{n} 105$, 108, 111-112, 190, 201, 203, 283

Aï Khanum 100-101, 104, 251

Ajantāā 31-32nn 87-93, 147-149, 207, 215

Ājīikas $\quad 72,81,85-86,93,180$, 313-314

Alam Bridge inscriptions $173,265-267$, 278, 285-286

Alberuni, Al-Bīrūnī. See Bīrūnī, al-

Alexander of Macedon 69n 9, 80-81, 96, 98-102, 196n 33, 233

Amu Darya. See Oxus River

An Shigao 6, 305

Anāthapiṇdada, Anāthapiṇ̣ika 27-28, 77

Apracas $117-119,122,125,131,135$, 255

Arachosia 100, 114, 116, 125, 185 (Map 3.1), 224, 244

archaeology artifacts and sources, $1-2,39-41,54-60,66-67,209$ n 82, 258, 265, 278-287, 307-308; Buddhist sites, 15, 19-21, 34, 138n 220, 141, 146, 164, 204 (map 3.2), 212-214, 216-217, 229-251, 230 (map 4.1), 273, 290 (map 6.1), 294-302; 311-313; comparative study, 11; excavations in Afghanistan, 100-101, 246-251, 247 (map 4.2); trade, 21-22, 94-95, 183, 186-187, 205, 219-220, 228, 316

Arikamedu 218 (map 3.3), 224-225

Āryāvarta 76, 152, 185 (map 3.1), 190, 193-197, 205, 227, 314

Arthaśāstra, attributed to Kautilya 29, 80n 42, 208-209n 82

Aśoka 81-94, 180-181; Buddhist patronage of, 9n 21, 79, 88-94; inscriptions of, 43, 52-53, 69-70, 83-91, 84 (map 2.2), 100, 129, 152153, 188-189, 199, 205-206, 212-214; interpretation and promulgation of Dharma, 85-88, 93; and Kaniska, 137-139, 144; and Taxila, 202-203. See also dates and dating systems,
Aśoka; dharma, dharmarājika stūpas; Mauryas

Aśpavarman 118-119, 125, 131, 255. See also Apracas

avadānas 28-29, 30 (fig. 1.2), 32, 44, $68 \mathrm{n} 6,77,82,105 \mathrm{n} \mathrm{115,118,127 \textrm {n }}$ 186, 131, 141, 231, 254-256, 308, 316; Avadānaśataka, 28; Divyāvadāna, 24n 68, 28-29, 32nn 89-91, 82, 93, 254n 75; Siṃhala Avadāna, 30 (fig. 1.2), 32, 254n 73

Avalokiteśvara 30 (fig. 1.2), 32-34, 38, 284, 316

Azes 103, 109-110, 116-119, 123-124 (Table 2.2). See also under dates and dating systems, Azes era and Sakas / Śakas

Bactria 27n 80, 62, 95, 97n 95, 98, 102-103, 109, 113-114, 132-135, 140, 144,159 n 299, 160-162, 169-170, 185 (map 3.1), 202, 224-225, 231-235, 240, 246, 247 (map 4.2), 250-257, 275, 291, 295-296, 299, 302, 312. See also inscriptions, Bactrian

Badakhshan 94, 186, 222n 124, 247 (map 4.2), 250, 261, 265-266, 276, 279

Bajaur 43n 126, 44, 61, 104n 113, 118, 200, 230 (map 4.1), 232-233, 238, 242, 244. See also under Kharosthì manuscripts, Bajaur collection

Balkh 247 (map 4.2), 251

Baltistan 176, 259 (map 5.1), 264-267, 271, 273n 54, 276-277, 300

Bamiyan 46, 59, 170, 232, 242, 247 (map 4.2), 249-250, 253, 315

Barbaricon 218 (map 3.3), 221-222, 227

Barygaza 126-127, 199, 204 (map 3.2), 214-216, 218 (map 3.3), 222-223, 227

bhadrakalpa $65,88 \mathrm{n} 68$

Bhadrakalpika sūtra 46n 134, 56n 155, 243n 42

Begram (ancient Kapiśa) 37n 109, 113-114, 144, 160n 302, 247 (map 4.2), 248-249, 251-252 
Bezeklik caves. See Turfan

Bhallika 26 (fig. 1.1), 27-28

Bharhut 24, 49-50 (fig. 1.3), 88n 68, 206, 185 (map 3.1), 204 (map 3.2), 206, 210 (fig. 3.1), 211-212, 228, 316

Bharukaccha. See Barygaza

Bīrūnī, al- 138, 196, 276-277

Bodh Gaya 2, 22n 64, 50-51, 70, 72, 84 (map 2.2), 88n 68, 145-146, 192

Bolor 176, 274-277

Brāhmī See inscriptions, Brāhmī

Brahmins 24, 31, 66, 71-74, 76, 80, $85,92-94,108,163,165,181,184$, 193-194, 209, 313-314

Butkara I 230 (map 4.1), 233, 236, 245

caitya 20 n $55,24,54-55$ n 151,57 n $159,178,185,207-208$ n 78, 215-217, $228,270,272,287,318$

cakravartin $2,55-56,81,92,105,139$ n $226,158,181,190,200$

Candragupta Maurya 69n 9, 78-81, 151. See also Mauryans

capillary routes $1,12,61-62,207,208 \mathrm{n}$ 80, 244, 257-268, 259 (map 5.2), 278, 286-287, 289, 291-292, 295, 302-303, $312-313$

caravan $4,28,31-34,36-38,201-202$, $225,258,264,267,301,317$

caravan-leader (särthavāha) 4, 28-29, $32-33,38,316$

Cașțana 124 (Table 2.2), 128-129. See also Western Kșatrapas

Central Asia 3-4, 15, 44, 52-53n 150, $62,109-114,122$ n 167, 132-134, 157-158, 176, 181, 201-202n 167, 225, 231, 239-240, 251-253, 256, 289-309, 290 (map 6.1), 311-312, 317-319; eastern Central Asia, 6, 12, $31,112-113,133,144,244,257,263$, 289-304, 290 (map 6.1), 306-308, 313, 315; western Central Asia, 23, 95, 97, 110-111, 159-162, 169-170, 186, 246, 250, 257, 265, 276, 292n 4, 302, 306. See also Bactria, Dunhuang, Endere, Khotan, Kucha, Lou-lan, Merv, Miran, Niya, Oxus River, Sogdia, Tarim Basin, Turfan, Yarkand Ch'ang-an (Xian) 252, 274, 292, 306 Chilas 58n 161, 173, 202, 259 (map 5.1), 262-263, 269, 272, 273 (fig. 5.1), 274, 277, 283-285 (fig. 5.4), 294-295

China $3-4,15,62,144,222-225,248$, 250, 257, 269-271, 289-309; Chinese Buddhism, 5-7, 17n 50, 18n 52, 23n
67, 35, 44n 128, 47n 136, 62, 105, 138-139, 141, 243, 302-309; Chinese history, 37n 109, 48, 112-113, 132-134, 159-162, 176, 266, 292-294, 299; Chinese inscriptions, 53, 258, 269, 271, 286

Chinese pilgrims $37,61-62,137-138$, 170n 331, 229, 251-253, 263, 272-276, 289; Faxian, 138, 201-202, 237, 252-253nn 71-72, 272-274, 287, Huisheng, 167, 253, 264, 274; Huizhao, 176, 275-276; Song Yun, 37n 109, 167, 253, 264, 274-275; Xuanzang 27n 80, 37n 109, 138, 168, 179, 196, 200-202, 249, 253, 275-276, 287; Wukong, 37n 109, 178n 358, Zhemong, 252-253

Chitral 160n 302, 230 (map 4.1), 233, 244, 253, 259 (map 5.1), 261-266, 274, 279, 295

Christianity, medieval $14 \mathrm{n} 35,23,36$, 124,236

coins $12,27,39-40,43,51,54,59-60$, 94, 183, 201, 205, 238-239, 241, 248, 250n 60, 295-296, 299; coins, Bactrian and Indo-Greek, 101-105; coins, Gupta, 151-154; coins, Hun, 165, 167; coins, Kidāra, 159-160, coins, Kuṣānạ, 134-143, 295; coins, Roman, 219-222, 226; coins, Saka, 115-118, 122n 167, 123-128, 131, 255;

commodities $10-12,17,21-24,29,35$, $37-38,48,127,144,165,183-184$, $186,189,209,217-227,258-259$, 261, 286, 291, 299, 302, 311-312. See also economy, economy of religion, endowments, long-distance trade, merchants, merit, religious markets, seven jewels, Silk routes, surplus, trade

contact expansion $\quad 4-7,302-304$, 308-309, 312-313. See also diffusion, long-distance transmission, Zürcher, Erik

Ctesias 97, 190

"cult of the book" 57-58, 172. See also "dharma body" (dharmakāya)

Dadam Das 259 (map 5.1), 269, 281-282

Dakṣināpatha. See Southern Route Dāna. See gift

Darada / Dard 190, 195-196, 263

dates and dating systems 20n 55, 28-29nn 82-83, 42-43, 52, 54, 59, 71, 
74, 78-81, 116, 178-180; 187-188n 9, 191n 19, 194n 28, 219n 110, 233n 8, 296n 19; date, Aśoka 68, 82-83; Azes era 109-110, 117-118, 123-125; dating, historical Buddha 67-69 (table 2.1), 180; Gupta era $51 \mathrm{n} 145$, 145, 151n 265, 156-157 (table 2.4); Indo-Greek (Yavana) era 102-103n 110; Kanișka era 136-137, 140-143, 145 (table 2.3); Laukika era, 162, 172-175, 177 (table 2.5); Śaka era 110, 126-129, 136-137; theory of "omitted hundreds" 137n 219, 142-143

devadharma / deyadharma 51, 58, 164, 172, 272, 281-282 (fig. 5.3), 284, 287, 311

dhāran̄is $\quad 57-58 \mathrm{n} \mathrm{160,172,} 252$

dharma Buddhist teachings, transmission of, 1, 47, 63, 89, 123, 140, 254, 315; concepts, 83-87, 92-93, 181, 193, 312; decline, 90, 255; dharmacakra ("wheel of dharma"), 2-3, 65, 114, 231; dharmakàya ("dharma body"), 57-58, 172, 318; dharmarāja, 78-94; dharmarājika stūpas, 177, 203, 233, 235, 315; naming element, 32, 139n 225, 166-167, 251-252, 274; titles, 134

Dharmapada $8,43,71,241,296$ Dharmarakșa 243n 43, 300, 306-307 Dharmaśāstra 29-31, 76n 32, 109n 129, 193n 25, 194,

Dharmasūtra 76, 194-196,

diffusion $2,4-7,59-60,235-236,260$, 292, 295, 302-303, 308-313, 319. See also contact expansion

digvijaya 152-153, 190-191, 254. See also praśasti

Divyāvadāna. See avadānas, Divyāvadāna

domestication 9, 231, 253-256

donors 5, 11-12, 14, 17-20, 24-34, 26 (fig. 1.1), 38, 49-51, 58, 77, 99 (fig. 2.1), 106-107, 117-119, 122-123, 131, 137-142 (figs. 2.2-2.3), 144-146, 148-149, 155-156, 162-166, 171-175 (fig. 2.4), 199, 206-208, 211-214, 217, 272, 285, 311-312. See also gift, patronage

Dunhuang 133n 203, 290 (map 6.1), 292-293, 299, 306

economy $2,4-5,9-10,17-24,29,45$, $74-75,80,91,94,145,149,183-184$, 187, 217, 226-227, 231, 238, 245-246,
260-261, 275-276, 287, 294-300, 308, 311-312. See also merchants, "moral economy", trade

economy of religion $12-17,34-39$, $66,181,315-317$. See also religious markets, trade, religion and

Endere 290 (map 6.1), 295, 297-299

endowments $35,38,51,145,181,239$, 316

epigraphy. See inscriptions

Faxian. See Chinese pilgrims

Foucher, Alfred. 51n 146, 100n 99, 104n 113, 107-108, 232, 234n 9, 235-240, 246-251 (map 4.2), 295

Gandhāra 12, 37n 109, 53, 61-62, 75 (map 2.1), 76, 80-81, 84 (map 2.2), 90, 95-98, 103-106, 112-115, 125, 131-134, 144, 159-161, 167-169, 185 (map 3.1), 192-193, 195, 200-201, 207n 74, 225, 229-256, 263-266, 274, 279, 282, 312-313; Gandhāran archaeology, 22-23nn 64-66, 230 (map 4.1), 233-239, 245-246, 248-251, 294-295, 299; Gandhāran art, 26 (fig. 1.1), 58, 107-108, 175, 239-240, 254, 284, 296-297, 299, 301, 314; Gāndhārī language, 31, $42-44,46,110,118,131,241-243$, 248, 254-255, 296-298, 314 (see also inscriptions, Kharoșțhì and Kharoșțhī manuscripts)

Ganga-Yamuna doāb 49, 74-76 (map 2.1), 121, 133, 140, 143-144, 149n 257, 152-153, 179, 184-194, 185 (map 3.1), 197-200, 208, 212-213, 228

Ganges River. See Ganga-Yamuna doāb Gichi Nala 259 (map 5.1), 269n 43, 282 gift (dāna) 5, 17-19n 53, 25, 26 (fig.1.1), 27, 34, 38-39, 49 (fig. 1.3), 50-51, 58, 85, 99 (fig. 2.1), 131, 144-145, 164, 172, 175, 212, 217, 241, 249, 262, 272, 280-281, 284, 287, 299n 24, 302, 311, 316-317. Also see devadharma/deyadharma

Gilgit 59, 61-62, 159, 163n 307, 171-177, 233, 244, 257-271 (map 5.1), 276-277, 285, 287, 295, 313; Gilgit bronzes, 173-175 (fig. 2.4); Gilgit manuscripts, 56n 156, 171-172, 296

Gondophares 119, 123-125, 135, 221n 118,295 n 18

graffiti 12, 25-26, 51-54, 122n 166, 137n 219, 169-170, 173, 221, 257-259 
(map 5.1), 261-262, 266-272, 276, 279-287 (figs. 5.1-5.4), 298, 301

grhapati. See householders

Guptas. 31n 86, 130-131, 137n 219, 145-157 (table 2.4), 162, 165-168, $179,191,199,208,213-214 n$ 94, See also dates and dating systems, Gupta era

Han shu 112-113, 133-134nn 203-206. See also China, Chinese history

Hanging Passages (Xuan du) 113n 141, 259 (map 5.1), 263, 274-275, 279

Harșavardhana 37n 109, 179, 191-192

Hāthīgumphā inscription 188-189n 12,191

Heliodoros pillar 99 (fig. 2.1), 106, 206

Hellenism 79, 83, 86n 61, 90, 96-109, 114-116, 126-127, 133-136, 181, 189-190, 199, 201n 56, 206, 213, 219, 223-225, 229, 234n 9, 239-241, 250-251, 255, 314

Herodotus 96-97, 111, 190, 196

Hindu Kush 62, 94-95, 103, 114-115, 132-134, 144, 160-162, 170n 231, $229,235,244,246-252$ (map 4.2), 259 (map 5.1) -266, 303, 316

Hodar 259 (map 5.1), 266. 269, 281-282 (fig. 5.3),

Hou Han shu 134nn 205-206, 144n 242, 293-294. See also China, Chinese history

householders (grhapati) 2, 5, 22n 64, 24, 71, 77, 85, 89n 69, 217

Huisheng. See Chinese pilgrims

Huns / Hūnas 159-170, 179, 191-192

Hunza 61, 173, 176n 254, 233, 257, 259 (map 5.1), 260-268, 270n 44, 271, 278,286

Huviṣka 50, 137, 140-145 (table 2.3), 201

Ikṣvākus $\quad 130,145$

images $1-4,6-7,12,25,50-51,54$, 57-60, 63, 102, 107, 135-136, 138, 141-144, 146, 153-155, 173-175, 178, 200, 208, 210 (fig. 3.1), 239-241, 257, 262, 272-273 (fig. 5.1), 275, 287, 296-297, 307, 317-318. See also petroglyphs)

"imperial metaphors" 158

"implantation" (of Buddhism) 105n $116,107,229$,
Indo-Greek. See dates and dating systems, Indo-Greek (Yavana) era; Hellenism; Yavanas

Indo-Scythian. See Sakas / Śakas

Indravarman 56n 156, 117n 156, 118-119, 122, 131. See also Apracas

Indus River 96-98, 143, 164n 314, 178, 184-185 (map 3.1), 191, 193n 25, 194, 221-222, 229, 232-234, 244; upper Indus, 113, 136, 173, 196, 202, 257-287, 259 (map 5.1), 294-295, 303, 313-315

inscriptions $11-12,24-26,33-35,39$, 48-54, 59, 61, 96, 100-101, 110-112, 179-181, 227, 229, 258-259 (map 5.1), 262, 313-317; Bactrian, 53, 132-133n 201, 135-136, 143n 240, 169, 200n 49, 269-270; Brāhmī, 24-25, 49-53 (fig. 1.3), 69-70, 99 (fig. 2.1), 106-107, 123, 126-130, 140-157, 162-167, 191-193, 199, 206-213 (fig. 3.1), 220-221, 266, 268-272, 280-287; Kharosțhī, 26-27n 78, 33, 43, 53, 56n 156, 103, 104n 113, 110n 131, 116-125 (figs. 2.2-3), 134-135, 138, 141, 221, 240-241, 268-273 (fig. 5.1), 280-283 (fig. 5.4), 285-287, 295n 18, 297n 25, 298, 312; Proto-Śāradā, 53, 172-175 (fig. 2.4), 280-281 (fig. 5.3); Sogdian, 53, 169-170, 269-271, 279-282 (fig. 5.2). See also Aśoka, inscriptions of, and China, Chinese inscriptions

Isidore of Charax. See Parthian Stations

Jaina, Jainism, Jains $8,18-19$ n 53, 25-27nn 77-79, 29, 69, 72-73, 75-76, 79-81, 86-87, 93, 123, 127, 146, $153-155,180,200,208,215,313-314$

Jalalabad (ancient Nagarahāra) 192, 232, 238, 246-248 (map 4.2), 264 jātakas 28, 31n 87, 32n 92, 62, 202, 210 (fig. 3.1 Bharhut Mahaumagga jātaka), 231, 272, 280n 70, 287, 308, 316; Jātakamālā 149; Śibi Jātaka 279-280 (fig. 5.2 and cover);

Viśvantara Jātaka 298; Vyāghrī Jātaka 201, 284. See also avadānas

Jibin 113, 134n 206, 251-252, 274, 306, Junagadh (Girnar) inscriptions 83, $129,155,199,208 \mathrm{n} 81$

Kabul River 193n 26, 230 (map 4.1), 232, 238, 247 (map 4.2) 
Kalhana. See Rājatarañgiñ

Kālidāsa. See Meghadūta and Raghuvamśa

Kalpanāmaṇditikā 141n 234

Kandahar 83-84 (map 2.2), 86n 61, 100, 218 (map 3.3), 224-225, 233, 244

Kanheri 25nn 74-75, 129, 145n 245, 204 (map 3.2), 207-208n 78, 217,

Kanisska 132-145, 181, 192, 237, 295. Also see dates and dating systems, Kaniska era)

Kapilavastu 2, 70, 75 (map 2.1)

Kapiśa. See Begram

Karakorum 51, 62, 94, 113-115, 170n 331, 171-176, 185 (map 3.1), 202, 229, 244, 250n 61, 257-268 (map 5.1), 277, 286, 295-296, 303, 313

Kārdamakas $115,124,126-131$

Kargah valley 171, 259 (map 5.1), 266,

Kashgar 144n 243, 252, 290 (map 6.1), 292-295, 306

Kashmir 53, 61, 113, 138n 234, 139, 164, 167-169, 175-178, 185 (map 3.1), 192, 195, 201-202, 222, 251, 254, 260, 263-264, 267, 271, 274-277, 286, 295, 301-303, 306, 313. See also Rājatarañgin̄ $\bar{\imath}$

Kauśāmbī 33, 75 (map 2.1), 84 (map 2.2), 89, 132n 201, 149n 257, 187, 198, 204 (map 3.2), 205-206, 212, 255,

Kauțilya. See Arthaśāstra

Kharaosta / Kharayosta 119, 122-124

Kharoșțī script, 43n 124, 52-54, 83, 98, 103, 115, 134, 136, 295-299, 302; Kharosthì manuscripts $42-44,110$, 131, 241-243, 312; Bajaur collection, 242n 39; British Library, 58n 162, 68n 6, 77, 118n 160, 127, 242, 254-255, 308; Khotan Dharmapada 43, 71, 241; Library of Congress, 88n 68, 242; Schøyen collection, 242n 38; Senior collection 140, 242n 37; "split" collection, 242n 50. See also Gandhāra, Gāndhārī language; inscriptions, Kharosthīi

Khotan 43, 59, 62, 144, 196n 34, 252, 264, 272-274, 290 (map 6.1), 292, 295-300, 304-306, 313-315; Khotanese Śaka, 177n 356, 260, 277, 301. See also Kharoșthī manuscripts, Khotan Dharmapada

Kidāras 159-162, 170n 230, 250n 60

Kizil caves. See Kucha

Kosala 77, 132, 75 (map 2.1), 77, 132, 141, 194,
Kroraina (Shan-shan) 144n 242, 297-300, 304

Kșaharātas 115, 126-128

Kșatrapas 116, 119, 121-124, 126-131, 199-200,

Kṣatriyas $\quad 24,31,70-71,92-94,109$, 131, 196

Kucha 43n 124, 62, 242, 252, 270, 290 (map 6.1), 292, 295, 300-302, 306,

Kujūla Kadphises 119, 132-135, 145, 295

Kumārajīva 252, 306-307

Kuṣānas $\quad 132-145,151,159-160$

land grants $38,149,181,208$. See also endowments, patronage

lay devotees (upāsakas/ upāsikās) 5, 14, 17-19, 24, 26-27 (fig. 1.1), 37, $51,55,58,87-90,105,139-140,240$, 305-306, 314-315. See also donors, gift, patronage

long-distance transmission $4-7,62$, 161, 259-260, 289, 300, 302-319.

See also contact expansion, diffusion, Zürcher, Erik

Lotus sūtra (Saddharma-pundarìka sūtra) 32n 93, 243n 43, 149

Lou-lan 290 (map 6.1), 293, 295, 298-299, 304

Loyang 252, 292, 299, 304-308, 313

Magadha 72, 75 (map 2.1)-81, 132, 151, 168, 184, 188n 10, 191, 194, 197, 228-229, 231, 314

Mahābhārata 91-93, 109n 129, 190-191, 195-196, 200n 52, 209-211n 23

Mahāvastu 22n 64, 28-29n 83, 32-33nn 90, 92, 95, 45-46

Mahāyāna 4n 8, 22, 32, 44, 46, 50-51, 57-58, 138, 140-142, 146, 149, 163, $172,180,243$ n 42, 284, 296, 298, 307, 318

Maitreya 273-275, 284, 287

Mathura 25, 30 (fig. 1.2), 45n 131, 50, $53,58,93 \mathrm{n} 81,108 \mathrm{n} 124,110,117,121$ (fig. 2.3) -124, 126-128, 131-132, 136, 140-147, 151n 265, 166, 185 (map 3.1)-186, 197-200, 205, 208n 80, 212, $215,228,234,270 \mathrm{n} 44,301,316$

Maues 115-117, 124 (table 2.2), 295n 18

Mauryas $11,52,60,68,78-94,98,104$, $151,181,188,203$ n 65, 205-206, 209n $82,214,228,233,314-315$ 
Megasthenes 79n 40, 81n 46, 97n 94, 189-190, 199n 46

Meghadūta 210-11, 214

Menander 104-106, 181, 200; Milindapañha, 33, 105n 115, 200 merchants 24- 34 (figs. 2.1-2.2), 37-38, 47, 51, 77, 100-101, 106n $120,133,158,165-166,168-170$ nn 326-328, 180-181, 184, 189, 201-202, 207, 212, 214, 216-227, 249-250, 263n 26, 270-271, 276, 280, 293-301, $308,311-317$. See also caravan, caravan-leader, economy, trade merit 12, 17-19, 23-24, 34, 38, 49-51, 56-59, 141, 164, 172, 180-181, 272, 281-282, 311-318. See also gift, "moral economy"

Milindapañha. See Menander

Miran 62, 290 (map 6.1), 292-293, 297-299, 304

Mogao caves. See Dunhuang monasteries, residential (vihāra) 1, 5-7, 9, 11-12, 14, 17-21, 24-27, $34-39,50-51,58-63,88-91,117-122$, $125,130-131,138-141,144-149,156$, 162-164, 167, 171n 335, 177-179, $181,189,192-193,203,207,211-217$, 228-239, 242, 245-250, 253-254, 272, 277-278, 286-289, 296-309, 312-317

"moral economy" 23-24, 311

Mūlasarvāstivāda-vinaya 28, 32n 92, $35 \mathrm{n} \mathrm{100,37n} \mathrm{111,} \mathrm{171,} 254$

Muziris 218 (map 3.3), 221, 223-224; Muziris papyrus, 220, 226

Nagarahāra. See Jalalabad Natural History. See Pliny the Elder network models 9-12; administrative networks, 81n 46, 96-97, 109, 116, 123-124, 132-133, 156, 171, 188-189, 205-206, 312; intellectual / literary networks, 48, 163, 296; maritime networks, 179, 217-226 (map 3.3); patronage networks, 24-28, 34, 38, 145-149, 180, 213-214n 92, 311, 314; trade networks, 15-22, 39-40, 59-61, 74-75, 94-95, 131-132, 144, 154, 158, 165-166, 169-170, 181, 183-228, 244-253 (maps 4.1-4.2), 257-260 (map 5.1), 270-271, 276-278, 286-287, 289-309 (map 6.1), 311-313, 316-319. See also capillary routes, Northern Route, Silk Routes, Southern Route
Niya 290 (map 6.1), 292, 295, 297-299, 304; Niya Kharoșțī documents, 53n 150, 297n 25

Northern Black Polished ware 74, 186, 205

Northern Route (Uttarāpatha) 61-62, 81, 133, 144, 184-204 (map 3.1), 208-209, 227, 257, 292, 312

Numismatics. See coins

"omitted hundreds". See dates and dating systems, theory of "omitted hundreds"

Oshibat 259 (map 5.1), 266, 269-271, 280-281

Oxus River (Amu Darya) 53, 94, 185 (map 3.1), 191, 265

Pāli language and literature, 41-42, 44-45, 70-71n 16, 89-90, 243; texts, 3n $5,8,28-29,31,33,40,57,72$ n 23, 74, 77nn 34-35, 86-87n 62, 196; vamsas, 67-68, 78nn 37-38, 81-82nn 48-51, 91, 315; Vinaya, 1, 17n 48, 36-37, See also jātakas, Menander, Milindapañha, Sutta Nipāta

Palola Șāhis 62, 159, 163n 307, 171177, 265-266, 275-276, 285-287, 296, 313

Pānini 187-188n 9

Parthian Stations 224-225, 291

Pāṭaliputra (Patna) 75 (map 2.1), 78-79, 81n46, 89, 132n 201, 139, 189-190, 198, 213n 90,

path (mārga) 3-4, 17, 86, 314

Patika 116n 151, 122-124, 131,

Patronage 5-7, 10-11, 16-34, 49-51, 55-63, 66, 77, 82-94, 104-106, 109-110, 116-122, 137-142, 145-149, 155-156, 148, 162-166, 170-177, 179-181, 199-200, 207-208, 213-214, $217,227,233-235,238-240,249-250$ n 58, 255-256, 284-287, 298, 300, 307-309, 313-319. See also networks, patronage networks

Periplus Maris Erythraei 126-127, 211, 214-227

Peshawar (ancient Purușapura) 138, 141-144, 160, 185 (map 3.1), 192, 234, 237, 252, 316; Peshawar basin, 230 (map 4.1), 232-238, 244

petroglyphs $12,32-33,54,58,62$, 113-114, 136, 246, 258-259 (map 5.1), 268-273 (fig. 5.1), 278-287 (figs. 5.2-5.4), 294-295, 313 
pilgrimage $4,8,37-38,59,69-70,88$, $138,170,188$ n 10, 190, 201-202, 210-211n 83, 213-214, 227, 239, 249-253, 258, 263-265, 272-275, 279, 285, 314, 319. See also Chinese pilgrims

Pliny the Elder, Natural History 189-190, 225-226

Prakrit 29, 45, 52-53, 83, 110, 129-131, 152, 212, 220, 297. See also Gandhāra, Gāndhārī language, Pāli, language and literature, Sanskrit

praśasti (eulogy) 110, 129, 148-155, 167-168n 326

Pratișthāna (Paithan) 149n 257, 204 (map 3.2), 207, 213, 215-216

Ptolemy, Geography 128n 189, 189n 14, 213

Purușapura. See Peshawar

Pușkalāvatī 134n 206, 189, 215, 230 (map 4.1), 234n 9, 236, 238, 244

Rabatak inscription $124 \mathrm{n} 171$, 132-133n 201, 135-136. See also inscriptions, Bactrian

Raghuvamiśa 191

Rājagṛha (Rajgir) 68n 8, 75 (map 2.1), 77-78, 187, 197

Rājataraniginī of Kalhaṇa $138 \mathrm{n} 224$, $168,177-178,192$,

religious markets 16-17, 36n 104

relics 26-28 (fig. 1.1), 105, 118, $122,131,144,162,229,305-307$, 318; bodily (śarirra), 54-57; commemorative (uddeśika dhātu), 57n 157, 59, 272, 287; contact (pāribhogika dhātu), 57, 252-253, 274; reliquaries, 22-23 118 (fig. 2.2), 169; reliquary inscriptions, $26 \mathrm{n} 78,33 \mathrm{n}$ 97, 116-118, 141n 231, 162-163. See also dharma, dharmakāya ("dharma body")

renunciation $2-5,8-9,14,16-19$, $36-38,60,66,72,180,254 \mathrm{n} 73,312$, 316-317. See also śramana

Rudradāman 124 (table 2.2), 129, 155, 199, 208n 51. See also Cașțana, Western Kṣatrapas

Saddharma-pundarīka sūtra. See Lotus sūtra

Śaiva. See Śiva

Sakas / Śakas 59, 93, 102-103, 109-132, 134, 153-154, 181, 189, 198-200, 225,
234, 255-256, 278, 295-296, 314. See also dates and dating systems, Azes era, Śaka era; Kārdamakas; Kșaharātas; Western Kṣatrapas; Maues, Patika; Śodāsa

Saakyamuni (historical Buddha) 1-3, 27-28, 34, 42-44, 54-56, 60-70, 77-78, 88-89, 180, 198, 229, 253-254, 284, 313-317. See also dates and dating systems, historical Buddha Samudragupta 151-153, 156 (table 2.4), 208n 51. See also Guptas

Sāñcī 22-24nn. 64, 70, 51, 84 (map 2.2), 89, 142n 238, 146, 155, 204 (map 3.2), 206-207, 212-214, 236n 15, 314-316

Sarigha $4-5,12,17-19,26-28,34-39$, $47,51,63,65-67,74,78,88-94$, 180-181, 228, 231, 253-254, 311-317; sanghabheda (division of the Buddhist community), 89, 180, 314

Sanskrit language of Buddhist transmission, 44-47, 53; manuscripts and texts, 8, 27-34, 40, 56n 156, 71-73, 82, 91-93, 95, 104, 115, 138n 224, 141, 171-172, 187, 190-197, 208-211, 296, 301; use in inscriptions, 52, 110, 129, 131, 152, 162-163, 172-175, 191-192, 208, 212. See also Arthaśāstra, avadānas, Avadānaśataka, Divyāvadāna, Dharmaśāstra, Dharmasūtra, jātakas, Jātakamālā, Kalpanāmanditikā, Lotus sūtra, Mahābhārata, Mahāvastu, Meghadūta, Mūlasarvāstivāda-vinaya, praśasti, Pānini, Raghuvamía, Rājatarañginī, Udānavarga, Upanișads, Vedas, Yavanajātaka saptaratna. See seven jewels

Sarnath 2-3, 70, 84 (map 2.2), 89, 146, 314

Sātavāhana 126-131, 191n 19, 207-208, 215-217, 223

Seistan 111, 114-115, 126, 185 (map 3.1), 193n 26, 224

Senavarman 33, 119-120 (fig. 2.2), $131,134-135$

seven jewels (saptaratna) 22-23, 144, 261

Shan-shan. See Kroraina

Shatial 26n 78, 113, 136, 170, 192n 22,259 (map 5.1), 266, 269-271, 274, 278-285 (fig. 5.2)

Shi ji 112, 132-134nn 199-205.

See also China, Chinese history 
Shing Nala 259 (map 5.1), 269, 284-285

Shortughai 21, 94-95, 247 (map 4.2)

Śibi Jātaka. See jātakas

Silk Routes 12, 44, 53, 62, 117, 144, 244, 246, 257, 260, 289-309, 290 (map 6.1), 313. See also Central Asia, Tarim Basin, Xinjiang

Siṃhala Avadāna. See avadānas

Śiva $142,148,158,166-167,238$ n 26,

Śodāsa 123-124 (table 2.2)

Sogdia 98, 160-162, 224, 250, 271, 291, 302, 305-306; Sogdian merchants, 158, 169-170, 270-271, 276, 279-282, 286. See also inscriptions, Sogdian

Song Yun. See Chinese pilgrims

Sophytos inscription 100-101, 108.

Southern Route (Daksināpatha) 61, 129, 149, 204 (map 3.2), 205-217, $227-228,312$

śramana 17, 72-76, 85, 94, 180-181, 228, 305, 313-314. See also Jain, renunciation, Sarigha

Śrāvastī 27, 75 (map 2.1), 77, 132n 201, 185 (map 3.1), 197

stūpa 12, 20-28, 34, 49, 54-59, 61-63, 88-93, 117-122 (fig. 2.2), 131,

$138-140,144,155,162-163,169$, 171n $335,177-178,184,201-203$, 211-216, 228-230 (map 4.1), 233-239, 245-254, 266, 271-272, 278-287 (figs. 5.1-5.4), 289-290 (map 6.1), 294-303, 311-318. See also archaeology, caitya, monasteries, residential (vihāra), relic

Subashi. See Kucha

surplus 5, 19n 54, 33-34, 38-39, 62, $74,144,186$ n 5, 217, 229, 234-238, 245-246, 303-308, 311-313, 318-319

Sutta-nipāta 8-9, 89n 72, 209

Swat valley (Uḍdìāna) 33, 50, 58-61, $108,113-119,132-135,160-161,167$, $175,178,185$ (map 3.1), 193, 230 (map 4.1), 231-239, 244-246, 251-253, 260-266, 274-275, 279, 286-287, 294-295, 299-301, 313-315

Tarim Basin 6, 12, 43, 45-46n 132, 53, $62,113,133,144,177,242-244$, 250-258, 261, 264, 270, 274, 277, 289-309, 290 (map 6.1), 313. See also Central Asia, eastern Central Asia

Taxila 22n 64, 82-84 (map 2.2), 93, 97, 106, 114-126, 131-132, 142-144, 162n 305, 184-186 (map 3.1), 197,
200-206, 214, 225, 228-230 (map 4.1), 232-233n 5, 244-246, 255, 303, $315-316$

Thalpan 259 (map 5.1), 266, 269, 280n $70,283-285,294$

Tibet $3,52 \mathrm{n} 149,270,276,319$;

Tibetan Buddhism, 4-5n 10, 40, 46-47, 138-139, 175nn 346-347, 196; Tibetan history, 158, 176, 266, 275, 299-300; Tibetan inscriptions, 53-54, 265n 27, 271n 51, 286

trade definition of, 183; long-distance trade, 11-12, 19-26, 48, 94-95, 117, 131-132, 144, 158, 184-187, 199, 214-226, 248-249, 261-263, 270-271, 291, 296-297; religion and, 2-3, 12-16, 27-39, 74-75, 166, 169-170, 207, 211-212, 238-240, 272, 304-308, 311-319; trade routes, 56-63, 97-98, $149,161,164 \mathrm{n} 314,184-228$ (maps 3.1-3.3), 230 (map 4.1), 236, 246-251 (map 4.2), 257-260 (map 5.1), 278-287, 290(map 6.1)-302. See also network models, trade networks traders. See merchants

Trapușa. See Bhallika

Turfan 62, 290 (map 6.1), 292-293, 300

Udānavarga $3 \mathrm{n} 5,8-9,71$

Uḍdịīna. See Swat valley

Ujjayinī 75 (map 2.1), 84 (map 2.2), 127-131, 149, 154, 166, 185 (map 3.1), 199, 204-205 (map 3.2), 211-215, 228

Upanișads 71n 17, 72-73, 193-194

upāsakas. See lay devotees

Upper Indus. See Indus River

urbanism, urbanization 20-21, 34, $74-76,78,149,186-187$ n 5, 203, 212, 227, 233-239, 244, 302-304, 316

Uttarāpatha. See Northern Route

Vaiṣnava. See Viṣnu

Vajrayāna 4n 8, 180,

Vākātakas 147-149, 154, 156-157 (table 2.4), 215,

vamisas. See Pāli, vamisas

Vedas, vedic religion $67,72-73,76,92$, 95, 180, 190, 193-194, 208, 313-314

Vidiśā 50, 99 (fig. 2.1), 106, 147, 153-155, 185 (map 3.1), 199, 204 (map 3.2), 205-214, 228

vihāra. See monasteries, residential 
Vihāra-master (vihāra-svāmin, -svāminī) 35, 163-164

Vinaya 1, 17, 32n 89, 34-39, 44, 70-71n 16, 89n 72, 180, 242, 285, 314, 316-317. See also Mūlasarvāstivādavinaya; Pāli, Vinaya

Viṣnu 99 (fig. 2.1), 106, 142, 146, 148, 153-155, 158, 165, 177-178, 214

Viśvantara Jātaka. See jātakas

Vyāghrī Jātaka. See jātakas

Weber, Max 13-14, 19n 54, 38, 74

Western Kșatrapas 110n 130, 115, 124 (table 2.2), 126-131, 136n 217, 144-145, 153-154, 207-208, 216-217, 222-223. See also Sakas / Śakas

xenology 109 n 129, 184, 190-197, 255, 314

Xinjiang. See Tarim Basin
Xiongnu 133-134, 159, 293, 302. See also China, Chinese history; Huns; Sakas; Yuezhi

Xuanzang. See Chinese pilgrims

Yamuna River. See Ganga-Yamuna doāb

Yavanajātaka 128n 188, 136-137

Yavanas 106-109, 127, 220. See also dates and dating systems, Indo-Greek (Yavana) era; Hellenism; xenology

Yuezhi 112-114, 132-134, 159-160, 293-294, 306. See also China, Chinese history; Kușānas

Zhemong. See Chinese pilgrims

Zürcher, Erik 4-7, 253, 289, 300, 302-309, 312-315 
Jason Neelis - 978-90-04-19458-8 Downloaded from Brill.com $04 / 26 / 2023$ 11:30:22AM via free access 